\title{
OECD $\$$
}

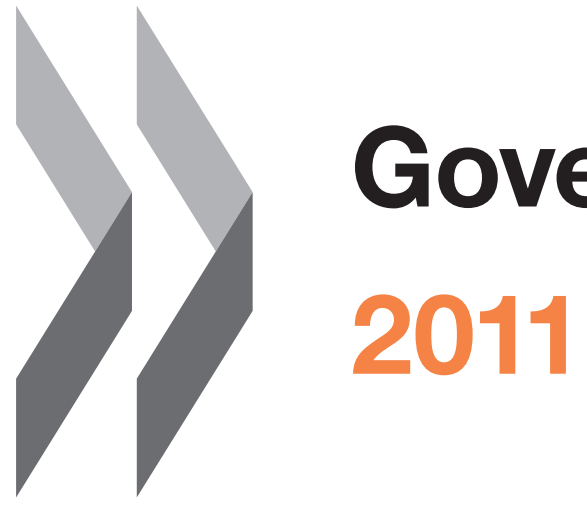

\section{Government at a Glance}

2011

for go guber

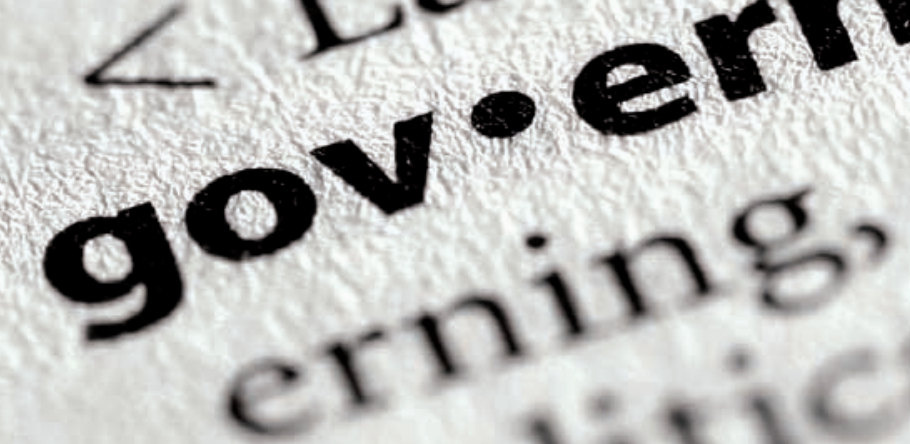





\section{Government at a Glance 2011}

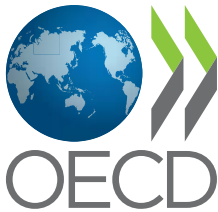


This work is published on the responsibility of the Secretary-General of the OECD. The opinions expressed and arguments employed herein do not necessarily reflect the official views of the Organisation or of the governments of its member countries.

\section{Please cite this publication as:}

OECD (2011), Government at a Glance 2011, OECD Publishing.

http://dx.doi.org/10.1787/gov_glance-2011-en

ISBN 978-92-64-09657-8 (print)

ISBN 978-92-64-09658-5 (PDF)

ISBN 978-92-64-09661-5 (HTML)

The statistical data for Israel are supplied by and under the responsibility of the relevant Israeli authorities. The use of such data by the OECD is without prejudice to the status of the Golan Heights, East Jerusalem and Israeli settlements in the West Bank under the terms of international law.

Photo credits: Cover @ Mark Poprocki - Fotolia.com.

Chapters III to XII @ Shutterstock/kentoh.

Corrigenda to OECD publications may be found on line at: www.oecd.org/publishing/corrigenda.

(c) OECD 2011

You can copy, download or print OECD content for your own use, and you can include excerpts from OECD publications, databases and multimedia products in your own documents, presentations, blogs, websites and teaching materials, provided that suitable acknowledgment of OECD as source and copyright owner is given. All requests for public or commercial use and translation rights should be submitted to rights@oecd.org. Requests for permission to photocopy portions of this material for public or commercial use shall be addressed directly to the Copyright Clearance Center (CCC) at info@copyright.com or the Centre français d'exploitation du droit de copie (CFC) at contact@cfcopies.com. 


\section{Foreword}

$T_{1}$ he second edition of Government at a Glance is being published at a time when the aftermath of the financial and economic crises that started in 2008 is being felt everywhere. Reforming the financial sector, addressing persistent high unemployment, the lack of economic growth, the volatility of markets, the risk of trade and foreign direct investment restrictions and the increase in migration flows are serious policy challenges of unprecedented scope. The room for manoeuvre in most countries is further reduced through high debt and deficit levels. In fact, the speed, scope and timing of fiscal consolidation are considered by many as crucial for progress in other public policy objectives. Government at a Glance 2011 provides key quantitative and qualitative data that can enable evidence-based decision making as well as help governments plan for the future. It allows for the comparison of government activities, practices and performance across a number of critical dimensions, and helps pinpoint areas that warrant further examination. Chapter II tackles questions about the quality of reforms announced to date in member countries.

This work was led by Zsuzsanna Lonti under the direction of Rolf Alter and Jón Ragnar Blöndal and drafted by Jordan Holt, Natalia Nolan Flecha and Alessandro Lupi. Major drafted contributions were received from Allen Schick (Chapter I on "Leveraged Governance"); Colin Forthun, Nikolai Malysheu and Elsa Pilichowski (Chapter II on "Fiscal Consolidation"); Colin Forthun, Dirk-Jan Kraan, Jean-François Leruste and William Oman (Chapter III on "Public Finance and Economics"); Elodie Beth, Janos Bertok, Maria Emma Cantera, Colin Forthun, Elsa Pilichowski and Barbara Ubaldi (Chapter IV on "Strategic Foresight and Leadership"); Elsa Pilichowski and Gabrielle Milosic (Chapter V on "Employment in General Government and Public Corporations"); Elsa Pilichowski, Jani Heikkinen and Gabrielle Milosic (Chapter VI on "Compensation in Selected Public Sector Occupations"); Elsa Pilichowski, Emmanuel Job and Gabrielle Milosic (Chapter VII on "Human Resources Management Practices"); Julio Bacio Terracino, Janos Bertok, Maria Emma Cantera, Marco Daglio, Anna Pons Vilaseca and Lisa Von Trapp (Chapter VIII on "Transparency in Governance"); Julio Bacio Terracino, Janos Bertok, Maria Emma Cantera and Anna Pons Vilaseca (Chapter IX on "Public Procurement"); Christiane Arndt, Gregory Bounds and Emmanuel Job (Chapter X on "Regulatory Governance"); Maria Emma Cantera, Marco Daglio, Jean-François Leruste and Barbara Ubaldi (Chapter XI on "Ways of Delivering Public Services"); Cumhur Bilen, Monica Brezzi, Bert Brys, Eric Charbonnier, Michael Förster, Gaetan Lafortune, Vladimir Lopez-Bassols and Jean Yip (Chapter XII on "Government Performance Indicators from Selected Sectors"). We thank Karena Garnier, Kate Lancaster, Hélène Leconte-Lucas, Jennifer Stein and Deirdre Wolfender for their help in preparing the document for publication.

This publication also benefited from input provided by the OECD Public Governance Committee and the Government at a Glance Steering Group (details in Annex I); the OECD Regulatory Policy Committee; the OECD Committee on Statistics; the OECD Public Employment and Management Working Party; the OECD Working Party of Senior Budget Officials; the OECD Expert Group of Conflict of Interest; the OECD Network of Senior E-government Officials; and the OECD Expert Group on Innovative and Open Government. Valuable comments have also been received from 
Nadim Ahmad and Catherine La Rosa-Elkaim (OECD Statistics Directorate); Peter Hoeller, Margit Molnar and Eckhard Wurzel (OECD Economics Directorate); Philippe Burger (University of the Free State, Johannesburg, South Africa); and Stéphane Jacobzone, Josef Konvitz, Edwin Lau and Christian Vergez (OECD Public Governance and Territorial Development Directorate). 


\section{Table of Contents}

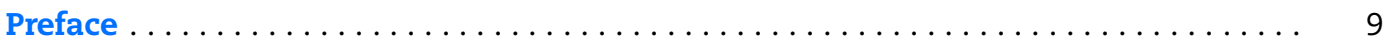

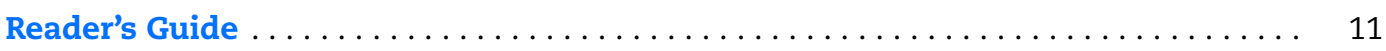

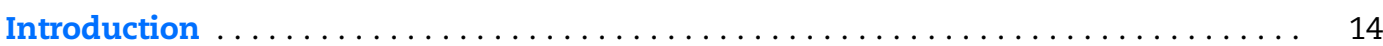

I. OECD 50th Anniversary - Leveraged Governance: Avoiding Fracture

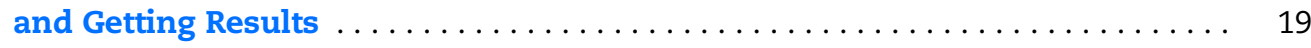

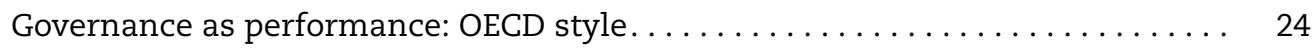

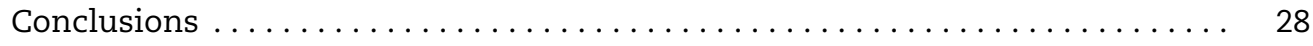

II. Fiscal Consolidation: The Need for Evidence-Based Decision Making. . . . . . . 31

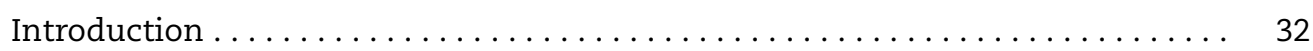

Most OECD countries are planning reforms to consolidate finances ....... 32

Ability of the government to reform under pressure .............. 34

Evaluating the quality of planned reforms: Key questions and risks . . . . . 38

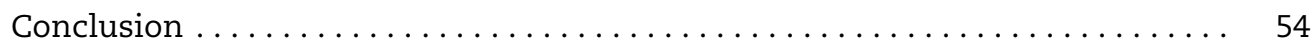

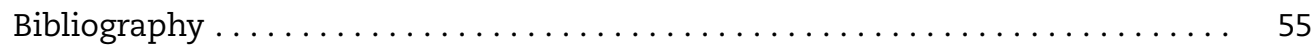

III. Public Finance and Economics . . . . . . . . . . . . . . . . . . . . 57

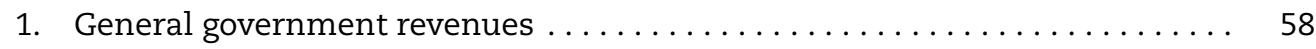

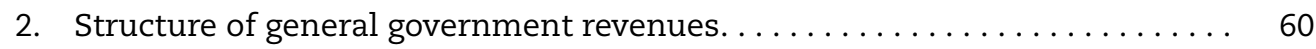

3. Revenue structure by level of government $\ldots \ldots \ldots \ldots \ldots \ldots \ldots \ldots \ldots . \ldots 2$

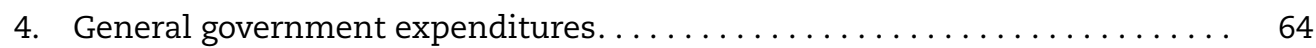

5. Structure of general government expenditures (by COFOG function) ...... 66

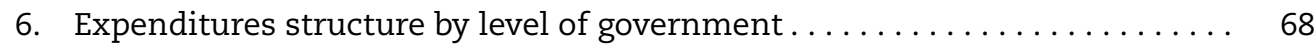

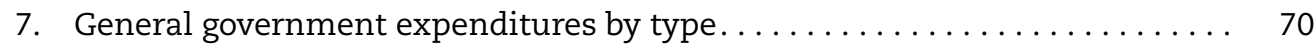

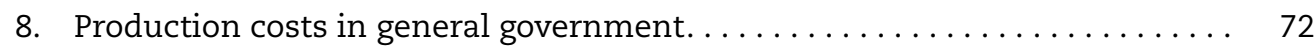

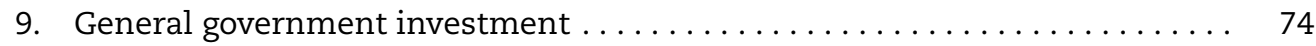

10. Final consumption expenditures by government and households....... 76

11. Size of general government financial assets and liabilities . . . . . . . 78

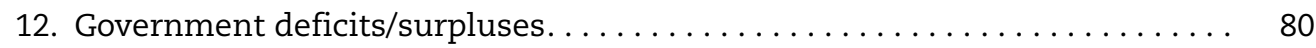

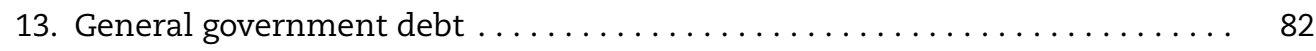

14. Special feature: Governments' role in promoting R\&D . . . . . . . . . . 84

IV. Strategic Foresight and Leadership $\ldots \ldots \ldots \ldots \ldots \ldots \ldots \ldots \ldots \ldots \ldots \ldots \ldots \ldots \ldots \ldots$

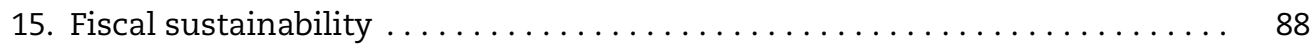

16. Strategic human resources management ................. 90

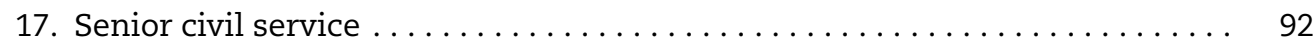

18. Political influence in senior staffing $\ldots \ldots \ldots \ldots \ldots \ldots \ldots \ldots \ldots \ldots \ldots \ldots \ldots$

19. Strategic decision making: Ministerial advisors. . . . . . . . . . . . 96

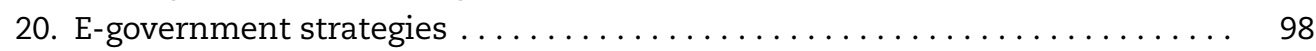


V. Employment in General Government and Public Corporations . . . . . . . . . . 101

21. Employment in general government and public corporations . . . . . . . 102

22. General government employment across levels of government . . . . . . . . . 104

23. Ageing central government workforce . . . . . . . . . . . . . . . . 106

24. Special feature: Public workforce restructuring . . . . . . . . . . . . . . 108

VI. Compensation in Selected Public Sector Occupations. . . . . . . . . . . . 111

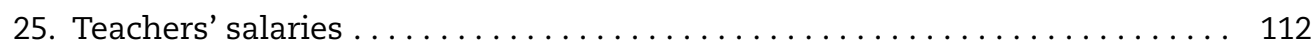

26. Doctors' and nurses' salaries . . . . . . . . . . . . . . . . . . . . . . . . 114

27. Compensation of senior management in central government . . . . . . . 116

28. Compensation of middle management in central government . . . . . . 118

29. Compensation of professionals in central government . . . . . . . . . . . 120

30. Compensation of secretarial staff in central government . . . . . . . . . 122

VII. Human Resources Management Practices. . . . . . . . . . . . . . . . . . . . . . 125

31. Delegation in human resources management . . . . . . . . . . . . 126

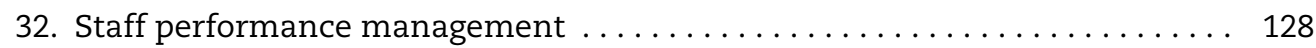

33. Industrial relations in central government. . . . . . . . . . . . . . . . . 130

34. Working conditions in central government . . . . . . . . . . . . . . . 132

VIII. Transparency in Governance . . . . . . . . . . . . . . . . . . . . 135

35. Legislative capacity to ensure transparency in the budget process . . . . . 136

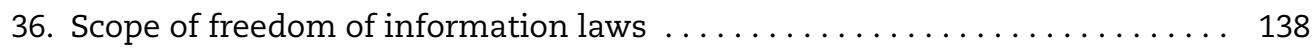

37. Ease of filing a request for public information . . . . . . . . . . . . . 140

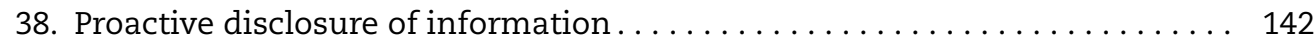

39. Conflict-of-interest disclosure by top decision makers . . . . . . . . . . . 144

IX. Public Procurement. . . . . . . . . . . . . . . . . . . . . . . . . . 147

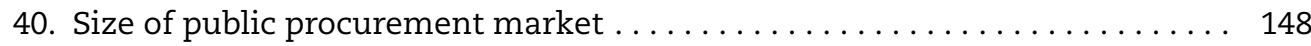

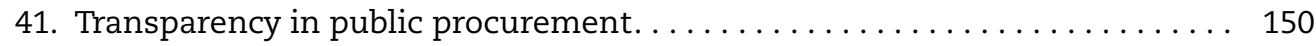

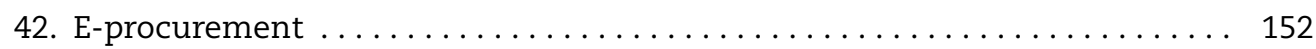

43. Special feature: Green procurement . . . . . . . . . . . . . . . . . . . . . . . 154

X. Regulatory Governance . . . . . . . . . . . . . . . . . . . . . 157

44. Regulatory institutional frameworks and oversight . . . . . . . . . . . 158

45. Improving the transparency of regulations $\ldots \ldots \ldots \ldots \ldots \ldots \ldots \ldots$

46. Preparing for effective compliance and enforcement of regulations . . . . . 162

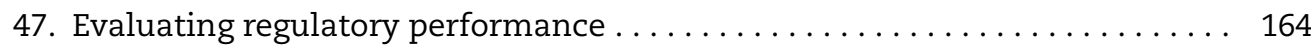

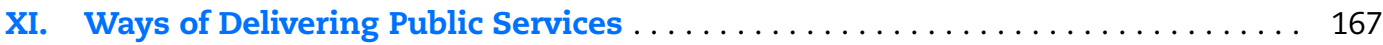

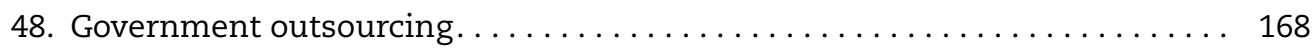

49. Uptake of e-government services. . . . . . . . . . . . . . . . . . . . 170

50. Special feature: Partnering with citizens in service delivery . . . . . . . . . 172

XII. Government Performance Indicators from Selected Sectors . . . . . . . . . . 175

51. Greater fairness through selected government policies . . . . . . . . . . 176

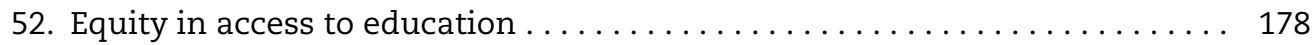

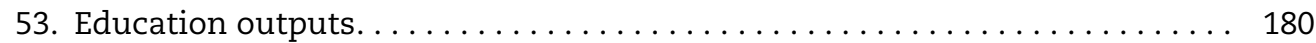


54. Education outcomes..................................... 182

55. Equity in access to health care . . . . . . . . . . . . . . . . . 184

56. Health outputs and output-based efficiency measures ........... 186

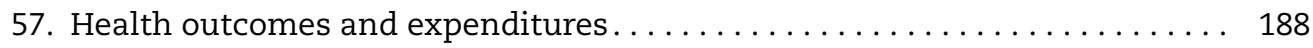

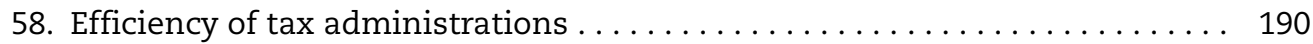

Annex A. Methodology for Revenue Aggregates .................... 193

Annex B. Classification of the Functions of Government (COFOG) . . . . . . . . . . . 194

Annex C. Fiscal Consolidation Model Assumptions...................... 196

Annex D. Methodology and Additional Notes on Compensation of Government Employees. . . . . . . . . . . . . . . . . . . . . . . . . . 199

Annex E. Composite Indexes for Human Resources Management Practices . . . . . 209

Annex F. Detailed Data on Conflict-of-Interest Disclosure

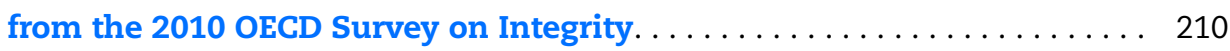

Annex G. Detailed Data from the 2010 OECD Survey on Public Procurement . . . . . 214

Annex H. Contextual Factors................................ 219

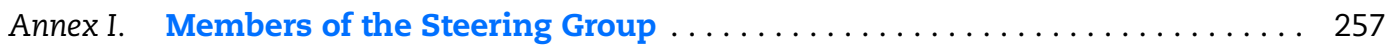

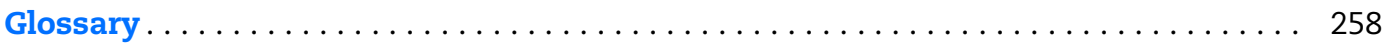

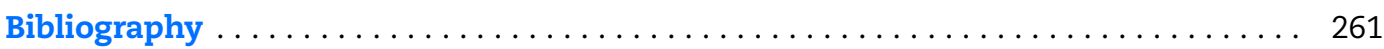

\section{This book has...}

\section{StatLinks 福 A service that delivers Excel $^{\circledR}$ files from the printed page!}

Look for the StatLinks at the bottom right-hand corner of the tables or graphs in this book. To download the matching Excel $^{\circledR}$ spreadsheet, just type the link into your Internet browser, starting with the http://dx.doi.org prefix.

If you're reading the PDF e-book edition, and your PC is connected to the Internet, simply click on the link. You'll find StatLinks appearing in more OECD books. 



\section{Preface}

$\mathrm{T}_{\mathrm{h}}$ he recent crisis has been caused by major failures in regulation and supervision by public authorities, as well as by shortcomings in risk management and corporate governance by the private sector. It has shaken many long-held assumptions about the functioning of markets and the role of governments, and as such has led to calls for changes to the global governance architecture and for the redefinition of the respective roles of the state and of markets, in order to restore citizens' trust in both.

Governments around the world have heard these calls and are rethinking and reforming the public sector.

The task is critical. Governments are major players in most national economies. By most measures, they have significantly expanded their footprint during the last 50 years. In 1961, when the OECD was established, the general government outlays of member countries averaged less than $30 \%$ of GDP; the average now exceeds $45 \%$, up from slightly more than $40 \%$ in 2007.

Public policies are the critical anchor of national economies as clearly demonstrated by the decisive and co-ordinated action by governments in the aftermath of the crisis. However, this action - as well as reduced revenues as output dropped - led to growing, and in some cases unsustainable, fiscal pressures. Fiscal consolidation should be accomplished in large part through a reduction in public expenditures. To avoid an excessive curtailing of public services, the state needs to be streamlined and made more efficient.

The efforts to restructure the state will necessarily include a reassessment of where and how government should intervene and where it can step back. In short, it is about better and more effective governance, about sound institutions and efficient rules and procedures as shown by our recent work on restoring public finances, and by our country reviews covering integrity, regulatory reform and e-government, among other topics.

In these stormy times, reforming the public sector is a policy priority and should be conducted on the basis of evidence and comparative analysis. With Government at a Glance, the OECD offers a unique source of internationally comparative data to help governments benchmark their performance. It provides insights into policy approaches and practical examples of what works and what does not. It also aims to inform public debate on public sector reform policies.

The 58 data sets of member and partner countries in this 2011 edition of Government at a Glance include:

- the first ever international comparison of public sector pay for selected professions and public service occupations, which points to a fairly egalitarian pay structure in the public sector;

- estimations of country-specific fiscal consolidation requirements, which have been found to be large in many countries. On average, an improvement of nearly $4 \%$ of GDP is needed from the fiscal positions in 2010 just to stabilise the debt-to-GDP ratio by 2026. In 
addition, offsets of about 3 percentage points of GDP on average will have to be found over the coming 15 years to meet spending pressures due to ageing;

- the level of disclosure of private interests in the three branches of government; and

- the implementation gap of Open Government policies to promote transparency, efficiency and trust.

Restoring trust in government and in political leadership is critical for the progress of societies. The OECD supports governments in their search for reform and innovations in the public sector, including achieving better budget transparency, promoting integrity, improving public service delivery through new ways of public private partnerships, and strengthening effective regulation and international regulatory co-operation.

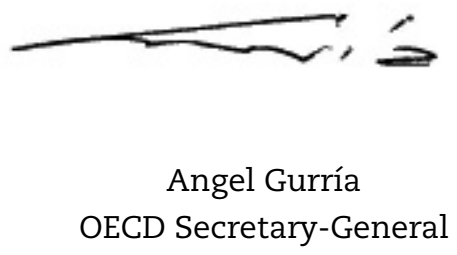




\section{Reader's Guide}

$I$

In order to accurately interpret the data found in Government at a Glance, readers need to be familiar with the following methodological considerations which cut across a number of indicators. The "Glossary" at the end of the publication, as well as the "Methodology and definitions" section for each indicator, offer additional important information.

\section{Calendar year/fiscal year in National Accounts data}

Unless specified, data from the OECD National Accounts are on the basis of calendar years.

Data for Australia and New Zealand refer to fiscal years: 1 July of the year indicated to 30 June for Australia and 1 April of the year indicated to 31 March for New Zealand. For Japan, data regarding certain sub-sectors of general government and expenditures by COFOG refer to fiscal years.

The data based on the System of National Accounts (SNA) were extracted from the OECD National Accounts Database on 28 February 2011.

\section{Composite indicators}

The publication includes several descriptive composite indexes in narrowly defined areas related to human resources management (HRM). These composite indexes are a practical way of summarising discrete, qualitative information. The composites presented in this publication adhere to the steps identified in the Handbook on Constructing Composite Indicators (Nardo et al., 2008).

Details about the variables and weights used to construct the HRM indices are available in Annex E. While the composite indicators were developed in co-operation with member countries and are based on theory and/or best practices, the variables composing the indexes and their relative weights are based on expert judgements and, as a result, may change over time. In some instances, composite indicators from Government at a Glance 2009 may not be comparable with those of the 2011 edition.

\section{Country coverage}

Government at a Glance includes data for all 34 OECD members countries based on availability of data. This is the first year where data are presented for the four new OECD member countries that joined the Organisation in 2010: Chile, Estonia, Israel and Slovenia. The statistical data for Israel are supplied by and under the responsibility of the relevant Israeli authorities. The use of such data by the OECD is without prejudice to the status of the Golan Heights, East Jerusalem and Israeli settlements in the West Bank under the terms of international law. 
Some additional countries, such as the Russian Federation (currently in the process of accession to the OECD) and others that have observer status to the Public Governance Committee of the OECD (Brazil, Ukraine and Egypt) also supplied data for several indicators. Data for non-member countries are presented separately at the end of tables and figures.

\section{Country codes (ISO codes)}

\begin{tabular}{llll}
\hline OECD member countries & & & \\
Australia & AUS & Poland & POL \\
Austria & AUT & Portugal & PRT \\
Belgium & SEL & Slovak Republic & SVKN \\
Canada & SAN & Spain & ESP \\
Chile & CHL & Sweden & SWE \\
Czech Republic & CZE & Switzerland & CHE \\
Denmark & DNK & Turkey & TUR \\
Estonia & EST & United Kingdom & GBR \\
Finland & FIN & United States & USA \\
France & FRA & & \\
Germany & OEU & Russian Federation & \\
Greece & GRC & & RUS \\
Hungary & HUN & Other major economies & \\
Iceland & ISL & China & CHN \\
Ireland & IRL & India & IND \\
Israel & ISR & Indonesia & IDN \\
Italy & ITA & South Africa & ZAF \\
Japan & JPN & & \\
Korea & KOR & Observers to the Public Governance Committee, OECD & \\
Luxembourg & LUX & Brazil & BRA \\
Mexico & MEX & Egypt & EGY \\
Netherlands & NLD & Ukraine & UKR \\
New Zealand & NZL & & \\
Norway & NOR & & \\
\hline
\end{tabular}

\section{OECD averages and totals}

\section{Averages}

In figures and text, the OECD average refers to the unweighted, arithmetic mean of the OECD member countries for which data are available. It does not include data for non-member countries.

OECD\# refers to the average for the number of OECD member countries listed and/or found in the corresponding figure or table. Notes indicate the countries for which data are unavailable.

In instances in which one or more years are depicted in a figure, the OECD average is a fixed composition of countries that includes all member countries for which data are available. For example, an OECD average for the year 2007 includes available data for that year for all current member countries, even if they were not an OECD member in that year.

\section{Totals}

OECD totals are most commonly found in tables and represent the sum of data in the corresponding column for the OECD countries for which data are available. Totals do not include data for non-member countries.

Total OECD\# refers to the number of OECD member countries listed and/or found in the corresponding table. Notes indicate the countries for which data are unavailable. 


\section{Online supplements}

Several indicators include online supplemental tables and figures that present countryspecific data. When available, these are noted in the "Methodology and definitions" section of the indicator. Government at a Glance 2011 also offers access to StatLinks, a service that allows readers to download the corresponding Excel files of the data featured. StatLinks are available at the bottom right-hand corner of the tables or figures and can be typed into web browsers or, from an electronic version of the publication, clicked on directly.

In addition, country notes that present key data by country compared with the OECD average are available on line. Both the country notes and supplemental data are available at: www.oecd.org/gov/indicators/govataglance.

\section{Per person indicators}

Some indicators (e.g. expenditures, revenues and government debt) are shown on a per person basis. The underlying population estimates are based on the System of National Accounts notion of residency. They include persons who are resident in a country for one year or more, regardless of their citizenship, and also include foreign diplomatic personnel, and defence personnel; together with their families and students studying and patients seeking treatment abroad, even if they stay abroad for more than one year. The "one year" rule means that usual residents who live abroad for less than one year are included in the population, while foreign visitors (for example, vacationers) who are in the country for less than one year are excluded. An important point to note in this context is that individuals may feature as employees of one country (contributing to the GDP of that country via production), but residents of another (with their wages and salaries reflected in the Gross National Income of their resident country).

\section{Purchasing Power Parities}

Purchasing Power Parities (PPPs) are the rates of currency conversion that equalise the purchasing power of different countries by eliminating differences in price levels between countries. When converted by means of PPPs, expenditures across countries are in effect expressed at the same set of prices, enabling comparisons across countries that reflect only the differences in the volume of goods and services purchased.

2000 and 2007: PPPs for all European countries are annual benchmark results provided by Eurostat. PPPs for non-European countries are OECD estimates.

2008: PPPs for all OECD countries are triennial benchmark results jointly calculated by the OECD and Eurostat.

2009: PPPs for all European countries are preliminary annual benchmark results provided by Eurostat. PPPs for non-European countries are OECD estimates. Estimates and preliminary results should be interpreted with caution as they are subject to revision.

More information is available on the OECD PPP Internet site: www.oecd.org/std/ppp.

\section{Signs and abbreviations}

.. Missing values.

n.a. Not applicable (unless otherwise stated).

EUR Euros.

USD US dollars. 


\section{Introduction}

\section{Structure of the publication}

The Government at a Glance series is designed to enable evidence-based policy making in member countries by allowing them to benchmark their activities and results in order to facilitate peer learning, and ultimately improve their own performance. The imperative of supplying internationally comparative evidence for public policy making is the guiding principle behind the selection of indicators for the publication. Policy makers and citizens need data on inputs, processes, outputs and outcomes to evaluate how their governments are performing and to make informed decisions about resources, policies and programmes. The framework for this publication reflects this important sequencing: it is structured according to the production chain of government performance (Figure 0.1).

\section{What's new in Government at a Glance 2011?}

Compared with Government at a Glance 2009, the 2011 edition is larger in scope both in terms of its country coverage and its data points. In this edition, the number of indicators has nearly doubled (from 31 to 58), building on many of the core indicators introduced in the 2009 edition. Additionally, data on public finance and economics in the 2011 edition are presented for years 2000, 2007 and 2009 to showcase both trends over this decade and the impact of the financial and economic crises. This edition also moves further up along the chain of government production, adding data on key aspects of governmental performance related to outputs and outcomes in selected sectors. New performance indicators include fiscal performance (government deficits, debt and fiscal sustainability); results related to fairness objectives, both in terms of income distribution and access to health and education services; as well as outputs, outcomes and some efficiency measures for tax administration, education and health. It thus responds to the strong interest expressed by OECD member countries for performance data. In addition, this year's edition includes a chapter on strategic foresight and leadership of government (Chapter IV). If anything, the crisis highlights the importance of governments' capacities to manage risk and consider long-term impacts. Fiscal sustainability is taken as a proxy of governments' abilities to forecast trends and adapt accordingly. This chapter also includes new data on the extent to which HRM practices at the top levels of government and in the civil service serve to foster a more strategic approach to policy making. Finally, there are indicators that are included as a special feature addressing topical issues at the time of publication, such as green procurement and co-production in service delivery.

Four countries (Chile, Estonia, Israel and Slovenia) joined the OECD in 2010. They are included in the 2011 edition when data are available. Government a Glance also includes data beyond the 34 OECD members, allowing countries to benchmark their performance against OECD accession countries (the Russian Federation) as well as other major economies on the world stage such as China, India, Indonesia and South Africa. Last, for some indicators, data from observer countries to the Public Governance Committee (Brazil, Egypt and the Ukraine) have been included. These countries are playing a significant and increasing role in the world economy and in international political structures. 
Figure 0.1. Conceptual framework for Government at a Glance

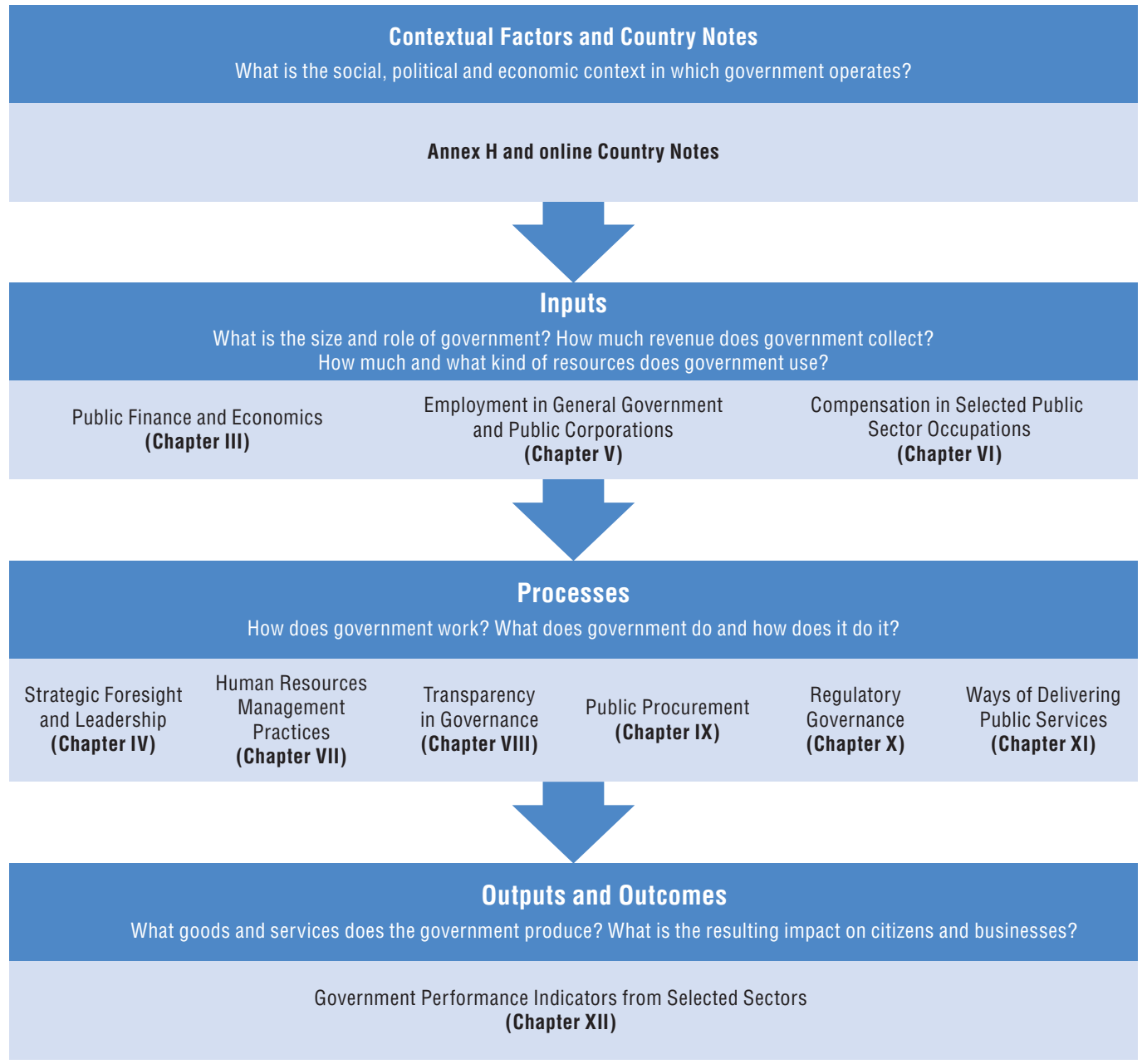

The release of Government at a Glance 2011 coincides with the 50th Anniversary of the OECD. The publication opens with a special chapter that reflects upon the role the OECD has played on the world stage in the areas of public management and public governance over the last 50 years and identifies some of the key challenges ahead. It is followed by a policy chapter that focuses on the topical issue of fiscal consolidation and the recent reforms announced in member countries. Data presented in Chapters III-XII highlight the need for better evidence on the impact and usefulness of various reform tools adopted.

\section{Typology of indicators}

Government at a Glance comprises three kinds of indicators: core, periodic and special features. Core indicators are those on government revenues, expenditures, employment, and those which reflect compliance with core public values such as integrity and transparency. Indicators on various public management and governance practices periodically alternate between editions, as these practices change less frequently. For example, the 2011 edition focuses in detail on human resource management practices, while the 2013 edition plans to showcase changes in the budget practices of OECD countries. Finally, some indicators are included as special features which address topical issues at the time of publication; the current edition features new data on green procurement, for example. 
Figure 0.2. Typology of indicators included in Government at a Glance
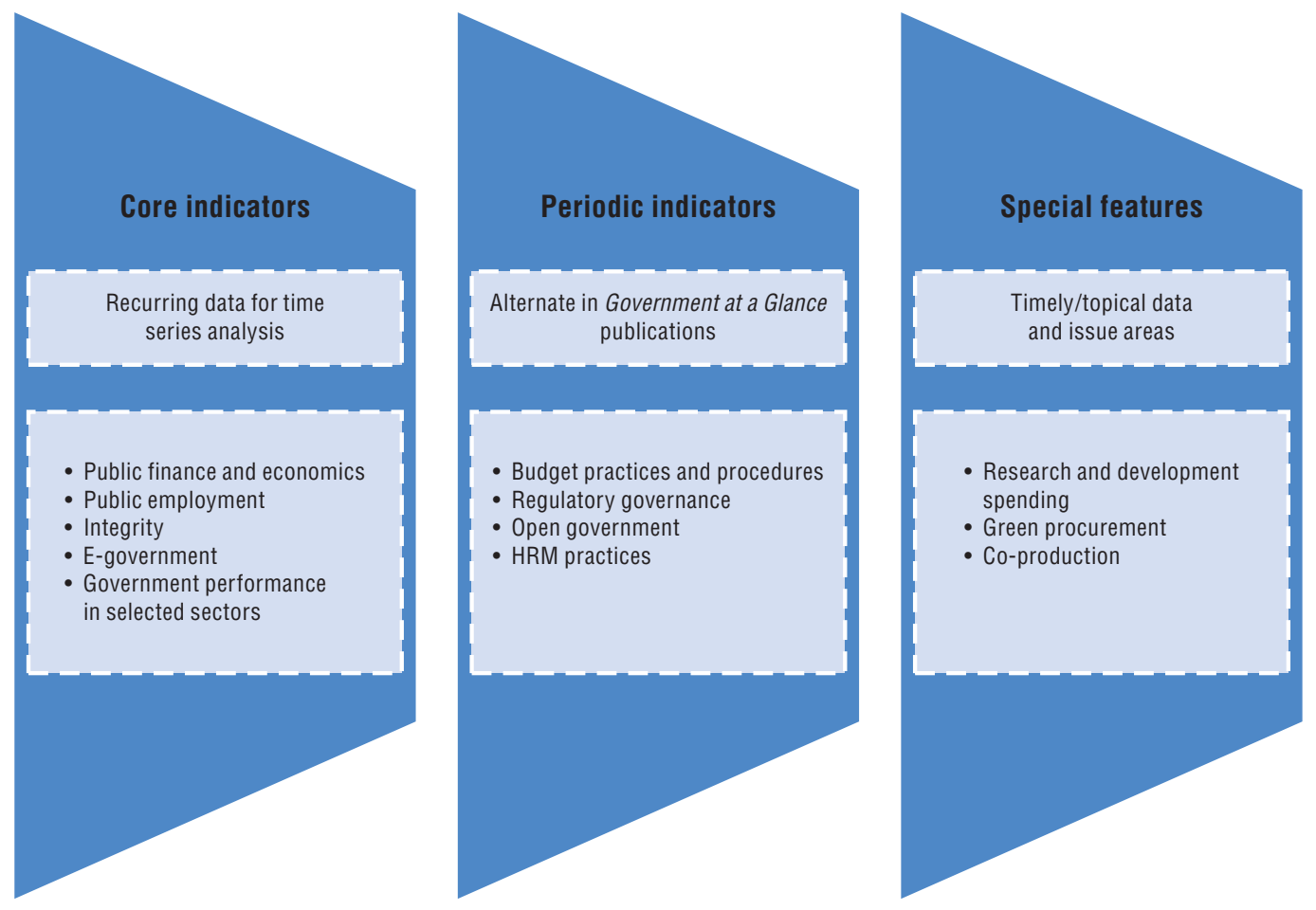

Planning for future editions is also currently underway, where the results of new work in performance measurement will be featured. Amongst the public management themes currently being explored for indicator development are: the quality of key services provided by governments, rule of law, civil servants' experiences with corruption in the public sector and e-government expenditures. In addition, indicators will be developed to assess the performance of regulatory governance systems, and indicators on budgeting practices and procedures will be renewed. Close co-operation with other organisations - among these, the World Justice Project and/or European Commission - will help ensure the comparability of data across countries as well as enlarge the sample of countries with available data (see Box 0.1).

\section{Presentation of indicators}

As in the 2009 edition, each indicator is presented on two pages. The first page is text that explains the relevance of the topic and highlights some of the major differences observed across OECD countries. The "Methodology and definitions" section provides important information necessary to interpret the data. The "Further reading" section cites useful background literature which provides context to the data displayed. The second page showcases the data. These figures show current levels and, where possible, trends over time.

\section{Definition of government}

Government at a Glance examines the performance of governments, but the meaning of this term can vary. In general, data on public finances presented in this publication are based on the definition of the sector "general government" found in the System of National Accounts (SNA). In these terms, government comprises Ministries/Departments, agencies, offices and some non-profit institutions at the central, state and local level as well as social security funds. Data on revenues and expenditures are presented both for central and 


\section{Box 0.1. Synergies between Government at a Glance and the World Justice Project}

Strengthening the rule of law is a key factor in achieving effective governance and, as such, the definition of government performance adopted by Government at a Glance refers not only to measures of efficiency or value-for-money, but also to how well countries are upholding core values of integrity and transparency, critical elements underpinning the rule of law. Government at a Glance is interested in expanding this base, developing also measures for other aspects of rule of law.

The World Justice Project (www.worldjusticeproject.org/rule-of-law-index/) is an international non-profit organisation that has developed composite indices which measure the extent to which countries around the world adhere to 9 different dimensions of rule of law. There are several interfaces between these indices and with data featured in Government at a Glance: both the first and second editions, for instance, examined aspects of the rule of law through indicators on conflict of interest and whistle-blowing protection, transparency in public procurement, regulatory management, and access to information legislation.

Given the complexity surrounding the scope and concept of the rule of law, future work in this field could benefit from the strong conceptual foundation developed by the World Justice Project for its Rule of Law Indices. Furthermore, co-operation between the World Justice Project and Government at a Glance could also lead to the exchange and triangulation of data to improve accuracy. Indeed, the OECD's approach to indicator development focuses on data collected directly from governmental sources, rather than population polls and expert judgments used by the WJP. Juxtaposition of the two datasets could help validate and improve the quality of both.

sub-central (state and local) levels of government and (where applicable) for social security funds. On the other hand, data on public management practices and processes refer to the central level of government only. Finally, data on employment refer to the public sector, which expands the definition of government to include public corporations, such as publicly-owned banks, harbours and airports.

\section{Data limitations}

True to its name, Government at a Glance provides a selection of the key indicators on various dimensions of government activities that are often based on more in-depth research and analysis. Taken individually, indicators included in this publication provide a window into dimensions of government performance which may warrant further attention and analysis. However, performance is best measured with a wider lens, taking into account several pieces of data.

Limitations in data comparability are described in the "Methodology and definitions" section as well as in the figure notes. While information for the indicators has been requested from all OECD member countries, occasionally non-response or insufficient quality of the data precluded the inclusion of countries in the publication. The figure notes indicate when data are not available for OECD members.

\section{Data sources and collection methods}

Most of the data in Government at a Glance 2011 has been compiled by the OECD. However, data are also drawn from the International Labour Organization (ILO), the International Monetary Fund (IMF) and Eurostat. Data sources are described in detail in the "Methodology and definitions" section of each indicator. 
OECD data are collected via standardised surveys that are filled out by representatives/ government officials of member countries. As such, the data represent either official government statistics or the country's own assessment of current practices and procedures. The only exception in this publication is the Programme of International Student Assessment (PISA) data, which represent the results of standardised tests completed by students in member countries. Every effort is made to ensure that the information that government officials provide is correct. To the extent possible, OECD data collection instruments use standardised definitions and common units of measurement. Member countries are consulted in the design of surveys, which are also piloted before data are collected from all members. Results of the questionnaires are verified by experts at the Secretariat and for some surveys, a peer review process is also used (e.g. for the regulatory governance data). Preliminary results are presented and discussed in detail by the working parties and expert groups of the various OECD Committees before they are published in Government at a Glance. 
Chapter I

\title{
OECD 50th Anniversary
}

\section{Leveraged Governance: Avoiding Fracture and Getting Results}

\author{
by \\ Allen Schick
}


$\mathrm{T}_{\mathrm{h}}$ hroughout its 50 years, the OECD has been a government-centred organisation. Representatives of member countries approve its budget, work programmes, codes and standards, and policy pronouncements. At the more than 1000 meetings convened under OECD auspices each year, delegates present their government's position on a broad range of economic and sectoral issues. OECD experts compile dozens of country-based statistical reports, conduct regular peer reviews of national policies, and carry out numerous analytical studies of government policies and actions. The flagship publication in which this essay appears is appropriately titled Government at a Glance.

It may be surprising, therefore, that the OECD Directorate responsible for government management is labelled "Public Governance". Although of old provenance, "governance" is very much in vogue and has displaced "government" in many organisations as the umbrella term for public-oriented policies and activities. The OECD's 1996 Ministerial Meeting on Public Management viewed governance "in terms of relationships, and thus includes more than public administration and the institutions, methods and instruments of governing". The seemingly minor shift in wording signals two actual or anticipated developments in policy and management: 1) government does not have a monopoly on public authority and resources; and 2) contemporary governments govern most effectively in concert with others. These developments sometimes are cast as statements of fact - government grip on power has weakened - and sometimes as normative positions - governments should purposely co-operate with other public, voluntary and even private power holders. More often, they refer to trends and tendencies, to a future in which the public map is more differentiated than it once was.

When it recast its Public Management Service (PUMA) into the Public Governance Directorate (GOV) a decade ago, the OECD recognised the importance of these trends. Although it (and others) are still adjusting to the age of governance, the OECD comprehends that government can be more effective by being open and accessible, by widening the circle of participants in policy making and service delivery, and by using a much broader range of tools to steer society.

The OECD is not alone, for now there is pervasive recognition in strong democracies that to govern is to share authority, ideas and information, often with partners, sometimes with rivals. National governments extend their reach or compensate for weakness by enlisting others in mobilising citizens and responding to their expectations, defining issues and options and translating them into workable policies, and delivering public services to diverse recipients. From the vantage point of government, governance is about leveraging; from the perspective of partners, it may be more about openness and inclusion. The two outlooks are not synonymous, but they need not be antagonistic. As befits the OECD's role and structure, this essay focuses on leveraging government to achieve public ends.

Leveraging takes many forms: opening once-closed meetings to non-government participants; transferring revenues to sub-national governments and mandating the provision of services; participating in regional and international policy-making forums; contracting with commercial vendors to supply public goods; and entering into formal 
arrangements, such as public-private partnerships (PPPs) to finance, build and operate infrastructure projects and other public activities. Though not formally part of government, the parties at the other end of these relationships are active, often influential participants in governance.

The signposts of a world in which governments network and share power and resources in order to govern are visible and ubiquitous. They can be found in the rise of non-governmental organisations, which are increasingly referred to as civil society organisations. The older term defines them by what they are not, the newer term confers legitimacy on non-elected power holders. They can be found in contemporary trends to both globalise and decentralise, with national governments sandwiched between these powerful forces, and in the capacity of multinational enterprises to easily move money, production and goods, often in disregard of national boundaries. They can be found in new forms of cyber governance spawned by the Internet and its seamless webs of googles, tweets and text messages, and in the 24/7 news machines which continuously bellow out their messages, even when government is in repose. They are in the modernist elevation of the individual above all collective institutions, and by the withdrawal of trust and confidence in government and leaders.

A logical response of governments to these powerful contemporary forces is to leverage their authority by drawing external actors into the orbit of governance. But, as in markets, there is risk that they will become over-leveraged by generating expectations and taking on commitments beyond their capacity to perform. One obvious risk is that the government's partners will have interests of their own, along with advantages such as elevated legitimacy and superior access to information that enable them to chart an independent course.

In a leveraged world, national governments still are potent centres of public authority and vast repositories of financial and other resources. By most standard measures, governments have significantly expanded their footprint during the OECD's half century. In 1960, the OECD's first year, government outlays of member countries averaged less than $30 \%$ of GDP; excluding recently added members, the average now is well in excess of $40 \%$. In fact, no member country now has a lower outlay (or revenue) to GDP ratio than 30 or 50 years ago. Although the pace of expansion has slowed in most countries and a few have moved to reduce the relative size of government in response to the Great Recession, big government is here to stay. Yet, enlarged government itself provides evidence of increased reliance on leverage. Since the OECD was established, most of the increase in public spending has been in social security and other income transfers. In some countries, escalating health care expenditures have accounted for approximately half of the total rise in relative spending. Hospitals, physicians and other providers are vital cogs in national governance, even in the many countries where they are outside government.

Enlargement of the state has made it more dependent on others, both to mobilise support for public policies and to satisfy the rising expectations of citizens. The corporatist political model that emerged in Europe's largest welfare states established quasi-formal means for major social and economic institutions to partner with government in making national policy. Governments with different political orientations have tended to rely more on market-based institutions, principally for service delivery rather than policy formation. However, the spread of leveraged government owes much more to the problem-solving acumen of political leaders and public managers than to a coherent ideology. Leveraging is a pragmatic response to limits on government capacity. Governments leverage because they do not possess all the IT skills required to run highly-developed economies, or because they do not want to operate complex 
health care systems. Many governments have turned to partners to ease pressure on their budgets or to improve the efficiency or quality of public services. Promotion of decentralisation by international organisations has also spurred leveraging, as have the profound impacts of globalisation and other trends mentioned earlier.

Although it has been driven principally by practical considerations, leveraging government has drawn impetus from parallel developments in business management and from steep declines in citizen trust. The market and public sectors have never been tightly walled off from one another; ideas and practices in currency flow between them. During the first half of the 20th century, when vertical integration was deemed the paragon of industrial organisation, functional integration was regarded as the model of competent government. Just as vertical integration combined production of all of the components assembled into the final product in a single firm, functional integration fused all the activities contributing to the same public objective in a single Ministry or Department. However, integration came to be viewed as an impediment to business efficiency in the last decades of the century, and firms increasingly outsourced production and decentralised operations, thereby recasting top management into strategic units which defined the firms' aims and the means of attaining them. In other words, large, successful enterprises were transformed into leveraged entities that exploited relationships with others to produce and market their wares.

The migration of this new concept to government was propelled by Peter Drucker, the century's most influential management eminence. In an article published in 1969 when the postwar economic boom and government expansion were nearing an end, Drucker asserted: "There is mounting evidence that government is big rather than strong; that it is flat and flabby rather than powerful; that it costs a great deal but does not achieve much."

Rather than urging shrinkage of government, Drucker urged its fundamental transformation, along the lines of modern business practices: "The purpose of government is to make fundamental decisions, and to make them effectively... The purpose of government, in other words, is to govern. This, as we have learned in other institutions, is incompatible with 'doing' ... If this lesson were applied to government, the other institutions of society would then rightly become the 'doers' ... It would rather be a systematic policy of using the nongovernmental institutions of the society - the hospital as well as the university, business as well as labor unions - for the actual 'doing'".

Terms such as "leveraged government" and "governance" do not appear in Drucker's article, but these were precisely the reforms he was urging. His argument gained traction in the new public management (NPM) prescription that government "should steer, not row", but has had a more difficult time penetrating government practice. A few OECD countries, most notably New Zealand, remodeled themselves along new political-management lines, but most found their public administration hardened into administrative silos that were protected by law, inertia and self-interest. NPM-inspired leveraging made the greatest headway in the "agencification" movement that restructured government operations in the United Kingdom, the Netherlands and a few other countries.

Other pressures, however, have impelled many countries to adopt piecemeal reforms that stop far short of the NPM model, but introduce elements of leveraging into national governance. One is lower economic growth which has spurred many OECD governments to seek more efficient means of delivering public services. Another has been a steep downturn in citizen regard of government. One prominent study of 16 member countries found that trust in government or political leaders had declined in all but one country during the period from the late 1960s (or earlier in a few countries) to the mid 1990s. Commenting on this trend, the distinguished sociologist Ralf Dahrendorf warned that 
"political democracy is historically, and perhaps institutionally, linked to the nation-state. Thus, democracy itself is at risk to the extent that the nation-state loses significance". His concern can be restated as: when democratic governments leverage, citizen influence through elections and other conventional means may be weakened.

Yet, in the nearly two decades since these trends appeared, national governments have neither lost significance nor regained public trust. Member countries are more overextended than before by legal commitments and elevated expectations, and more challenged by skeptical citizens who are wary of their capacity to perform. Recent data from Eurobarometer and the World Values Survey indicate that since 1980 there has been no clear trend across OECD countries, but only 15-30\% of respondents trust political parties and $40-60 \%$ trust the civil service.

Although there is no explicit link between low levels of trust and leveraging, a solid case can be made that this trend has motivated governments to reach out to partners, sometimes in delivering public services, sometimes in building support for public policies. Additionally, governments pulled by international and global pressures are more dependent than in the past on supranational institutions.

\section{Box I.1. Evidence of leveraged governance from the PGC 2010 Ministerial}

Nowhere were displays of leveraged governance more apparent than at the recent Ministerial of the Public Governance Committee (PGC) held in Venice in November of 2010. With the financial and economic crises fresh in the collective conscious and fiscal consolidation plans looming, the importance of government stewardship - particularly in times of uncertainty and volatility - was certainly and rightfully stressed. However, Ministers quickly recognised that the tough choices facing them (e.g. where to cut, how to distribute the burdens) would not be made in isolation. Greater trust in governments would be paramount as the success of the pressing reforms needed to secure the recovery and restore long-term sustainable growth would require the backing and - more importantly - the active participation and involvement of citizens, firms and civil society. Ministers called on the OECD to provide further guidance for strengthening trust, openness and integrity, and in particular on how to raise citizens' involvement. The Venice Initiative for Dialogue with Civil Society Organisations, pledged at the Ministerial, invited the OECD to open dialogue on best practices with civil society organisations with the goal of increasing the exchange over the challenges and opportunities of reform.

Also high on the Ministerial agenda was the need for greater innovation in the public service. Indeed, perhaps one of the most daunting challenges on the table at the Ministerial was avoiding that "doing more with less" lapse into "doing less with less". Especially since renewed growth and trust in both governments and markets depends, in part, on an effective and efficiently functioning public sector. One key to achieving this, Ministers recognised, would be by promoting greater innovation, in short, "doing things better". The OECD was asked to provide best practices that would create an environment conducive to innovation geared towards better performance and greater productivity at no additional cost. Again, Ministers recognised, this would require a leveraged governance approach, one in which the public sector would need to draw on the expertise and creativity of the private and non-profit sectors. At times, as has shown to be the case with the co-production and delivery of some public services, governments would have to consider ceding control or authority of some aspects of service delivery.

Finally, the principles of leveraged governance reared their head in Venice with louder calls for better global governance. The impact of the financial and economic (and later, fiscal) crises were due in part to the close economic linkages between countries, a result of the growing flows of people, trade and capital since the end of the Cold War. While the tide of globalisation brought riches for many, it also brought greater vulnerability. This was evident in the speed and the extent to which economic and fiscal woes spread across the OECD. One of the principal conclusions of the Ministerial, then, was the need to promote good public governance globally, including with non-member economies. In addition to welcoming new members (Chile, Estonia, Israel and Slovenia) and working closely with accession countries (the Russian Federation), the Public Governance and Territorial Development Directorate has increasingly embraced partnerships with other major economic actors (Brazil, China, India, Indonesia and South Africa). In the same spirit, Government at a Glance seizes the opportunity to expand the "club of best practices" and extend the debate on improving public sector performance to other important players on the world stage. 


\section{Governance as performance: OECD style}

The cover of the OECD's report, Government of the Future, published in 2000, graphically portrays the organisation's concept of governance. With a globe of the world as background and a large steering wheel representing government in the foreground, the word "governance" appears on the periphery. The implied message is that in the future governments will be steering mechanisms for society. It is noteworthy, however, that the wheel is placed somewhat off-centre; in the future, government will not occupy all of the centre. Government, the report asserted, "has become just one player among many seeking to represent and serve the public. The loss of the government monopoly on services means that the public sector faces greater competition. Government is also exposed to a much greater array of outside forces... In order to understand and serve the public, national governments need to act as mediators, co-coordinators, policy makers and regulators, in concert with other centres of power, including international and sub-national levels of government, the media, industry, and non-profit groups".

Actualising this broadened agenda has been a challenge for the Public Governance Directorate, for the OECD remains a government-centred entity. However, the task has been greatly eased by its operating culture, which promotes an open and active exchange of ideas and experiences among member and partner countries. Congruent with this style, the Directorate offers advice and sometimes issues guidelines, but national governments retain the freedom to respond to changing ideas as befits their particular circumstances. For example, when the Directorate published a statement on "Best Practices for Budget Transparency" in 2002, it noted that the statement is "not meant to constitute a formal 'standard' for budget transparency".

Leveraging gives governments alternative means of fulfilling public responsibilities; they have multiple choices in selecting partners, as well as in the form of relationships, division of responsibilities and modes of accountability. They therefore need criteria to assess alternatives and construct relations with partners. In the watchman role that once defined its boundaries, government relied on its own administrative units and public employees to carry out limited responsibilities. Efficiency was regarded as a satisfactory measure of government performance. In contemporary welfare states, impacts on citizens and socio-economic outcomes are critical determinants of how well government is performing and in selecting appropriate instruments, including partners, to achieve public objectives. The OECD's work has paralleled this transition. Regulation converts enterprises and other affected entities into agents of the state; national budgets transfer most expenditures to outside recipients; modern management seeks to make the state more responsive, transparent and accountable; e-government connects public agencies to citizens and firms. In each of these areas, early public governance efforts focused on specific practices; the central aim was to modernise government systems or policies by disseminating data and ideas about the good practices of member countries. Over time, the Directorate has moved toward a whole-of-government approach, conducting country reviews and encouraging systematic rather than piecemeal reforms. Snapshots of the OECD's activities in public governance demonstrate its progressively broader agenda.

Public integrity. Good performance in these areas, and indeed in all facets of governance, rests on integrity in the public service. If this pillar is neglected, there would be substantial risk of misuse of public funds, weak accountability of public officials and low morale in the civil service. Combating fraud, corruption, and conflicts of interest has been a perennial OECD concern, but when governments contract with partners to purchase goods and deliver public services, build and operate public facilities, or design and manage 
complex information systems the risk of malfeasance escalates. In the 19 member countries that are also members of the European Union, public procurement averages approximately $17 \%$ of GDP.

Two main threads run through the OECD's many initiatives to strengthen public integrity. One has been to make relationships between government and outside parties more transparent, the other has been to spur member countries to establish comprehensive systems and frameworks to manage these relationships. Data presented in this publication reveal a significant opening up of these relationships during the past decade. Almost twice as many member countries now have legally-defined procedures for reporting misconduct than a decade ago, and almost all now have laws governing access to public information and ombudsman institutions. The broader approach has been to assist countries in establishing and improving their "integrity frameworks" in accordance with OECD principles on ethics, integrity and procurement. These frameworks facilitate identification of "at risk" areas and appropriate corrective action.

Because leveraged governance brings new risks, upholding public integrity will continue to be a core OECD concern. It is essential, as the OECD has recognised, that countries nurture a culture of integrity, and that public officials internalise norms of ethical conduct. Without these supporting conditions, new procedures might not suffice.

E-Government. Although Public Governance's newest focus, e-government is most directly related to networking with partners. Launched early in this century, after most member countries had taken first (usually tentative) steps to make selected data or actions accessible through the Internet, the OECD issued a policy brief, The e-Government Imperative (2003) that made a strong case for countries to actively exploit the new technology. Beginning with the argument that Internet-based applications can generate significant efficiencies in mass processing tasks and administrative operations, the policy brief foresaw improvements in public services and policy outcomes. Although the plea for greater use of the Internet focused on internal operations, it also recognised the Internet's potential to change relations between citizens and government and to facilitate open government.

In retrospect, this was a winning argument. The rapid spread of the Internet, including broadband and search portals, was sufficient inducement for governments to publish vast amounts of previously-concealed information in electronic form. To the OECD, however, e-government often appeared to be old forms of government in a new format. Citizens and other stakeholders had more information, administrative tasks were performed more efficiently, but the business of government was conducted through the same mechanisms and relationships as in pre-Internet times. Half a dozen years after its initial policy brief, the OECD urged a shift in focus from a "government-centric" to a "citizen-centric" approach to actively promote use, simplify access and reorganise the delivery of services. Consistent with this emphasis, the OECD is developing basic indicators to monitor and measure progress in integrating e-government within each country. It has also published more than half a dozen country reviews that examine utilisation, efficiencies, services and other outcomes.

Although there are some notable exceptions, the new electronic technology still is more about disseminating information than about establishing interactive relations between outside parties and government. Citizens in efficient e-government countries can download forms and access much data with ease, but they still are passive participants in governance. One should not be surprised if 50 years hence, today's e-governments are seen as primitive first steps compared to the socio-political transformations that loom ahead. 
Regulatory policy. Regulation has followed a similar trajectory in the OECD, beginning with checklists to stimulate reform and moving to country reviews. But unlike e-government, regulatory policy is inherently more leveraged because its effects depend in substantial part on the behaviour of those subject to regulation. The current state-of-the-art is "regulatory impact analysis" (RIA) which has been successfully promoted by the OECD and is now applied by most member countries. RIAs can be thought of as "efficient leveraging", with government favouring policies that give enterprises and other affected parties incentive and flexibility to comply in a cost-effective manner.

The OECD's first major pronouncement on regulation was a regulatory checklist (1995) in the form of ten questions, beginning with "Is the problem correctly defined?" and including "Have all interested parties had the opportunity to present their views?". Two years later, the OECD moved from questions to recommendations, urging member countries to adopt comprehensive reform strategies. It insisted that: "All governments have a continuing responsibility to review their own regulations and regulatory structures and processes to ensure that they promote efficiently and effectively the economic and social well-being of their people." In the context of the times, reform meant deregulation, stripping away rules and requirements that impair market efficiency. Regulatory reform was part of a larger package of market opening initiatives that included privatisation, removal of trade barriers, and use of market-type instruments in the public sector.

Yet the period has also been characterised as "the golden age of regulation". Spurred by new environmental, consumer, health, safety and other rules, "No government activity in OECD countries has grown faster since 1980 than government regulatory functions". The two tendencies fed one another. The more government regulated, the greater the demand for deregulation; and the more deregulation advanced, the greater the pressure for new restrictions. To reform, therefore, the OECD had to balance conflicting doctrines and interests. Reform, it declared in 1997 "means deregulation and better regulation".

Regulatory impact analysis (RIA) is the main instrument promoted by the OECD and others to balance free markets and restrictive rules. RIA assesses regulations from the perspective of those impacted, both the entities subject to the rules and overall economic conditions. Although countries differ in their RIA implementations, they generally require regulators to justify proposed rules in terms of net benefits, to assess alternatives that may be less costly, and to estimate differential impacts on various sectors or interests. Although most frequently applied to proposed rules, RIAs have been adapted in some innovative countries to the existing stock of regulations. The OECD has actively encouraged this broadened scope in its country reviews.

RIAs have become the gold standard in regulatory policy, but they have not reversed the steady rise in the volume of regulation. The propensity to regulate depends more on political conditions than on economic analysis. To counter "regulatory inflation" it may be necessary to view regulation as one of several policy tools rather than as a stand-alone process.

Managing and budgeting. In government, managing and budgeting are intertwined; government cannot manage for results if it does not budget for results. Logically, therefore, the OECD's efforts to modernise budgeting have been closely linked throughout the past three decades to broader administrative reform. Of course, public management sprawls well beyond budgeting to human resources, the reliability of internal controls, organisational capacity to learn and adapt, and much more. At times, this sprawl has made it difficult to establish a consistent work programme within available resources. Over the years, the OECD 
has invested significantly in civil service reform and the use of market-type tools for delivering public services, but its constant focus has been on orienting public management and budgeting to performance and results.

When the OECD was established, centralised control of expenditures, personnel and other administrative actions was regarded as good public management. Almost all member countries had line item budgets that specified the inputs to be purchased, a central civil service agency that hired and set the pay of each public employee, and other central agencies to manage procurement, travel, office accommodation and other administrative needs. The job of a successful manager was to comply with detailed rules and procedures. In its heyday, during the first half of the 20th century, control-based public administration had truly extraordinary accomplishments - building the modern nation-state, achieving near universal literacy, extending life-expectancy, establishing efficient road and transport systems, and much more.

The expansion of government, rising citizen expectations and declining trust, slower economic growth accompanied by fiscal stress, transformations in business management and other factors, called control-oriented public administration into question in the final decades of the 20th century and concepts associated with new public management (NPM) gained currency. Although a significant number of member countries, including some of the largest, retained key features of traditional public administration, many countries embraced results-based management along the lines advocated by NPM. They accepted the central NPM argument that public managers and organisations can be held accountable for results only when they are released from most procedural controls and can apply their professional skills and public ethic to produce results.

NPM took root shortly after the OECD began to be recognised as the international centre for budget research and innovation. Although it (and many others) were captivated by the promise of better governance, the OECD was never captured by NPM. For one thing, the OECD's management and budgeting agenda included many issues and practices that had no bearing on NPM; for another, the OECD gave expression to the diversity of administrative orientations among member countries. The strongest and most lasting imprint of NPM has been the OECD's focus on results, not on particular practices. For various reasons, including the OECD's strong interest in economic and fiscal issues, budgeting has long been at the centre of its management agenda.

From modest beginnings in 1980 as an annual meeting of senior budget officials (SBO), the OECD's budget-related work has expanded into a vast network of regional and issuebased meetings, as well as to country reviews and specialised reports and studies, all of which are published in the OECD's Journal on Budgeting.

At the outset, the OECD's greatest challenge in establishing the SBO process was to overcome the insular, guarded demeanour of budget officials. They work the inside game in government, reviewing confidential bids for money, advising cabinet and privately negotiating expenditures with departmental counterparts. Few have a public profile. This cloistered style does not fit well with the governance trends discussed earlier. Leveraged governance means that many others outside the small circle of budget makers have stakes in expenditure decisions. SBO has broadened budget discussion, though mostly within the ambit of government.

When they met in the early 1980s, budget officials found that they had much to talk about: common problems and objectives, stories of success and failure, a shared sense that the machinery of budgeting needed renovation, and efforts to base allocations on substantive results. Three decades later, the concerns and issues are pretty much the 
same: the impact of fiscal stress, linkage of current budget decisions to medium and longer-term prospects, making space in the budget for policy initiatives, integrating performance measures into the budget, and more. The recurrence of these themes is partly due to rising standards of good budget practice. The roster of innovations that have been mainstreamed into budget practice includes fiscal rules, medium-term frameworks, performance-based budgets and fiscal risk analysis. These techniques have significantly improved budgeting but have not insulated government finances from economic disturbances or political pressures. Moreover, some problems of budgeting are perennial, as if they were hard-wired into the process: imbalance between resources and demands, looking to the past to decide how much to spend in the future, time pressures, and the pervasive sense that decisions should be better informed.

SBO has greatly widened discussion within the community of budget practitioners and scholars. To the extent the process has been opened to "outsiders" it has been due mostly to closer monitoring of budget matters by the media, international organisations (including the OECD), and interest groups. There may be just cause for sequestering internal budget deliberations - a public process would likely stir more conflict and complicate the task of balancing demands and resources. But as leveraged governance becomes more widespread, budget officials will face increased pressure to widen the circle of participants.

\section{Conclusions}

Leveraged governance furnishes fresh challenges and opportunities, for both governments and the OECD. The key challenge for governments occurs when they steer in one direction and partners row in another. It is a big mistake to assume that governments and collaborators have identical interests and perspectives; they rarely do. Yet, political leaders remain accountable for the performance of others over whom they have limited, sometimes negligible, control. Worse yet, national governments have hundreds, possibly thousands, of partners with diverse, sometimes antagonistic interests. Fragmentation - by sector, region, socio-economic groups, etc. - is how governments work their ways through political and managerial minefields.

The OECD also faces risk of fragmentation, if only because its constituent units are siloed into different sectors and issues, each with its own ties to governments and Ministries. In the OECD, as in many complex organisations, compartmentalisation exists between and within Directorates. This common arrangement has several advantages, not the least of which are reducing conflict and strengthening relationships with counterparts in government and policy communities. From the vantage point of leveraged governance, there is, however, one significant disadvantage. The managerial justification for leveraged governance is that it improves results by giving governments a broader range of policy and delivery options. This case is undermined if fragmentation thwarts the generation and assessment of alternatives.

The portfolio of leveraged governance instruments includes government-provided services, grants, contracts, loans, guarantees, regulation, tax concessions and penalties, transfer payments, in-kind benefits, and vouchers. Although they may appear to be substitutes, different instruments produce different results, and have different distributive impacts. Selecting instruments is a political, not only an analytical, decision, for it determines who gets the benefit and who bears the cost. Compartmentalising instruments into different administrative entities impairs results-based decisions, for the focus shifts from who benefits to what each entity does, wants or needs. 
The range of policy instruments within the purview of the Public Governance Directorate is narrower than that of national governments. Yet it illustrates how fragmentation may get in the way of a results orientation. Suppose, for example, that a government aims to improve health outcomes. One course of action would be to use more IT to inform citizens of available services and conditions requiring medical attention; another would be to regulate services provided by hospitals and others; a third would be for government to provide loans or grants to providers through the public budget; a fourth would be to restructure public management so that a government agency offers health. Each of these is in the jurisdiction of a different government authority, and most are in different divisions within the Directorate. Every defender has its own advocate within government; most have their own organisational homes in the OECD.

Note, however, that some of these instruments may be complements, not substitutes. In seeking to enhance health outcomes, government may invest in IT modernisation, regulate providers and subsidise their services, and operate government clinics. It is in the complementarity of these instruments that government generates cost-effective results. However, fragmentation isolates the complements from one another.

Thus, leveraged government both expands the menu of options and complicates the task of integrating public policies and services. The OECD is not the author of this predicament, but its organisational structures should not make matters worse. Solutions are not easy to come by because every instrument requires cadres of specialists to make informed judgments and recommendations. E-government and budget experts at the OECD are not interchangeable, nor are regulators and management experts. Much is heard about the virtues of inter-disciplinary work, but organisations need strong disciplines before they can productively interact with one another. The OECD certainly has critical masses of expertise in the facets of governance discussed in this essay.

It is therefore most appropriate at this 50th anniversary of the OECD for the Public Governance Directorate to have launched cross-disciplinary country reviews that combine IT, regulation, management and budgeting. The aim is not simply to broaden these reviews, but to focus them more sharply on substantive results. For example, comprehensive country reviews not only examine the regulatory framework, but inquire how regulation compares to other policy instruments and how it fits together with them. This is quite a challenge, but in a world of leveraged governance and proliferating options, it is a most worthwhile effort. 

Chapter II

\section{Fiscal Consolidation: The Need for Evidence-Based Decision Making}




\section{Introduction}

Over the past three years, governments acted decisively on national and international fronts to avoid a global financial and economic meltdown. Although governments have heeded the call to action, their job is far from over. While governments pursue policies to create jobs, grow their economies, improve fairness, reduce inequalities and rebuild trust, many also need to introduce reforms to address rising debt levels that resulted from the crisis.

Fiscal consolidation has become the cornerstone of the current policy debate across the OECD area. Rising debt levels have called into question the sustainability of the status quo, and the prevailing wisdom is that governments must consolidate finances in order to ensure future growth. However, fiscal consolidation is not in itself a policy. Rather, it links to underlying issues and imbalances in individual sectors, such as welfare, pensions, health care and education: fiscal consolidation is a key tool for addressing these other concerns.

Politicians across the OECD area are currently discussing and debating fiscal consolidation, and many governments have begun announcing plans. Building on the recent OECD Restoring Public Finances (OECD, 2011b) and using the data presented in Government at a Glance 2011, this chapter begins to assess the quality of the planned reforms. It takes a critical look at whether the announcements will fulfil the objectives of consolidation, and identifies risks and missed opportunities. The data presented in Government at a Glance 2011 can help governments identify best practices by providing evidence of what works and what doesn't, and how policies can be strengthened and better implemented. International benchmarking and data collection on public management practices and arrangements are relatively new and are still evolving; the OECD is working with member countries to expand our evidence base.

\section{Most OECD countries are planning reforms to consolidate finances}

\section{Fiscal consolidation is needed to reduce debt to sustainable levels}

Government measures to rescue the financial sector, stimulate the economy, and provide safety nets for workers and the unemployed averted a serious global breakdown. However, compounded with sharply reduced revenues, they also left governments with sizeable deficits. The crisis aggravated existing imbalances in public finance, as many OECD countries ran structural deficits when their economies were growing. The average deficit across the OECD was 5.6\% in 2010 compared to 1.3\% in 2007 (Indicator 12). These deficits, combined with low economic growth, have sharply increased debt levels in many countries. On average, debt stands at $74.2 \%$ of GDP across the OECD area in 2010, up from 55.6\% in 2007 (Indicator 13).

For some countries, high levels of debt have led to fiscal solvency concerns, manifested in large interest rate hikes on sovereign bonds and downgrading by rating agencies. High levels of debt can have negative long-term consequences, as revenues are diverted from policies and programmes that can create economic and social value to cover interest payments. Likewise, higher interest rates resulting from larger levels of debt can impede future economic growth, increase the vulnerability of public finances to shifting 
market sentiments and crowd out private investments. Furthermore, the ability of the government to address future economic downturns via fiscal policy is hampered. It also means that the programmes and benefits that are enjoyed by citizens today are paid for by future generations.

OECD projections indicate that as economic growth resumes, automatic stabilisers (such as increased revenues and reduced expenditures on unemployment insurance) will not be enough to reduce deficits or stanch the growth of debt as a share of GDP in many member countries. Fiscal sustainability indicators developed by the OECD show that on average, governments need to improve their fiscal balance by $3.6 \%$ of potential GDP over the next 16 years in order to just stabilise debt ratios by 2026 (Indicator 15). Governments will need to run even higher surpluses if they want to bring debt as a share of GDP back to pre-crisis levels. Accomplishing this will require governments to take politically difficult steps to both restore fiscal discipline and work towards fiscal consolidation.

\section{Fiscal consolidation requires agreement about the function of government}

The size of fiscal consolidation needs across countries is related to government's ability to match revenues to expenditures - not the overall size of government relative to the economy. For example, Belgium (where government expenditures totalled $54.2 \%$ of GDP in 2009) and New Zealand (where government expenditures totalled $41.9 \%$ of GDP in 2008) demonstrate similar fiscal consolidation needs.

\section{Figure II.1. Fiscal consolidation requirements are unrelated to the size of government}

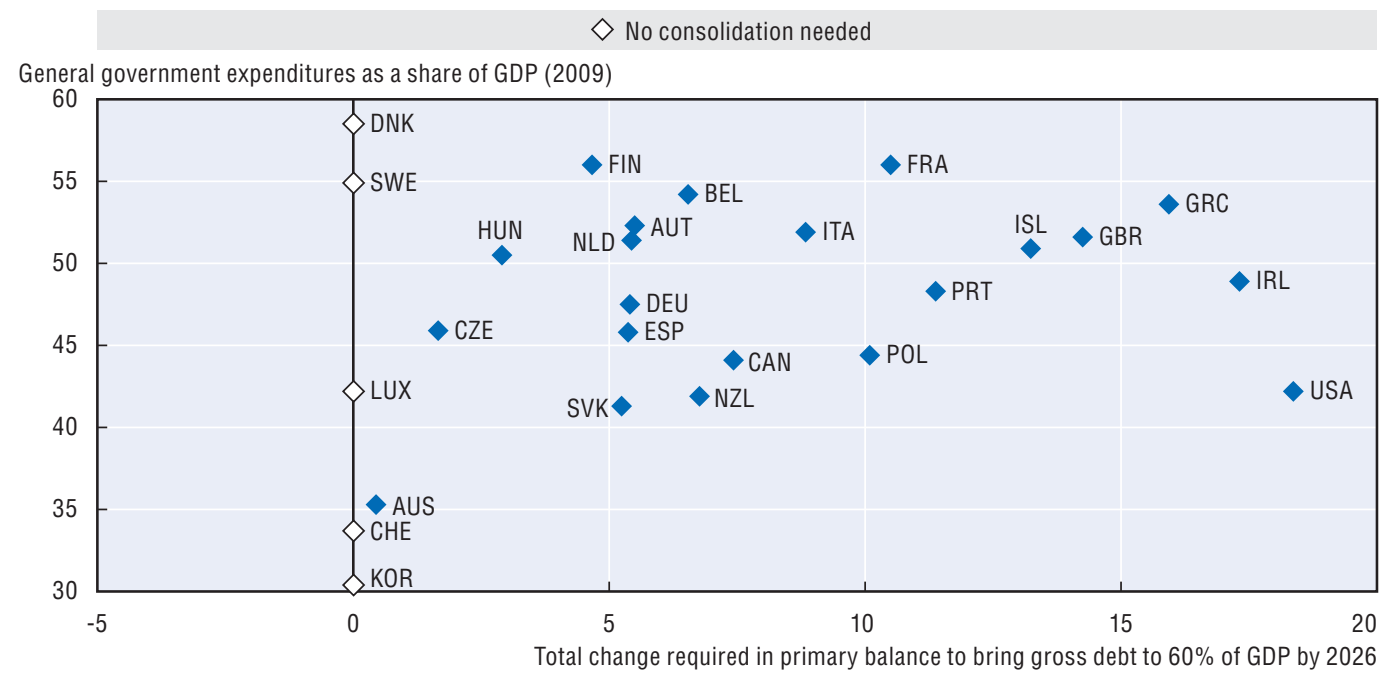

Note: Data are not available for Chile, Estonia, Israel, Mexico, Slovenia and Turkey. Data on general government expenditures for Australia and New Zealand refer to 2008. Data for Japan and Norway are not presented.

Source: OECD Economic Outlook, No. 89 (Preliminary Version), May 2011 and OECD National Accounts Statistics. StatLink iाts http://dx.doi.org/10.1787/888932389284

Achieving fiscal consolidation has triggered a public discussion on what should be the appropriate role of government in society and the economy. While government efforts to cushion the effects of the financial and economic crisis were applauded, the rhetoric has sharply switched in many countries as government debt as a share of GDP has risen as a result of these efforts. Across the OECD area members of the public are calling on governments to consolidate their finances and, in particular, target aspects of operations that may be wasteful or inefficient. As unemployment has soared in many countries, the 
level and relative stability of public sector jobs and wages has come under fire. Yet, in many countries, citizens are simultaneously demonstrating an increased demand for public services and their expectations regarding quality are reaching ever higher. Consequently, sound, sustainable public finances will result from an agreement between governments, citizens and businesses about what level of services the government should provide (and to whom) and how the public will pay for them.

\section{Ability of the government to reform under pressure Evidence-based reforms are more long-lasting}

Achieving fiscal consolidation involves a realignment of the role of government in society. It entails questioning what is the need for public goods and services and whether the government is best placed to provide these directly, indirectly or not at all. Answering these questions requires evidence and data. Evidence-based decision making examines and measures the likely benefits, costs and effects of government decisions. Evidence can be gathered using a 360-degree approach: looking to the future to identify risks and opportunities, looking to the past to evaluate what has worked and what has not, and looking horizontally to identify synergies across Ministries and levels of government. A whole-of-government approach that is open and inclusive can identify linkages between different sectors and groups (particularly because a risk in one area may be an opportunity somewhere else, or a benefit to some may come at a cost to others) and prioritise goals and objectives.

Countries that have undergone consolidation programmes in the 1990s, including Canada and Sweden, have found that programme reviews, value-for-money assessments and cost/benefit analyses have helped decision makers identify the best ways to generate savings (Box II.1). This requires detailed information on how much is spent, what (and how much) is produced, what is achieved and what impact the changes will have on different parts of society.

\section{Box II.1. Canada's Programme Review Initiative}

In the mid-1990s, Canada introduced the Programme Review initiative, a 10\% reduction in federal government programme spending and a reduction in the size of the public service by over 55000 full-time equivalents which led to the debt to GDP ratio being cut by more than half over the next ten years. The expenditure reductions were identified by the centre of government (the special Cabinet Committee on Programme Review) based on data and information gathered by the Department of Finance and the Treasury Board Secretariat over the years, and the results of self-reviews undertaken by departments and agencies. Canada's Programme Review looked at all programmes in a Ministry at once; this large scale helped to balance single interests with the collective interest. It allowed the public to judge the relative fairness of the proposals among regions, groups and income levels.

Source: Blöndal, J. (2001), "Budgeting in Canada", OECD Journal on Budgeting, Paris.

\section{Do governments have the capabilities to conduct evidence-based decision making?}

The public administration's role in evidence-based decision making is to seek out, consult and engage with actors in key knowledge areas, and analyse and package that knowledge to inform policy options. In particular, deficit reduction of the scale required in many OECD countries is a social project that calls for a more open and inclusive approach, not a normal budget exercise. 
Unfortunately, comparative data on governments' ability to implement evidence-based decision making are weak and represent an area for future development by the OECD. However, the data that do exist suggest that room for improvement remains and that countries can learn from best practices in the leading countries.

OECD countries have varied experience with embedding evidence-based decision making in their everyday operations. Although not directly linked to cost containment efforts, one area where countries have made strides in using evidence-based decision making is in the process for making rules and laws. Regulatory impact analysis (RIA), which is used to examine and measure the likely benefits, costs and effects of new or existing regulations, has been adopted by all OECD member countries. However, the depth of RIA systems varies and the analysis may not provide a full view of the trade-offs needed to take decisions. For example, while 24 countries reported systematically quantifying the costs of regulation in 2008, only 16 reported quantifying the benefits. In addition, OECD countries can do more to close the policy loop: ex post assessment can help monitor quality and compliance, and evaluate the assessment methodologies themselves. As of 2008, only six countries mandate ex post evaluations for all policy areas: Australia, Greece, Hungary, Japan, Korea and Norway (Indicator 47).

Consultations with stakeholders, a key aspect of evidence-based decision making, are uneven across policy areas in OECD countries. Information and communication technologies (ICTs) are allowing governments to obtain information directly from individuals, households and communities compared to intermediation through non-governmental organisations (NGOs), expanding the set of views available to inform policy options. For example, OECD country reviews indicate that consultation processes on proposed regulations have improved, helped by e-government. Consultation in other areas, such as procurement, is not as widespread. Around a third of OECD members involve citizens at some point in the procurement process, most often to monitor the integrity of the award process (via inviting the public to attend bid opening ceremonies) or to monitor the implementation of the contract (Indicator 41).

Japan has found that ICTs can help build public support for fiscal consolidation plans. Japan has embarked on a series of public budget hearings that are streamed and televised; they are among the most watched and discussed events in Japan. Spending Ministries and the Minister of Finance must defend every aspect of the budget to a committee of "cross-examiners" consisting of members of Parliament and academics.

\section{Do governments have the discipline to stick to reforms?}

\section{Strong budget institutions can reinforce fiscal discipline}

The existence of a strong institutional framework for decision making can help to ensure that governments stick to reforms. In particular, a multi-year fiscal programme, such as a medium-term expenditure framework, combined with clear fiscal rules that limit spending, can help policy makers adhere to an appropriate fiscal path and give investors and businesses confidence in the government's capacity to manage public finance (Schick, 2010). For example, Sweden successfully consolidated its finances following a fiscal crisis in the early 1990s, in part by adopting a medium-term target (a surplus of $2 \%$ of GDP over the cycle) and implementing fiscal rules based on expenditure targets.

Prior to the crisis, OECD members had taken steps to adopt budget practices that introduce fiscal discipline, and debt as a share of GDP in many countries was stable or decreasing (Indicator 13). While the institutional framework is to a large extent in place, it may need to be strengthened. In many countries, medium-term expenditure frameworks 
put rules in context of a 3-5 year horizon, and reduce incentives to shift revenues or expenditures to future years to get around the constraints imposed by rules. As of 2007, all but 6 of the (then) 30 OECD member countries used fiscal rules to constrain debt, total revenues or expenditures, or other aggregates. However, experience with fiscal rules indicates that the design of rules is important; expenditure rules (used in 15 OECD countries in 2007) couple deficit and debt reduction with spending constraints, are simpler to explain to elected officials and the public, and are more difficult to evade.

In addition, the creation of independent fiscal councils or parliamentary budget offices can reinforce discipline by serving as an institutional check against the assumptions and forecasts underlying the budget. In less than a decade, the number of specialised budgetary research units has more than doubled, and in some cases their size has increased. In 2000, only seven OECD country legislatures had specialised budget research offices. This number increased to 10 in 2003 and 14 in 2007 (Indicator 35).

Finally, an inclusive budget formulation process can build ownership and buy-in which are critical for making and sustaining hard choices. As part of its process of fiscal consolidation in the mid-1990s, Sweden introduced top-down budgeting which involved setting priorities at a political level, allocating financial envelopes to line Ministries, and then giving Ministers and managers authority to make final allocations of the funds within a given envelope. Among OECD member countries, there is a large range in the level and type of flexibility granted to the executive to use budgeted funds for different purposes (see Government at a Glance 2009, Indicator 21).

\section{Trust promotes legitimacy}

Trust is a key ingredient in effective governance. In particular, the public is more likely to support reforms through their implementation if it has confidence in political institutions and political leaders. While overall levels of trust vary across the OECD area, there is a strong association between trust in the national government and trust in leadership $\left(R^{2}=0.82\right)$, implying that citizens are apt to think of political leaders when judging the trustworthiness of government. Thus, to a certain extent, strong leadership is the sine qua non of successful reform (OECD, 2010c). It is important that the administrative leadership be seen as acting in the public interest, as interpreted by the duly elected government, and in conformity with the laws of the country.

\section{Cross-partisanship can lead to more sustainable reforms}

Given that most reforms span multiple years that go beyond the average term of government, those reforms developed and supported by a coalition of political parties may be more likely to last. Reform reversals have two causes: either a decrease in political attention to reform, or a political decision by a newly elected government to reverse the reform of the previous one. Case studies of OECD country experience with fiscal and pension reform suggest that governments that engage multiple parties and factions in developing the reforms are more likely to enact consolidations that are sustained over time. Some governments in OECD countries have more of a tradition than others in forming coalitions. 


\section{Figure II.2. Confidence in national government and approval of leadership} are strongly correlated

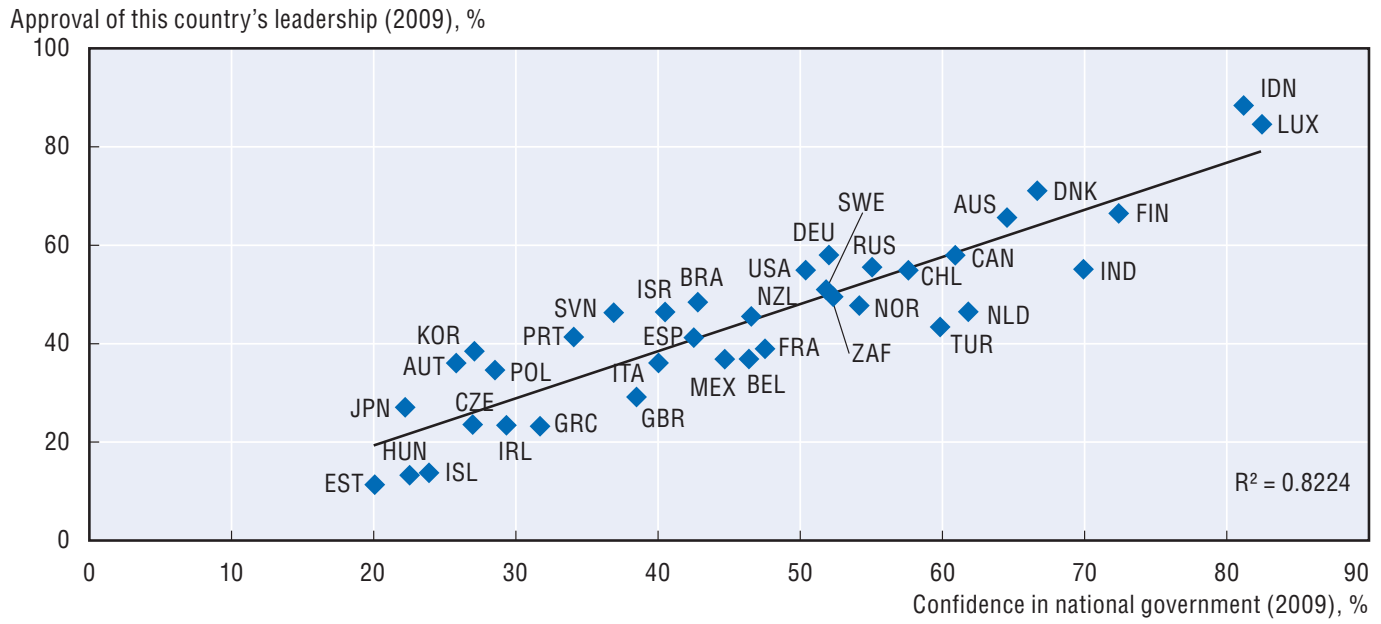

Notes: Data refer to the share of respondents who answered affirmatively to the following questions: In this country, do you have confidence in the National government? Do you approve of the job performance of the leadership of this country? Data are not available for the Slovak Republic and Switzerland. Data for the Czech Republic refer to 2007. Data for Australia, Austria, Belgium, Denmark, Finland, Iceland, Japan, the Netherlands, New Zealand, Norway, Portugal, Sweden and Turkey refer to 2008.

The Gallup World Poll is conducted in approximately 140 countries around the world based on a common questionnaire, translated into the predominant languages of each country. With few exceptions, all samples are probability based and nationally representative of the resident population aged 15 and over in the entire country (including rural areas). While this assures a high degree of comparability across countries, results may be affected by sampling and non-sampling errors. Sample sizes are limited to around 1000 persons in each country.

Source: Gallup World Poll.

\section{Figure II.3. Frequency of coalition governments (1990-2010)}

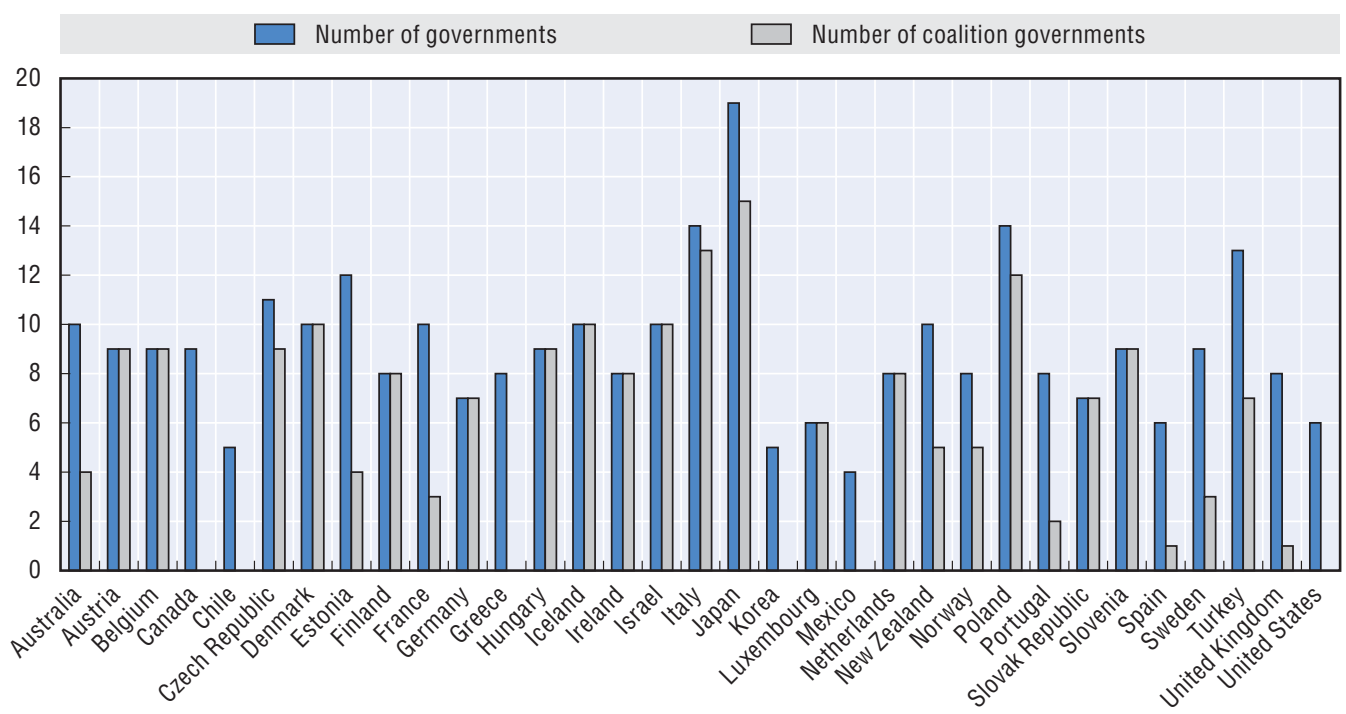

Note: Data for Switzerland are not presented.

Source: OECD member country government websites. 


\section{Accountability for achieving results is supported by openness and transparency}

Communication helps to build credibility for the reforming government, increase the sense of ownership of reforms by keeping civil servants and citizens informed, and reduce information asymmetries by making the information available to each stakeholder. In addition, transparency of decision making and the results of reforms can help the public hold governments accountable for sticking to reforms and achieving results.

Governments in member countries are taking steps to become more transparent and open. Countries are proactively making more and more information publicly available about their activities, performance and decisions. While almost all OECD countries have laws on access to information, many also require the publication of or routinely make available budget documents, audit reports, government assessments of the potential impact of regulations and tender documents (Indicators 38, 41, 45). Increasingly, governments are opening up administrative data sets to the public in the hopes that the information can be reused by entrepreneurs and civil society in innovative ways to improve current government services or create new ones.

While the trend across the OECD area is to release more information proactively, are governments doing so in a way that promotes trust and accountability? Many governments are grappling with how to make information available in ways that maximise benefits and minimise costs. Some information may not be useful to the public. Should governments provide interfaces to interact and interpret the data or provide the raw data? Under certain circumstances, transparency can be the reverse of accountability: the release of large volumes of information in inaccessible formats can overwhelm the public and discourage active reuse and scrutiny. Participation rates may decline, followed by a loss of trust in government. In addition, information can be used by special interest groups to protect certain expenditures from cuts.

To maximise the benefits of transparency, many member country governments are actively focusing on accessibility and the quality of information. For example, many government-run websites include search features to help find key documents and data. Over half of OECD countries have established provisions in laws or policies requiring electronic information to be published in formats that allow for reuse and manipulation (Indicator 38).

\section{Evaluating the quality of planned reforms: Key questions and risks}

In addition to the extent to which it is based on evidence, key aspects of quality of the reform process include its size, pace and interface with other public policy goals. For example, reforms work better when they are applied in a predictable, gradual way that allows administrators and stakeholders to adapt. Likewise, in high-quality reform programmes, effectiveness in attaining fiscal goals is not made at the expense of other priority public policy goals - or at a minimum expense of these goals. As governments in OECD countries design and implement reforms as part of their fiscal consolidation plans, a key challenge is to do more (or the same) with less. The main risk is that governments end up doing less with less. 
In addition, the ability of governments to carry out well-conceived reforms may be distorted by the interplay between fiscal accounting and politics. For example, it is oftentimes more politically palatable to apply spending cuts to line items (usually operational expenses such as salaries, travel costs, investment, etc.) than at the programme level because the impact on service delivery is less evident. Whereas many members of the public can get behind cutting travel or even compensation, opposition is higher when cuts more clearly target aspects of programmes, such as ending after hours care in schools. However, it is possible to find an intersection between politics and evidence. For example, at the programme level, reforms that cut the least effective or lower priority programmes may be more likely to garner support. In addition, plans that are large in scale are often more politically feasible, as the pain of cuts is spread across the population and thus perceived as more fair. In fact, OECD research suggests that the most successful consolidation plans involve large, multi-year adjustments.

\section{Key characteristics of fiscal consolidation plans}

By the end of December 2010, around half of OECD member countries had announced medium-term plans to consolidate government finances (OECD, 2011b), and the analysis below is based on these announcements. ${ }^{*}$ The announcement of plans to consolidate finances is an important signal to markets and the public about the steps governments will take to address sustainability concerns. The transparency of planned actions can help build trust and enables the public to judge the relative effects and fairness of the plans on regions, groups and income levels.

In this publication, fiscal consolidation is defined as concrete policies aimed at reducing government deficits and debt accumulation. These consolidation plans and detailed measures are given as a per cent of nominal and potential GDP. Merely announcing an ambitious deficit target over the medium term with no accompanying consolidation plan on how to achieve the deficit target is not regarded as a consolidation plan in this analysis. See Restoring Public Finances (OECD, 2011b) for further information on the quantification of fiscal consolidation plans.

\section{Fiscal consolidation plans emphasise cutting expenditures over raising revenues}

Empirical research suggests that expenditure cuts, including cuts to government wages and social transfers, are more effective than revenue measures in achieving long-term consolidation (although the empirical association could reflect that those governments more determined to consolidate are more willing to cut spending) (Guichard et al., 2007). Most of the fiscal consolidation plans rely more heavily on cutting spending compared to increasing revenues. Fiscal consolidation is weighted two-thirds towards spending cuts on average, and one-third towards revenue enhancements. While potentially more effective in the long term, expenditure-based measures often take time to fully implement, while increases to taxes can provide immediate gains.

\footnotetext{
* It does not include measures decided after this cut off date. Additional fiscal consolidation measures could result in a reclassification of countries.
} 
Figure II.4. Expenditure versus revenue-based measures in fiscal consolidation plans (2010)

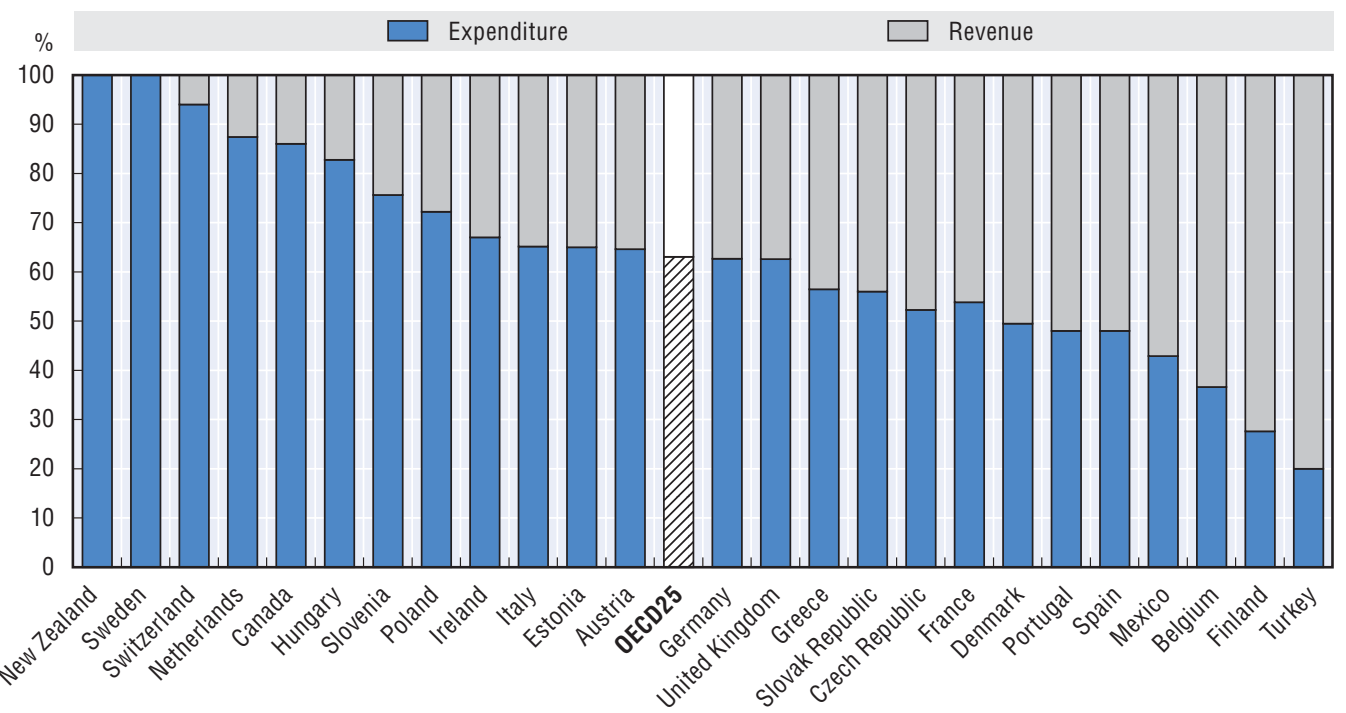

Notes: Figures are the contribution to consolidation from expenditure and revenue measures, weighted by the incremental volume of consolidation across each year reported.

Source: OECD Fiscal Consolidation Survey 2010 as presented in OECD (2011), Restoring Public Finances, Paris.

StatLink ताIst $h t t p: / / d x . d o i . o r g / 10.1787 / 888932389360$

\section{Most expenditure cuts focus on programme areas}

In most countries, plans focus predominately on reducing programme expenditures. Expenditure cuts concentrate on two main areas: 1) reducing spending on programmes (such as health, changes to social benefit systems, old-age pensions, capital infrastructure and official development assistance) which includes all spending except for compensation costs; and 2) reducing operational spending by cutting compensation costs (through staff reductions or wage and benefit cuts), reorganising government, or implementing across-the-board efficiency cuts. Some countries have announced other types of cuts, such as overall spending freezes. While the System of National Accounts includes compensation costs in its expenditures by function (which broadly correlate to programme areas, see Annex B), these are considered operational cuts in Figure II.5.

\section{Cuts target big and small programmes}

Many OECD country governments are cutting funding for the programmes that absorb the most resources, although their cuts do not go deep enough to restore fiscal sustainability. On average, governments in OECD member countries spend the most money on social protection programmes (such as unemployment benefits, welfare and pensions), followed by health programmes, general public services (which includes interest payments on debt), education programmes and economic affairs (which includes spending on agriculture, transport and communication). Most fiscal consolidation plans focus on structural reforms in these "big ticket" areas which can reduce expenditures over time, leading to improvements in fiscal sustainability. A few countries, particularly those under market pressure to reform, also plan one-off or short-term adjustments that will reduce deficits immediately but do little to address the long-term drivers of expenditure increases (OECD, 2011b). 
Figure II.5. Composition of quantified expenditure measures in fiscal consolidation plans

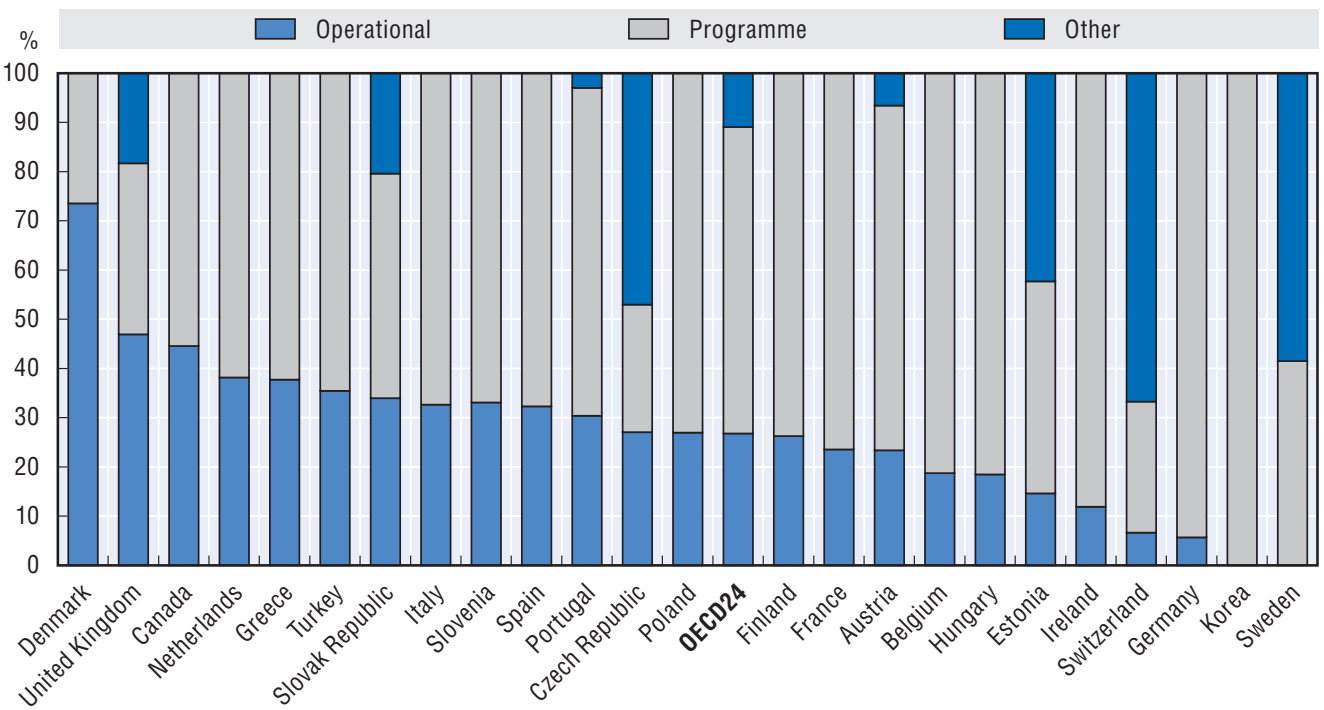

Source: OECD Fiscal Consolidation Survey 2010 as presented in OECD (2011), Restoring Public Finances, Paris.

\section{Figure II.6. Structure of government expenditures by function and number of countries targeting these areas for cuts, average for OECD29 (2008)}

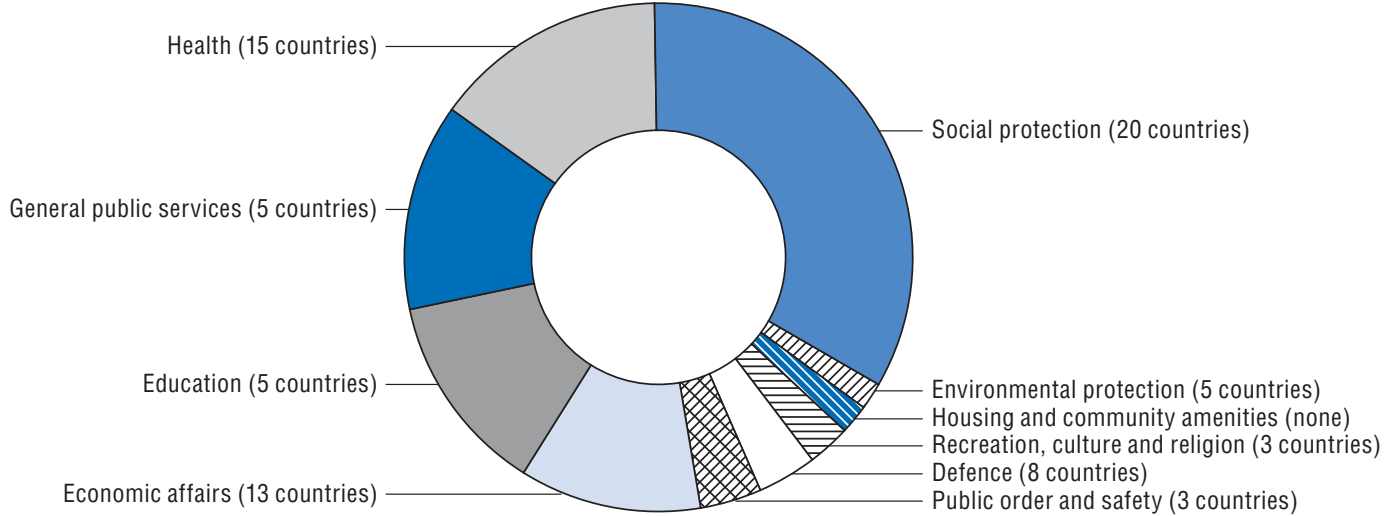

Note: Average does not include Australia, Chile, Mexico, Switzerland and Turkey. Thirteen countries have planned cuts to infrastructure, which is included in economic affairs in the figure above, although may span to spending in other functional areas such as housing and community amenities, health and education. The 20 countries focussing cuts on social protection programmes include 6 countries cutting welfare, 2 cutting pensions and 12 cutting both areas. The five countries included in the general public services category have all focussed cuts on development aid programmes. Source: OECD National Accounts Statistics and OECD Fiscal Consolidation Survey 2010 as presented in OECD (2011), Restoring Public Finances, Paris.

StatLink तiाst $h t t p: / / d x . d o i . o r g / 10.1787 / 888932389398$

In addition, some governments are focusing on areas that form a relatively small portion of total public spending. For example, environmental protection, targeted by five countries, comprises $1.7 \%$ of spending or $0.7 \%$ of GDP on average. Likewise, three countries are targeting recreation, culture and religion which comprises only $2.7 \%$ of spending or $1.2 \%$ of GDP. Defence, targeted by eight countries, forms on average $3.7 \%$ of spending or $1.6 \%$ of GDP. While general public services comprises $13 \%$ of spending, the five countries targeting this area are focusing on foreign aid, which accounts for only $5 \%$ of spending in this area (or $0.3 \%$ of GDP). 


\section{Pension reforms aim to address rising costs}

As OECD projections based on demographic change indicate that pension costs will continue to rise in most countries, reforms in this area are important for longer-term sustainability. Fourteen countries are looking to reform their pension systems as part of their fiscal consolidation plans. In several of these countries, such as Italy, Poland and Portugal, pension expenditures represent a large and increasing share of GDP. However, other countries with above-average and increasing expenditures have yet to address reforms in this area.

Most reforms focus on reducing the costs of pensions for future retirees and will not affect those currently receiving benefits. In part to reflect that citizens are living longer, eight countries have announced increases in the retirement age ranging from two to five years, which can positively affect economic growth due to higher labour force participation of older people and the potential increased demand (and consumption) as older people need to save less since they will be retired for fewer years. New Zealand curbed growth in general government pension expenditures between 1990 and 2007 in part by increasing the pension age from 60 to 65 and by freezing the basic value of the pension in 1992-94. However, these effects could be mitigated to the extent that age discrimination in the labour force prevents older workers from finding jobs. Recent OECD research suggests that ageism remains, despite legislative efforts to combat this form of discrimination (OECD, 2011a). In addition, older workers need help to preserve and augment their skills and knowledge to make them more employable. Evidence exists that younger workers are favoured over older staff, in part due to seniority-based wage structures, which make it expensive to employ older workers, and strict employment-protection regulations which may encourage employers to use early-retirement pathways to adjust their workforce.

Figure II.7. Some fast-ageing countries are not reforming pensions

Public expenditures on old-age and survivors' benefits as a percentage of GDP (2007 and change 1990-2007)

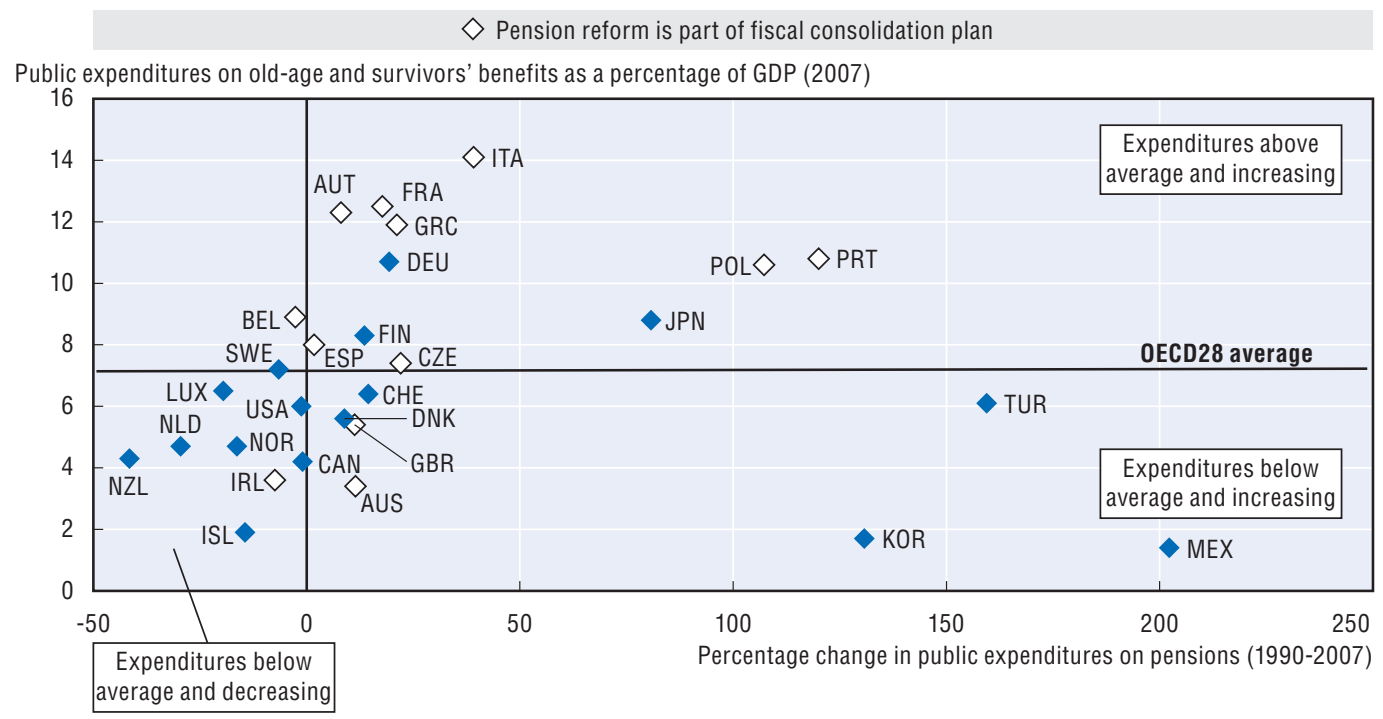

Note: Data are not available for Chile, Estonia, Hungary, Israel, the Slovak Republic and Slovenia. Hungary has included pension reform as part of its fiscal consolidation plan.

Source: OECD Social Expenditures Database (SOCX); OECD Main Economic Indicators Database; OECD Fiscal Consolidation Survey 2010 as presented in OECD (2011), Restoring Public Finances, Paris.

StatLink काIsL http://dx.doi.org/10.1787/888932389417 
Eight countries have announced pension benefit reductions. In seven of these countries, pensions account for an above-average share of older citizens' incomes. While cutting benefits could achieve substantial savings to the government, it also presents risks that will need to be addressed. For example, in these countries, cuts in support could affect the poverty rates among this segment of the population if citizens do not compensate by increasing their private savings. There is some relationship between the incomes of older people and public expenditure on old-age benefits, especially when account is taken of differences between countries' demographic situations. A 10\% increase in public pension expenditure is associated with a 1.5 percentage point increase in older people's relative incomes (OECD, 2009c). The precise design of retirement-income systems also has an effect. Austria, France, Luxembourg and Poland have large public, earnings-related pensions and they have among the highest relative incomes in old age.

\section{Figure II.8. Public pensions help fight old-age poverty in many OECD countries}

Public transfers as a share of old-age income and old-age income poverty rate (mid-2000s)

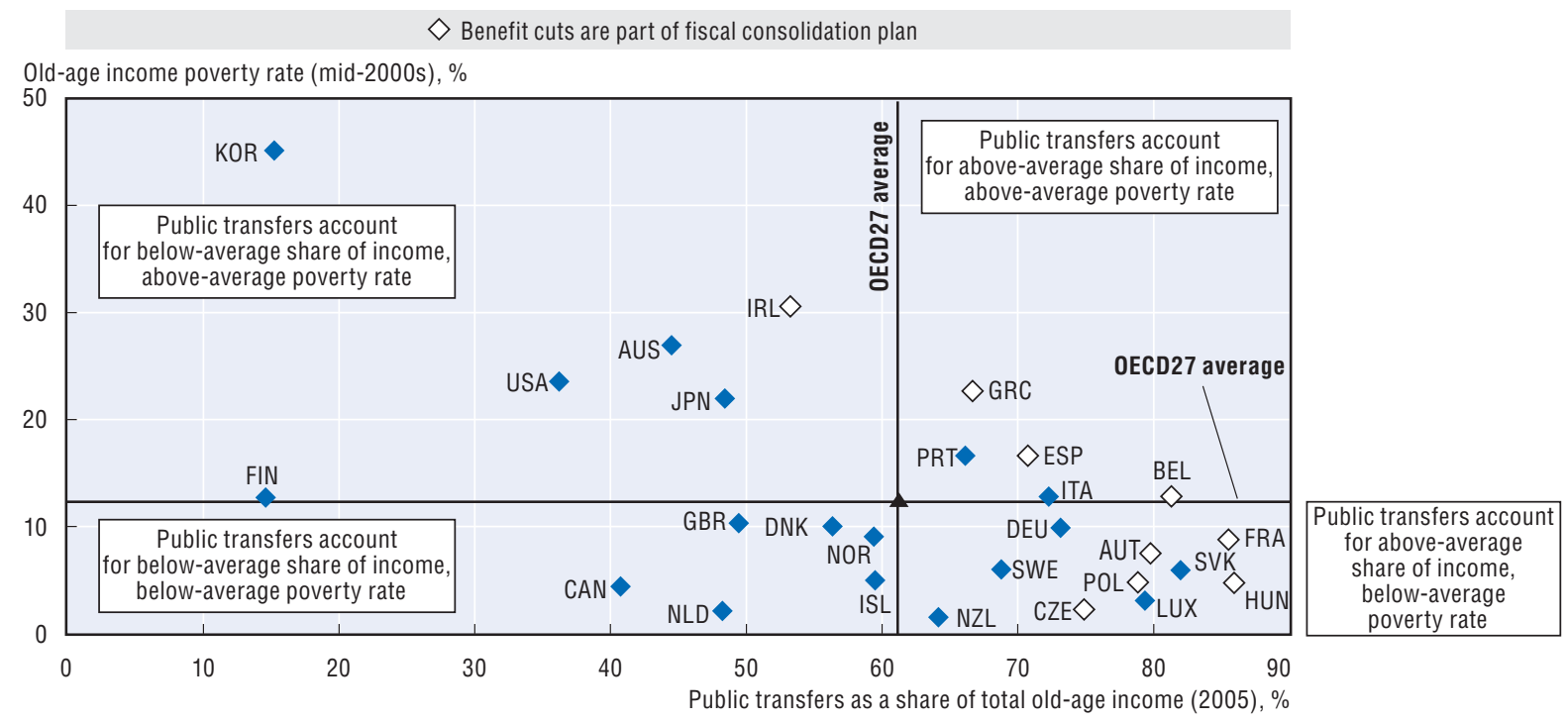

Note: The poverty rate is defined as the percentage of over $65 \mathrm{~s}$ with incomes of less than half median equivalised population incomes. Public transfers include retirement, family, unemployment, housing and disability benefits. In Finland, mandatory occupational plans are included as capital income, whereas the national accounts and Pensions at a Glance treat these schemes as part of the public sector. The share of old-age income derived from public transfers is very low in Korea because the public pension scheme was only established in 1988.

Source: OECD (2009), Pensions at a Glance 2009 and OECD (2008), Growing Unequal? Income Distribution and Poverty in OECD Countries, OECD Publishing, Paris and OECD Fiscal Consolidation Survey 2010 as presented in OECD (2011), Restoring Public Finances, Paris.

StatLink Ailst http://dx.doi.org/10.1787/888932389436

\section{Countries with biggest potential for health savings are not exploiting this area in consolidation plans}

Health programmes account for a large and increasing share of government expenditures in OECD countries. On average, OECD countries devote $15 \%$ of total general government expenditure to health and this share has increased by 1.7 percentage points since 2000 (Indicator 5). However, in those 15 countries targeting health programmes as part of fiscal consolidation plans, health spending is not necessarily above the OECD average nor has it been increasing at an above-average pace since 2000. Furthermore, apart from Greece and Turkey, where health reforms focus on reducing pharmaceutical expenses, health expenditure savings do not constitute a major share of consolidation, contributing less than $0.4 \%$ of GDP on average (OECD, 2011b). 
The Slovak Republic and Ireland, two countries planning health reform, stand out as having relatively large portions of total general government expenditures devoted to health, with this share increasing since 2000. While the United States and Japan have not yet announced large fiscal consolidation measures, health forms a substantial and increasing portion of government expenditures in these countries. As data refer to 2008, they do not reflect the health reform adopted in the United States in 2010. Decreases in government expenditures in health could shift costs to households, which currently account for about a third of expenditures on health on average across the OECD area (Indicator 10).

\section{Figure II.9. General government health spending is large and increasing across most of the OECD area}

General government health expenditures as a share of GDP (2008 and change 2000-08)

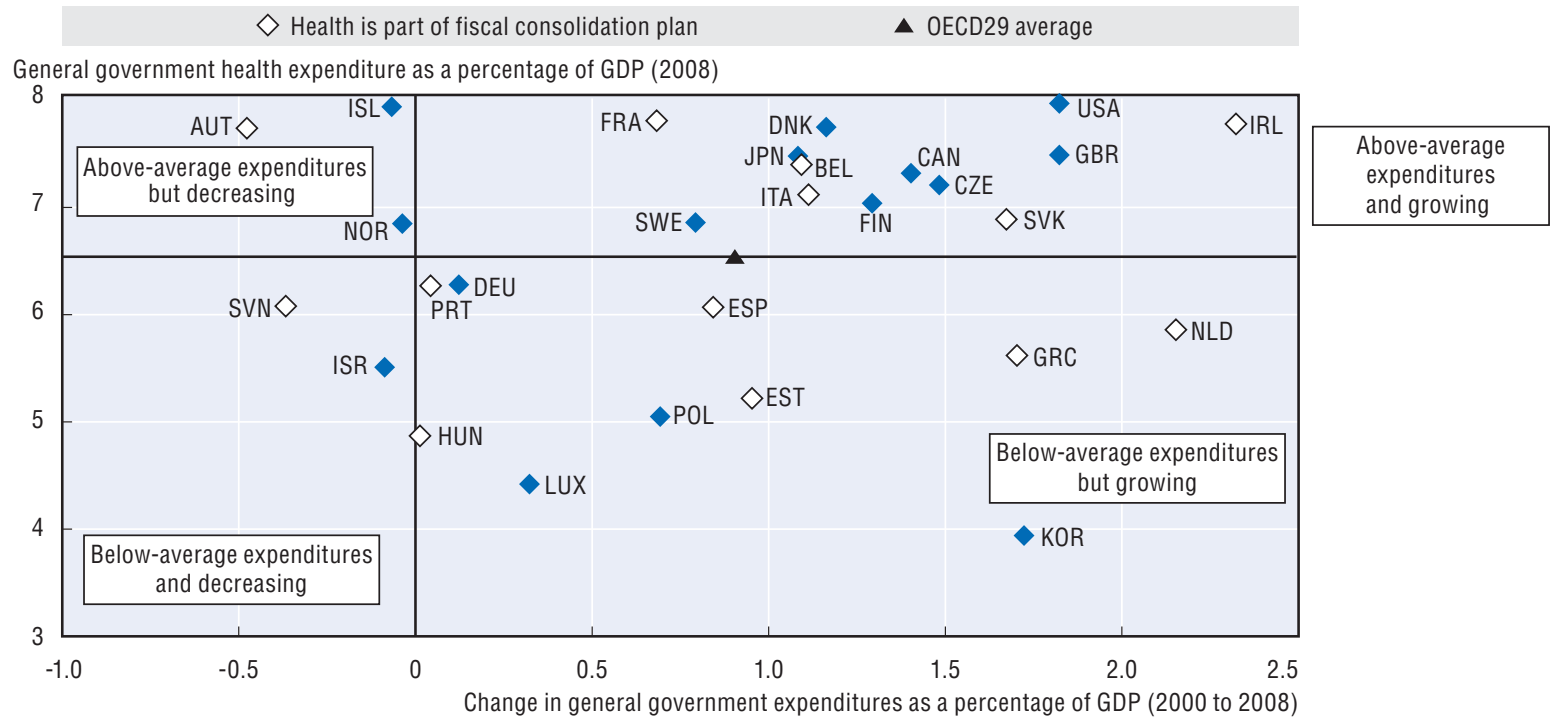

Note: Data are not available for Australia, Chile, Mexico, New Zealand, Switzerland and Turkey. New Zealand and Turkey have included health as part of their fiscal consolidation plans. Data for Canada refer to 2006.

Source: OECD National Accounts and OECD Fiscal Consolidation Survey 2010 as presented in OECD (2011), Restoring Public Finances, Paris. StatLink (ills http://dx.doi.org/10.1787/888932389455

OECD estimates of efficiency in the health sector indicate that room for improvement exists. International studies of efficiency in health care delivery are relatively new and still under development. Efficiency is calculated by comparing the ratio of inputs to outputs (or outcomes). Improvements in efficiency can occur by achieving the same level of outputs using fewer inputs, or by achieving more outputs using the same level of inputs.

The OECD conducted exploratory work to assess the potential savings from greater efficiencies in public health care spending using data on health expenditures and life expectancy. The OECD estimates that public spending savings could approach $2 \%$ of potential GDP in 2017 on average by improving the efficiency of the health care system (OECD, 2010b). Efficiency gains in Greece and Ireland, two countries targeting health care as part of their fiscal consolidation plans, could top 3\% of potential GDP in 2017. Currently, Australia, Iceland, Japan, Korea and Switzerland perform best in transforming spending into health outcomes. In order to achieve efficiency gains in this programme area without sacrificing quality, detailed data on the costs and the benefits of each programme are needed. 


\section{Education spending is generally not targeted in fiscal consolidation plans}

While prior OECD work suggests that room for efficiency improvements in educational programmes exist, well-performing schools are critical to ensure the competitiveness of the labour force and securing future economic growth and societal well-bring. Few countries are targeting education programmes for cuts: five countries have identified education as a target for programme spending cuts, while an additional three countries have shielded this area from cuts (OECD, 2011b). In both countries shielding and targeting educational programmes, the population is getting older: the share of the total population that is school-aged (younger than 15) will decrease between 2010 and 2025 in all OECD countries except Estonia, Sweden and Slovenia. The share of the population that is school-aged will drop most dramatically in Mexico, Turkey and Korea over the next 15 years (by over 4 percentage points), followed by Chile, Japan and New Zealand (between 2 and 4 percentage points). New Zealand is the only country in this group that has targeted education programmes for cuts. Of the four other countries targeting education for cuts, the school-age population will decline at a faster pace than the OECD average in the Netherlands and Denmark while the declines in the school-age population are slower than average in Austria and Switzerland.

\section{Figure II.10. School-aged population is decreasing across the OECD area}

Population younger than 15 as a share of total population (2010 and 2025)

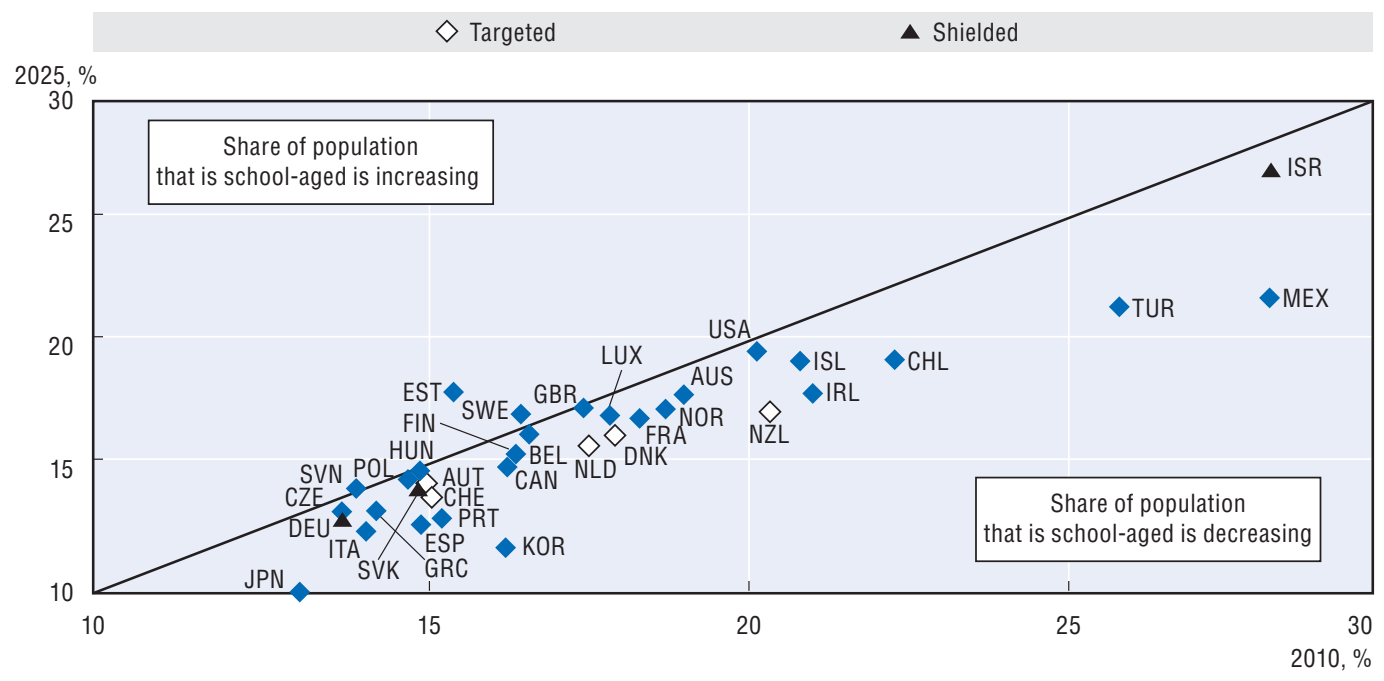

Source: OECD Population Statistics.

StatLink काISL http://dx.doi.org/10.1787/888932389474

The Netherlands and Switzerland, two countries targeting education for cuts, showed above-average PISA scores in reading in 2009 with below-average government spending on education. The challenge in these countries will be to ensure that the cuts do not hurt student achievement. In comparison, the challenge in Denmark, another country targeting education programmes for cuts which has above-average expenditures but average scores, will be to improve efficiency by increasing achievement using fewer resources. 
Figure II.11. Countries shielding education from cuts score below average on PISA scales

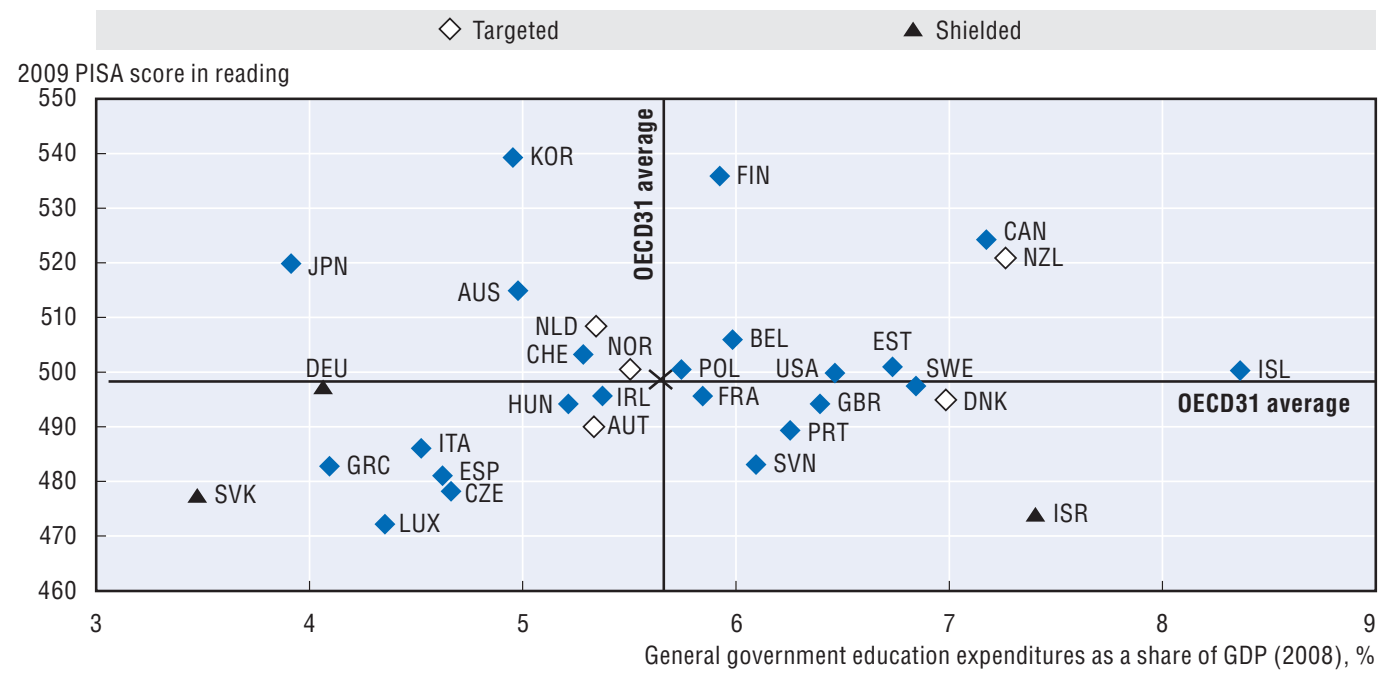

Note: Data are not available for Chile, Mexico and Turkey. Expenditure data for Canada refer to 2006. Expenditure data for New Zealand refer to 2005. PISA reading scores for Austria refer to 2006.

Source: OECD National Accounts, PISA 2009 and OECD Fiscal Consolidation Survey 2010 as presented in OECD (2011), Restoring Public Finances, Paris.

StatLink Aाst http://dx.doi.org/10.1787/888932389493

Some countries targeting infrastructure for cuts already show declining investment in this area

Although comprising less of government spending than social protection, education and health, infrastructure spending is a large ticket item in many OECD countries, representing $4.5 \%$ of GDP in 2009 on average. Maintaining transportation and communication networks, as well as building schools, hospital and community housing, is an important foundation for a productive economy. While postponing infrastructure spending is often an easy way to save money, failing to make key investments to repair or update the nation's public infrastructure can ultimately hurt economic growth and international competitiveness. Of the 13 countries planning to decrease infrastructure spending as part of their fiscal consolidation plans, Ireland, the Czech Republic, Estonia and Slovenia exhibit above average spending currently and have invested more heavily in infrastructure over the past decade, suggesting that they have been building up their infrastructure stock. On the other hand, countries such as Switzerland, Austria and Portugal spent below average on infrastructure in 2009 and spending as a share of GDP has decreased since 2000. These data suggest that these countries have not been investing as heavily in building up or maintaining stocks over the past decade, potentially because they already had high levels of stock established. However, further reducing investments could lead to deteriorations of the infrastructure stock by postponing needed repairs or modernisations.

\section{Are operational reforms targeting the areas that are likely to bring about efficiency and productivity gains?}

Little empirical evidence exists regarding which public administration reforms result in efficiency gains

Despite a plethora of reforms implemented by countries over the past decade, little empirical evidence currently exists about which public administration reforms bring about efficiency and productivity gains. This scarcity of evidence is due to a lack of resources within governments to conduct evaluations; a lack of pre-reform measures of performance 
Figure II.12. Infrastructure spending has mostly increased in recent years

General government infrastructure spending as a share of GDP (2000 and change 2000-09)

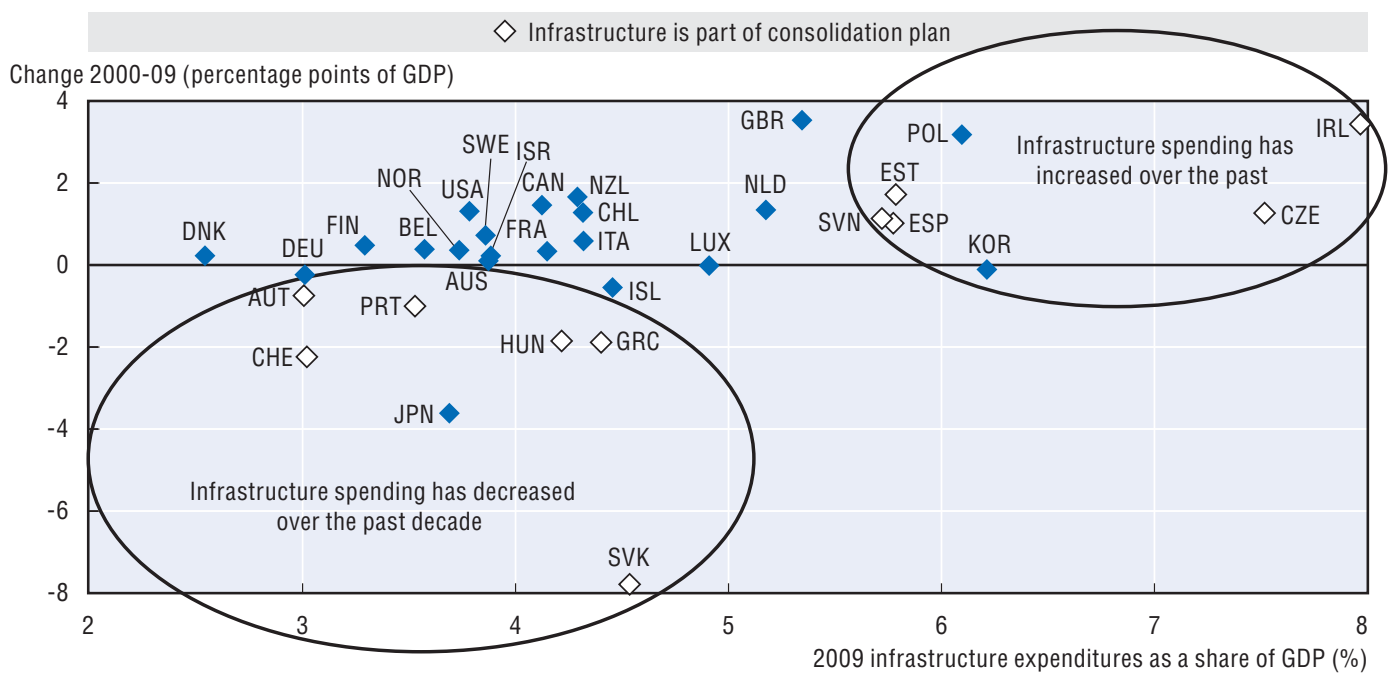

Note: Infrastructure spending is calculated from government expenditures on gross fixed capital formation and capital transfers in all programme areas. Data for Australia, Chile, Japan, Korea, and New Zealand refer to 2008. Data for 2000 are not available for Mexico and Turkey and these countries are not depicted in the figure above. Turkey focuses on infrastructure in its fiscal consolidation plans.

Source: OECD National Accounts and OECD Fiscal Consolidation Survey 2010 as presented in OECD (2011), Restoring Public Finances, Paris.

StatLink ताइस http://dx.doi.org/10.1787/888932389512

that can serve as a baseline against which to measure progress; complexities in measuring efficiency in the public sector; and problems with isolating the effects of specific institutional reforms on efficiency from other external influences (Curristine et al., 2007). In addition, there could be substantial differences in the short- and long-term effects of these reforms, such as efficiency gains dissipating over time.

Of the common public administration or management reforms implemented by OECD countries over the past decades, empirical evidence points to three institutional factors that may improve public sector performance:

- Decentralisation of political power and spending responsibility to sub-national governments.

- Human resource management practices that improve employee satisfaction and morale.

- Adjusting operations to maximise economies of scale (particularly in the education and health sectors) (van Dooren et al., 2007).

Findings are inconclusive on the impact of ownership (such as privatisation), competition (including outsourcing) and agencification. Private ownership is not a guarantee for efficiency and public ownership does not necessarily lead to inefficiencies. Likewise, not all services can benefit from competition which can impact prices but also costs and quality. Given the heterogeneity of public services, from refuse collection to municipal buses, the nature of service delivery (such as low asset specificity and low information costs) is crucial for successful competition in public services. Regarding agencification, there is some evidence that a reduction of input controls combined with steering for results, financial incentives and competition could lead to increased efficiency. However, the impact on the quality of service delivery and policy effectiveness is unclear. Agencification is also not without risks, which can affect financial and human resources and increase opportunities for political patronage and corruption. 


\section{Operational cuts focus on reducing compensation costs}

Most operational cuts focus on reducing compensation costs (Figure II.13). Compensation costs account for about $24 \%$ of government expenditures (11\% of GDP). On average, governments in OECD countries employ $15 \%$ of the labour force. In most countries, government employees include teachers, doctors and police officers, many of whom are employed by local governments (Indicator 22).

\section{Figure II.13. Measures in fiscal consolidation plans to reduce operating expenditures (2010)}

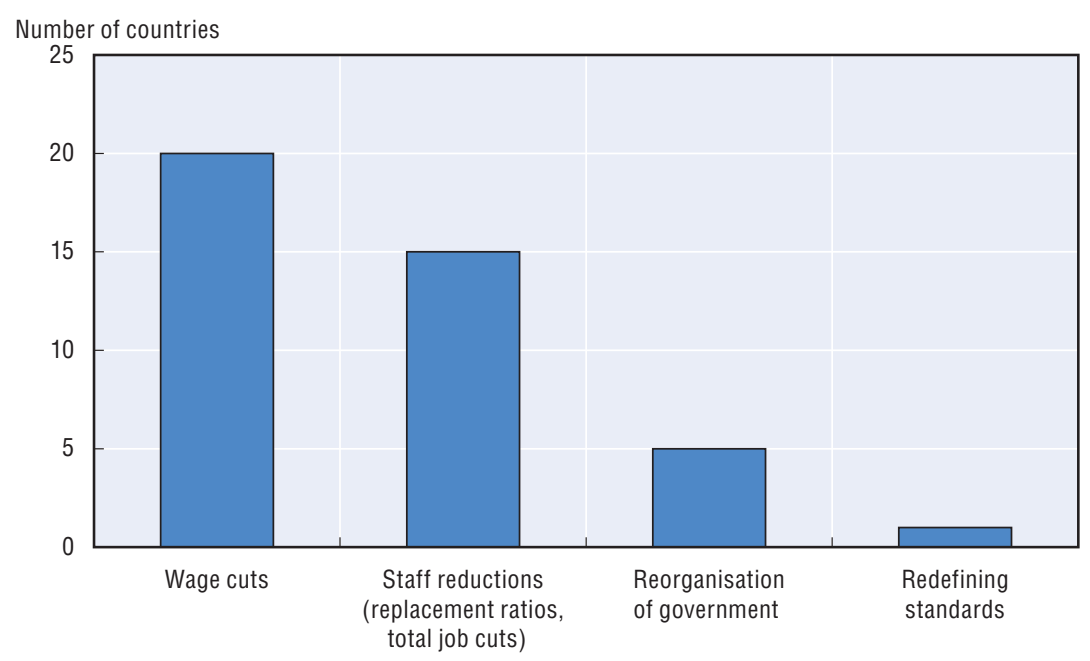

Note: Some countries have announced cuts in more than one category. Data refer to consolidation plans in 29 countries as of December 2010.

Source: OECD Fiscal Consolidation Survey 2010 as presented in OECD (2011), Restoring Public Finances, Paris. StatLink ants http://dx.doi.org/10.1787/888932389531

Compensation costs can be lowered by reducing the size of the workforce and/or cutting wages. While government employment tends to be sticky and has been stable over the past decade, over half of governments across the OECD have announced workforce reduction measures and/or cuts to salaries and benefits in order to cut costs (Indicators 21 and 24). Nordic countries where compensation costs are highest as a share of GDP have not announced reductions in this area.

Eleven OECD countries have set replacement ratios to fill the gaps left by central government staff leaving through retirement. These policies will likely have a large effect on the size of the central government workforce in Italy, given the large share of workers approaching retirement age (over $53 \%$ of central government workers are 50 years or older) and the low replacement ratio (only 1 in 5 staff will be replaced). Similar large effects may also occur in Spain and Greece, given the low replacement ratios and ageing profile (for example, Spain aims to replace 1 worker for every 10 who leave). Replacement ratios could be used in other countries that have yet to announce plans and where older workers make up over $40 \%$ of central government staff, such as Belgium, Germany, Sweden and the United States.

Twenty OECD member countries have announced plans to freeze or cut public sector wages. Cuts to salaries and wages could affect the government's ability to attract and retain staff, with high performers leaving (or forgoing) the public sector to pursue higher-paid opportunities with private companies. 
Figure II.14. Compensation costs account for a significant portion of government expenditures

Compensation of general government employees as a percentage of GDP (2009)

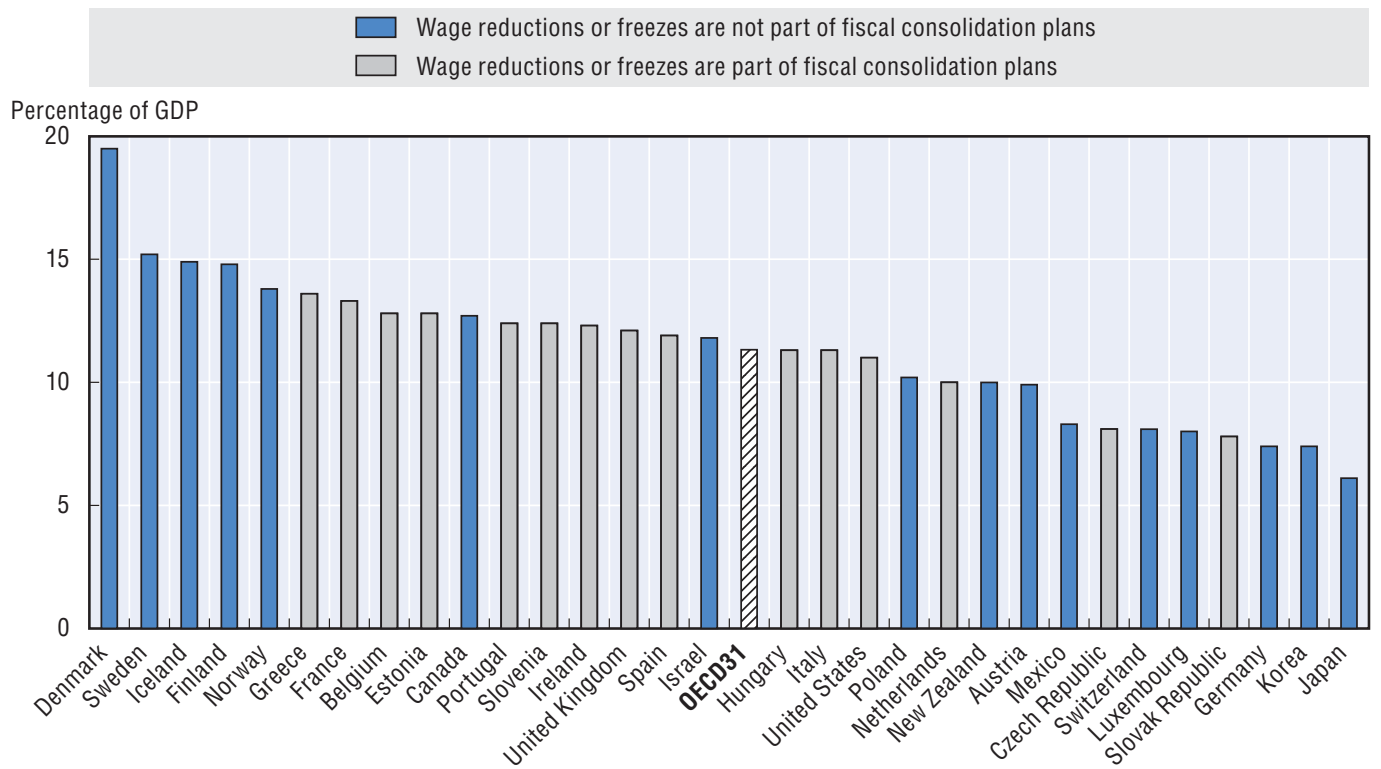

Note: Data are not available for Australia, Chile and Turkey. Turkey has planned wage reductions as part of its fiscal consolidation plan.

Source: OECD National Account Statistics; OECD Fiscal Consolidation Survey 2010 as presented in OECD (2011), Restoring Public Finances, Paris.

StatLink AाISt $h t t p: / / d x . d o i . o r g / 10.1787 / 888932389550$

Figure II.15. Government workforces are ageing

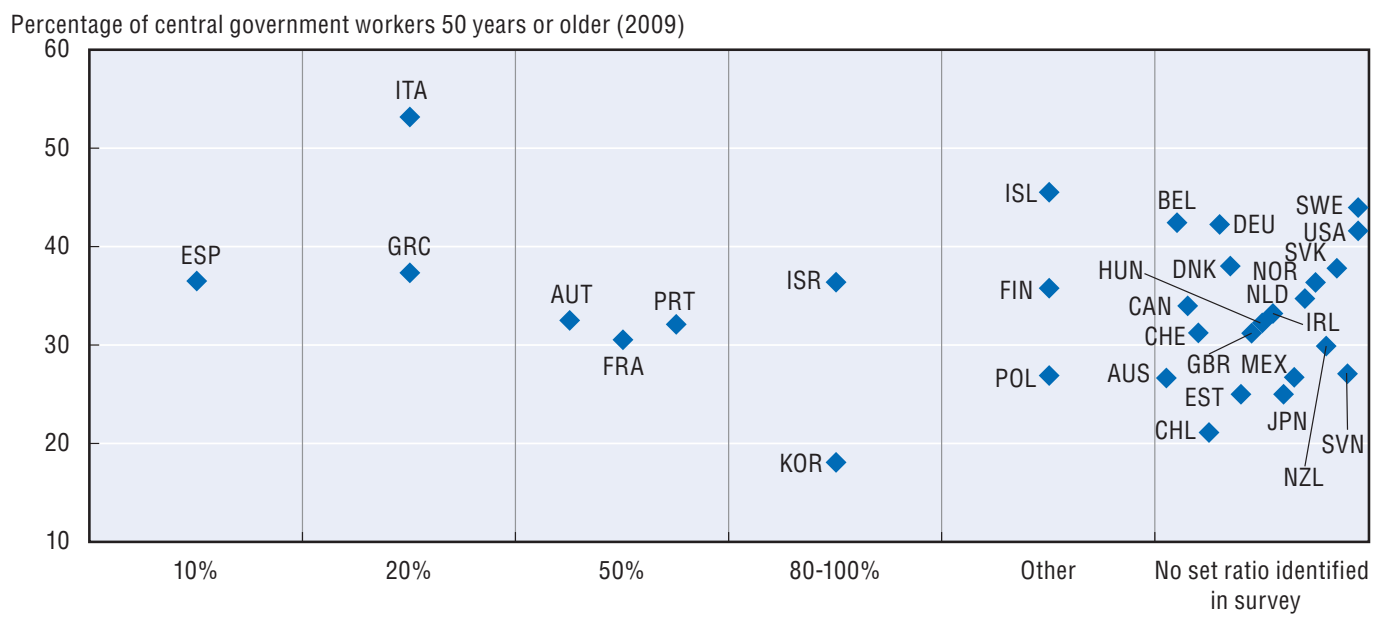

Replacement ratios (2010)

Note: The Czech Republic and Turkey have also set replacement ratios (less than $50 \%$ of departing workers will be replaced in both of these countries) but are not included in the figure due to missing data on the age profile of their workforces. Source: 2010 OECD Survey on Strategic Human Resource Management in Government.

StatLink त्ञाज http://dx.doi.org/10.1787/888932389569

Unfortunately, evidence is scarce to guide decision makers in this area. Many countries do not have the data they need to determine whether public sector staff are overpaid or underpaid compared to private sector counterparts. Salaries and wages are not a monolithic item across the government; they vary by position, by the share of remuneration that is based on performance, working hours and benefits. For example, in 
Australia, performance-related pay can represent either over $20 \%$ of the basic salary or less than $10 \%$ depending on the position. While there is a large variation across countries in the average annual compensation paid for certain positions (see Chapter VI) teachers and nurses tend to make less than the average wage for university-educated adults in most countries (Indicators 25 and 26). OECD data on remuneration for key public sector positions show that wages and salaries represent on average $80 \%$ of total compensation. In addition, government (as an employer) contributes to retirement plans or pensions, and private health insurance costs or other social contributions. Thus, reforms to the pension and health systems (discussed above) could also have important effects on government compensation costs. However, changes in these areas may be more difficult to implement for current staff as they involve altering long-term contracts.

In addition, experience with prior reform indicates that ministerial rearrangements, wage cuts and voluntary retirement schemes (three common reforms included in the announced fiscal consolidation plans to date) tend to perform below expectations in terms of fiscal savings or may have adverse consequences on performance. Wage freezes may be reversed and may reduce public sector efficiency by lowering salaries and compressing salary scale differentials. Across-the-board expenditure cuts may be inefficient and less likely to lead to permanent cuts in expenditure. In addition, they can affect segments of the population unevenly, particularly women and children who benefit most from government programmes.

Prior experience with reforms suggests that operating expenses can be adjusted in a sustainable fashion by using sophisticated workforce planning, accompanied by good use of the departures due to ageing; automatic productivity cuts; long-term policy reviews; skills strategies and redesign of work. However, recent data collected by the OECD suggest that many governments can do more to manage staff strategically (Indicator 16). For example, fewer than half of OECD member countries require senior and middle managers to plan and report on workforce strategies to close competency gaps in a cost-efficient manner.

Spending cuts to operational expenses may be more effective when managers are given flexibility to decide how to apply them across the portfolio, because they may have a better idea than decision makers removed from daily operations where inefficiencies exist. In addition, involving workers or their representatives in developing restructuring plans can build buy-in and reduce the reform's negative effects on morale. While unions are often involved in negotiating remuneration, OECD data indicate that they are less involved in workforce restructuring plans (Indicator 33).

\section{Uncovering the drivers of rising production costs is needed}

Governments produce goods and services using a mix of their own staff (48\%), private contractors (43\%) and capital (9\%) (Indicator 8). Between 2000 and 2009, governments' use of outsourcing (contracting with private and non-profit actors) has increased from $8.7 \%$ to $10.3 \%$ of GDP (Indicator 48). As it represents a large proportion of government expenditures, it is important to understand the reasons behind this growth, whether outsourcing is yielding value for money and quality services for tax-payers, and whether further productivity savings can also come from these private contractors, either directly or by improving the way that governments interact with them. A forthcoming OECD review of the federal procurement system in the United States has identified that potential productivity gains could be achieved through better leveraging of the knowledge held in the market. For example, engaging with potential suppliers of goods and services enables governments to understand the trends and innovations within the market and how these can be used to improve the delivery of public services. By focusing on outcomes rather than inputs and processes, performance-based 
procurement enables the government to give scope to the market and suppliers to propose innovative solutions to the government's desired objectives. Ongoing work on measuring quality of public service delivery in different OECD countries could add further insights into the advantages and/or disadvantages of outsourcing.

In addition, some countries are looking beyond traditional contracting to focus on involving citizens and users in the design, production and delivery of services (Indicator 50). For example, the "Big Society" plans announced in the United Kingdom are based on the idea that communities can be given more power and to encourage individual citizens, co-operatives, charities and volunteers to take more responsibility for service delivery. This rebalancing of the relationship between government and citizens puts service delivery in an obscure space somewhere between market and government provision. While some governments are hoping that these new forms of collaboration will generate cost savings for governments, they also pose questions about accountability, transparency, efficiency and effectiveness in the delivery of those services. Business cases would need to be developed, including a focus on managing the risks posed by these new relationships.

\section{Efficiency gains from ICT use}

Although not a specific part of fiscal consolidation plans, ICT development and support is critical to helping all the branches of government work in a collaborative fashion and to achieve back-office efficiencies, which can lower operating costs. ICTs enable efficiency improvements in mass processing tasks and public administration operations. Internet-based applications can generate savings on data collection and transmission, provision of information and communication with customers. Significant future efficiencies are likely through greater sharing of data within and between governments. E-government is most effective when agencies work together in customer-focused groupings that allow them to share infrastructure, ensure interoperability, maximise implementation efficiency and avoid duplication.

While the use of ICT to interface with citizens and businesses in service delivery is fairly established in OECD countries, fewer countries have developed policies or strategies to realise internal efficiency gains. For example, only 6 of the 23 countries surveyed by the OECD have laws or policies regarding knowledge management (Indicator 20). The wide sharing of information electronically across sectors and boundaries within government is critical to foster innovation and reducing administrative burdens. Standardising knowledge management practices within Ministries or Agencies and across government can improve communication and decrease duplication - saving time and money. Unfortunately, internationally comparable data providing evidence on cost savings resulting from the use of ICT are scarce, although the OECD plans to develop these data in the future. As cloud computing and other new technologies become more widely used by governments in OECD countries, monitoring their costs and benefits will be key to learning more about the potential efficiency gains enabled by ICT and better contribute to the development of good practice.

In addition, governments are increasingly using ICT to improve service delivery, leading to reductions in red tape and saving time and money for citizens and businesses. Most countries have established a legal framework to enable widespread use of e-government by citizens and businesses (Indicator 20). For example, all countries have legislation or policies regarding the recognition and use of digital signatures and protecting the privacy and security of personal data. More and more citizens and businesses are looking on line: on average, $75 \%$ of businesses and $35 \%$ of citizens report using the Internet 
Figure II.16. Citizens' use of the Internet to interact with public authorities (2010)
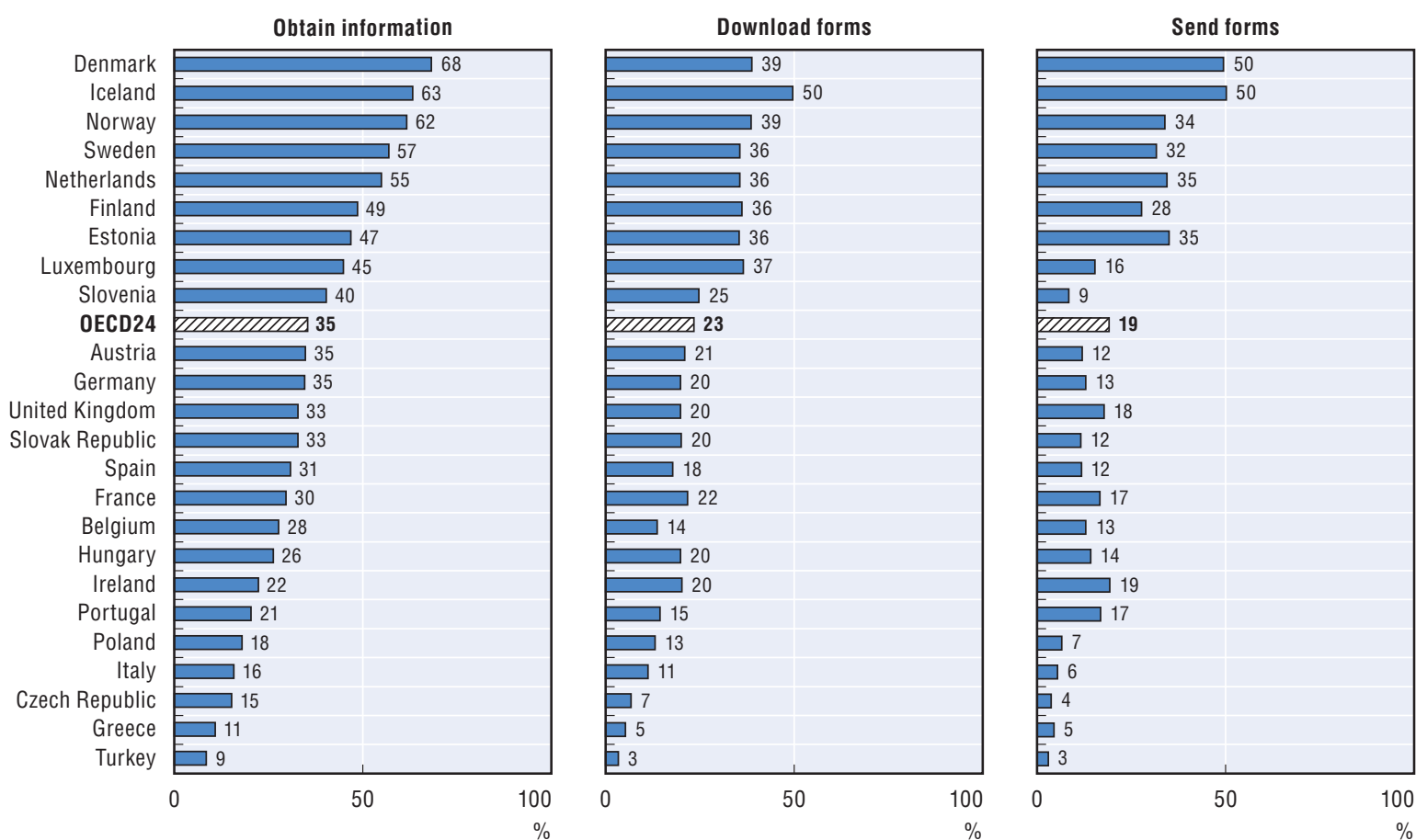

Note: Data are not available for Australia, Canada, Chile, Israel, Japan, Korea, Mexico, New Zealand, Switzerland and the United States. Data for Iceland refer to 2009.

Source: Eurostat.

\section{Figure II.17. Business' use of Internet to interact with public authorities (2010)}
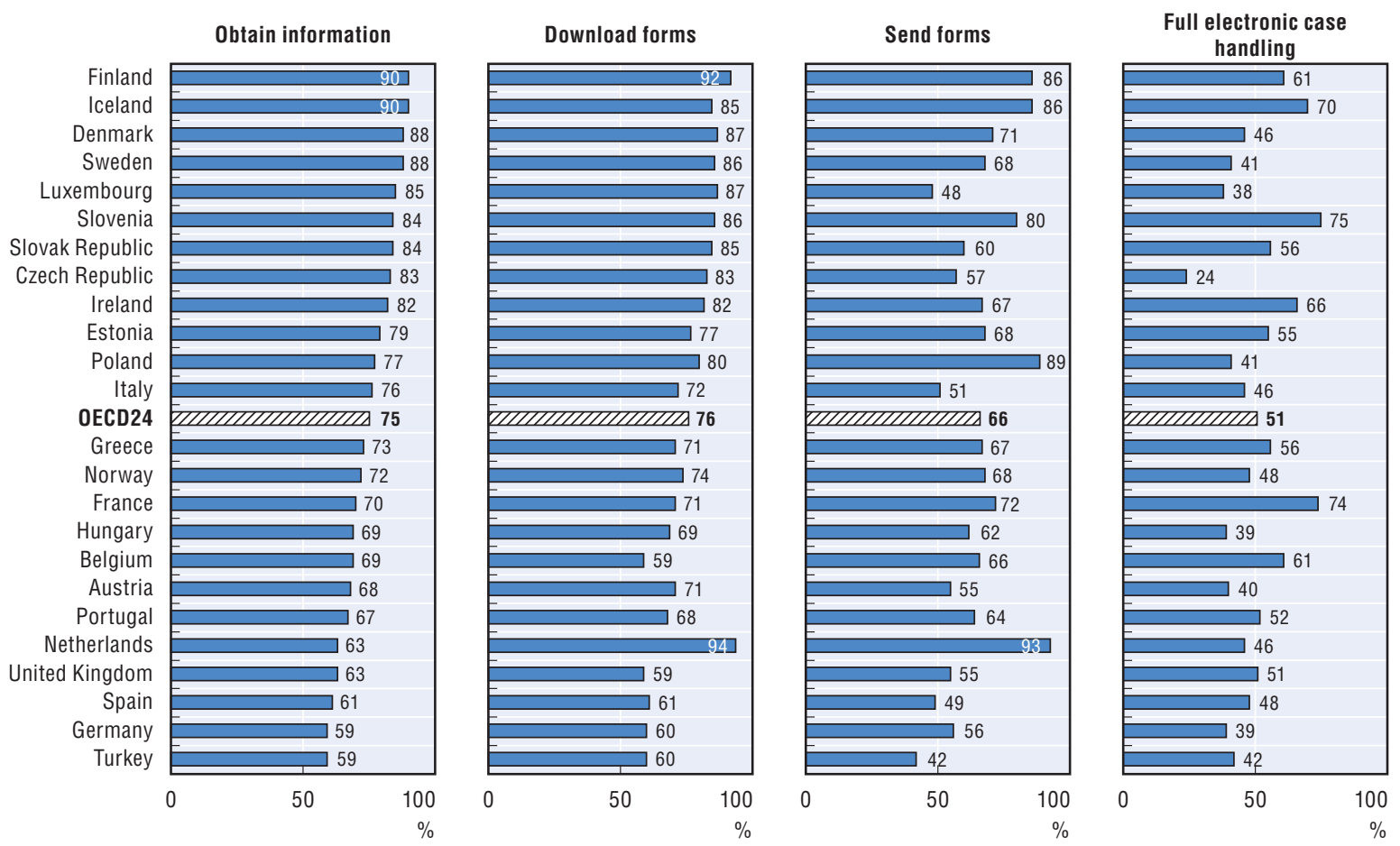

Note: Data are not available for Australia, Canada, Chile, Israel, Japan, Korea, Mexico, New Zealand, Switzerland and the United States. Source: Eurostat. 
to interact with public authorities in 2010. However, room for improvement exists. Data indicate that most citizens and businesses go to government websites to find information, but fewer use the websites to complete transactions. For example, on average $51 \%$ of businesses report using full case handling on line whereas only $23 \%$ of citizens report downloading forms, with even fewer (19\%) sending forms.

E-procurement is one area in which governments are using ICT to improve service delivery, lowering transaction costs and improving the timeliness and transparency of communications. Sixty per cent of procurement websites in OECD countries allow for two-way communication between government officials, bidders and the general public and over $50 \%$ permit bids to be submitted electronically. Over half of OECD countries provide contract management tools via their portals, such as tracking contract outcomes or statistics related to past procurements. Electronic payment schemes (e.g. e-invoicing) are less common (Indicator 42).

Figure II.18. Share of enterprises using e-procurement (2010)

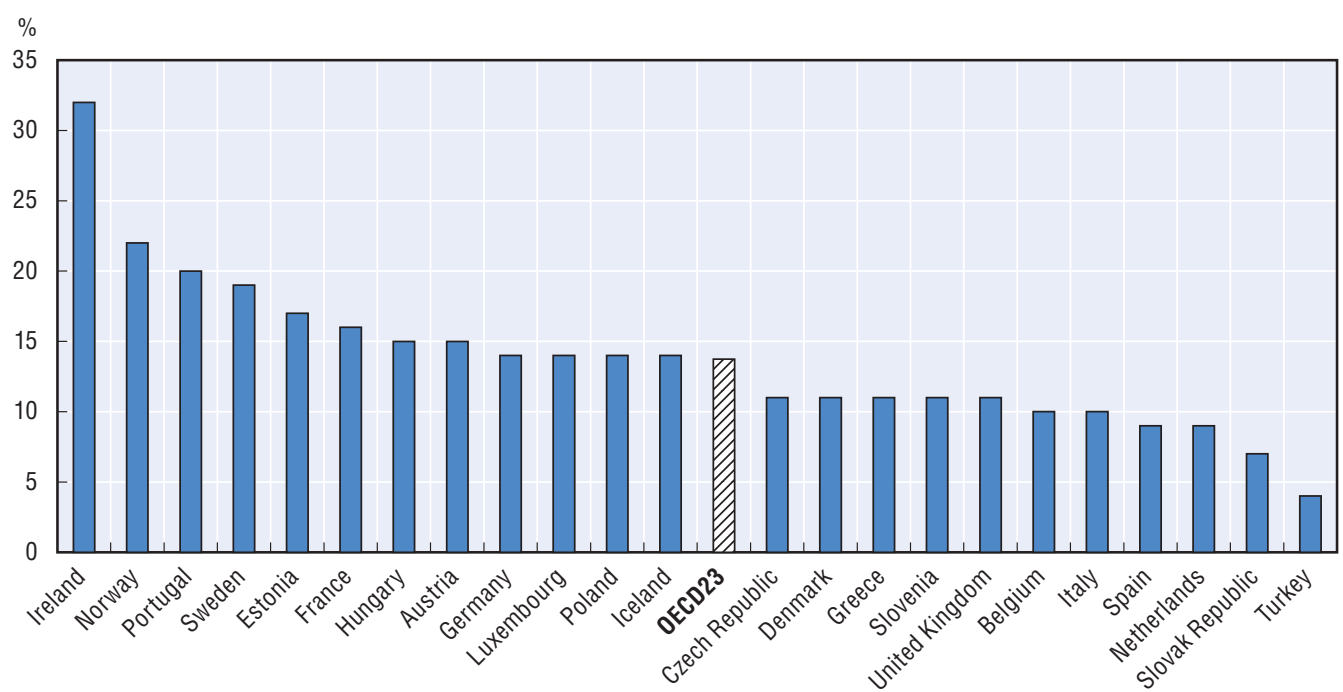

Note: Data are not available for Australia, Canada, Chile, Finland, Israel, Japan, Korea, Mexico, New Zealand, Switzerland and the United States.

Source: Eurostat.

StatLink 시내 $h t t p: / / d x . d o i . o r g / 10.1787 / 888932389645$

In addition, new technologies have the potential to introduce a paradigm shift, where service delivery is entirely rethought from a user-centred perspective (e.g. around life events for citizens and businesses). However, while many OECD countries (20 of 23 respondents) identify e-government as a key tool to enhance innovation in the design and delivery of public services, fewer countries see this innovation as stemming from enabling users to participate more directly in service design and delivery (11 of 23 countries) (Indicator 20).

\section{Revenue measures could have negative effects on equity}

The most frequently announced tax measure in fiscal consolidation plans is raising consumption taxes, followed by reducing tax expenditures and increasing income taxes (OECD, 2011b). In contrast, increases in property taxes are used by only three countries. The effectiveness of tax measures depends on how they influence production and income distribution. In general, OECD research suggests that those taxes which are least 
distortionary should be targeted for increases: property taxes (particularly taxes on immovable property) seem to be the most growth-friendly (least distortionary) followed by consumption taxes and then by personal income taxes. Corporate taxes seem to be the most harmful for growth.

There is considerable variance between OECD member countries in terms of relative reliance on tax sources, and the revenue mix has important implications for the responsibility placed on different segments of society for funding government operations (Indicator 2). While consumption taxes may be relatively growth-friendly, they are regressive and disproportionally affect the services sector, which can compound the negative effect on lower income households whose members hold jobs in this part of the economy. First, as consumption taxes (such as the value-added tax, or VAT) are a flat tax placed on certain goods and services, they constitute a larger proportion of salaries for low income households than for high income households. Second, the public may reduce consumption in reaction to the tax, which can have knock-on effects on employment. For example, if demand for certain services decreases as a result of the tax, then companies operating in these areas may decrease their payrolls.

\section{Conclusion}

While the announced fiscal consolidation plans represent a first step in identifying areas for savings in government spending and signalling to citizens and markets that changes will come, they do not go far enough to achieve fiscal sustainability for a number of countries. Policy makers face a dilemma when devising and implementing plans: while there is general public support for consolidation, resistance occurs when cuts get specific or tax increases are proposed. While health consumes a large portion of government resources, reforms in this area may not generate enough savings to balance budgets. Infrastructure is a comparatively smaller portion of government expenditures and yet it is targeted by many countries. While shielding education from cuts may be important to ensure future economic growth, the magnitude of fiscal consolidation needs in some countries may not make this feasible. In addition, putting off needed reforms until market pressures force changes means that cuts have to be more drastic and are less likely to be based on evidence.

Practicing strategic insight can help governments identify when and where more changes are needed. Strategic insight here is the ability to understand and balance government values, societal preferences, current and future costs and benefits, and expert knowledge and analysis, and to use this understanding coherently for planning, objective setting, decision making and prioritisation. Strategic insight is based on assessing and managing risk, and embedding evidence-based decision making in policy development and implementation. It requires strong leadership from the centre of government to assume a whole-of-government approach that incorporates views from multiple actors to help prioritise goals and minimise unintended consequences. Almost all OECD member countries produce long-term fiscal projections that assess the likely consequences of continued current spending with the impact of demographic change and other factors. However, while international data exist on government performance in key policy areas - such as health and education - decision makers are not using this information to make strategic decisions regarding programme cuts. Governments also need to understand how efficient their spending is and make cuts or changes to areas identified as inefficient. To accomplish this, governments need data on costs (inputs), outputs and outcomes. 
A role for the OECD continues to be to monitor the quality, implementation and success of reforms using data on government expenditures, revenues, processes and performance. Future editions of Government at a Glance aim to further broaden the evidence base by developing performance indicators, including those on service quality, and moving from measuring the existence of laws to evaluating their implementation. In addition, implementing reforms provides governments with the opportunity to put in place new performance measures that can help track and monitor the effectiveness of their actions, and report to citizens on their progress. As governments forge a new role, a key challenge for governments will be measuring and monitoring public perceptions to ensure that reforms are on the right track and capture the sentiment of the electorate.

\section{Bibliography}

Blöndal, J. (2001), "Budgeting in Canada”, OECD Journal on Budgeting, Vol. 1(2).

Curristine, T. et al. (2007), "Improving Public Sector Efficiency: Challenges and Opportunities", OECD Journal on Budgeting, Vol. 7, No. 1.

Guichard, S. et al. (2007), "What Promotes Fiscal Consolidation: OECD Country Experiences", OECD Economics Department Working Papers, No. 553.

OECD (2003), The E-government Imperative, OECD Publishing, Paris.

OECD (2008), Public Private Partnerships: In Pursuit of Risk Sharing and Value for Money, OECD Publishing, Paris.

OECD (2009a), Government at a Glance 2009, OECD Publishing, Paris.

OECD (2009b), OECD Public Governance Reviews: Finland 2010 - Working Together to Sustain Success, OECD Publishing, Paris.

OECD (2009c), Pensions at a Glance 2009, OECD Publishing, Paris.

OECD (2010a), OECD Economic Outlook, Vol. 2010/2, OECD Publishing, Paris

OECD (2010b), "Health Care Systems: Getting more Value for Money", OECD Economics Department Policy Notes, No. 2, OECD Publishing, Paris.

OECD (2010c), Making Reform Happen: Lessons from OECD Countries, OECD Publishing, Paris.

OECD (2010d), Regulatory Policy and the Road toward Sustainable Growth, OECD Publishing, Paris.

OECD (2010e), Restoring Fiscal Sustainability: Lessons for the Public Sector, Paris.

OECD (2010f), Risk and Regulatory Policy: Improving Governance of Risk, OECD Publishing, Paris.

OECD (2011a), Pensions at a Glance 2011, OECD Publishing, Paris.

OECD (2011b), Restoring Public Finances, Paris.

OECD (2011c), OECD Public Governance Reviews: Estonia 2011, OECD Publishing, Paris.

OECD (forthcoming), OECD Public Procurement Review of the United States, OECD Publishing, Paris.

OECD (forthcoming), Partnering with Citizens and Civil Society for Innovative Service Delivery, OECD Publishing, Paris.

Schick, A. (2010), "Post-Crisis Fiscal Rules: Stabilising Public Finance while Responding to Economic Aftershocks", OECD Journal on Budgeting, Vol. 2010/2, OECD Publishing, Paris.

Van Dooren, W. et al. (2007), "Institutional Drivers of Efficiency in the Public Sector", GOV/PGC(2007)16/ANN, OECD, Paris. 


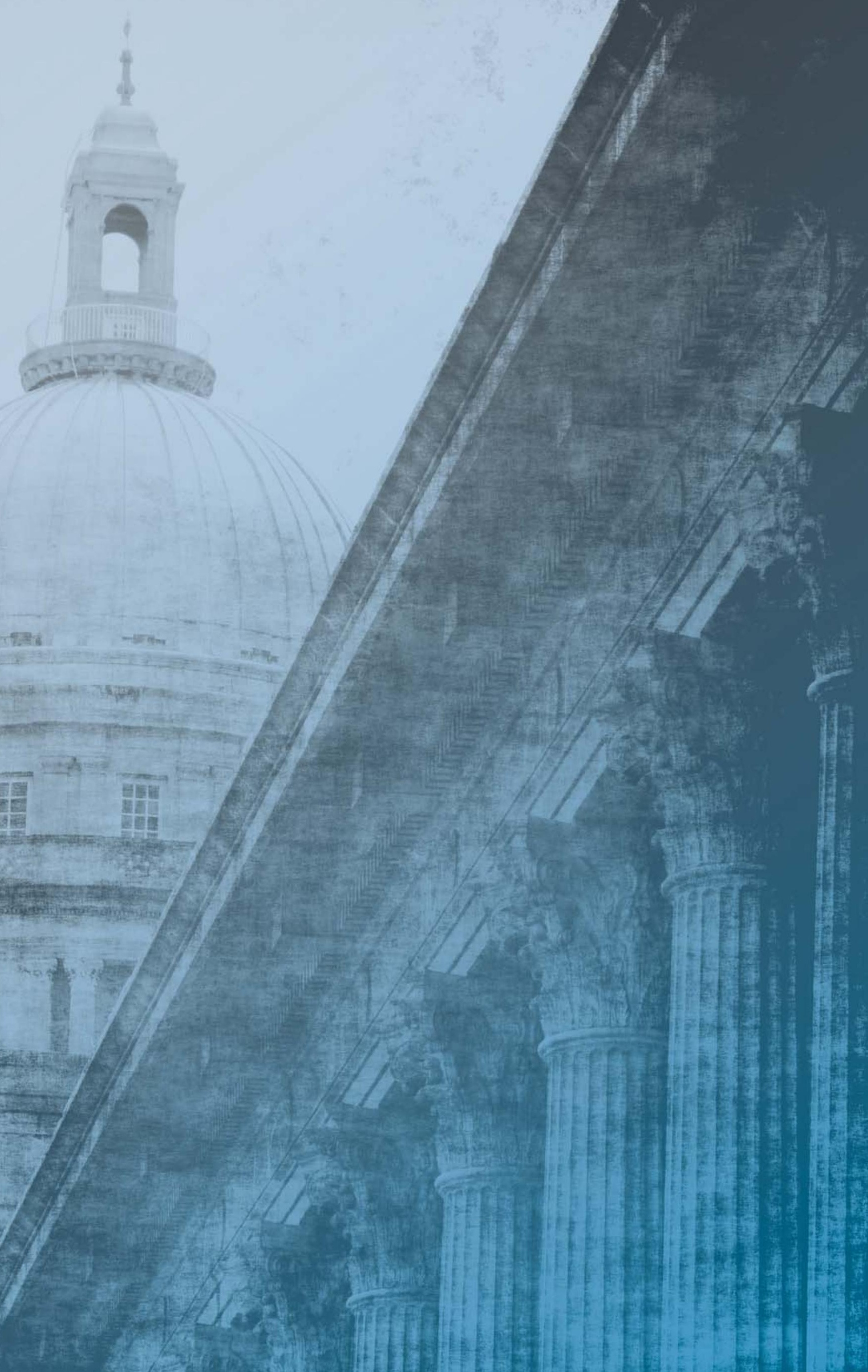




\section{. \\ -}

\section{PUBLIC FINANCE AND ECONOMICS}

Traditional tasks of government include the provision of goods and services (e.g. education and health care) and the redistribution of income (e.g. social benefits and subsidies). In addition, governments manage globalisation and risks, address fairness in society, fight corruption and protect the environment. To finance these activities, governments must raise money in the form of revenues (e.g. taxation) and/or through borrowing. The financial and economic crisis that started in 2008 led to a strong deterioration in both government deficits and debt in most OECD countries as falling revenues coincided with sharp increases in government spending due to aid to the financial sector and increased use of the social safety nets, such as unemployment benefits. Furthermore, governments' stimulus spending - designed to soften the blow of the crisis - raised general government expenditures directly as well as indirectly through increased debt financing resulting in higher interest payments. Stimulus measures are now being followed by fiscal consolidation in many countries.

This chapter describes and analyses the variation among member countries in key indicators in public finance and economics, helping to shed light on how governments are responding to fiscal pressures. It assesses trends in the size and structure of government revenues and expenditures, the costs of producing public services and goods and the role of government in providing these, as well as the magnitude of government investment. In addition, indicators on government deficits/surpluses and debts are included. Given the importance of innovation for future growth, the chapter presents recent data on government outlays on research and development as well. In order to offer insights into both longer-term trends and the impact of the economic crisis, for most indicators data are presented for 2000 (the base year), 2007 (the year prior to the start of the crisis) and the latest year for which data are available (in most cases, 2009). 
Governments raise revenues to finance the goods and services they provide and to fulfil their redistributive role. The amount of revenues collected is mainly determined by historical and current political decisions, but is also strongly influenced by economic fluctuations.

The size of government revenues varies considerably across OECD member countries, ranging from less than a quarter of gross domestic product (GDP) in Mexico to almost $60 \%$ of GDP in Norway. Nordic countries generally collect more revenues than any other group of countries, partly reflecting the fact that most social benefits to individuals and households are taxable in these countries. This is not the case in many other countries.

Government revenues as a share of GDP remained fairly stable in most countries, decreasing slightly on average across the OECD between 2000 and 2009. Only a few OECD countries experienced large changes in revenues as a share of GDP during this time period: it decreased in Israel and the Slovak Republic by 6.6 and 6.3 percentage points respectively - due to changes in tax systems - whilst it increased by 7.5 percentage points in Estonia and 5.5 percentage points in Korea. While in Estonia, the increase in the share of government revenues in GDP was caused by the fall of GDP, tax reform and an increased level of grants from the EU, in Korea it was mostly due to changes in the social security system.

The global financial and economic crisis had a strong negative impact on government revenues as a share of GDP in most OECD member countries. Between 2007 and 2009, government revenues as a share of GDP amongst OECD member countries decreased on average by 0.7 percentage points compared to an average decline of nearly 0.1 percentage points between 2000 and 2007. Iceland and Spain experienced the strongest decrease during 2007-09, by respectively 6.7 and 6.4 percentage points. The strongest increase during the same period was in Estonia (+6.5 percentage points).

The amount of revenues collected per person is an alternative way of comparing the size of government revenues across countries. Luxembourg and Norway have the highest government revenues per capita in the OECD, topping more than USD 30000 per person in 2009, reflecting the importance of cross-border workers and corporate tax in Luxembourg and oil revenues in Norway. Central European countries collect comparatively less revenues per person than most OECD countries. On average, government revenues per person grew by $1.4 \%$ a year in OECD member countries between 2000 and 2009. Two countries (Estonia and Korea) experienced real annual growth in government revenues per person greater than $6 \%$ during the same period. In comparison, real government revenues per person declined in five OECD member countries, with the largest decline in the United States (almost -1\%).

\section{Methodology and definitions}

Government revenues data are derived from the OECD National Accounts Statistics, which are based on the System of National Accounts (SNA), a set of internationally agreed concepts, definitions, classifications and rules for national accounting. Using SNA terminology, general government consists of central government, state government, local government and social security funds. Revenues encompass social contributions, taxes other than social contributions, and grants and other revenues. Gross domestic product (GDP) is the standard measure of the value of goods and services produced by a country during a period.

Government revenues per person were calculated by converting total revenues to USD 2009 using the OECD/Eurostat purchasing power parities (PPP) for GDP and dividing it by population. For the countries whose source is the IMF Economic Outlook an implied PPP conversion rate was used. PPP is the number of units of country B's currency needed to purchase the same quantity of goods and services in country A.

\section{Further reading}

OECD (2011), National Accounts at a Glance 2010, OECD Publishing, Paris.

\section{Figure notes}

Data for Australia, Japan, Korea, New Zealand and the Russian Federation are for 2008 rather than 2009. Data for Mexico are for 2003 rather than 2000. Data for the Russian Federation are for 2002 rather than 2000.

1.1: Data for 2000 for Turkey and for 2000 and 2007 for Chile are not available and these countries are not included in the average (OECD32).

1.3: Data for Chile and Turkey are not available.

Information on data for Israel: http://dx.doi.org/10.1787/888932315602. 


\subsection{General government revenues as a percentage of GDP $(2000,2007$ and 2009)}

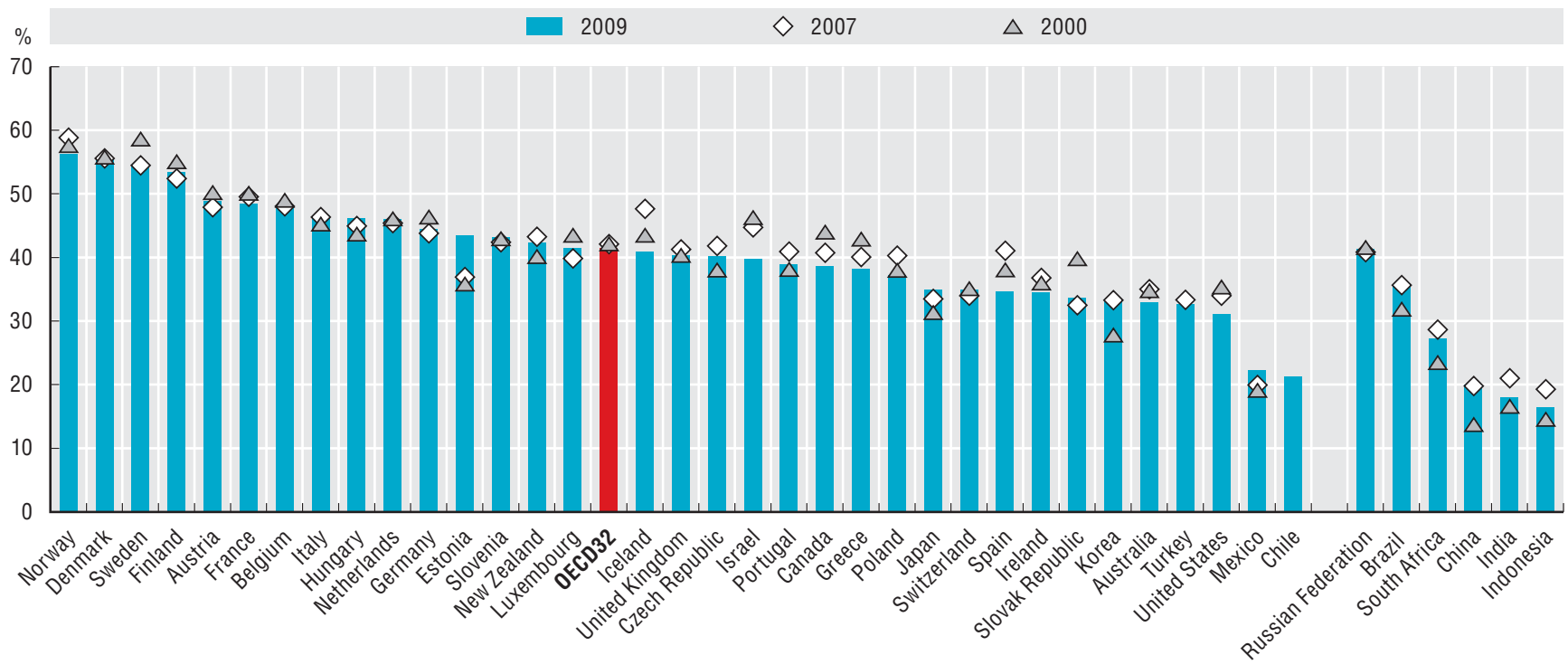

Source: For OECD countries: OECD National Accounts Statistics. For the other major economies (excluding the Russian Federation): International Monetary Fund (2010), Economic Outlook, April 2011, IMF, Washington DC.

StatLink काIsL http://dx.doi.org/10.1787/888932389664

\subsection{Government revenues} per person (2009)

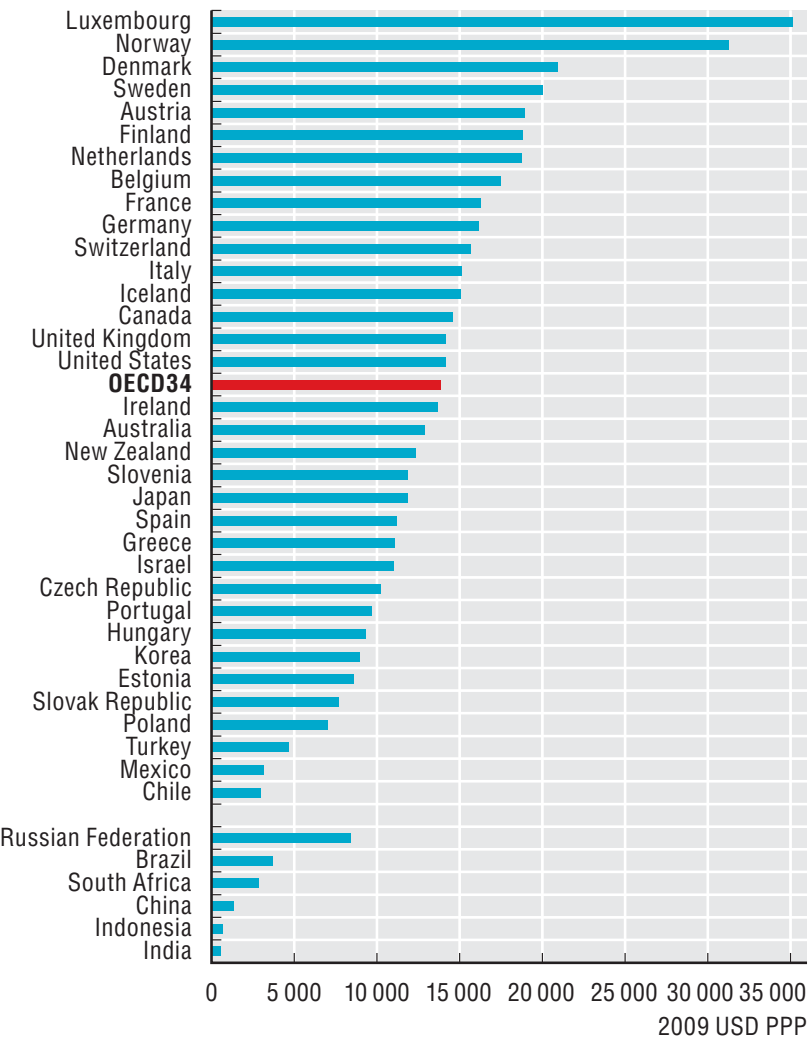

Source: For OECD countries: OECD National Accounts Statistics. For the other major economies (excluding the Russian Federation): International Monetary Fund (2010), Economic Outlook, April 2011, IMF, Washington DC.

StatLink AाIsय http://dx.doi.org/10.1787/888932389683

\subsection{Annual real percentage change of general} government revenues per person (2000 to 2009)

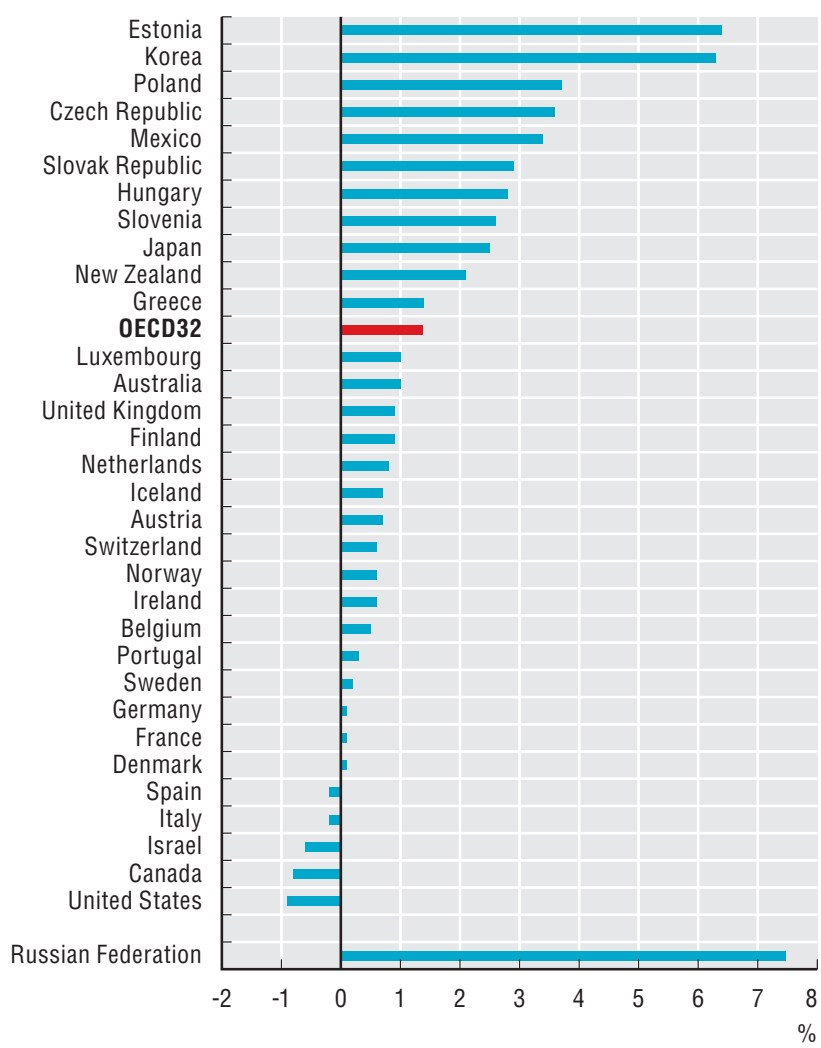

Source: OECD National Accounts Statistics.

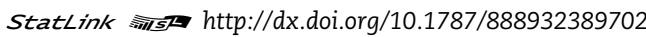


A breakdown of government revenues into its different sources can shed light on the relative contributions from citizens and/or sectors of the economy to pay for public expenditures.

Taxes other than social contributions represent the largest share of general government revenues (on average around three-fifths) in all OECD member countries. Social contributions account for approximately a quarter of total revenues, while grants and other revenues comprise the remainder. OECD member countries finance their public expenditures in different ways. Denmark, New Zealand and Australia, for example, rely mostly on taxes other than social contributions (over $80 \%$ of total revenues) and finance welfare spending through general taxation. France, Germany, Spain, the Slovak Republic and the Czech Republic are more dependent on social contributions (almost $40 \%$ of total revenues). Norway is the only country whose contribution of grants and other revenues to total revenues exceeded 25\% (mostly explained by the government pension fund which receives national petroleum profits).

Between 2007 and 2009, the share of revenues collected as taxes other than social contributions decreased on average by 2.5 percentage points, as economic activity declined and many governments cut taxes to alleviate the effects of the financial and economic crisis. Mexico, Spain and Ireland experienced the largest change in their structure of government revenues, as their share of taxes other than social contributions decreased by at least 7 percentage points.

On average, the structure of tax revenues was relatively stable in OECD member countries between 2000 and 2008. However, there is considerable variance among countries in the relative emphasis placed on different taxes. In general, taxes on income and profits constitute the largest share of tax revenues, followed by taxes on goods and services (of which value added tax (VAT) represents a significant component). Recent research (OECD, 2008) has suggested that taxes on goods and services may be less detrimental to economic growth than taxes on income and profits.

\section{Methodology and definitions}

Revenues data are derived from the OECD National Accounts Statistics, which are based on the System of National Accounts (SNA), a set of internationally agreed concepts, definitions, classifications and rules for national accounting. Using SNA terminology, general government consists of central, state, local government and social security funds. Revenues encompass taxes other than social contributions (e.g. taxes on consumption, income, wealth, property and capital), social contributions (e.g. contributions for pensions, health and social security), and grants (from foreign governments or international organisations) and other revenues (e.g. sales, fees, property income and subsidies). These aggregates are not directly available in the OECD National Accounts, and were constructed using sub-account line items (see Annex A). The data presented in 2.3 are from OECD Revenue Statistics.

There are some differences between the definitions of tax revenues used in OECD Revenue Statistics and SNA. In the SNA, taxes are compulsory unrequited payments, in cash or in kind, made by institutional units to the general government. Social contributions are actual or imputed payments to social insurance schemes to make provision for social insurance benefits. These contributions may be compulsory or voluntary and the schemes may be funded or unfunded. OECD Revenue Statistics treat compulsory social security contributions as taxes whereas the SNA considers them social contributions because the receipt of social security benefits depends, in most countries, upon appropriate contributions having been made, even though the size of the benefits is not necessarily related to the amount of the contributions.

\section{Further reading}

OECD (2008), “Taxation and Economic Growth", Economics Department Working Papers, No. 620, OECD Publishing, Paris. OECD (2010), Revenue Statistics 1965-2009, OECD Publishing, Paris.

\section{Figure notes}

2.1 and 2.2: Australia does not collect revenues via social contributions because it does not operate government social insurance schemes. Data for Australia, Japan, Korea and New Zealand are for 2008 rather than 2009. Data for the Russian Federation are for 2008 rather than 2009, and capital taxes are not available.

2.1: 2000 data for Turkey and Chile are not available and these countries are not included in the average (OECD32). Data for Mexico are for 2003 rather than 2000. Data for the Russian Federation are for 2002 rather than 2000, and capital taxes are not available.

2.2: Data for Chile are not available.

2.3: Data are not available for Estonia. For the OECD countries that are part of the European Union, total taxation includes custom duties collected on behalf of the European Union.

Information on data for Israel: $h t t p: / / d x . d o i . o r g / 10.1787 / 888932315602$. 


\section{PUBLIC FINANCE AND ECONOMICS}

2. Structure of general government revenues

\subsection{Structure of general government revenues (2000 and 2009)}

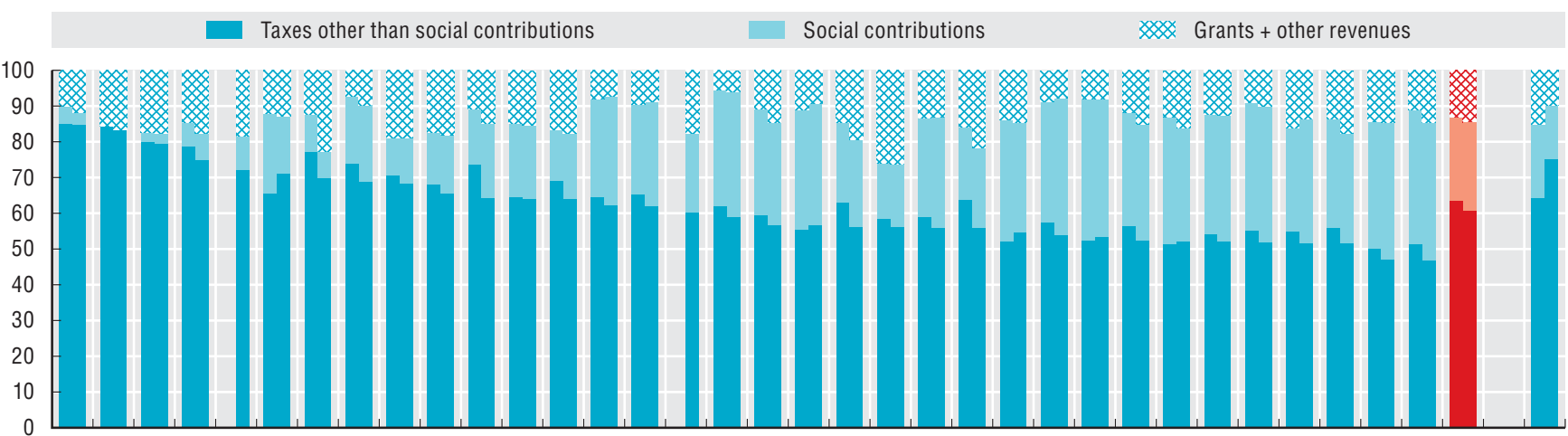

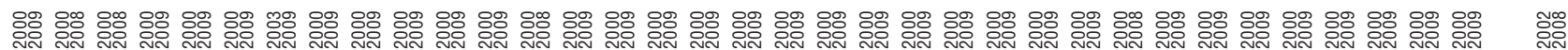

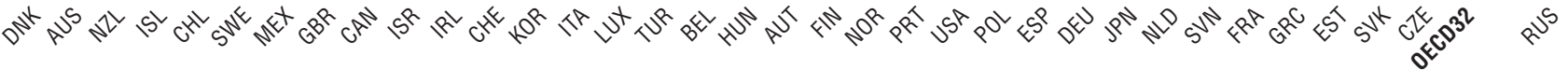

Source: OECD National Accounts Statistics.

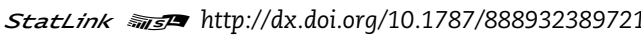

\subsection{Change in the structure of general government revenues (2007 to 2009)}

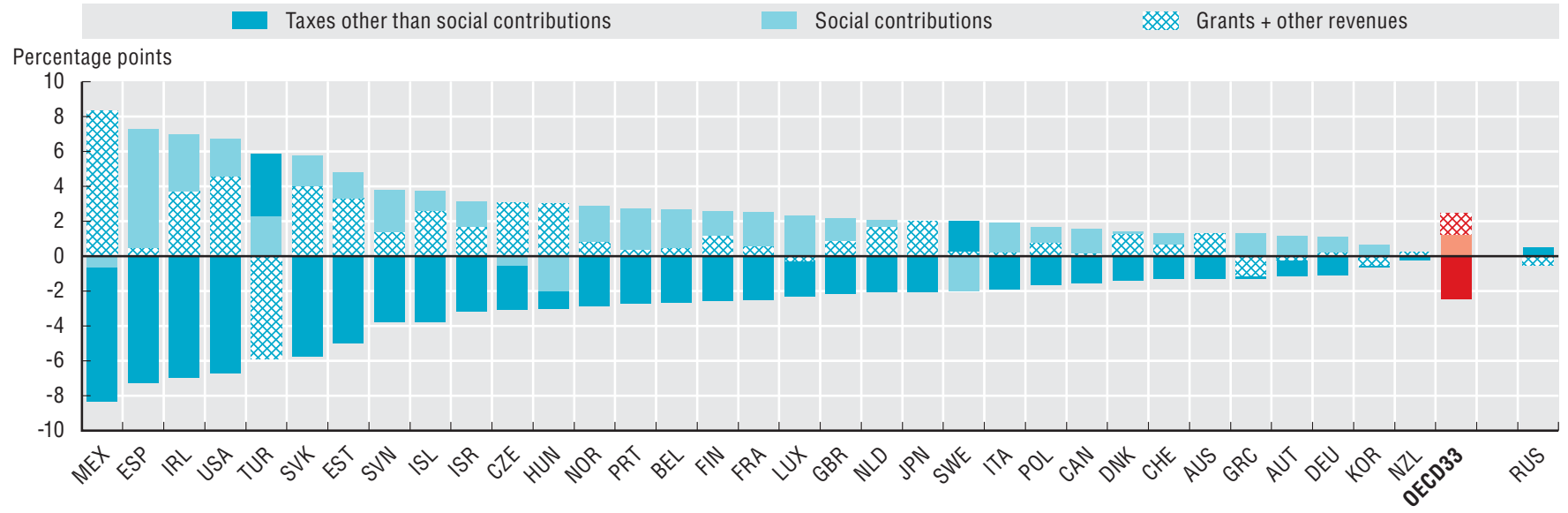

Source: OECD National Accounts Statistics.

StatLink ला1st http://dx.doi.org/10.1787/888932389740

\subsection{Breakdown of tax revenues as a percentage of total taxation (2000 and 2008)}

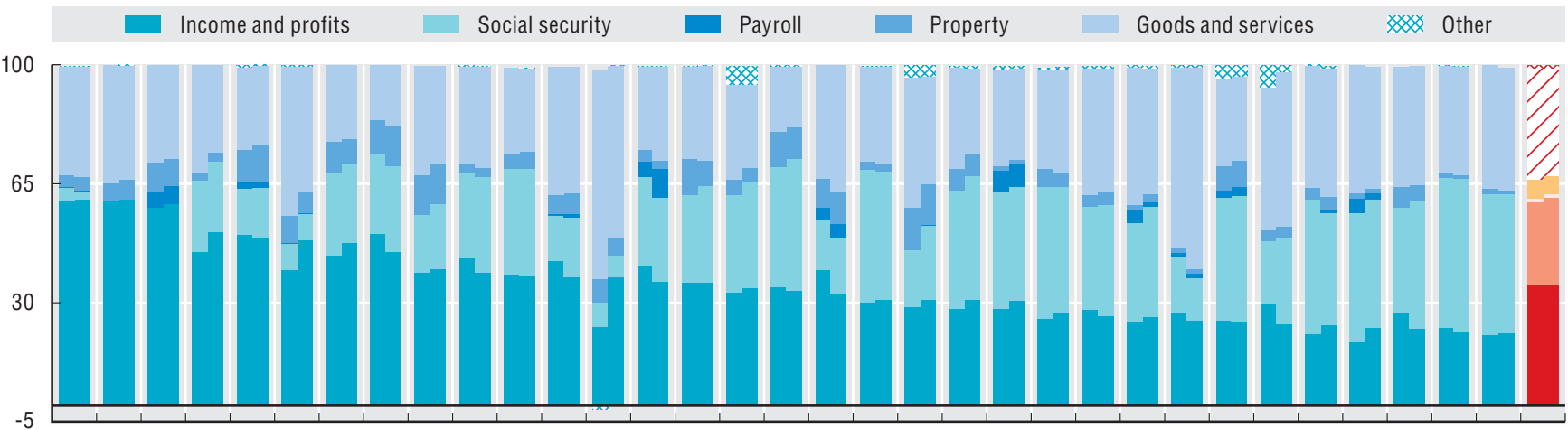

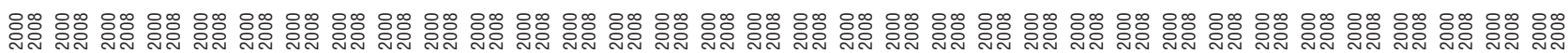

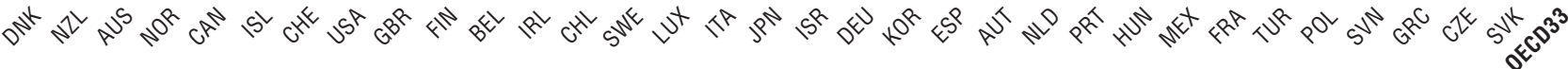


Central, state and local governments vary in terms of their ability to levy taxes and collect social contributions. Revenue transfers between levels of government illustrate the financial interdependence among different levels of government, while collected taxes can be considered a proxy of the fiscal autonomy of sub-central governments.

In most OECD member countries, central governments collect the majority of general government revenues (almost $60 \%$ on average), and this share remained fairly stable between 2000 and 2007. However, between 2007 and 2009, due to the financial and economic crisis, the percentage of total revenues collected by the central government decreased by 1.8 percentage points. Nordic countries - except Norway - as well as Japan, collect a relatively high share of revenues through their local governments (equal to or above $27 \%$ of total government revenues as compared to an OECD average of 15\%).

Taxes other than social contributions are the main source of financing of central government budgets, representing on average $77 \%$ of revenues in 2009 . In almost all countries, grants and other revenues constitute the second largest source of central government revenues, accounting for between $5 \%$ and $29 \%$. Mostly due to the financial and economic crisis, the share of central government revenues derived from taxes other than social contributions decreased in all OECD member countries, except in Sweden and Turkey, by an average of 3 percentage points between 2007 and 2009 .

In contrast to the relative homogeneity of central government revenue structures, fiscal resources available to state and local governments vary considerably. Of the OECD member countries with federal systems, German states raise the most revenues via taxes other than social contributions, representing over $70 \%$ of state finances. In contrast, Mexican states collect less than $6 \%$ of their revenues from taxes and social contributions. Intergovernmental grants and other revenues are the key feature of local governments' finances in most countries, representing over $61 \%$ of local revenues on average. Limits on sub-central governments' ability to set their own local tax bases, rates and reliefs reduce their power to generate their own revenue sources and potentially their ability to provide more tailored public services.

\section{Methodology and definitions}

Revenues data are derived from the OECD National Accounts Statistics, which are based on the System of National Accounts (SNA), a set of internationally agreed concepts, definitions, classifications and rules for national accounting. Using SNA terminology, general government consists of central, state and local governments, and social security funds. State government is only applicable to the nine OECD member countries that are federal states: Australia, Austria, Belgium, Canada, Germany, Mexico, Spain (considered a de facto federal state in the National Accounts data), Switzerland and the United States. Data in 3.1 and 3.2 (on line) exclude transfers between levels of government, except for Australia and Japan. Figure 3.2 "Distribution of general government revenues across levels of government (2007 and 2009)" as well as Figures 3.3, 3.4 and 3.5 (structure of central, state and local government revenues) are available on line at: $h t t p: / / d x . d o i . o r g / 10.1787 / 888932389797$, http:// dx.doi.org/10.1787/888932389816, http://dx.doi.org/ 10.1787/888932389835, http://dx.doi.org/10.1787/ 888932389854 respectively.

Revenues encompass taxes (e.g. taxes on consumption, income, wealth, property and capital), social contributions (e.g. contributions for pensions, health and social security), and grants and other revenues. Grants can be from foreign governments, international organisations or other general government units. Other revenues include sales, fees, property income and subsidies. These aggregates are not directly available in the OECD National Accounts, and were constructed using sub-account line items (see Annex A).

\section{Further reading}

OECD (2010), “OECD Network on Fiscal Relations across Levels of Government - Fiscal Policy across Levels of Government in Times of Crisis", OECD Working Paper, OECD Publishing, Paris.

OECD (2010), “OECD Network on Fiscal Relations across Levels of Government - Tax Competition between Sub-Central Governments: Main Issues", OECD Working Paper, OECD Publishing, Paris.

\section{Figure notes}

Australia does not operate government social insurance schemes; central government refers to commonwealth and multi-jurisdictional sector. Local government is included in state government for the United States. Social security funds are included in central government in New Zealand, Norway, the United Kingdom and the United States. Data for Chile, Mexico and Turkey are not available. Data for Australia, Japan, Israel, Korea and New Zealand are for 2008 rather than 2009.

Information on data for Israel: $h t t p: / / d x$.doi.org/10.1787/888932315602. 


\section{PUBLIC FINANCE AND ECONOMICS}

3. Revenue structure by level of government

3.1 Structure of general government revenues across levels of government (2000 and 2009)

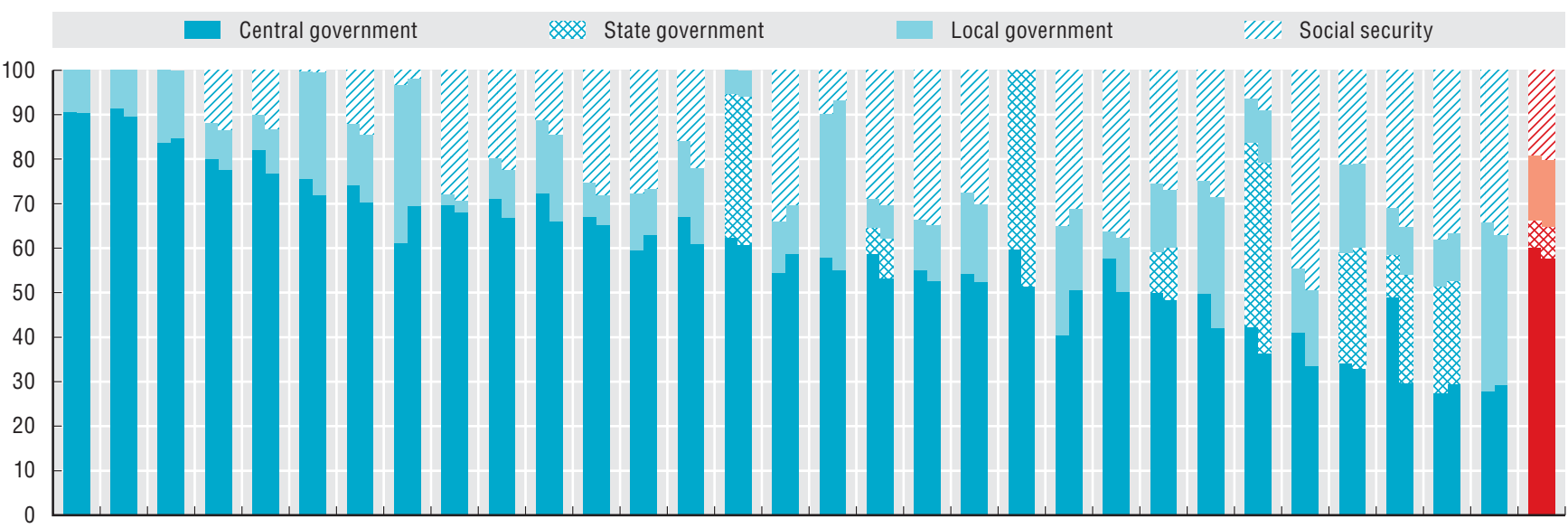

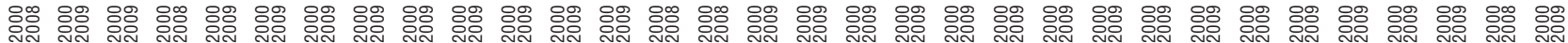

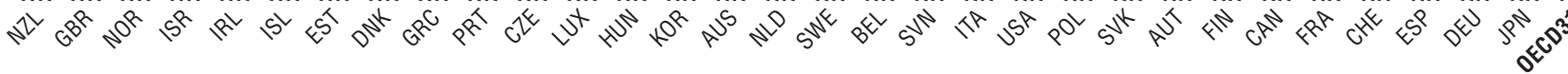

Source: OECD National Accounts Statistics.

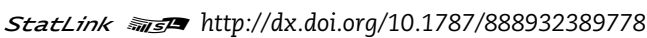


Governments spend money to provide goods and services and redistribute income. Like government revenues, government expenditures reflect historical and current political decisions but are also highly sensitive to economic developments. General government spending as a share of GDP and per person provide an indication of the size of the government across countries. However, the large variation in these ratios highlights different approaches to delivering public goods and services and providing social protection, not necessarily differences in resources spent. For instance, if support is given via tax breaks rather than direct expenditures, expenditure/GDP ratios will naturally be lower. In addition, it is important to note that the size of expenditures does not reflect government efficiency or productivity.

Government expenditures represented $46 \%$ of GDP across OECD member countries in 2009. In general, OECD-EU member countries have a higher ratio than other OECD member countries. Denmark, Finland and France spend the most as a share of GDP, with government expenditures equal to or above $56 \%$, whereas Mexico, Chile, Korea and Switzerland spend the least, with shares between $24 \%$ and $34 \%$ of GDP.

Since 2000 , the size of government spending increased in the majority of OECD member countries by an average of 4.3 percentage points of GDP. Most of this increase occurred since the start of the financial and economic crisis. Between 2000 and 2007, OECD member countries decreased their share of government spending on average by 0.6 percentage points of GDP. After the start of crisis, the share of government spending increased by 4.9 percentage points across the OECD during 2007-09. Only part of this increase reflects declining GDP; part also reflects increased government expenditures precipitated by the need to ensure the stability of the financial system and to stimulate the economy in response to the crisis. During 2007-09, the largest increases in government expenditures as a share of GDP occurred in Ireland (+12.1 percentage points) and Estonia (+10.8 percentage points), whereas Israel was the only OECD member country that recorded a decrease in the ratio (-0.7 percentage points).

The difference in government expenditures per person is very large between OECD member countries. Luxembourg spends almost eleven times more per person than Mexico, although expenditures per person in Mexico have been increasing at an above average pace. Though government expenditures per person rose in all OECD member countries except Israel since 2000, there have been significant differences between countries. Between 2000 and 2009, the largest increases in government expenditures per person were recorded in Korea, Estonia and Ireland (over 6\%) while in Austria, Italy, Japan and Switzerland the increases were equal to or below 1\%; and in Israel there was no change.

\section{Methodology and definitions}

Government expenditures data are derived from the OECD National Accounts Statistics, which are based on the System of National Accounts (SNA), a set of internationally agreed concepts, definitions, classifications and rules for national accounting. In SNA terminology, general government consists of central, state and local governments and social security funds.

Gross domestic product (GDP) is the standard measure of the value of the goods and services produced by a country during a period. Government expenditures per person were calculated by converting total government expenditures to USD 2009 using the OECD/Eurostat purchasing power parities (PPP) for GDP and dividing by population (for the countries whose source is the IMF Economic Outlook an implied PPP conversion rate was used). PPP is the number of units of country B's currency needed to purchase the same quantity of goods and services in country A.

\section{Further reading}

OECD (2011), National Accounts at a Glance 2010, OECD Publishing, Paris.

\section{Figure notes}

Data for Australia, Japan, Korea, New Zealand and the Russian Federation are for 2008 rather than 2009. Data for Mexico are for 2003 rather than 2000. Data for the Russian Federation are for 2002 rather than 2000.

4.1: Data for 2000 for Turkey and for 2000 and 2007 for Chile are not available and these countries are not included in the average (OECD32).

4.3: Data for Chile and Turkey are not available.

Information on data for Israel: $h t t p: / / d x . d o i . o r g / 10.1787 / 888932315602$. 


\subsection{General government expenditures as a percentage of GDP $(2000,2007$ and 2009)}

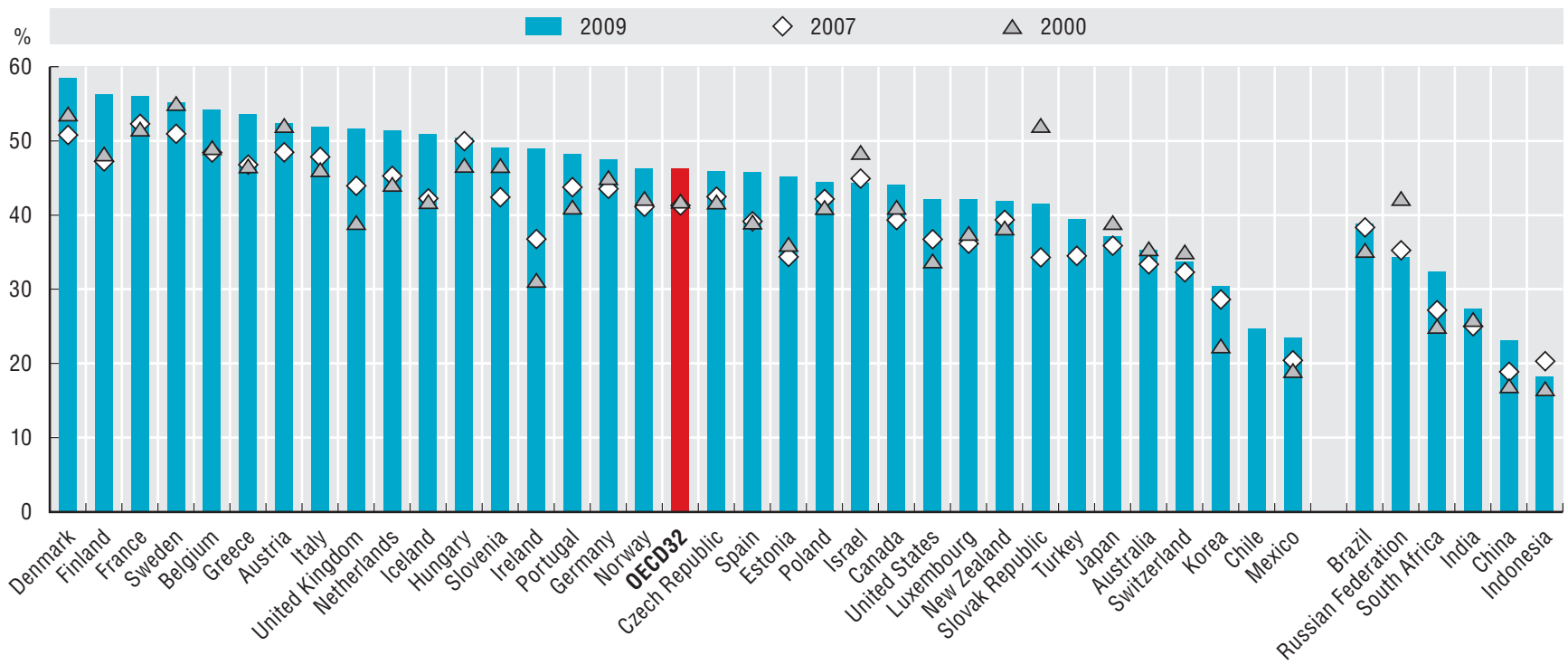

Source: For OECD countries: OECD National Accounts Statistics. For the other major economies (excluding the Russian Federation): International Monetary Fund (2010), Economic Outlook, April 2011, IMF, Washington DC.

\subsection{General government expenditures per person (2009)}

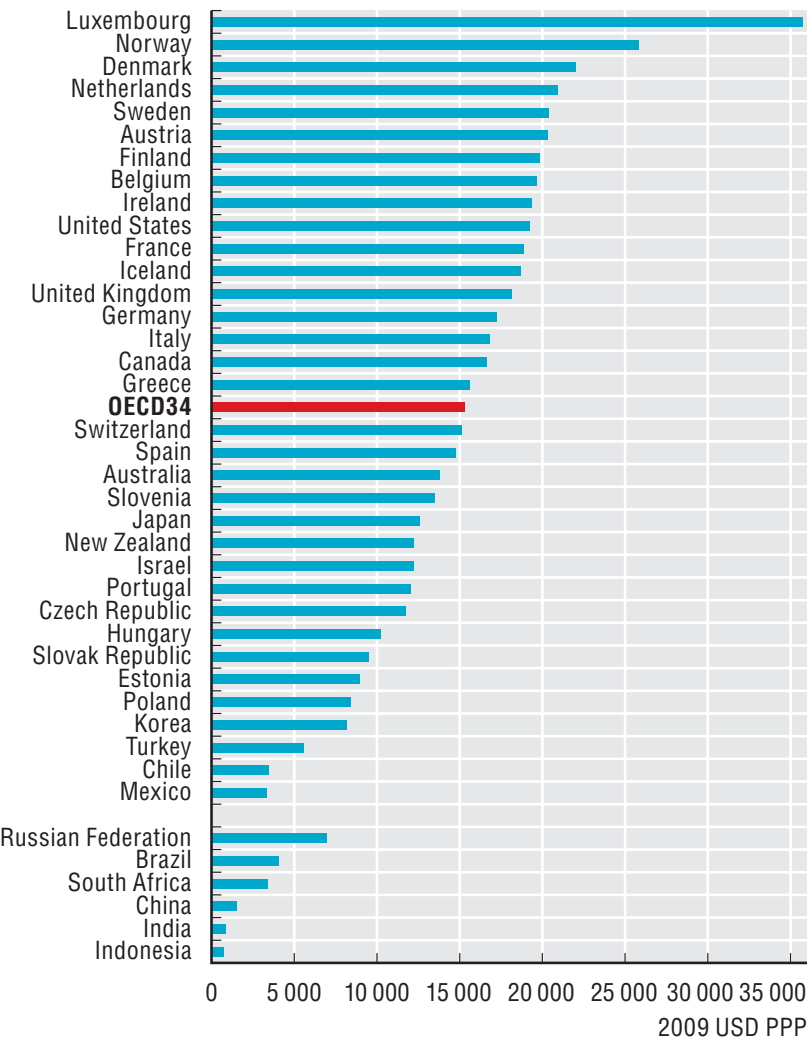

Source: For OECD countries: OECD National Accounts Statistics. For the other major economies (excluding the Russian Federation): International Monetary Fund (2010), Economic Outlook, April 2011, IMF, Washington DC.

StatLink AाIsय http://dx.doi.org/10.1787/888932389892
4.3 Annual real percentage change of general government expenditures per person (2000 to 2009)

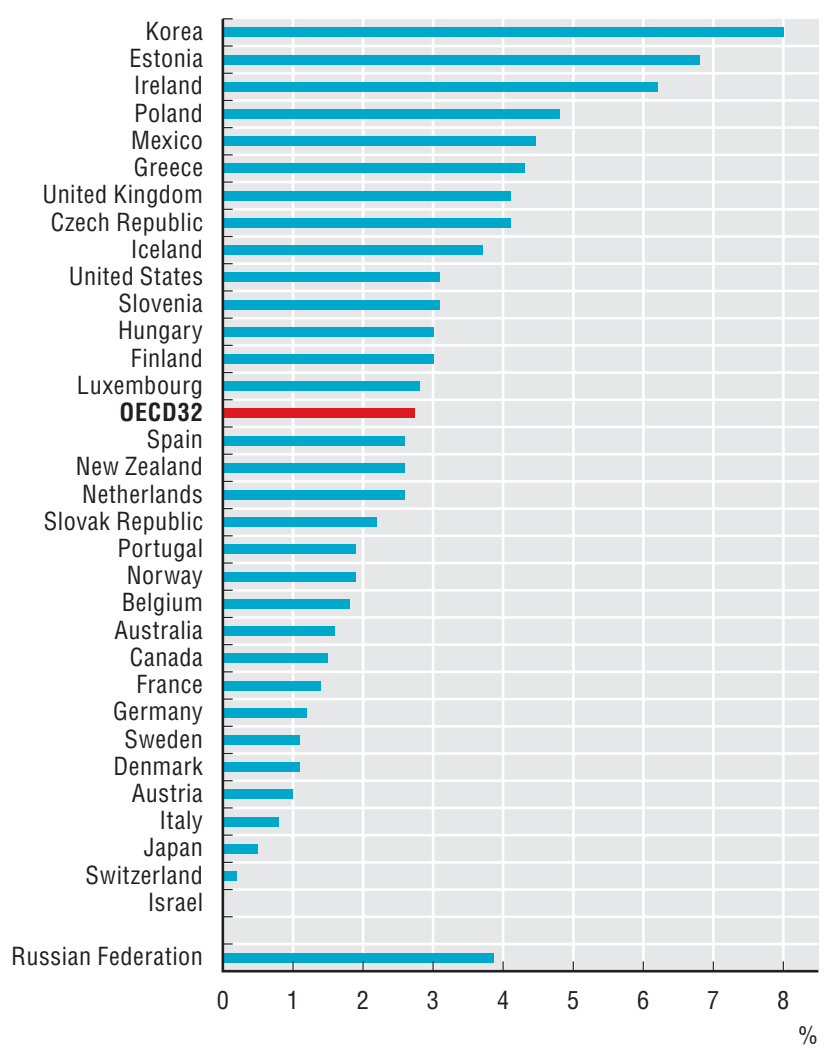

Source: OECD National Accounts Statistics.

StatLink क्ञाज्ड http://dx.doi.org/10.1787/888932389911 
Governments finance a variety of public goods and services, from providing unemployment benefits to building new schools to subsidising alternative energy sources. For OECD-EU member countries, common EU policy goals regarding economic growth, agriculture, energy, infrastructure, and research and development (among others) may also affect the structure of expenditures.

The variance among countries in their expenditure structure is mainly explained by different choices concerning the redistributive role of government in providing social protection (e.g. unemployment benefits, old age pensions and disability benefits). Social protection is the largest category of expenses in all countries (representing on average $34 \%$ of total expenditures in 2008) except three: Iceland and Korea spend most on economic affairs (which includes support for the banking system in Iceland and for other industries in Korea); and the United States spends most on health (data reflect the situation prior to the recent reform). However, other factors, such as an ageing population or a high level of national debt requiring substantial amounts of interest payments, also influence the structure of general government expenditures.

Aside from social protection, OECD member countries spend the most on health, general public services (which include interest payments on debt) and education. Defence spending as a share of total expenditures is notably high in Israel and the United States compared to other OECD member countries. Switzerland devotes a relatively smaller share of expenditures to health (indicating a larger role for private spending in this area) whereas Greece has relatively low levels of public spending on education. In general, OECD member countries spend the least (on average less than $2 \%$ ) on environmental protection and housing and community amenities.

The share of resources devoted to different policy sectors has shifted since the early 2000s. As of 2008, OECD member countries spend a larger proportion of their resources on health (+1.7 percentage points), economic affairs $(+0.4$ percentage points) and social protection ( +0.5 percentage points) compared to 2000. The spending increase on economic affairs and social protection are most likely due to the impact of the financial and economic crisis whereas an ageing population likely accounts for the shift of resources towards health. On average, the proportional increases in funds allocated to health, economic affairs and social protection were balanced by proportional decreases in general public services ( -2.2 percentage points) and defence ( -0.4 percentage points). Iceland and the Slovak Republic experienced the strongest change in their structure of government expenditures during this period whereas Luxembourg and Slovenia maintained a relatively stable structure.

\section{Methodology and definitions}

Expenditures data are derived from the OECD National Accounts Statistics, which are based on the System of National Accounts (SNA), a set of internationally agreed concepts, definitions, classifications and rules for national accounting. Data represent government expenditures in 2008, the latest data available for a majority of OECD member countries at the time of writing. Data on expenditures are disaggregated according to the Classification of the Functions of Government (COFOG), which divides government spending into ten functions: general public services; defence; public order and safety; economic affairs; environmental protection; housing and community amenities; health; recreation culture and religion; education; and social protection. Further information about the types of expenditures included in each category is available in Annex B. General government consists of central, state and local governments and social security funds. Data in 5.3 (available online at: http://dx.doi.org/10.1787/888932391830) and 5.4 (available online at: $h t t p: / / d x . d o i . o r g / 10.1787 / 888932391849)$ illustrate general government expenditures by function as a percentage of GDP in 2008 and the change from 2000 to 2008.

\section{Further reading}

OECD (2009a), Health at a Glance 2009: OECD Indicators, OECD Publishing, Paris.

OECD (2010), Education at a Glance 2010: OECD Indicators, OECD Publishing, Paris.

OECD (forthcoming), Society at a Glance 2011: OECD Social Indicators, OECD Publishing, Paris.

\section{Table notes}

Data for Chile, Mexico and Turkey are not available. Data for Canada are for 2006 rather than 2008.

5.1: Data for New Zealand are for 2005.

5.2: Times series data are not available for New Zealand and Switzerland. Data for Poland are for 2002 rather than 2000.

Information on data for Israel: http://dx.doi.org/10.1787/888932315602. 
5.1 Structure of general government expenditures by function (2008)

\begin{tabular}{|c|c|c|c|c|c|c|c|c|c|c|}
\hline & $\begin{array}{l}\text { General public } \\
\text { services }\end{array}$ & Defence & $\begin{array}{l}\text { Public order } \\
\text { and safety }\end{array}$ & $\begin{array}{l}\text { Economic } \\
\text { affairs }\end{array}$ & $\begin{array}{l}\text { Environmental } \\
\text { protection }\end{array}$ & $\begin{array}{l}\text { Housing and community } \\
\text { amenities }\end{array}$ & Health & $\begin{array}{l}\text { Recreation, culture } \\
\text { and religion }\end{array}$ & Education & $\begin{array}{c}\text { Social } \\
\text { protection }\end{array}$ \\
\hline Australia & 10.1 & 4.2 & 4.8 & 11.4 & 1.9 & 2.4 & 18.1 & 2.2 & 14.1 & 30.8 \\
\hline Austria & 13.1 & 2.0 & 3.0 & 10.0 & 0.9 & 1.2 & 15.9 & 2.1 & 10.9 & 40.9 \\
\hline Belgium & 16.9 & 2.2 & 3.5 & 10.8 & 1.2 & 0.7 & 14.7 & 2.5 & 11.9 & 35.6 \\
\hline Canada & 18.6 & 2.6 & 4.0 & 8.6 & 1.4 & 2.3 & 18.7 & 2.3 & 18.3 & 23.4 \\
\hline Czech Republic & 10.4 & 2.6 & 4.8 & 16.8 & 2.3 & 2.6 & 16.8 & 2.9 & 10.9 & 30.0 \\
\hline Denmark & 13.1 & 2.9 & 2.1 & 5.2 & 1.0 & 1.1 & 14.9 & 3.1 & 13.4 & 43.3 \\
\hline Estonia & 7.3 & 4.4 & 6.9 & 12.1 & 2.7 & 1.6 & 13.1 & 5.8 & 16.9 & 29.4 \\
\hline Finland & 13.4 & 3.0 & 2.7 & 9.5 & 0.6 & 0.9 & 14.3 & 2.3 & 12.0 & 41.3 \\
\hline France & 13.6 & 3.3 & 2.4 & 5.4 & 1.6 & 3.6 & 14.8 & 2.9 & 11.1 & 41.4 \\
\hline Germany & 13.6 & 2.4 & 3.6 & 7.6 & 1.0 & 1.7 & 14.3 & 1.4 & 9.3 & 45.1 \\
\hline Greece & 19.8 & 6.2 & 3.4 & 11.4 & 1.3 & 0.7 & 11.4 & 1.2 & 8.3 & 36.5 \\
\hline Hungary & 18.8 & 1.8 & 4.2 & 12.0 & 1.8 & 1.8 & 10.0 & 2.9 & 10.7 & 36.2 \\
\hline Iceland & 11.3 & 0.1 & 2.6 & 33.8 & 1.2 & 0.9 & 13.7 & 6.6 & 14.5 & 15.5 \\
\hline Ireland & 7.9 & 1.2 & 4.3 & 13.8 & 2.9 & 4.7 & 18.3 & 2.1 & 12.6 & 32.3 \\
\hline Israel & 12.7 & 16.4 & 3.8 & 6.1 & 1.5 & 1.2 & 12.4 & 3.8 & 16.7 & 25.5 \\
\hline Italy & 18.3 & 2.9 & 3.8 & 7.8 & 1.8 & 1.5 & 14.6 & 1.7 & 9.3 & 38.5 \\
\hline Japan & 12.8 & 2.5 & 3.9 & 10.0 & 3.3 & 1.6 & 20.1 & 0.3 & 10.5 & 35.0 \\
\hline Korea & 14.1 & 8.9 & 4.4 & 21.8 & 3.2 & 3.6 & 13.0 & 2.5 & 16.3 & 12.4 \\
\hline Luxembourg & 10.8 & 0.7 & 2.4 & 11.4 & 2.6 & 1.7 & 12.0 & 4.6 & 11.8 & 42.1 \\
\hline Netherlands & 16.1 & 2.9 & 4.0 & 10.7 & 1.8 & 2.1 & 12.7 & 2.9 & 11.6 & 35.2 \\
\hline New Zealand & 13.3 & 2.6 & 4.9 & 10.5 & 3.3 & 1.8 & 16.6 & 2.8 & 18.6 & 25.8 \\
\hline Norway & 10.8 & 3.9 & 2.2 & 9.2 & 1.5 & 1.6 & 16.9 & 2.8 & 13.0 & 38.2 \\
\hline Poland & 12.6 & 3.2 & 4.5 & 11.5 & 1.4 & 2.7 & 11.7 & 3.0 & 13.3 & 36.1 \\
\hline Portugal & 16.1 & 2.8 & 4.5 & 6.5 & 1.5 & 1.6 & 14.4 & 2.4 & 14.3 & 35.9 \\
\hline Slovak Republic & 10.5 & 3.8 & 6.3 & 14.4 & 1.9 & 1.9 & 19.7 & 2.6 & 9.9 & 29.0 \\
\hline Slovenia & 11.6 & 3.2 & 3.6 & 10.7 & 1.8 & 1.9 & 13.8 & 3.7 & 13.8 & 35.9 \\
\hline Spain & 11.3 & 2.5 & 4.9 & 12.6 & 2.2 & 2.6 & 14.7 & 4.1 & 11.2 & 33.9 \\
\hline Sweden & 14.8 & 2.8 & 2.6 & 8.2 & 0.7 & 1.5 & 13.3 & 2.2 & 13.2 & 40.7 \\
\hline Switzerland & 12.0 & 2.6 & 5.1 & 12.8 & 1.6 & 0.6 & 5.4 & 2.3 & 17.1 & 40.7 \\
\hline United Kingdom & 9.5 & 5.4 & 5.5 & 10.2 & 2.0 & 2.5 & 15.8 & 2.3 & 13.5 & 33.5 \\
\hline United States & 12.7 & 11.9 & 5.8 & 10.6 & 0.0 & 1.8 & 20.5 & 0.8 & 16.6 & 19.4 \\
\hline OECD31 & 13.1 & 3.8 & 4.0 & 11.4 & 1.7 & 1.9 & 14.7 & 2.7 & 13.1 & 33.5 \\
\hline
\end{tabular}

Source: OECD National Accounts Statistics. Data for Australia are based on Government Finance Statistics provided by the Australian Bureau of Statistics. StatLink 角实 http://dx.doi.org/10.1787/888932391792

5.2 Change in the structure of general government expenditures by function (2000 to 2008)

\begin{tabular}{|c|c|c|c|c|c|c|c|c|c|c|}
\hline & $\begin{array}{c}\text { General public } \\
\text { services }\end{array}$ & Defence & $\begin{array}{l}\text { Public order } \\
\text { and safety }\end{array}$ & $\begin{array}{l}\text { Economic } \\
\text { affairs }\end{array}$ & $\begin{array}{l}\text { Environmental } \\
\text { protection }\end{array}$ & $\begin{array}{l}\text { Housing and community } \\
\text { amenities }\end{array}$ & Health & $\begin{array}{l}\text { Recreation, culture } \\
\text { and religion }\end{array}$ & Education & $\begin{array}{c}\text { Social } \\
\text { protection }\end{array}$ \\
\hline Australia & -3.6 & -0.1 & 0.4 & -0.8 & 0.4 & 0.2 & 2.0 & -0.3 & -0.1 & 1.8 \\
\hline Austria & -2.0 & 0.2 & 0.1 & 1.7 & -0.1 & -0.3 & 0.1 & 0.3 & -0.4 & 0.4 \\
\hline Belgium & -5.1 & -0.3 & 0.4 & 1.4 & -0.3 & -0.1 & 1.9 & 0.5 & 0.4 & 1.0 \\
\hline Canada & -5.5 & -0.2 & 0.1 & 0.1 & 0.1 & 0.2 & 4.3 & 0.1 & 0.5 & 0.3 \\
\hline Czech Republic & 0.5 & -1.5 & -0.8 & -0.8 & 0.0 & -0.1 & 3.1 & 0.5 & 1.0 & -2.0 \\
\hline Denmark & -2.5 & -0.1 & 0.3 & -1.1 & -0.1 & -0.4 & 2.7 & 0.2 & -0.3 & 1.3 \\
\hline Estonia & -2.9 & 0.5 & -0.5 & 1.5 & 1.2 & 0.1 & 1.3 & 0.6 & -1.6 & -0.2 \\
\hline Finland & -1.0 & 0.1 & -0.1 & -0.3 & 0.0 & -0.1 & 2.4 & -0.1 & -0.2 & -0.6 \\
\hline France & -1.2 & -0.7 & 0.1 & -0.9 & 0.3 & 0.4 & 1.0 & 0.7 & -1.2 & 1.5 \\
\hline Germany & 5.0 & -0.3 & -0.1 & -1.6 & -0.4 & -0.6 & 0.7 & -0.2 & 0.0 & -2.5 \\
\hline Greece & -3.9 & -2.4 & 1.9 & -1.4 & 0.1 & -0.1 & 3.0 & 0.6 & 2.2 & 0.0 \\
\hline Hungary & -2.0 & -0.6 & -0.1 & -1.5 & 0.4 & -0.3 & -0.4 & -0.1 & -0.3 & 4.9 \\
\hline Iceland & -3.3 & 0.1 & -1.0 & 17.6 & -0.6 & 0.0 & -5.4 & -1.1 & -3.4 & -2.9 \\
\hline Ireland & -4.7 & -0.8 & -0.7 & 1.1 & 0.3 & 0.1 & 0.8 & 0.2 & -1.2 & 5.0 \\
\hline Israel & -2.8 & -0.6 & 0.6 & 0.0 & 0.3 & -0.6 & 0.9 & 0.2 & 1.0 & 1.0 \\
\hline Italy & -2.8 & 0.5 & -0.5 & 1.9 & 0.0 & -0.4 & 1.6 & -0.1 & -0.8 & 0.6 \\
\hline Japan & -3.6 & 0.0 & 0.1 & -4.0 & -1.5 & -0.8 & 3.5 & -0.2 & -0.2 & 6.6 \\
\hline Korea & 0.5 & -2.9 & -1.4 & -0.7 & 0.1 & -0.4 & 3.1 & -0.3 & -1.1 & 3.3 \\
\hline Luxembourg & -1.9 & 0.0 & 0.1 & 0.3 & -0.3 & -0.3 & 1.1 & 0.4 & 0.3 & 0.4 \\
\hline Netherlands & -3.4 & -0.8 & 0.8 & 0.9 & -0.1 & -0.1 & 4.3 & -0.3 & 1.0 & -2.4 \\
\hline Norway & 1.4 & -0.5 & -0.1 & -2.3 & -0.3 & 0.2 & 0.6 & 0.3 & -0.4 & 1.2 \\
\hline Poland & -1.0 & 0.5 & 1.1 & 3.5 & 0.1 & -1.0 & 1.9 & 0.6 & -0.5 & -5.3 \\
\hline Portugal & 1.9 & -1.0 & 0.5 & -4.6 & -0.1 & -0.8 & -0.8 & -0.5 & -1.2 & 6.6 \\
\hline Slovak Republic & -7.2 & -0.5 & 1.1 & -6.8 & -0.7 & -0.5 & 9.7 & 0.7 & 3.0 & 1.2 \\
\hline Slovenia & -1.2 & 0.8 & -0.4 & -0.3 & 0.4 & 0.5 & 0.0 & 1.0 & 0.4 & -1.2 \\
\hline Spain & -3.0 & -0.3 & 0.5 & 0.5 & 0.4 & -0.4 & 1.3 & 0.5 & 0.0 & 0.5 \\
\hline Sweden & -2.4 & -1.4 & 0.3 & 1.5 & 0.2 & -0.2 & 2.3 & 0.3 & 1.0 & -1.4 \\
\hline United Kingdom & -2.2 & -1.0 & -0.2 & 5.3 & 0.3 & 0.6 & 1.3 & -0.3 & 0.7 & -4.4 \\
\hline United States & -3.5 & 2.5 & -0.1 & -0.3 & 0.0 & 0.2 & 2.3 & -0.1 & -0.9 & -0.1 \\
\hline OECD29 & -2.2 & -0.4 & 0.1 & 0.4 & 0.0 & -0.2 & 1.7 & 0.1 & -0.1 & 0.5 \\
\hline
\end{tabular}

Source: OECD National Accounts Statistics. Data for Australia are based on Government Finance Statistics provided by the Australian Bureau of Statistics. 
The responsibility for financing public goods and services and redistributing income is shared between different levels of government. For example, in some countries, policing is financed by local governments while in others it is funded by central government. In some cases, the provision of goods and services is jointly funded by central, state and/or local governments.

Across the OECD, in $2009,46 \%$ of general government expenditures were undertaken by central government. Sub-central governments (state and local) covered $32 \%$ and social security funds accounted for the remaining share. However, the level of fiscal decentralisation varies considerably. For example, in New Zealand (a unitary state), almost $90 \%$ of total spending is by central government. In contrast, central government accounts for less than $15 \%$ of total expenditures in Switzerland, a federal state where regional and local governments play a much larger role in financing the public goods and services that they deliver themselves.

In general, central governments spend a relatively larger proportion of their budgets on social protection (e.g. pensions and unemployment benefits), general public services (e.g. executive and legislative organs, public debt transactions) and defence compared to sub-central governments. Expenditures on social protection represent the largest share of central government budgets for over half of OECD member countries. The central governments of Spain and Belgium allocate most of their budgets to general public services, accounting for over $50 \%$ of total expenditures. Defence accounts for $6 \%$ of central government expenditures on average. Education, recreation, environmental protection, and housing and community amenities are mostly financed by sub-central governments.

In the past decade, some countries have become more fiscally decentralised. The share of expenditures attributed to sub-central governments rose in several countries including - Canada, the Czech Republic, Denmark, Finland, Poland, the Slovak Republic, Slovenia, Spain, Sweden and Switzerland - between 2000 and 2009. The Slovak Republic, for example, transferred responsibilities for the execution of certain policies and programmes from central to local governments beginning in 2002 accompanied by fiscal decentralisation in 2005.

\section{Methodology and definitions}

Expenditures data are derived from the OECD National Accounts Statistics, which are based on the System of National Accounts (SNA), a set of internationally agreed concepts, definitions, classifications and rules for national accounting. Data on expenditures are disaggregated according to the Classification of the Functions of Government (COFOG), which divides government spending into ten functions: general public services; defence; public order and safety; economic affairs; environmental protection; housing and community amenities; health; recreation, culture and religion; education; and social protection. Further information about the types of expenditures included in each category is available in Annex B. General government consists of central, state and local governments and social security funds. State government is only applicable to the nine OECD member countries that are federal states: Australia, Austria, Belgium, Canada, Germany, Mexico, Spain (considered a de facto federal state in the National Accounts data), Switzerland and the United States.

Data in 6.1 and 6.2 (distribution of general government expenditures across levels of government in 2007 and 2009) exclude transfers between levels of government and thus provide a rough proxy of the overall responsibility for providing goods and services borne by each level of government. However, data on expenditures at the central, state and local levels $(6.3,6.4$ and 6.5) include transfers between the different levels of government and therefore illustrate how much is spent on each function at each level of government. Figure 6.2 (http://dx.doi.org/10.1787/888932389949), and Tables 6.3 (http://dx.doi.org/10.1787/888932391868), 6.4 (http://dx.doi.org/10.1787/888932391887) and 6.5 (http:// $d x$.doi.org/10.1787/888932391906) are available online.

\section{Further reading}

OECD (2011), National Accounts at a Glance 2010, OECD Publishing, Paris.

\section{Figure notes}

6.1: Australia does not operate government social insurance schemes; central government refers to commonwealth and multi-jurisdictional sector. Data for Australia and Japan include transfers between levels of government. Local government is included in state government for the United States. Social security funds are included in central government in New Zealand, Norway, the United Kingdom and the United States. Data for Chile, Mexico and Turkey are not available. Data for Australia, Japan, Israel, Korea and New Zealand are for 2008 rather than 2009.

Information on data for Israel: http://dx.doi.org/10.1787/888932315602. 


\section{PUBLIC FINANCE AND ECONOMICS}

6. Expenditures structure by level of government

6.1 Distribution of general government expenditures across levels of government (2000 and 2009)

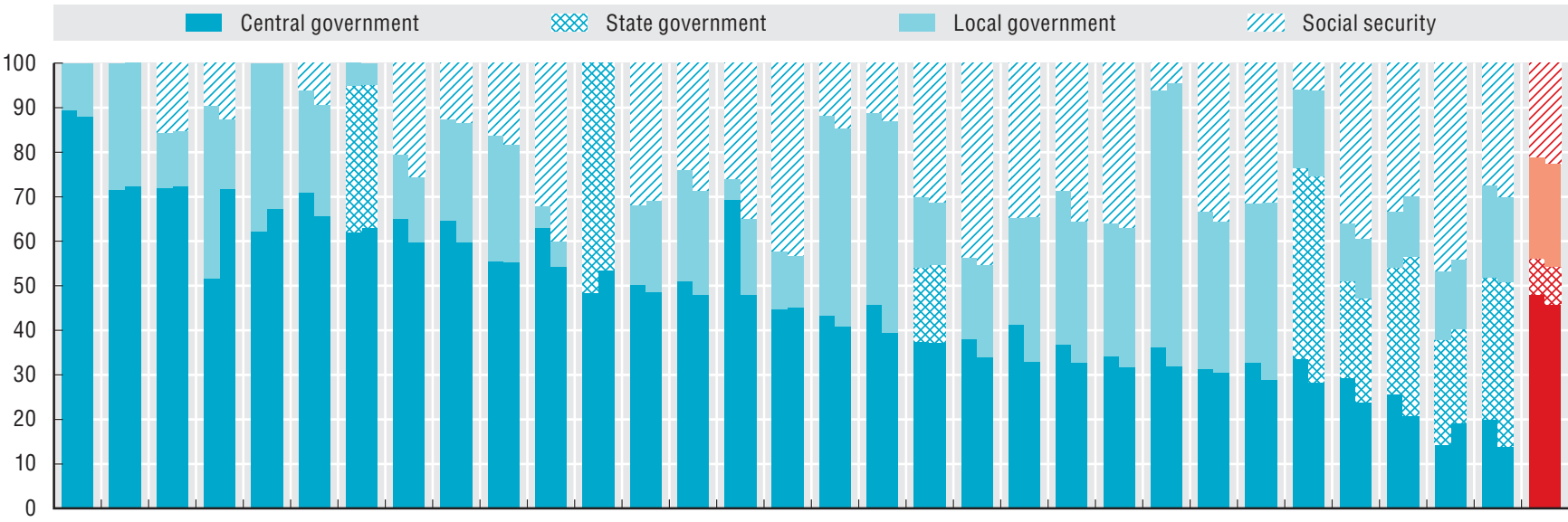

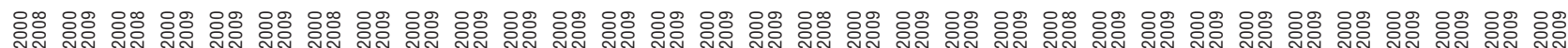

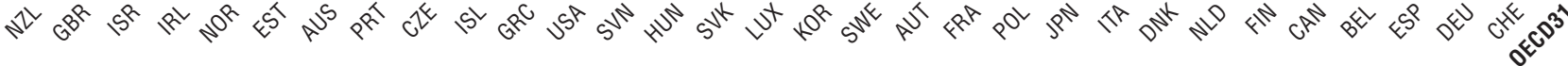

Source: OECD National Accounts Statistics. 


\section{PUBLIC FINANCE AND ECONOMICS}

Traditional tasks of government are defence, maintenance of public order and safety, and the construction and maintenance of infrastructure. The goods that the government provides in these areas are known as "collective goods". Tasks of government that have come to the fore in connection with the development of the welfare state, such as health, education, social services and social benefits, are known as "individual goods" and have accounted for a larger share of spending since the 1950s in most OECD countries.

Cash transfers and goods and services in kind are another important split of government expenditures by type. For instance, in the sphere of individual goods of social assistance, governments can provide support by cash benefits (unemployment benefits, old age pensions, etc.) or by providing services in kind (e.g. health care services, homes for the elderly). The cash/in kind split also applies to collective goods, where cash transfers include interest payments and foreign aid.

Differences in the organisation of service provision among countries affects the overall size of general government expenditures and also its composition by type. For example, civil service pensions can be funded (increasing expenditures on cash collective goods) or pay-as-you-go. Health care can be provided predominately by government doctors and hospitals or by private ones. Support for housing and industry can be through tax expenditures (lower level of overall expenditures) or via subsidies and transfers. Furthermore, some countries rely more on markets than others in the provision of individual goods, or draw the line differently between citizens who are eligible for publicly provided services.

In OECD countries, government expenditures on individual goods are larger than those on collective goods. Expenditures on individual goods range from $16 \%$ of GDP (Korea) to $39 \%$ of GDP (Sweden) with an average of $30 \%$. Expenditures on collective goods range from $9 \%$ of GDP (Luxembourg and Switzerland) to $27 \%$ of GDP (Iceland) with an average of $15 \%$. Most collective goods (over $80 \%$ ) are provided in kind. Only countries with large public debt (leading to high interest payments) may have somewhat larger cash shares in collective goods, but still lower than the in-kind shares (e.g. Belgium, Greece, Hungary and Italy). Countries vary to the extent that they provide individual goods in cash or in kind due to differences in the organisation of education and health care (e.g. the extent to which the private sector is involved) and the development of social security (mostly based on cash transfers).

\section{Methodology and definitions}

Expenditures data are derived from the OECD National Accounts Statistics, which are based on the System of National Accounts (SNA), a set of internationally agreed concepts, definitions, classifications and rules for national accounting. The split between collective and individual goods is made by building on the existing split in the OECD National Accounts between individual and collective consumption expenditures. For consumption expenditures the split is identical to that of the OECD National Accounts. For other public expenditures (property income, capital and other current transfers, gross capital formation, etc.), the split is made either on the basis of the nature of the expenditures (for instance, property income in the COFOG group "General public services" is mostly interest and hence collective; gross capital formation in the COFOG group "Health" is mostly hospital construction and hence individual), or in a manner proportional to the split of consumption expenditures (for instance, output for own final use).

The cash/in-kind split is made on the basis of the nature of the expenditures [for instance other current transfers and capital transfers in the COFOG group "General public services" are mostly foreign aid and contributions to international organisations and hence considered as cash (collective) and social benefits other than social transfers in kind are considered as cash (individual)]. All other government expenditures are considered as in kind.

\section{Further reading}

OECD (2011), National Accounts at a Glance 2010, OECD Publishing, Paris.

\section{Figure notes}

Data for Turkey are not available. Data for New Zealand are for 2005

7.1: Data for Australia, Canada, Chile and Mexico are not available.

7.2: Australia, Canada, Chile and Mexico are not included in the average (OECD29) because data on government expenditures in kind and on collective goods in cash are not available for these countries.

Information on data for Israel: $h$ ttp://dx.doi.org/10.1787/888932315602. 


\subsection{General government expenditures on individual and collective goods as percentage of GDP (2008)}

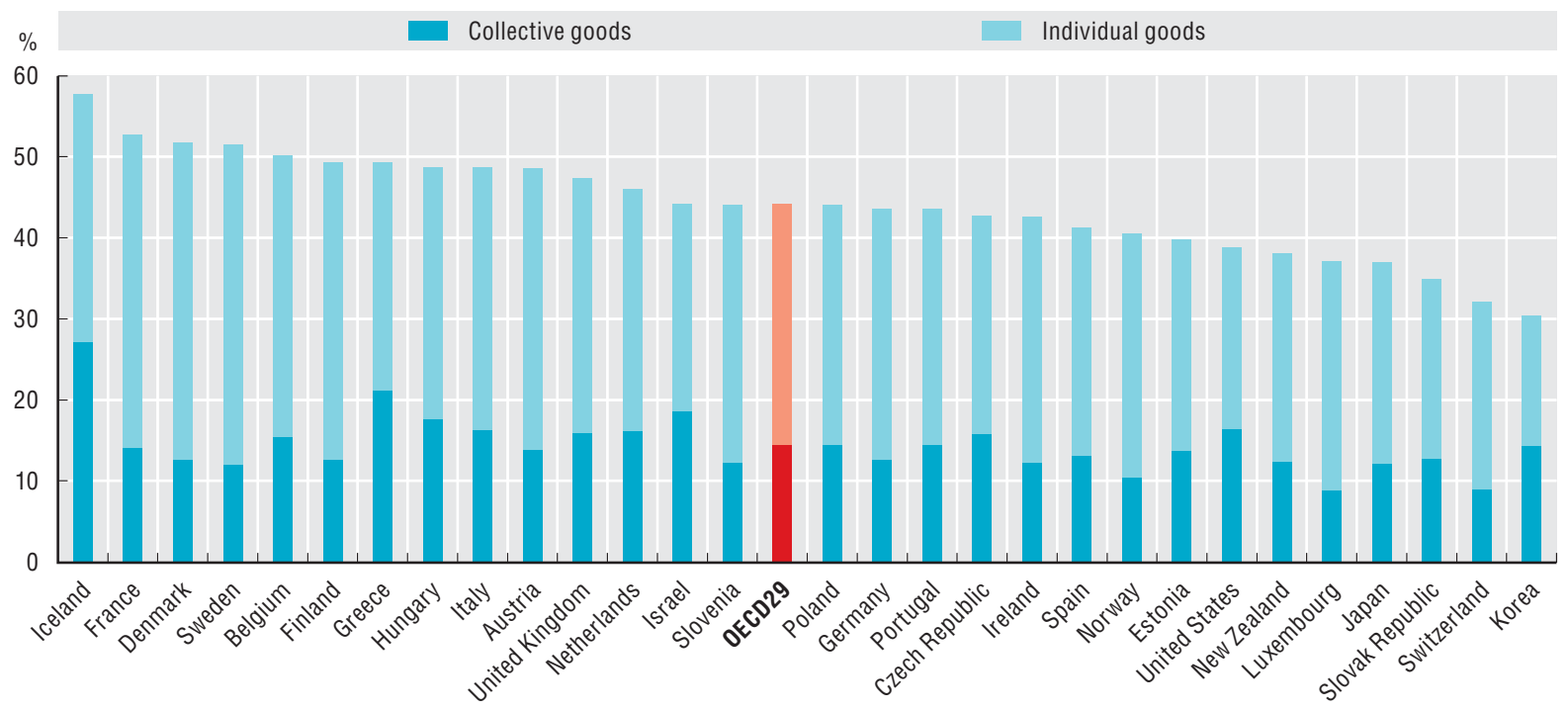

Source: OECD National Accounts Statistics.

7.2 General government expenditures on individual and collective goods in cash transfers and in kind as percentage of GDP (2008)

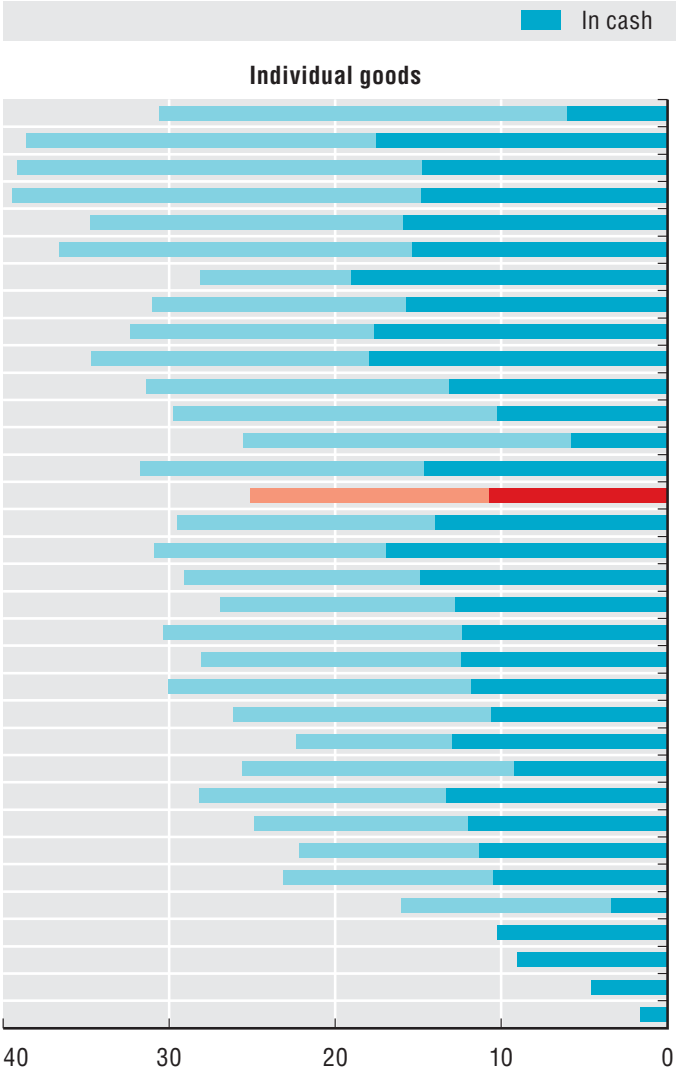

Source: OECD National Accounts Statistics.
In kind

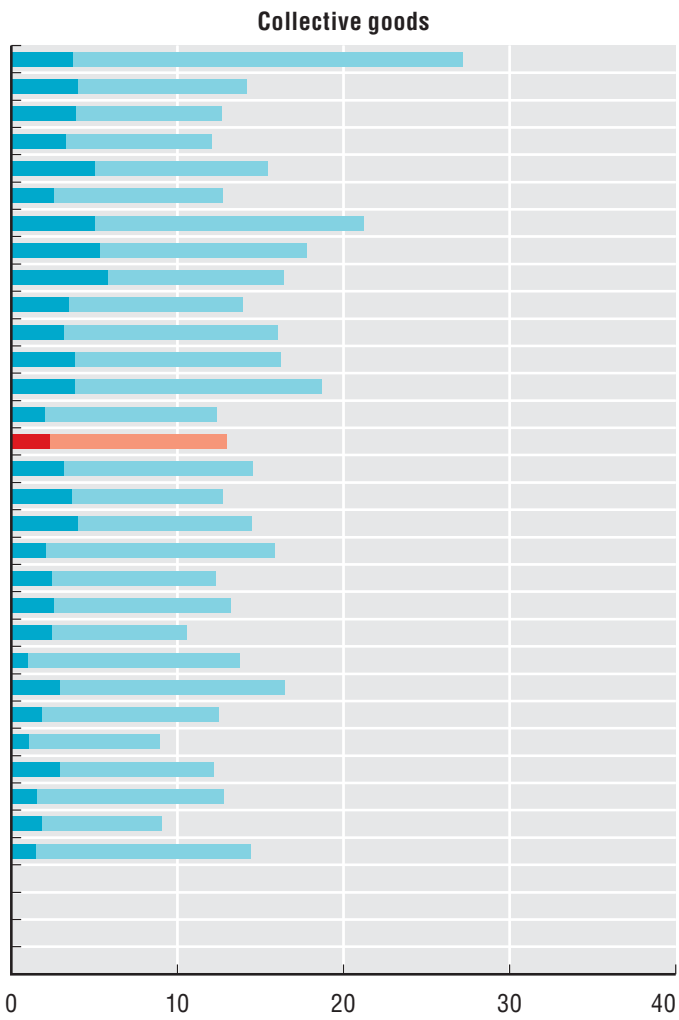

StatLink क्ञाड http://dx.doi.org/10.1787/888932389987 
Decisions on the amount and type of goods and services to produce, as well as on how best to produce them, are often political in nature and based on a country's social and cultural context. While some governments choose to outsource a large portion of the production of goods and services to non-governmental or private entities, others decide to produce the goods and services themselves.

In 2008 , the proportion of the economy devoted to producing government services and goods represents on average almost a quarter of GDP, varying significantly among OECD member countries. For example, production costs of government services and goods as a percentage of GDP in Denmark are roughly three times higher than in Mexico reflecting, in part, the different roles for government in these countries.

Governments use a mix of their own employees, capital and outside contractors (non-profit institutions or private sector entities) to produce goods and services. On average among member countries, production by own employees is still somewhat more prevalent than outsourcing: compensation of employees accounts for $49 \%$ of the cost of producing goods and services, compared to $43 \%$ paid to nongovernmental actors for intermediate goods and services or to deliver services directly to households. Consumption of fixed capital represents the remaining $9 \%$ of total production costs. The Netherlands and Germany, where close to $60 \%$ of the value of government goods and services is outsourced, rely comparatively more on corporations and non-profit institutions to produce goods and services than other OECD member countries.

Total production costs as a share of GDP increased in all but four OECD member countries (Israel, Austria, the Slovak Republic, Australia and Poland) between 2000 and 2009. This increase was primarily driven by increases in the costs of goods and services produced by corporations and non-profit providers (+1.5 percentage points) and to a lesser extent by increases in compensation costs of government employees (+0.8 percentage points). These increases could reflect that governments are providing more goods and services and/or that input costs have increased.

\section{Methodology and definitions}

The concept and methodology of production costs builds on the existing classification of public expenditures in the System of National Accounts (SNA). Specifically, government production costs include:

- Compensation costs of general government employees, including cash and in-kind remuneration plus all mandatory employer (and imputed) contributions to social insurance and voluntary contributions paid on behalf of employees. Cross-country differences in how employee pension schemes are funded can impair the comparison of compensation costs.

- Costs of goods and services produced by nongovernment entities paid for by government (these include goods and services provided to both government and citizens). In SNA terms, this includes intermediate consumption (procurement of intermediate products required for government production such as accounting or information technology services,) and social transfers in kind via market producers (including those that are initially paid for by citizens but are ultimately refunded by government, such as medical treatments refunded by public social security payments).

- Consumption of fixed capital (depreciation of capital). The data include government employment and intermediate consumption for output produced by the government for its own use, such as roads and other capital investment projects built by government employees. The production costs presented here are not equal to the value of output in the SNA.

\section{Further reading}

OECD (2008a), The State of the Public Service, OECD Publishing, Paris.

Pilichowski, E. and E. Turkisch (2008b), "Employment in Government in the Perspective of the Production Costs of Goods and Services in the Public Domain", OECD Working Papers on Public Governance, No. 8, OECD Publishing, Paris.

\section{Figure notes}

Data for Australia, Japan, Korea, New Zealand and the Russian Federation are for 2008 rather than 2009.

8.1: 2000 data for Turkey are not available and this country is not included in the average (OECD33). Costs of goods and services financed by general government are not available for Chile in 2000. Data for Mexico are for 2003 rather than 2000. Data for the Russian Federation are for 2002 rather than 2000.

Information on data for Israel: $h t t p: / / d x . d o i . o r g / 10.1787 / 888932315602$. 


\subsection{Production costs as a percentage of GDP (2000 and 2009)}

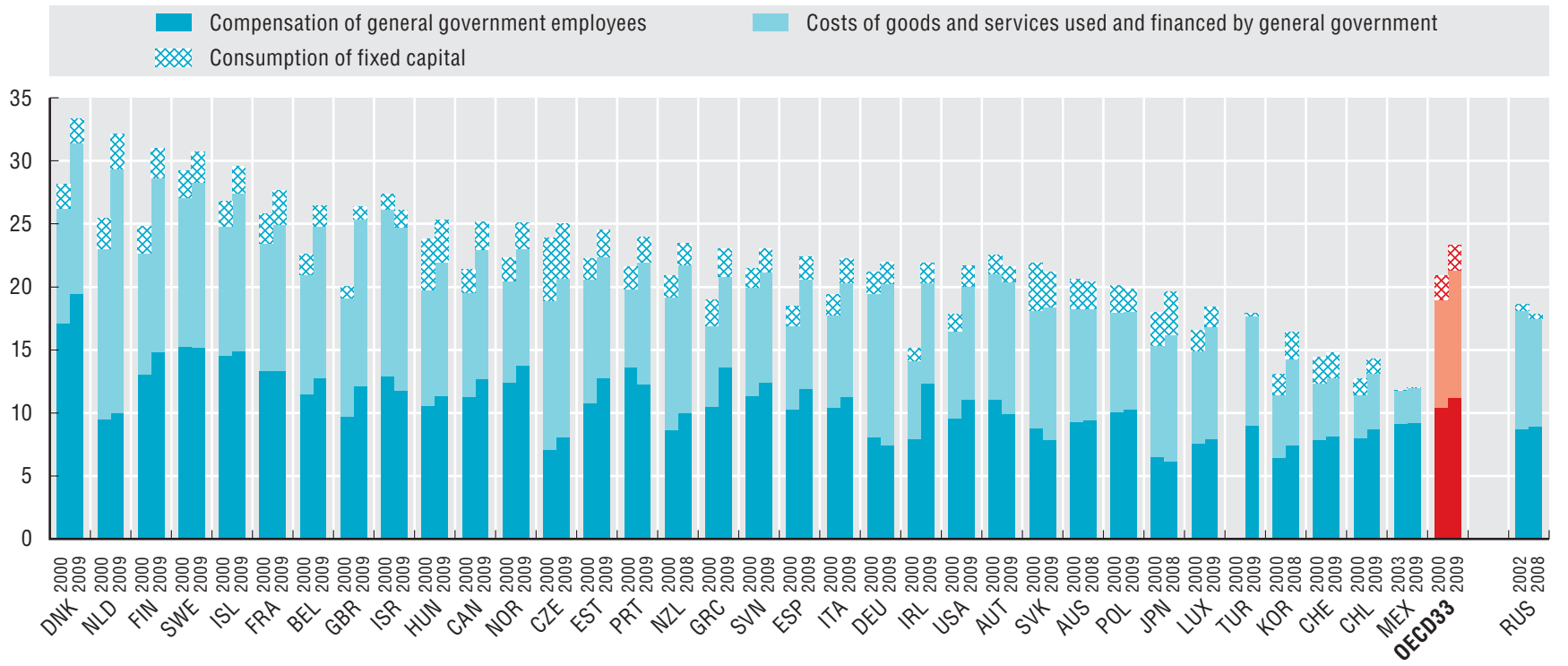

Source: OECD National Accounts Statistics. Data for Australia are based on a combination of Government Finance Statistics and National Accounts data provided by the Australian Bureau of Statistics.

StatLink AाIst http://dx.doi.org/10.1787/888932390006

\subsection{Structure of production costs (2009)}

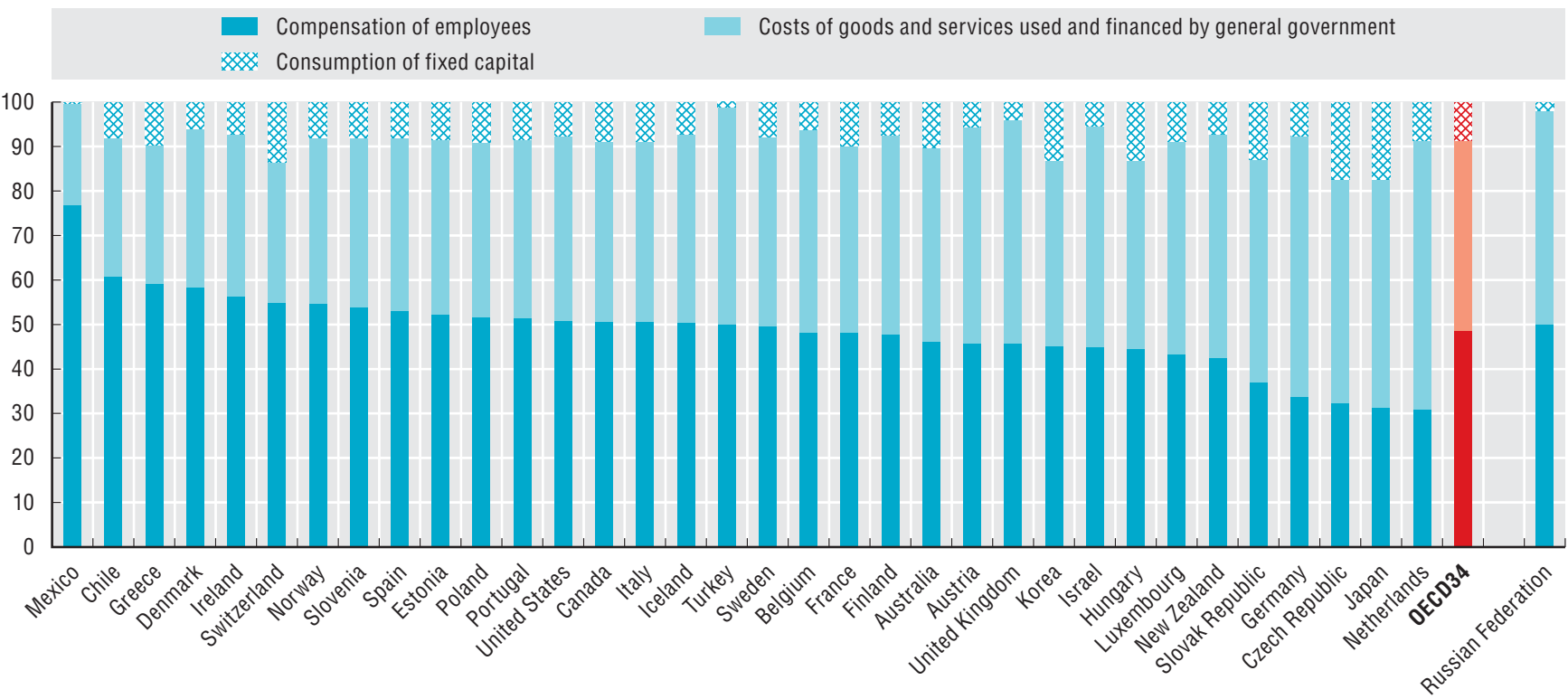

Source: OECD National Accounts Statistics. Data for Australia are based on a combination of Government Finance Statistics and National Accounts data provided by the Australian Bureau of Statistics. 
Government investment creates a public infrastructure that is essential for long-term economic growth and societal well-being. Governments spend money on building roads, housing, schools and hospitals, as well as communications networks. In addition, governments can provide grants (transfers) to the private sector to encourage their investment activities. In response to the economic downturn, many OECD governments introduced stimulus plans in 2008 featuring an increase in government capital expenditures through investments in soft and hard infrastructure.

General government investment as a share of total investment spending in the economy is increasing. In 2009, government investment represented on average one-fifth of total investment in the economy in OECD member countries, up 3 percentage points from 2000 and more than 4 percentage points since 2007.

The marked increase in government investment as a share of total investment from 2007 to 2009 shows the impact of the financial and economic crisis both in terms of shrinking private sector investment and increasing government investment. In Ireland, government's share of total investment spending doubled from 2007 to 2009 (from 20\% to $40 \%$ ) and substantial growth was also seen in the United Kingdom, the United States and Estonia during this period. In Poland, government investment as a share of total investment increased the most between 2000 and 2007. Contrary to this trend, in the Slovak Republic the share of government investment in total investment declined dramatically from 35\% in 2000 to $10 \%$ in 2007 and then doubled to $20 \%$ by 2009 .

There is a large variance across countries in the share of total government expenditures devoted to investment activities. Some governments are actively investing (for example, devoting over $15 \%$ of total expenditures to investment activities) to build up or update their infrastructure stock. In other countries, the infrastructure stock may be more established or the private sector may play a larger role. Between 2000 and 2009, government investment as a share of general government expenditures markedly decreased in the Slovak Republic from $24 \%$ to $11 \%$. Investment also decreased during this time in ten countries: Japan, Korea, Switzerland, Greece, Hungary, Portugal, Iceland, Luxembourg, Austria and Germany. Conversely, government investment increased substantially in Mexico and Poland (+7 percentage points) and more than doubled in the United Kingdom (from $4.6 \%$ to $10.3 \%$ ) over these 9 years. The increase in Mexico has been caused by the changes in the social security system, while in Poland the increase was part of the stimulus package, and helped to avoid a recession in the country in 2009.

\section{Methodology and definitions}

Data are derived from the OECD National Accounts Statistics, which are based on the System of National Accounts (SNA), a set of internationally agreed concepts, definitions, classifications and rules for national accounting. General government investment includes gross fixed capital formation and capital transfers. It consists mainly of road infrastructure but also includes infrastructure such as office buildings, housing, schools and hospitals. Capital transfers consist of investment grants paid by government and other capital transfers. General government refers to central, state and local government and social security funds.

Total investment refers to the investment spending of the entire economy, including expenditures by general government, non-financial corporations, financial corporations, households and non-profit institutions.

\section{Further reading}

OECD (2011), National Accounts at a Glance 2010, OECD Publishing, Paris.

\section{Figure notes}

Data for Australia, Japan, Korea and the Russian Federation are for 2008 rather than 2009. Data for Mexico are for 2003 rather than 2000. Data for the Russian Federation are for 2002 rather than 2000. Differences in the data availability between 9.1 and 9.2 are due to the use of different data tables within the OECD National Accounts Statistics.

9.1: Data for Iceland and Turkey are not available. 2009 data for Israel and New Zealand are not available and these countries are not included in the average (OECD30). Data for Luxembourg and Korea do not include capital transfers. Data for Greece and Switzerland are for 2008 rather than 2009. Data for Israel are for 2006 rather than 2007. Data for Ireland and the Russian Federation are for 2002 rather than 2000.

9.2: Data for 2000 for Turkey and for 2000 and 2007 for Chile are not available and these countries are not included in the average (OECD32). Data for New Zealand are for 2008 rather than 2009.

Information on data for Israel: http://dx.doi.org/10.1787/888932315602. 
9.1 Government investment as a share of total investment (2000, 2007 and 2009)

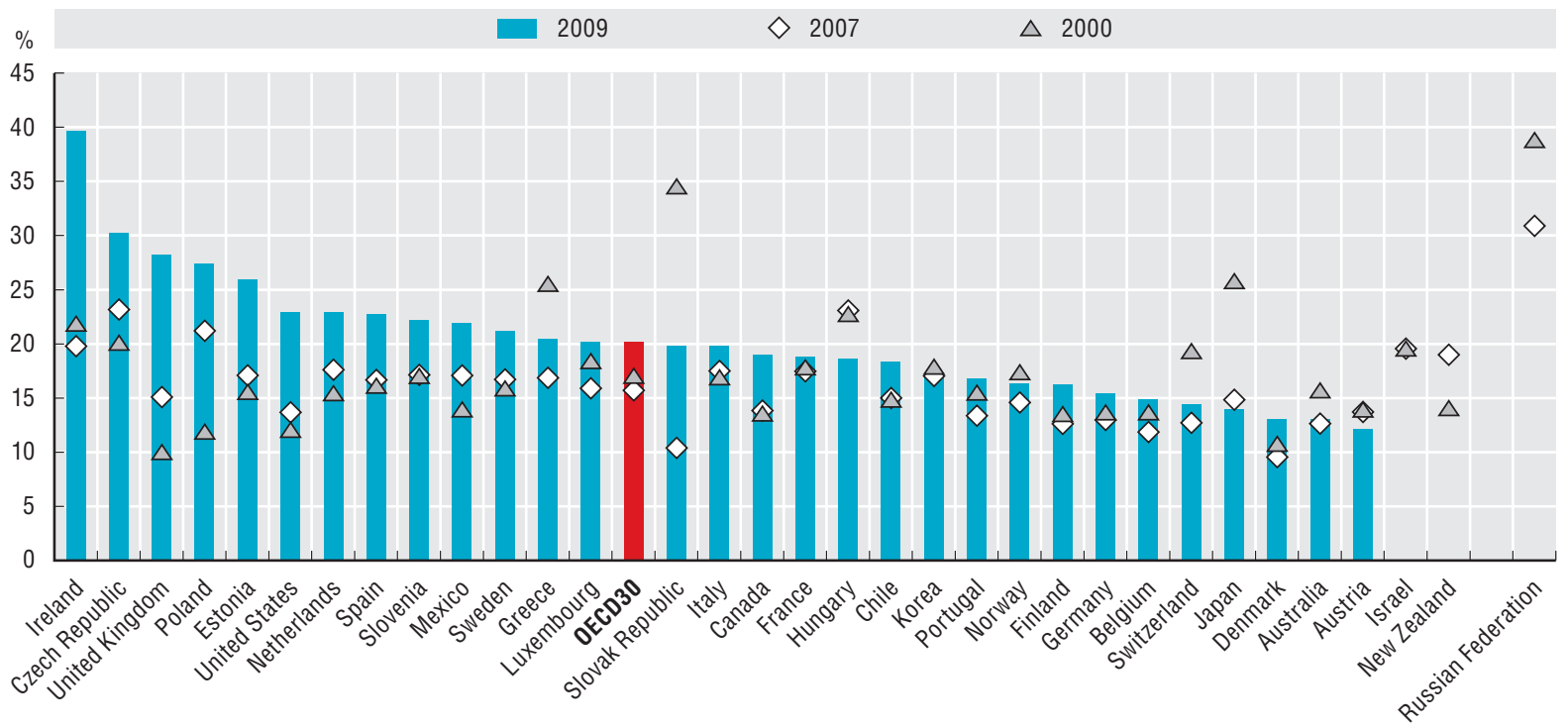

Source: OECD National Accounts Statistics.

9.2 Government investment as a share of total government expenditures (2000, 2007 and 2009)

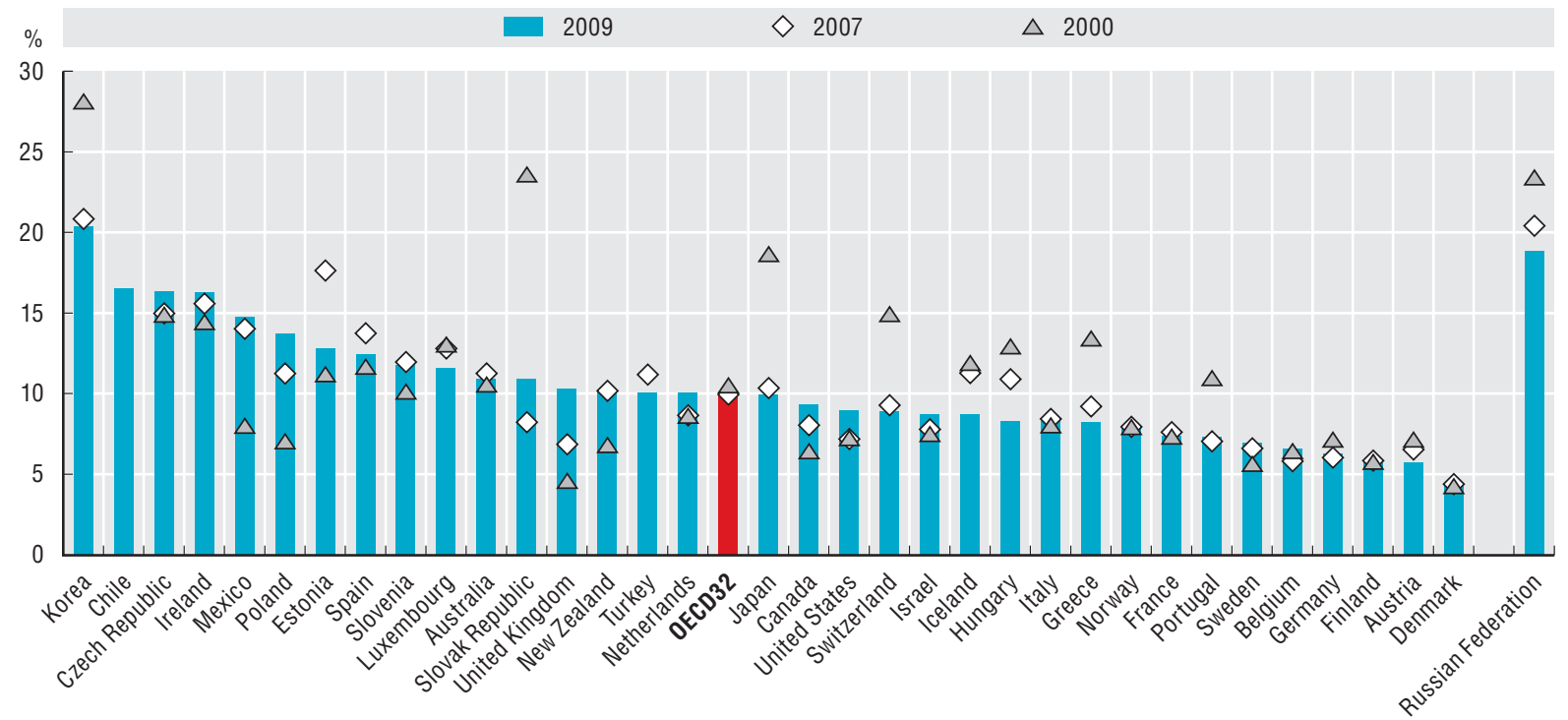

Source: OECD National Accounts Statistics. 
The role of government in providing goods and services varies greatly across OECD countries: some governments assume more of a regulatory role whereas others are more involved in service delivery. On average, governments provide just over a quarter of the goods and services consumed in the economy each year, including those services that the government provides directly via its own staff and indirectly via outside contractors. However, there is much variation amongst OECD countries: in countries such as Mexico, Switzerland, Chile, Turkey and the United States, governments play a smaller role in service delivery. In comparison, in the Netherlands, Norway, Sweden and Denmark, governments have a more prominent role, which is also reflected in their higher expenditures and revenues as a share of GDP.

Governments play an important role in providing health and education goods and services. On average, governments are responsible for almost $70 \%$ of final consumption expenditures on health goods and services. Almost all OECD countries have universal public health insurance coverage, although households may still bear the costs of some health services, such as co-payments for doctor visits. The role of government in providing health goods and services has remained relatively stable since 2000 with a few exceptions. In the Netherlands, health care reform implemented in 2006 created one mandatory national health insurance system, which has increased the role of the government. In comparison, health care reforms passed in 2003-04 in the Slovak Republic decreased the relative role of government by introducing co-payments, the opportunity to select health insurance companies, and changing the status of several state-owned hospitals and health insurance companies.

On average, governments are responsible for about $85 \%$ of final consumption expenditures on education. In all OECD countries, schooling is compulsory until at least the age of 15 and the majority of primary and secondary students are enrolled in government-operated institutions. Thus, most differences between countries lie in the extent to which the governments finance pre-primary and tertiary education. For example, Korea has a relatively higher enrolment rate in private educational institutions at the pre-primary and university levels as well as a higher use of private tutoring.

\section{Methodology and definitions}

Data are derived from the OECD National Accounts Statistics, which are based on the System of National Accounts (SNA), a set of internationally agreed concepts, definitions, classifications and rules for national accounting. The data refer to final consumption expenditure, which represents the amount spent by governments, non-profit institutions and households on goods and services consumed during the year. The corporate sector does not incur any final consumption expenditure because it only produces final goods for sale in the market. Expenditures are attributed to the institutional unit (government, nonprofit institution or household) that bears the costs. For example, fees charged by governments for certain goods and services (such as fees for passports) are counted as part of household expenditures. Thus, government final consumption expenditures represent the non-market goods and services that are produced each year. Compared to total expenditures, final consumption expenditures exclude spending on goods and services not consumed during the year, such as investments, and exclude social benefits provided to households which are not tied to the consumption of specific goods and services, such as pension payments. Data reporting final consumption expenditures by health and education sectors are derived from COFOG and Classification of Individual Consumption According to Purpose (COICOPP).

\section{Figure notes}

10.2 and 10.3: Data for Canada, Chile, Mexico and Turkey are not available. Data for Norway and Portugal are for 2007 rather than 2008. Data for Hungary are for 2005 rather than 2008 and data for 2000 are not available.

10.2: Data for New Zealand are for are for 2005 rather than 2008 and data for 2000 are not available. Data for the United States do not reflect the 2010 health care reform and some government expenditures on health are recorded as social benefit transfers and therefore are not included in this figure. Health insurance and hospitals in Switzerland are privately operated.

10.3: Data for New Zealand are not available. 2000 data are not available for Switzerland and Poland.

Information on data for Israel: http://dx.doi.org/10.1787/888932315602. 


\subsection{Share of total final consumption expenditures by general government, households and non-profit institutions serving households (2000 and 2009)}

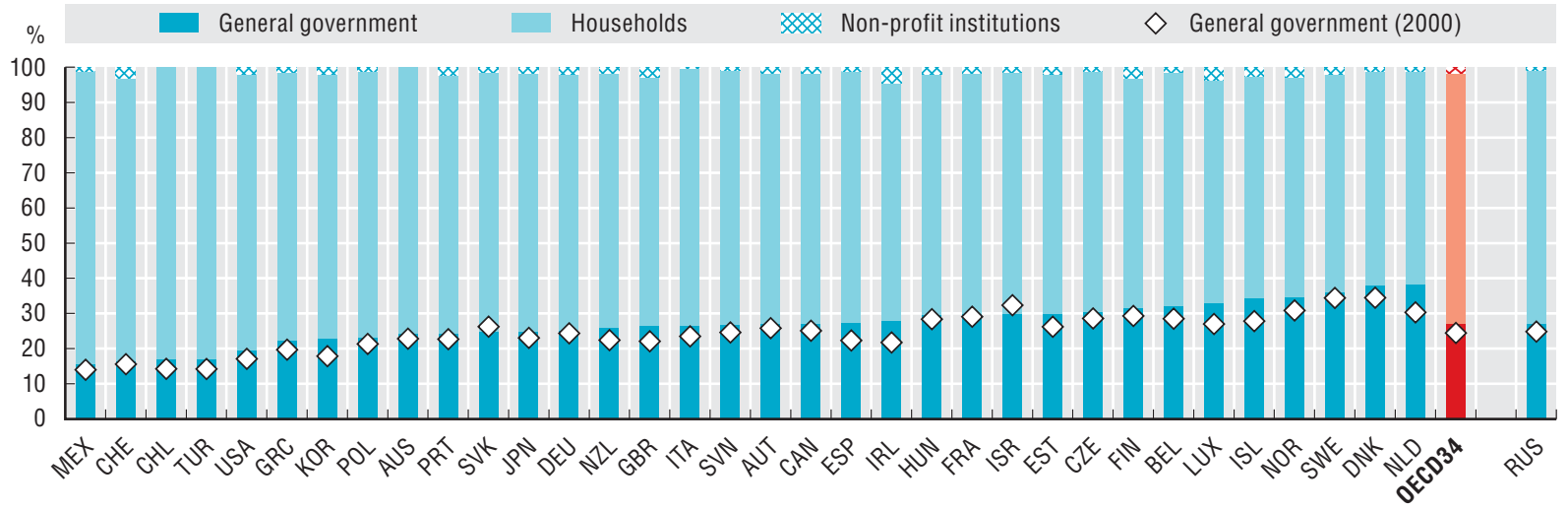

Source: OECD National Accounts Statistics.

10.2 Share of total final consumption expenditures on health by general government and households (2000 and 2008)

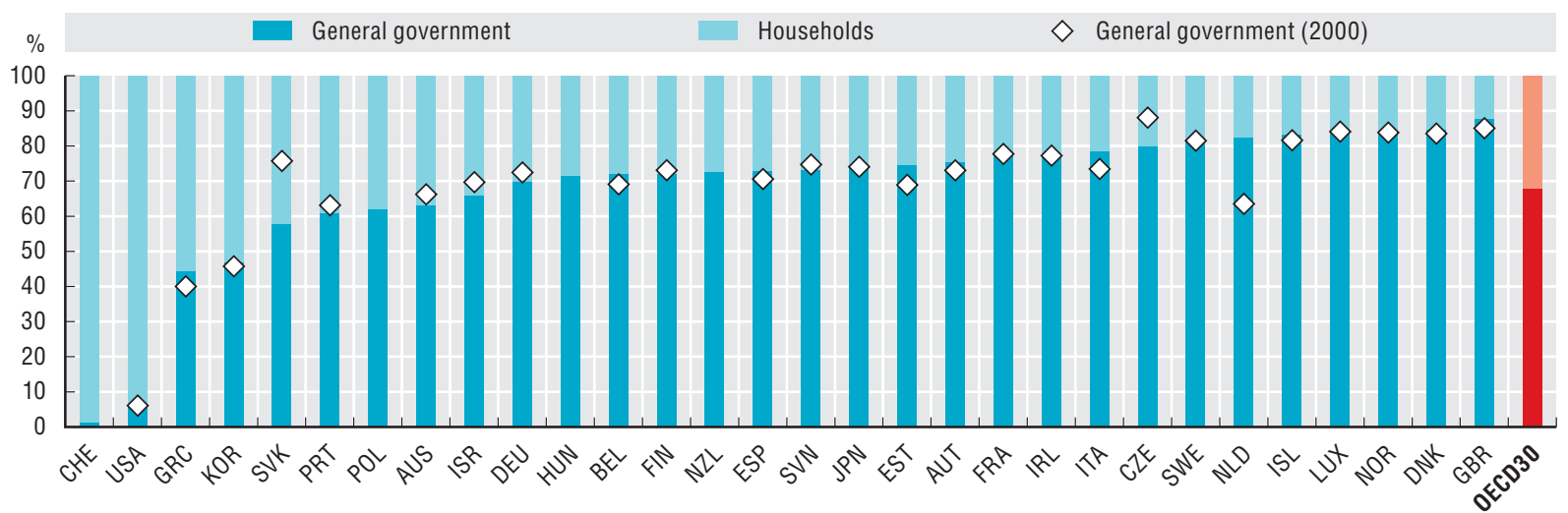

Source: OECD National Accounts Statistics. Data for Australia are based on a combination of Government Finance Statistics and National Accounts data provided by the Australian Bureau of Statistics.

StatLink AाIsL http://dx.doi.org/10.1787/888932390101

\subsection{Share of total final consumption expenditures on education by general government and households (2000 and 2008)}

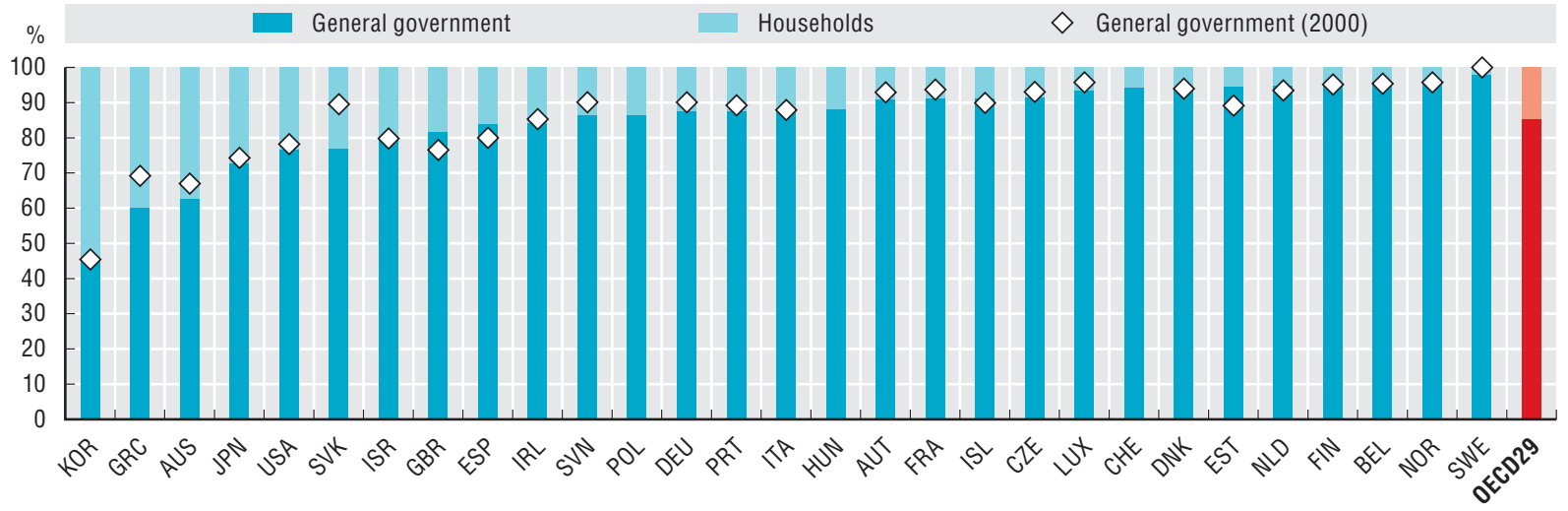

Source: OECD National Accounts Statistics. Data for Australia are based on a combination of Government Finance Statistics and National Accounts data provided by the Australian Bureau of Statistics. 


\section{PUBLIC FINANCE AND ECONOMICS}

\section{Size of general government financial assets and liabilities}

Like households and corporations, governments hold both financial assets (such as accumulated cash or currency) and liabilities (debt). The amount of government-held financial assets and liabilities broadly correlates to the difference between revenues and expenditures over time: deficits are financed by either depleting savings (spending financial assets) or borrowing money (increasing liabilities). Along with other indicators, the net balance between government-held assets and liabilities can be one key measure of fiscal sustainability. In general, the higher a government's liabilities, the higher the perceived risk by markets on the probability of a government defaulting on loans and therefore the higher risk premium required by the market, which in turn raises the cost of debt.

The share of assets and liabilities held by government in the domestic economy relative to non-government actors (such as corporations and households) can also provide an indication of the government's influence in financial markets as a borrower and a lender. For example, a larger share of assets indicates that the government possesses a major share of financial resources in the economy. On average in OECD countries, governments hold about $7 \%$ of financial assets in the economy; the major part of assets are held by households, non-profit institutions and corporations. The large share of assets held by the Norwegian government $(27 \%)$ represent wealth management funds established with the proceeds from oil sales. In terms of financial assets and liabilities, most governments became smaller between 2000 and 2009. In comparison to financial assets, governments account for a slightly larger share of liabilities in the economy (about $10 \%$ on average). Financial liabilities do not include unfunded pension liabilities.

The financial net worth of the government (also known as net financial debt) represents the difference between its financial assets and liabilities, and provides some information about government's capacity to meet its financial obligations. A decrease in the government's financial net worth over time indicates a worsening fiscal position and that a higher share of current spending will be borne by future generations. Financial net worth as a share of GDP improved in 11 OECD countries between 2000 and 2009 - most dramatically in Norway, due to increases in the value of oil revenues. In 2009, only seven OECD countries had a positive financial net worth, meaning that assets exceeded liabilities. The general improvements in net worth experienced by most countries since 2000 were tempered by the global financial and economic crisis. All but two OECD countries (Denmark, Estonia and Norway) saw their net worth drop between 2007-09 due to sharp decreases in the value of assets and increased liabilities from fiscal stimulus packages.

\section{Methodology and definitions}

Data are derived from the OECD National Accounts Statistics, which are based on the System of National Accounts (SNA), a set of internationally agreed concepts, definitions, classifications and rules for national accounting. The SNA classifies financial assets and liabilities in seven major categories of financial instruments: monetary gold and special drawing rights (assets only), currency and deposits, securities other than shares, loans, shares and other equity, insurance technical reserves (net equity of households in life insurance and pension fund reserves), and other accounts receivable (assets)/ payable (liabilities). Financial assets do not include physical assets such as land or buildings.

The valuation of assets and liabilities should be at market prices at the end of the year. Thus, fluctuations in prices can account for year-to-year differences in the levels of assets and liabilities. Data are based on the non-consolidated financial accounts except for Australia and Israel.

\section{Further reading}

OECD (2011), National Accounts at a Glance 2010, OECD Publishing, Paris.

Robinson, M. (2009), "Accrual Budgeting and Fiscal Policy", OECD Journal on Budgeting, Vol. 2009/1, OECD Publishing, Paris.

\section{Figure notes}

Data for Chile, Iceland, Luxembourg, New Zealand and Turkey are not available. Data for Switzerland are for 2008 rather than 2009. Data for Korea are for 2002 rather than 2000. Data for Israel and Slovenia are for 2001 rather than 2000.

11.1 and 11.2: Data for Ireland are for 2001 rather than 2000.

Information on data for Israel: http://dx.doi.org/10.1787/888932315602. 

The fiscal balance is the difference between government revenues and spending. A fiscal deficit occurs when, in a given year, a government spends more than it receives in revenues. On the other hand, a government will run a surplus when revenues exceed expenditures. Fiscal balances include a structural component (adjusted for one-offs in revenues and spending) as well as a cyclical one. A structural deficit occurs when the economy is running at full capacity and governments continue to spend more than their revenues. The cyclical component of a deficit, however, is sensitive to the economic cycle and results from the difference between actual and potential output. For example, during an economic downturn, cyclical deficits result from the lower revenues and higher expenditures on social programmes such as unemployment benefits.

On average, OECD deficits have increased since 2000 due partly to the pursuit in some countries of pro-cyclical policies (increasing public spending as a share of GDP when growth was strong, or, "not saving for a rainy day"). Between 2000 and 2008 the average annual GDP growth in the OECD was 3\%, however, the majority of OECD countries (21) ran, on average, deficits during this time. Countries such as Greece, Hungary, Israel and Japan ran deficits of over $5 \%$ of GDP over this period on average. Conversely, fiscal balances in Australia, Canada, Denmark, Estonia, Finland, Ireland, Korea, Luxembourg, New Zealand, Norway and Sweden were positive on average during the same period of growth.

The financial and economic crisis caused further increases in the fiscal deficits of OECD member countries through lost output, lower tax revenues and increased spending to support recovery efforts. The fiscal balance of 29 OECD member countries in 2010 was $-5.6 \%$ of GDP, the majority of which was structural (3.4\% of GDP). Despite having run a surplus, on average, from 2000 to 2008, Ireland had a fiscal deficit of $32.4 \%$ of GDP in 2010, with a large cyclical component ( $25 \%$ of GDP). Among the OECD member countries for which data are available, Norway had a positive fiscal balance in 2010, although it also had a negligible structural deficit. Estonia and Switzerland are the only other OECD member countries with available data which had positive fiscal balances in 2010 .

To improve fiscal discipline, many countries have adopted fiscal rules which require balanced budgets. Additionally, budget practices such as the use of medium-term expenditure frameworks that include targets or ceilings for spending can also help control excessive government spending.

\section{Methodology and definitions}

Data on both general government financial balances and GDP are drawn from the OECD Economic Outlook Database, No. 89 (Preliminary Version).

Financial balances include one-off factors, such as those resulting from the sale of the mobile telephone licenses, but exclude most financial transactions. As data follow the System of National Accounts (SNA), government financial balances may differ from the numbers reported to the European Commission under the Excessive Deficit Procedure for some EU countries. The underlying balances, or structural balances, are adjusted for the cycle and one-offs. For more details, see OECD Economic Outlook "Sources and Methods" (www.oecd.org/eco/sources-and-methods).

\section{Further reading}

Anderson, B. and J.J. Minarik (2006), “Design Choices for Fiscal Policy Rules", OECD Journal on Budgeting, Vol. 2006/4, OECD Publishing, Paris, pp. 159-208.

OECD (2010), OECD Economic Outlook, Vol. 2011/1 (Preliminary Version), May 2011, OECD Publishing, Paris.

\section{Figure notes}

Data for Chile and Mexico are not available. OECD averages are unweighted.

12.2: Data for the Slovak Republic, Slovenia and Turkey are not available. Data for Norway are shown as a percentage of mainland potential GDP; the financial balances shown are adjusted to exclude net revenues from petroleum activities.

Information on data for Israel: $h$ ttp://dx.doi.org/10.1787/888932315602. 
Government debt represents governments' outstanding liabilities stemming from the need to finance deficits through borrowing. Although deficits increased in many countries since 2000, between 2000 and 2007 debt levels as a share of GDP in many countries dropped due to economic growth. However, the recent economic crisis has reversed this trend. Debt levels have sharply increased due to low GDP growth and large deficits resulting from lower revenue collections (due to tax reductions designed to stimulate the economy and/or declines in economic activity) and increased spending on stimulus measures, social transfers or support for financial institutions. As a result, the average OECD member country's public debt rose from $57 \%$ of GDP in 2007 to $74 \%$ in 2010.

Japan, Italy and Greece had the highest levels of general government debt as a share of GDP in 2010, while debt levels were lowest in countries such as Estonia and Luxembourg. Some OECD countries reduced government debt between 2000 and 2010 by running fiscal surpluses and using the excess revenues to pay down debt and/or by having an economy that grows faster than debt. Sweden, for example, reduced its debt burden by 15 percentage points, from $64 \%$ of GDP in 2000 to $49 \%$ in 2010 . The debt burden per person varies considerably ranging from about USD 2550 per person in Estonia to about USD 67400 per person in Japan. On average, debt per person in the OECD increased by 39\% between 2007 and 2010. However, the nature of government debt (e.g. ownership and when interest payments are due) differs across the OECD. In Japan, for instance, the majority of government debt is owned by Japanese citizens, and therefore the risk of default (and hence risk premiums) is considered to be lower. In 2009 governments' interest payments represented on average $2.4 \%$ of GDP (or $5 \%$ of general government expenditures), with an increase of 0.1 percentage points compared to 2007.

\section{Methodology and definitions}

Data on gross general government debt and GDP are from the Preliminary Version of the OECD Economic Outlook Database, No. 89. Population estimates are from the OECD National Accounts Statistics.

"Gross general government debt" refers to general government gross financial liabilities that require payments of principal and interest. These data are not always comparable across countries due to different definitions or treatment of debt components. Notably, they include the funded portion of government employee pension liabilities for some OECD countries, including Australia and the United States.
The debt position of these countries is thus overstated relative to countries that have large unfunded liabilities for pensions, and that are not recorded in the core accounts of the 1993 SNA, which instead recommends their inclusion as a memorandum item. For most countries, data on gross debt used for the purpose of these calculations refer to the liabilities (short and long-term) in the general government as defined in the system of national accounts. This definition differs from the definition of debt under the Maastricht Treaty which is used to assess EU fiscal positions.

Gross debt is used here rather than net debt due to the difficulties in making cross-country comparisons of the value of government-held assets, and because it is more relevant in the context of debt interest payments. For more details, see OECD Economic Outlook "Sources and Methods" (www.oecd.org/eco/ sources-and-methods). Gross debt per person is calculated by dividing PPP-adjusted gross debt by total population. Non-adjusted 2009 population data were used for 2010.

Interest payments are based on the System of National Accounts definition: under the terms of the financial instrument agreed between them, interest is the amount that the debtor becomes liable to pay to the creditor over a given period of time without reducing the amount of principal outstanding.

\section{Further reading}

OECD (2010), OECD Economic Outlook, Vol. 2011/1 (Preliminary Version), May 2011, OECD Publishing, Paris.

Schick, A. (2009), "Budgeting for Fiscal Space", OECD Journal of Budgeting, Vol. 9/2, OECD Publishing, Paris.

\section{Figure notes}

Data for Chile, Mexico and Turkey are not available. OECD averages are unweighted.

13.1: Data for Slovenia and the Czech Republic are for 2001 rather than 2000. See StatLink for country-specific notes.

13.3: Data for Australia, Japan, Korea and New Zealand are for 2008 rather than 2009.

Information on data for Israel: http://dx.doi.org/10.1787/888932315602. 
13.1 General government gross debt as a percentage of nominal GDP (2000, 2007 and 2010)

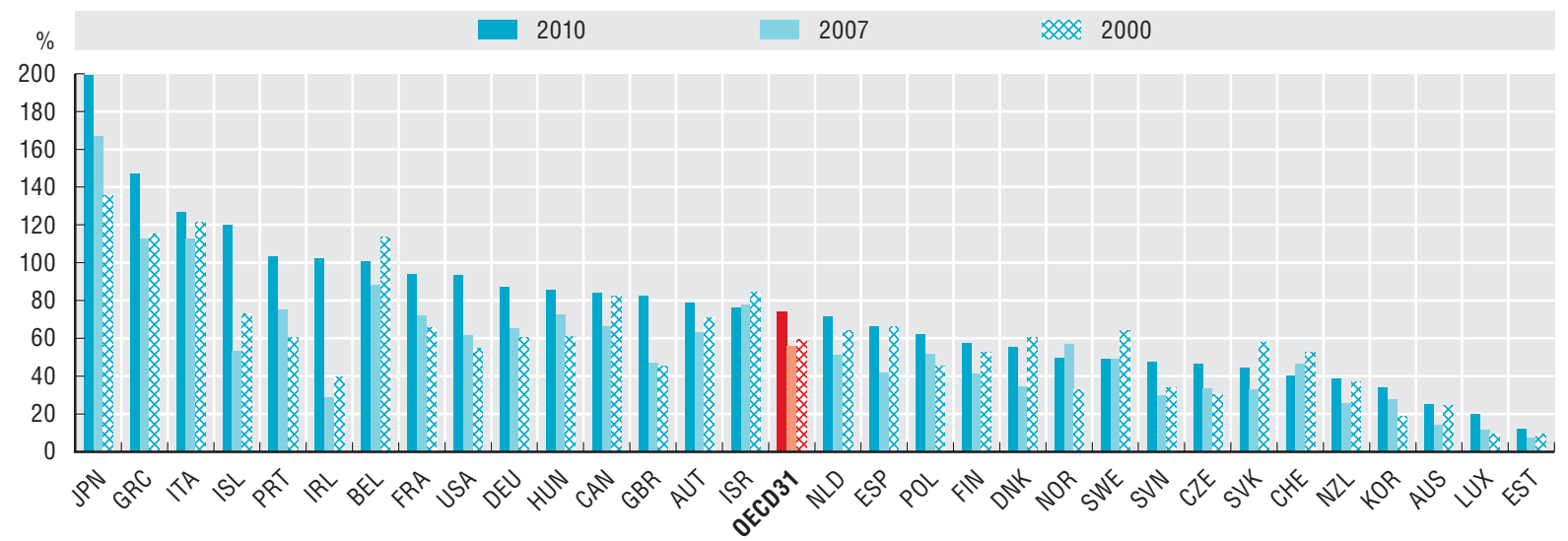

Source: OECD Economic Outlook, No. 89 (Preliminary Version), May 2011.

StatLink काist http://dx.doi.org/10.1787/888932390234

13.2 Gross public debt per person (2007 and 2010)

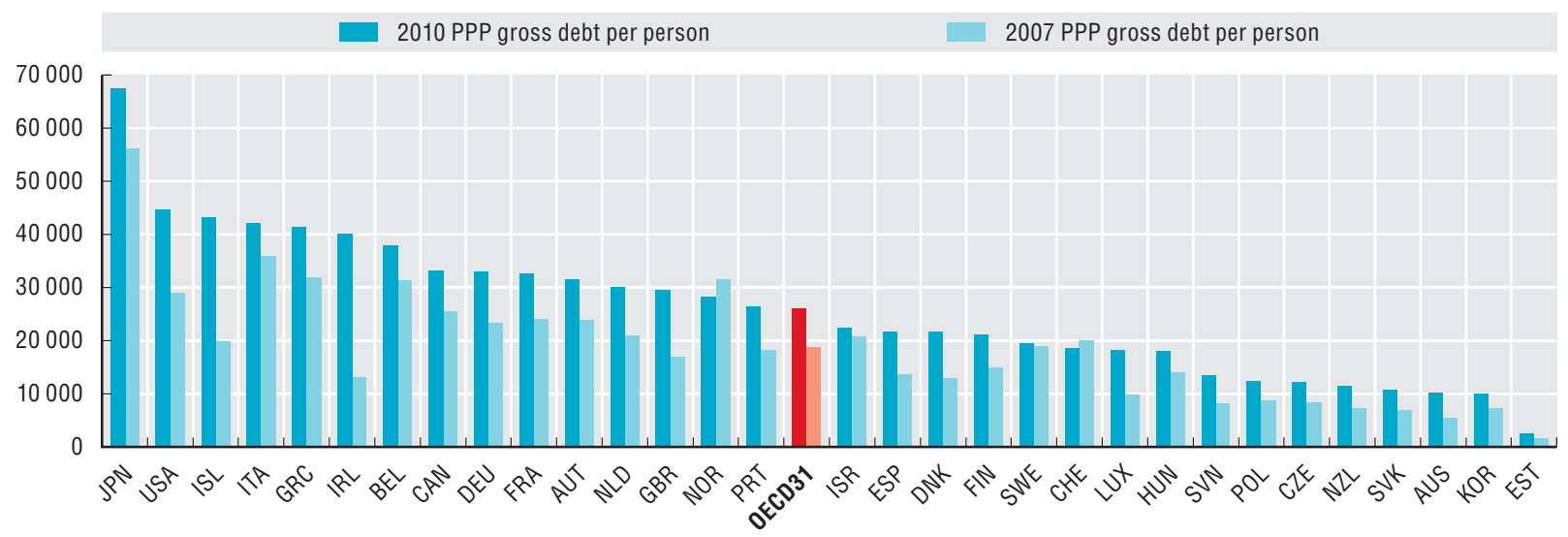

Source: OECD Economic Outlook, No. 89 (Preliminary Version), May 2011. OECD National Accounts Statistics.

\subsection{General government interest payments as a percentage of GDP (2007 and 2009)}

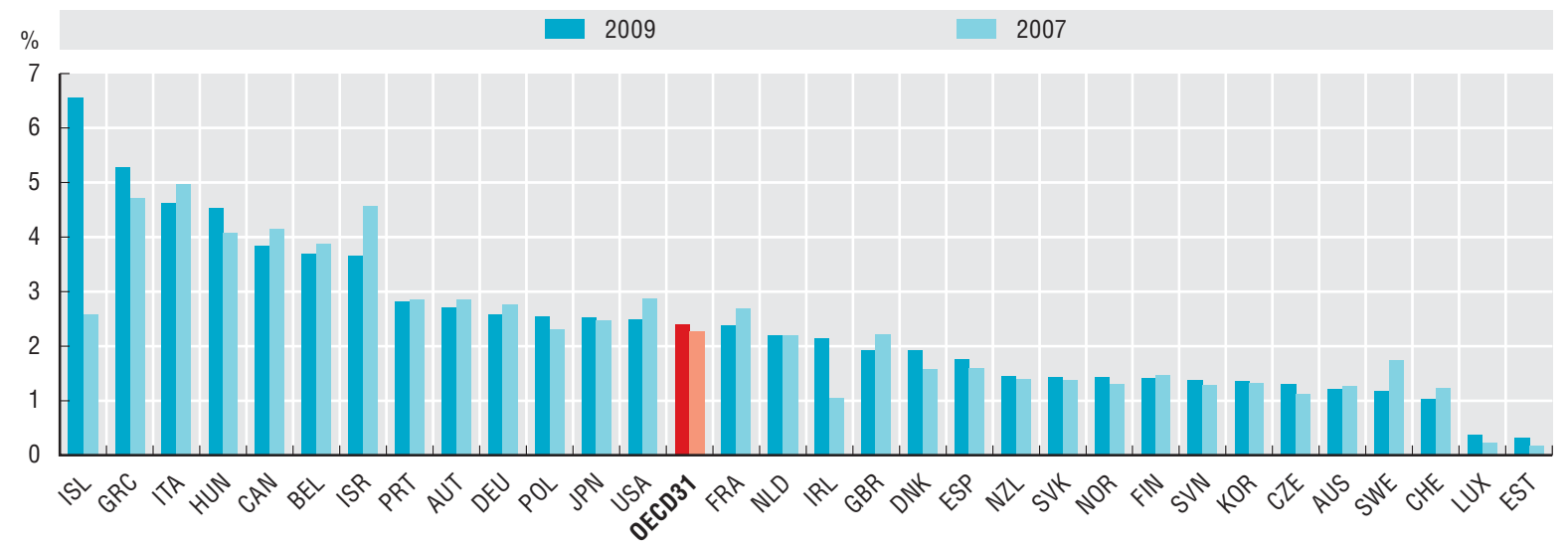

Source: OECD National Accounts Statistics. 
Following the global financial and economic crisis, most OECD member countries developed long-term strategic responses focused on promoting innovation and encouraging research and development (R\&D) to restore sustainable growth. As both financiers of R\&D activities throughout the economy and also performers of R\&D themselves, governments play a key role in supporting a country's innovation system. In addition to directly supporting the innovation efforts of firms via grants or other transfers, governments provide education, training and skills development, and foster knowledge creation and diffusion.

The OECD Innovation Strategy highlighted the importance of publicly funded R\&D as one of the key foundations of future innovation. In 2008, OECD central governments invested $1 \%$ to $6 \%$ of their total budget in R\&D activities. Between 2004 and 2008, the share of R\&D in total budgets increased in 15 of the 26 countries with available data; Spain had the largest increase during this period. Conversely, this share decreased most notably in Iceland, the United States, France and the United Kingdom over the same period. However, these decreases can also be a result of faster increases in total budgets.

Countries vary widely in terms of the importance of funding by socio-economic objective and by performance sectors, reflecting national priorities and differences in countries' national innovation systems. For instance, the United States, France and the United Kingdom allocate a considerable amount of their government budget appropriations or outlays for R\&D (GBAORD) to defence, respectively $57 \%, 28 \%$ and $22 \%$ in 2008 . However, on average, it is general university funds and economic development which receive the most funds across the OECD.

Although in most OECD countries the private sector is the largest performer of $R \& D$, governments play an important role in conducting R\&D. In 2008, the level of R\&D performed within the government sector as a share of gross domestic expenditure on R\&D (GERD) was relatively high in Poland $(35 \%)$ and in the Slovak Republic (33\%) whilst it was relatively low in Switzerland (1\%), Denmark (3\%), and Israel and Sweden (both 4\%).

\section{Methodology and definitions}

Government budget appropriations or outlays for R\&D (GBAORD) measure the funds committed by the central government for R\&D to be carried out. The data are usually based on budgetary sources and reflect the views of the funding agencies. Total government outlays are current outlays (e.g. current consumption, transfer payments, subsidies) and capital outlays. Data refer to the central/federal government to be consistent with the definition of GBAORD. For countries which include regional and local R\&D expenditures in their GBAORD estimates (Belgium, Denmark, Germany, Ireland and the United Kingdom), total government outlays include the sub-national aggregates. General University funds (GUF) are the estimated R\&D content of government block grants to universities.
Budgetary outlays are different from government expenditures in that they describe governments' intentions. For the majority of countries shown here, figures represent those budget appropriations voted on by parliament for the coming year.

Data on expenditure by sectors of performance are from R\&D surveys which are used to construct a national aggregate: gross domestic expenditure on R\&D (GERD). GERD is calculated by adding together the intramural expenditures of the four performing sectors (government, higher education, business enterprise, private and non-profit) and includes R\&D performed within a country and funded from abroad, while excluding payments for R\&D performed abroad. For details regarding definitions used here, please see Frascati Manual, 2002.

\section{Further reading}

OECD (2010), Measuring Innovation: A New Perspective, OECD Publishing, Paris.

OECD (2010), OECD Science, Technology and Industry Outlook 2010, OECD Publishing, Paris.

OECD (2010), The OECD Innovation Strategy: Getting a Head Start on Tomorrow, OECD Publishing, Paris.

\section{Figure notes}

Data for Greece are for 2007 rather than 2008. Data for Chile and Estonia are not available.

14.1: Data on total government outlays for Australia refer to general government. Data for Japan, Israel, Mexico, New Zealand, Switzerland and Turkey are not available. Data for Korea and Portugal are for 2007 rather than 2008. Data for Canada are for 2006 rather than 2008. Data for Hungary and Italy are for 2005 rather than 2004.

14.2: For Japan, military procurement contracts are excluded from defence GBAORD. In the United States, general support for universities is the responsibility of state governments, and therefore general university funds are not included in total GBAORD. Data for Canada are for 2007. Data for Mexico are for 2006. Data for Israel, Slovenia and Turkey are not available.

14.3: Data for Austria, Germany, Hungary, Japan, Korea, Mexico, New Zealand and Turkey are for 2007.

Information on data for Israel: $h$ ttp://dx.doi.org/10.1787/888932315602. 
14.1 Government budget appropriations or outlays for R\&D as a percentage of total government outlays (2004 and 2008)

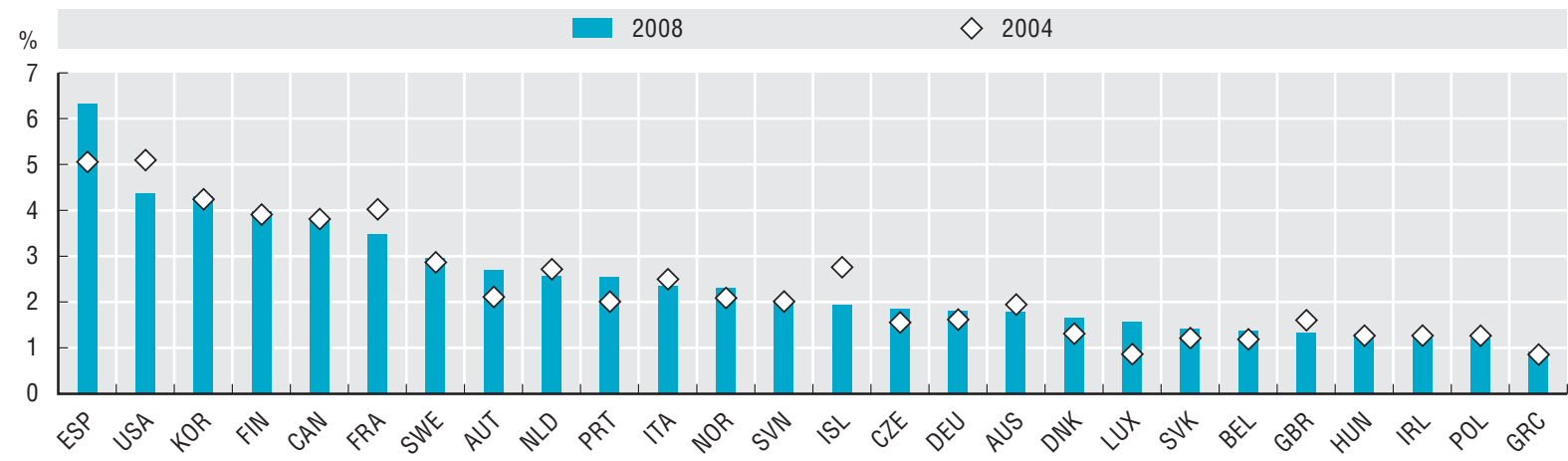

Source: OECD (2010), Measuring Innovation: A New Perspective, OECD Publishing, Paris. OECD Research and Development Statistics, OECD National Accounts Statistics, November 2010.

14.2 Government budget appropriations or outlays for R\&D by selected socio-economic objectives (2008)

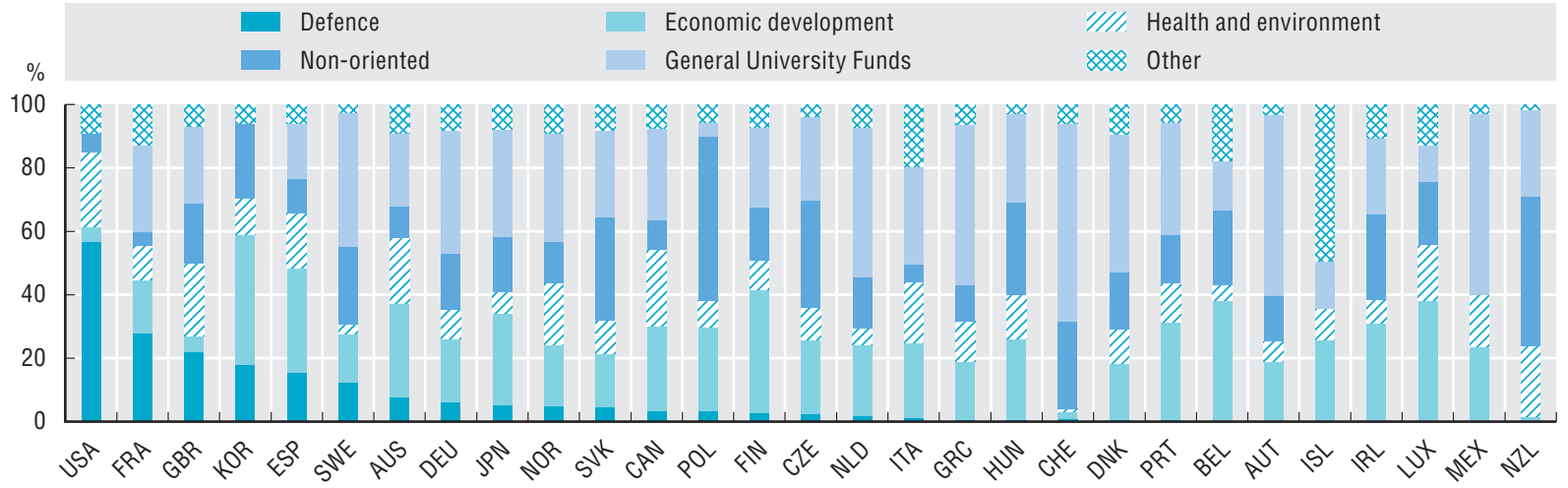

Source: OECD (2010), Measuring Innovation: A New Perspective, OECD Publishing, Paris. OECD Research and Development Statistics, December 2010.

StatLink aाts http://dx.doi.org/10.1787/888932390310

14.3 Share of total gross domestic expenditure on R\&D by sector of performance (2008)

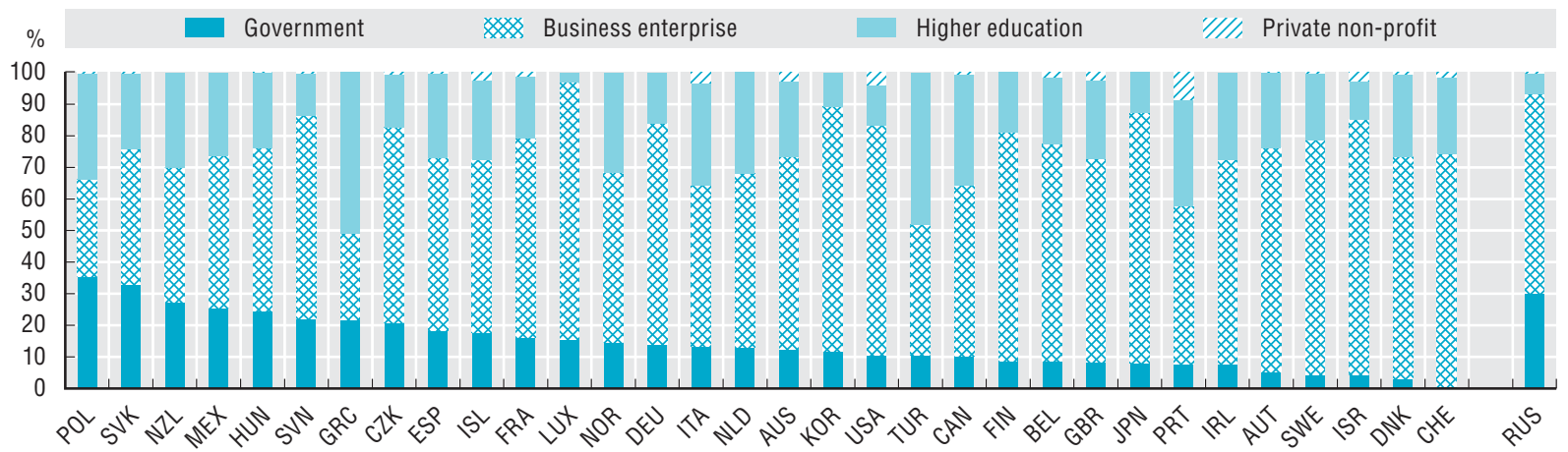

Source: OECD Research and Development Statistics, December 2010. 


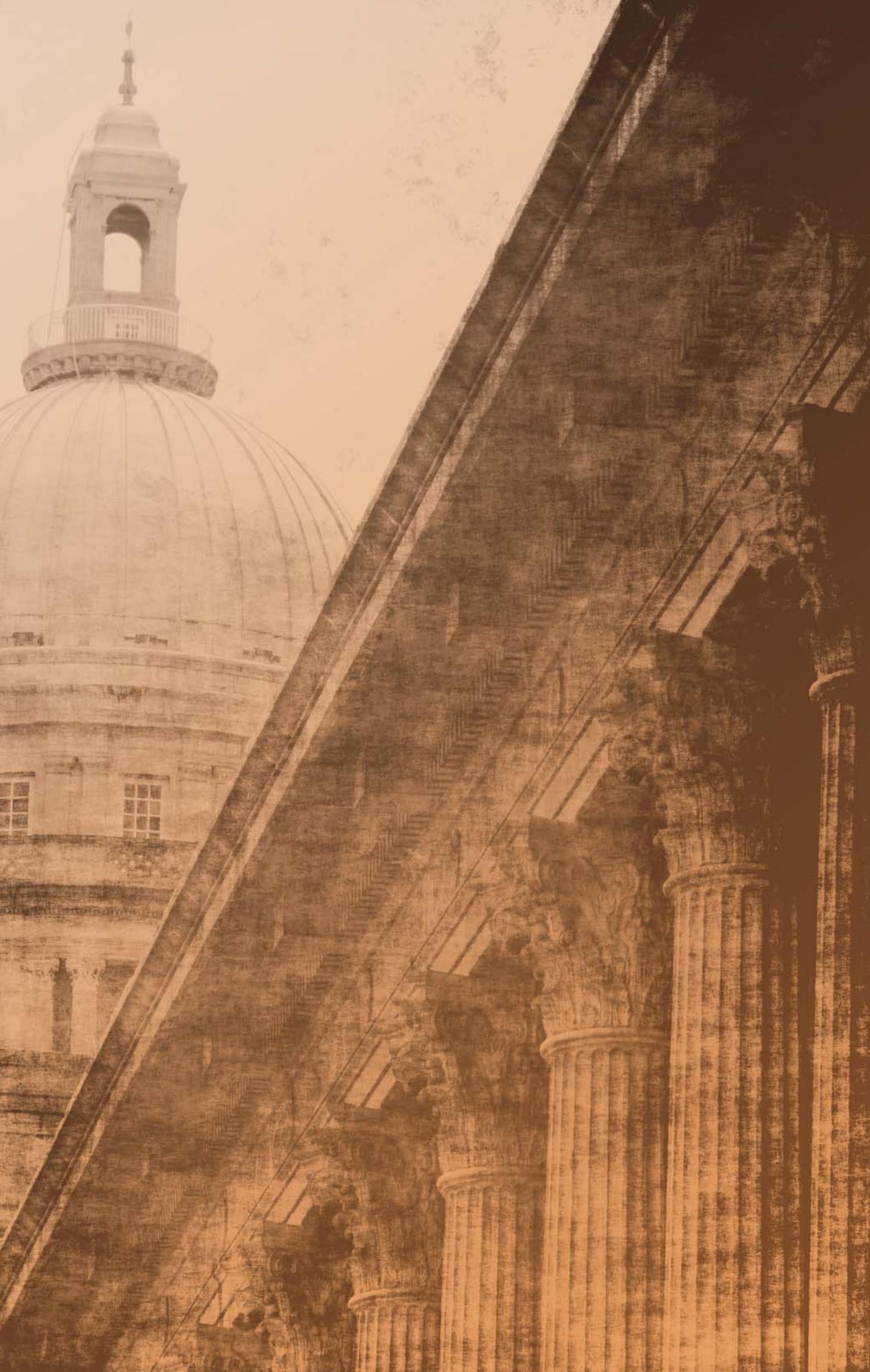


Ensuring long-term fiscal sustainability requires that governments engage in continual strategic forecasting of future liabilities and macroeconomic trends in order to adapt financial planning accordingly. Indeed, increasing debt levels are harmful to governments' fiscal positions, and can cause a vicious cycle of growing debt and reduce potential for economic growth as funds are diverted away from productive investments. Currently however, many OECD countries face rising public debt-to-GDP ratios following the financial and economic crises, and there is a general consensus that the fiscal trajectory of most member countries is unsustainable. The costs associated with addressing the economic crisis, as well as projected increases in ageing-related spending, present difficult challenges for the sustainability of public finances.

The OECD has produced estimates of the surpluses that would be required to stabilise debt-to-GDP ratios by 2026. According to this model (described in Annex C), Ireland, the United Kingdom and Poland require a total increase from their respective 2010 primary underlying balances of over $7 \%$ of potential GDP in order to stabilise public debt in this time frame. The United States and Japan require 11\% and $10 \%$ of potential GDP respectively to stabilise their debt-to-GDP ratios, however the required consolidation efforts are so large that they are not expected to reach this target by 2026 in this scenario. Conversely, the current states of public finances (e.g. fiscal balances and levels of debt) in Denmark, Hungary, Luxembourg, Norway, Sweden and Switzerland are such that these countries are not expected to require surpluses to achieve debt stabilisation.

This model's projections can be seen as the minimum effort required to improve the sustainability of public finances, since debt stabilisation may still coexist with undesirably high levels of debt in 2026. More stringent models examine the efforts needed to reduce debt to $60 \%$ of GDP and to pre-crisis (2007) levels by this same year. Ireland, the United States and Japan require the most effort to reduce debt to 2007 levels. In order to reduce debt to $60 \%$ of GDP (the maximum level of debt in the EU according to the Maastricht agreement), Japan currently faces the largest fiscal tightening efforts (31\% of potential GDP).

Good strategic forecasting exercises should consider the costs associated with demographic changes; especially since most OECD member countries face growing budgetary pressures due to expected increases in ageing-related spending on health care, long-term care and pensions. On average, ageing-related public spending in OECD countries is expected to increase by nearly 3 percentage points of GDP between 2010 and 2025. In Luxembourg ageing-related spending is expected to increase by 5.7 percentage points of GDP over the next 15 years. However, relative to other OECD countries, Luxembourg is in a better fiscal position to respond to these growing demands and changing societal needs. Conversely, Ireland, Iceland and Spain face above average ageing-related expenditures but are considered to be in a weaker fiscal position currently.

Improving fiscal discipline will be key in stabilising finances, and many OECD member countries have adopted fiscal rules which can require balanced budgets. Budget practices such as the use of medium-term expenditure frameworks that include targets or ceilings for spending can also help control excessive government spending.

\section{Methodology and definitions}

The data are drawn from the Preliminary Version of the OECD Economic Outlook, No. 89. The assumptions made to generate the primary balance required to stabilise the debt-to-GDP ratio can be found in the OECD Economic Outlook, No. 89, in Box 4.1 and Tables 4.1-4.4. See Annex C for further information on the model's assumptions.

The general government underlying balance is the cyclically adjusted balance excluding one-offs in revenues and spending, as well as interest payments. For most countries, data on gross debt used for the purpose of these calculations refer to the liabilities (short and long-term) in the general government as defined in the system of national accounts. This definition differs from the definition of debt under the Maastricht Treaty which is used to assess EU fiscal positions.

\section{Further reading}

OECD (2010), OECD Economic Outlook, No. 88, OECD Publishing, Paris.

OECD (2011), "Restoring Public Finances", Special Issue of the OECD Journal on Budgeting, Vol. 2011/2, OECD Publishing, Paris.

Schick, A. (2010), "Post-Crisis Fiscal Rules: Stabilising Public Finance while Responding to Economic Aftershocks", OECD Journal on Budgeting, Vol. 2010/2, OECD Publishing, Paris.

\section{Figure notes}

See StatLink for important country-specific notes. OECD averages are unweighted.

Data on consolidation requirements are not available for Chile, Estonia, Israel, Mexico, Slovenia and Turkey. Data for ageing-related spending are not available for: Chile, Estonia, Israel and Slovenia.

15.1: For Japan and the United States, the required consolidation to stabilise debt is so large in 2012 that is it not achieved in the baseline scenario by 2026 given the assumed pace of consolidation. The estimated number of years of consolidation for these and other OECD countries is provided in Table 4.3 of the OECD Economic Outlook, No. 89.

15.2: Luxembourg, Sweden, Switzerland and Norway are not included in the figure because no consolidation efforts are needed in these countries to achieve either of the targets shown. In addition, in Denmark and Korea no consolidation is needed to achieve the $60 \%$ debt-to-GDP ratio by 2026 . Countries that do not require consolidation efforts are included in the OECD28 average. 
15.1 Total change required in underlying primary balance between 2010 and 2026 in order to stabilise gross public debt-to-GDP

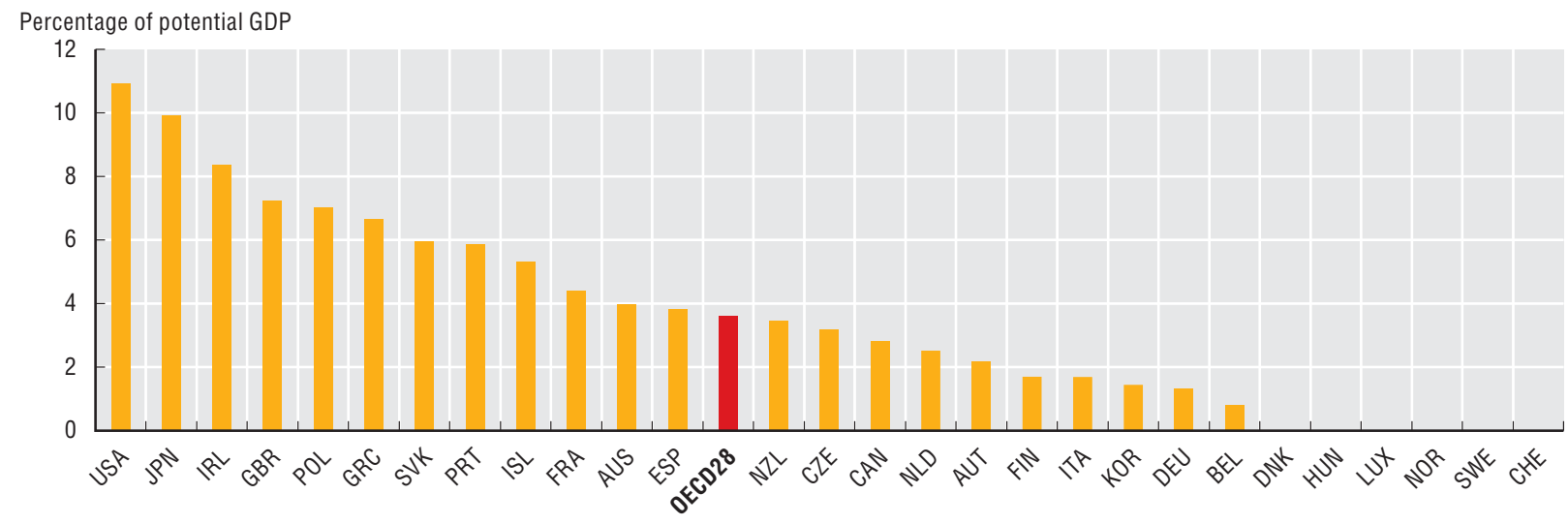

Source: OECD calculations. OECD Economic Outlook, No. 89 (Preliminary Version), May 2011.

StatLink काIsL http://dx.doi.org/10.1787/888932390348

\subsection{Total consolidation efforts required to reduce debt by 2026 to $60 \%$ of GDP and pre-crisis levels}

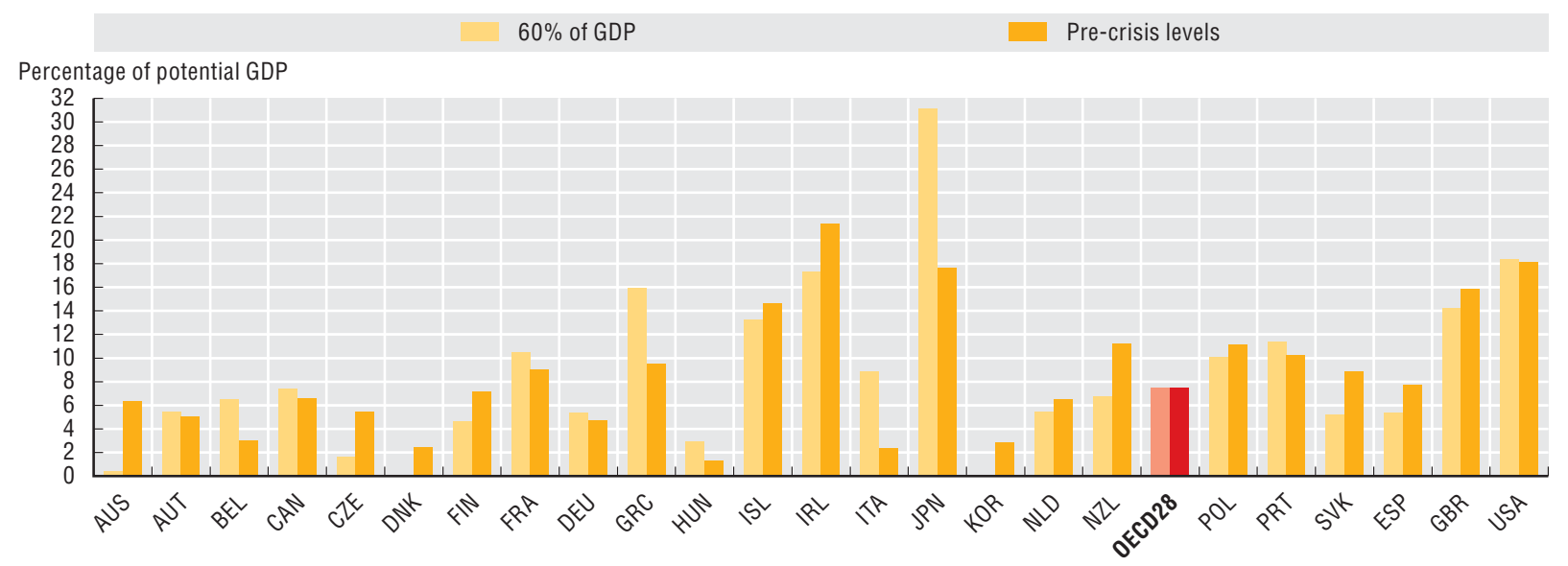

Source: OECD calculations. OECD Economic Outlook, No. 89 (Preliminary Version), May 2011.

StatLink काजि http://dx.doi.org/10.1787/888932390367

15.3 Fiscal consolidation requirements and projected change in ageing-related spending as a percentage of potential GDP

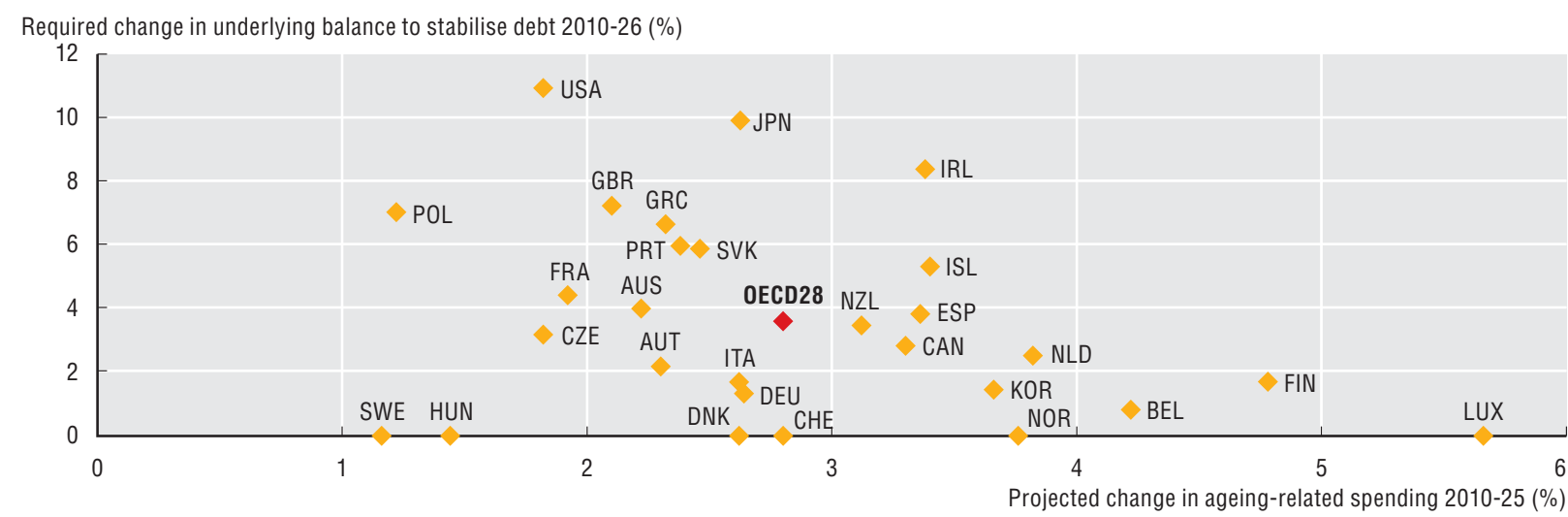

Source: OECD calculations. OECD Economic Outlook, No. 89 (Preliminary Version), May 2011. 
Strategic human resources management (HRM) is key to align people management with the strategic goals of public sector organisations. It allows governments to have the right number of people at the right place and with the right competencies. Such practices not only help governments meet strategic objectives, but also increase efficiency, responsiveness and quality in service delivery. Strategic HRM also encourages governments to look to the future, thinking strategically about the right mix of people and skills that will be needed to respond to changing societal needs.

The composite indicator of strategic human resources management looks at the extent to which centralised HRM bodies use performance assessments, capacity reviews and other tools to engage in and promote strategic workforce planning. The index benchmarks countries according to several factors including the existence of a general accountability framework for middle and top managers which incorporates strategic HRM components; the use of HRM targets in the performance assessment of middle and top managers; assessments of Ministries'/Departments' performance in terms of following good HRM practices; and the use of workplace planning. There is a large variance among OECD countries in the use of such strategic HRM practices. Australia, Canada and the United Kingdom are leaders in this regard, while the Czech Republic, the Slovak Republic, Greece and Hungary report not yet having many of these practices in place in central government.

Twelve OECD countries (Australia, Belgium, Canada, Denmark, Israel, Italy, Korea, Mexico, Portugal, Switzerland, the United Kingdom and the United States) report the existence of a general accountability framework in which strategic HRM practices are a core component and are fully linked to ministerial planning and reporting requirements. This finding suggests there is room for improvement in strategic HRM in OECD governments. Most countries have workforce planning mechanisms in place which consider such issues as demographic changes, new policies and possibilities for outsourcing, amongst others. However, some OECD countries only implement such practices in an ad hoc manner (Chile, the Czech Republic, Estonia, Greece, Ireland and Israel).

When interpreting the results of the composite indicator, it is important to consider that in some OECD countries responsibilities for strategic HRM practices are delegated to the Ministry/Department/Agency level which are not reflected in this index. Annex E includes further countryspecific information on strategic HRM practices, as well as on the other variables which constitute the index.

\section{Methodology and definitions}

Data refer to 2010 and were collected through the 2010 OECD Survey on Strategic Human Resources Management. Respondents were predominately senior officials in central government HRM departments, and data refer to HRM practices in central government. The survey was completed by all OECD member countries except Luxembourg. Definitions of the civil service, as well as the organisations governed at the central level of government, differ across countries and should be considered when making comparisons. The terms public and civil service/ servants are used interchangeably throughout this chapter. Due to insufficient data, composite indexes are unavailable for Brazil, Japan and Mexico.

The index is composed of the following variables: the existence of a general accountability framework; the existence of HRM targets built into performance assessments of top and middle managers; elements that top and middle management should take into account when planning and reporting within the general accountability framework; regular review and assessment of Ministries'/Departments' HRM capacity; existence of forward planning to adjust for adequate workforces to deliver services; and elements considered in governments' forward planning. The index ranges between 0 (low utilisation of strategic HRM practices) and 1 (high utilisation of strategic HRM practices).

See Annex E for further country-specific information as well as details on the methodology and factors used in constructing the index. The variables composing the index and their relative importance are based on expert judgements. They are presented with the purpose of furthering discussion, and consequently may evolve over time.

\section{Further reading}

OECD (forthcoming), Public Servants as Partners for Growth: Strengthening a Leaner and More Equitable Public Service, OECD Publishing, Paris.

\section{Figure and table notes}

See Annex E for further country-specific information as well as details on the methodology and factors used in constructing the index.

Information on data for Israel: $h t t p: / / d x . d o i . o r g / 10.1787 / 888932315602$. 
16.1 Utilisation of strategic HRM practices in central government (2010)

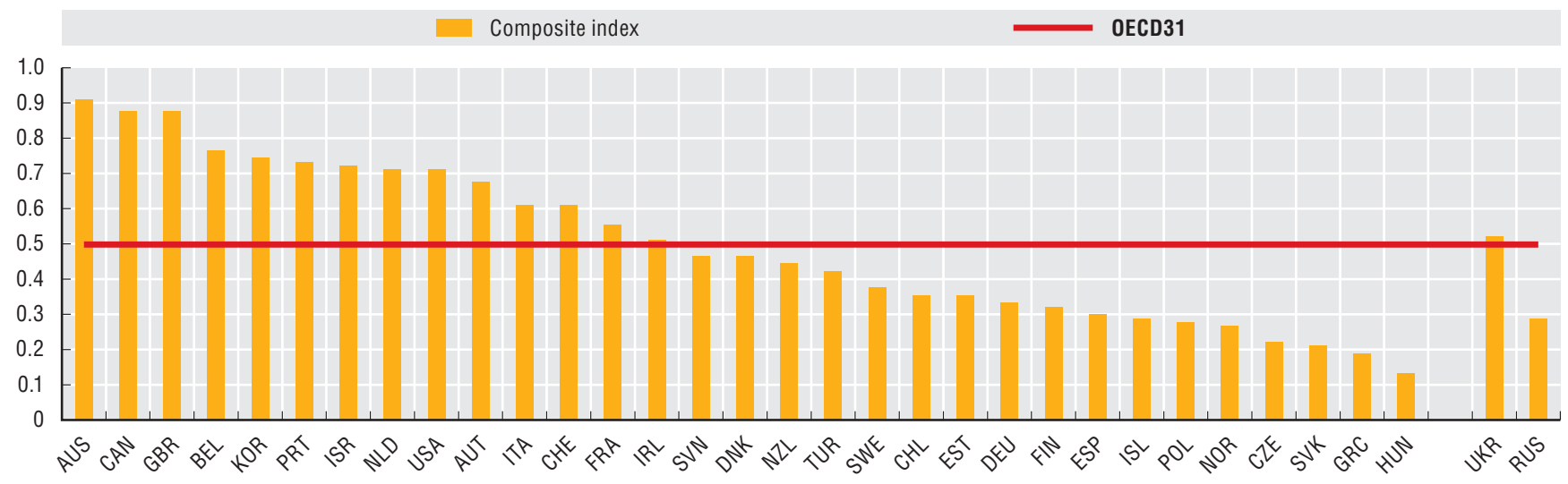

Source: 2010 OECD Survey on Strategic Human Resources Management in Central/Federal Governments.

StatLink क्ञाs $h t t p: / / d x . d o i . o r g / 10.1787 / 888932390405$

16.2 Aspects of strategic HRM in central government (2010)

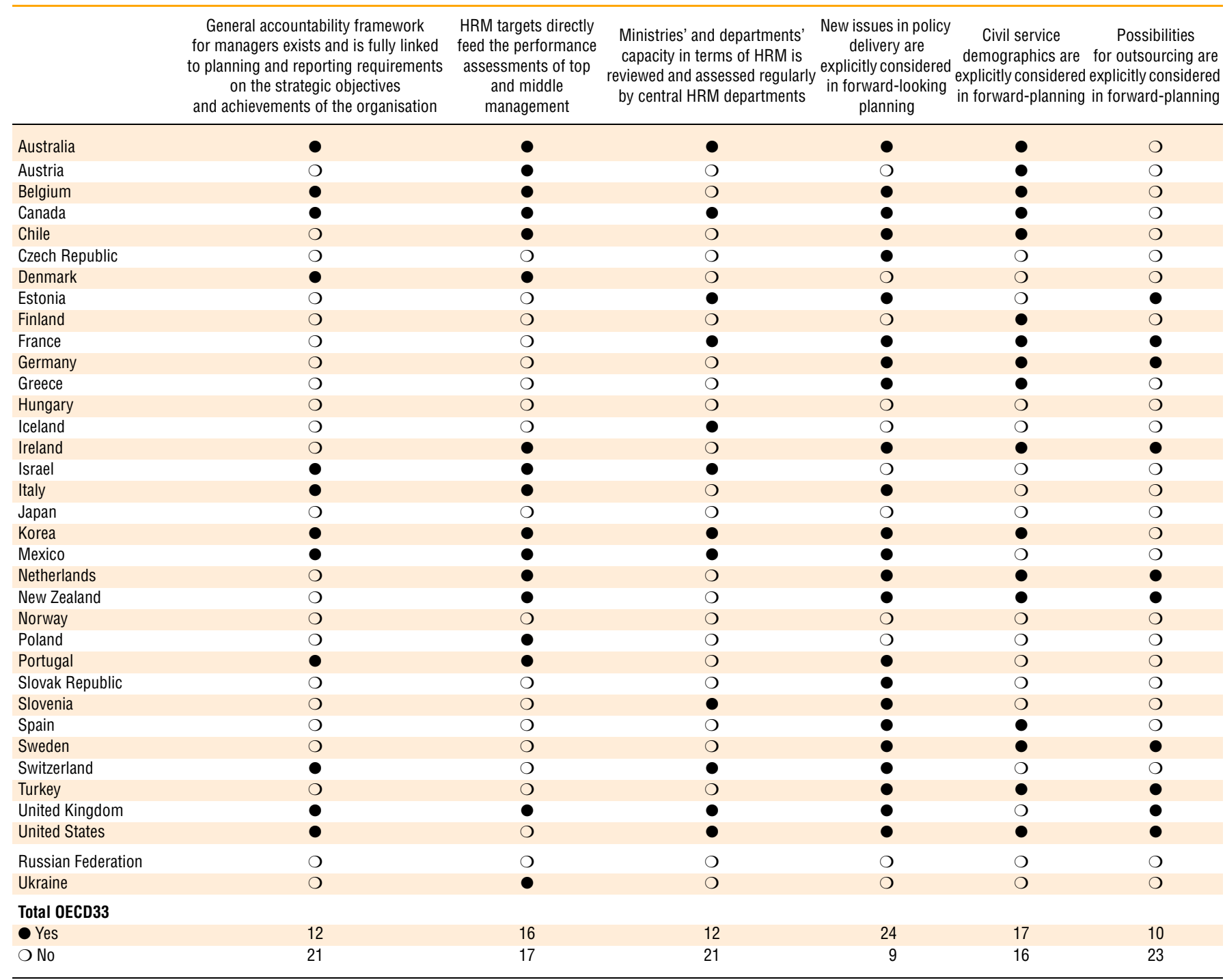

Source: 2010 OECD Survey on Strategic Human Resources Management in Central/Federal Governments. 
Senior civil servants (SCS) are located at a critical junction between strategy making and strategy execution in government. They must display the leadership capabilities to execute high-level policy directives quickly and effectively (particularly in times of crisis) as well as draw from bottom-up institutional knowledge and the experience of the civil service to contribute to evidence-based decision making. Improving governmental performance, agility and efficiency therefore rests partly on the quality and capacity of the senior civil service.

The senior civil service composite indicator shows the extent to which separate management rules and practices are applied to senior civil servants. It examines such factors as whether senior civil servants are considered to be a separate group of public servants; whether policies exist for identifying leaders and potential talent early in careers; or whether SCS have separate performance assessment practices. The index is not an indicator of how well senior civil servants are managed or how they perform. Among OECD member countries, Israel, the United Kingdom and the United States stand out as having institutionalised the management of their senior civil servants the most. HRM practices for senior management are the least differentiated from the rest of the central government civil service in Spain, the Slovak Republic and Sweden.

Because of their strategic roles in government, there is an increased tendency among OECD countries to group senior civil servants separately and manage them under different HRM policies, as is the case in 23 of responding OECD countries and 2 non-member countries. In this group, greater emphasis is placed on capacity building and on incentivising improved performance. For instance, 22 OECD member countries report paying greater attention on the management of senior civil servants' performance, and in 12 countries the portion of their remuneration that is performance-related is higher than for other staff.

Senior civil servants also tend to be recruited through a more centralised process than the rest of the civil servants and, in a majority of countries, there is a defined skills profile applying to them specifically. However, only four of the responding OECD countries (France, Israel, Korea and the United Kingdom) report having mechanisms in place to identify potential senior civil servants early in their careers. Offering opportunities for career development and leadership to qualified candidates early in their careers could help not only attract talent to the civil service but also allow for early mentoring and capacity building.

\section{Methodology and definitions}

Data refer to 2010 and were collected through the 2010 OECD Survey on Strategic Human Resources Management. Respondents were predominately senior officials in central government HRM departments, and data refer to HRM practices in central government. The survey was completed by all OECD member countries except Luxembourg. Definitions of the civil service, as well as the organisations governed at the central level of government, differ across countries and should be considered when making comparisons. The terms public and civil service/servants are used interchangeably throughout this chapter.

The index is composed of the following variables: the existence of separate group of SCS; the existence of policies for the identification of potential SCS early in their careers; the use of centrally defined skills profile for SCS; and the use of separate recruitment, performance management and performance-related-pay practices for SCS. The index ranges between 0 (HRM practices are not differentiated for SCS) and 1 (HRM practices are very differentiated for SCS). Missing data for countries were estimated by mean replacement.

See Annex E for further country-specific information as well as details on the methodology and factors used in constructing the index. The variables composing the index and their relative importance are based on expert judgements. They are presented with the purpose of furthering discussion, and consequently may evolve over time.

\section{Further reading}

Matheson, A. et al. (2007), "Study on the Political Involvement in Senior Staffing and on the Delineation of Responsibilities Between Ministers and Senior Civil Servants", OECD Working Papers on Public Governance, No. 6, OECD Publishing, Paris.

OECD (2008), The State of the Public Service, OECD Publishing, Paris.

\section{Figure and table notes}

See Annex E for further country-specific information as well as details on the methodology and factors used in constructing the index. Denmark and New Zealand do not have a centralised HRM policy regarding senior civil servants and have therefore been removed from the index.

Information on data for Israel: $h$ ttp://dx.doi.org/10.1787/888932315602. 
17.1 Use of separate HRM practices for senior civil servants in central government (2010)

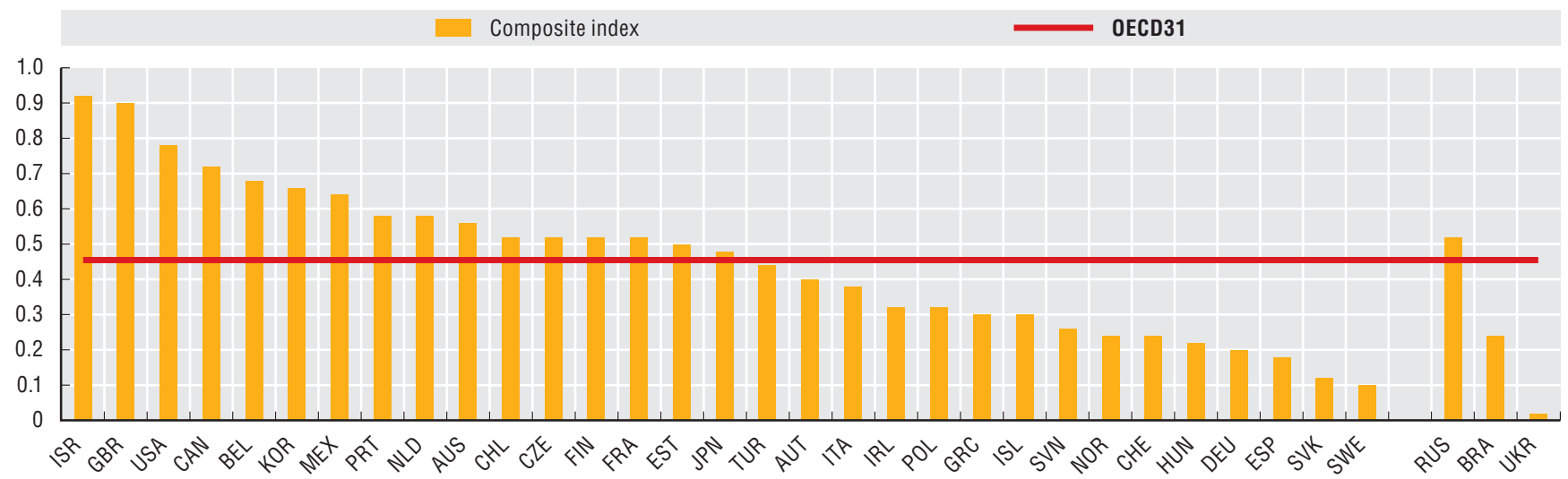

Source: 2010 OECD Survey on Strategic Human Resources Management in Central/Federal Governments.

StatLink क्ताडस http://dx.doi.org/10.1787/888932390424

\subsection{Central government HRM practices for SCS (2010)}

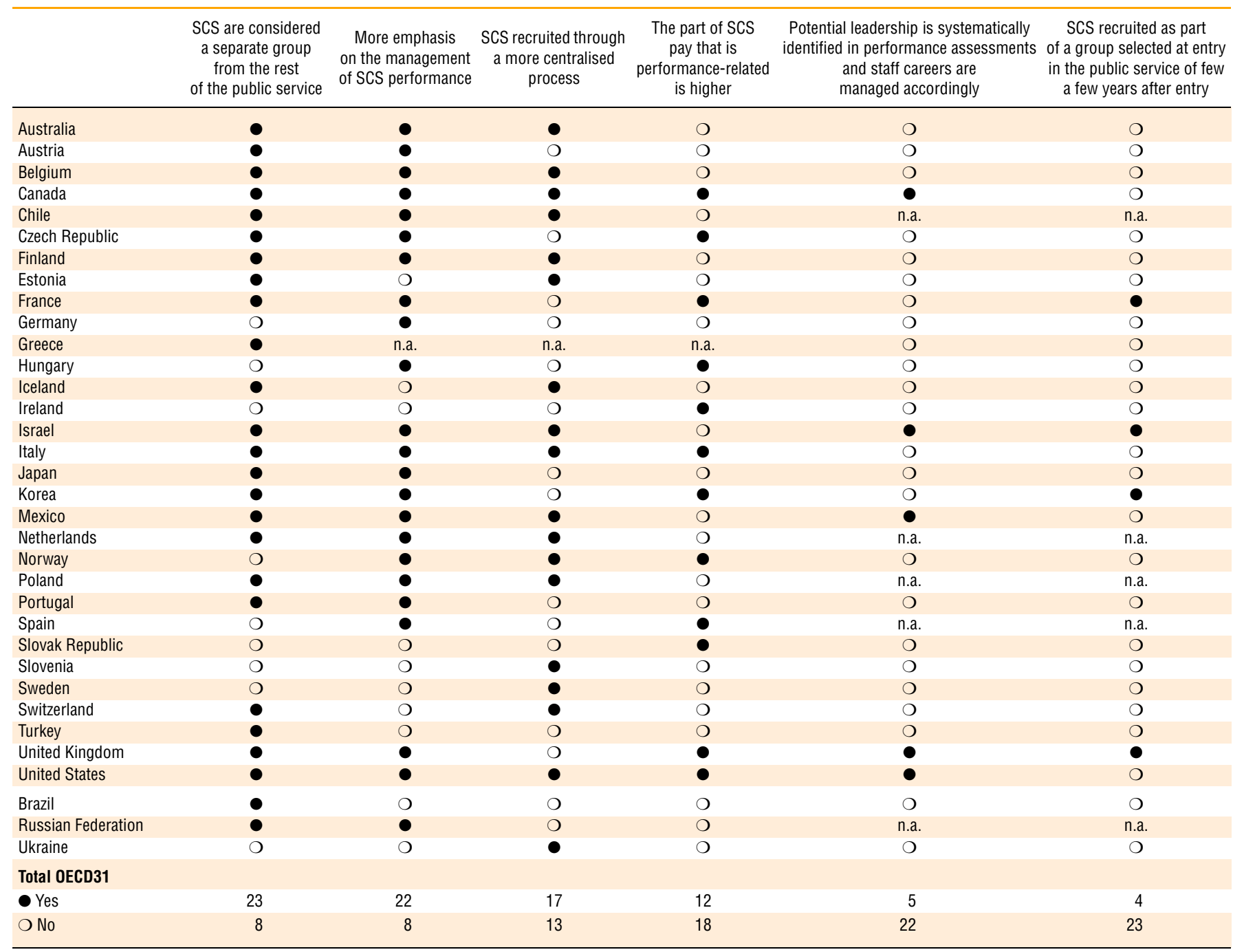

Source: 2010 OECD Survey on Strategic Human Resources Management in Central/Federal Governments. 
Exerting political influence in senior staffing decisions can stem from the need to ensure responsiveness from the civil service, as well as the need to overcome the challenges posed by complex procedures and (at times) slow-moving bureaucracies or institutions. In times of economic and social crises, for example, greater agility and responsiveness from the civil service may be particularly important in designing and implementing policy decisions quickly and effectively. However, although political influence in senior staffing may help increase strategic agility in government, it can also indicate tendencies towards patronage and favouritism that may undermine good governance.

The level of politically influenced turnover in OECD member countries is one indication of the extent to which politics and/or political affiliation play a role in staffing the civil service. Among the six levels of senior civil servants (with Level 1 representing the most senior staff and 6 representing the least senior), the lower levels (Levels 3-6) tend to experience little if any turnover with a change of government. On the other hand, politically motivated turnover is relatively higher in the upper levels (Levels 1 and 2). The group with the highest turnover is advisors to Ministries' leadership, who are often appointed by the Minister (see also Indicator 19).

In the Czech Republic, Hungary and Turkey all positions change systematically in the two top echelons after the election of a new government. All public service positions change in the top echelon with a new government in Korea and the Slovak Republic. In 11 of the OECD member countries surveyed (Australia, Austria, Canada, Denmark, Estonia, Ireland, Japan, New Zealand, Norway, Sweden and the United Kingdom), there is no turnover in any of the six levels of senior civil servants when there is a change in government.

\section{Methodology and definitions}

Data refer to 2010 and were collected through the 2010 OECD Survey on Strategic Human Resources Management. Respondents were predominately senior officials in central government HRM departments, and data refer to HRM practices in central government. The survey was completed by all OECD member countries except Luxembourg. Definitions of the civil service, as well as the organisations governed at the central level of government, differ across countries and should be considered when making comparisons. The terms public and civil service/servants are used interchangeably throughout this chapter.

\section{Further reading}

Matheson, A. et al. (2007), "Study on the Political Involvement in Senior Staffing and on the Delineation of Responsibilities Between Ministers and Senior Civil Servants", OECD Working Papers on Public Governance, No. 6, OECD Publishing, Paris.

OECD (2004), Policy Brief - Public Sector Modernisation: Modernising Public Employment, OECD Observer, OECD Publishing, Paris.

OECD (2008), The State of the Public Service, OECD Publishing, Paris.

\section{Table notes}

In New Zealand, a change of government does not affect the employment of public servants. The exception to this is a small number of public servants who are employed in Ministerial offices on an event-based contract, with the event triggering the termination of their contract being the conclusion of their relevant Minister's term in office.

Information on data for Israel: http://dx.doi.org/10.1787/888932315602. 
IV. STRATEGIC FORESIGHT AND LEADERSHIP

18. Political influence in senior staffing

18.1 Turn-over of civil servants with a change in government (2010)

\begin{tabular}{|c|c|c|c|c|c|c|c|}
\hline & $\begin{array}{l}\text { Advisors to the Ministry's } \\
\text { leadership }\end{array}$ & $\begin{array}{l}\text { (Highest) } \\
\text { Level } 1\end{array}$ & Level 2 & Level 3 & Level 4 & Level 5 & $\begin{array}{c}\text { (Lowest) } \\
\text { Level } 6\end{array}$ \\
\hline Australia & 口 & 0 & ○ & 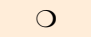 & O & 0 & O \\
\hline Austria & - & 0 & 0 & O & 0 & $\mathrm{O}$ & $\mathrm{O}$ \\
\hline Belgium & $\bullet$ & - & O & O & O & O & O \\
\hline Canada & n.a. & 0 & O & O & 0 & O & O \\
\hline Chile & n.a. & 口 & 口 & $\bullet$ & - & 0 & O \\
\hline Czech Republic & n.a. & $\bullet$ & 0 & $\mathbf{\square}$ & O & $\bigcirc$ & n.a. \\
\hline Denmark & $O$ & O & O & O & O & 0 & $O$ \\
\hline Estonia & $\bullet$ & O & $\bigcirc$ & ○ & O & $\bigcirc$ & O \\
\hline Finland & $\bullet$ & - & O & O & O & O & O \\
\hline France & $\mathbf{\square}$ & $\bullet$ & 0 & O & O & $O$ & O \\
\hline Germany & n.a. & $\mathbf{\square}$ & $\square$ & O & O & O & O \\
\hline Greece & $\bullet$ & $\boldsymbol{\square}$ & $\square$ & O & O & O & O \\
\hline Hungary & 口 & $\bullet$ & - & 口 & - & 0 & n.a. \\
\hline Iceland & $\bullet$ & $\bullet$ & O & $O$ & O & $O$ & $O$ \\
\hline Ireland & $\bullet$ & O & O & O & O & O & O \\
\hline Israel & $\bullet$ & $\mathbf{\square}$ & $\bullet$ & O & O & O & n.a. \\
\hline Italy & $\bullet$ & $\mathbf{\square}$ & - & O & O & O & $O$ \\
\hline Japan & n.a. & O & O & O & O & O & O \\
\hline Korea & 0 & $\bullet$ & 0 & O & O & 0 & O \\
\hline Mexico & घ & घ & $\square$ & 0 & O & $\bigcirc$ & O \\
\hline Netherlands & O & - & O & O & O & O & 0 \\
\hline New Zealand & O & O & O & O & O & O & O \\
\hline Norway & O & O & O & O & O & O & O \\
\hline Poland & $\bullet$ & $\bullet$ & O & $O$ & $O$ & $O$ & $O$ \\
\hline Portugal & $\bullet$ & 口 & $\mathbf{\square}$ & O & O & n.a. & n.a. \\
\hline Slovak Republic & $\mathbf{\square}$ & $\bullet$ & $\square$ & - & $\bullet$ & $O$ & $\bigcirc$ \\
\hline Slovenia & $\mathbf{\square}$ & $\bullet$ & 0 & O & O & 0 & 0 \\
\hline Spain & n.a. & 口 & $\bullet$ & $O$ & O & $\bigcirc$ & n.a. \\
\hline Sweden & $\bullet$ & O & O & $O$ & O & O & 0 \\
\hline Switzerland & $\bullet$ & - & O & O & O & O & O \\
\hline Turkey & n.a. & $\bullet$ & - & 口 & 口 & 口 & $\bullet$ \\
\hline United Kingdom & $\bullet$ & O & O & $O$ & O & $O$ & $O$ \\
\hline United States & $\bullet$ & - & ○ & $\bullet$ & $\bullet$ & n.a. & n.a. \\
\hline Russian Federation & O & $\bullet$ & $\mathbf{\square}$ & - & O & $\bigcirc$ & $O$ \\
\hline Ukraine & - & $\bullet$ & $\square$ & $\square$ & 0 & ○ & ○ \\
\hline \multicolumn{8}{|l|}{ Total OECD33 } \\
\hline - Yes, all & 14 & 5 & 3 & 1 & 0 & 0 & 0 \\
\hline - Yes, many & 7 & 8 & 6 & 3 & 1 & 1 & 0 \\
\hline Yes, few & 1 & 9 & 5 & 3 & 4 & 2 & 1 \\
\hline None & 4 & 11 & 19 & 26 & 28 & 28 & 26 \\
\hline
\end{tabular}

n.a.: Not applicable.

Source: 2010 OECD Survey on Strategic Human Resources Management in Central/Federal Governments.

StatLink AाISL http://dx.doi.org/10.1787/888932391963 
Strategic decision making relies on effective co-ordination to enhance the coherence of government actions, continual monitoring of and responsiveness to the external environment, and providing evidence-based data for informed decisions. The provision of high-quality advice and support to government leaders is essential in achieving these objectives and informing the decisions of government. Alongside the public service, ministerial advisors have the potential to contribute to each of these functions.

It is not a new phenomenon in many OECD member countries that government leaders appoint ministerial advisors, and in general the influence advisors have with Ministers and heads of government has grown over time. Their appointments are mainly motivated by the need to increase the agility and responsiveness of government and help address government's strategic challenges (identified by $84 \%$ of countries in both cases). There is no single definition of what constitutes a ministerial advisor across OECD member countries; however, there are common characteristics in terms of their appointment process and the range of functions they carry out. In $70 \%$ of countries, for example, the appointment of ministerial advisors is at the sole discretion of the Minister or the head of government and their employment is tied to his/her mandate.

The most common functions of ministerial advisors include providing strategic advice in the design of policies or reforms (95\%); co-ordinating with stakeholders including parliament, interest groups, lobbyists, political party, etc. (84\%); and giving political/partisan advice in light of the Minister's political outlook or governing party's priorities (79\%). In some countries that have a strong tradition of political neutrality in the public service such as Finland and the Netherlands, the functions of ministerial advisors may be more confined (e.g. focusing on political/partisan advice or media assistance).

Due to their co-ordination function with the private sector and their potential influence on policy making, ministerial advisors are potentially vulnerable to undue influence of private interests. Ministerial advisors have become a source of public concern in $70 \%$ of responding countries in the last decade, often due to their increasing number. In some countries, the rising use of ministerial advisors has been seen as increasing the distance between Ministers and the bureaucracy, resulting in a lack of connectedness between the government and the public service which could in turn threaten capacities for strategic foresight, particularly if critical flows of information are hindered. Despite the concerns raised in countries about the lack of transparency in government decision making, information is still not readily available on ministerial advisors. Although the number of advisors is made public in $55 \%$ of countries, public information on profiles of advisors (15\%), job descriptions (25\%) and their total cost (25\%) is sparse.

\section{Methodology and definitions}

Data were collected via two surveys conducted in 2010 by the OECD. The first consisted of a survey on existing legal, institutional and procedural frameworks governing ministerial advisors. Respondents were OECD senior civil servants in charge of integrity policies in central government. A total of 23 OECD member countries responded as well as Egypt and Ukraine. A second survey was designed specifically for ministerial advisors to gather their direct insights, and was completed by 17 member countries.

"Head of government" usually refers to the Prime Minister although depending on the political-administrative systems it may be President of the Republic, President of the Council of Ministers, Chancellor, Taoiseach, President of the Government, etc.

\section{Further reading}

Matheson, A. et al. (2007), "Study on the Political Involvement in Senior Staffing and on the Delineation of Responsibilities between Ministers and Senior Civil Servants", OECD Working Papers on Public Governance, No. 6, OECD Publishing, Paris.

OECD (forthcoming), Transparency in Strategic Decisionmaking: Ministerial Advisors, OECD Publishing, Paris.

OECD (2007), "Political Advisors and Civil Servants in European Countries", Sigma Papers, No. 38, OECD Publishing, Paris.

Zussman, D. (2009), Political Advisors, OECD Publishing, Paris.

\section{Figure notes}

19.1: Based on the responses provided by senior civil servants in 20 countries and ministerial advisors in 17 countries.

19.2 and 19.3: Data are based on the responses received from 20 OECD member countries. 
19.1 Functions of ministerial advisors: Views from ministerial advisors and senior civil servants (2010)

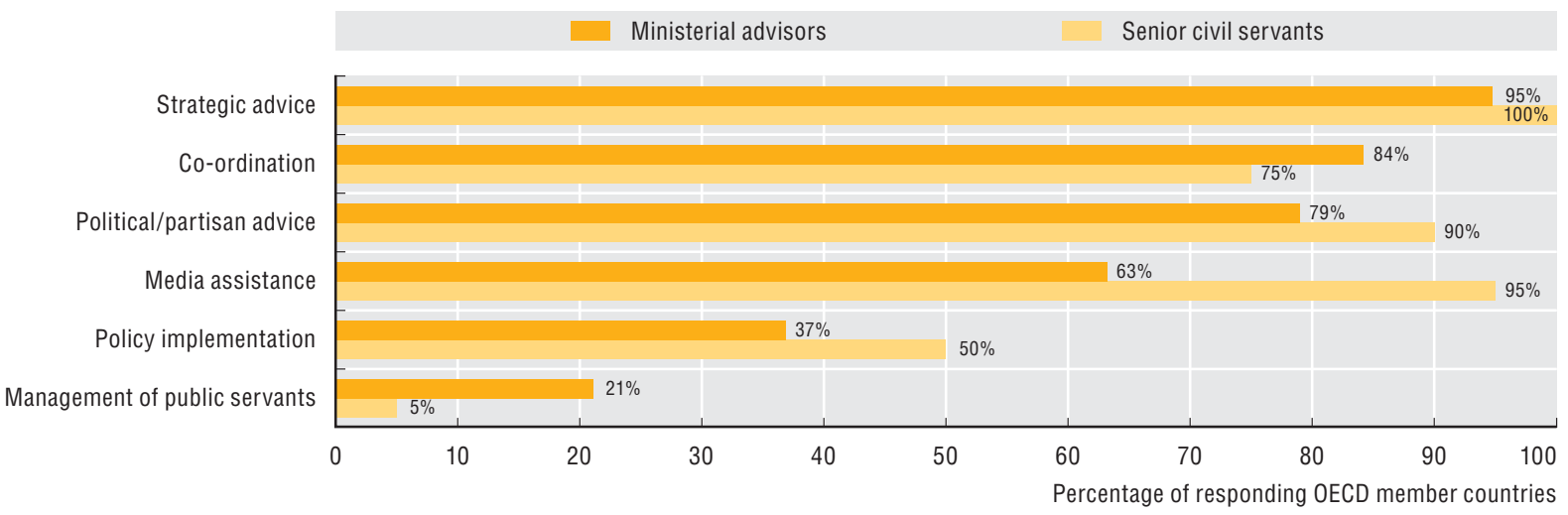

Source: OECD (2010), Ministerial Advisors Survey, responses to the questionnaires for senior civil servants and ministerial advisors.

StatLink AाsL http://dx.doi.org/10.1787/888932390443

\subsection{Ministers' discretion in human resource management of ministerial advisors (2010)}

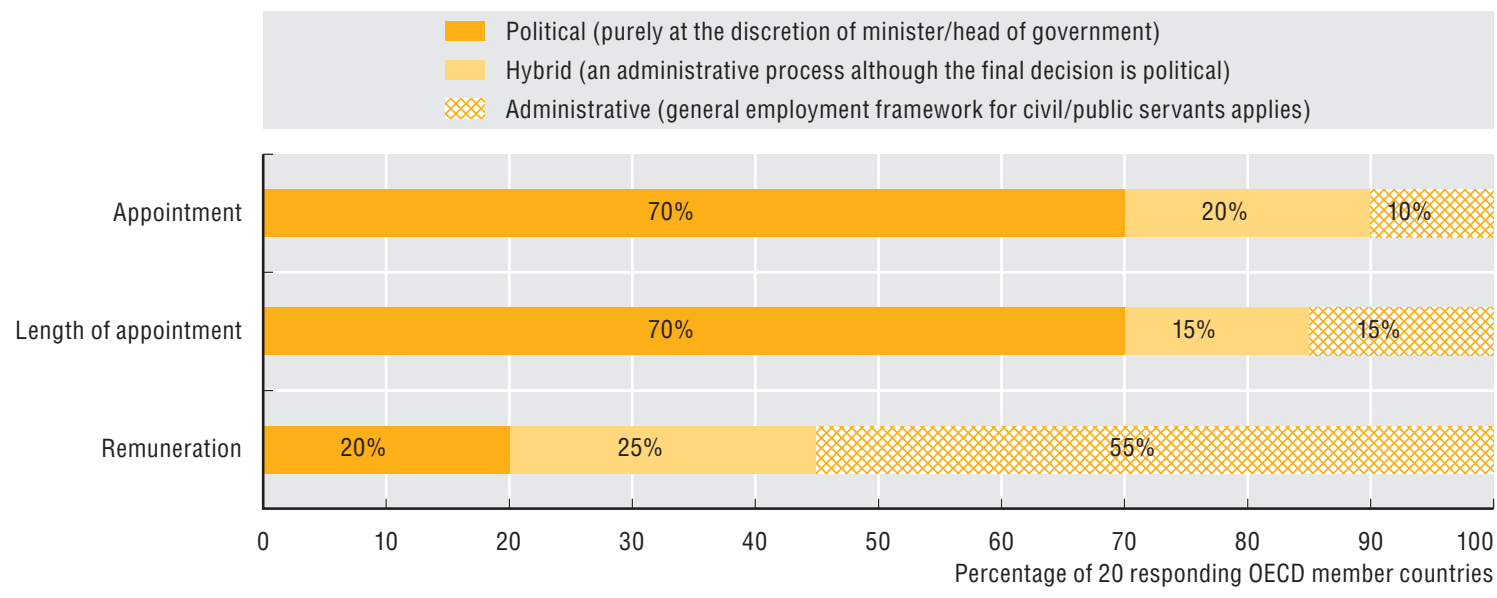

Source: OECD (2010), Ministerial Advisors Survey, responses to the questionnaire for senior civil servants.

StatLink (Alls http://dx.doi.org/10.1787/888932390462

\subsection{Information available on ministerial advisors (2010)}

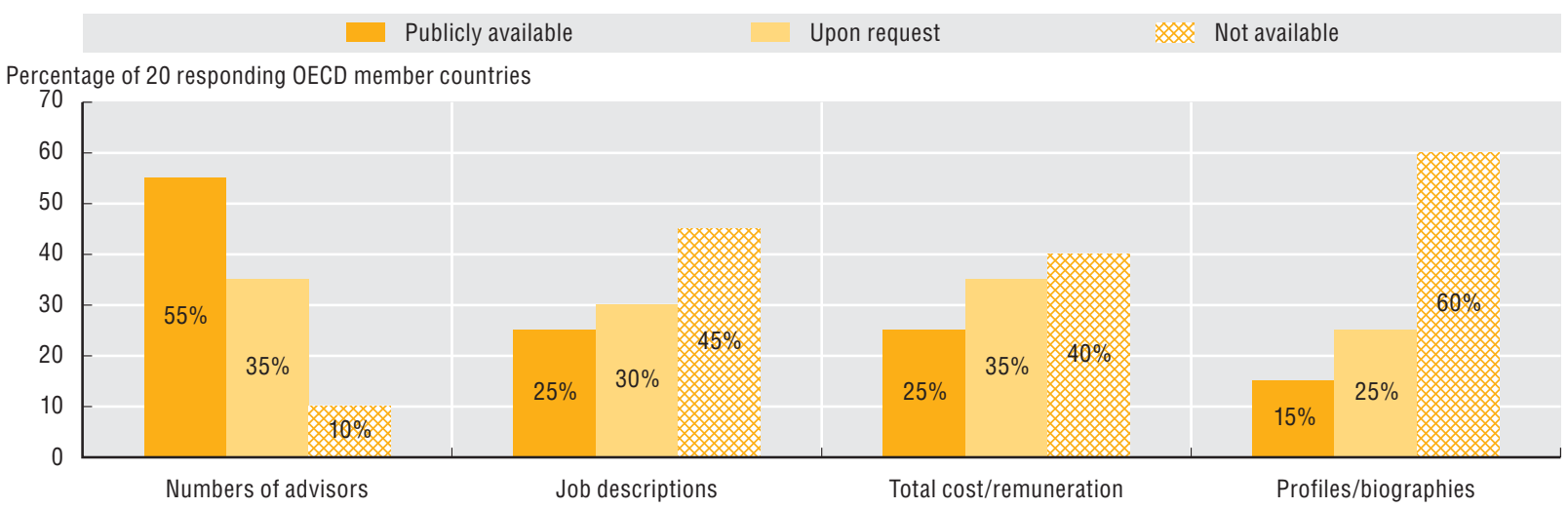

Source: OECD (2010), Ministerial Advisors Survey, responses to the questionnaire for senior civil servants.

StatLink AाIst http://dx.doi.org/10.1787/888932390481 
In the aftermath of the crisis, tough austerity initiatives have spurred many OECD governments to rethink their e-government priorities and boost e-government's strategic role in supporting the recovery. E-government is seen more than ever as at the core of public sector reforms, and policy makers consider it as a pivotal policy tool to enable governments to do more with less. As such, national e-government strategies aim to exploit new efficiencies, create more effective ways of working and improve productivity within the public sector. The implementation of e-government initiatives can be a reflection of a government's capacity for strategic foresight and leadership, as successful execution of these large-scale initiatives requires that the public administration co-ordinate various stakeholders across a wide breadth of administrative silos.

The 2010 OECD e-Government Survey asked member countries about the expected results of national e-government initiatives to better understand how governments are adapting e-government strategic objectives in the current economic context. Responses show that e-government initiatives are designed to contribute to wider economic objectives: they are seen as a means to achieve cost savings and promote growth by fostering a business-friendly environment. The main priorities of e-government initiatives of member countries are indeed reducing administrative burdens (96\%) and cutting costs (86\%) followed by spurring innovation (74\%) and improving effectiveness and responsiveness (67\%).

A complex, incomplete or obsolete legal and regulatory environment, however, may hinder the provision of integrated and responsive e-government services or their uptake by users. Countries reported that while they are fairly advanced in tackling issues like privacy and digital signature (all respondents regulate these areas), promoting e-business (92\%), regulating electronic filing and preventing cybercrime (88\%), they are not as prepared in managing public and private partnerships in e-government initiatives (67\%).

Lastly, e-government can also be used as an internal management tool for increasing governments' capacities for decision making and forward planning. OECD countries are increasingly exploring the use of new technologies (e.g. web 2.0, cloud computing, mobile technology) to change how the public sector works and interacts with citizens and businesses. However, survey results show that more efforts are needed in this regard; for instance, only $25 \%$ of responding OECD countries have ongoing initiatives to promote better knowledge management in the public sector. This is important to facilitate information sharing across government silos, and to breakdown interoperability barriers.

\section{Methodology and definitions}

Data are drawn from the 2010 OECD Survey on e-Government Structural and Economic Data. Respondents were government officials in the central level of government responsible for national e-government strategies. The survey was completed by 25 OECD member countries and Egypt. Data are not available for Belgium, Canada, the Czech Republic, Germany, Ireland, Israel, Korea, Norway and the United States. Additional country-specific data on e-government objectives are available on line at: $h t t p: / / d x . d o i . o r g /$ 10.1787/888932391982. Additional country-specific data on enabling laws or policies are available on line at: http://dx.doi.org/10.1787/888932392001.

\section{Further reading}

OECD (2009), Rethinking e-Government Services: User-Centred Approaches, OECD Publishing, Paris.

OECD (2010), Denmark: Efficient e-Government for Smarter Public Service Delivery, OECD Publishing, Paris. 
20.1 Top e-government objectives identified in central government (2010)

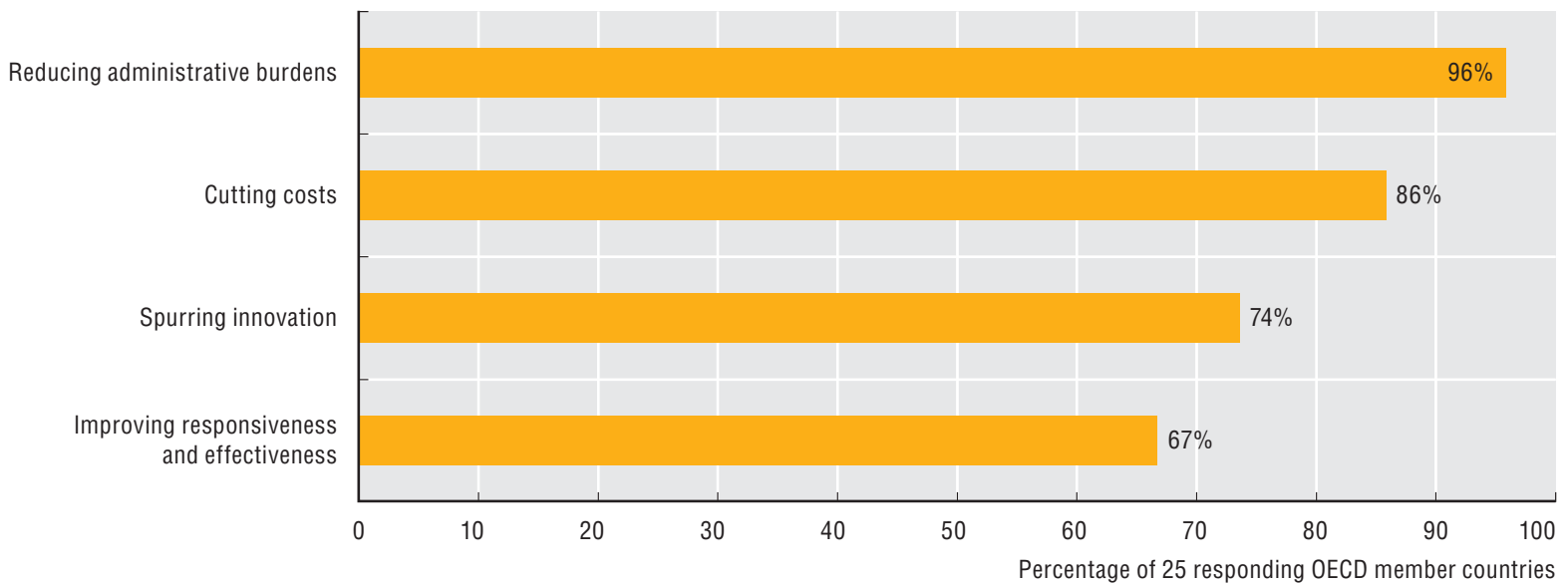

Source: OECD 2010 Survey on e-Government Structural and Economic Data.

StatLink -iाs http://dx.doi.org/10.1787/888932390500

20.2 Central government laws or policies enabling e-government (2010)

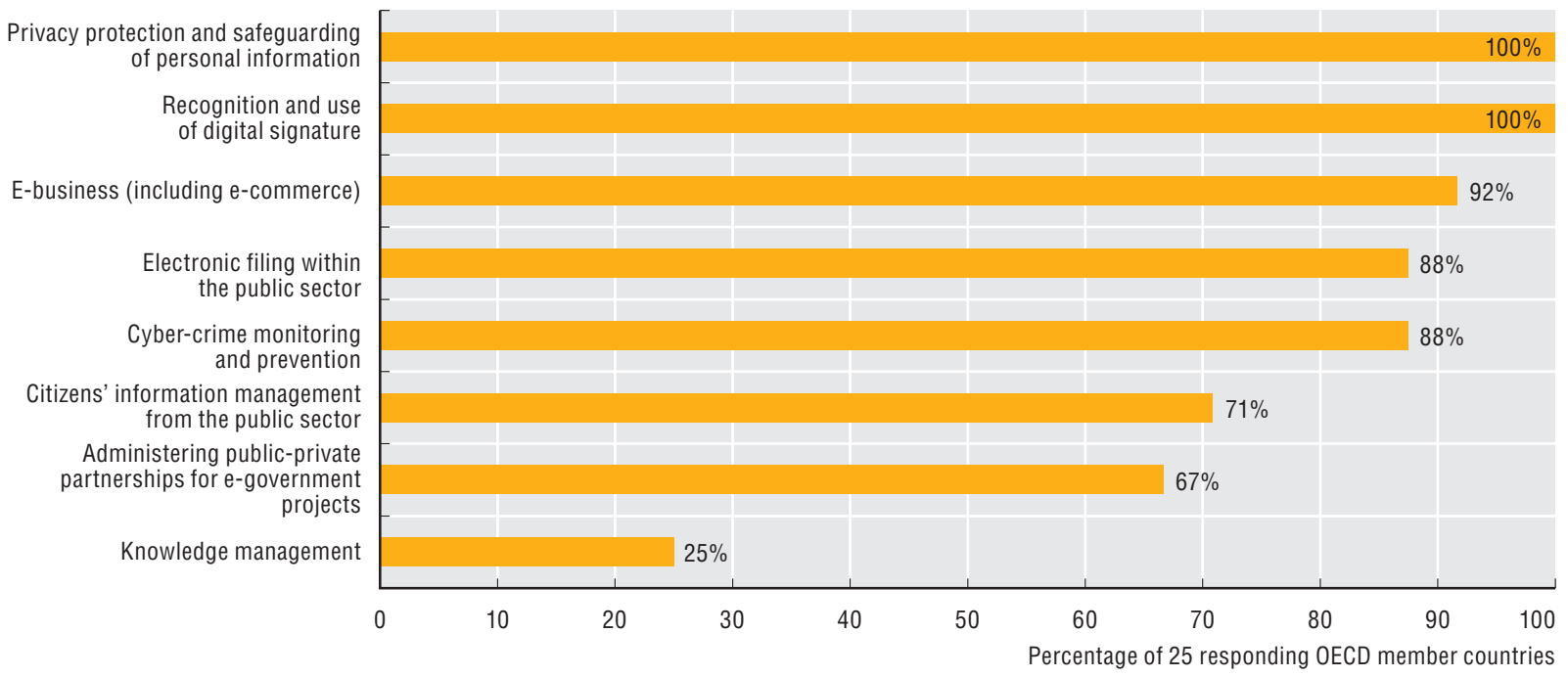

Source: OECD 2010 Survey on e-Government Structural and Economic Data. 



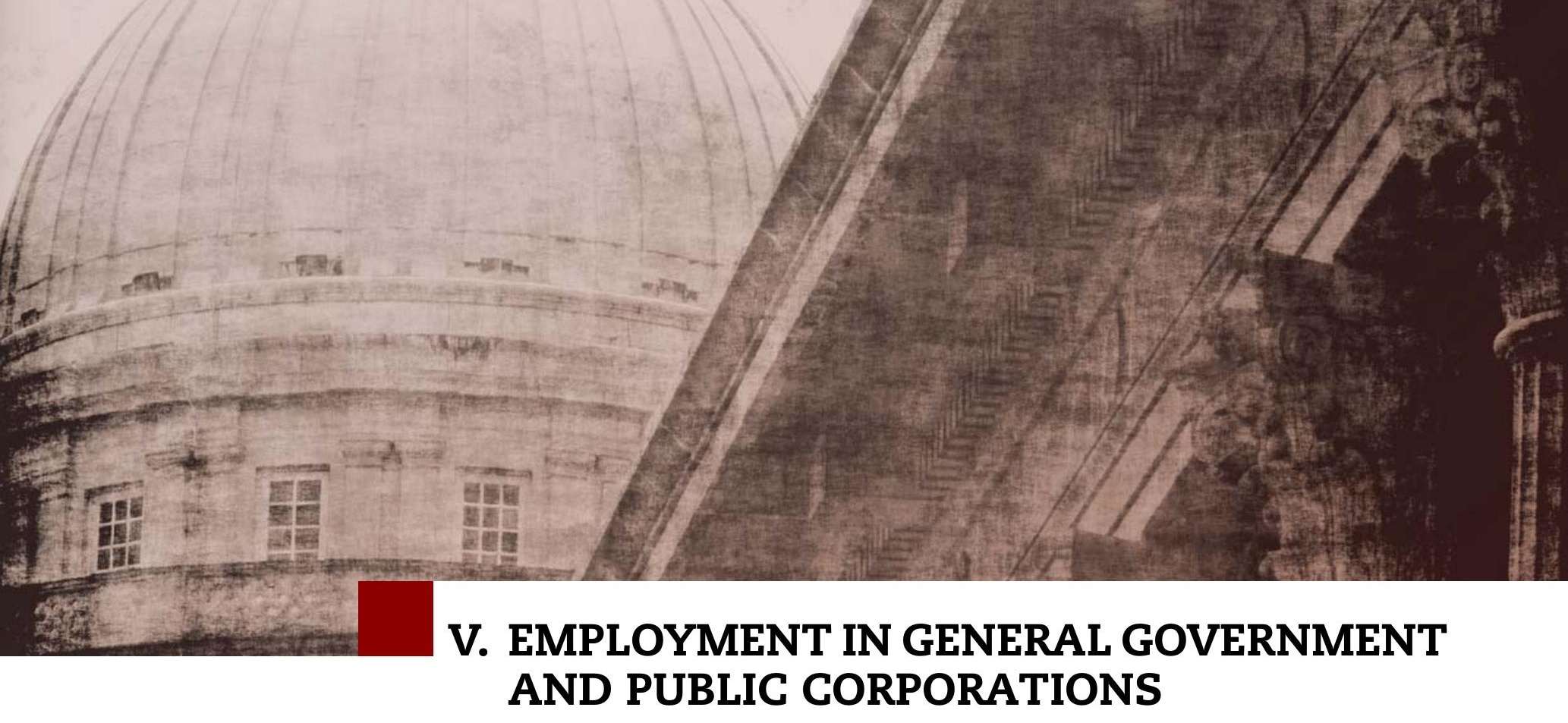

Governments produce services and goods through their own employees or through the use of private and non-profit companies and organisations. Government employment is thus a core determinant of public sector costs, quality and productivity. This chapter compares the size of government workforces across countries, which reflects the choices countries make regarding the level and modes of public service delivery. A second indicator of the mode of delivery is the division of government workforces across levels of government.

This chapter also presents data that indicate the intention and room for manoeuvre that governments have to decrease the size of the civil service. With the present levels of public debt, governments are under pressure to produce greater savings by reducing the size of government workforces and reallocating personnel more effectively. Indicators about public service demographics show how an ageing public service can offer governments an opportunity to restructure their workforces as civil servants retire, provided they have enough management capacity to avoid losing expertise as a side effect of a large number of departures. 


\section{Employment in general government and public corporations}

The proportion of the labour force working for the government is one indication of how public services are delivered in a country (whether predominantly by government workers or through the private and non-profit sectors as well) and is an important factor determining the costs of service delivery. In countries where a large proportion of the labour force works for government, government employment could also crowd out private sector employment.

Large differences exist across OECD countries in the size of government staff. For example, in 2008 governments in Norway and Denmark employed close to $30 \%$ of the labour force in contrast to Korea whose government employed only $5.7 \%$ of the labour force. However, employment data should be interpreted with caution and together with data on production costs (Indicator 8) and outsourcing (Indicator 48) since, alone, they are an unreliable indicator of the size of government.

On average across the OECD, government employment as a percentage of the labour force remained stable between 2000 and 2008 at $15 \%$. However, the available data do not yet reflect the potential effects that the financial and economic crises and/or fiscal austerity measures could have on the size of government employment.

In most OECD member countries, employment in public corporations constitutes a minor part of the labour force. However, in certain countries (e.g. Greece and Poland), public corporations employ more workers than the general government. In the future, this trend may change as governments look to privatise some of these corporations to lower the high levels of debt that have accrued since the financial and economic crises.

\section{Methodology and definitions}

Data refer to 2000 and 2008 and were collected by the International Labour Organization (ILO). The data are based on System of National Accounts (SNA) definitions and cover employment in general government and public corporations. The general government sector comprises all levels of government (e.g. central, state, regional and local) and includes core Ministries, agencies, departments and non-profit institutions that are controlled and mainly financed by public authorities. Public corporations are legal units mainly owned or controlled by the government which produce goods and services for sale in the market. Examples of public corporations in some OECD countries include post offices, railways and mining operations. Public corporations also include quasi-corporations.
Data represent the number of employees except for Austria, the Czech Republic, Italy, the Netherlands, New Zealand and Poland where data represent full-time equivalents (FTEs). In New Zealand FTEs are included for education, health and community services and personal and other services As a result, employment numbers for these six countries are understated in comparison. The labour force comprises all persons who fulfil the requirements for inclusion among the employed or the unemployed.

\section{Further reading}

OECD (2008), The State of the Public Service, OECD Publishing, Paris.

Pilichowski, E. and E. Turkisch (2008), "Employment in Government in the Perspective of the Production Costs of Goods and Services in the Public Domain", OECD Working Papers on Public Governance, No. 8, OECD Publishing, Paris.

\section{Figure notes}

Data for Iceland are not available. Employment data for Japan are not classified according to SNA definitions and are substituted by direct employment figures provided by central or sub-central governments. Data for Australia, Chile and the United States refer to the public sector (both general government and public corporations). Data for Finland, Israel, Mexico, Poland and Sweden are for 2007 rather than 2008. Data for France, Japan and New Zealand are for 2006 rather than 2008. Data for the Russian Federation are for 2005 rather than 2008. Data for Brazil are for 2003 rather than 2008. Data for Ireland, Japan, Luxembourg, Slovenia and Switzerland are for 2001 rather than 2000. Data for 2000 are not available for Brazil, Korea and the Russian Federation and Korea is not included in the OECD average.

21.1: Data for Portugal are for 2006 rather than 2008. Data for South Africa are for 2003 rather than 2008. Data are not available for South Africa for 2000.

21.2: Data on public corporations for Austria, Belgium, Korea, Portugal and Sweden and South Africa are not available. Data for the Czech Republic and Norway are for 2007 rather than 2008. Data for the Netherlands are for 2005 rather than 2008. Data on public corporations for Japan refer to employment in Incorporated Administrative Institutions and Agencies.

Information on data for Israel: http://dx.doi.org/10.1787/888932315602. 


\section{EMPLOYMENT IN GENERAL GOVERNMENT AND PUBLIC CORPORATIONS}

21. Employment in general government and public corporations

21.1 Employment in general government as a percentage of the labour force (2000 and 2008)

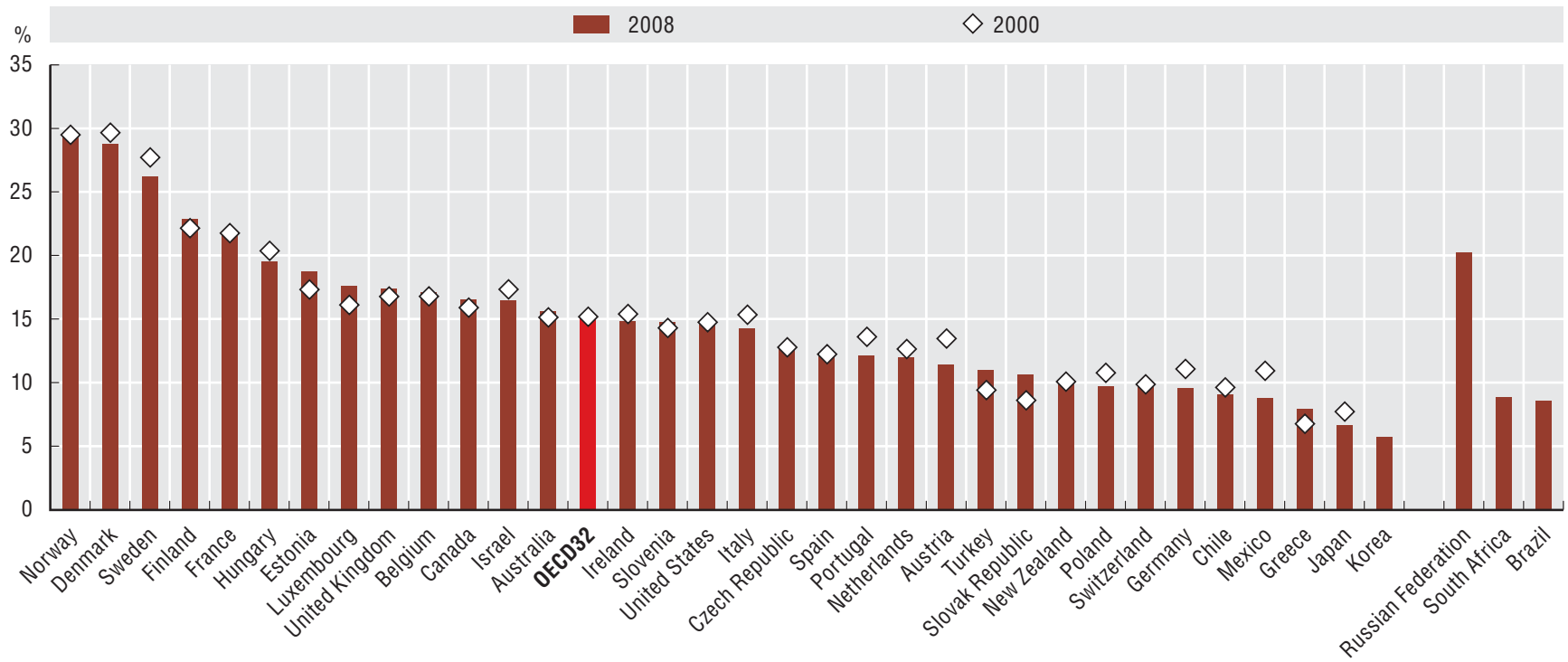

Source: International Labour Organization (ILO), LABORSTA Database. Data for Turkey are from the Ministry of Finance and the Turkish Statistical Institute. Data for Japan for employment are from the Establishment and Enterprise Census. Data for Korea were provided by government officials.

StatLink Aाst http://dx.doi.org/10.1787/888932390538

21.2 Employment in general government and public corporations as a percentage of the labour force (2000 and 2008 )

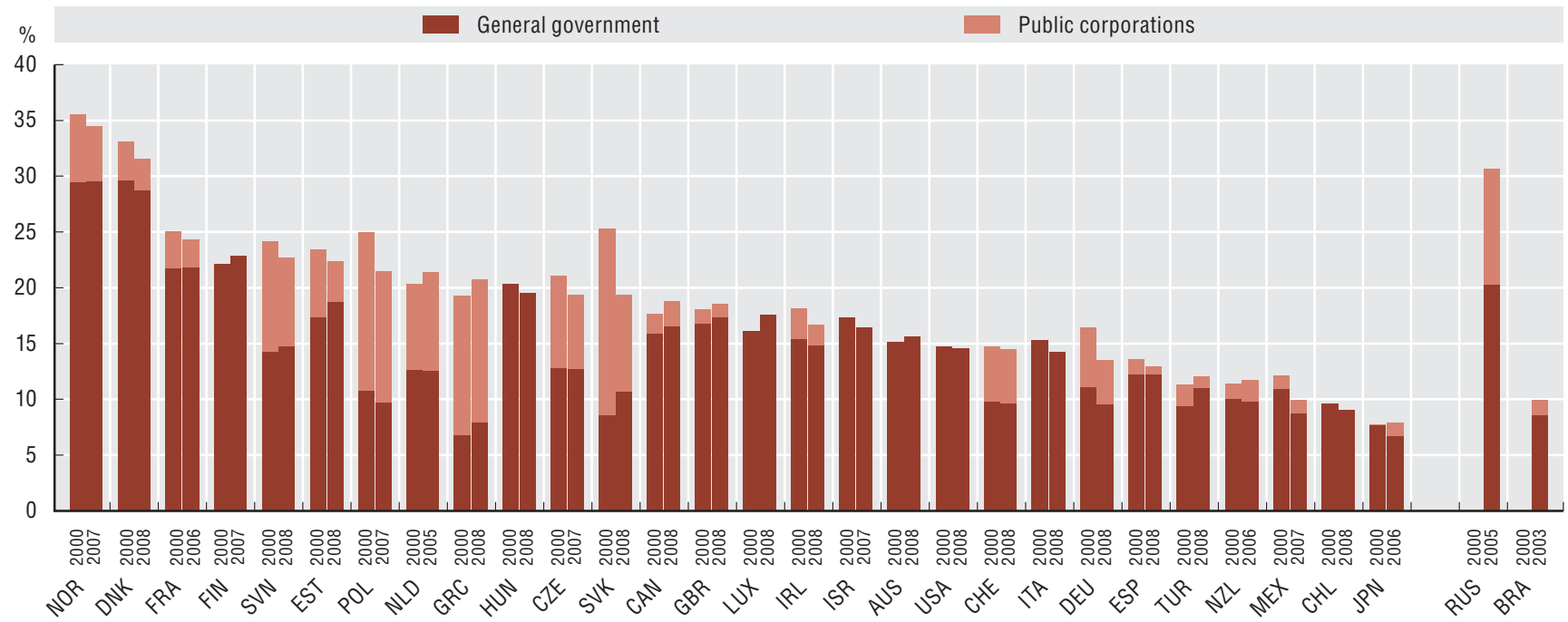

Source: International Labour Organization (ILO), LABORSTA Database. Data for Turkey are from the Ministry of Finance and the Turkish Statistical Institute. Data for Japan for employment are from the Establishment and Enterprise Census. 


\section{General government employment across levels of government}

The share of government staff employed at sub-central levels is an indicator of the level of decentralisation of public administrations. In general, larger shares of government employees at the sub-central level indicate that more responsibilities are delegated to regional and local governments.

In 2008, the majority of OECD member countries had more employees at the sub-central level than at the central level of government. Federal states (with the exception of the Russian Federation) employ less than one-third of all government employees at the central level, confirming higher levels of decentralisation. For unitary states, the variance in the proportion of government employees at the central level of government is much larger, ranging from less than $18 \%$ in Japan and Sweden to almost $90 \%$ in New Zealand.

The percentage of government staff employed at the central level has remained relatively constant between 2000 and 2008. Some exceptions, however, include the Czech Republic, Japan and Spain which demonstrate significant decentralisations of staff during this period. For example, in the Czech Republic the data reflect the growing delegation of responsibilities to newly established administrative regions and regional offices. In comparison, Norway has experienced a significant centralisation of staff during this period, with a 12.5 percentage point increase in staff employed at the central level.

\section{Methodology and definitions}

Data refer to 2000 and 2008 and were collected by the International Labour Organization (ILO). The data are based on the System of National Accounts (SNA) definitions and cover employment in central and subcentral levels of government. Sub-central government is comprised of state and local government including regions, provinces and municipalities. Together the central and sub-central levels comprise general government. Some countries provided information on employment in the social security funds component of general government, which were included in each level of government. However, in a few cases, employment in social security funds was recorded separately and by consequence was not accounted at either the central or sub-central level. Social security represents a small number of employees and is of minor importance as a percentage of the total workforce. The following countries are federal states in the dataset: Australia, Belgium, Canada, Germany, Mexico, Switzerland, the Russian Federation and the United States.
Data represent the number of employees except for Austria, the Czech Republic, Italy, the Netherlands, New Zealand and Poland where data represent full-time equivalents (FTEs). In New Zealand, FTEs are included for education, health and community services and personal and other services. As a result, employment numbers for these six countries are understated in comparison.

\section{Further reading}

OECD (2008), The State of the Public Service, OECD Publishing, Paris.

Pilichowski, E. and E. Turkisch (2008), "Employment in Government in the Perspective of the Production Costs of Goods and Services in the Public Domain", OECD Working Papers on Public Governance, No. 8, OECD Publishing, Paris.

\section{Figure notes}

Data for Austria, Chile, Estonia, France, Iceland, Korea, Poland, Slovenia, the Slovak Republic and the United Kingdom are not available. General government employment data for Japan are not classified according to SNA definitions and are substituted by direct employment figures provided by central or sub-central governments. Data for Australia and the United States refer to the public sector (both general government and public corporations). Data for Hungary do not include other non-profit institutions at the central/sub-central level. Data for Finland, Israel, Mexico and Sweden are for 2007 rather than 2008. Data for Japan, New Zealand and Portugal are for 2006 rather than 2008. Data for the Russian Federation are for 2005 rather than 2008. Data for South Africa are for 2003 rather than 2008.

22.1: Data for Brazil are for 2003.

22.2: Data for Japan and Switzerland are for 2001 rather than 2000. Information on data for Israel: http://dx.doi.org/10.1787/888932315602. 


\section{EMPLOYMENT IN GENERAL GOVERNMENT AND PUBLIC CORPORATIONS}

22. General government employment across levels of government

22.1 Distribution of general government employment between the central and sub-central levels of government (2008)

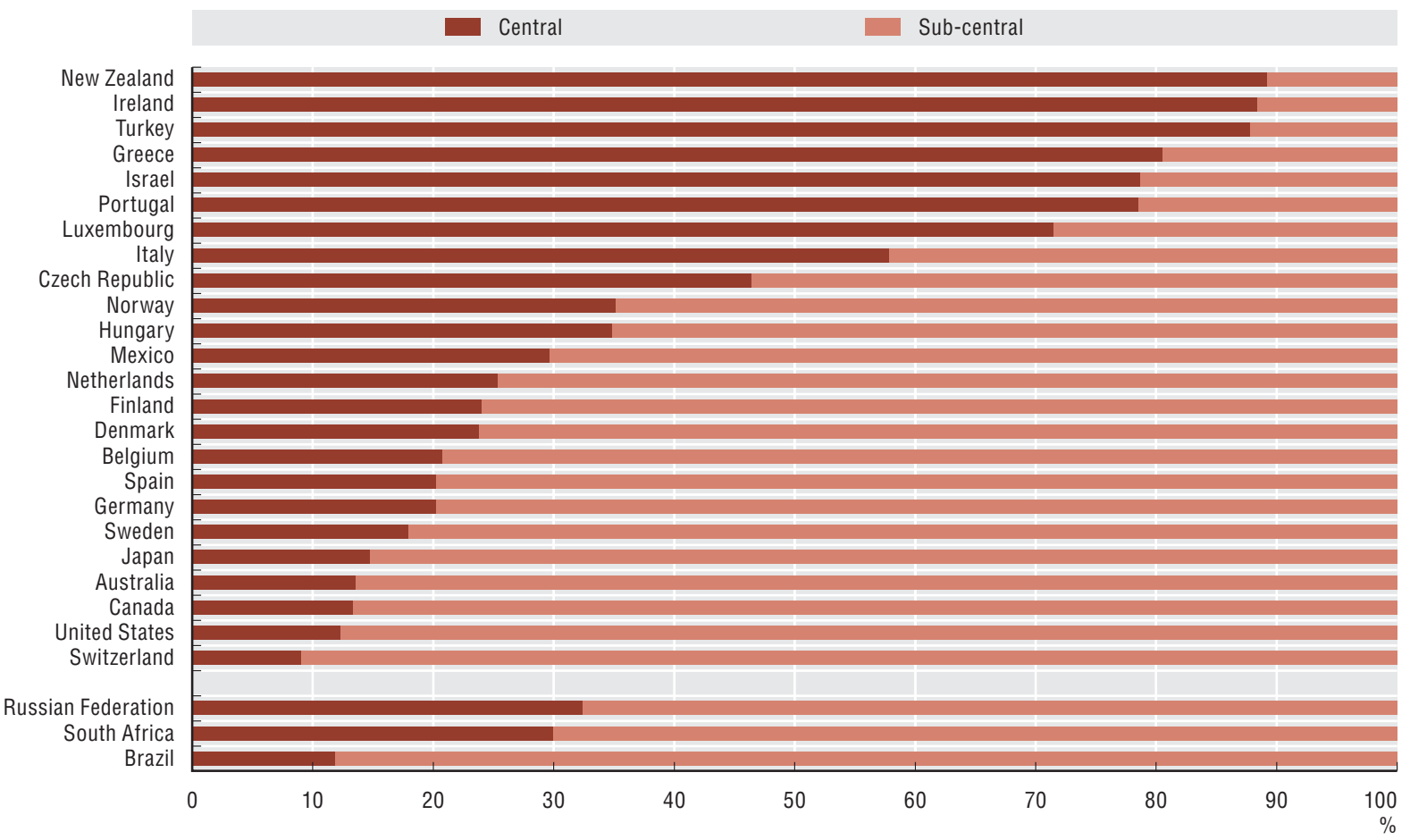

Source: International Labour Organization (ILO), LABORSTA Database. Data for Turkey are from the Ministry of Finance and the Turkish Statistical Institute. Data for Japan are from the Establishment and Enterprise Census.

StatLink AाISt http://dx.doi.org/10.1787/888932390576

22.2 Change in the percentage of government staff employed at the central level (2000 and 2008)

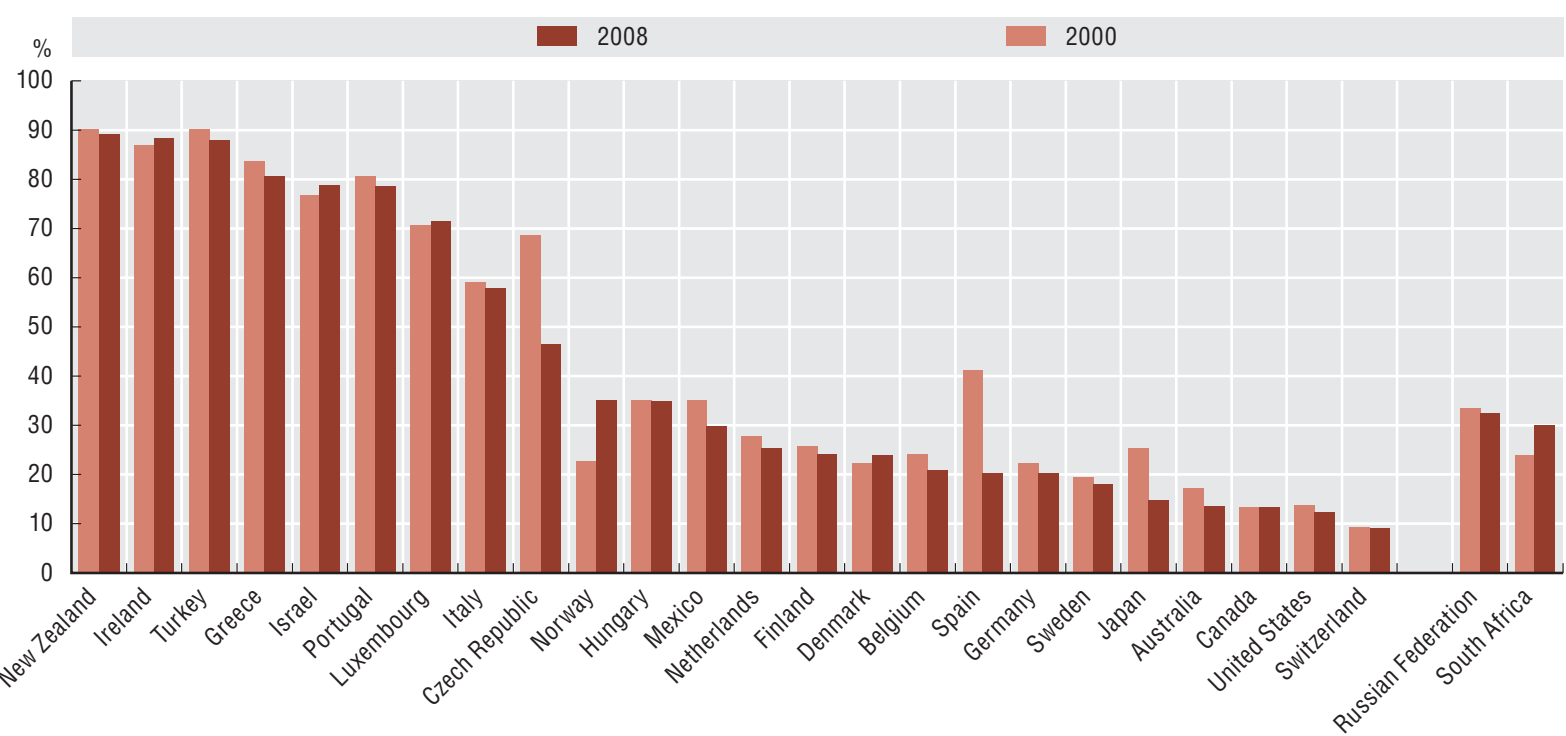

Source: International Labour Organization (ILO), LABORSTA Database. Data for Turkey are from the Ministry of Finance and the Turkish Statistical Institute. Data for Japan are from the Establishment and Enterprise Census. 


\section{Ageing central government workforce}

The majority of OECD member countries are experiencing population ageing, with changes occurring at a faster pace in some countries (e.g. Italy) than in others (e.g. Estonia). Ageing is even more marked in the central governments of OECD countries, where the ratio of government workers aged 50 years or older is on average $26 \%$ higher than in the total labour force. Indeed, in all but four OECD member countries (Japan, Estonia, Chile and Korea) central government workforces have a higher ratio of workers 50 years or older than in the total labour force. The difference is the most pronounced in Italy and Belgium.

Of the OECD countries with available data, Italy (49.2\%) and Iceland (45.5\%) had the highest percentage of persons aged 50 years or older working in central government in 2009, followed closely by four other countries: Sweden, Belgium, Germany and the United States, which all reported shares over $40 \%$ for this age group. An ageing government workforce is not a concern for Chile, Korea and the Ukraine.

The central government workforce is continuing to age in the majority of OECD member countries with the exception of Mexico, Hungary and Japan. Ageing in Denmark and Switzerland has remained relatively stable from 2005 to 2009. Brazil and Italy present the highest levels of change since 2000: the percentage of civil servants aged 50 years or over rose 16.9 and 16 percentage points respectively. Ireland and Greece also demonstrated higher than average ageing during this period, and since 2005 the central government workforce in the Netherlands has also aged relatively rapidly (8.2 percentage points).

The expected wave of retirements could provide an opportunity for governments to restructure their workforce by decreasing employment levels and/or reallocating resources according to sectoral priorities. At the same time, however, the departure of central government staff could also lead to a loss of organisational knowledge and experience. Mitigating these effects could require human resources management (HRM) practices aimed at increasing the attractiveness of the central government as an employer, especially among young university graduates.

\section{Methodology and definitions}

Data refer to 2009 and have been collected through the 2010 OECD Survey on Strategic Human Resources Management. Respondents were predominately senior officials in central government HRM departments, and data refer to the core civil service in the central level of government. The survey was completed by all OECD members except of Luxembourg. Definitions of the civil service, as well as the organisations governed at the central level of government, differ across countries and should be considered when making comparisons. The terms public and civil service/servants are used interchangeably.

Data for total labour force originate from the OECD Labour Force Statistics Database. The total labour force, or currently active population, comprises all persons who fulfil the requirements for inclusion among the employed or the unemployed during a specified brief reference period.

\section{Further reading}

Kings, J., E. Turkisch and N. Manning (2007), "Public Sector Pensions and the Challenge of an Ageing Public Service", OECD Working Papers on Public Governance, No. 2, OECD Publishing, Paris.

OECD (2007), Ageing and the Public Service: Human Resource Challenges, OECD Publishing, Paris.

Pilichowski, E., E. Arnould and E. Turkisch (2007), Ageing and the Public Sector: Challenge for Financial and Human Resources, OECD Publishing, Paris.

\section{Figure notes}

Data are not available for the Czech Republic, the Russian Federation and Turkey. Data are not available for Luxembourg and Spain for 2009. Data for Brazil, Italy, Japan and Korea are for 2008 rather than 2009. Data for Portugal are for 2010 rather than 2009. For Brazil, Estonia and Hungary, the data represent the percentage of government employees over 51 years old. For Chile, data represent the percentage of government employees over 55 years old.

23.1: Data are not available for Austria, Belgium, France, Hungary, Luxembourg, Mexico, Poland, Portugal, Slovenia, Spain and Ukraine for 2000. Data are not available for France and Poland for 2005. Data for Italy are for 2001 rather than 2000. Data for Korea are for 1998 rather than 2000. Data for Switzerland are for 2002 rather than 2000. Data for Austria, Mexico and Norway are for 2006 rather than 2005. Data for Korea are for 2003 rather than 2005. Data for the United States are for 2004 rather than 2005.

23.2: Total labour force data for Israel refer to 2008. Data are not presented for Brazil and Ukraine as total labour force data are not available.

Information on data for Israel: http://dx.doi.org/10.1787/888932315602. 


\section{EMPLOYMENT IN GENERAL GOVERNMENT AND PUBLIC CORPORATIONS}

23. Ageing central government workforce

23.1 Percentage of central government employees aged 50 years or older (2000, 2005 and 2009)

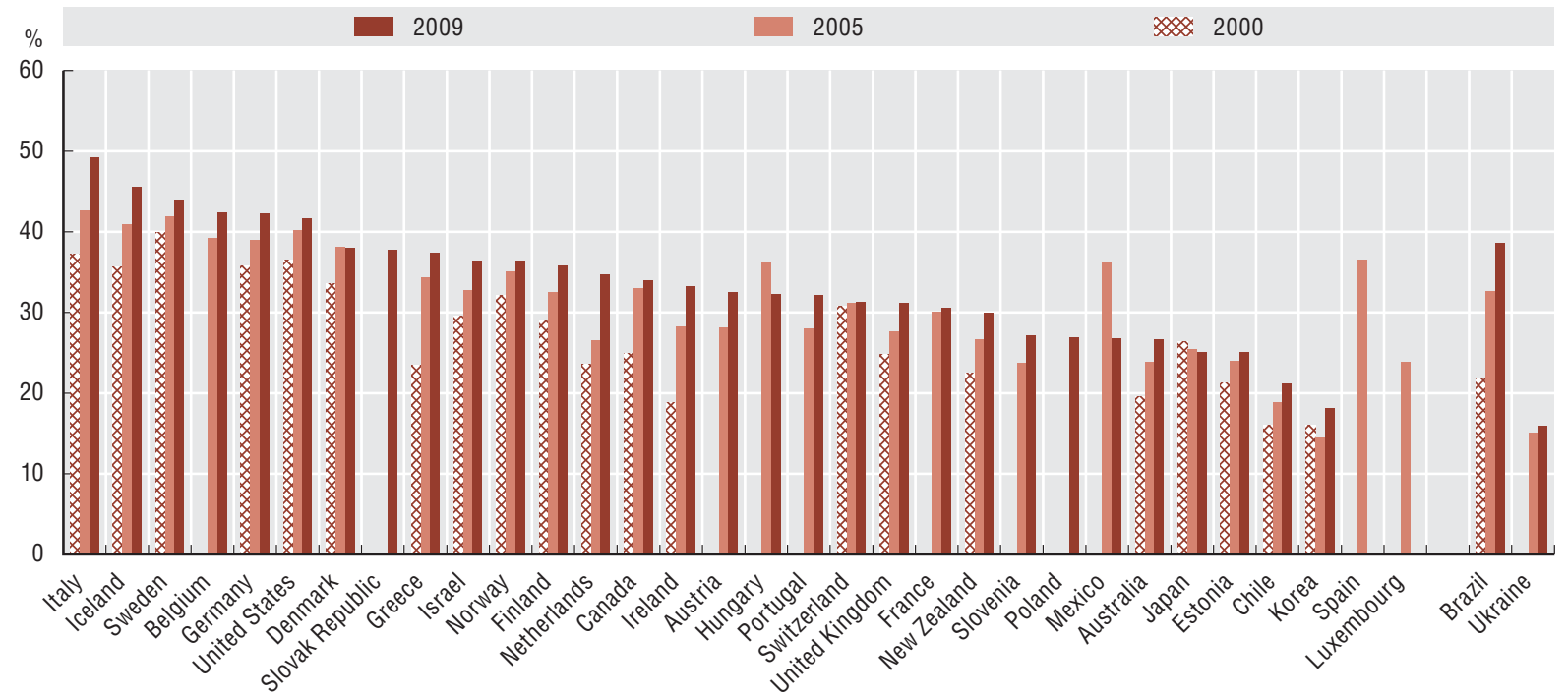

Source: 2010 OECD Survey on Strategic Human Resources Management in Central/Federal Governments.

23.2 Percentage of employees aged 50 years or older in central government and total labour force (2009 or latest available year)

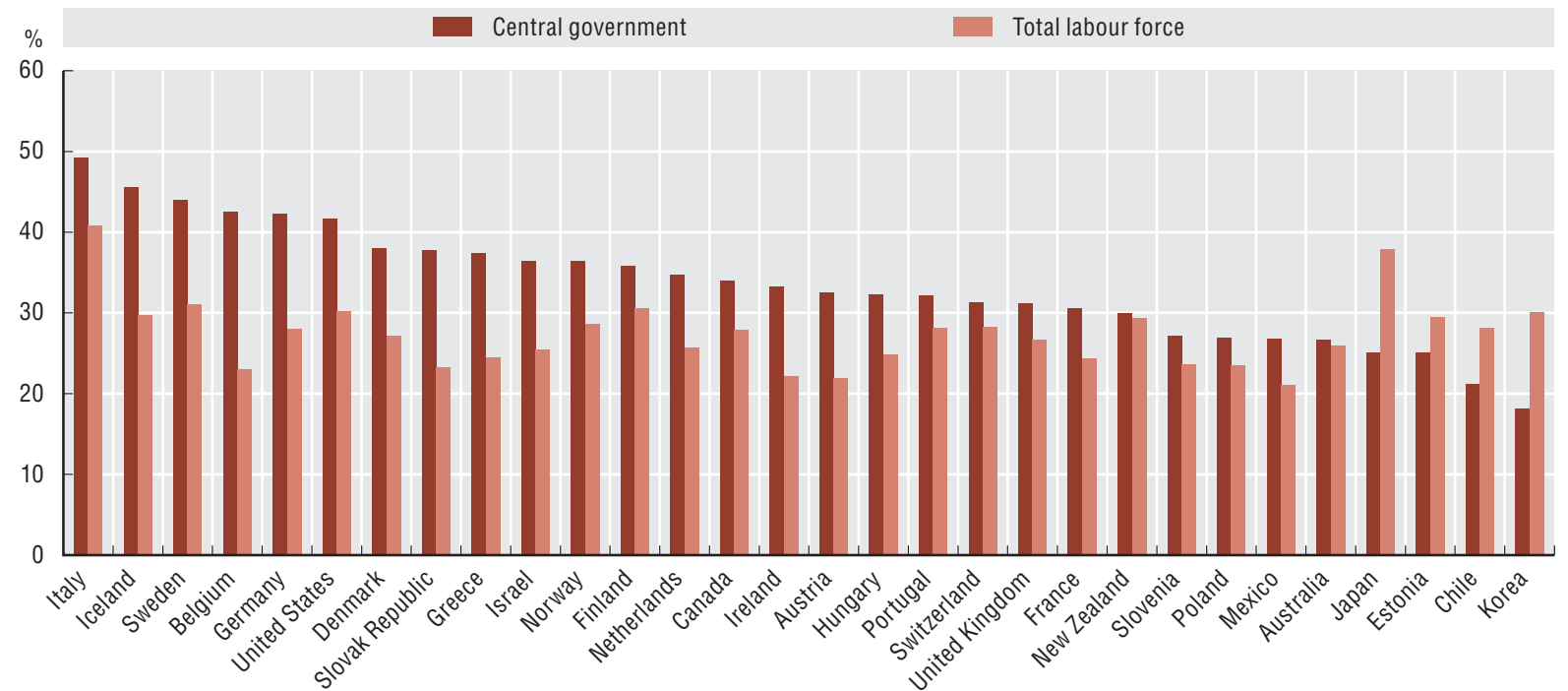

Source: 2010 OECD Survey on Strategic Human Resources Management in Central/Federal Governments and OECD Labour Force Statistics Database. 


\section{Special feature: Public workforce restructuring}

Achieving the most efficient and effective size and allocation of the public service workforce is an ongoing challenge for OECD member countries, where the compensation of government employees represented about $24 \%$ of general government expenditures in 2009 (see Indicator 8). Today, this challenge is exacerbated by a confluence of factors which include the fiscal pressures following the economic crisis, but also new public service demands resulting from population ageing and the possibilities offered by information and communications technologies. To face these challenges, careful workforce planning and strategic human resources management reforms help to ensure that governments continue to deliver quality public services while responding to the need to reduce or maintain budgets.

Today, over three-quarters of OECD countries indicate that they are engaged in, or are planning, reforms that will decrease the current size of their public service workforce in more than half of the Agencies and Ministries within central government. In addition, while seven countries have indicated that they do not plan to decrease workforce levels, none plan to increase workforce levels.

Fifteen countries have established replacement ratios to fill the gaps left by staff leaving through retirement. These ratios represent the percentage of staff to be replaced after leaving the civil service. In countries such as Austria, France and Portugal, the target replacement rate is set at $50 \%$, meaning that they will hire 1 worker for every 2 who leave. In other countries the ratio is much lower; in Italy and Greece for instance the aim is to replace 1 in 5 public servants who are leaving while Spain plans to replace 1 in 10. However, in some countries certain sectors are protected from planned cuts. For example in Spain the sectors of health, education and security forces in particular have higher replacement ratios. In Israel, Korea, Brazil and Ukraine target replacement ratios are much higher, at between $80 \%$ and $100 \%$.

Twelve OECD countries offer options for voluntary early departures on a regular basis. This can include early retirement programmes (Germany, Hungary, Ireland, Israel, Norway, Korea, Switzerland, the United Kingdom and the United States) and/or early leave programmes (Chile, France, Ireland, Israel, Mexico, Norway, the United Kingdom and the United States). All OECD countries except Belgium, Germany, Ireland, Spain and Turkey allow dismissal of employees with open term contracts when a Ministry/Agency wants to restructure or decrease the number of its employees. However, they must either offer a leaving allowance and/or propose reallocation possibilities beforehand.

\section{Methodology and definitions}

Data refer to 2010 and were collected through the 2010 OECD Survey on Strategic Human Resources Management. Respondents were predominately senior officials in central government HRM departments, and data refer to restructuring plans at the central level of government. However, countries' reports of planned staff reductions may exclude some sectors within their governments. The survey was completed by all OECD member countries except Luxembourg. Definitions of the civil service, as well as the organisations governed at the central level of government, differ across countries and should be considered when making comparisons. The terms public and civil service/servants are used interchangeably.

Early retirement packages are financial advantages and/or benefits that are added to the retirement package that an individual would receive upon leaving the public service (before retirement age or before full benefits). Leave allowances are financial allowances and/or benefits an individual receives when he/she is asked to leave the public service.

\section{Further reading}

OECD (2010), "Getting it Right", Document prepared for the annual meeting of the Public Employment and Management Working Party, OECD/GOV/PGC/PEM(2010)4, OECD Publishing, Paris.

OECD (forthcoming), Public Servants as Partners for Growth: Strengthening a Leaner and More Equitable Public Service, OECD Publishing, Paris.

\section{Figure and table notes}

24.1: Data are not available for Chile, Luxembourg and Mexico. Data for Canada are not applicable.

24.2: Data not available for Luxembourg. In the Czech Republic, the administration is required to propose another position within the same central administration body. In Poland, legislation must be passed in order to allow for dismissal of government employees. In Portugal, for staff hired after January 2009, dismissal due to restructuring is now possible and an unemployment allowance may be granted to them within the social protection scheme. In the United States, the dismissal of employees with open term contracts when restructuring or reducing numbers of employees means that employees receive an allowance and/or the government is required to propose reallocation possibilities beforehand. The latter is less common. In Iceland, there are no formal or centralised programmes for the number of personnel.

Information on data for Israel: $h t t p: / / d x$.doi.org/10.1787/888932315602. 


\section{EMPLOYMENT IN GENERAL GOVERNMENT AND PUBLIC CORPORATIONS}

24. Special feature: Public workforce restructuring

24.1 Anticipated changes in employment levels in more than $50 \%$ of Agencies and Ministries (2010)

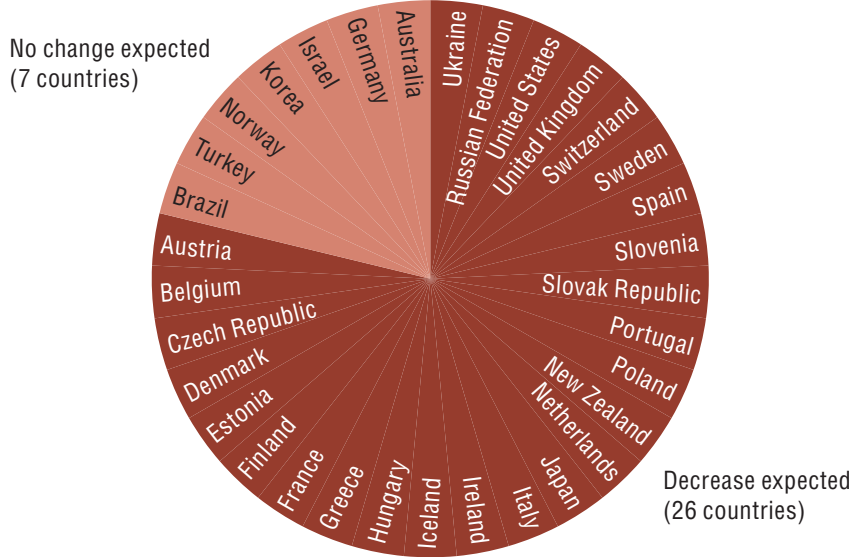

Source: 2010 OECD Survey on Strategic Human Resources Management in Central/Federal Governments.

StatLink Aाsय $h t t p: / / d x . d o i . o r g / 10.1787 / 888932390652$
24.2 Restructuring plans and leaving conditions (2010)

\begin{tabular}{|c|c|c|c|c|}
\hline & \multicolumn{2}{|c|}{$\begin{array}{l}\text { Possibility to dismiss employees } \\
\text { with open term contracts } \\
\text { when a Ministry/Agency seeks } \\
\text { to restructure or decrease } \\
\text { the number of its employees }\end{array}$} & \multicolumn{2}{|c|}{$\begin{array}{l}\text { Existence of regular plans } \\
\text { to encourage voluntary } \\
\text { departures in order } \\
\text { to implement workforce } \\
\text { allocation changes }\end{array}$} \\
\hline & $\begin{array}{l}\text { Yes, and } \\
\text { the employee } \\
\text { receives } \\
\text { an allowance }\end{array}$ & $\begin{array}{l}\text { Yes, but } \\
\text { government } \\
\text { is required } \\
\text { to propose } \\
\text { reallocation } \\
\text { possibilities } \\
\text { before hand }\end{array}$ & $\begin{array}{c}\text { Yes, } \\
\text { with attractive } \\
\text { leave } \\
\text { allowances }\end{array}$ & $\begin{array}{c}\text { Yes, } \\
\text { with attractive } \\
\text { early retirement } \\
\text { packages }\end{array}$ \\
\hline Australia & - & O & O & O \\
\hline Austria & - & - & O & O \\
\hline Belgium & 0 & O & 0 & 0 \\
\hline Canada & - & - & O & 0 \\
\hline Chile & n.a. & n.a. & - & O \\
\hline Czech Republic & - & - & O & O \\
\hline Denmark & - & O & O & 0 \\
\hline Estonia & - & - & O & O \\
\hline Finland & $\bullet$ & $\bullet$ & 0 & 0 \\
\hline France & - & O & - & $\mathrm{O}$ \\
\hline Germany & O & O & O & $\bullet$ \\
\hline Greece & O & $\bullet$ & O & O \\
\hline Hungary & - & O & O & - \\
\hline Iceland & - & - & O & O \\
\hline Ireland & O & O & - & - \\
\hline Israel & O & - & - & - \\
\hline Italy & 0 & $\bullet$ & 0 & O \\
\hline Japan & O & $\bullet$ & O & O \\
\hline Mexico & $\bullet$ & O & $\bullet$ & O \\
\hline Netherlands & O & - & O & O \\
\hline New Zealand & - & O & O & O \\
\hline Norway & $\bullet$ & $\bullet$ & $\bullet$ & $\bullet$ \\
\hline Poland & - & O & O & 0 \\
\hline Portugal & - & O & O & O \\
\hline Korea & O & $\bullet$ & - & O \\
\hline Slovak Republic & $\bullet$ & $\bullet$ & O & $O$ \\
\hline Slovenia & 0 & - & 0 & 0 \\
\hline Spain & O & O & 0 & O \\
\hline Sweden & - & O & n.a. & n.a. \\
\hline Switzerland & - & - & O & - \\
\hline Turkey & O & O & n.a. & n.a. \\
\hline United Kingdom & - & - & $\bullet$ & $\bullet$ \\
\hline United States & $\bullet$ & $\bullet$ & $\bullet$ & $\bullet$ \\
\hline Brazil & O & - & 0 & - \\
\hline Russian Federation & 0 & - & 0 & O \\
\hline Ukraine & $O$ & $\bullet$ & n.a. & n.a. \\
\hline Total OECD33 & 20 & 18 & 9 & 8 \\
\hline
\end{tabular}

- Yes.

O No.

n.a.: Not available.

Source: 2010 OECD Survey on Strategic Human Resources Management in Central/Federal Governments.

StatLink काISL http://dx.doi.org/10.1787/888932392020 


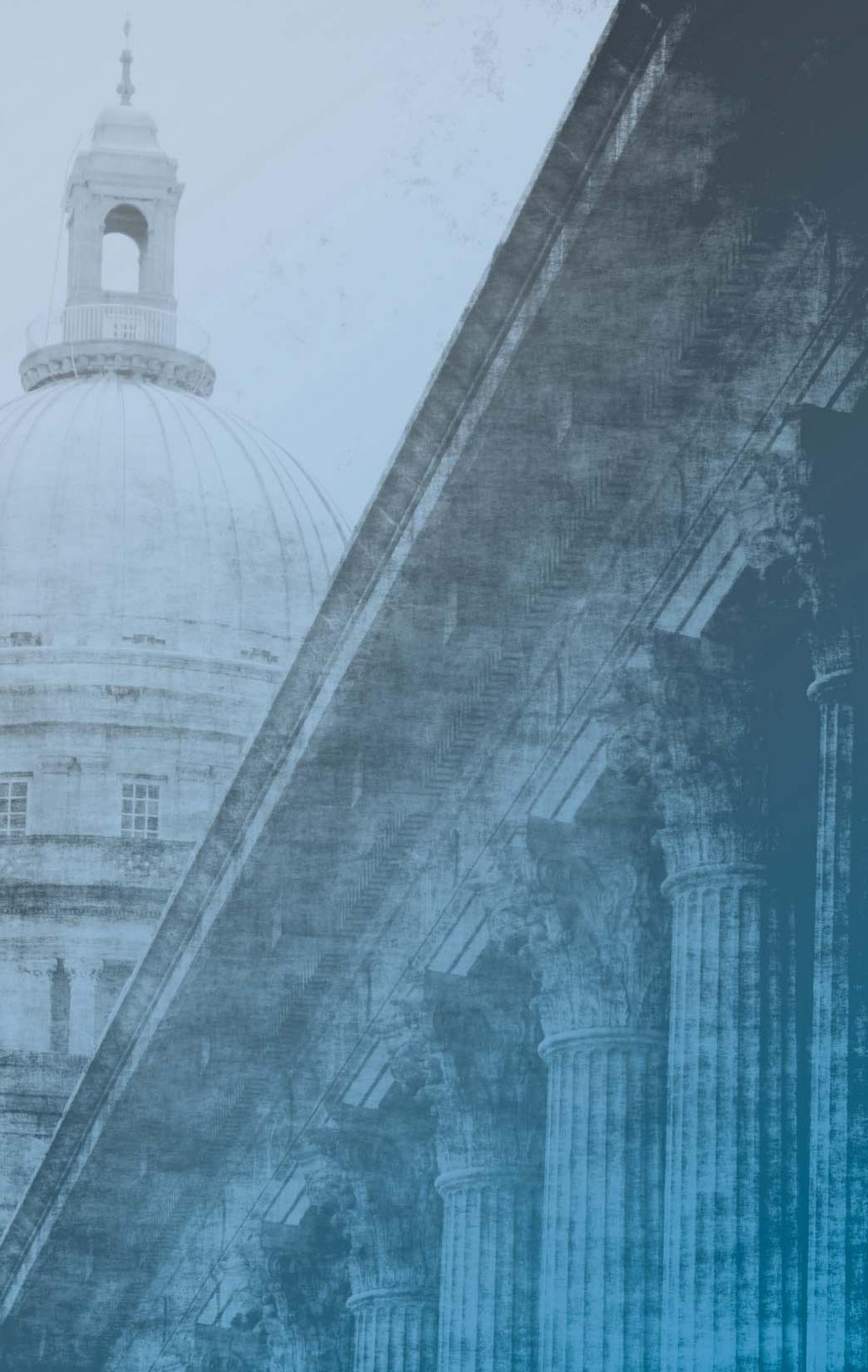




\section{$=$}

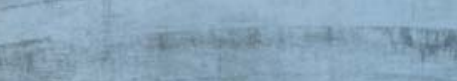

-

:

\section{COMPENSATION IN SELECTED PUBLIC SECTOR OCCUPATIONS}

Employee compensation plays an important role in attracting, motivating and retaining qualified workers to government jobs. It also forms a significant part of government expenditures as compensation costs depend on the number and remuneration of staff that governments employ. As part of fiscal consolidation efforts in many OECD countries, the level of compensation of government employees is being called into question, involving in some cases decreases in salaries and/or benefits or pay freezes.

This chapter contains compensation data for key public sector occupations. Public service delivery positions represent the bulk of public sector staff, and data for teachers, doctors and nurses are presented first, followed by data for senior managers, middle managers, professionals and secretaries working in central government core Ministries. Compensation data for teachers, doctors and nurses allows for comparisons within countries to the average wage paid to tertiary-educated workers, reflecting the relative attractiveness of these professions to others requiring similar levels of education.

The comparison of compensation levels for senior managers, middle managers, professionals and secretaries intends to show their relative total remuneration across OECD countries, which includes not only salaries and wages but also social benefits and future pension earnings. Data for these four occupations are drawn from the OECD Survey on the Compensation of Employees in Central Government, conducted for the first time in 2010. The survey uses the International Standard Classification of Occupations to standardise job categories, but full comparability of occupations across countries can present difficulties. Annex $D$ fully details these and other potential limitations to the data, including those related to the measurement of employers' social contributions. It should be noted that differences in compensation policies can be the result of different bargaining powers, the varying attractiveness of the government as an employer, and differences in labour markets (such as compensation in the private sector for similar positions or specific labour shortages). 
Teachers are the backbone of the education sector and their salaries represent the single largest cost item in education expenditures. Salaries and working conditions play an important role in attracting, motivating and retaining skilled teachers. In many OECD countries, salaries of teachers are set centrally, often through collective bargaining.

In most countries there are three categories of teachers: primary, lower secondary and upper secondary school teachers. In most OECD member countries, salary brackets increase not only with experience and qualifications, but also with the level of education taught. The data presented here compare the starting, mid-career and maximum statutory salaries of lower secondary teachers in public institutions who have the minimum level of training. These can provide an indication of differences in the returns to teaching experience in OECD member countries. However, international comparisons should consider that statutory salaries are just one, albeit a major, component of teachers' overall compensation. Variations between countries in social benefit and taxation systems as well as in the use of other financial incentives, such as regional allowances, can result in differences in total compensation.

The annual statutory salaries of lower secondary teachers with 15 years of experience range from less than USD 16000 PPP in Hungary and Estonia to over USD 54000 PPP in Germany, Ireland, Korea and Switzerland, and to more than USD 98000 PPP in Luxembourg. In Korea and Portugal, top-of-the-scale salaries are more than 2.5 times greater than starting salaries, but it takes 37 and 31 years (respectively) to reach the top of the scale.

In general, teachers' salaries are less than the average annual wage for employees with a similar level of education (full-time, full-year workers with a tertiary education aged 25-64 years). Spain is the only country where teachers earn more. In New Zealand, Germany, Australia, Finland, Belgium and Sweden teachers' statutory salaries are almost at par with the average earnings of tertiaryeducated workers. However, in the United States, Italy, Israel, Slovenia, Hungary, Iceland and the Czech Republic, teachers' salaries are considerably below the average earnings of workers with a tertiary degree. Teachers' salaries have not been adjusted for the differences in contractual working hours and holidays that may be relevant for national and international comparisons.

\section{Methodology and definitions}

Data refer to the school year 2007-08, from 1 July 2007 to 30 June 2008. Statutory salaries refer to scheduled salaries according to official pay scales. The salaries reported are gross (total sum paid by the employer before tax) less the employer's contribution to social security and pension (according to existing salary scales). They are for a full-time teacher with the minimum training necessary to be fully qualified at the beginning of the teacher career, after 15 years of teaching experience and at the maximum annual salary (top of the scale). Gross teachers' salaries were converted to USD using PPPs for GDP from the OECD National Accounts Database.

The relative salary indicator is calculated for the latest year with earnings data available. Teachers' salaries represent those paid after 15 years of work experience. Earnings for workers with a tertiary education are average earnings for full-time, full-year workers in the age group of 25-64 years with education at ISCED 5A/5B/6. For countries for which teachers' salary and workers' earnings information are not available for the same year, the indicator is adjusted for inflation using the GDP deflator.

\section{Further reading}

OECD (2005), Teachers Matter: Attracting, Developing and Retaining Effective Teachers, OECD Publishing, Paris.

OECD (2009), Evaluating and Rewarding the Quality of Teachers: International Practices, OECD Publishing, Paris.

OECD (2010), Education at a Glance 2010: OECD Indicators, OECD Publishing, Paris.

\section{Figure notes}

Data are not available for Canada, Chile, the Slovak Republic and Turkey. Belgium is presented as Belgium (Fr.) and Belgium (Fl.). The United Kingdom is presented as England and Scotland.

25.2: Data are not available for Ireland, Japan, Luxembourg, Mexico and Switzerland. Data for Finland, Korea, New Zealand, Norway, Spain and Sweden refer to 2007. Data for Austria, Belgium, Denmark, France, Greece, Iceland, Italy, Portugal and Slovenia refer to 2006.

Information on data for Israel: http://dx.doi.org/10.1787/888932315602. 


\subsection{Teachers' salaries in lower secondary education in public institutions (2008)}

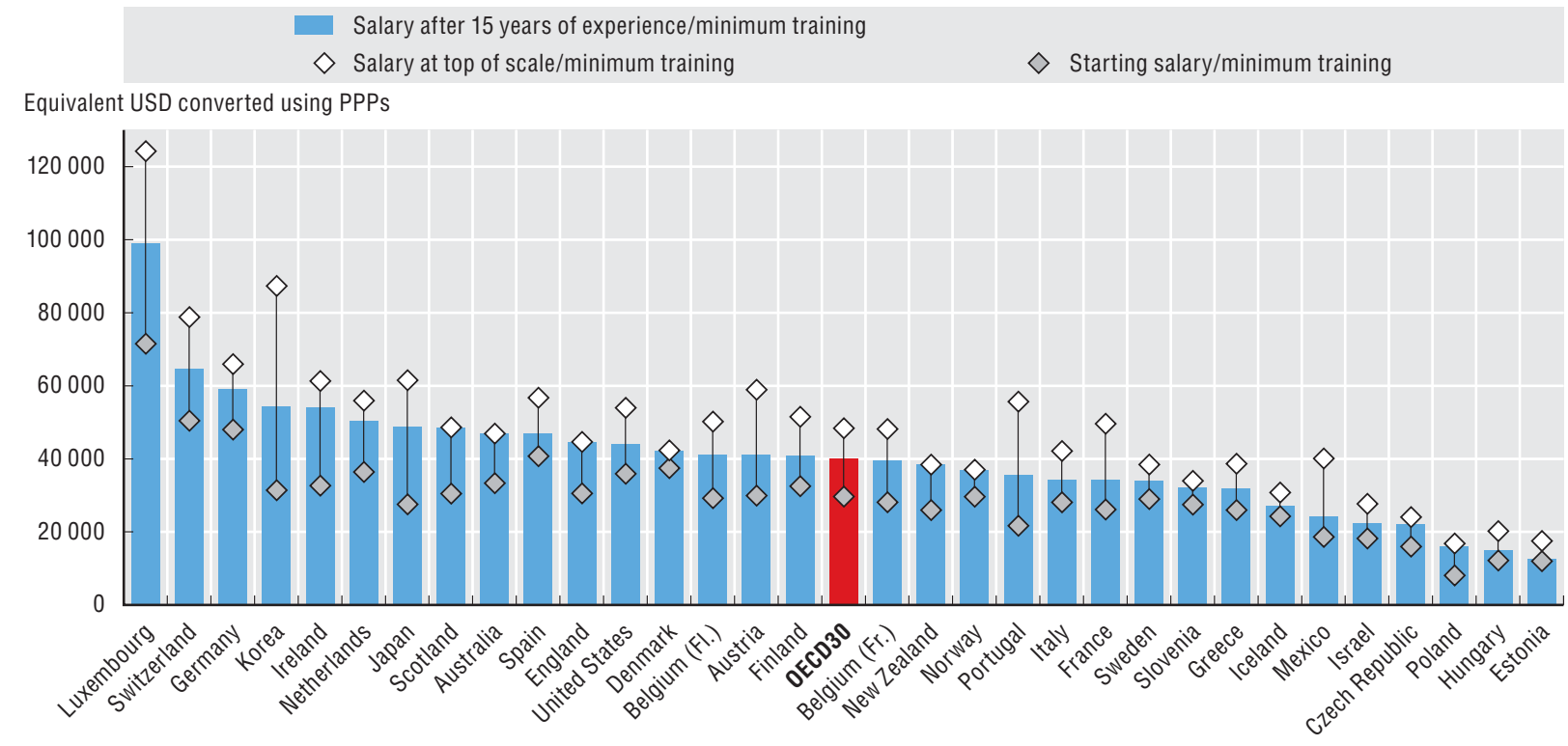

Source: OECD (2010), Education at a Glance 2010: OECD Indicators, OECD Publishing, Paris.

StatLink काIs $h$ ttp://dx.doi.org/10.1787/888932390671

\subsection{Ratio of teachers' salaries to earnings of tertiary-educated workers (2008)}

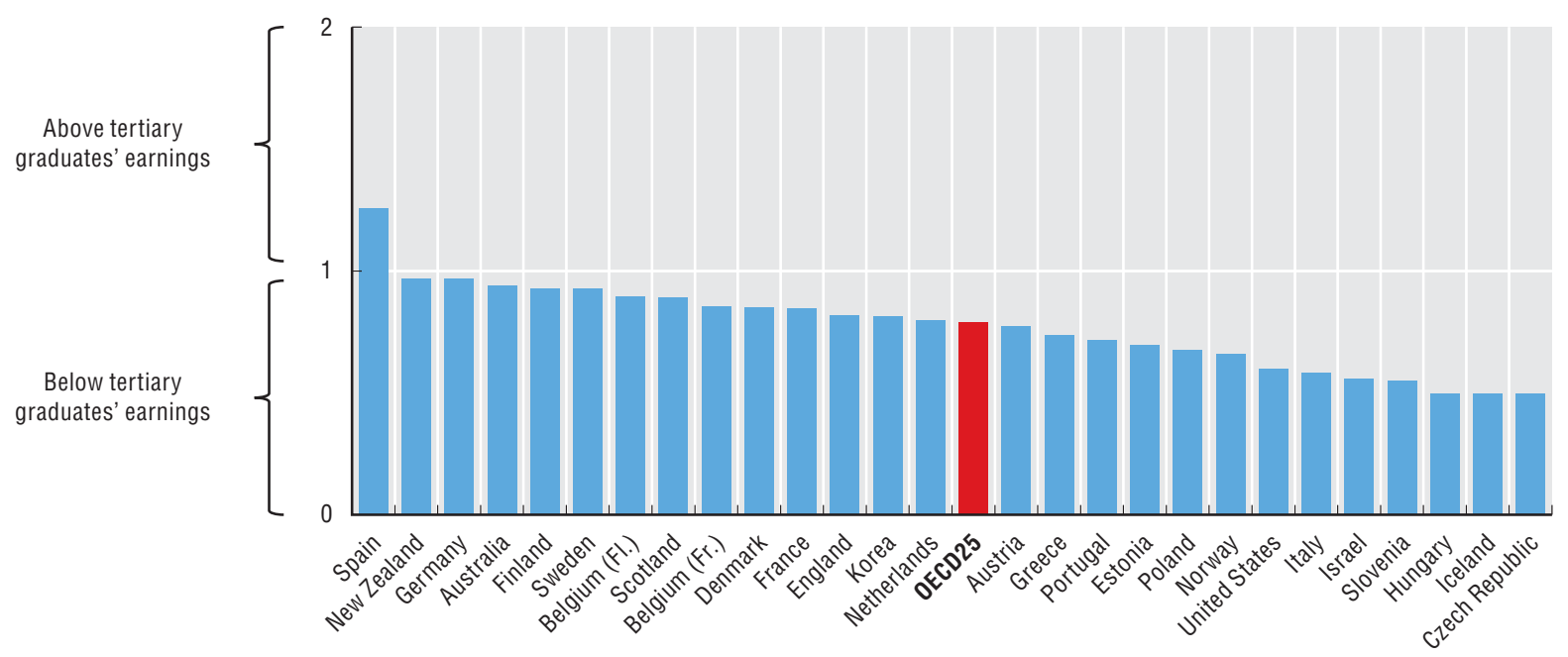

Source: OECD (2010), Education at a Glance 2010: OECD Indicators, OECD Publishing, Paris. 
Compensation levels are among the factors affecting the attractiveness of different professions in the health sector and the job satisfaction of incumbents. They also have a direct impact on health care costs, as wages represent one of the main spending items in health systems.

Data are included for general practitioners (GPs) and specialists who are salaried and for nurses who work in hospitals, as the focus is primarily on government workers. Self-employed doctors have been excluded, as they are not employed by government, although in many countries they are paid from public sources on a fee-for-service basis (data for self-employed doctors are available in Health at a Glance 2009 and OECD Health Data).

In all three occupational groups, there are very substantial differences across countries in their absolute level of compensation. The average salary of nurses and general practitioners is lowest in eastern European countries, Mexico and Turkey, and highest in Luxembourg. In 2008, the salary of medical specialists was highest in Ireland, although the remuneration of self-employed specialists in some other European countries such as the Netherlands and Luxembourg was higher (data not shown). The range in salaries across countries is highest for specialists where the difference between the highest and lowest paying country is around six-fold. Both doctors and nurses in Hungary have the lowest reported remuneration, although this does not include the extensive use of informal out-of-pocket payments.

In all countries, specialists earn the most, followed by general practitioners and by nurses. This partially reflects the varying skill sets of the three occupations as well as the time needed to be fully trained. The compensation gap is particularly large across the occupations in Luxembourg, Turkey, New Zealand, Finland, Israel and the United Kingdom.

The compensation of specialists compared to the tertiaryeducated wage ranges from almost equal in Hungary to 2.5 times greater in New Zealand. Hungarian GPs earn close to the tertiary-educated wage, while in Iceland they earn almost twice as much. Finally, Hungarian nurses make half of the tertiary-educated wage, while New Zealand nurses earn slightly above the average tertiary wage.

\section{Methodology and definitions}

Remuneration of doctors refers to average gross annual income, including social security contributions and income taxes payable by the employee. It should normally include all extra formal payments, such as bonuses and payments for night shifts, on-call and overtime. Salaries were converted to USD using PPPs for GDP from the OECD National Accounts Database.

Payment for overtime work or social security contributions is excluded for salaried specialists in Mexico and the Netherlands, and for general practitioners and specialists in New Zealand and Switzerland. In Ireland and Mexico, data on nurses do not include overtime payments. Incomes from private practices of salaried doctors are not included in some countries. Informal payments, which may be common in certain countries (e.g. Hungary and Mexico), are not included. Data for some countries include part-time workers (Australia, Luxembourg, Mexico, the United Kingdom for specialists and the United States). In the United States and New Zealand, the data cover not only nurses working in hospitals but in other settings as well.

In Australia and Norway, data refer only to registered nurses, resulting in an overestimation compared to other countries where lower levels of nurses are also included. In countries where hospitals are both publicly and privately run, nurses' salaries will also reflect remuneration paid in the private sector.

Earnings for workers with a tertiary education are average earnings for full-time, full-year workers in the age group of 25-64 years with education of ISCED 5A/5B/6.

\section{Further reading}

OECD (2009), Health at a Glance 2009: OECD Indicators, OECD Publishing, Paris.

\section{Figure notes}

Data for Austria, Belgium, Canada, Chile, Denmark, Estonia, France, Greece, Korea, Poland, Portugal, Spain, Sweden and Switzerland are not available. Data for the Netherlands refer to 2006.

26.1: Data for Australia, New Zealand (general practitioners) and the United Kingdom (general practitioners) refer to 2007. Data for Germany and Luxembourg (general practitioners and specialists) refer to 2006.

26.2: Data for Australia, the Czech Republic, Germany, Ireland, Japan, Luxembourg, Mexico and Turkey are not available. Data for Finland and Iceland refer to 2007. Data for Iceland for tertiary-educated workers refer to 2006. Data for Italy and Slovenia refer to 2006.

Information on data for Israel: $h t t p: / / d x . d o i . o r g / 10.1787 / 888932315602$. 
26.1 Compensation of salaried doctors and nurses (2008)

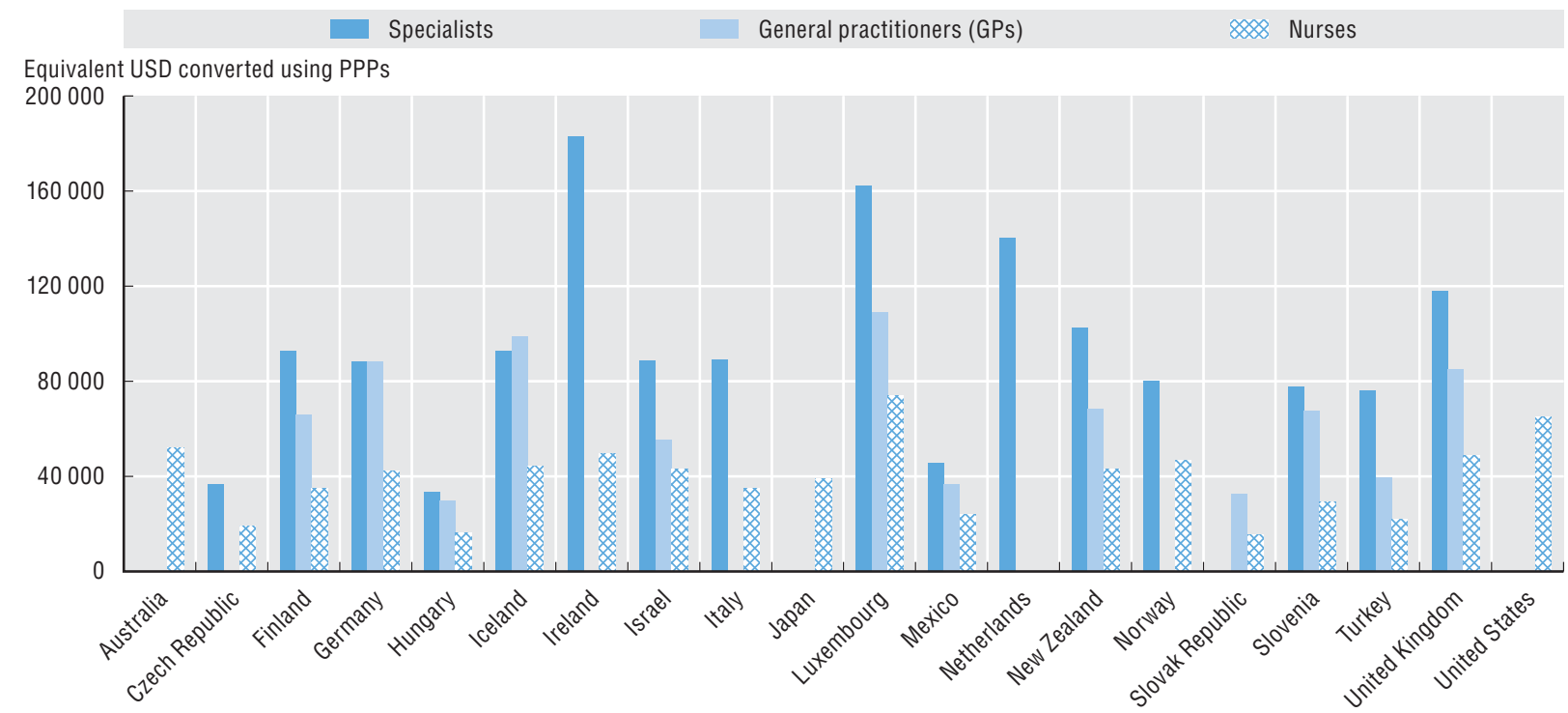

Source: OECD Health Data 2010.

StatLink ताIsL http://dx.doi.org/10.1787/888932390709

26.2 Ratio of salaried doctors' and nurses' compensation to the earnings of tertiary-educated workers (2008)

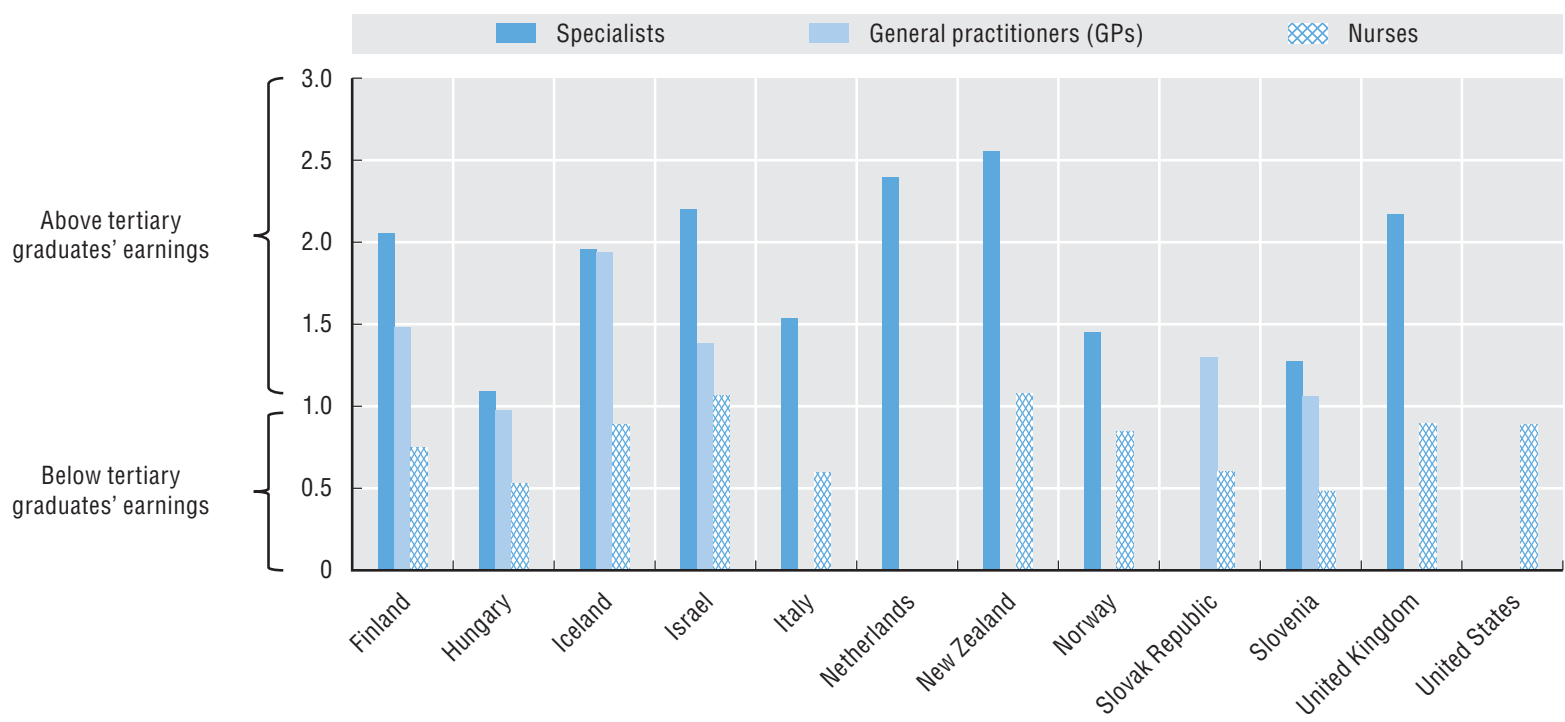

Source: OECD Health Data 2010 for the compensation of salaried doctors (e.g. specialists, general practitioners) and nurses; OECD (2010), Education at a Glance 2010: OECD Indicators, OECD Publishing, Paris for the earnings of tertiary-educated workers. 
Due to their smaller numbers, the total compensation costs of senior management are relatively insignificant in the context of total government spending. Nevertheless, their levels of compensation are considered crucial for attracting and keeping talent for positions with high levels of responsibility in government. Compensation in these positions has an important symbolic value as they are usually at the top salary scales, and concern staff whose appointment tends to be more discretionary (see Indicators 17 and 18).

The compensation of the two highest levels of senior managers (excluding the political level) are shown. D1 managers are top public servants below the Minister or Secretary of State, and D2 are usually just below D1 (see Annex D for details). The data are adjusted for holidays but not for hours worked per week, since senior managers are formally or informally expected to work longer hours during the week than the rest of the civil service.

Data suggest that the yearly compensation of senior managers varies significantly across countries and between D1 and D2 Levels. On average, D1 Level senior managers' total compensation in responding countries amounts to just under USD 230000 PPP (fully adjusted for employers' social contributions and holidays), and to about USD 162000 PPP in wages and salaries. D2 Level managers' total compensation nearly reaches USD 180000 PPP (fully adjusted for employers social contributions and holidays), and to USD 127000 PPP in wages and salaries.

The survey shows that top managers (D1 Level) in Australia, Italy, New Zealand and the United Kingdom have significantly higher compensation than their counterparts in other OECD member countries. Senior managers in Estonia, Iceland and Slovenia, on the other hand, earn significantly below those of other OECD countries. Countries such as Australia, Belgium, Chile, Ireland, New Zealand and the United Kingdom seem to invest proportionately more than other countries in the compensation of their top management level (D1) compared to the immediate level below (D2).

Differences in compensation levels across countries can be a result of differences in national labour markets, in particular the remuneration in the private sector for comparable positions. They can also indicate different organisational structures in countries (e.g. Sweden has a flat government with numerous D1s) and different levels of seniority in similar occupations.

Data also show that countries differ in the way they organise the structure of the compensation of government employees, through relatively more or less employers' social contributions compared to wages and salaries. Sweden, Italy, the United States, Hungary and Estonia have the highest share of employers' social contributions in total compensation, and Ireland, Korea, and New Zealand have the lowest.

\section{Methodology and definitions}

Data refer to 2009 and were collected by the 2010 OECD Survey on the Compensation of Employees in Central/Federal Governments. Officials from central Ministries and Agencies responded to the survey through the OECD Public Employment and Management Working Party.

Total compensation includes wages and salaries, employers' social contributions to statutory social security schemes or privately funded social insurance schemes, as well as unfunded employee social benefits paid by the employer, including pension payments paid through the state budget rather than through employer social contributions (mostly for some pay-as-you-go systems). The focus on total compensation allows a comparison of the degree with which governments remunerate their employees via social contributions or via higher wages and salaries. Compensation was converted to USD using PPPs for GDP from the OECD National Accounts Database. Working time adjustment compensates for differences in time worked (various holidays for senior managers). A larger working time adjustment generally means that employees work fewer hours and/or days per year. In most cases data are for six central government Ministries/Departments only (Interior, Finance, Justice, Education, Health and Environment or their equivalents). Positions are based on the International Standard Classification of Occupations (ISCO). The main limitations of the data are the less-than-full comparability of occupations across countries, the way countries have interpreted the definition of the positions, and some lack of clarity regarding the level of social contributions and the differing costs of living across countries in capital cities. Compensation levels are calculated by averaging the compensation of the staff in place. (It is not the middle point between the minimum and maximum salary.) This may explain higher averages in D2 compared to D1 positions in some countries, while in others these differences may come from the more tightly regulated remuneration for D1 positions that tend to include more politically appointed staff. See Annex D for the full methodology. 


\subsection{Average annual compensation of central government senior managers (2009)}

Adjusted for differences in holidays

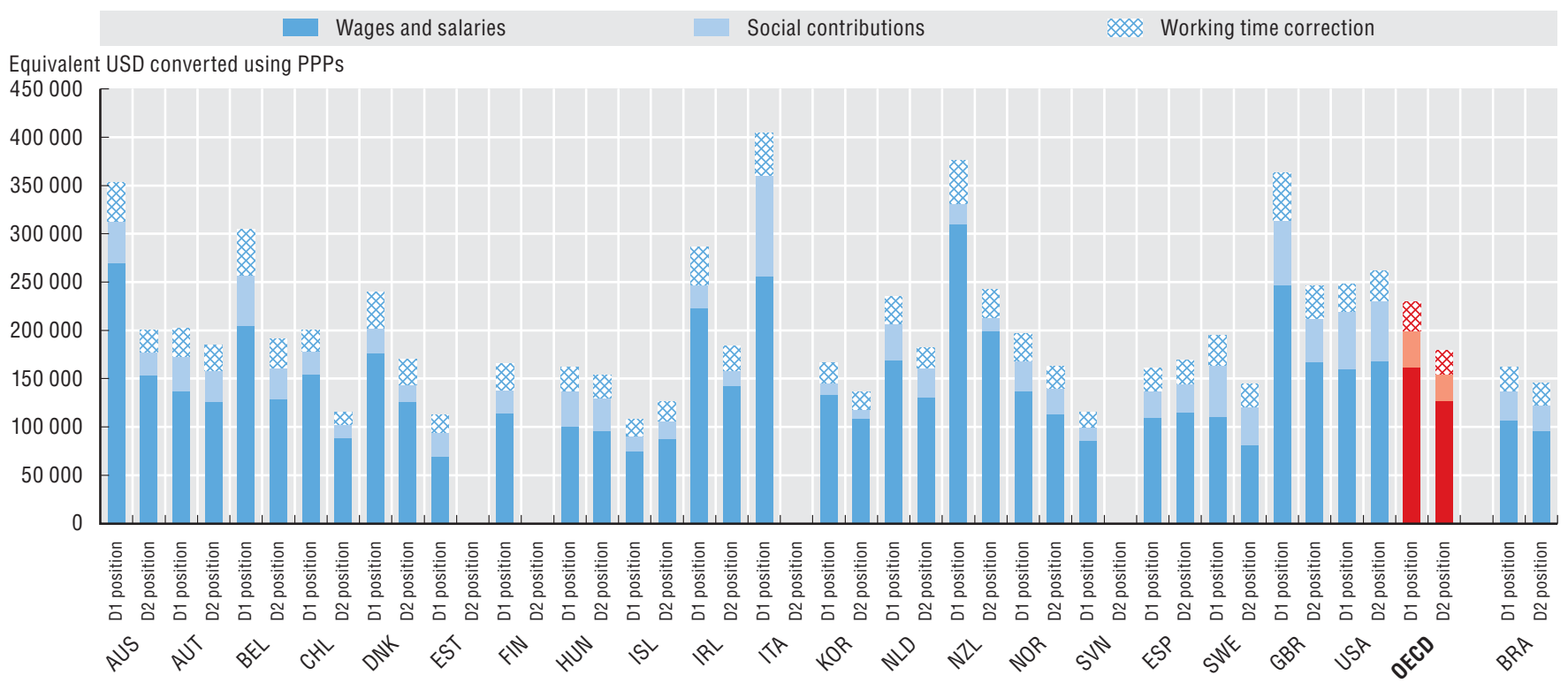

Notes: Compensation data for D2 positions are missing or mixed with D1 positions in Estonia, Finland, Italy and Slovenia. Austria: Value is median rather than average. Brazil: Source of social contribution: IBGE, source of PPP: World Bank. Data include career salary $+60 \%$ of Direção e Assessoramento Superiores. Chile: Data exclude bonuses for critical functions. This affects cross-country comparisons by one to two percentage points depending on the occupational group but may be much higher for top ranking positions. Ireland: Data take into account the decrease in salaries following the Financial Emergency Measures in the Public Interest Act 2009. Social contribution rates are for staff hired after 1995 and exclude unfunded pension schemes through the pay-as-you-go system. Italy: Public managers' compensation is comprehensive in that it rewards "all functions, tasks, and assignments performed in relation to their office" and also includes social contributions paid by the manager (11\% of gross salary). The government introduced cuts in 2011 to the wages of all public managers with a total gross remuneration above EUR 90000 . Reductions amount to $5 \%$ for the share of gross remuneration between EUR 90000 and EUR 150 000, and 10\% for the part exceeding EUR 150 000. Korea: Civil servants are entitled to 3-21 days of annual leave per year depending on the length of service. New Zealand: Data do not include all social payments including sick leave and other unfunded leave payments made by the employers. The D1 and D2 managers' compensation of the particular organisations surveyed are among the highest of all the New Zealand public service departments. Spain: Data are from 2009 and a major reduction in compensation in May 2010 is not reflected. The United Kingdom: Data exclude additional payments. Please see Annex D for additional notes.

Data are not available for the Czech Republic, France, Germany, Greece, Israel, Japan, Luxembourg, Mexico, Poland, Portugal, the Slovak Republic, Switzerland and Turkey. Canada withdrew its data.

Source: 2010 OECD Survey on the Compensation of Employees in Central/Federal Governments, OECD STAN Database.

StatLink तiाsय http://dx.doi.org/10.1787/888932390747 
Middle managers are located between senior management and professionals in the central government workforce hierarchy. D4 managers are directly below the D3 Level. A detailed description of their responsibilities and the various categories of middle managers are contained in Annex D. Data presented for middle managers are fully adjusted for differences in working time, including weekly hours and holidays.

There are significant differences in the amount of compensation between the two levels of middle managers. In the OECD countries that responded to the survey, the higher level of middle managers' (D3) total compensation amounts to on average about USD 135000 PPP annually, including wages and salaries, employers' social contributions, and the value of all working time adjustments. In contrast, the average annual compensation of lower level middle managers (D4) amounts to around USD 112000 PPP. However, wages and salaries alone are about USD 90000 PPP per year for the D3 Level, and about USD 75000 PPP for D4 positions. In addition, the compensation of middle managers is significantly lower than that of senior managers - for example, middle managers in D3 positions only earn $59 \%$ of what senior managers in D1 positions earn, and $76 \%$ of what managers in D2 positions earn (Indicator 27). The level of compensation of middle management also varies much less across OECD countries than that of senior managers.

Data suggest that middle managers in the United States earn the most relative to other OECD countries, and their annual compensation exceeds just over USD 220000 PPP for D3 Levels and USD 170000 PPP for D4 Levels. As is the case for other occupations, the division of total remuneration between wages and salaries and employers' social contributions varies across countries. In Sweden, the United States, Italy, Hungary and Estonia employers' social contributions constitute a relatively large share of total remuneration of middle managers while they tend to represent less in other countries (see Annex D for details).

Differences in remuneration levels across countries can be a result of differences in national labour markets, in particular the remuneration in the private sector for comparable positions. They can also indicate different organisational structures in countries and different levels of seniority in similar occupations.

\section{Methodology and definitions}

Data refer to 2009 and were collected by the 2010 OECD survey on the Compensation of Employees in Central/ Federal Governments of OECD countries. Officials from central Ministries and Agencies responded to the survey through the OECD Public Employment and Management Working Party.

Total compensation includes wages and salaries, employers' social contributions to statutory social security schemes or privately funded social insurance schemes, as well as unfunded employee social benefits paid by the employer, including pension payments paid through the state budget rather than through employer social contributions (mostly for some pay-as-you-go systems). Compensation was converted to USD using PPPs for GDP from the OECD National Accounts Database. Working time adjustment compensates for differences in time worked (both weekly working time and holidays). A larger working time adjustment generally means that employees work fewer hours and/or days per year. The focus on total compensation allows a comparison of the varying degrees with which governments remunerate their employees via social contributions or via higher wages and salaries. In most cases data are for six central government Ministries/Departments only (Interior, Finance, Justice, Education, Health and Environment or their equivalents). Positions are based on the International Standard Classification of Occupations (ISCO). The main limitations of the data are the less-than-full comparability of occupations across countries, the way countries have interpreted the definition of the positions, and some lack of clarity regarding the level of social contributions and the differing costs of living across countries in capital cities.

Compensation levels are calculated by averaging the compensation of the staff in place. (It is not the middle point between the minimum and maximum salary.) See Annex D for the full methodology. 
28.1 Average annual compensation of middle managers in central government (2009)

Adjusted for differences in working hours and holidays

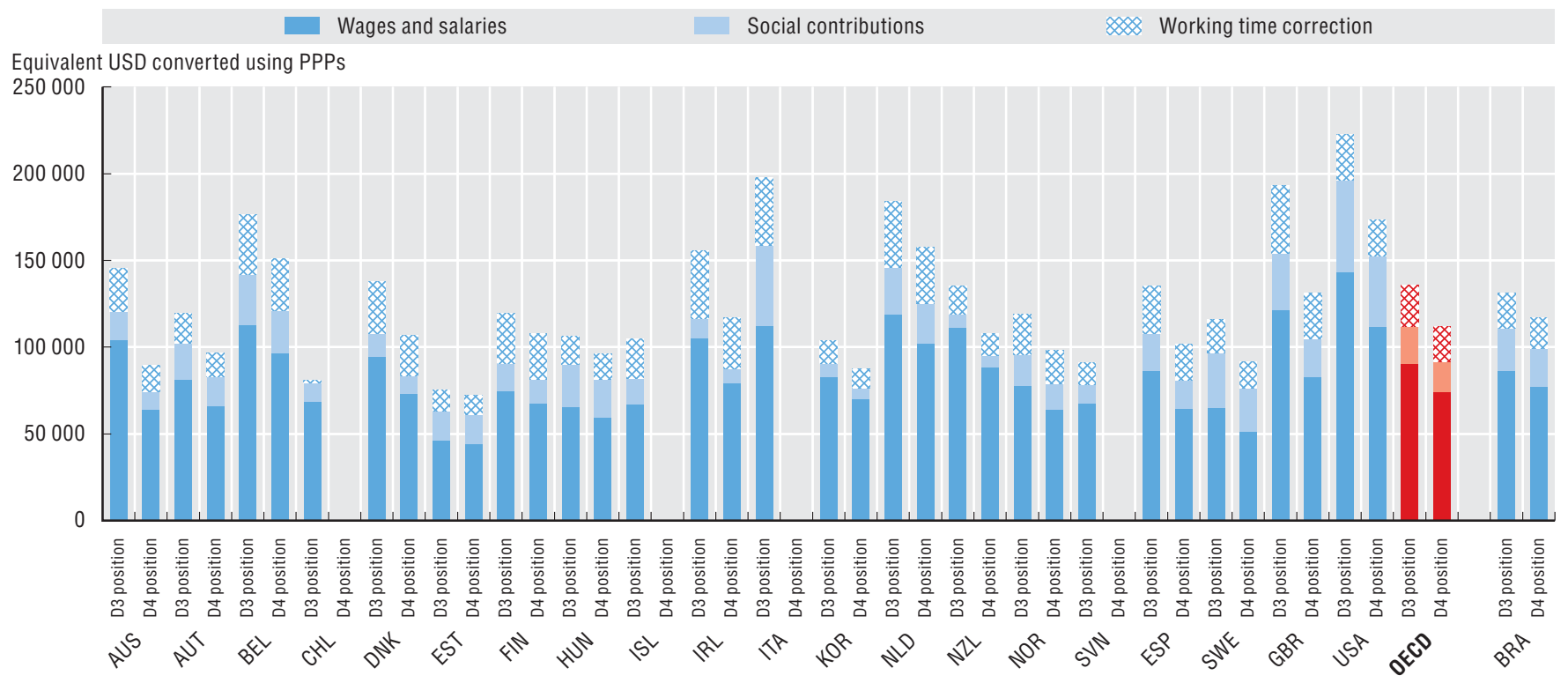

Notes: Compensation data for D4 positions are missing or mixed with D3 positions for Chile, Iceland, Italy and Slovenia. Austria: Value is median rather than average. Brazil: Source of social contribution: IBGE. Source of PPP: World Bank. Data include career salary $+60 \%$ of Direção e Assessoramento Superiores. Chile: Data exclude bonuses for critical functions. This affects cross-country comparisons by one to two percentage points depending on the occupational group but may be much higher for top ranking positions. Estonia: Data for managers in policy making/basic units of Ministries are presented under D3 and data for managers in support units of the Ministries (budgeting, personnel, IT, etc.) are presented under D4. Ireland: Data take into account the decrease in salaries following the Financial Emergency Measures in the Public Interest Act 2009. Social contributions rates are for staff hired after 1995 and exclude unfunded pension schemes though the pay-as-you-go system. Italy: Public managers' compensation is comprehensive in that it rewards "all functions, tasks, and assignments performed in relation to their office" and also includes social contributions paid by the manager (11\% of gross salary). The government introduced cuts in 2011 to the wages of all public managers with a total gross remuneration above EUR 90000. Reductions amount to 5\% for the share of gross remuneration between EUR 90000 and EUR 150 000, and 10\% for the part exceeding EUR 150 000. Korea: Civil servants are entitled to 3-21 days of annual leave per year depending on the length of service. New Zealand: Data do not include all social payments including sick leave and other unfunded leave payments made by the employers. Spain: Data are from 2009 and a major reduction in compensation in May 2010 is not reflected. The United Kingdom: Data exclude additional payments. Please see Annex D for additional notes.

Data are not available for the Czech Republic, France, Germany, Greece, Israel, Japan, Luxembourg, Mexico, Poland, Portugal, the Slovak Republic, Switzerland and Turkey. Canada withdrew its data.

Source: 2010 OECD Survey on the Compensation of Employees in Central/Federal Governments, OECD STAN Database.

StatLink तiाsय http://dx.doi.org/10.1787/888932390766 
Professionals are a key employee group in central government Ministries and Departments that are represented in the data by two subgroups: economists and statisticians. Economists' and statisticians' research and analytical skills are key to improving governments' ability to take decisions based on evidence. The detailed responsibilities of these positions are described in Annex D.

In the OECD countries responding to the survey, the average annual compensation of the two professional groups amounts to approximately USD 90000 PPP, including wages and salaries, employers' social contributions, and adjusted for differences in actual working time (both weekly hours and holidays). Their wages and salaries constitute twothirds of their annual compensation (on average almost USD 60000 PPP) and the remainder is divided relatively equally between employers' social contributions and the value of working time adjustments. As in the case of other occupations, the way that remuneration is divided is very different across countries. Sweden, the United States, Italy, Hungary and Estonia have the highest share of employers' social contributions in total compensation, while Korea, Ireland and New Zealand have the lowest.

The survey suggests that the differences in the level of compensation for these two professional groups across countries are less pronounced than for senior managers and, to a lesser extent, than for middle managers. Data also indicate that both positions are the best compensated in the United States and Spain. In addition, in the case of economists in Belgium and the Netherlands, and statisticians in Ireland, the overall remuneration is significantly higher than the OECD average. On the other end, governments in Estonia, New Zealand and Slovenia pay statisticians significantly lower amounts than economists. Differences in remuneration levels across countries can be a result of differences in national labour markets, in particular the remuneration in the private sector for comparable positions. They can also indicate different organisational structures in countries and different levels of seniority in similar occupations.

\section{Methodology and definitions}

Data refer to 2009 and were collected by the 2010 OECD survey on the Compensation of Employees in Central/Federal Governments. Officials from central Ministries and Agencies responded to the survey through the OECD Public Employment and Management Working Party.

Total compensation includes wages and salaries, employers' social contributions to statutory social security schemes or privately funded social insurance schemes, as well as unfunded employee social benefits paid by the employer, including pension payments paid through the state budget rather than through employer social contributions (mostly for some pay-as-you-go systems). Compensation was converted to USD using PPPs for GDP from the OECD National Accounts Database. Working time adjustment compensates for differences in time worked (both weekly working time and holidays). A larger working time adjustment generally means that employees work fewer hours and/or days per year. The focus on total compensation allows a comparison of the varying degrees with which governments remunerate their employees via social contributions or via higher wages and salaries. In most cases data are for six central government Ministries/Departments only (Interior, Finance, Justice, Education, Health and Environment or their equivalents). Positions are based on the International Standard Classification of Occupations (ISCO). The main limitations of the data are the less-than-full comparability of occupations across countries, the way countries have interpreted the definition of the positions, and some lack of clarity regarding the level of social contributions and the differing costs of living across countries in capital cities.

Compensation levels are calculated by averaging the compensation of the staff in place. (It is not the middle point between the minimum and maximum salary.) See Annex D for the full methodology. 


\subsection{Average annual compensation of economists and statisticians in central government}

Adjusted for differences in working hours and holidays

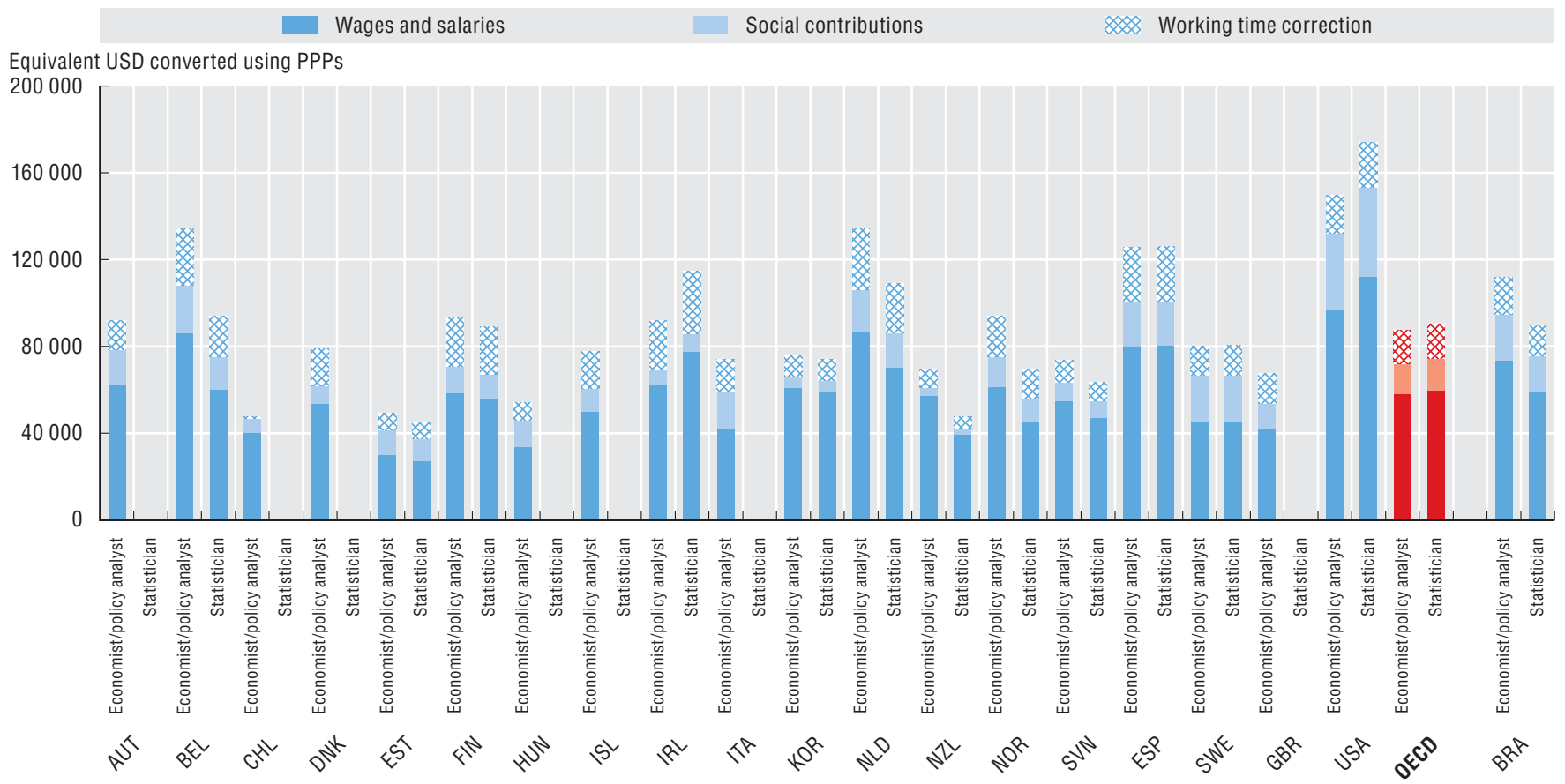

Notes: Compensation data for statisticians are missing or mixed with economist/policy analyst positions for Austria, Chile, Denmark, Hungary, Iceland, Italy and the United Kingdom. Austria: Economists/policy analysts and statisticians have the same compensation. Brazil: Source of social contribution: IBGE. Source of PPP: World Bank. Data include career salary $+60 \%$ of Direção e Assessoramento Superiores. Chile: Data exclude bonuses for critical functions. This affects cross-country comparisons by one to two percentage points depending on the occupational group but may be much higher for top ranking positions. Ireland: Data take into account the decrease in salaries following the Financial Emergency Measures in the Public Interest Act 2009. Social contributions rates refer to staff hired after 1995 and exclude unfunded pension schemes though the pay-as-you-go system. Estonia: The information does not correspond exactly to the ISCO occupational groups. Economists/policy analysts cover all professionals that are employed in policy-making or basic units in Ministries, and statisticians cover all professionals in support units. Korea: Civil servants are entitled to 3-21 days of annual leave per year depending on the length of service. New Zealand: Data do not include all social payments including sick leave and other unfunded leave payments made by the employers. Spain: Major reductions in compensation made in May 2010 are not reflected. The United Kingdom: Data exclude additional payments. Please see Annex D for additional notes.

Data are not available for Australia, the Czech Republic, France, Germany, Greece, Israel, Japan, Luxembourg, Mexico, Poland, Portugal, the Slovak Republic, Switzerland and Turkey. Canada withdrew its data.

Source: 2010 OECD Survey on the Compensation of Employees in Central/Federal Governments, OECD STAN Database.

StatLink त्ञाs http://dx.doi.org/10.1787/888932390785 
Among the different central government occupations, the remuneration of staff in executive assistant and secretarial positions seems to vary the least across OECD member countries. Executive assistants may supervise the work of secretaries and generally have more responsibility. Annex D provides a detailed description of these positions.

Data from the survey show that on average executive secretaries earn about USD 57000 PPP per year and secretaries about USD 50000 PPP. This includes wages and salaries, employers' social contributions and the monetary value of working time adjustments (both weekly working time and holidays). However, the annual wages and salaries alone for these two groups do not surpass USD 40000 PPP. The Netherlands, the United States, and to a lesser extent Belgium, Norway and Finland, pay their secretaries significantly above the OECD average. Chile, Hungary, Estonia and Slovenia pay these positions the lowest relative to the OECD average.

There is a larger difference between the levels of compensation of secretaries and professionals than between professionals and middle management. As in the case of other occupations, the way countries structure remuneration (through relatively more or less employers' social contributions compared to wages and salaries) is very different across countries. Sweden, Italy, the United States, Estonia and Hungary provide the most in employers' social contributions. Differences in remuneration levels across countries can be a result of differences in national labour markets, in particular the remuneration in the private sector for comparable positions. They can also indicate different organisational structures in countries and different levels of seniority in similar occupations.

\section{Methodology and definitions}

Data refer to 2009 and were collected by the 2010 OECD survey on the Compensation of Employees in Central/Federal Governments. Officials from central Ministries and Agencies responded to the survey through the OECD Public Employment and Management Working Party.

Total compensation includes wages and salaries, employers' social contributions to statutory social security schemes or privately funded social insurance schemes, as well as unfunded employee social benefits paid by the employer, including pension payments paid through the state budget rather than through employer social contributions (mostly for some pay-as-you-go systems). Compensation was converted to USD using PPPs for GDP from the OECD National Accounts Database. Working time adjustment compensates for differences in time worked (both weekly working time and holidays). A larger working time adjustment generally means that employees work fewer hours and/or days per year. The focus on total compensation allows a comparison of the varying degrees with which governments remunerate their employees via social contributions or via higher wages and salaries. In most cases data are for six central government Ministries/Departments only (Interior, Finance, Justice, Education, Health and Environment or their equivalents). Positions are based on the International Standard Classification of Occupations (ISCO). The main limitations of the data are the less-than-full comparability of occupations across countries, the way countries have interpreted the definition of the positions, and some lack of clarity regarding the level of social contributions and the differing costs of living across countries in capital cities.

Compensation levels are calculated by averaging the compensation of the staff in place. (It is not the middle point between the minimum and maximum salary.) See Annex D for the full methodology. 


\subsection{Average annual compensation of employees in secretarial positions (2009)}

Adjusted for differences in working hours and holidays

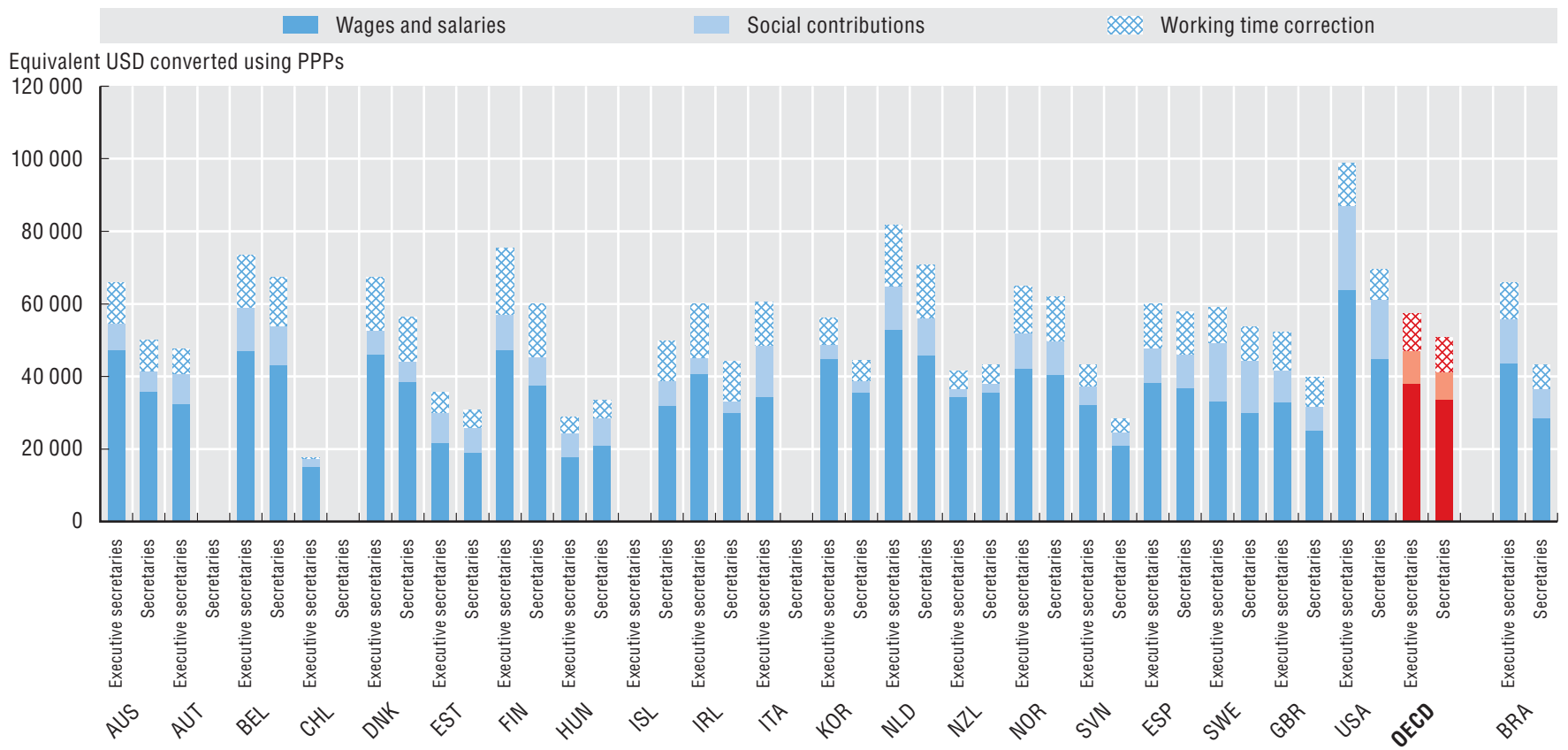

Notes: Compensation data for secretaries are missing or mixed with executive secretaries for Austria, Chile and Italy; compensation data for executive secretaries are missing or mixed with secretaries for Iceland. Austria: Value is median rather than average. Executive secretaries and secretaries are not differentiated in Austria, therefore their compensation has been averaged. Brazil: Source of social contribution: IBGE. Source of PPP: World Bank. Data include career salary $+60 \%$ of Direção e Assessoramento Superiores. Chile: Data exclude bonuses for critical functions. This affects cross-country comparisons by one to two percentage points depending on the occupational group but may be much higher for top ranking positions. Ireland: Data take into account the decrease in salaries following the Financial Emergency Measures in the Public Interest Act 2009. Social contributions rates are for staff hired after 1995 and exclude unfunded pension schemes though the pay-as-you-go system. Korea: Civil servants are entitled to 3-21 days of annual leave per year depending on the length of service. New Zealand: Data do not include all social payments including sick leave and other unfunded leave payments made by the employers. Spain: Major reductions in compensation were introduced in May 2010 that are not reflected. The United Kingdom: Data exclude additional payments. Please see Annex D for additional notes.

Data are not available for the Czech Republic, France, Germany, Greece, Israel, Japan, Luxembourg, Mexico, Poland, Portugal, the Slovak Republic, Switzerland and Turkey. Canada withdrew its data.

Source: 2010 OECD Survey on the Compensation of Employees in Central/Federal Governments, OECD STAN Database.

StatLink Aाst http://dx.doi.org/10.1787/888932390804 


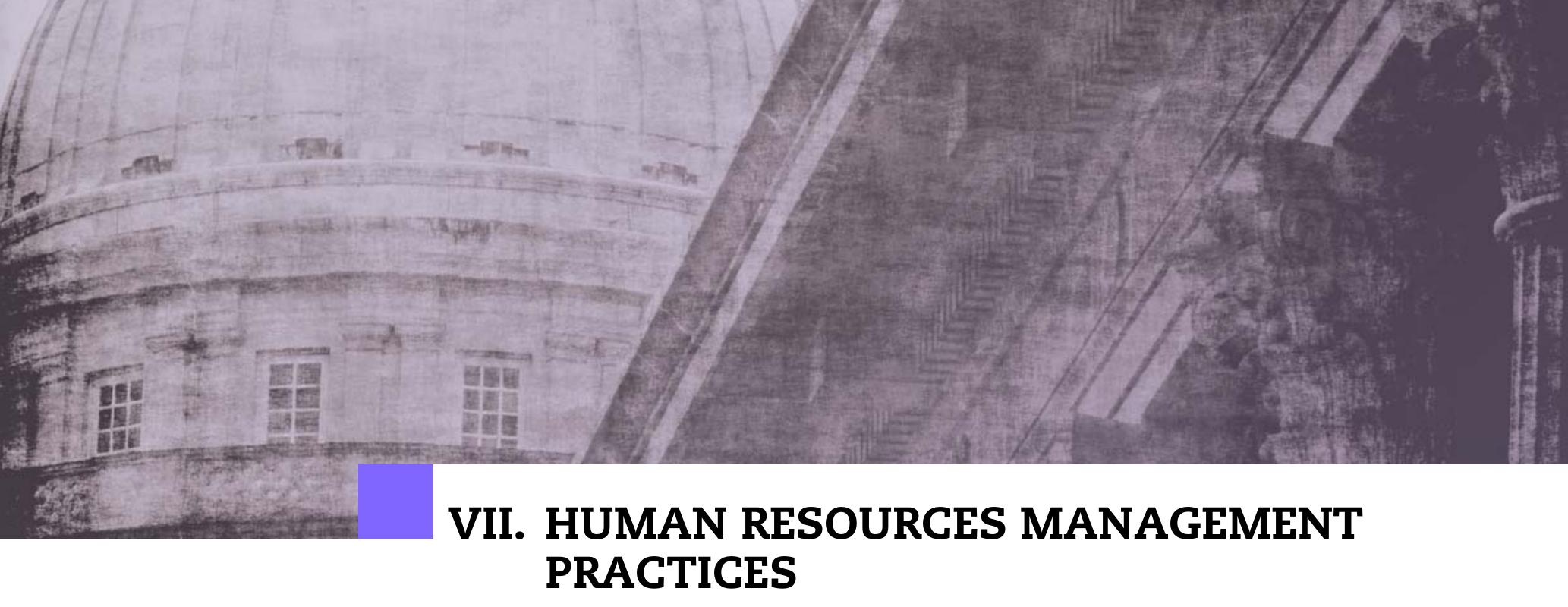

As with any organisation, good public sector performance rests with its staff: their capacities and skills, and the fit of these to the needs of the organisation, as well as the ability of the leadership to motivate staff to do their best in achieving organisational objectives. Human resources management (HRM) practices are the mechanisms through which these traits can be incentivised and developed, contributing towards increasing the effectiveness and efficiency of the public sector. This chapter includes four indicators related to HRM practices that are key for allowing governments to respond to the unique challenges they face in times of fiscal consolidation, and which can provide valuable information for governments considering workforce restructuring. Two of these indicators were included in Government at a Glance 2009: the extent to which HRM functions are delegated to line Departments/Ministries/Agencies and the use of performancerelated practices in managing staff. Two new indicators show elements of industrial relations, focusing on union involvement in workplace decision making and the funding arrangements for central government unions, and the differences across countries in basic working conditions in central government, including the length of the working week, the number of public holidays and vacations, and the use of sick leave.

The delegation in HRM practices and use of performance-related practices are described by composite indicators in order to provide a broad comparison of their extent of use. At the same time, data on all component variables that form the composites are also provided in Annex E. Based on feedback received, there have been some small changes in the variables selected for the composite indicators and their scoring and weighting, since their publication in Government at a Glance 2009. As a result, direct comparisons to this previous publication are not possible. 
Many OECD countries are moving towards a model of human resources management (HRM) whereby major decisions regarding employee selection, recruitment, remuneration, working conditions and dismissal are delegated from a centralised HRM body to line Ministries/Departments/ Agencies. The key motive behind delegation is to empower and enable public managers to better direct their staff, allowing them to consider in their HRM decisions both the unique requirements of their own organisations and the merits of individual employees. As HRM authority is delegated, the role of the central HRM body is also changing to one of setting minimum standards and formulating HRM policies rather than implementing them.

There is no single model or common standard of delegation in HRM in the OECD, and the variance in the extent of delegation across member countries is considerable. In 2010 several OECD member countries demonstrated a high degree of delegation, with Sweden and Australia standing out as the most prominent examples. In these countries, Departments and line Ministries have greater flexibility to determine their staffing needs, recruit staff and set conditions of employment. In comparison, Turkey and Ireland display relatively lower levels of delegation, with central HRM bodies in these countries retaining greater responsibility over such decisions.

The majority of OECD member countries (18) have a central HRM body responsible for at least some key HRM functions. The exceptions are Germany and the Slovak Republic that do not have a centralised HRM body. In 13 OECD countries (Australia, Austria, Belgium, Chile, the Czech Republic, France, Greece, Iceland, New Zealand, Portugal, Slovenia, Sweden and the United Kingdom) a central HRM body exists but plays more of a co-ordinating role across line Ministries and is not formally responsible for HRM functions.

Today, many OECD countries have given a large amount of managerial room for manoeuvre to Ministries and Agencies, allowing them more flexibility regarding staffing levels, recruitment and some working conditions. Performance-related pay and performance appraisal systems also tend to be delegated to Ministries and Agencies, although the general management of the overall pay systems remains centralised in a majority of countries. The imperative of cost control and the institutional structure of collective bargaining in member countries may partly explain these trends.

\section{Methodology and definitions}

Data refer to 2010 and were collected through the 2010 OECD Survey on Strategic Human Resources Management. Respondents were predominately senior officials in central government HRM departments, and data refer to HRM practices in central government. The survey was completed by all OECD member countries except Luxembourg. Definitions of the civil service as well as the organisations governed at the central level of government, differ across countries and should be considered when making comparisons. The terms public and civil service/servants are used interchangeably throughout this chapter.

The index is composed of the following variables: the existence of a central HRM body, and the role of line Ministries in determining: the number and types posts within organisations; the allocation of the budget envelope between payroll and other expenses; staff compensation levels; position classification, recruitment and dismissals; and conditions of employment. The index ranges from 0 (no delegation) to 1 (high level of delegation). Missing data for countries were estimated by mean replacement.

See Annex E for further country-specific information as well as details on the methodology and factors used in constructing the index. The variables composing the index and their relative importance are based on expert judgements. They are presented with the purpose of furthering discussion, and consequently may evolve over time. Comparisons between the indexes from Government at a Glance 2009 and 2011 should be made with caution, as weightings and the number of country responses vary between the two. Some questions taken into account in the composite index have changed as well.

\section{Further reading}

Ketelaar, A., N. Manning and E. Turkisch (2007), "PerformanceBased Arrangements for Senior Civil Servants OECD and other Country Experiences", OECD Working Papers on Public Governance, No. 5, OECD Publishing, Paris.

OECD (2008), The State of the Public Service, OECD Publishing, Paris.

\section{Figure and table notes}

See Annex E for further country-specific information as well as details on the methodology and factors used in constructing the index.

Information on data for Israel: $h$ ttp://dx.doi.org/10.1787/888932315602. 
31.1 Extent of delegation of human resources management practices to line Ministries in central government (2010)

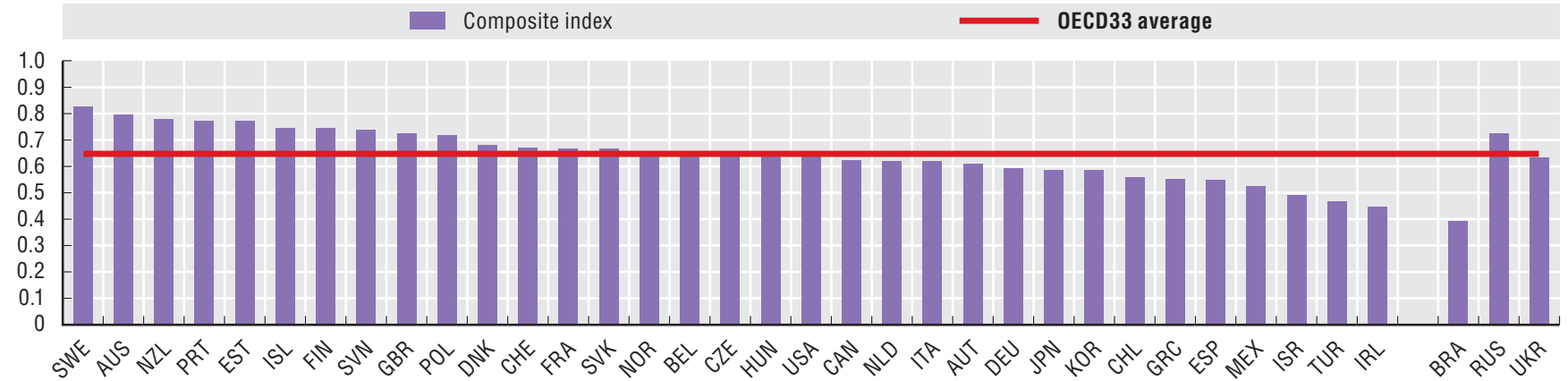

Source: 2010 OECD Survey on Strategic Human Resources Management in Central/Federal Governments.

StatLink काIsL http://dx.doi.org/10.1787/888932390823

31.2 Delegation of key HRM responsibilities to line Ministries in central government (2010)

\begin{tabular}{|c|c|c|c|c|c|c|c|}
\hline & $\begin{array}{l}\text { General management of pay } \\
\text { systems (salary levels, } \\
\text { progressions) }\end{array}$ & $\begin{array}{l}\text { Flexibility of working } \\
\text { conditions } \\
\text { (number of hours, etc.) }\end{array}$ & $\begin{array}{l}\text { Allocation of budget } \\
\text { envelope between payroll } \\
\text { and other expenses }\end{array}$ & $\begin{array}{l}\text { Performance } \\
\text { appraisal } \\
\text { systems }\end{array}$ & $\begin{array}{l}\text { Management of the variable } \\
\text { portion of pay benefits; } \\
\text { performance-related pay }\end{array}$ & $\begin{array}{l}\text { Number and types } \\
\text { of posts within } \\
\text { organisations }\end{array}$ & $\begin{array}{l}\text { Recruitmen } \\
\text { into the civil } \\
\text { service }\end{array}$ \\
\hline Australia & - & - & - & - & - 0 & - & - \\
\hline Austria & - & - & - & - & $\bullet$ & - & - \\
\hline Belgium & - & - & - & घ & me & - & - \\
\hline Canada & - & - & - & - & $\bullet$ 口 & - & - \\
\hline Chile & - & - & - & घ & $\bullet$ & घ & - \\
\hline Czech Republic & - & - & - & $\bullet$ & - & - & $\bullet$ \\
\hline Denmark & - & $\bullet$ & - & $\bullet$ & $\bullet$ & $\bullet$ & 0 \\
\hline Estonia & - & 0 & - & - 0 & $\bullet$ & - & $\bullet$ \\
\hline Finland & - & घ0 & घ & $\bullet$ & - 0 & - & - \\
\hline France & - & 0 & $\bullet \bullet$ & $\bullet$ & घ0 & $\bullet \bullet$ & - \\
\hline Germany & - & $\bullet$ & $\bullet \bullet$ & $\bullet$ & I & $\bullet$ & - \\
\hline Greece & - & $\bullet$ & $\bullet$ & - & $\bullet$ & घ & - \\
\hline Hungary & - & $\bullet$ & • घ० & - & $\bullet \bullet \bullet$ & $\bullet$ & - 0 \\
\hline Iceland & $\bullet$ & - 0 & 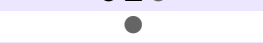 & n.a. & 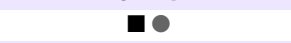 & 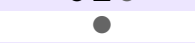 & - 0 \\
\hline Ireland & $\bullet$ & $\bullet$ & - & घ & $\bullet$ & - & $\bullet$ \\
\hline Israel & $\bullet \boldsymbol{\square}$ & - & - & - & 由 & - & - \\
\hline Italy & $\bullet$ & - & - & - & - 0 & - & - \\
\hline Japan & - & - & 匹 & - & - & घ & - \\
\hline Korea & - & ! & 匹 & - & - & 匹 & - \\
\hline Mexico & घ & $\bullet \square \bullet$ & n & - & घ & घ & • घ \\
\hline Netherlands & - & $\bullet \bullet$ & - & $\bullet$ & 0 & - & - 0 \\
\hline New Zealand & - & $\bullet$ & - & 0 & - & - & $\bullet$ \\
\hline Norway & - & $\bullet \bullet$ & - & - & - & - & - 0 \\
\hline Poland & $\bullet$ & - 0 & घ & $\bullet$ & $\bullet$ & - & mo \\
\hline Portugal & - & $\bullet$ & - & n.a. & - & - & - \\
\hline Slovak Republic & $\bullet$ & - & - & " & n.a. & - & - \\
\hline Slovenia & $\bullet$ & - & - & - & - & - & - \\
\hline Spain & $\bullet$ & - & - & $\mathrm{O}$ & $\bullet$ & a & mo \\
\hline Sweden & - & - 0 & - & - 0 & - 0 & - & - 0 \\
\hline Switzerland & - & $\bullet$ & п & $\bullet$ & - 0 & $\bullet$ & 0 \\
\hline Turkey & - & " & - & - & $\bullet$ & - & ! \\
\hline United Kingdom & 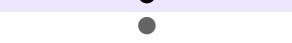 & $\overrightarrow{0}$ & $\bullet$ & 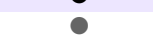 & - & - & 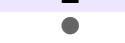 \\
\hline United States & - & n.a. & - & - & - & - & - \\
\hline Brazil & - & $\bullet$ & • & • & - & - & - \\
\hline Russian Federation & n.a. & - & n.a. & - & - & n.a. & - \\
\hline Ukraine & - & - & - & - & - & - & $\bullet \bullet$ \\
\hline \multicolumn{8}{|l|}{ Total OECD } \\
\hline - & 20 & 12 & 11 & 8 & 7 & 6 & 2 \\
\hline घ & 6 & 11 & 7 & 7 & 11 & 7 & 8 \\
\hline - & 9 & 19 & 19 & 16 & 21 & 23 & 26 \\
\hline O & 1 & 3 & 0 & 5 & 8 & 0 & 8 \\
\hline
\end{tabular}

- Central HRM body (which sets the rules and is closely involved in applying them) and/or Ministries of Finance.

- Central HRM body but with some latitude for Ministries/Departments/Agencies in applying the general principles.

- Ministries/Departments/Agencies within established legal and budgetary limits.

O Unit/team level

n.a.: Not available.

Source: 2010 OECD Survey on Strategic Human Resources Management in Central/Federal Governments.

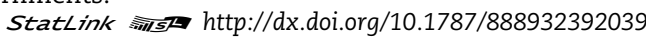


Over the past two decades, the majority of OECD member countries have implemented reforms to modernise their public administrations with the aim of increasing efficiency and quality in service delivery. A cornerstone of these reforms has been the implementation of performance-oriented management of public sector organisations. As such, the use of performance assessments for individual staff, work groups and at the organisational level has been rolled out in order to strengthen incentives to improve performance. When used properly, performance assessments allow for the recognition of individual and collective efforts in an objective and transparent manner. Such practices also function to clarify organisational goals for staff so that they gain a better understanding of their role within the organisation and therefore how to best implement change and contribute towards strategic organisational objectives.

On a scale of 0 (no use) to 1 (high use), Portugal and Denmark have put performance assessments at the core of their decision-making process regarding individual staff (career, promotions, pay). In comparison, Finland and Greece use performance assessments to a lesser extent. Today, almost all OECD member countries have formal performance assessments that are mandatory for central government employees, except in Canada, Iceland, Mexico and Norway where they are used for some staff only.

Relating performance assessment results to rewards for staff remains a challenging issue in many OECD countries. Performance incentives include career opportunities (such as promotions) and pay. Performance-related pay (PRP) in the form of bonuses or merit increases to basic pay has been used more frequently in recent years. PRP can vary according to the range of staff positions to which it applies, whether the targets and the incentives apply to individuals or to groups, the extent to which rankings are used, and the size of awards. The United Kingdom, Switzerland and the Czech Republic apply PRP more extensively than countries such as New Zealand, Austria and the Netherlands. In Finland, for example, the maximum proportion of basic salary that PRP can represent can constitute over $40 \%$. Six OECD countries (Belgium, Greece, Iceland, Mexico, Poland and Turkey) report not using PRP at all.

\section{Methodology and definitions}

Data refer to 2010 and were collected through the 2010 OECD Survey on Strategic Human Resources Management. Respondents were predominately senior officials in central government HRM departments, and data refer to HRM practices in central government. The survey was completed by all OECD member countries except Luxembourg. Definitions of the civil service, as well as the organisations governed at the central level of government, differ across countries and should be considered when making comparisons. The terms public and civil service/servants are used interchangeably throughout this chapter.
The index on performance assessment is composed of the following variables: existence of a formalised performance assessment; use of performance assessment tools (meetings with supervisors, frequency of meetings, written feedback, etc.); performance assessment criteria used; and the importance of good performance assessments for career advancement, remuneration, contract renewal on the same job/ remaining in the same job and employment contract renewal in the public service. The index on PRP is composed of the following variables: the use of a PRP mechanism and for which staff categories; the use of one-off bonuses and/or merit increments; and the maximum proportion of basic salary that PRP represents. Both indexes range between 0 (no use) and 1 (high use). Missing data for countries were estimated by mean replacement. These indexes provide information on the formal use of performance assessments and PRP in central government, but do not provide any information on their implementation or on the quality of work performed by public servants.

See Annex E for further country-specific information as well as details on the methodology and factors used in constructing the index. The variables composing the index and their relative importance are based on expert judgements. They are presented with the purpose of furthering discussion, and consequently may evolve over time. Comparisons between the indexes from Government at a Glance 2009 and 2011 should be made with caution, as weightings and the number of country responses vary between the two. Some questions taken into account in the composite index have changed as well.

\section{Further reading}

Ketelaar, A., N. Manning and E. Turkisch (2007), "PerformanceBased Arrangements for Senior Civil Servants OECD and other Country Experiences", OECD Working Papers on Public Governance, No. 5, OECD Publishing, Paris.

OECD (2008), The State of the Public Service, OECD Publishing, Paris.

\section{Figure notes}

See Annex E for further country-specific information as well as details on the methodology and factors used in constructing the index.

32.2: The average for OECD countries includes the six countries that have reported not having a PRP system: Belgium, Greece, Iceland, Mexico, Poland and Turkey. In addition, Ukraine reported that it does not use PRP and is therefore not included in the index.

Information on data for Israel: $h t t p: / / d x . d o i . o r g / 10.1787 / 888932315602$. 


\section{HUMAN RESOURCES MANAGEMENT PRACTICES}

32. Staff performance management

32.1 Extent of the use of performance assessments in HR decisions in central government (2010)

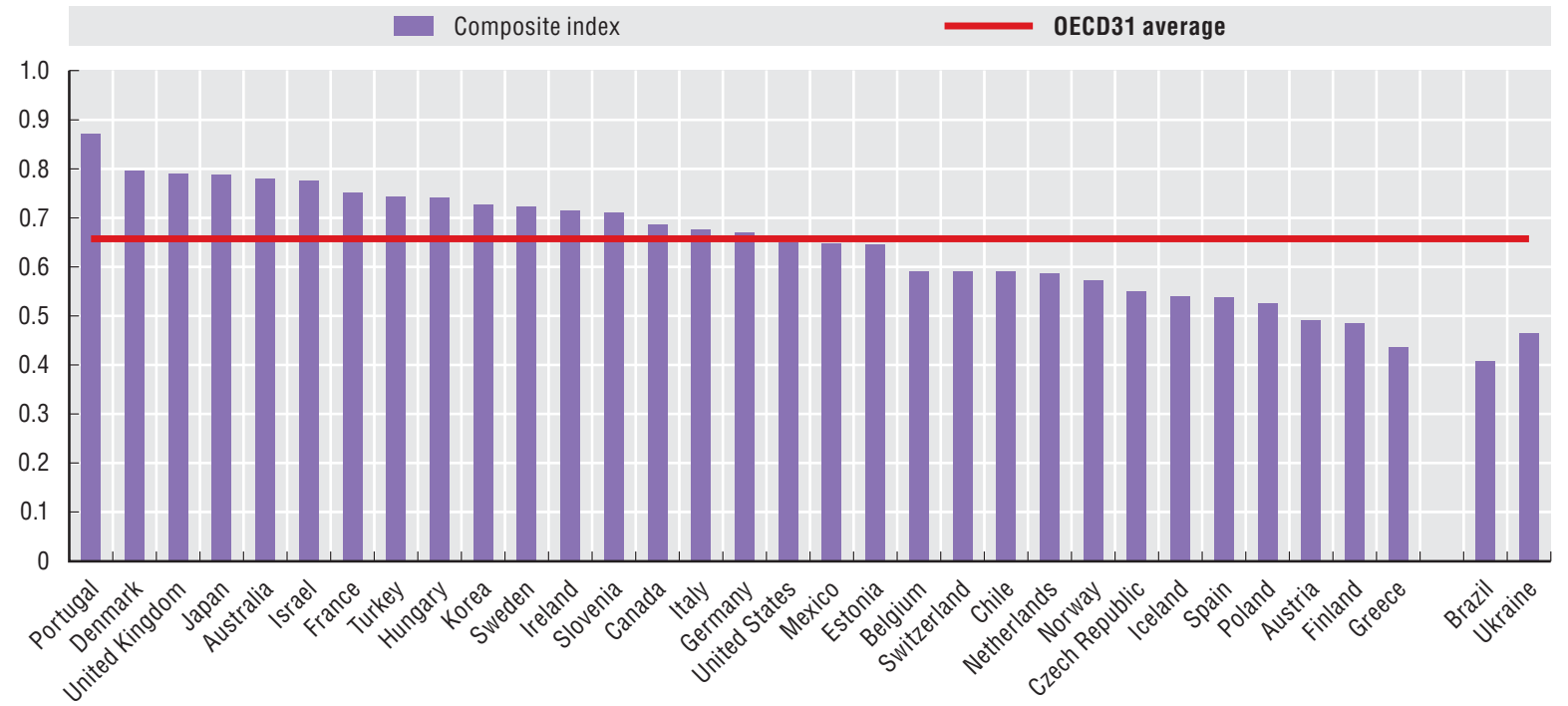

Source: 2010 OECD Survey on Strategic Human Resources Management in Central/Federal Governments.

32.2 Extent of the use of performance-related pay in central government (2010)

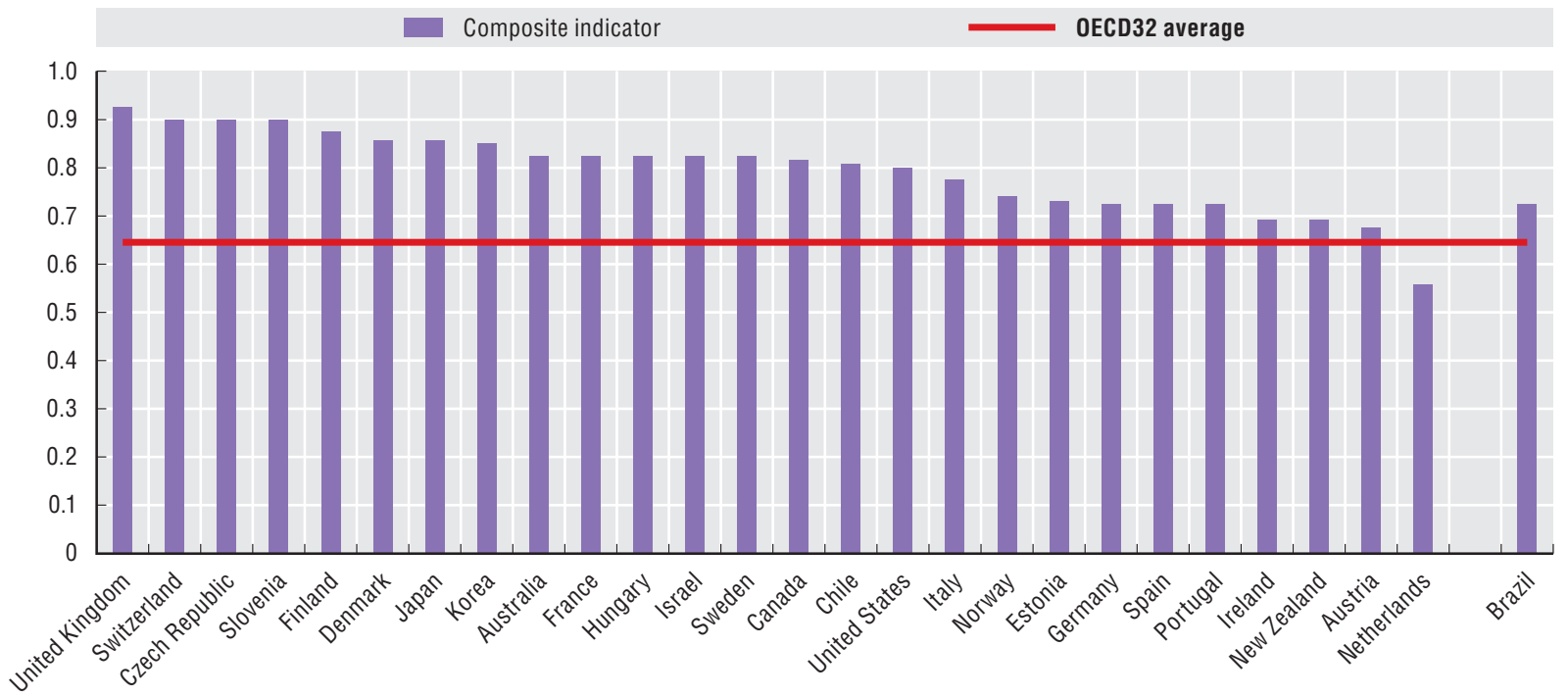

Source: 2010 OECD Survey on Strategic Human Resources Management in Central/Federal Governments. 
Industrial relations refer to the relationship between unions and employers, and have the goal of including employee representatives in the decision making process on workforce policies. Unions are involved to varying degrees in HRM decisions on compensation elements, working conditions, statutory employment provisions, code of conduct, right to strike, introduction of new management tools and government restructuring. In the wake of the economic crisis, good industrial relations between civil servants and governments are a particularly useful asset in terms of facilitating sustainable solutions to adapt workforce conditions and organisations to the changing social and economic environment. Well managed, healthy industrial relations are also useful in anticipating future changes and reducing associated costs of reforms.

The funding arrangements of central government unions are important especially for transition economies where the foundations for social dialogue are still being built. In nine responding OECD countries and one non-member country, central government unions are partially funded by public funds. Only two member countries indicated that unions are funded mostly by public funds: Spain and Hungary. In the far majority of OECD countries (22) public sector unions receive no public funding.

Collective negotiations on working conditions, wages and overall remuneration take place both mandatorily and voluntarily. Some agreements are binding by law, others are political commitments, and still others are voluntary collective agreements as illustrated in Table 33.1. Union agreement for compensation and performance pay is mandatory in 11 and 10 OECD countries respectively. Indeed, in Canada, Denmark, Finland, Iceland, Israel, Italy, Mexico, the Netherlands, Norway, Slovenia and Sweden union agreement over basic salary and social benefits is mandatory. Likewise, the right to strike, working conditions and statutory employment rules are further issues where consultation with public sector unions is required by law and/or where agreement is mandatory. In the cases of changes to the Code of Conduct or the introduction of new management tools, consultation with unions is mostly voluntary (16 and 15 OECD countries respectively).

In contrast, public sector unions are not normally involved in the process of government restructuring. With the exception of the Russian Federation, none of the respond- ing countries require mandatory agreement with the unions on such issues. In the Czech Republic, Finland, France, Italy, Norway, Slovenia and Switzerland, however, unions must be at least consulted on restructuring. There are also great differences across the countries in the ability of unions to influence employment conditions, with the Nordic countries leading in this regard.

\section{Methodology and definitions}

Data refer to 2010 and were collected through the 2010 OECD Survey on Strategic Human Resources Management. Respondents were predominately senior officials in central government HRM departments, and data refer to HRM practices in central government. The survey was completed by all OECD member countries except Luxembourg. Definitions of the civil service, as well as the organisations governed at the central level of government, differ across countries and should be considered when making comparisons. The involvement of unions in the daily management of individual staff is not measured in the survey. The terms public and civil service/servants are used interchangeably throughout this chapter. See Annex E for further country-specific information.

\section{Further reading}

European Commission (2008), Industrial Relations in Europe, Office for Official Publications of the European Communities, Luxembourg.

OECD (2010), OECD Reviews of Human Resource Management in Government - Brazil 2010: Federal Government, OECD Publishing, Paris.

\section{Table notes}

See Annex E for further country-specific information as well as details on the methodology and factors used in constructing the index.

Information on data for Israel: http://dx.doi.org/10.1787/888932315602. 
33.1 Extent of union involvement in HRM issues and sources of financial support (2010)

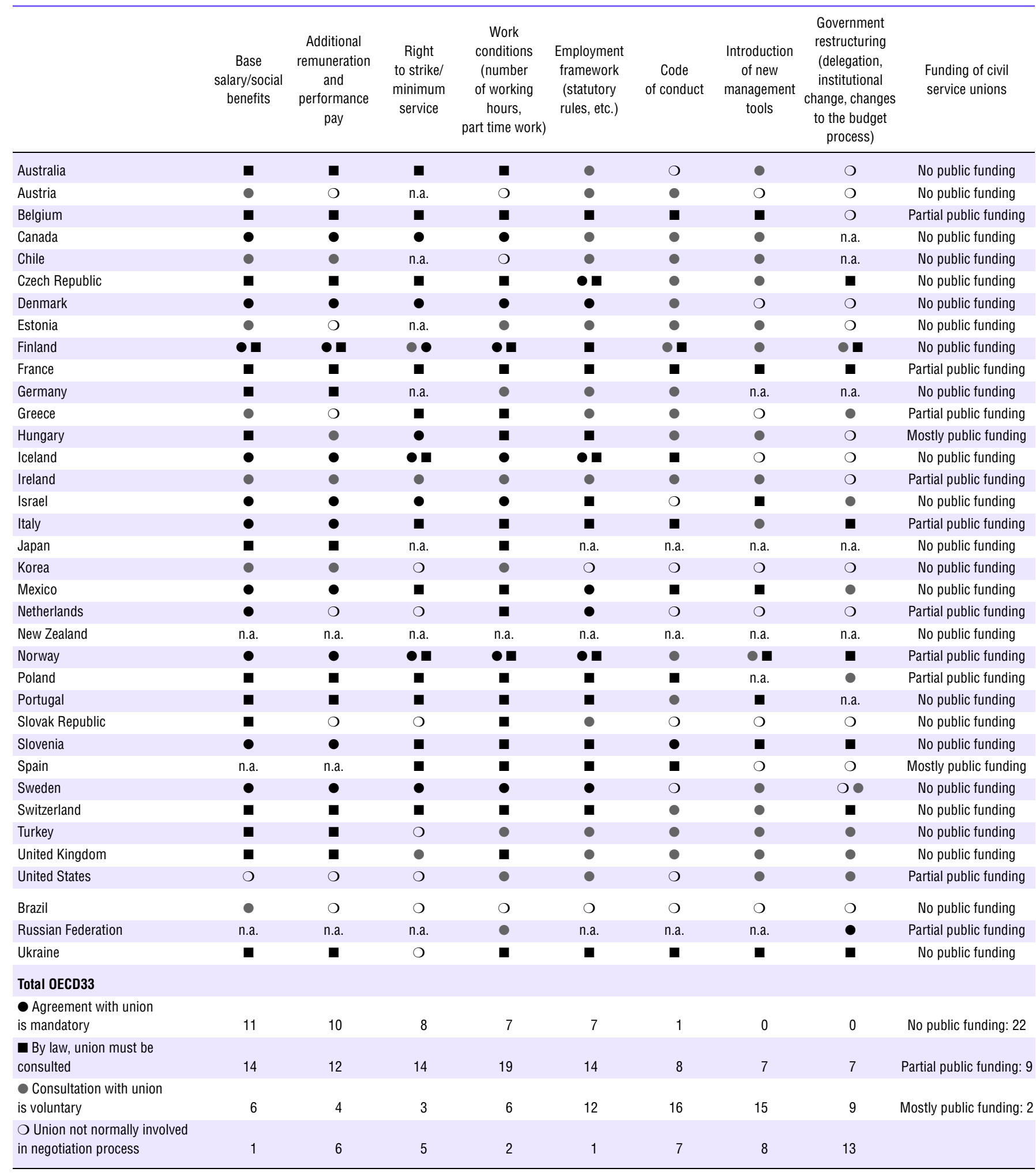

n.a.: Not available.

Source: 2010 OECD Survey on Strategic Human Resources Management in Central/Federal Governments. 
The special staff arrangements and employment conditions for core government employees are at the heart of the state's relationship to its employees and they are often firmly rooted in national tradition and administrative culture. As such, employment conditions and human resources systems such as recruitment procedures, career development, pay systems and social security benefits have traditionally been rather different in the public and private sectors in many countries. Until recently, some of the working conditions such as working hours and employee benefits tended to be more attractive in the public service than in the private sector in many countries. They remain an important part of the overall remuneration package of employees today and a tool for attracting qualified staff to government employment.

The total amount of time spent working during a year is an indicator of the overall working conditions in the civil service and is critical when comparing compensation packages. The total working hours per year are dependent on regular weekly working hours, the amount of annual leave and the number of bank/public holidays. The first two employment standards are usually set by a combination of minimum statutory rules and collective bargaining (see also Indicator 33).

The average number of working hours per year among civil servants in OECD countries is 1742 hours. Average annual working hours range from 1545 hours in Portugal to 2048 hours in Chile; but in the majority of respondent countries, employees in the central government tend to work between 1600 to 1850 hours per year. The statutory weekly working hours for civil servants are lowest in France and Portugal at 35 hours, and highest in Chile and Israel (44 and 42.5 hours respectively). Civil servants in the Russian Federation are entitled to the highest average number of annual holiday leave (43.5 days) while in Canada the average is 15 days. Annual holiday leave however often depends on length of service.

A second key indicator of working conditions is the average number of working days public employees are absent on sick leave each year. It an important indicator of workforce costs, since employees continue receiving a salary. In addition, it can be considered an outcome governance indicator for HRM policies, since poor working environments can lead to a greater incidence of employees requiring time off. Seventeen OECD countries and one non-member country have been able to provide information on the average amount of sick leave in central government workplaces. In responding countries, on average about 11 days are taken each year, varying from about 6 days in the Netherlands to
16 days in Germany. Interestingly, in Chile where the annual working hours are highest, civil servants also report amongst the highest in sick leave usage with 15.7 days on average in 2009 .

\section{Methodology and definitions}

Data on average working hours per year were collected through the 2010 Survey on Compensation of Employees in Central/Federal Governments. Data on sick leave were collected from the 2010 OECD Survey on Strategic Human Resources Management. Respondents to both surveys were predominately senior officials in central government HRM departments, and data refer to working conditions for civil servants at the central level of government. The survey was completed by all OECD member countries except Luxembourg. Definitions of the civil service, as well as the organisations governed at the central level of government, differ across countries and should be considered when making comparisons. The terms public and civil service/servants are used interchangeably throughout this chapter.

Data on average working hours per year refer to 2010 with the exception of data regarding sick leave which refer to 2009 or the latest year available.

The average hours worked per year is the total number of working hours per calendar year less annual leave and bank/public holidays. It refers to contractual working time and does not include lunch breaks.

See Annex E for further country-specific information and details on methodology used.

\section{Further reading}

OECD (2008), The State of the Public Service, OECD Publishing, Paris.

\section{Figure notes}

See Annex E for further country-specific information as well as details on the methodology and factors used in constructing the index.

Information on data for Israel: $h$ ttp://dx.doi.org/10.1787/888932315602. 


\section{HUMAN RESOURCES MANAGEMENT PRACTICES}

34. Working conditions in central government

34.1 Average working hours per year by central government employees (2010)

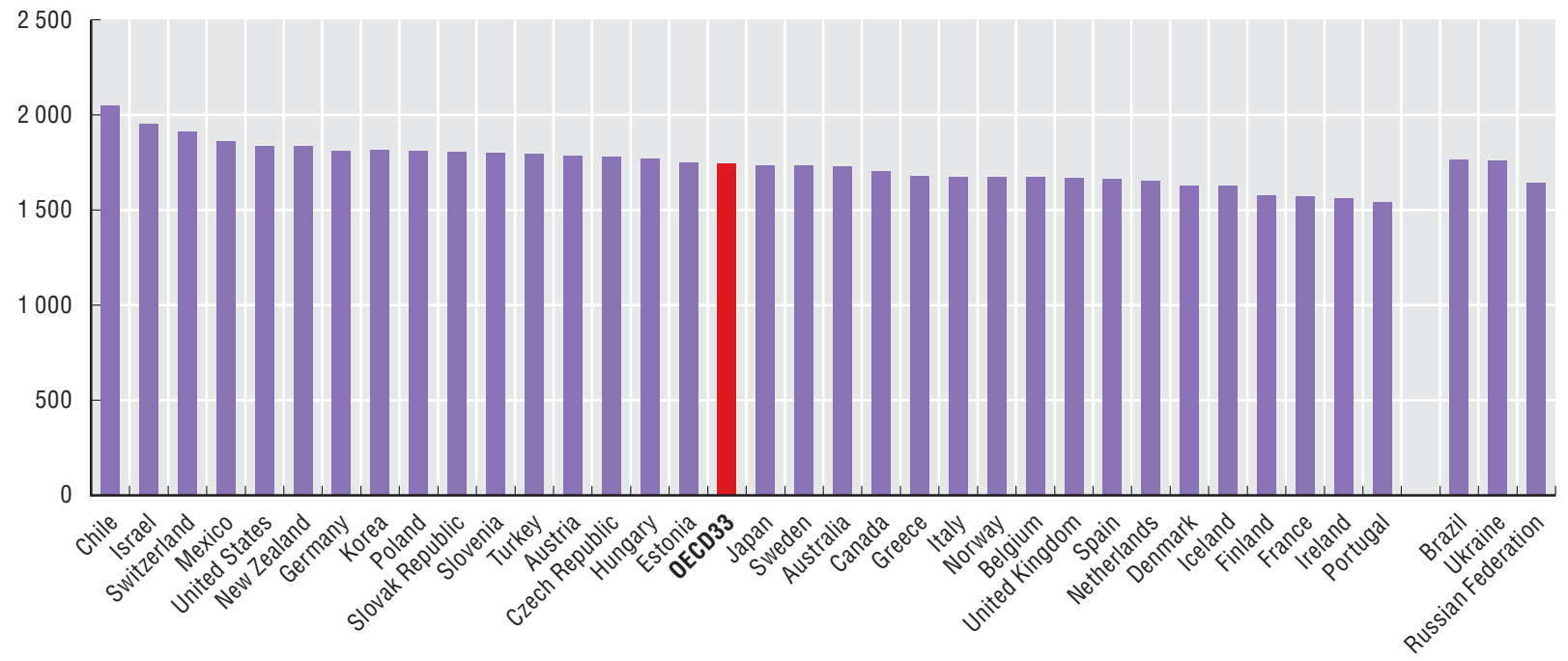

Source: 2010 Survey on Compensation of Employees in Central/federal Governments.

StatLink काISL $h t t p: / / d x . d o i . o r g / 10.1787 / 888932390880$

34.2 Average number of working days public employees are absent on sick leave per year (2009 or latest available year)

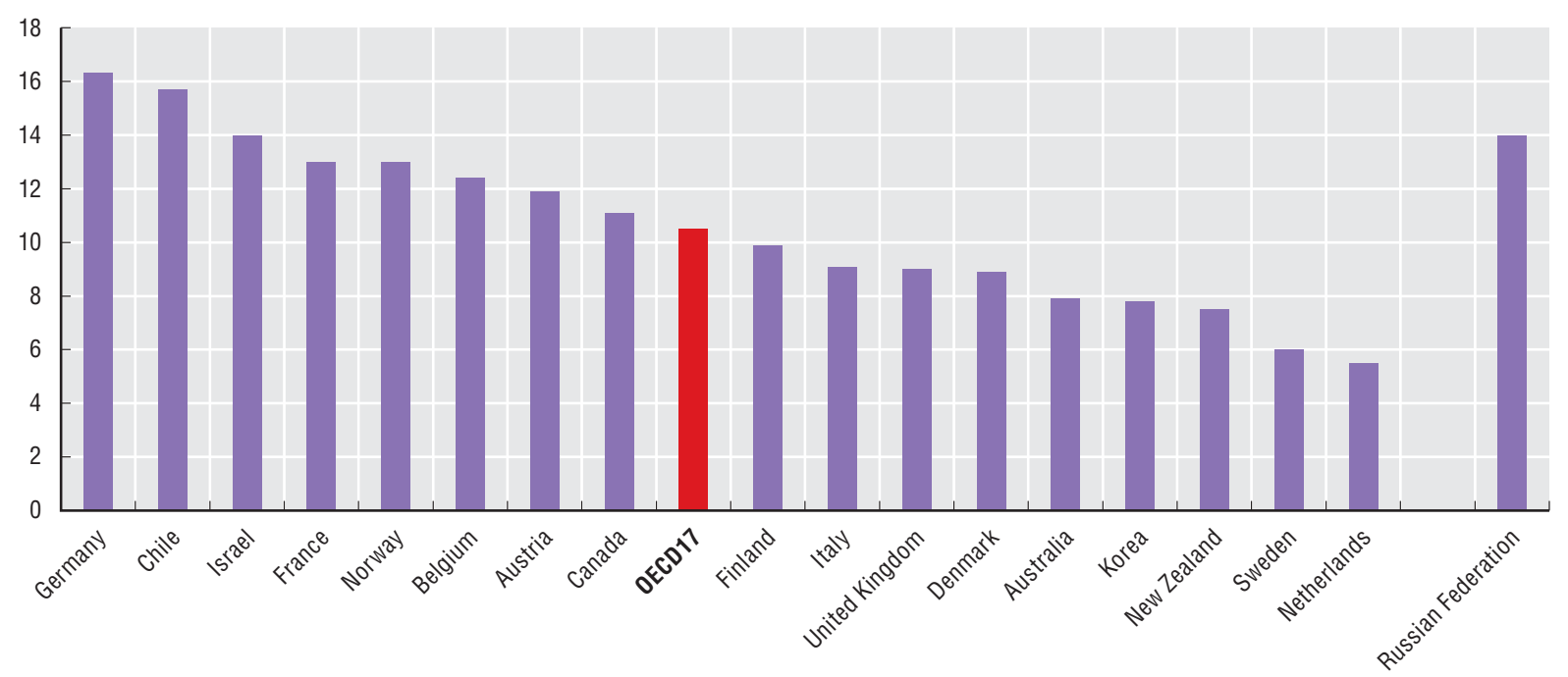

Source: 2010 OECD Survey on Strategic Human Resources Management in Central/Federal Governments. 


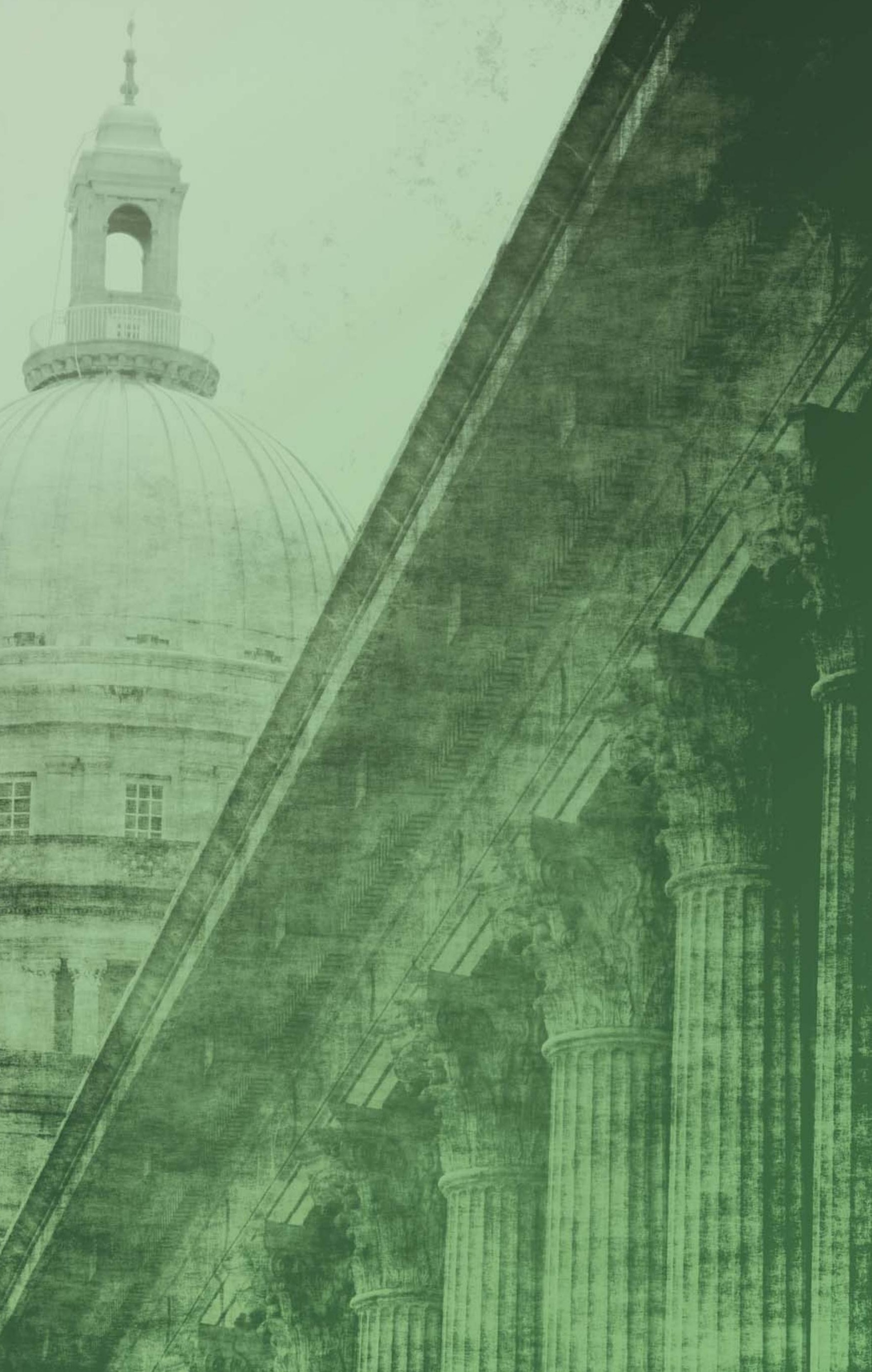




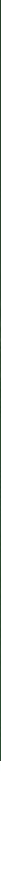

Today, more than ever, citizens demand greater transparency from government. Information on the who, why and how of decision making is essential to hold government to account, maintain confidence in public institutions and support a level playing field for business. Greater transparency is not only key to upholding integrity in the public sector, it also contributes to better public sector performance. Indeed, openness and transparency can ultimately improve policy outcomes by minimising the risk of fraud, corruption and mismanagement of public funds, as well as providing opportunities for the use of public data in innovative ways.

This chapter examines OECD member countries' institutional frameworks for promoting transparency in government. Such frameworks include legislation on access to information, as well as the rules governing the disclosure of potential conflicts of interest and roles of top advisors. 
Legislatures' budgetary oversight function contributes to transparency and public financial accountability. The presentation of the budget and related documentation in the legislature is normally the first opportunity for public scrutiny of the government's spending priorities. Legislative debate in both the plenary and committees facilitates public participation in the budget process.

To meaningfully engage in the budget process rather than simply serving as a rubber stamp, legislatures require reliable, unbiased information as well as strong analytical capacity. While comprehensive budget documentation is available to most OECD legislatures, there is a trend among OECD legislatures (and legislatures worldwide) to establish specialised budget research units within parliaments, or independent parliamentary budget offices or fiscal councils. Across the OECD, these bodies vary in terms of size, constituents and core functions, but all help to simplify the complexity of the budget, eliminate the executive's monopoly of information in the budget process, and improve the budget's credibility and accountability. Key tasks, for example, may include analysis of the executive's budget proposal and economic forecasting. Some are long standing institutions such as the Central Planning Bureau in the Netherlands (1947) and the United States Congressional Budget Office (1974).

In less than a decade, the number of specialised budgetary research units has more than doubled, and in some cases their size has increased. In 2000, only seven OECD legislatures had specialised budget research offices. This number increased to ten in 2003 and 14 in 2007. In 2010, several new bodies have been, or are in the process of being established in countries such as Australia, Ireland and Spain.

In addition to support throughout the budgetary process, legislatures and their committees require an adequate amount of time to reflect upon and debate budget documentation prior to approval. This is particularly important in order to ensure that legislative committees (which exist in all OECD legislatures and which provide the most in-depth scrutiny of the budget) have sufficient time to review, debate, and propose amendments. The OECD (2002), Best Practices on Budget Transparency recommend that the executive's draft budget should be submitted far enough in advance to allow for its proper review by the legislature. This should be no less than three months prior to the start of the fiscal year and the budget should be approved by the legislature prior to the start of the fiscal year. In 20 OECD member countries, the budget is presented to the legislature three months before the start of the fiscal year, and the vast majority of OECD countries also approve the budget prior to the start of the fiscal year. Legislative debate on the budget ranges from one month in Australia to up to eight months in the United States. In around half of OECD countries the legislature has up to three months to debate the budget, in 12 it has two months and in three it has only one month.

\section{Methodology and definitions}

The data are derived from the OECD International Budget Practices and Procedures Survey (2000, 2003 and 2007), and include information on time available for legislative debate of the government's budget proposal and the existence of specialised budget research offices to assist the legislature. The survey was completed by senior officials in central budget authorities and responses represent the countries' own assessments of current practices and procedures. The data from the OECD survey are complemented by data from the Inter-parliamentary Union's (IPU) online database, Parline, which includes a module on parliamentary oversight and the budget process. Parline is completed by IPU member parliaments. The IPU Parline Database is available online at: www.ipu.org. Additional information presented here draws from OECD country budget reviews and articles in the OECD Journal on Budgeting. The terms parliament and legislature are used interchangeably.

\section{Further reading}

Anderson, B. (2009), “The Changing Role of Parliament in the Budget Process", OECD Journal on Budgeting, Vol.2009/1, OECD Publishing, Paris, pp 37-47.

OECD (2002), "OECD Best Practices for Budget Transparency”, OECD Journal on Budgeting, Vol. 1, No. 3, OECD Publishing, Paris, pp. 7-14.

OECD (forthcoming in 2011), Budgeting Practices and Procedures in OECD Countries, OECD Publishing, Paris.

\section{Figure notes}

35.1: For 2007, numbers in parentheses denote reported number of staff for that year. Staffing data are unavailable for Chile and Israel. Core staff working on budget analysis may be far fewer, for example around 20 in the United States Congressional Budget Office. The UK Parliament established an internal budget scrutiny unit with around 15 staff in 2002. A new Office for Budget Responsibility was formed in May 2010 to make an independent assessment of the public finances and the economy for each Budget and Pre-Budget Report. It has around 20 staff. In November 2010, Spain created a Budget Office to assist the Legislature. As part of the Agreement for a Better Parliament following the August 2010 federal election, Australia has proposed a Parliamentary Budget Office. The Irish Government has also committed to introducing a Budget Advisory Council to provide an independent assessment of the Government's economic forecasts as part of the National Recovery Programme 2011-2014.

35.2: See $h t t p: / / d x . d o i . o r g / 10.1787 / 888932390937$ for important countryspecific notes.

Information on data for Israel: http://dx.doi.org/10.1787/888932315602. 


\subsection{Legislative budget offices in OECD countries and their staffing $(2000,2003$ and 2007)}
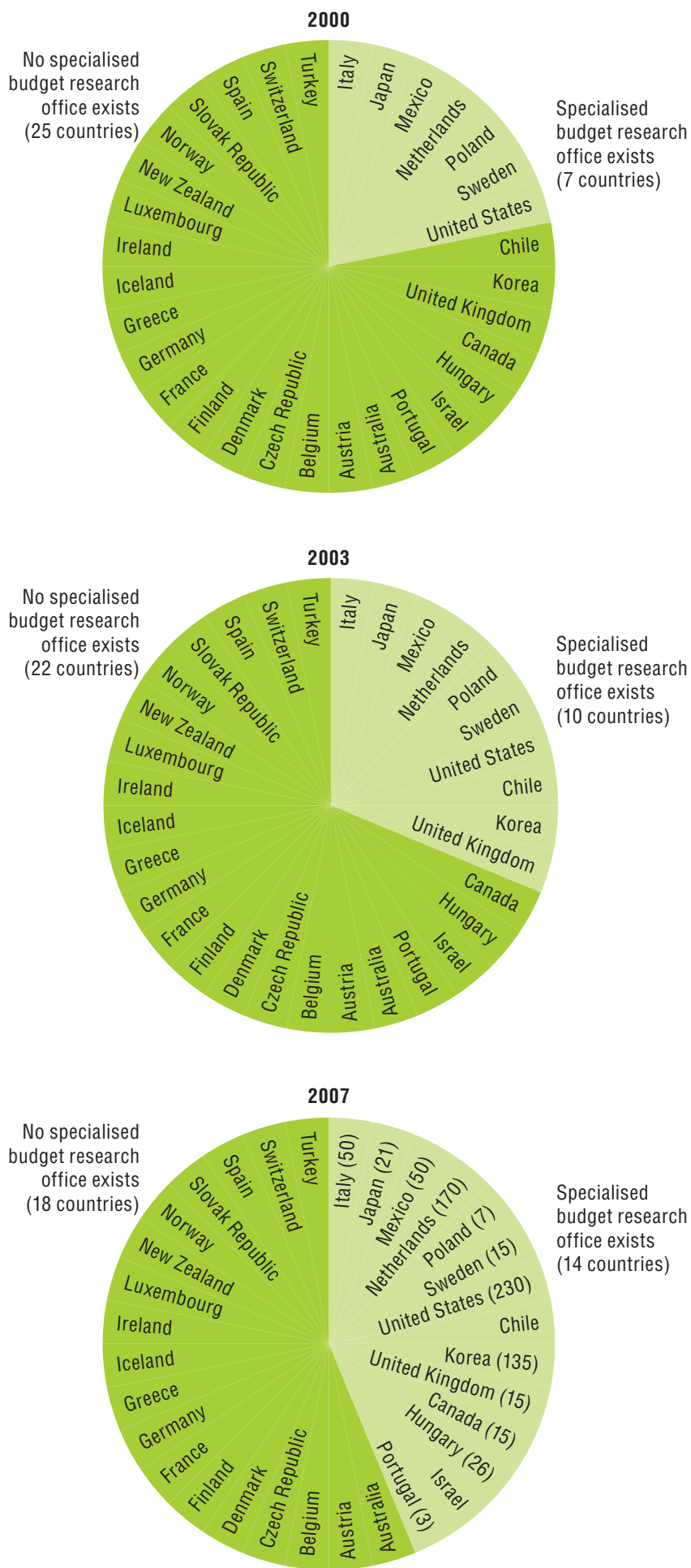

Source: OECD (2000, 2003, 2007), OECD International Budget Practices and Procedures Database and other research, www.oecd.org/gou/budget/database. statLink ताIs $h t t p: / / d x . d o i . o r g / 10.1787 / 888932390918$

\subsection{Time available for legislative debate of the government's budget proposal (2007)}

$\diamond$ Budget presented to legislature

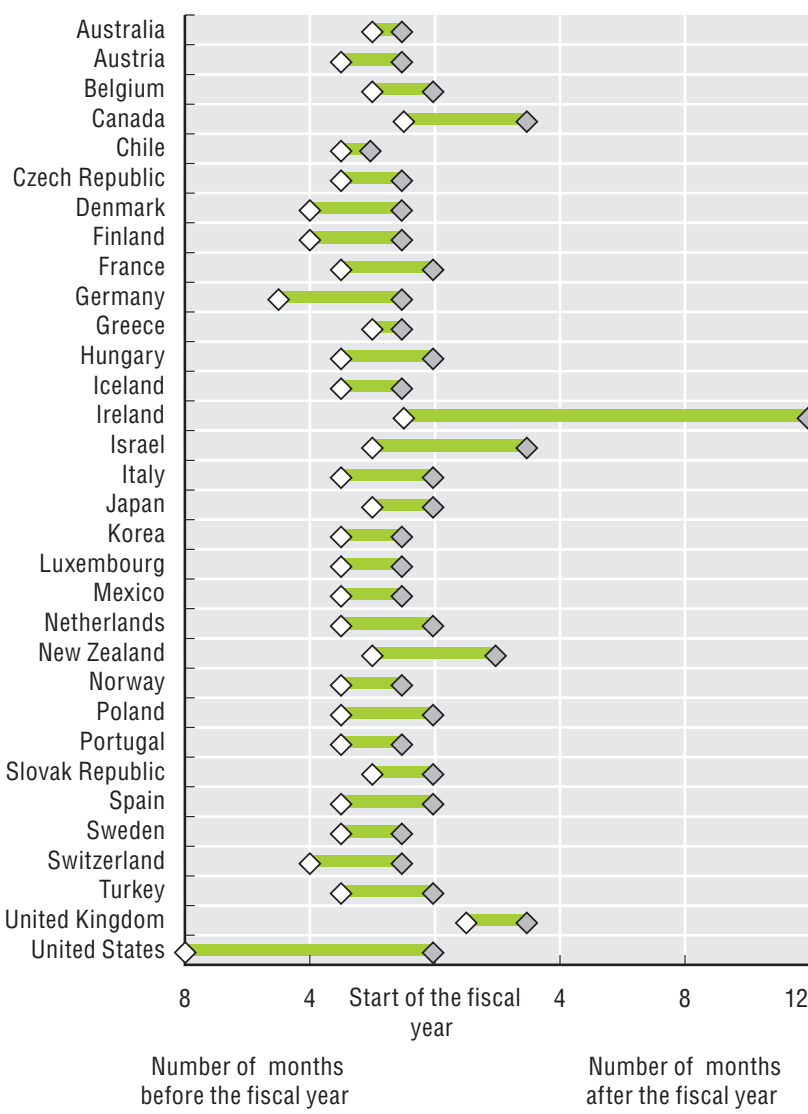

Source: OECD (2000, 2003, 2007), OECD International Budget Practices and Procedures Database and other research, www.oecd.org/gov/budget/database. StatLink ants http://dx.doi.org/10.1787/888932390937 
Freedom of information laws (FOI) - also referred to as access to information laws - are a fundamental pillar of open government. These laws contribute to strengthening transparency, enhancing government accountability and promoting informed participation in policy making. Today, all but one of the countries responding to the OECD 2010 Open Government Survey has FOI legislation/regulations. However, the strength and scope of these laws varies considerably in terms of the institutions and types of information covered, reflecting different institutional and legal systems across countries.

In most OECD countries, the reach of FOI laws extends vertically to all levels of government and, for about half of them, horizontally to all branches of central government (legislative, judicial and executive). In the majority of countries, all bodies that form the executive branch of the central government (e.g. Ministries/Departments and executive agencies) are subject to FOI legislation. Private entities managing public funds, such as those contracted by the government to provide services to citizens, are subject to FOI laws in over half of member countries.

In all OECD countries the FOI law presumes a principle of maximum disclosure of information, i.e. the information held by the state is in principle available to the public. However, FOI laws also contain a list of exemptions that may be applied to justify withholding certain information from disclosure. Class tests and harm tests are two common ways to exempt information. Under class tests, any information that falls within a certain category (such as national security) can be denied. Under harm tests, the government can deny a request for information on the basis that disclosure would cause potential prejudice, for example, to an individual or harm to the defence of the state (the two most commonly used harm tests). The class tests applied by the greatest number of OECD countries concern exemptions related to national security, international relations and personal data. Exemptions to FOI requests can be both mandatory (public entity is required to withhold the information) or discretionary (public entities can use their judgement to withhold or disclose information).

Although certain kinds of information may be exempt from disclosure for the reasons described above, additional mechanisms exist in FOI laws that can be applied to override these exemptions. In most OECD countries, a public interest test can lead to information disclosure if the public benefits from the information outweigh any harm that may be caused by disclosing it. However in only nine countries (Belgium, Chile, Finland, Israel, Japan, Korea, Mexico, Poland and Spain), public interest tests in all cases supersede the exemption in case of conflict. Provisions of FOI laws can also include the possibility of partial disclosure of exempt information (in all countries with the exception of Spain). In Canada and Chile, partial disclosure results from applying the principle of "severability" under which entire documents cannot be withheld from disclosure if only a portion qualifies for exemption. The same principle applies in practice in the Netherlands, although the FOI law does not contain a separate provision. Finally, ministerial discretion can be applied to override information deemed exempt by class and/or harm tests in 11 countries (Canada, the Czech Republic, Denmark, Estonia, France, Japan, Mexico, Norway, Poland, the United Kingdom and the United States).

\section{Methodology and definitions}

Data were collected through the 2010 OECD Open Government Survey. This survey focused on collecting data on the scope and the implementation of freedom of (or access to) information laws at the central level of government. Respondents to the survey were central government officials responsible for implementing open government initiatives. The survey was completed by 32 OECD countries, as well as by the Russian Federation and Ukraine.

\section{Further reading}

OECD (2003), Open Government: Fostering Dialogue with Civil Society, OECD Publishing, Paris.

OECD (2005), Policy Brief - Public Sector Modernisation: Open Government, OECD Publishing, Paris.

OECD (2009), Focus on Citizens: Public Engagement for Better Policies and Services, OECD Publishing, Paris.

\section{Table notes}

Data are not available for Germany and Greece. Luxembourg is currently drafting a law on access to information and is not included in the tables.

36.1: The Russian Federation and Ukraine are not included in the OECD totals. The Italian FOI law applies only to administrative acts and does not refer to legislative acts. According to the Italian system, all legislative acts are published on the Gazzetta Ufficiale (freely available on line). Also preliminary legislative acts, as well as judgements and judicial acts, are available on line.

36.2: According to the Australian law, documents that contain personal data, internal government discussions and health and safety information must be disclosed unless there is a public interest against it. Different criteria are applied to satisfy the "harm" tests for each individual category of exemptions indicated in the table.

Information on data for Israel: $h t t p: / / d x . d o i . o r g / 10.1787 / 888932315602$. 


\subsection{Breadth of central government freedom of information laws (2010)}

Total OECD countries

\begin{tabular}{|c|c|c|}
\hline \multicolumn{3}{|l|}{ Level of government } \\
\hline Central & 31 & $\begin{array}{l}\text { Australia, Austria, Belgium, Canada, Chile, the Czech Republic, Denmark, Estonia, Finland, France, Hungary, Iceland, Ireland, Israel, } \\
\text { Italy, Japan, Korea, Mexico, the Netherlands, New Zealand, Norway, Poland, Portugal, the Russian Federation, the Slovak Republic, } \\
\text { Slovenia, Spain, Sweden, Switzerland, Turkey, Ukraine, the United Kingdom and the United States. }\end{array}$ \\
\hline Sub-national & 25 & $\begin{array}{l}\text { Austria, Belgium, Chile, the Czech Republic, Denmark, Estonia, Finland, France, Hungary, Iceland, Ireland, Israel, Italy, Korea, } \\
\text { the Netherlands, New Zealand, Norway, Poland, Portugal, the Russian Federation, the Slovak Republic, Slovenia, Spain, Sweden, } \\
\text { Turkey, Ukraine and the United Kingdom. }\end{array}$ \\
\hline \multicolumn{3}{|l|}{ Branches of power at the central level } \\
\hline Executive & 31 & $\begin{array}{l}\text { Australia, Austria, Belgium, Canada, Chile, the Czech Republic, Denmark, Estonia, Finland, France, Hungary, Iceland, Ireland, Israel, } \\
\text { Italy, Japan, Korea, Mexico, the Netherlands, New Zealand, Norway, Poland, Portugal, the Russian Federation, the Slovak Republic, } \\
\text { Slovenia, Spain, Sweden, Switzerland, Turkey, Ukraine, the United Kingdom and the United States. }\end{array}$ \\
\hline Legislative & 16 & $\begin{array}{l}\text { Belgium, Chile, Estonia, Finland, Hungary, Ireland, Israel, Italy, Korea, Mexico, Poland, the Russian Federation, the Slovak Republic, } \\
\text { Slovenia, Sweden, Turkey, Ukraine and the United Kingdom. }\end{array}$ \\
\hline Judicial & 16 & $\begin{array}{l}\text { Australia, Belgium, Chile, Estonia, Finland, France, Hungary, Israel, Italy, Korea, Mexico, Norway, Poland, the Russian Federation, } \\
\text { the Slovak Republic, Slovenia, Sweden and Ukraine. }\end{array}$ \\
\hline \multicolumn{3}{|l|}{ Other bodies } \\
\hline Private entities managing public funds & 18 & $\begin{array}{l}\text { Australia, Belgium, the Czech Republic, Estonia, Finland, France, Hungary, Iceland, Italy, Korea, the Netherlands, Poland, Portugal, } \\
\text { the Slovak Republic, Sweden, Switzerland, Turkey, Ukraine and the United Kingdom. }\end{array}$ \\
\hline
\end{tabular}

Source: OECD 2010 Open Government Survey.

StatLink क्ञाs $h$ ttp://dx.doi.org/10.1787/888932392077

36.2 Depth of central government freedom of information laws (2010)

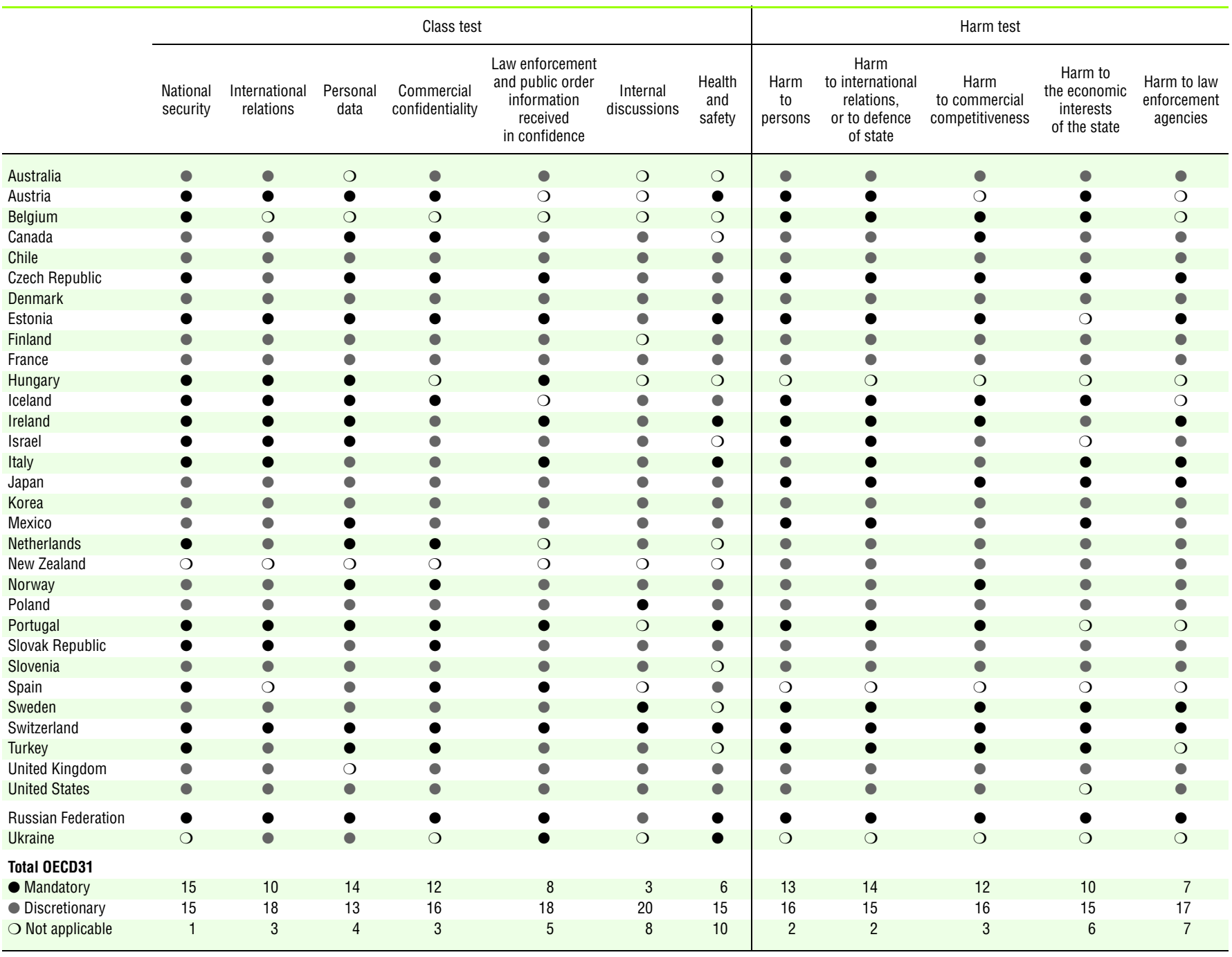

Source: OECD 2010 Open Government Survey. 
The possibility for individuals to exercise their right to information depends on (among other factors) the degree of accessibility of freedom of information laws (FOI), the ease of filing requests and individual protection granted to those requesting information. Narrow eligibility conditions to file a request, long response times or unjustifiably high fees are a few factors that can limit or undermine the right to know.

Some countries have enacted strong provisions to protect the privacy and integrity of parties and individuals requesting information. FOI laws in seven countries contain a provision to allow anonymity for the requestors. In Canada, the identity of the requestor is protected by federal law. Other countries, such as Australia, Ireland, the Czech Republic, Mexico, the United Kingdom and the United States, provide de facto anonymity because they do not require requestors to provide proof of identity. Likewise, FOI laws in six countries provide protection for requestors from retaliation by public officials, whereas in other countries this may be included under separate laws governing whistleblower protection.

In the large majority of OECD countries (71\%), there are no restrictions stated in FOI laws on which legal person can file a request for information. However, certain restrictions apply in some countries. France, Italy, Portugal and Turkey allow only individuals above the legal age or their representatives to file a request. In Italy, Korea and Turkey, requestors must provide personal information (e.g. proof of citizenship or residency, social security identity, identity card or photo identification) in order to file a request. In Spain, only national citizens or permanent residents can file requests and the requestor must provide a proof of legitimate interest in the issue.

Countries have adopted a range of measures to ensure equal access to and easy use of FOI laws. In $74 \%$ of countries, it is considered a formal duty of civil servants to assist requestors to identify and locate the relevant information. Also, $45 \%$ of countries have introduced provisions to facilitate access to information for disabled requestors. Information requests can be submitted in writing in all OECD countries responding to the survey. Moreover, most member countries offer additional channels, including: online ( $84 \%$ of countries), in person $(77 \%)$ or by telephone (55\%). Almost all countries have established standards for timely responses to requests for information in their laws or in related legal documents, usually within 20 working days or less. Requestors are able to track online the progress of an information request in only $26 \%$ of countries (Chile, Estonia, Korea, Mexico, the Slovak Republic, Spain, Switzerland and the United States).

All OECD countries, with the exception of Iceland and Poland, apply fees at one or more stages of the information request process, most often to cover the cost of reproduction. In about half of countries, fees are also related to the cost of sending the documents although several countries (such as Australia and Finland) waive these fees if the information is sent electronically. Most fees are variable, meaning that they depend on the number of pages to be reproduced or the amount of time to process the request (for example). When a variable fee can be charged, a cap on the size of this fee is applied only in a limited number of countries (Austria, Finland, France, Italy, Norway and Portugal).

Just over half of OECD countries charging fees provide fee waiver reductions. Rarely do fees cover the full cost of implementing FOI programmes; for example, in Canada, fees collected represent on average about $1 \%$ of the cost of processing.

\section{Methodology and definitions}

Data were collected through the 2010 OECD Open Government Survey. This survey focused on collecting data on the scope and the implementation of freedom of (or access to) information laws at the central level of government. Respondents to the survey were central government officials responsible for implementing open government initiatives. The survey was completed by 32 OECD countries, as well as by the Russian Federation and Ukraine.

\section{Further reading}

OECD (2003), Open Government: Fostering Dialogue with Civil Society, OECD Publishing, Paris.

OECD (2005), Policy Brief - Public Sector Modernisation: Open Government, OECD Publishing, Paris.

OECD (2009), Focus on Citizens: Public Engagement for Better Policies and Services, OECD Publishing, Paris.

\section{Table notes}

The Russian Federation and Ukraine are not included in the OECD totals. Data are not available for Germany and Greece. Luxembourg is currently drafting a law on access to information and is not included in the table.

37.2: In Australia, no fees for processing requests are charged for accessing personal information.

Information on data for Israel: $h t t p: / / d x . d o i . o r g / 10.1787 / 888932315602$. 
37.1 Ease of filing a request (2010)

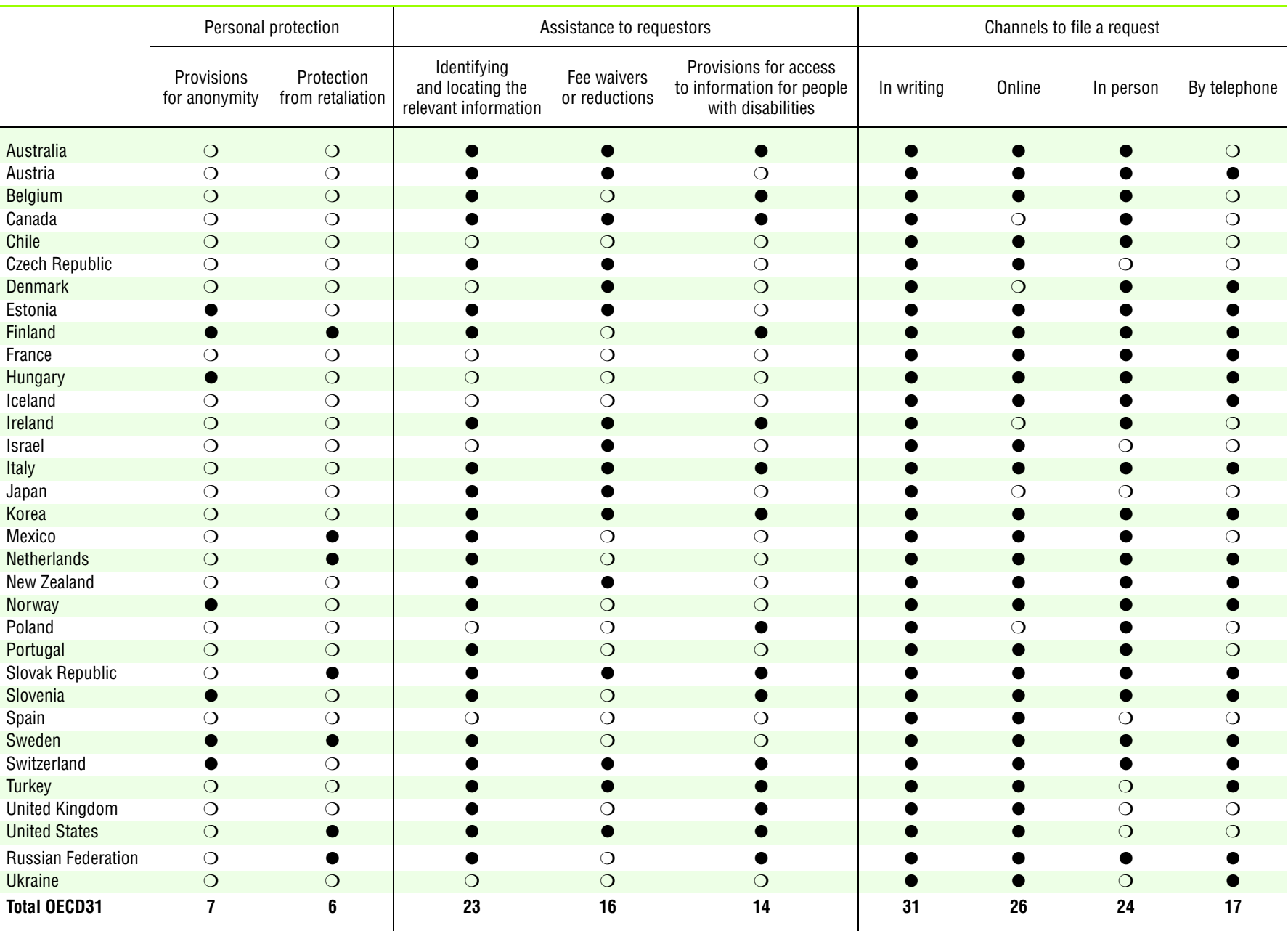

- Yes.

O No.

Source: OECD 2010 Open Government Survey.

37.2 Fees applied at different stages of the request process (2010)

\begin{tabular}{|c|c|c|c|c|}
\hline & No fee & Variable fee & Fixed fee & Fixed and variable fee \\
\hline Making a request & $\begin{array}{l}\text { Australia, Belgium, Chile, the Czech Republic, } \\
\text { Denmark, Estonia, Finland, France, Hungary, } \\
\text { Iceland, Italy, Korea, Mexico, the Netherlands, } \\
\text { New Zealand, Norway, Poland, Portugal, } \\
\text { the Slovak Republic, Slovenia, Spain, Sweden, } \\
\text { Switzerland, Turkey, the United Kingdom, } \\
\text { the United States. }\end{array}$ & - & $\begin{array}{l}\text { Austria, Canada, } \\
\text { Ireland, Israel, } \\
\text { Japan. }\end{array}$ & - \\
\hline Processing a request & $\begin{array}{l}\text { Austria, Belgium, Chile, the Czech Republic, } \\
\text { Denmark, Estonia, Finland, France, Hungary, } \\
\text { Iceland, Italy, Japan, Korea, Mexico, } \\
\text { the Netherlands, Norway, Poland, Portugal, } \\
\text { the Slovak Republic, Sweden, Switzerland, Turkey, } \\
\text { the United Kingdom. }\end{array}$ & $\begin{array}{l}\text { Canada, Ireland, Israel, New Zealand, Slovenia, } \\
\text { Spain, the United States. }\end{array}$ & - & Australia. \\
\hline Reproducing the information & Austria, Iceland, Poland. & $\begin{array}{l}\text { Australia, Belgium, Canada, Estonia, Finland, France, } \\
\text { Hungary, Ireland, Israel, Italy, Japan, Korea, Mexico, } \\
\text { the Netherlands, New Zealand, Norway, the Slovak } \\
\text { Republic, Slovenia, Spain, Sweden, Switzerland, } \\
\text { Turkey, the United Kingdom, the United States. }\end{array}$ & $\begin{array}{l}\text { Chile, the } \\
\text { Czech Republic, } \\
\text { Denmark. }\end{array}$ & Portugal. \\
\hline Sending the information & $\begin{array}{l}\text { Austria, Canada, Chile, Denmark, Estonia, Hungary, } \\
\text { Iceland, Ireland, Italy, Japan, the Netherlands, } \\
\text { New Zealand, Poland, Turkey, the United States. }\end{array}$ & $\begin{array}{l}\text { Belgium, Finland, France, Israel, Korea, Norway, } \\
\text { Portugal, the Slovak Republic, Slovenia, Spain, } \\
\text { Sweden, Switzerland, the United Kingdom. }\end{array}$ & $\begin{array}{l}\text { Australia, the } \\
\text { Czech Republic, } \\
\text { Mexico. }\end{array}$ & - \\
\hline
\end{tabular}

Source: OECD 2010 Open Government Survey. 
The principle of proactive disclosure (i.e. that information must be publicly available prior to public request) is instrumental in achieving greater transparency and openness in government. Proactive disclosure (also known as "affirmative publication") ensures that information seekers get immediate access to public information and avoid the costs of filing a request or engaging in administrative procedures. For public organisations, proactive disclosure can reduce the burden of complying with FOI requests.

All OECD countries are proactively publishing public information, and in $72 \%$ of them, proactive disclosure is required by FOI laws for certain categories of information. The type of information proactively disclosed varies across countries. While a majority of countries proactively disclose budget documents (94\%), annual Ministry reports (84\%), and audit reports (72\%), only a smaller number $(28 \%)$ (including Chile, Estonia, Iceland, Israel, Italy, Mexico, the Netherlands, Turkey and the United Kingdom) proactively publish lists of public servants and their salaries.

Applying the principle of proactive disclosure is facilitated by the use of information and communication technologies. Some $81 \%$ of OECD countries have developed central portals as a means of proactively disseminating information from a single location. In all OECD countries, central portals provide a search function to enable users to find specific information. However, despite the existence of central portals, countries also make information available through a variety of online channels (e.g. central portals, Ministry and agency websites, and other websites). For example, $50 \%$ of OECD members publish budget documents only on a Ministry/Agency/other website, while $13 \%$ only in the central portal and $28 \%$ in both locations.

In addition to distributing public information, new technologies increasingly provide opportunities to further enhance transparency and create new added-value services through the re-use of government-held information (such as geo-spatial data). Some $63 \%$ of OECD countries publish administrative data sets, and a majority have established provisions in laws or policies requiring electronic information to be published in formats that allow for re-use and manipulation of the information (e.g. open formats). Countries like Australia, New Zealand, the United Kingdom and the United States are providing access to public data in a reusable format through a central website (e.g. data.gov), and other countries (such as Chile and Spain) have also taken steps in this direction.

\section{Methodology and definitions}

Data were collected through the 2010 OECD Open Government Survey. This survey focused on collecting data on the scope and the implementation of freedom of (or access to) information laws at the central level of government. A section of the survey explored the extent to which information is proactively disseminated and is available electronically. Respondents to the survey were central government officials responsible for implementing open government initiatives. The survey was completed by 32 OECD countries, as well as by Brazil, Egypt, the Russian Federation and Ukraine.

Detailed country-by-country information on the accessibility of most commonly available information is available online: $h t t p: / / d x$.doi.org/10.1787/888932392172.

"Open format" refers to a published specification for storing digital data, usually maintained by a standards organisation, which can therefore be used and implemented by anyone. Definitions of open formats may vary across countries.

\section{Further reading}

OECD (2003), Open Government: Fostering Dialogue with Civil Society, OECD Publishing, Paris.

OECD (2005), Policy Brief - Public Sector Modernisation: Open Government, OECD Publishing, Paris.

OECD (2009), Focus on Citizens: Public Engagement for Better Policies and Services, OECD Publishing, Paris.

\section{Figure and table notes}

Data are not available for Germany and Greece. Luxembourg and Brazil are currently drafting laws on access to information.

38.1: Some categories of information are required to be disclosed by laws other than FOI legislation.

Information on data for Israel: $h$ ttp://dx.doi.org/10.1787/888932315602. 
38.1 Proactive disclosure of information by central government (2010)

\begin{tabular}{|c|c|c|c|c|c|c|c|c|c|c|c|c|}
\hline & 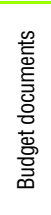 & 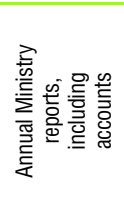 & 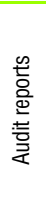 & 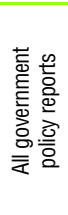 & 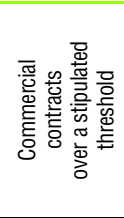 & 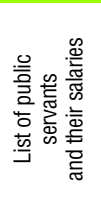 & 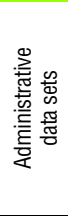 & 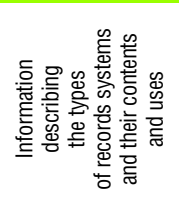 & 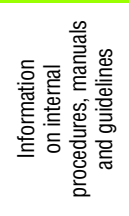 & 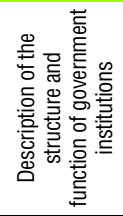 & 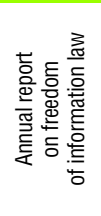 & 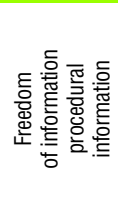 \\
\hline Australia & - & - & - & O & - & O & - & - & - & - & - & - \\
\hline Austria & - & O & - & O & O & O & - & O & $\bullet$ & $\bullet$ & O & - \\
\hline Belgium & - & O & 0 & - & O & O & - & 0 & O & - & - & - \\
\hline Canada & - & - & - & O & - & O & - & - & - & - & - & - \\
\hline Chile & - & - & $\bullet$ & o & 0 & - & 0 & 0 & O & - & - & - \\
\hline Czech Republic & - & • & O & O & 0 & O & O & 0 & - & • & - & - \\
\hline Denmark & - & - & - & - & 0 & O & $\bullet$ & - & - & $\bullet$ & 0 & O \\
\hline Estonia & • & • & - & • & • & • & • & - & - & • & - & • \\
\hline Finland & $\bullet$ & $\bullet$ & $\bullet$ & $\bullet$ & $\bullet$ & 0 & $\bullet$ & $\bullet$ & 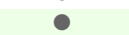 & 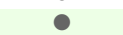 & 0 & - \\
\hline France & - & $\bullet$ & O & - & O & O & O & 0 & O & - & - & - \\
\hline Hungary & - & - & - & - & - & O & - & - & - & • & - & - \\
\hline Iceland & - & - & - & - & O & - & - & O & $\bullet$ & - & - & - \\
\hline Ireland & 0 & - & O & O & - & 0 & O & - & - & - & - & - \\
\hline Israel & - & - & - & O & 0 & - & O & - & - & - & - & - \\
\hline Italy & - & $\bullet$ & • & $\bullet$ & $\bullet$ & $\bullet$ & - & - & - & $\bullet$ & - & $\bullet$ \\
\hline Japan & - & O & - & O & - & O & O & - & O & - & - & - \\
\hline Korea & - & - & - & - & - & O & - & - & - & - & - & - \\
\hline Luxembourg & - & - & O & O & o & O & O & - & o & - & 0 & O \\
\hline Mexico & - & - & - & - & - & - & - & - & - & - & - & - \\
\hline Netherlands & - & - & - & - & o & - & - & 0 & - & - & - & - \\
\hline New Zealand & - & - & O & O & - & O & - & 0 & O & O & - & - \\
\hline Norway & - & O & O & - & O & O & O & - & - & - & O & - \\
\hline Poland & 0 & - & O & O & O & 0 & - & O & O & - & 0 & - \\
\hline Portugal & - & - & - & - & - & O & O & - & - & - & - & O \\
\hline Slovak Republic & - & O & O & - & o & O & - & - & - & - & O & - \\
\hline Slovenia & - & - & - & - & O & O & - & - & - & - & - & - \\
\hline Spain & - & - & - & O & - & 0 & - & - & - & - & O & 0 \\
\hline Sweden & - & - & - & - & o & O & - & - & o & - & O & - \\
\hline Switzerland & - & - & - & O & 0 & 0 & O & O & - & - & - & - \\
\hline Turkey & - & - & - & - & o & - & o & - & o & - & - & - \\
\hline United Kingdom & - & - & - & O & - & - & - & - & O & - & - & - \\
\hline United States & $\bullet$ & $\bullet$ & - & $\bullet$ & $\bullet$ & O & $\bullet$ & $\bullet$ & $\bullet$ & $\bullet$ & $\bullet$ & $\bullet$ \\
\hline Brazil & $\bullet$ & - & - & $\bullet$ & - & $\bullet$ & - & $\bullet$ & $\bullet$ & $\bullet$ & O & O \\
\hline Egypt & - & - & O & - & O & O & - & O & - & - & O & O \\
\hline Russian Federation & - & O & 0 & - & 0 & - & - & - & - & 0 & - & - \\
\hline Ukraine & - & - & - & - & 0 & o & - & - & - & - & - & $\bullet$ \\
\hline \multicolumn{13}{|l|}{ Total 0ECD32 } \\
\hline $\begin{array}{l}\text { Required to be proactively published } \\
\text { by FOl law }\end{array}$ & 17 & 17 & 12 & 8 & 11 & 5 & 6 & 11 & 12 & 19 & 16 & 16 \\
\hline $\begin{array}{l}\text { Not required by FOI law, but routinely } \\
\text { published }\end{array}$ & 13 & 10 & 11 & 10 & 5 & 4 & 15 & 11 & 10 & 11 & 7 & 12 \\
\hline Neither required nor routintely published & 2 & 5 & 9 & 14 & 16 & 23 & 11 & 10 & 10 & 2 & 9 & 4 \\
\hline
\end{tabular}

Source: OECD 2010 Open Government Survey.

38.2 Accessibility of most commonly available information released by central government (2010)

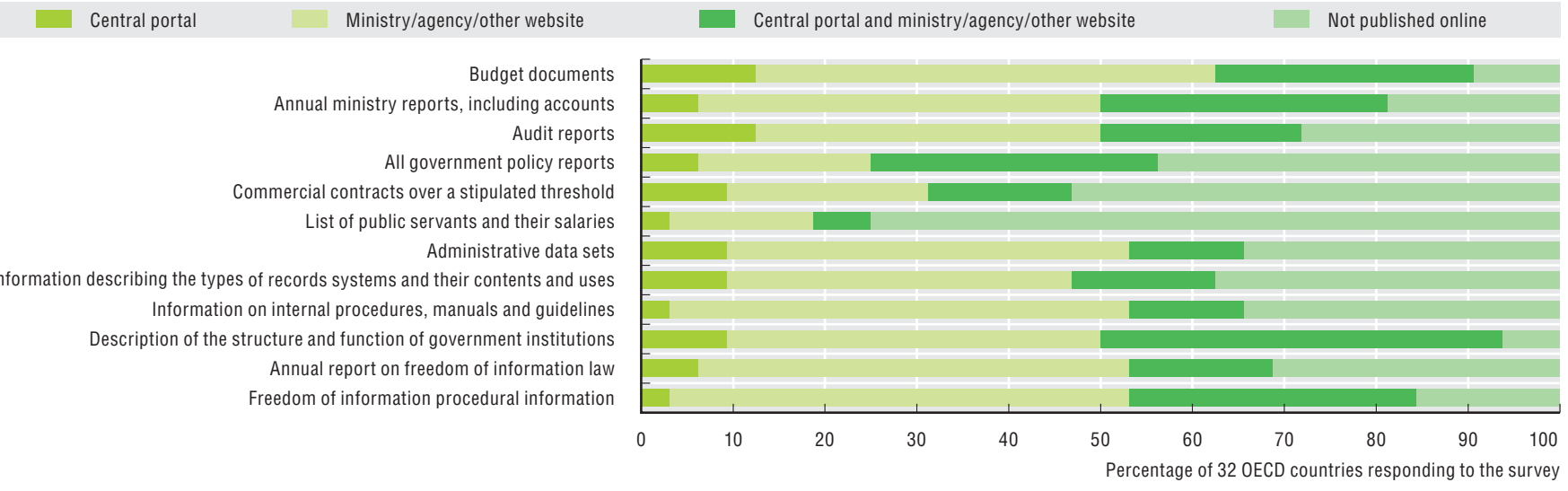

Source: OECD 2010 Open Government Survey. 
Ensuring that the integrity of government decision making is not compromised by conflicts of interest is key to maintaining trust in government. A conflict of interest arises when a public official's private interests could improperly influence the performance of official duties. If not adequately identified and managed, conflict-of-interest situations can lead to corruption.

In OECD member countries, the disclosure of private interests by top decision makers is a common practice. While the majority of disclosures are required by law, some top decision makers provide disclosures voluntarily. The level of disclosure in the executive and legislative branches is comparably high relative to disclosure requirements in the judiciary. For example, top decision makers within the executive and legislature are required to disclose private assets in $86 \%$ and $84 \%$ of OECD countries, respectively. For officials working in the judiciary, however, only $41 \%$ of countries require the same. In some countries, such as Hungary and Korea, certain family members of top decision makers are also required to file separate disclosure statements.

Paid outside positions are the most regulated private interests across the three branches of government. Of the three branches of government, the judiciary branch in particular regulates paid outside positions, albeit a relatively few number of OECD countries prohibit these positions for judges and prosecutors entirely (Greece, Hungary, Israel, Mexico, Portugal, Turkey and the United Kingdom). Over half of responding OECD member countries require that paid outside positions be disclosed. Several countries, such as Estonia, Hungary, Spain and Belgium, have indicated that they do not require disclosure of teaching and research positions. The acceptance of gifts by decision makers is prohibited altogether in less than a quarter of member countries while around half call for disclosure. Gifts are particularly regulated in the judiciary. For example, gifts are prohibited in 13 countries for judges and in 12 countries for prosecutors.

The public availability of disclosed information by top decision makers is also important to ensure accountability and reinforce trust in government. Yet, nearly all OECD member countries only partially make disclosed information public. Certain countries, like Israel, make no information public. For others, only few types of disclosed information are public, such as the assets and liabilities of the president in France, non-paid outside positions and previous employment of the president in Turkey, or gifts received by decision makers across branches of government in Slovenia.

Countries also increasingly require disclosure of private interests by officials in at-risk areas, such as tax and customs officials, procurement officers and financial authorities. These disclosures are made publicly available in only a few countries, for example in Belgium, Mexico and New Zealand. Data further show that the prevention of conflict of interest in at-risk areas focuses primarily on the disclosure and prohibition of outside positions and gifts. With the exception of the judges and prosecutors, the prohibition of acceptance of gifts is higher for officials in at-risk areas in the public sector than for top decision makers in the three branches of government: 11 countries prohibit gifts for tax and customs officials, 10 countries prohibit them for financial authorities, and 9 do so for procurement officials.

\section{Methodology and definitions}

The data collected focus on conflict-of-interest disclosure for top decision makers in the central government and build upon data presented in Government at a Glance 2009. Data were collected by the 2010 OECD Survey on Integrity. Compared to 2009, the survey has been extended to collect data on judges, prosecutors and selected public officials considered to be in at-risk areas, namely in procurement, tax and customs administration and financial authorities. 2010 data also cover information about disclosure of income (separated by source and amount) and outside positions (paid and unpaid).

Respondents to the survey were country delegates responsible for integrity policies in central government. A total of 33 OECD member countries responded as well as Brazil, the Russian Federation, Egypt and Ukraine. Data are not available for Luxembourg.

Country-specific data are available in Annex F.

The term "decision makers" refers to the following positions: President, Prime Minister, Minister or members of cabinet, Upper and Lower House legislators, judges, prosecutors, tax and customs officials, procurement officers and financial authorities.

The terms "judiciary" and "judicial branch" cover judges and prosecutors, although in some countries prosecutors do not form part of the judiciary.

\section{Further reading}

OECD (2003), Recommendation of the Council on Guidelines for Managing Conflict of Interest in the Public Service, OECD Publishing, Paris.

OECD (2007), OECD Guidelines for Managing Conflict of Interest in the Public Service: Report on Implementation, OECD Publishing, Paris.

OECD (2010), Post-Public Employment: Good Practices for Preventing Conflict of Interest, OECD Publishing, Paris.

\section{Figure notes}

The category "disclosure is not required" is not included in the figure. See StatLink below each figure and/or Annex F for country-specific data and notes.

Information on data for Israel: $h$ ttp://dx.doi.org/10.1787/888932315602. 


\subsection{Level of disclosure of private interests in the three branches of government (2010)}

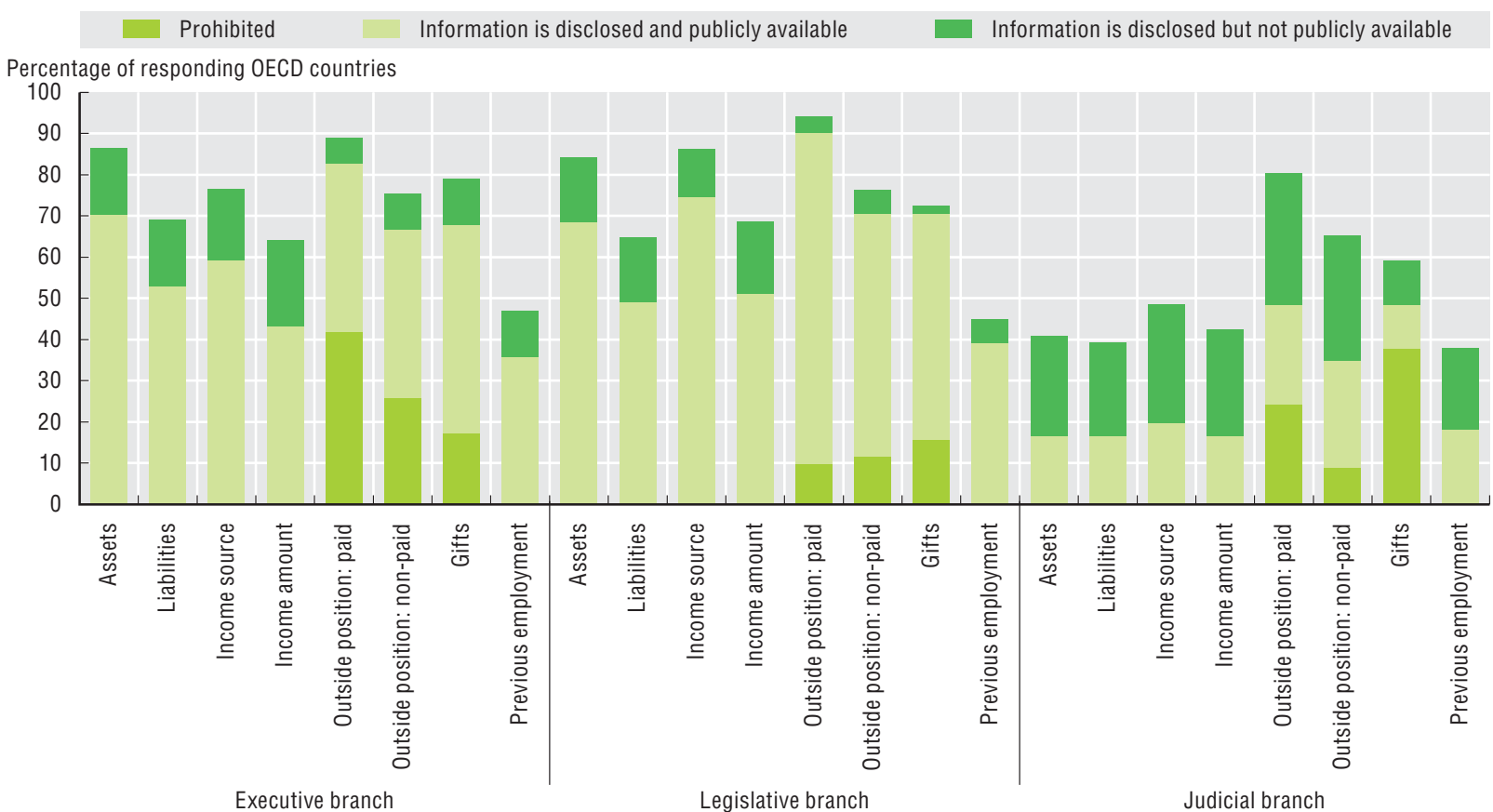

Source: OECD Survey on Integrity (2010).

\subsection{Level of disclosure of private interests of selected officials in at-risk areas (2010)}

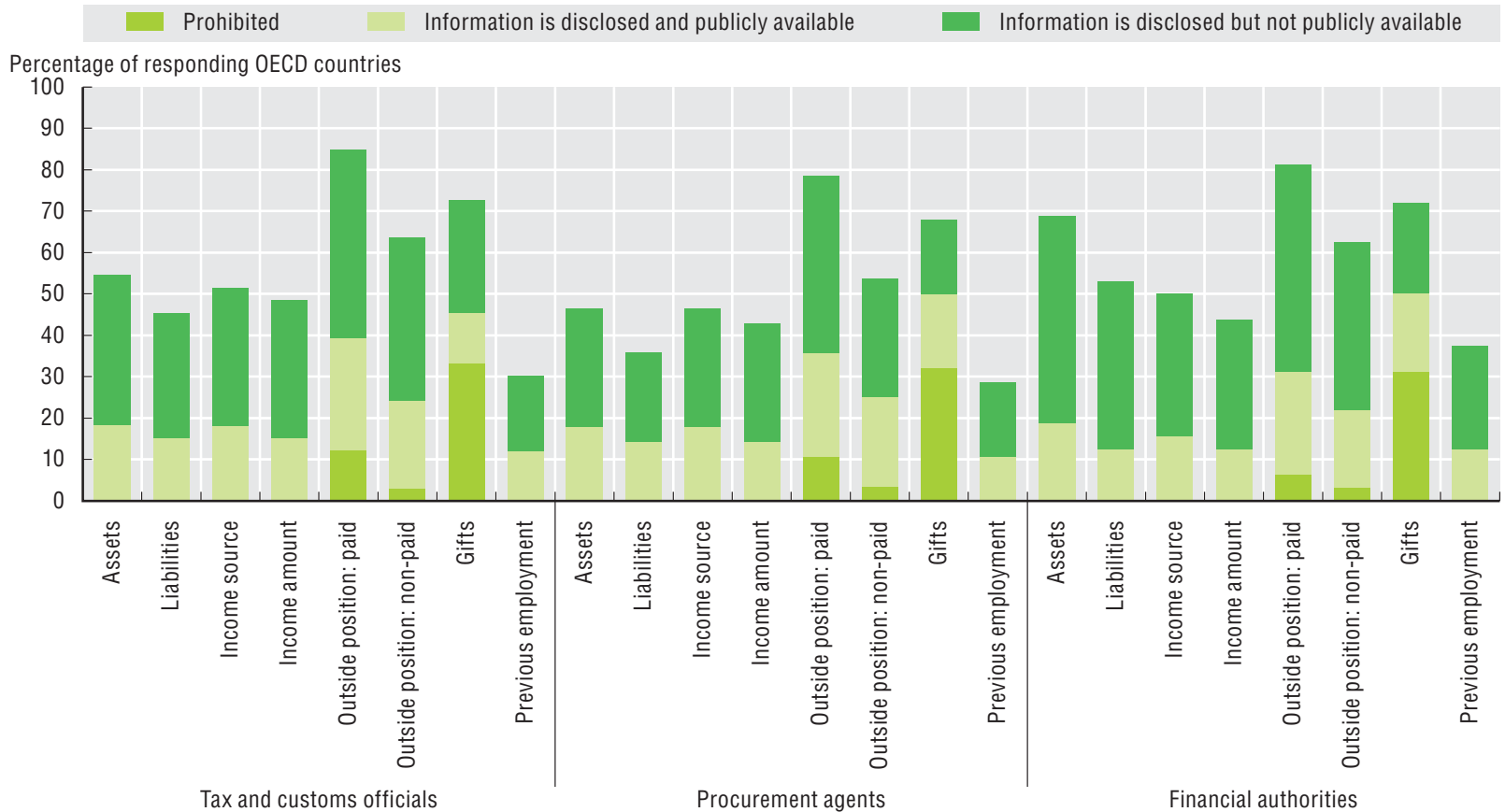

Source: OECD Survey on Integrity (2010). 


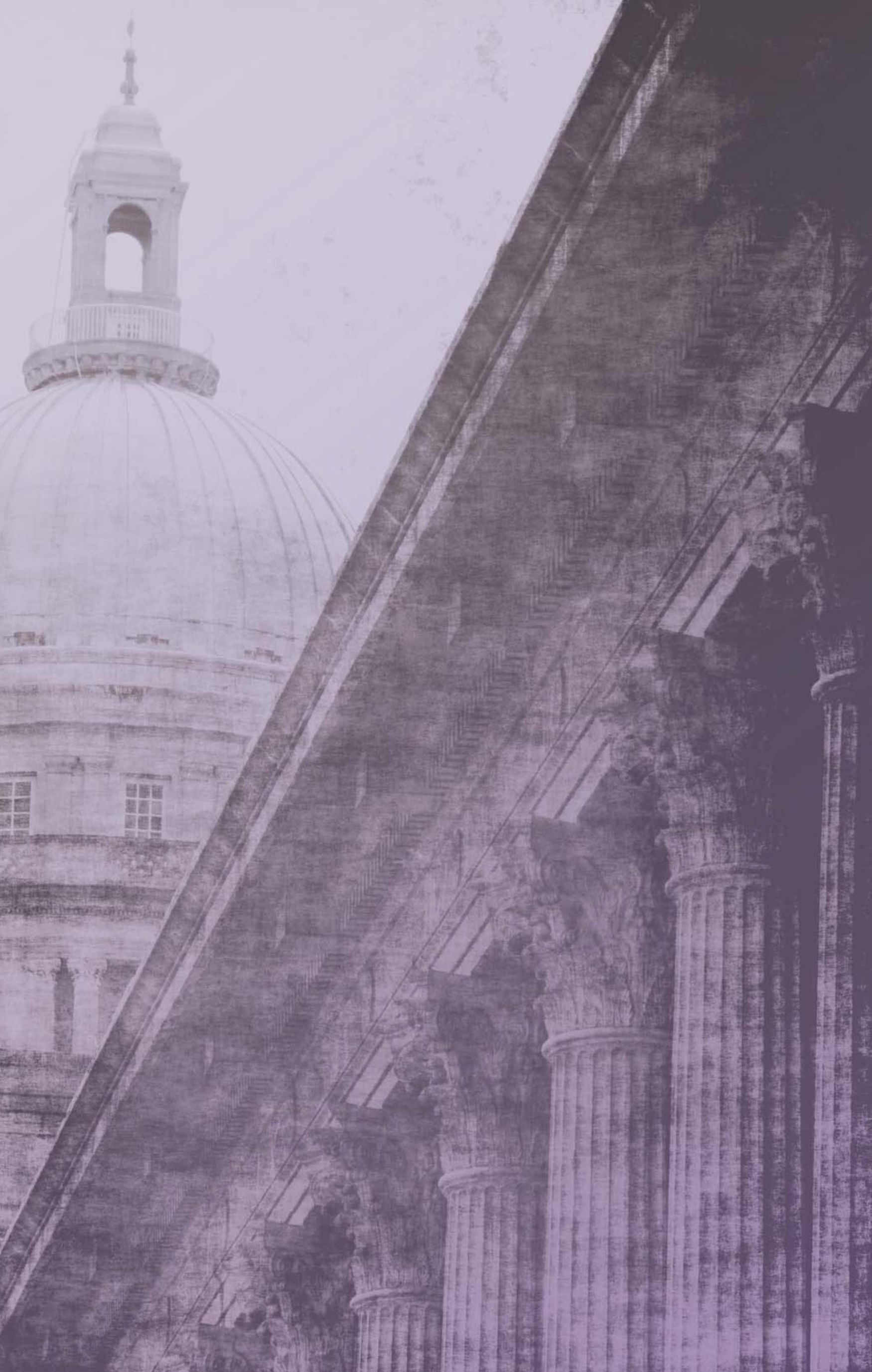




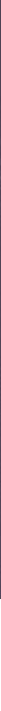

Public procurement is one of the largest government spending activities in any country, representing on average almost 13\% of GDP in OECD member countries. It is also vulnerable to waste, fraud and corruption due to its complexity, the size of the financial flows it generates and the close interaction between the public and the private sectors. For these reasons, efforts to promote an efficient and transparent public procurement system are high on the agenda of OECD member countries.

This chapter examines the central elements of a well-functioning, transparent and accountable public procurement system, building on the 2008 OECD Principles for Enhancing Integrity in Public Procurement. Central to the relevance of this issue and the impact of spending by way of public procurement on society and the economy, estimations of the size of public procurement markets are first provided. Furthermore, because transparency is critical to minimise the risk of mismanagement of public funds, additional data are included on the public availability of key procurement documents; the review and remedy systems available to bidders; and opportunities for citizens to participate in the procurement process. Experience shows that the use of information and communication technologies (ICTs) in the procurement process contributes to a more competitive, accountable and efficient system, and new survey results on the extent that governments are using e-procurement solutions are presented for the first time. Finally, public procurement can also be an effective instrument for governments to pursue various policy objectives. As a special feature, survey results on green procurement activities in the OECD highlight the potential for and constraints of governments in promoting environmental policies via public procurement. 
Public procurement (the purchase by governments and state-owned enterprises of goods, services and works) accounts for a significant percentage of GDP and has a direct impact on the economy. Obtaining more accurate and comprehensive information about one of governments' largest spending processes, therefore, is key to improving the quality of government services, better allocating resources and providing greater value for taxpayers' money.

According to estimations drawing from National Accounts data, governments in OECD member countries spend on average $12 \%$ of their GDP on public procurement (excluding procurement by state-owned utilities). Variations reflect the different size of the state, its role in the economy and the existence of big spending projects (e.g. infrastructure investments). In 2008, the Netherlands, the Czech Republic and Iceland spent over $15 \%$ of GDP by way of public procurement transactions, the largest shares amongst OECD countries. In comparison, procurement expenditures in Mexico, Chile and Switzerland represented less than 7\% of GDP.

For some member countries there are also data available on the estimated value of the procurement contracts of stateowned utilities. When these purchases are also accounted for, the size of procurement markets increases by an additional 2 to 13 percentage points of GDP. For example, in 2008, stateowned utilities in Austria and the Czech and Slovak Republics spent between 8 and 13\% of GDP through public procurement.

As a response to the economic downturn, many countries have launched fiscal stimulus programmes that include a large procurement component, often related to infrastructure projects. The majority of OECD member countries increased procurement activities between 2006 and 2008 relative to their GDP.

For EU countries, tenders above a legally prescribed value must be advertised in the Official Journal of the EU (OJEU). The value of the announced tenders as a share of the estimated total value of the national public procurement market is a good proxy of the extent to which national public procurement opportunities are made open to foreign bidders. Indeed, significant progress has been made in recent years in opening national procurement markets to international competition. The share of tenders published varies greatly across EU countries, from 7\% in Germany and the Netherlands to $45 \%$ in Estonia. On average, $22 \%$ of the total value of public procurement in OECD countries that are also members of the EU are published in the OJEU.

\section{Methodology and definitions}

The size of national procurement markets is estimated using data from the OECD National Accounts Database, based on the System of National Accounts (SNA). General government procurement is defined as the sum of intermediate consumption (goods and services purchased by governments for their own use, such as accounting or IT services), gross fixed capital formation (acquisition of capital excluding sales of fixed assets, such as building new roads) and social transfers in kind via market producers (goods and services produced by market producers, purchased by government and supplied to households). It represents the amount of disbursements (expenditures) within a given year. The SNA data may provide an overestimation, as the above categories may include certain expenditures not carried out through government procurement.

The general government component includes the values of procurement by central, state and local governments, and social security funds, but exclude public corporations, such as state-owned utilities. Therefore, where available, data on expenditures of state-owned utilities on procurement transactions are also included in order to better approximate the size of procurement markets. Expenditures by state-owned utilities on procurement are estimated by the European Commission.

A second approach in assessing the size of procurement markets consists of using data collected from published tenders. The European Commission estimates the total value of tenders published in the OJEU based on the number of tenders and the values of contract awards reported by countries, which may not represent disbursements in the year indicated. This estimation is calculated as a percentage of the total estimated value of the national public procurement market, which includes the SNA estimation for general government procurement and the European Commission approximation of state-owned utilities procurement.

\section{Further reading}

Audet, D. (2002), "The Size of Government Procurement Markets", OECD Journal on Budgeting, Vol. 2, No. 3, OECD Publishing, Paris.

European Commission (2008), Measurement of Indicators for the Economic Impact of Public Procurement Policy, Working document, European Commission, Brussels.

OECD (2009), OECD Principles for Integrity in Public Procurement, OECD Publishing, Paris.

\section{Figure notes}

40.1 and 40.2: Canada, Greece, Iceland, Israel, Mexico, the United Kingdom and the United States do not report separate data on social transfers in kind via market producers in their National Accounts. Spending in these areas may be reported under other categories included in general government procurement or may be accounted for elsewhere and not included in the figure.

40.1: Estimations of the public procurement transactions of state-owned utilities are only available for some OECD countries that are also members of the EU. The missing countries are not included in the OECD average for this transaction.

40.2: Excludes public procurement spending of state-owned utilities. 40.3: Data for non EU members are not available.

Information on data for Israel: $h t t p: / / d x . d o i . o r g / 10.1787 / 888932315602$. 


\subsection{General government and state-owned utilities procurement as percentage of GDP (2008)}

General government procurement State-owned utilities

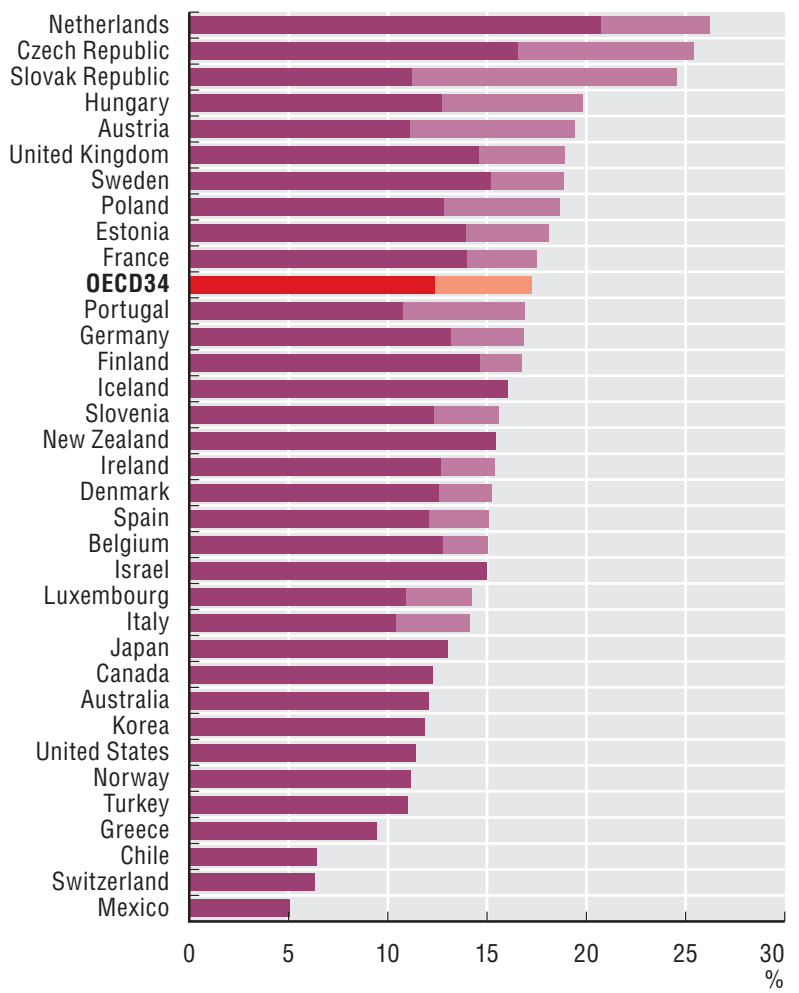

Source: OECD National Accounts Statistics and Eurostat. Data for Australia are based on a combination of Government Finance Statistics and National Accounts data provided by the Australian Bureau of Statistics. StatLink काISL http://dx.doi.org/10.1787/888932391013

\subsection{Size of general government procurement as a percentage of GDP (2006 and 2008)}

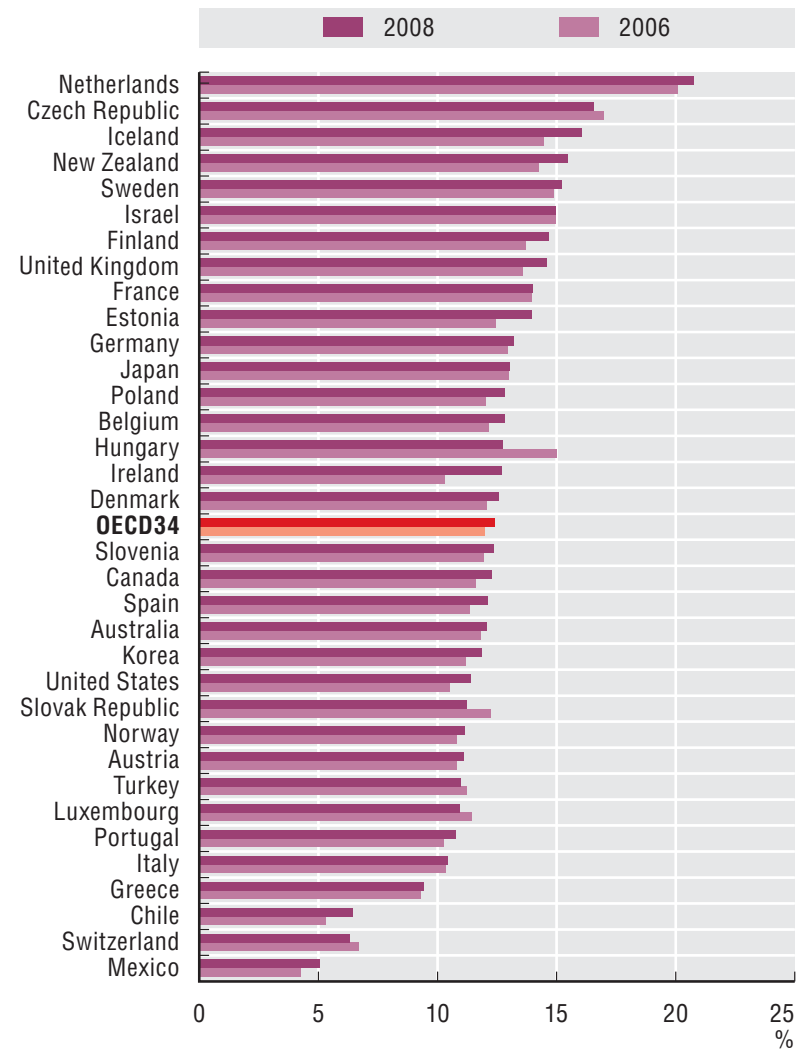

Source: OECD National Accounts Statistics. Data for Australia are based on a combination of Government Finance Statistics and National Accounts data provided by the Australian Bureau of Statistics.

StatLink Aाs $h t t p: / / d x . d o i . o r g / 10.1787 / 888932391032$

40.3 Public procurement tenders advertised in the OJEU as a percentage of total national procurement market (2008)

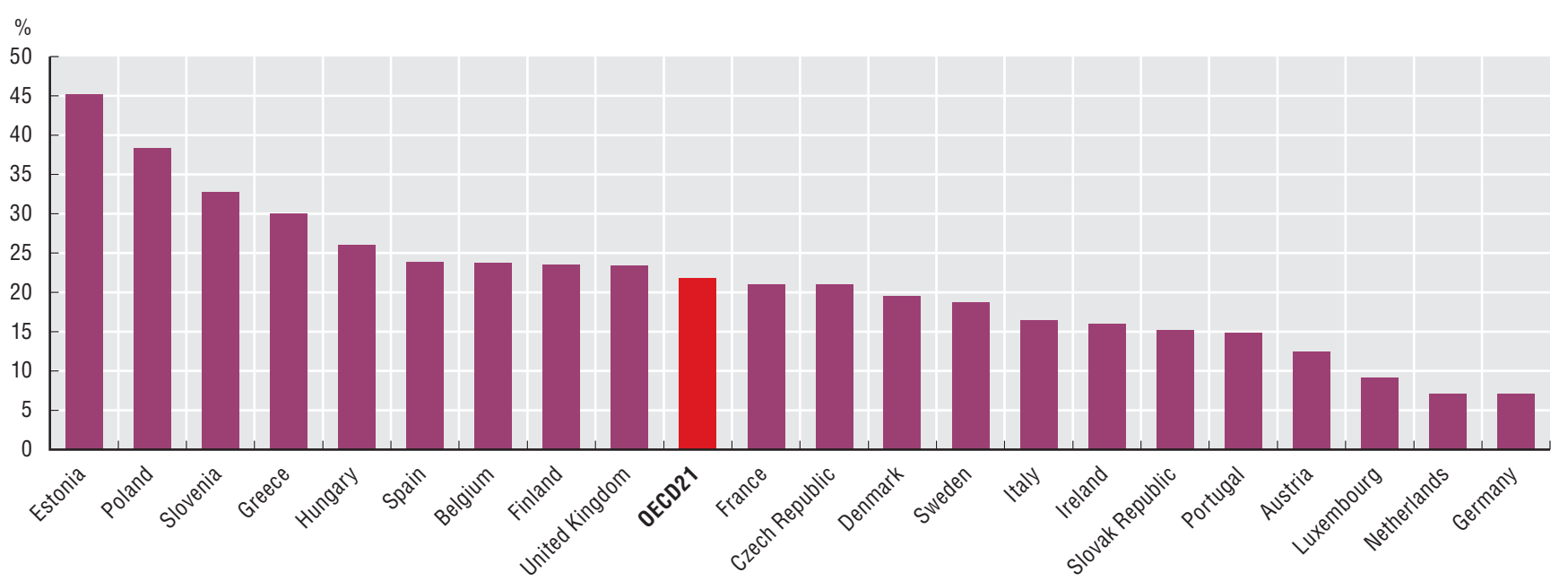

Source: Eurostat 
In public procurement, the financial interests at stake, the volume of transactions, and the close interaction between the public and the private sectors create multiple opportunities for private gain and waste at the expense of taxpayers. Providing an adequate degree of transparency throughout the entire public procurement cycle is critical to minimising the risk of fraud, corruption and mismanagement of public funds, and to levelling the playing field for businesses thereby promoting competition. The accessibility of information, stakeholder participation in key stages of the procurement cycle, and the possibility of review and remedy in case of dispute are essential to transparency and accountability in public procurement.

Public availability of procurement information is largely determined by the type of information. OECD member countries more frequently make information available about the pre-tendering and tendering phases of the procurement cycle, including laws and policies (always publically available in 34 OECD countries) and selection and evaluation criteria (21 countries). In comparison, fewer countries publish information about events that occur post-award, such as justification for awarding contracts (available in 13 countries), contract modifications (11 countries) or information that allows the tracking of procurement spending (6 countries). Estonia, Iceland, Italy, Japan and Korea stand out as making the most types of procurement information available to the public.

Citizen participation in key stages of the public procurement cycle promotes direct public scrutiny and transparency. Thirteen OECD countries have mandatory or voluntary participation mechanisms in place, mostly for the bid opening process and public hearings on the terms of a contract. Notably, Japan and Korea involve citizens in one or more stages of the procurement cycle. The Czech Republic, Poland and the United States have relatively more voluntary consultation mechanisms in place.

Review and remedy mechanisms are important to provide a check against fraud in the contract award process. In cases of dispute, all responding member countries (with the exception of Slovenia) allow contract award decisions to be reviewed by the courts. Yet, access to the judicial review system can be costly and time-consuming. In order to respond to disputes in a more timely manner, more than half of OECD member countries have introduced special review bodies. In addition, 19 OECD countries provide alternative dispute resolution mechanisms, either through the ombudsman, conciliation procedures or arbitration panels. Data on the number of public procurement disputes filed each year are available in a few countries.

\section{Methodology and definitions}

Data were collected by the OECD 2010 Survey on Public Procurement which focused on the level of transparency, participation and available remedies in central government procurement processes. Respondents to the survey were OECD country officials responsible for procurement at the central government level. A total of 33 OECD members, as well as Brazil, Egypt and Ukraine responded to the survey.

Further country-specific data on the mechanisms to routinely involve citizens in key stages of the procurement cycle and the review and remedy mechanisms available to bidders are available in Annex G.

A special review body is a body independent of the contracting authority and the administrative and civil courts. In certain countries it may be part of the public procurement agency. The decisions of the review body are usually binding, subject to an appeal in civil or administrative courts (source: adapted from SIGMA, OECD).

\section{Further reading}

OECD (2007), "Public Procurement Review and Remedy Systems in the European Union", SIGMA Paper, No. 41, OECD Publishing, Paris.

OECD (2009), OECD Principles for Integrity in Public Procurement, OECD Publishing, Paris.

OECD (2010), Enhancing Integrity in Public Procurement: A Toolbox, available at www.oecd.org/governance/procurement/toolbox.

\section{Table notes}

41.1: In Australia, justification for awarding a contract to a selected contractor may be withheld in certain situations.

Information on data for Israel: $h t t p: / / d x . d o i . o r g / 10.1787 / 888932315602$. 
41.1 Public availability of procurement information at the central level of government (2010)

\begin{tabular}{|c|c|c|c|c|c|c|c|c|c|c|}
\hline & $\begin{array}{l}\text { Laws } \\
\text { and policies }\end{array}$ & $\begin{array}{c}\text { General } \\
\text { information for } \\
\text { potential bidders }\end{array}$ & $\begin{array}{c}\text { Selection } \\
\text { and evaluation } \\
\text { criteria }\end{array}$ & $\begin{array}{c}\text { Contract } \\
\text { award }\end{array}$ & $\begin{array}{l}\text { Specific guidance } \\
\text { on application } \\
\text { procedures }\end{array}$ & $\begin{array}{c}\text { Tender } \\
\text { documents }\end{array}$ & $\begin{array}{c}\text { Procurement plan } \\
\text { of anticipated } \\
\text { tenders }\end{array}$ & $\begin{array}{l}\text { Justification } \\
\text { for awarding contract } \\
\text { to selected contractor }\end{array}$ & $\begin{array}{c}\text { Contract } \\
\text { modifications }\end{array}$ & $\begin{array}{l}\text { Tracking } \\
\text { procurement } \\
\text { spending }\end{array}$ \\
\hline Austria & - & - & - & - & - & - & - & O & - & O \\
\hline Belgium & 0 & - & 0 & $\bullet$ & - & 0 & 0 & - & - & O \\
\hline Canada & $\bullet$ & $\bullet$ & 口 & $\bullet$ & - & 口 & O & घ & $\bullet$ & O \\
\hline Chile & $\bullet$ & • & - & - & - & • & - & - & - & - \\
\hline Estonia & $\bullet$ & - & $\bullet$ & - & - & 口 & - & - & 口 & $\bullet$ \\
\hline Finland & 0 & 0 & 0 & - & - & 口 & - & - & 0 & O \\
\hline France & - & 0 & - & - & - & - & - & 口 & - & 口 \\
\hline Germany & - & - & - & - & 0 & - & 0 & 0 & 0 & 0 \\
\hline Greece & 0 & 0 & 0 & $\bullet$ & $\bullet$ & - & - & - & O & O \\
\hline Hungary & • & • & • & • & - & • & - & • & $\bullet$ & • \\
\hline Japan & 0 & - & 0 & • & - & - & - & - & $\bullet$ & 口 \\
\hline Korea & - & - & - & - & - & - & - & - & - & $\bullet$ \\
\hline Luxembourg & $\bullet$ & $\bullet$ & $\bullet$ & 0 & - & $\bullet$ & - & 口 & घ & 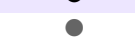 \\
\hline Mexico & $\bullet$ & $\bullet$ & $\bullet$ & $\bullet$ & $\bullet$ & $\bullet$ & $\bullet$ & $\bullet$ & - & $\bullet$ \\
\hline Netherlands & • & - & - & - & - & • & - & $\bullet$ & - & O \\
\hline New Zealand & $\bullet$ & 口 & $\bullet$ & $\bullet$ & 口 & $\bullet$ & - & 口 & 口 & O \\
\hline Norway & - & 0 & 0 & - & - & 口 & - & घ & 口 & 口 \\
\hline Poland & - & $\bullet$ & - & - & - & - & - & - & 口 & O \\
\hline Portugal & 0 & $\bullet$ & $\bullet$ & - & - & - & - & - & - & $\bullet$ \\
\hline Slovak Republic & - & $\bullet$ & - & $\bullet$ & - & 口 & - & 0 & $\bullet$ & O \\
\hline Slovenia & $\bullet$ & - & - & - & - & $\overline{0}$ & - & 口 & ? & 口 \\
\hline Spain & $\bullet$ & $\bullet$ & $\bullet$ & $\bullet$ & - & $\bullet$ & - & 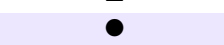 & $\bullet$ & 0 \\
\hline \multicolumn{11}{|l|}{ Total OECD34 } \\
\hline Always & 34 & 26 & 21 & 21 & 19 & 18 & 17 & 13 & 11 & 6 \\
\hline - Upon request & 0 & 1 & 1 & 0 & 1 & 5 & 0 & 10 & 7 & 6 \\
\hline Sometimes & 0 & 7 & 11 & 13 & 13 & 10 & 14 & 7 & 10 & 5 \\
\hline Not available & 0 & 0 & 1 & 0 & 1 & 1 & 3 & 4 & 6 & 17 \\
\hline
\end{tabular}

Source: OECD 2010 Survey on Public Procurement.

41.2 Central government review and remedy mechanisms available for public procurement (2010)

\begin{tabular}{lccl}
\hline Review mechanisms & Total OECD34 & \\
\hline Courts & 33 & $\begin{array}{l}\text { Australia, Austria, Belgium, Canada, Chile, the Czech Republic, Denmark, Estonia, Finland, France, Germany, Greece, Hungary, } \\
\text { Iceland, Ireland, Israel, Italy, Japan, Korea, Luxembourg, Mexico, Netherlands, New Zealand, Norway, Poland, Portugal, } \\
\text { the Slovak Republic, Spain, Sweden, Switzerland, Turkey, the United Kingdom, the United States. }\end{array}$ \\
Alternative dispute mechanisms & 20 & $\begin{array}{l}\text { Australia, Austria, Belgium, Canada, Chile, the Czech Republic, France, Hungary, Iceland, Israel, Italy, Korea, Luxembourg, Mexico, } \\
\text { New Zealand, Norway, Portugal, Spain, the United Kingdom, the United States. }\end{array}$ \\
Special review bodies & 20 & $\begin{array}{l}\text { Austria, Belgium, Canada, Chile, the Czech Republic, Estonia, Germany, Hungary, Iceland, Japan, Korea, Mexico, Norway, Poland, } \\
\text { the Slovak Republic, Slovenia, Spain, Switzerland, Turkey, the United States. }\end{array}$
\end{tabular}

Source: OECD 2010 Survey on Public Procurement. 
E-procurement, the use of information and communication technologies in public procurement, facilitates access to public tenders and increases competition. It also improves the transparency of the procurement cycle, empowering citizens and businesses to hold public authorities more accountable. In addition, the use of information technologies in public procurement can decrease administrative burdens and reduce costs for both governments and businesses. Electronic channels can also lead to a shorter order cycle and increase compliance levels, helping - potentially to lower prices.

In order to take full advantage of the efficiency and cost savings achieved through e-procurement, 21 OECD member countries have developed a single-entry procurement website providing a one-stop-shop for public procurement. Others have chosen to create more than one website according to the type of purchase (e.g. Japan provides information via contracting entity websites) or type of operation/ transaction (e.g. Belgium and Norway). In countries like Sweden with no government website, private companies are providing certain online facilities, usually centralising tender announcements.

As the use of e-procurement grows, more and more information is becoming available online. In seven OECD countries (e.g. Korea, Mexico, Chile, Ireland, Spain, Italy and Turkey) $80 \%$ or over of key procurement information can be found on the single-entry procurement website. Other OECD member countries provide most of the information on contracting entity websites (e.g. the Czech Republic and Japan).

The range of services offered by single-entry procurement websites is evolving from tendering to contract management and payment. Data suggest a trend towards extending the use of electronic channels in public procurement and introducing more sophisticated applications that facilitate the interface between the government and bidders and assist in the management of contracts. Most countries offer through their websites the possibility to search for tender announcements (90\%) and to download all related documents (90\%). Some countries offer more advanced functionalities on their procurement websites, such as electronic submission of bids (52\%) or reverse auction (33\%). More than half of the countries provide contract management tools, such as data on past procurement contracts $(62 \%)$ and tracking the outcomes of contracts $(48 \%)$. Only a minority of countries have electronic payment schemes including Chile, France, Israel and Korea.

\section{Methodology and definitions}

Data were collected by the OECD 2010 Survey on Public Procurement which focused on the level of transparency, participation and available remedies in central government procurement processes. Respondents to the survey were OECD country officials responsible for procurement at the central government level. A total of 34 OECD members, as well as Brazil, Egypt and Ukraine responded to the survey.

Further country-specific data on the online availability of public procurement information and services offered by government e-procurement websites are available in Annex G.

A single-entry procurement website centralises procurement information at one single location on the Internet, which is accessible via an online address.

An e-catalogue is a listing of available products and/or services that can be viewed in an electronic format and can include information such as illustrations, prices, and product and/or service descriptions. An electronic reverse auction is an online, real time dynamic auction between a buying organisation and a number of suppliers who compete against each other to win the contract by submitting successively lower-priced bids during a scheduled timed period.

\section{Further reading}

OECD (2007), Integrity in Public Procurement: Good Practice from $A$ to $Z, O E C D$ Publishing, Paris.

OECD (2009), OECD Principles for Integrity in Public Procurement, OECD Publishing, Paris.

OECD (2010), Enhancing Integrity in Public Procurement: A Toolbox, available at www.oecd.org/governance/procurement/toolbox.

\section{Figure notes}

42.1: Figure 42.1 represents the percentage of public procurement information publicly available (always or sometimes) on: laws and policies; general information for potential bidders; specific guidance on application procedures; procurement plan; tender documents; selection and evaluation criteria; contract award; justification for awarding a contract; contract modifications; tracking procurement spending; and other data. Information made public upon request is not included. Other locations include domestic printed/electronic journals, international central website and other websites.

42.2: As a percentage of the 22 OECD countries that have a single-entry procurement website.

Information on data for Israel: http://dx.doi.org/10.1787/888932315602. 


\subsection{Online availability of selected public procurement information in central governments (2010)}

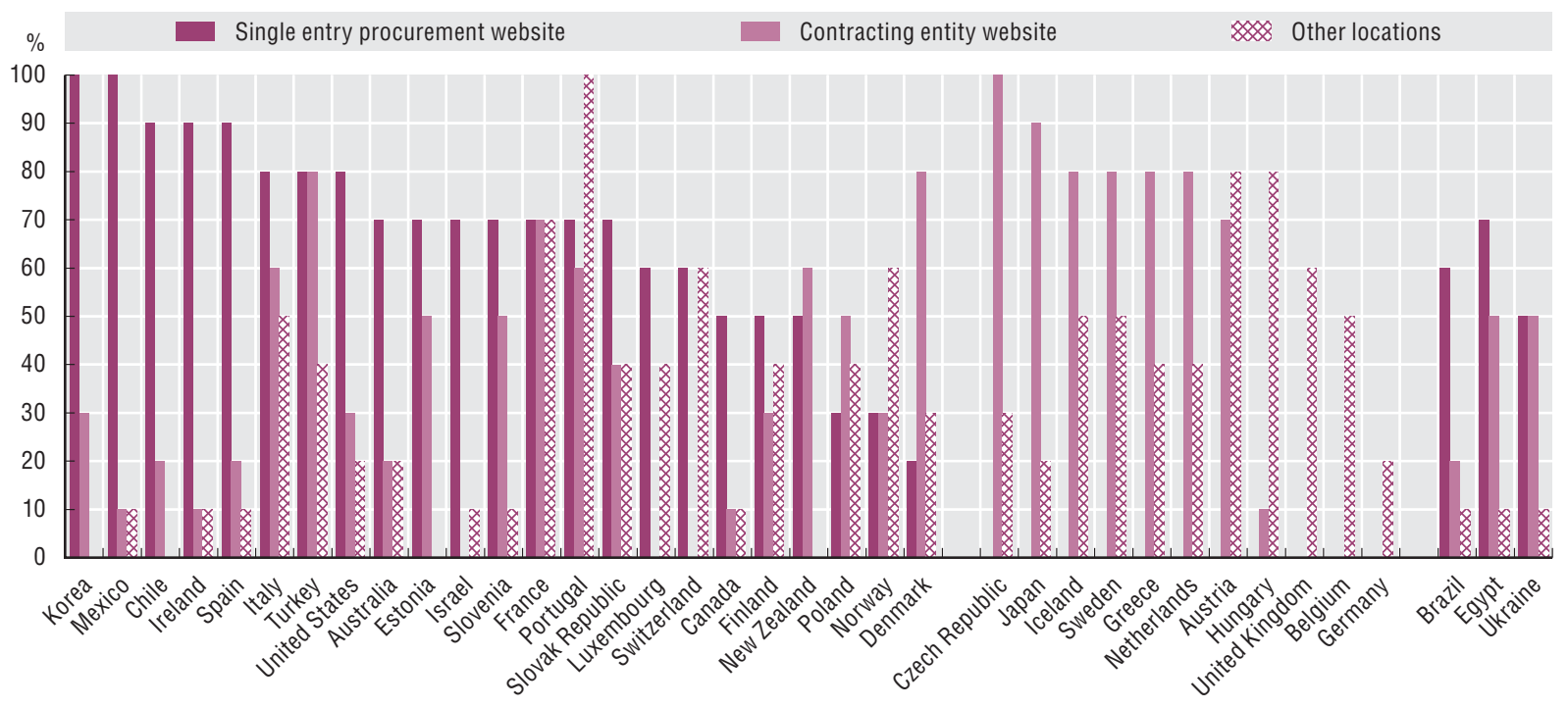

Source: OECD 2010 Survey on Public Procurement.

42.2 Most common services offered by the single-entry procurement website (2010)

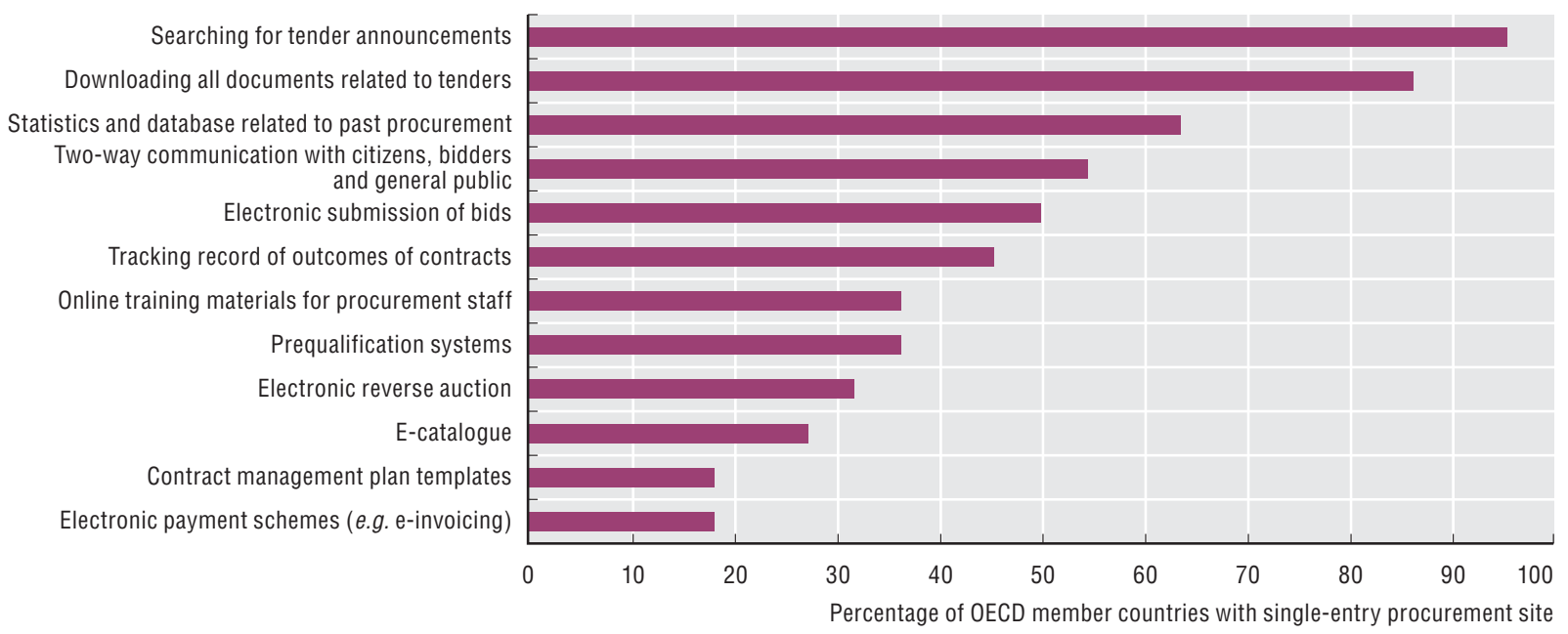

Source: OECD 2010 Survey on Public Procurement. 
OECD member countries are increasingly taking greater account of environmental sustainability in public procurement. Through green procurement, member countries make an important contribution to sustainable consumption and production. However, despite green policies being front and centre, less than half of OECD member countries have not established a standard definition for green procurement. Only six countries (Denmark, France, Italy, Japan, Luxembourg and Slovenia) incorporate a definition in the law, while the majority of the countries that have defined green procurement have done so in an environmental policy or strategy document.

In order to promote environmental standards in the whole product and services life cycle, the majority of OECD member countries introduce green criteria in the technical specifications of the procurement contract (24 countries), and many also include them in the award phase (18 countries). Fewer OECD countries consider green criteria as a contract performance clause (13 countries).

In 2007, an OECD survey indicated that a common barrier to successfully implementing green procurement was a lack of know-how among procurement officials on how to achieve it. As a response, by 2010 more than three-quarters of OECD countries have designed practical guides (e.g. manuals), and about half have developed training materials or offered ad hoc advice. Codes of practice are not widespread as a guidance tool and have been adopted in only ten OECD countries (Austria, Denmark, France, Korea, the Netherlands, New Zealand, Poland, Slovenia, Spain and Sweden).

The 2010 OECD Public Procurement Survey has revealed that a number of barriers remain to implementing green procurement. The most common concern across OECD countries today is the possibility of higher prices (79\%) resulting from more stringent environmental criteria. Assessing the costs of a good or service over its entire life cycle rather than at its market price could address this, but implementation of this practice remains a challenge. Other limitations perceived are the lack of monitoring mechanisms (45\%), the absence of incentives to take green criteria into account in procurement decision making (42\%) and the lack of sufficient suppliers (36\%).

The extent to which green procurement is put into practice is difficult to measure. Only a few countries (e.g. Estonia,
Norway and Sweden) collect quantitative information on the number of contracts awarded that take into account green criteria.

\section{Methodology and definitions}

Data were collected by the OECD 2010 Survey on Public Procurement which focused on the level of transparency, participation and available remedies in central government procurement processes. Respondents to the survey were OECD country officials responsible for procurement at the central government level. A total of 34 OECD members, as well as Brazil, Egypt and Ukraine responded to the survey.

Green procurement is defined by the European Commission as "a process whereby public authorities seek to procure goods, services and works with a reduced environmental impact throughout their life cycle when compared to goods, services and works with the same primary function that would otherwise be procured".

\section{Further reading}

European Commission (2008), Communication from the Commission to the European Parliament, the Council, the European Economic and Social Committee and the Committee of Regions, Public Procurement for a Better Environment, European Commission, Brussels.

OECD (2003), "Recommendation of the Council on Improving the Environmental Performance of Public Procurement", Vol. (2003)8, OECD Publishing, Paris.

OECD (2007), Improving the Environmental Performance of Public Procurement: Report on Implementation of the Council Recommendation, OECD Publishing, Paris.

\section{Table note}

Information on data for Israel: http://dx.doi.org/10.1787/888932315602. 
43.1 Stages of procurement cycle where green criteria are applied and available guidance tools (2010)

\begin{tabular}{|c|c|c|c|c|c|c|c|}
\hline & \multicolumn{3}{|c|}{ Stages of procurement where green criteria are applied } & \multicolumn{4}{|c|}{ Guidance to promote green procurement in practice } \\
\hline & $\begin{array}{l}\text { In the technical } \\
\text { specifications }\end{array}$ & $\begin{array}{l}\text { In the award } \\
\text { phase }\end{array}$ & $\begin{array}{c}\text { As a contract } \\
\text { performance clause }\end{array}$ & Practical guide & Training materials & Ad hoc advice & Code of practice \\
\hline Australia & O & 0 & O & - & 0 & 0 & 0 \\
\hline Austria & - & - & - & - & 0 & 0 & - \\
\hline Belgium & - & - & - & - & 0 & - & 0 \\
\hline Canada & - & - & - & - & - & - & 0 \\
\hline Chile & - & - & 0 & - & - & O & 0 \\
\hline Czech Republic & 0 & O & 0 & O & O & O & O \\
\hline Denmark & - & - & 0 & - & 0 & - & - \\
\hline Estonia & • & - & $\bullet$ & - & - & - & O \\
\hline Finland & - & 0 & 0 & - & - & - & 0 \\
\hline France & $\bullet$ & $\bullet$ & $\bullet$ & - & $\bullet$ & - & $\bullet$ \\
\hline Germany & 0 & 0 & 0 & - & • & 0 & 0 \\
\hline Greece & O & O & 0 & O & O & O & 0 \\
\hline Hungary & 0 & 0 & 0 & - & - & 0 & 0 \\
\hline Iceland & - & 0 & 0 & - & - & - & 0 \\
\hline Ireland & - & - & 0 & - & 0 & 0 & 0 \\
\hline Israel & $\bullet$ & - & $\bullet$ & O & • & $\bullet$ & O \\
\hline Italy & - & - & - & - & - & - & 0 \\
\hline Japan & - & 0 & 0 & - & O & - & 0 \\
\hline Korea & - & 0 & 0 & - & - & - & - \\
\hline Luxembourg & - & - & - & - & 0 & O & O \\
\hline Mexico & • & 0 & 0 & O & 0 & O & 0 \\
\hline Netherlands & $\bullet$ & $\bullet$ & $\bullet$ & - & $\bullet$ & $\bullet$ & $\bullet$ \\
\hline New Zealand & - & - & - & - & 0 & 0 & - \\
\hline Norway & 0 & O & O & - & - & - & O \\
\hline Poland & $\bullet$ & $\bullet$ & $\bullet$ & 0 & - & 0 & $\bullet$ \\
\hline Portugal & - & - & $O$ & $\mathrm{O}$ & $O$ & O & $O$ \\
\hline Slovak Republic & 0 & 0 & 0 & O & 0 & 0 & 0 \\
\hline Slovenia & $\bullet$ & • & $\bullet$ & - & $\bullet$ & - & $\bullet$ \\
\hline Spain & - & • & - & O & 0 & - & - \\
\hline Sweden & 0 & O & 0 & - & - & - & - \\
\hline Switzerland & - & - & 0 & - & - & - & 0 \\
\hline Turkey & 0 & O & 0 & O & 0 & O & O \\
\hline United Kingdom & - & 0 & 0 & - & - & 0 & 0 \\
\hline United States & . & . & . & $\bullet$ & - & - & O \\
\hline Brazil & - & - & O & - & - & 0 & O \\
\hline Egypt & O & 0 & O & O & O & O & O \\
\hline Ukraine & $O$ & $O$ & $O$ & 0 & 0 & $O$ & O \\
\hline \multicolumn{8}{|l|}{ Total OECD34 } \\
\hline - Yes & 24 & 18 & 13 & 26 & 19 & 18 & 10 \\
\hline ONo & 9 & 15 & 20 & 8 & 15 & 16 & 24 \\
\hline
\end{tabular}

Source: OECD 2010 Survey on Public Procurement.

43.2 Limitations to green procurement identified by central government procurement officials (2010)

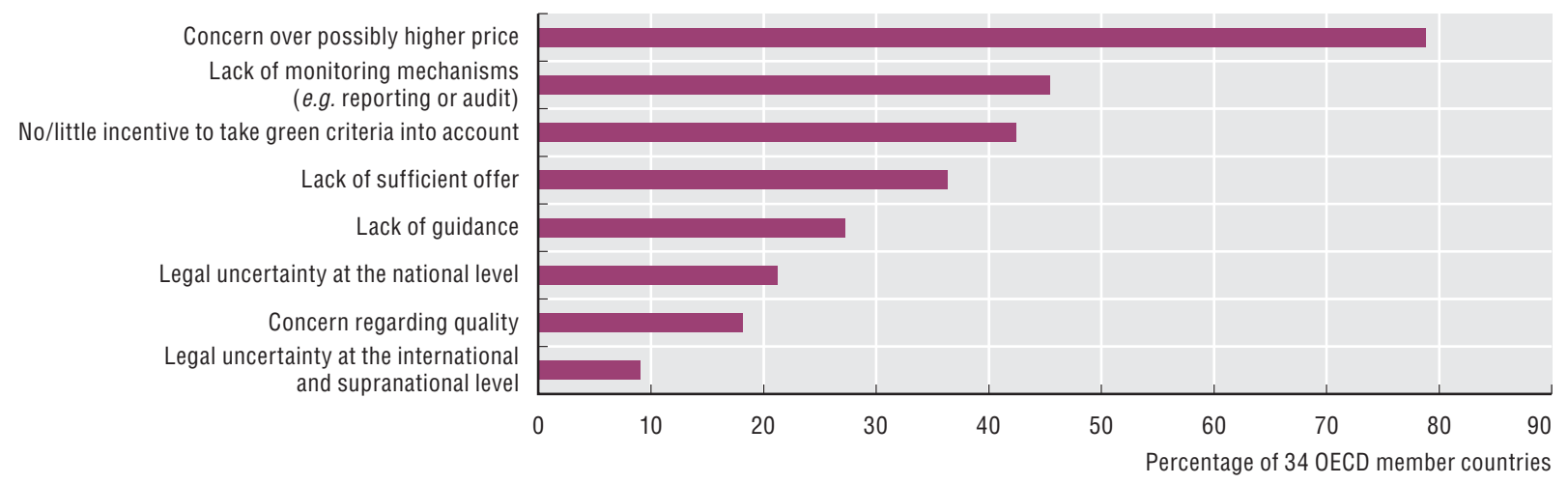

Source: OECD 2010 Survey on Public Procurement. 


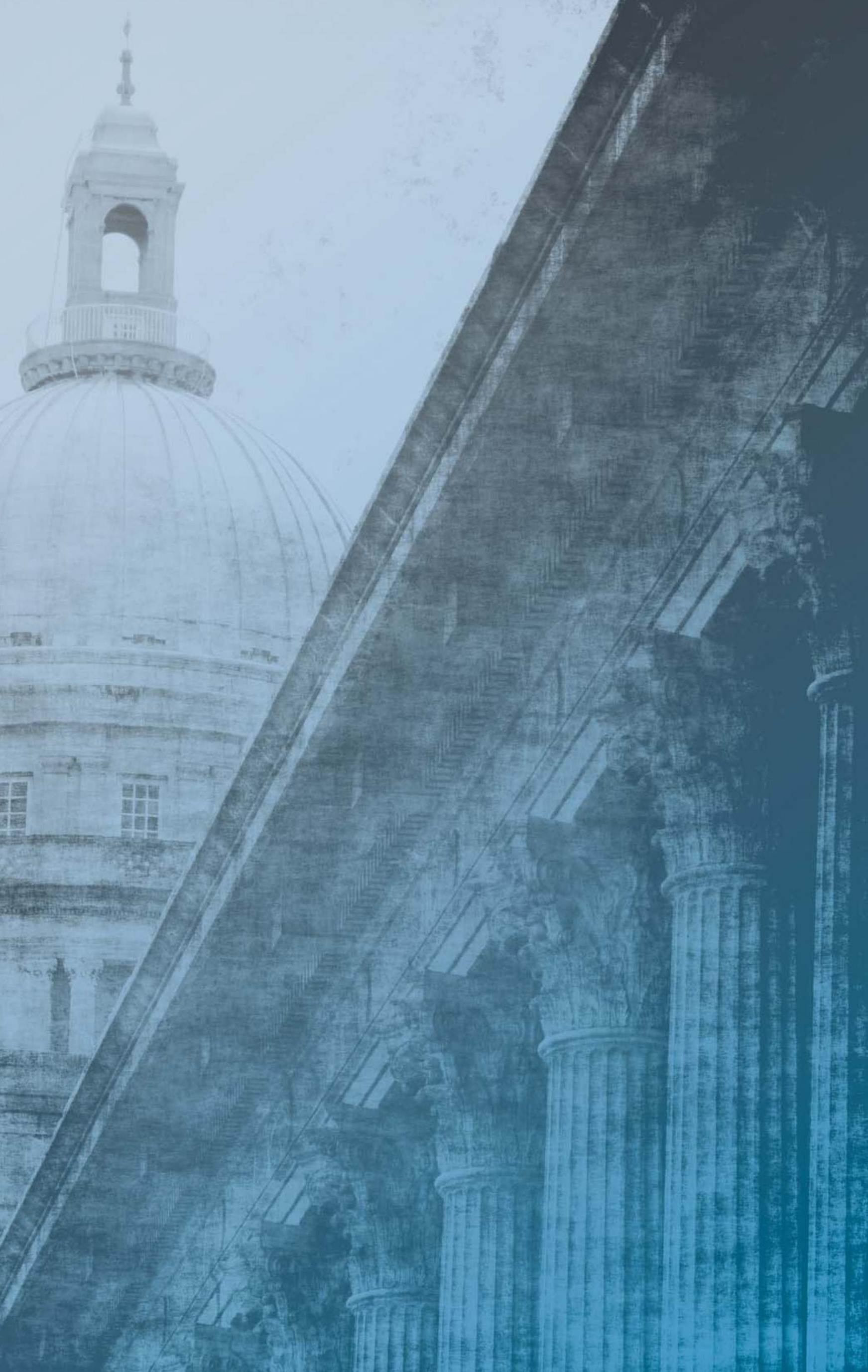




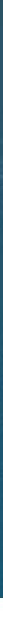

\section{REGULATORY GOVERNANCE}

Regulations are necessary to protect the interests of citizens and businesses, preserve the environment, and achieve economic growth and development. Regulatory failures were one factor leading to the global financial and economic crisis, illustrating the need for strong regulatory governance to manage risk and promote sustainable growth. Greater transparency in making new regulations, as well as in managing existing ones, will be necessary to help rebuild trust in government and prevent future regulatory capture. The OECD is working to strengthen the application of its Guiding Principles for Regulatory Quality and Performance by OECD members in order to assist governments to anticipate and avert future crises.

The indicators selected here are among the key issues identified in OECD reviews, including those of $15 \mathrm{EU}$ countries, for ensuring that regulations are well designed and support policy goals. They include measures of how countries prepare new rules and how they review and reform existing rules. Specifically, this chapter includes data on the role of governance institutions, and how governments aim to achieve transparency in the regulatory system, secure compliance and enforcement with laws, and evaluate regulatory performance. These factors are essential for promoting government accountability, increasing confidence in the legal environment and supporting evidence-based policy making. Regulatory governance indicators compare the focus and scope of regulatory management systems across countries and identify trends over time. They are based on country responses to the OECD Survey on Regulatory Management Systems and refer to institutional practices as reflected in administrative arrangements and procedures (www.oecd.org/regreform/indicators). More specific country assessments can be found in in-depth country reviews of the OECD which analyse how governments implement these procedures in practice (www.oecd.org/regreform/backgroundreports). 
Regulatory institutions play an important role in delivering regulatory policy and ensuring the quality of regulations. Regulatory oversight bodies located at the centre of government monitor the progress of regulatory policy from a whole-of-government perspective. These bodies advocate the consistent application of regulatory policy across government, often challenging the merits of regulatory proposals from line Ministries. External advisory bodies can give further impetus to the regulatory reform process. They receive reference from the government to review broad areas of regulation, collecting the views of citizens and businesses.

The number of countries that report having a body entrusted with authority for government-wide regulatory oversight has nearly doubled since 1998 to include almost all OECD member countries in 2008. The functions of these bodies vary. While in 2008 almost all countries reported that the body is consulted as part of the process of developing new regulations, only about half of regulatory oversight bodies had the authority to review and monitor impact assessments of regulatory proposals conducted in individual Ministries. Furthermore, the scope of regulatory policies that fall under the auspices of oversight bodies also varies across the OECD from narrow to broad. In some countries for example, oversight bodies may be limited to monitoring the progress of administrative simplification initiatives, and in others they may have a broad regulatory reform agenda.

Successful regulatory reform also needs strong high-level leadership. The majority (28) of OECD member countries have assigned a specific Minister with responsibility for promoting government-wide regulatory reform; 15 of these Ministers report on progress to Parliament. This political commitment highlights the government's determination for regulatory reform, helps to deal with potential reluctance among officials and builds confidence among stakeholders. Chile, Israel, Luxembourg, New Zealand, Switzerland and Turkey do not have a specific Minister responsible for regulatory reform.

Some OECD member countries have also made use of an advisory body to review broad areas of regulation, and to ensure that the views of public and private stakeholders are taken into account. Countries with an advisory body include: Australia, Belgium, Canada, Germany, Iceland, Ireland, Japan, Korea, Luxembourg, Mexico, the Netherlands, Switzerland and the United Kingdom. Such bodies, which report their findings to the government, bring an expert view to the review process and often act as a powerful institution to support the systematic process of regulatory reform. For instance, the Australian Productivity Commission is an effective part of the Australian institutional framework. It is a notable example of an advisory body that is both independent from the government and has a permanent status.

\section{Methodology and definitions}

The indicators draw upon country responses to the OECD Regulatory Management Systems' Indicators Survey conducted in 2005 and 2008 for the (then) 30 OECD member countries. Responses were provided by OECD delegates and central government officials. Data were subsequently collected for the four countries that joined the OECD in 2010 (Chile, Estonia, Israel and Slovenia) as well as three other major economies (Brazil, the Russian Federation and South Africa). Data for these countries refer to 2009. Country-specific data are available on line at: $h t t p: / / d x . d o i . o r g / 10.1787 / 888932392248$.

A regulatory oversight body is a dedicated body responsible for promoting as well as monitoring and reporting on regulatory reform and regulatory quality in the central administration from a whole-of-government perspective.

A regulatory advisory body is a dedicated body that receives references from government to review broad areas of regulation, collecting the views of citizens and business.

\section{Further reading}

Cordova-Novion, C. and S. Jacobzone (2011), "Strengthening the Institutional Setting for Regulatory Reform: The Experience from OECD Countries", OECD Working Papers on Public Governance, No. 19, OECD Publishing, Paris.

OECD (2009), Indicators of Regulatory Management Systems, OECD, Paris, www.oecd.org/regreform/indicators.

OECD (2010), Regulatory Policy and the Road to Sustainable Growth,OECD Publishing, Paris, www.oecd.org/regref/eu15.

\section{Figure notes}

Data for 1998 are not available for Luxembourg, Poland and the Slovak Republic. Data for 1998 and 2005 are not available for Chile, Estonia, Israel and Slovenia. Therefore, the figure is based on data for 27 OECD countries for 1998, 30 countries for 2005, and 34 countries for 2008. Data for Chile, Estonia, Israel and Slovenia refer to 2009.

Information on data for Israel: http://dx.doi.org/10.1787/888932315602. 
44.1 Role of the regulatory oversight body at the central government level (1998, 2005 and 2008)

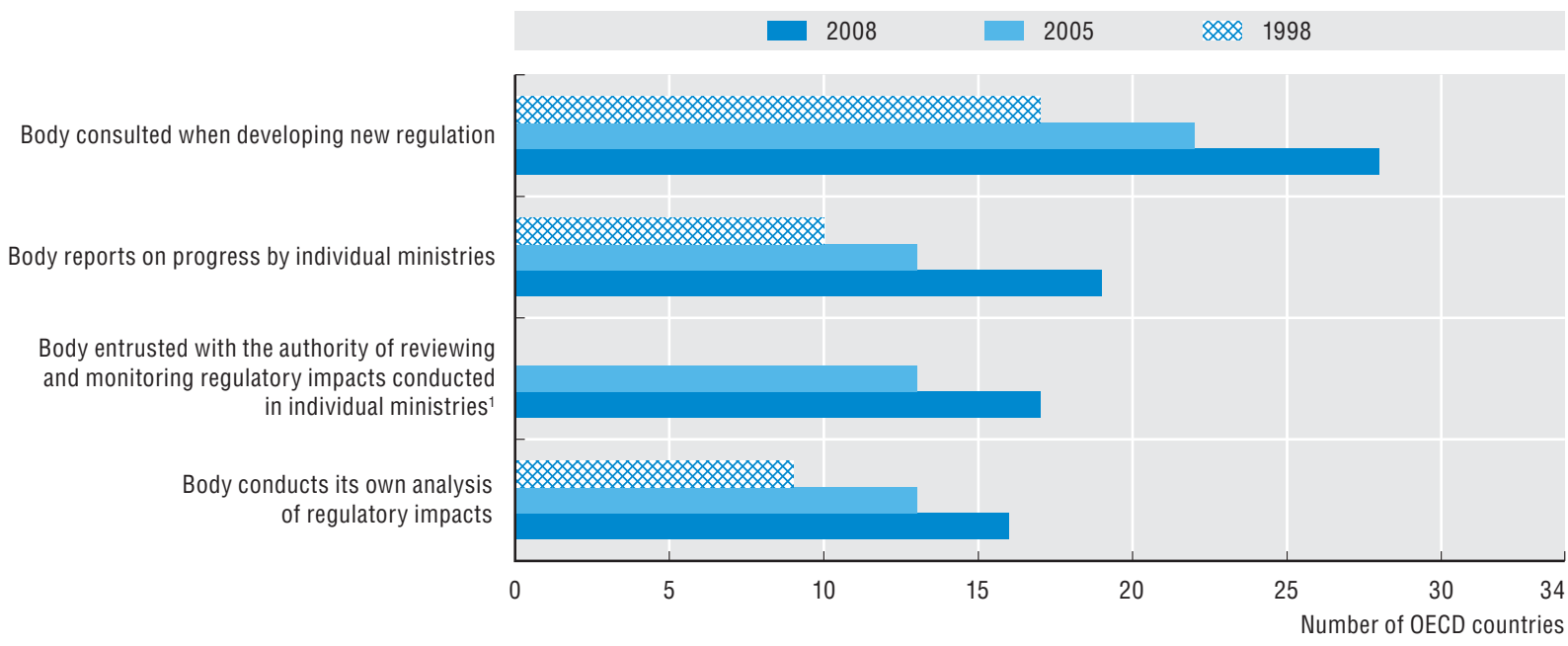

1. No data are available for 1998.

Source: OECD Regulatory Management Systems' Indicators Survey 1998, 2005, and 2008/09, www.oecd.org/regreform/indicators. See StatLink for country-specific data.

44.2 Regulatory advisory body and ministerial responsibility at the central government level (1998, 2005 and 2008)

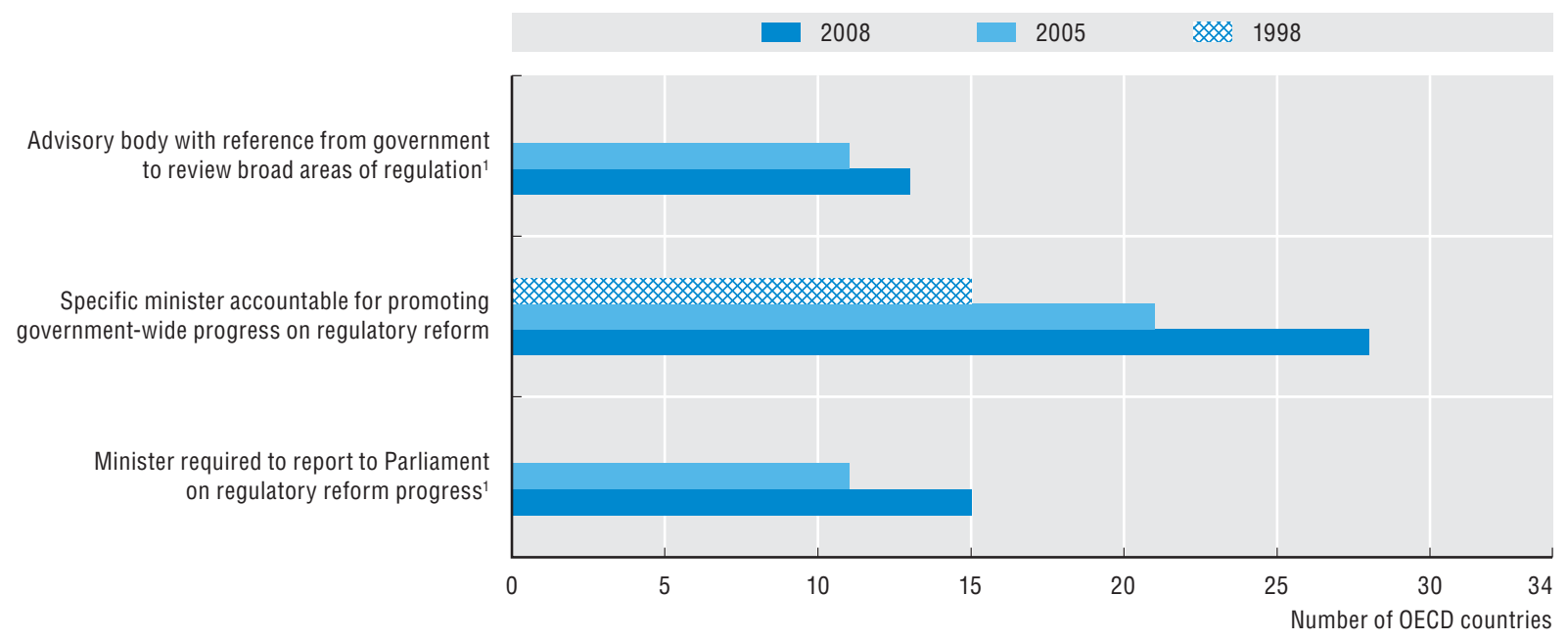

1. No data are available for 1998.

Source: OECD Regulatory Management Systems' Indicators Survey 1998, 2005, and 2008/09, www.oecd.org/regreform/indicators. See StatLink for country-specific data. 
Increased transparency is a goal of the 2005 OECD Guiding Principles for Regulatory Quality and Performance. Transparency in communication and open access to regulations promotes government accountability and sustains confidence in the legal environment, which in turn fosters a business-friendly environment and helps build trust in government institutions. Indeed, a country's regulations contain much information about how a society is organised, i.e. about the rules of the game and the political decisions taken. If citizens and businesses can readily access and understand regulations, it is more likely that they will participate in the legislative process and comply with the rules. Furthermore, the easier it is for foreign nationals to understand a country's regulations, the easier trade and investment becomes.

It is now common practice in all OECD member countries to make the text of regulations available publically on the Internet. It is less common for member countries to publish their plans for new or changing regulations. This forward planning would provide a greater opportunity for citizens, businesses and government Ministries to offer suggestions for improvement, highlight potentially adverse aspects of plans and anticipate potential changes that will affect them. For example, in Korea, the Ministry of Legislation publishes on the Internet the yearly law enactment/ amendment plans by each Ministry. It is also increasingly common for OECD countries to publish the views of participants in the consultation process: 20 OECD member countries disclose the views expressed by stakeholders on draft subordinate regulations.

As the number and complexity of regulatory instruments have increased over time, governments have taken steps to help citizens and businesses to understand and comply with rules. Plain language drafting is the most common method used by countries to enhance the accessibility of regulations. Publication of a consolidated register and the codification of laws can also help increase transparency. For instance, primary laws are codified in 28 OECD member countries, but only 20 countries have a mechanism in place for the codification to be regularly updated.

Regulatory impact analysis (RIA) can be a key tool for enhancing transparency when citizens' and business' views are taken into account in the process and the results are made available to the public. While an increasing number of OECD countries report that they incorporate the views of the public in RIA (in 2008, 24 OECD countries did so for primary laws and 21 for subordinate ones), OECD country reviews indicate that few countries do so systematically and that the quality of consultation varies significantly. Less than two-thirds of OECD members report releasing RIA documents for consultation. The practice of regularly monitoring the compliance of government
Ministries with the requirements of RIA and releasing these reports to the public is also not widespread. In 2008, 10 OECD countries reported doing so, including Australia, Belgium, the Czech Republic, Denmark, Finland, Ireland, New Zealand, Switzerland, the United Kingdom and the United States.

\section{Methodology and definitions}

The indicators draw upon country responses to the OECD Regulatory Management Systems' Indicators Survey conducted in 2005 and 2008 for the (then) 30 OECD member countries. Responses were provided by OECD delegates and central government officials. Data were subsequently collected in 2010 for the four countries that joined the OECD in 2010 (Chile, Estonia, Israel and Slovenia), as well as three other major economies (Brazil, the Russian Federation and South Africa). Data for these countries refer to 2009. Country-specific data are available on line at: http:// dx.doi.org/10.1787/888932392267.

Primary laws are those approved by the legislature, while subordinate regulations are those that can be approved by delegation to the executive (that is, by an authority other than the legislature). A consolidated register compiles all regulations into one place. Codification is the systematic arrangement of laws in force, often by areas (e.g. penal code or company law).

\section{Further reading}

OECD (2009), Regulatory Impact Analysis: A Tool for Policy Coherence, OECD Publishing, Paris.

OECD (2010), “Open Government and E-Rulemaking: A Discussion Note", paper prepared for the Regulatory Policy at the Crossroads Conference, Paris, 28-29 October 2010, OECD Publishing, Paris.

OECD (2010), Regulatory Policy and the Road to Sustainable Growth, OECD Publishing, Paris, www.oecd.org/regref/eu15.

\section{Figure notes}

45.1: Data for Chile, Estonia, Israel and Slovenia refer to 2009.

45.2: Data for Chile, Estonia, Israel and Slovenia are not available for 2005. Therefore, the figure is based on data for 30 countries for 2005, and 34 countries for 2008.

Information on data for Israel: $h t t p: / / d x . d o i . o r g / 10.1787 / 888932315602$. 


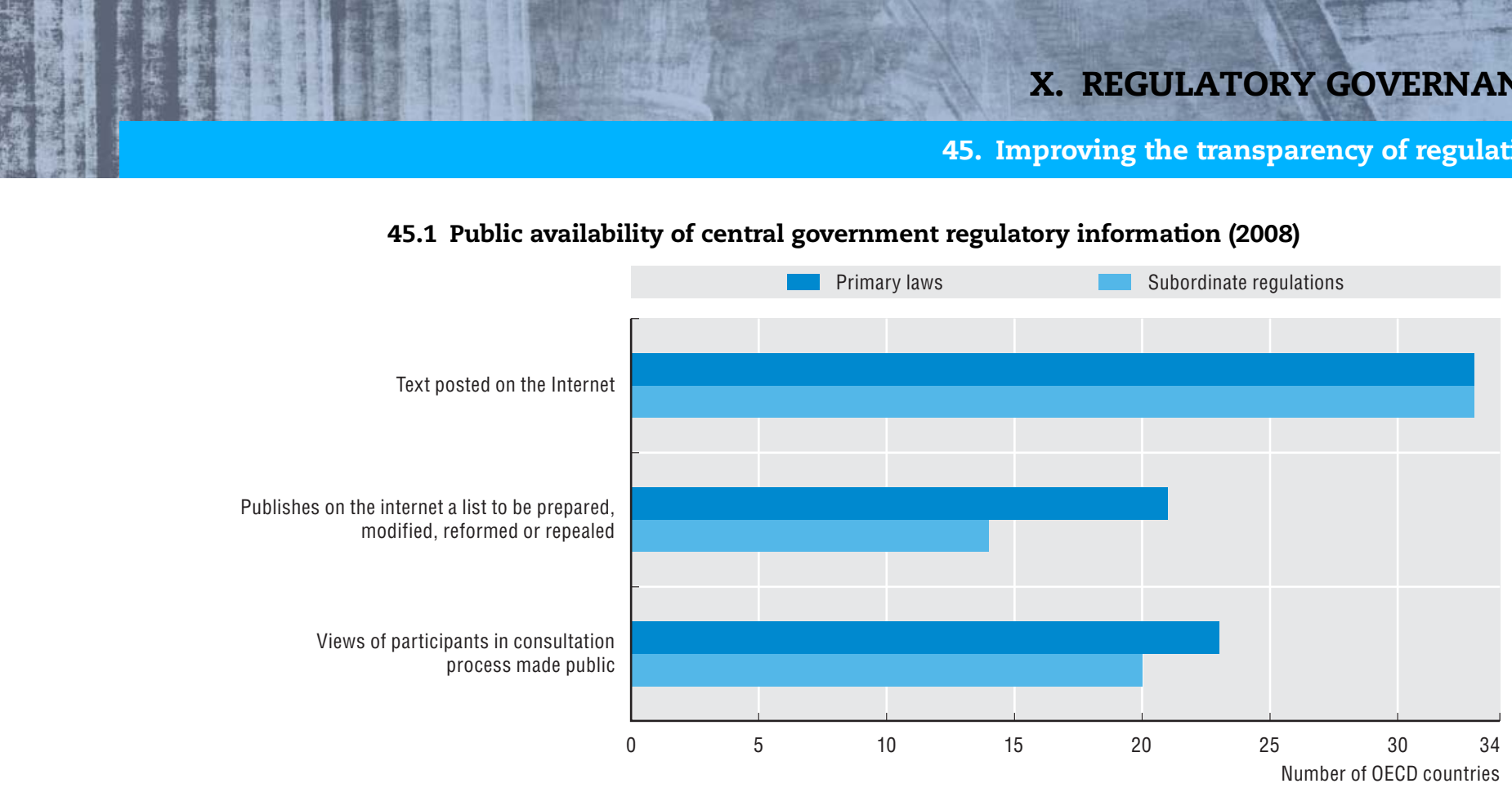

Source: OECD Regulatory Management Systems' Indicators Survey 2008/09, www.oecd.org/regreform/indicators. See StatLink for country-specific data.

\subsection{Transparency of central government RIA (2005 and 2008)}

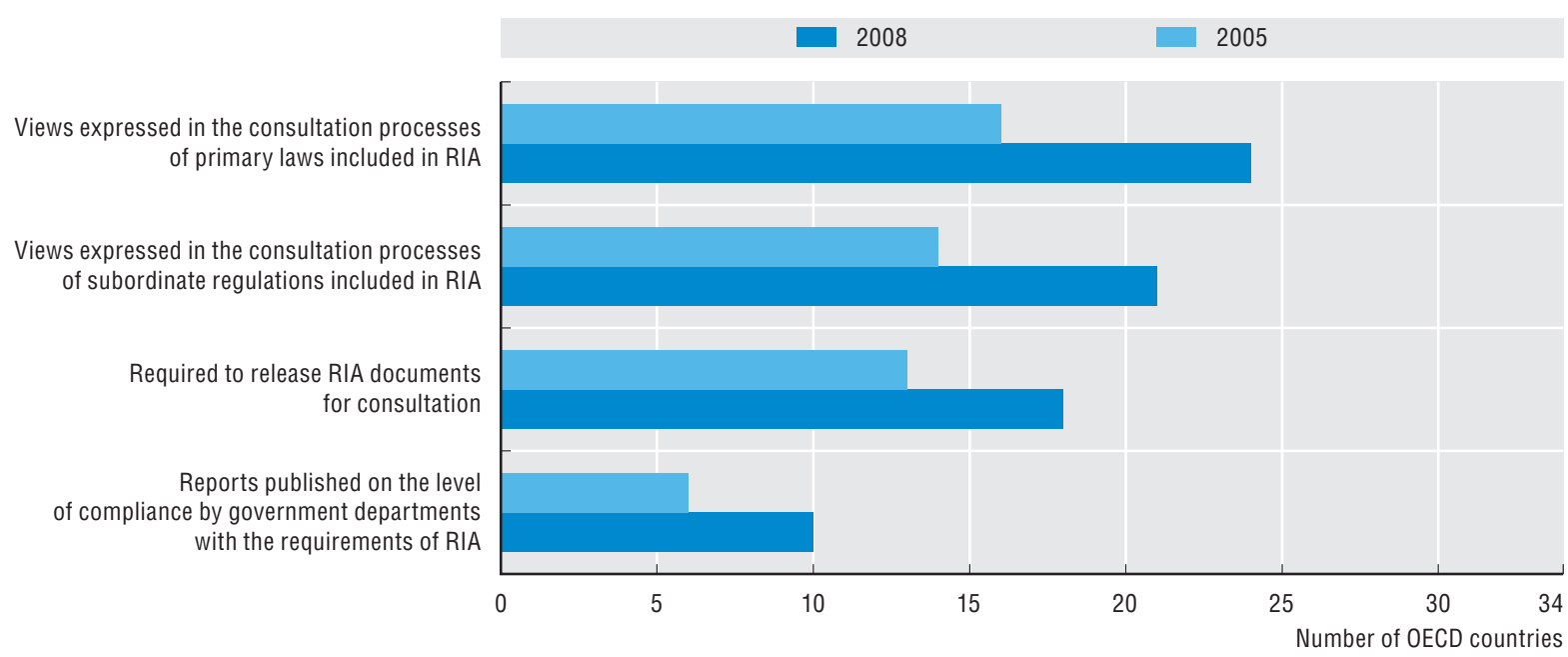

Source: OECD Regulatory Management Systems' Indicators Survey 2005 and 2008/09, www.oecd.org/regreform/indicators. See StatLink for country-specific data. 
How regulations are designed is important. Poorly designed regulations are difficult to comply with by businesses and citizens, and are costly to enforce. Good regulatory design depends on regulators anticipating and preparing for compliance and enforcement issues when evaluating the potential impact of draft regulations. A well functioning ex ante impact assessment process, therefore, includes an assessment of likely compliance by business and citizens, and of the ease and costs of enforcement. Evaluating this aspect of regulation also contributes to the underlying policy goals. Early analysis can help anticipate and prevent the conditions for corruption, wilful failures to observe the law and the growth of an informal economy.

Many (21) of OECD member countries in 2008 reported having some form of a requirement to consider compliance and enforcement issues when developing new regulations. However, policy guidance for regulators on how to do this is less common (14 member countries). Yet guidance contributes to building competency within government, and is an important part of a systematic approach to developing compliance and enforcement-friendly regulations.

In many areas, the enforcement of regulations can be optimised through risk-based enforcement. The general aim of a risk-based enforcement policy is to ensure that a proportionate share of the scarce resources available for enforcement are rationally allocated, concentrating on the prevention of (proscribed) activities with significant consequences. There is a growing interest in the potential for risk-based enforcement to optimise compliance procedures and reduce burdens on business. For example, inspection procedures may be directed towards businesses with demonstrably higher risks. However, only Australia, Belgium, Canada, Denmark, Finland, the Netherlands, New Zealand, Sweden and the United Kingdom reported having developed policies on risk-based enforcement.

In the United Kingdom, for instance, the Hampton review (2005) sought to embed a new policy approach of proportionality and the use of risk-based assessment to target resources to high-risk businesses that are less likely to comply with regulations, and to reduce the administrative burdens on those that are in compliance. The Danish government has also combined risk-based inspections, reinforced sanctioning and increased guidance to business as a strategy to promote higher compliance.

\section{Methodology and definitions}

The indicators draw upon country responses to the OECD Regulatory Management Systems' Indicators Survey conducted in 2005 and 2008 for the (then) 30 OECD member countries. Survey respondents were OECD delegates and central government officials. Data for Chile, Estonia, Israel and Slovenia, who joined the OECD in 2010, are not available.

Regulatory impact analysis (RIA) is a systematic policy tool used to examine and measure the likely benefits, costs and effects of new or existing regulation.

\section{Further reading}

OECD (2010), Better Regulation in Europe - The EU 15 project, OECD Publishing, Paris, www.oecd.org/regref/eu15.

OECD (2010), Cutting Red Tape - Why is Administrative Simplification so Complicated?, OECD Publishing, Paris.

OECD (2010), Risk and Regulatory Policy: Improving the Governance of Risk, OECD Publishing, Paris, www.oecd.org/regreform/risk.

\section{Figure and table notes}

These questions were not included in the 2009 OECD Regulatory Management Systems' Indicators Survey addressed to new OECD member countries, accession and enhanced engagement countries. Data for Chile, Estonia, Israel, Slovenia, Brazil, the Russian Federation and South Africa are therefore not available. 


\subsection{Regulatory compliance and enforcement issues at the central government level (2005 and 2008)}

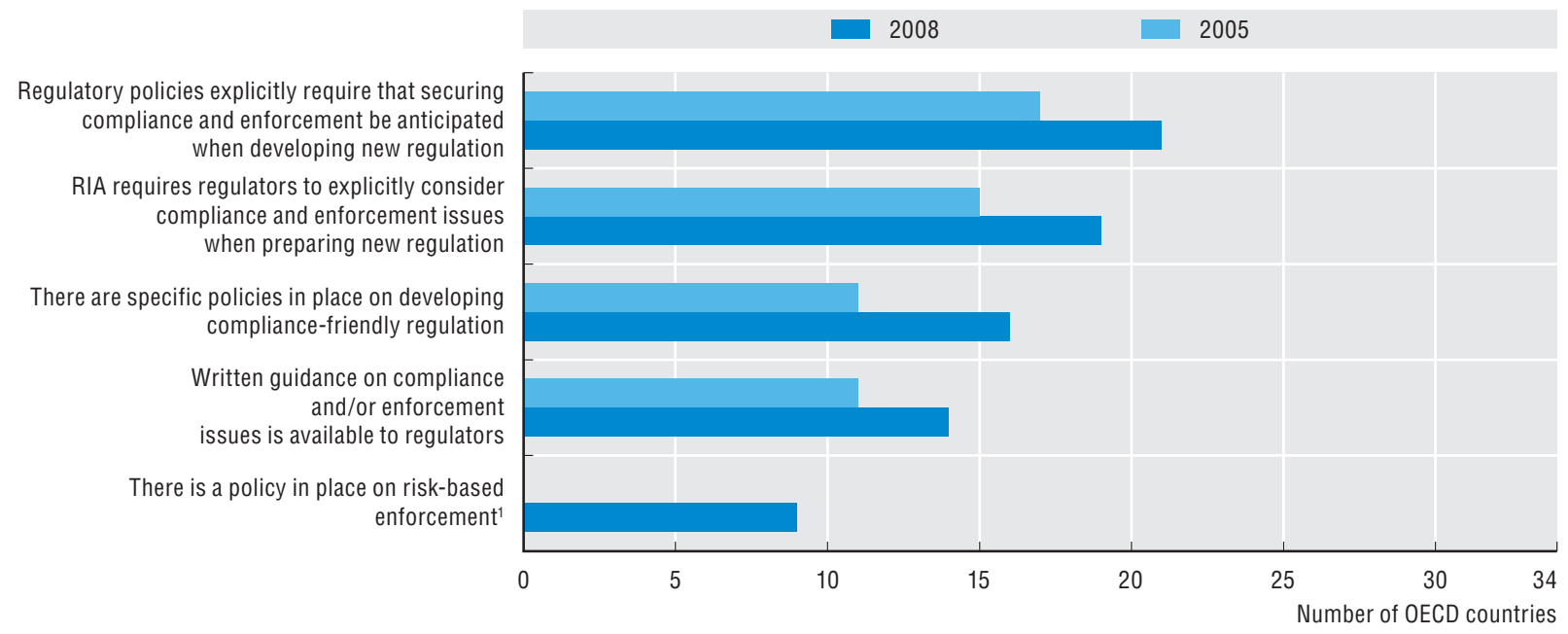

1. No data are available for 2005.

Source: OECD Regulatory Management Systems' Indicators Survey 2005 and 2008, www.oecd.org/regreform/indicators.

46.2 Regulatory compliance and enforcement at the central government level (2008)

\begin{tabular}{|c|c|c|c|c|c|}
\hline & $\begin{array}{c}\text { Regulatory policies explicitly require } \\
\text { that securing compliance } \\
\text { and enforcement be anticipated } \\
\text { when developing new regulation }\end{array}$ & $\begin{array}{l}\text { RIA requires regulators } \\
\text { to explicitly consider compliance } \\
\text { and enforcement issues } \\
\text { when preparing new regulation }\end{array}$ & $\begin{array}{l}\text { There are specific policies } \\
\text { in place on developing } \\
\text { compliance-friendly } \\
\text { regulation }\end{array}$ & $\begin{array}{l}\text { Written guidance } \\
\text { on complianceand/or } \\
\text { enforcement issues is } \\
\text { available to regulators }\end{array}$ & $\begin{array}{l}\text { There is a policy } \\
\text { in place on risk-based } \\
\text { enforcement }\end{array}$ \\
\hline Australia & - & - & - & - & - \\
\hline Austria & - & - & - & - & 0 \\
\hline Belgium & - & O & - & - & - \\
\hline Canada & - & - & - & - & - \\
\hline Czech Republic & • & - & 0 & 0 & 0 \\
\hline Denmark & - & O & - & - & - \\
\hline Finland & - & - & - & 0 & - \\
\hline France & O & - & O & O & O \\
\hline Germany & 0 & 0 & 0 & 0 & 0 \\
\hline Greece & 0 & 0 & O & 0 & O \\
\hline Hungary & 0 & 0 & O & 0 & O \\
\hline Iceland & 0 & 0 & O & 0 & O \\
\hline Ireland & - & - & - & - & O \\
\hline Italy & - & - & - & 0 & O \\
\hline Japan & 0 & 0 & 0 & 0 & 0 \\
\hline Korea & - & - & - & - & O \\
\hline Luxembourg & $\bullet$ & O & 0 & 0 & 0 \\
\hline Mexico & - & - & $\mathrm{O}$ & - & O \\
\hline Netherlands & - & 0 & 0 & $\bullet$ & - \\
\hline New Zealand & 0 & 0 & 0 & - & 0 \\
\hline Norway & 0 & 0 & O & 0 & O \\
\hline Poland & - & - & - & - & O \\
\hline Portugal & 0 & 0 & 0 & 0 & 0 \\
\hline Slovak Republic & - & - & 0 & 0 & O \\
\hline Spain & O & 0 & O & O & O \\
\hline Sweden & - & $\bullet$ & - & $\bullet$ & - \\
\hline Switzerland & - & - & - & - & O \\
\hline Turkey & O & 0 & $\mathrm{O}$ & 0 & $\mathrm{O}$ \\
\hline United Kingdom & • & - & - & - & • \\
\hline United States & O & - & O & O & O \\
\hline Total OECD30 & 21 & 19 & 16 & 14 & 9 \\
\hline
\end{tabular}

Yes.

O No.

Source: OECD Regulatory Management Systems' Indicators Survey 2008, www.oecd.org/regreform/indicators. 
Evaluation is core to evidence-based and accountable policy making. It helps to ensure that the policy aims of regulations are met, while maximising benefits and minimising costs. Regulatory impact analysis (RIA) is a systematic policy tool used to examine and measure the likely benefits, costs and effects of new or existing regulation. If undertaken ex ante, RIA assists decision makers to choose among the best alternative policy options. Conducted ex post, RIA helps to identify whether existing regulations should be revised. Cost-benefit analysis informs both the ex ante and ex post evaluation of a regulation and its alternatives. Consideration is best given early in the policy cycle to the criteria for ex post evaluation, including whether the objectives of the regulation are clear and what data will be used to measure performance, as well as the allocation of institutional responsibilities for review and evaluation.

Typically, OECD countries appear to commit fewer resources to identifying the benefits of regulations than they do to assessing the burdens and costs of regulation. In 2008, 24 countries reported quantifying the costs of regulation and only 16 reported quantifying benefits. This may be because intangible benefits are difficult to quantify. For example, while it is relatively straightforward to calculate the economic costs of reducing airport traffic through regulations that limit flights at night, quantifying the expected benefits of the resulting noise reduction requires making more complex assumptions.

The number of countries adopting mechanisms for ex post evaluation of regulations has increased over the last decade. Regulations can become obsolete over time, producing undesired side effects, and may no longer be the most efficient way of achieving the desired policy objectives. In some policy areas, the majority of OECD member countries report now having automatic review requirements for primary laws (20 countries). However, systematic ex post evaluation is less common. Only six OECD countries reported in 2008 that periodic evaluation of existing regulation was mandatory for all policy areas and 12 countries report using sunsetting including, Australia, Austria, Canada, Finland, France, Germany, Iceland, Korea, New Zealand, Switzerland, the United Kingdom and the United States.

\section{Methodology and definitions}

The indicators draw upon country responses to the OECD Regulatory Management Systems' Indicators Survey conducted in 2005 and 2008 for the (then) 30 OECD member countries. Responses were provided by OECD delegates and central government officials. Data were subsequently collected for the four countries that joined the OECD in 2010 (Chile, Estonia, Israel and Slovenia) as well as three other major economies (Brazil, the Russian Federation and South Africa). Data for these countries refer to 2009. Country-specific data are available on line at: $h t t p: / / d x$.doi.org/10.1787/888932392305.

Primary laws are those approved by the legislature, while subordinate regulations are those that can be approved by the executive only (that is, by an authority other than the legislature).

Sunsetting is the automatic repeal of regulations a certain number of years after they have come into force.

\section{Further reading}

OECD (2009), Indicators of Regulatory Management Systems, OECD Publishing, Paris, www.oecd.org/regreform/indicators.

OECD (2009), Regulatory Impact Analysis - A Tool for Policy Coherence, OECD Publishing, Paris.

OECD (2010), Regulatory Policy and the Road to Sustainable Growth, OECD Publishing, Paris, www.oecd.org/regref/eu15.

\section{Figure notes}

Data for 1998 are not available for Luxembourg, Poland and the Slovak Republic. Data for 1998 and 2005 are not available for Chile, Estonia, Israel and Slovenia. Therefore, the figure is based on data for 27 OECD countries for 1998, 30 countries for 2005, and 34 countries for 2008. Data for Chile, Estonia, Israel and Slovenia refer to 2009.

Information on data for Israel: http://dx.doi.org/10.1787/888932315602. 


\section{REGULATORY GOVERNANCE}

47. Evaluating regulatory performance

47.1 Requirement for RIA at the central government level: Quantification of costs and benefits (1998, 2005 and 2008)

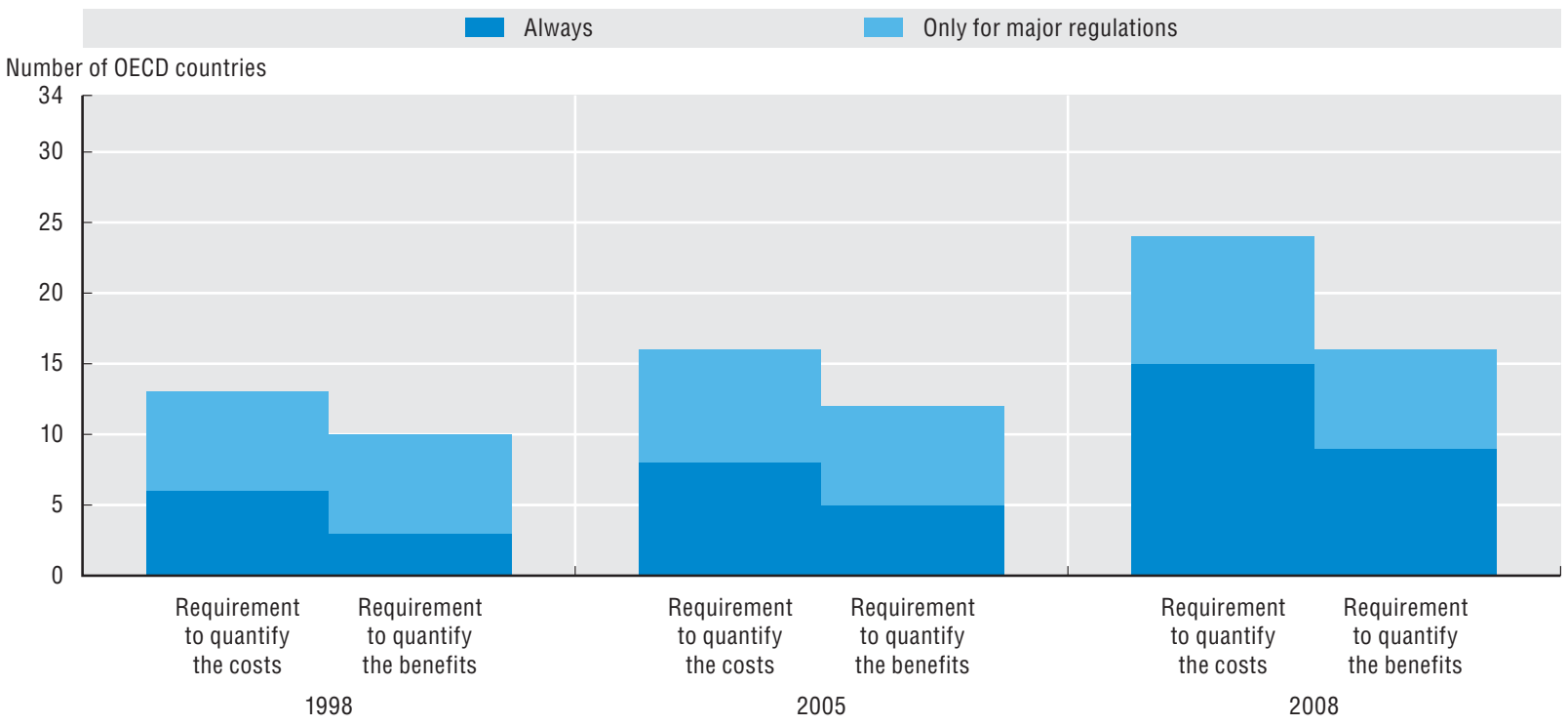

Source: OECD Regulatory Management Systems' Indicators Survey 1998, 2005, and 2008/09, www.oecd.org/regreform/indicators. See StatLink for country-specific data.

47.2 Regulatory review and evaluation at the central government level (1998, 2005 and 2008)

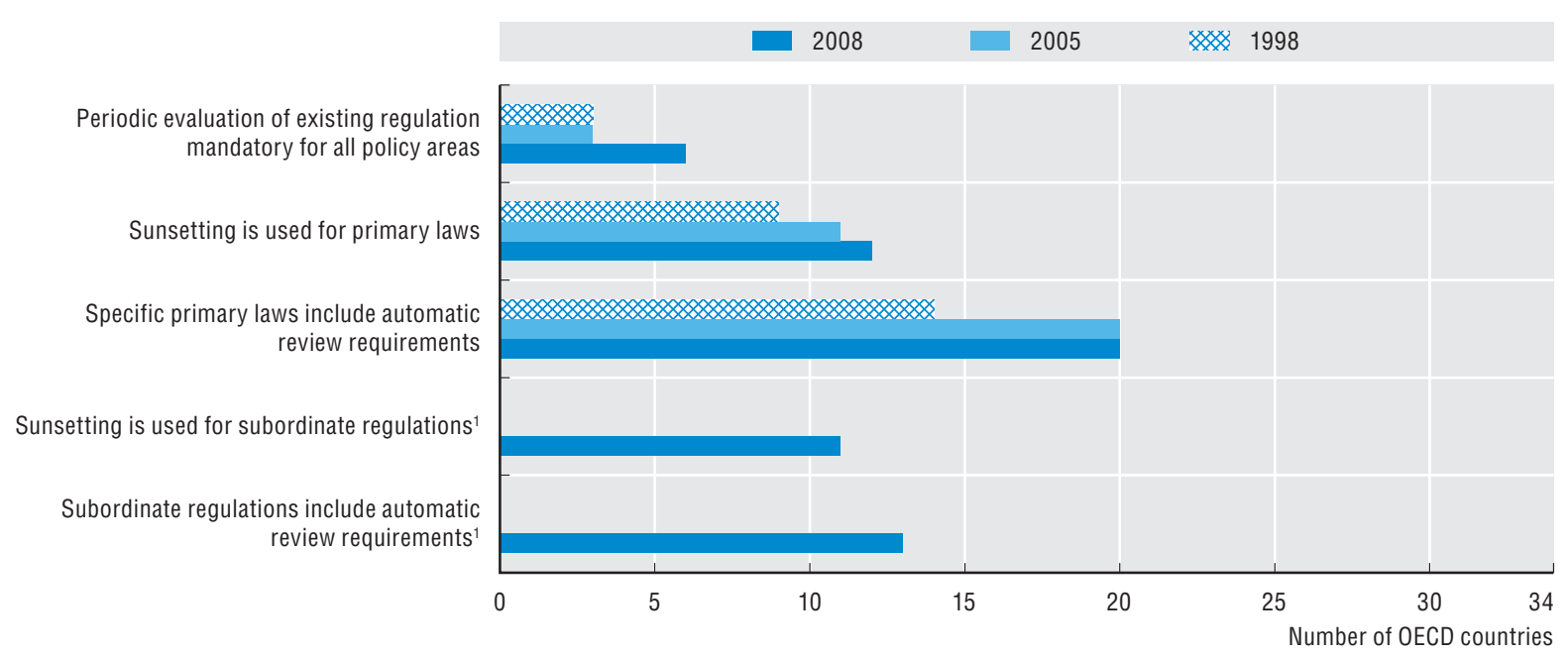

1. No data are available for 1998 and 2005.

Source: OECD Regulatory Management Systems' Indicators Survey 1998, 2005, and 2008/09, www.oecd.org/regreform/indicators. See StatLink for country-specific data. 


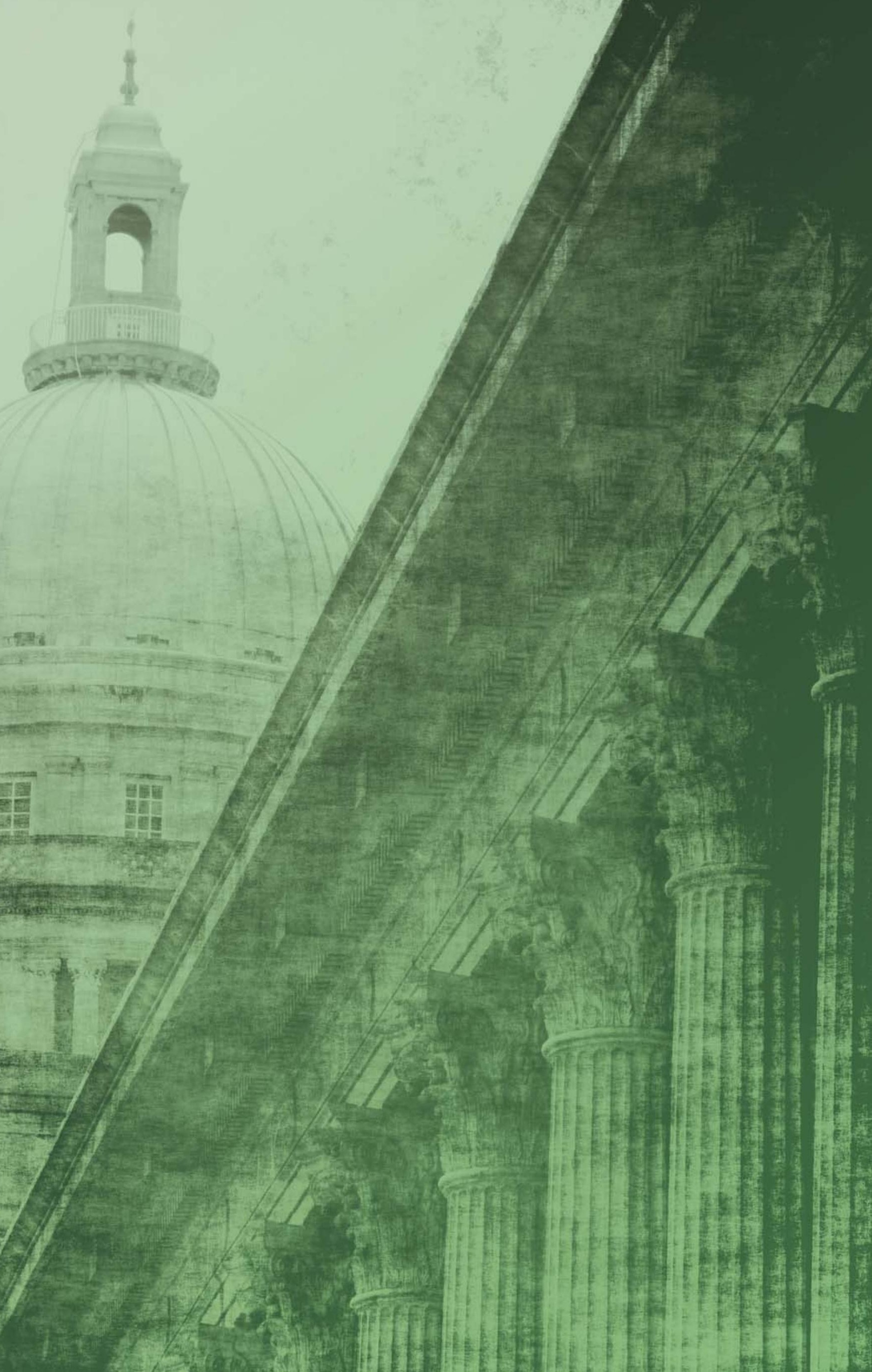




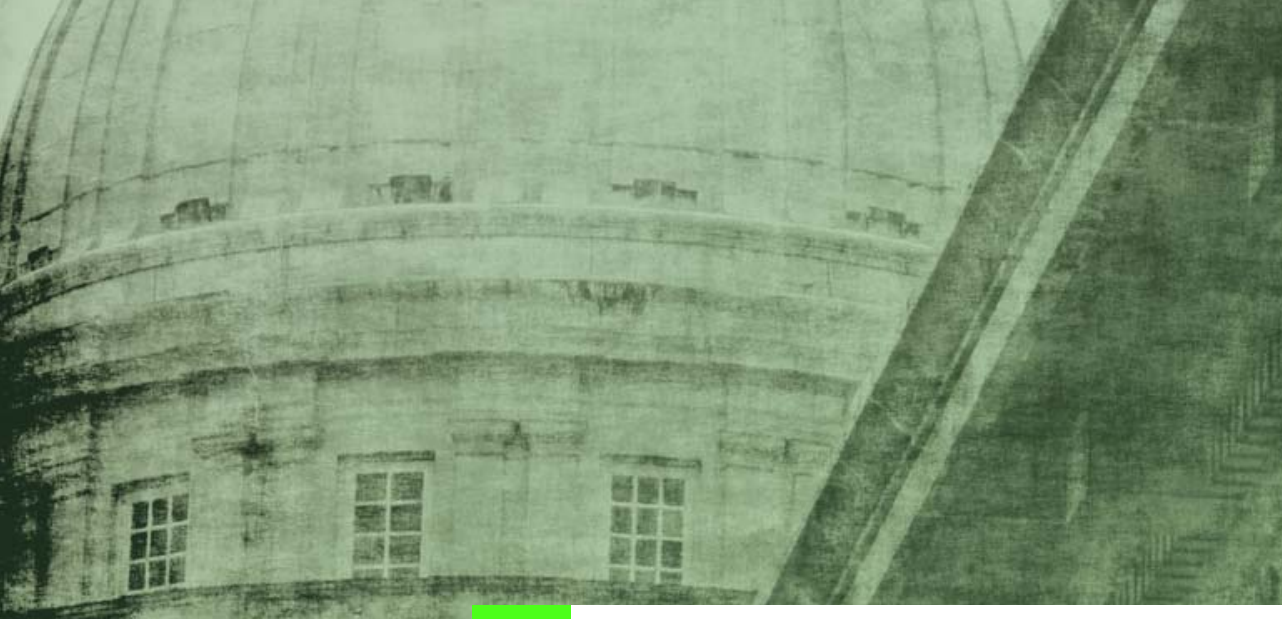

\section{WAYS OF DELIVERING PUBLIC SERVICES}

High-performing public services are fundamental to the functioning of the economy and citizens' well-being. However, many governments currently find themselves in a context of fiscal austerity requiring that they reduce costs while at the same time address structural changes which put additional strain on resources (e.g. ageing populations). In response, many OECD governments are relying on the use of new technologies choosing increasingly to outsource the delivery of public services to the private or non-profit sectors, or incorporating citizens and non-government stakeholders in service design and delivery. Over time, governments' role and approach to service delivery may change. Nevertheless, in the eyes of citizens and businesses, their capacity to deliver high-quality public services which respond to diversified needs and expectations will remain a key dimension by which their performance is judged.

In addition to expenditures on government outsourcing, this chapter presents data on the use of e-government services by businesses and citizens. It discusses how the provision and uptake of online services can open access, enable more customised service delivery, increase convenience, and support the reorganisation of the back office in more cost-effective and efficient ways. Additionally, new data are included on delivery models based on service professionals and citizens working together in the design and delivery of public services. Such approaches have shown potential in terms of leading to better outcomes in the form of increased user satisfaction and reduced costs for the taxpayer, but also pose challenges in terms of accountability and risk management. 
Governments have turned to outsourcing as a way of accessing external expertise and delivering services more cost-effectively. Government outsourcing is measured as the size of expenditures on goods and services purchased by central, state and local governments. The level of total government outsourcing shows the role of governments in creating demand and, indirectly, employment in the nongovernment sector.

Governments can outsource the delivery of government services in two ways. First, they may purchase goods and services from the non-government sector in order to use them as inputs into their own supply chain (termed "intermediate consumption"). For example, this can occur when governments use private contractors to provide support services or perform back-office functions. Secondly, governments may decide to pay a firm to deliver goods or services directly to the end user (termed "social transfers in kind via market producers"). This may include the outsourcing of "mainline" functions previously conducted by government. Home care provided by the corporate sector or non-profit institutions is an example of this kind of outsourcing.

In 2009 , government outsourcing represented on average $10 \%$ of GDP in OECD member countries. Its importance, however, varies significantly across countries, ranging from $2.7 \%$ of GDP in Mexico to $19.4 \%$ of GDP in the Netherlands. From 2000 to 2009, the share of outsourcing in GDP increased on average 1.5 percentage points in member countries, with the Netherlands and Finland showing the largest increases during this period. On average this increase is due slightly more to the increase in the goods and services financed by government, although this varies across the OECD. For instance, in the Netherlands, there was an increase of about 4 percentage points in this component. Relatively higher expenditures in the goods and services financed by government in the Netherlands could be due, in part, to the country's system of scholastic grants as well as the country's mandatory health insurance system whereby the government subsidises individuals' purchase of coverage from private providers. The total size of government outsourcing as a share of GDP decreased slightly in Israel, Estonia, Australia and Poland between 2000 and 2009. In general, Nordic countries, as well as Switzerland and Estonia, rely less on non-profits or private institutions to provide services directly to end users. In these countries, over $75 \%$ of expenditures on outsourcing are for intermediate consumption. On the contrary, Belgium, Japan and
Germany rely more on the non-government sector to deliver services directly to households. In these three countries, this share of outsourcing ranged between $64 \%$ and $67 \%$ of total outsourcing expenditures in 2009.

\section{Methodology and definitions}

Data are derived from the OECD National Accounts Database based on the System of National Accounts (SNA), a set of internationally agreed concepts, definitions, classifications and rules for national accounting. In SNA terminology, general government consists of central, state and local governments, and social security funds.

The goods and services used by general government are the intermediate consumption component of government outsourcing, and include the procurement of intermediate products required for government production such as accounting or information technology (IT) services. The goods and services financed by government reflect social transfers in kind via market producers (including those that are initially paid for by citizens but are ultimately refunded by government, such as medical treatments refunded by public social security payments).

\section{Further reading}

OECD (2010), National Accounts at a Glance 2010, OECD Publishing, Paris.

\section{Figure notes}

Canada, Greece, Iceland, Israel, Mexico, the United Kingdom and the United States do not account separately for goods and services financed by general government in their National Accounts.

48.1: 2000 data for Turkey are not available. OECD33 does not include Turkey. Data for Australia, Japan, Korea, and New Zealand are for 2008 rather than 2009. Data for Mexico are for 2003 rather than 2000. Data for the Russian Federation are for 2008 rather than 2009, 2002 rather than 2000.

48.2: Data for Australia, Japan, Korea, New Zealand and the Russian Federation are for 2008.

Information on data for Israel: http://dx.doi.org/10.1787/888932315602. 


\subsection{Expenditures on general government outsourcing as a percentage of GDP (2000 and 2009)}

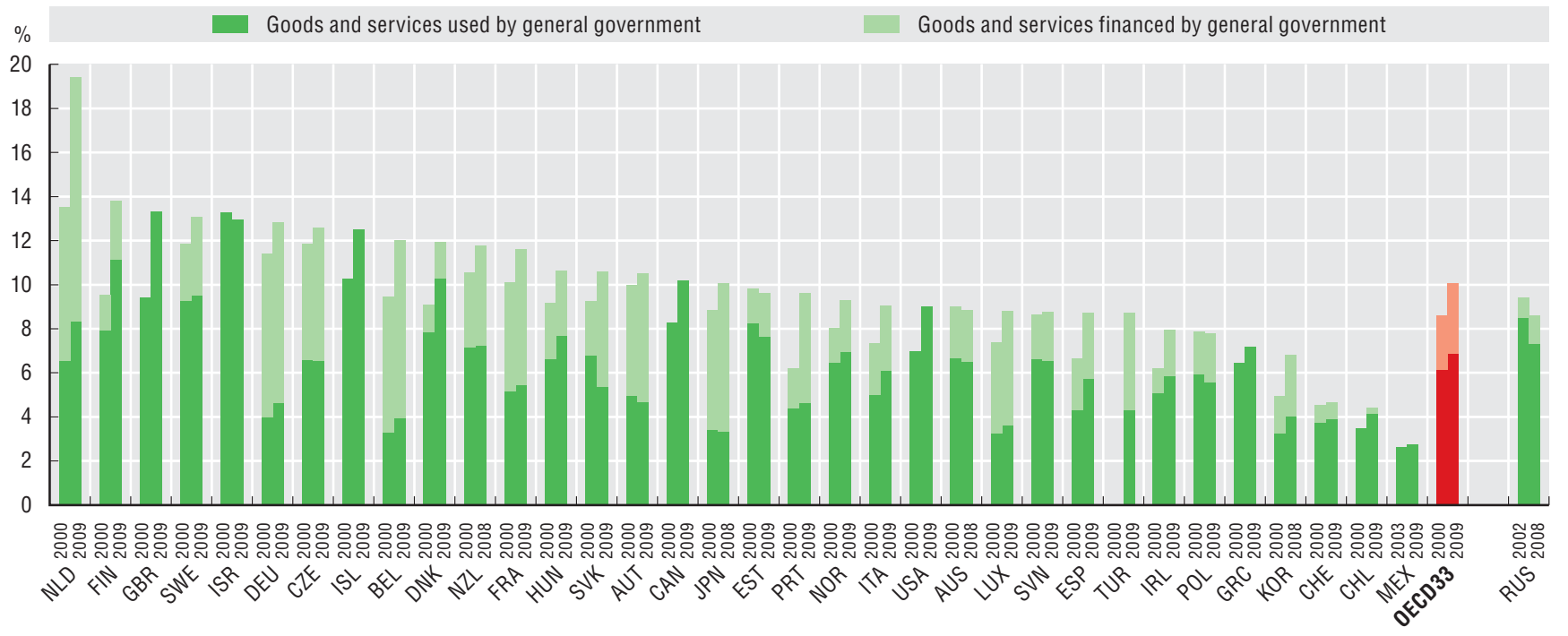

Source: OECD National Accounts Statistics. Data for Australia are based on a combination of Government Finance Statistics and National Accounts data provided by the Australian Bureau of Statistics.

StatLink काओs http://dx.doi.org/10.1787/888932391260

\subsection{Structure of general government outsourcing expenditures (2009)}

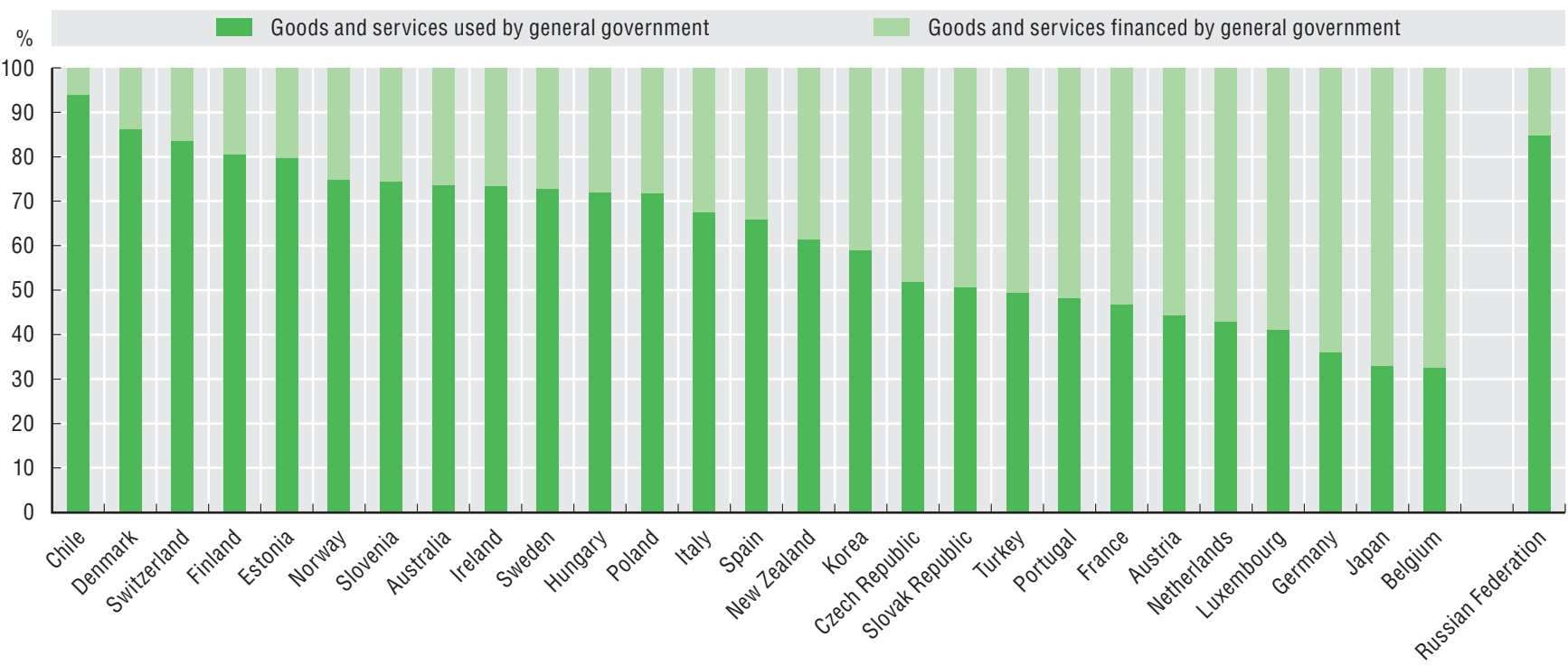

Source: OECD National Account Statistics. Data for Australia are based on a combination of Government Finance Statistics and National Accounts data provided by the Australian Bureau of Statistics. 
Citizens and businesses increasingly prefer and use digital channels to interact with governments. The online provision of public services increases access and provides greater convenience for users, while reducing costs for all involved, including governments. For these reasons, governments around the world invest significant resources in the delivery of online services, particularly in the current context of fiscal austerity when they are trying to do more with less. Ensuring the cost-effectiveness of these investments relies heavily on the uptake of e-government services by citizens and businesses.

Citizens' use of online services has increased in recent years in all OECD member countries monitored by the European Commission while businesses' use has grown in most of them except Greece, Iceland and Norway. Businesses are still taking better advantage of e-government services than citizens (on average, almost double the amount of citizens' use). The relatively higher uptake of online services by businesses may be explained by the fact that in most OECD countries at least three-quarters of businesses with ten or more employees are connected to high-speed broadband, and that many government programmes either provide incentives for businesses to interact with them electronically, or make the use of digital communications mandatory for them for certain transactions.

Citizens' uptake of e-government services remains lower than expected even in the best-performing countries. In general, older people and persons living in rural areas are less likely to utilise the Internet to interact with government. Data show that Ireland, Denmark and Slovenia had the highest increases in the past five years in individuals' e-government usage, with the Nordic countries maintaining leading positions in usage. In contrast, individuals in Italy and Turkey show the lowest increases in usage.

Because access to the Internet is a prerequisite for the use of online services, a key driver for e-government uptake is the penetration of broadband infrastructure, but it is not the only one. In fact, despite growing levels of broadband penetration (over $50 \%$ of OECD households have highspeed broadband connections), the usage of online services has not improved much over time. One possible explanation is that vulnerable segments of society are unable to utilise digital channels due to lack of awareness or IT skills. Another is that the online services offered are not always responsive to individuals' needs. Even for countries with high levels of e-government sophistication, understanding and addressing user needs, and expanding the possibilities for interacting with governments is pivotal to reach the desired levels of uptake.

National strategies foresee a mix of measures to increase the use of public services online. Many countries are exploring new venues and multiple channels for accessing online services, e.g. post offices in the United Kingdom, public libraries in the United States, digital television in Portugal, or banks and pharmacies in Italy. The continued expansion and improvement of broadband and wireless infrastructure, as well as the extension of e-government services to mobile platforms (m-government) could help increase the reach of e-government services. Furthermore, enhancing the use of online services requires the creation of incentives for citizens and business to embrace more e-government services (respecting the principle of equity in access), and the development of a marketing strategy to raise awareness of services and information digitally provided by governments.

\section{Methodology and definitions}

The indicators on citizen and business uptake of e-government services are based on data collected by Eurostat (for OECD member countries who are also members of the EU) and the OECD Directorate for Science, Technology and Industry (for the remaining OECD members). Both sources utilise the same indicators and questionnaire tools. The data are part of Eurostat's Information Society Statistics Database and the OECD's ICT Database which evaluate the share of citizens and businesses using the Internet to interact with public authorities. The e-government uptake by citizens' indicator measures the percentage of individuals (aged 16-74) who have used the Internet to interact with public authorities in the three months preceding the survey. Data are collected through Eurostat's annual Community Survey on ICT Usage in Households and by Individuals. The e-government uptake by business' indicator measures the percentage of enterprises using the Internet to interact with public authorities (only businesses with ten or more employees are included in the survey). Data are collected by national statistical offices based on Eurostat's annual Model Survey on ICT Usage and E-Commerce in Businesses.

\section{Further reading}

OECD (2009), Rethinking e-Government Services: User-Centred Approaches, OECD Publishing, Paris.

OECD (2010), Denmark: Efficient e-Government for Smarter Public Service Delivery, OECD Publishing, Paris.

\section{Figure notes}

49.1: 2005 data for Denmark, Germany, Spain and France refer to 2006; 2010 data for Iceland refer to 2009; 2005 data for Canada refer to 2007; 2005 data for New Zealand refer to 2006; 2005 data for Switzerland refer to 2004; 2005 data for Australia and the United States refer to 2003. 2010 data refer to 2007 in Mexico. 2010 data are unavailable for Canada, New Zealand, Switzerland, the United States, Japan and Australia and these countries are not included in the average.

49.2: 2005 data for Mexico refer to 2003. 2005 data for France, Luxembourg and Iceland refer to 2006; 2005 data for Turkey refer to 2007; 2010 data for Belgium, Luxembourg, and Finland refer to 2009; 2010 data for Korea refer to 2007. 2010 data unavailable for Mexico and Switzerland. 
49.1 Percentage of citizens using the Internet to interact with public authorities (2005 and 2010)

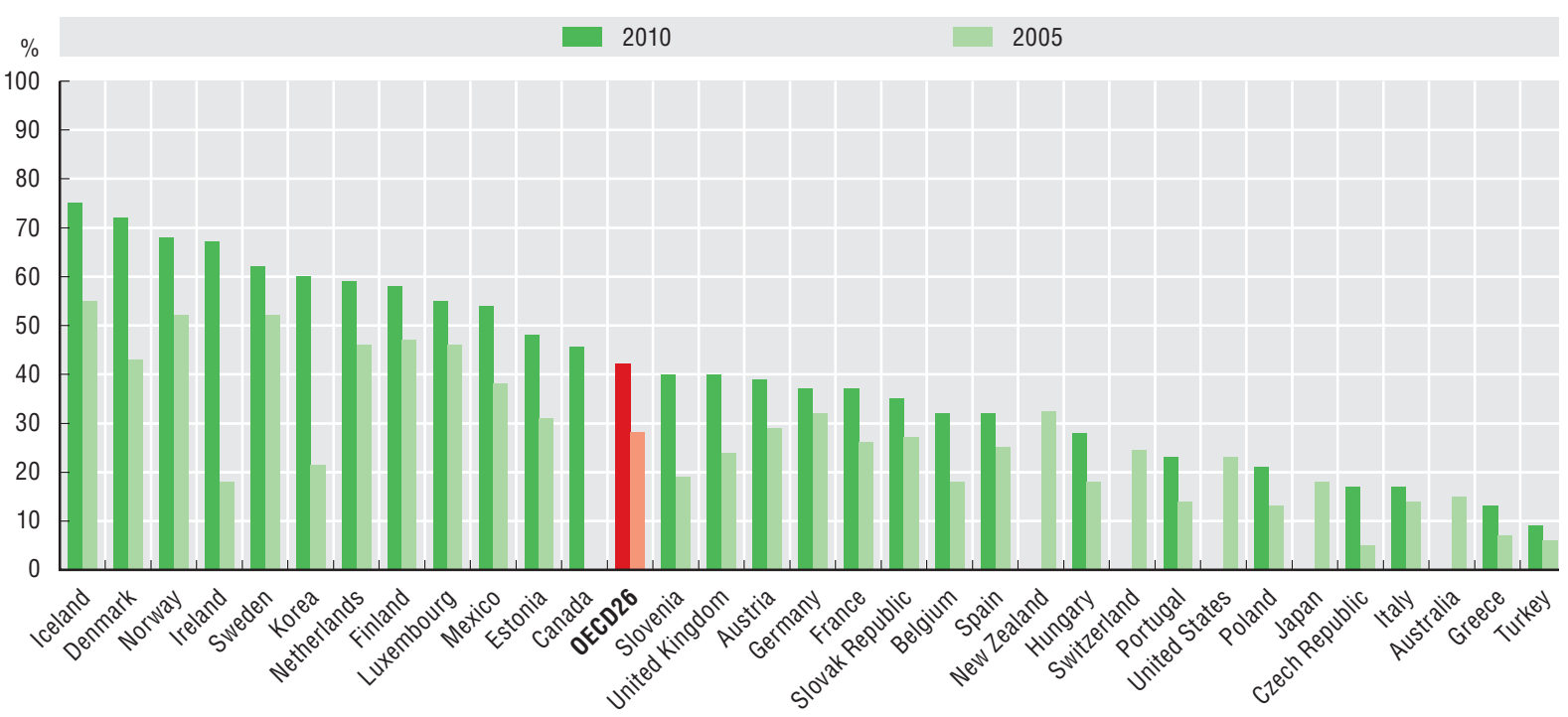

Source: Eurostat, Information Society Statistics Database and OECD, ICT Database and Korean Survey by Ministry of Public Administration and Security on ICT usage.

StatLink काISL http://dx.doi.org/10.1787/888932391298

\subsection{Percentage of businesses using the Internet to interact with public authorities (2005 and 2010)}

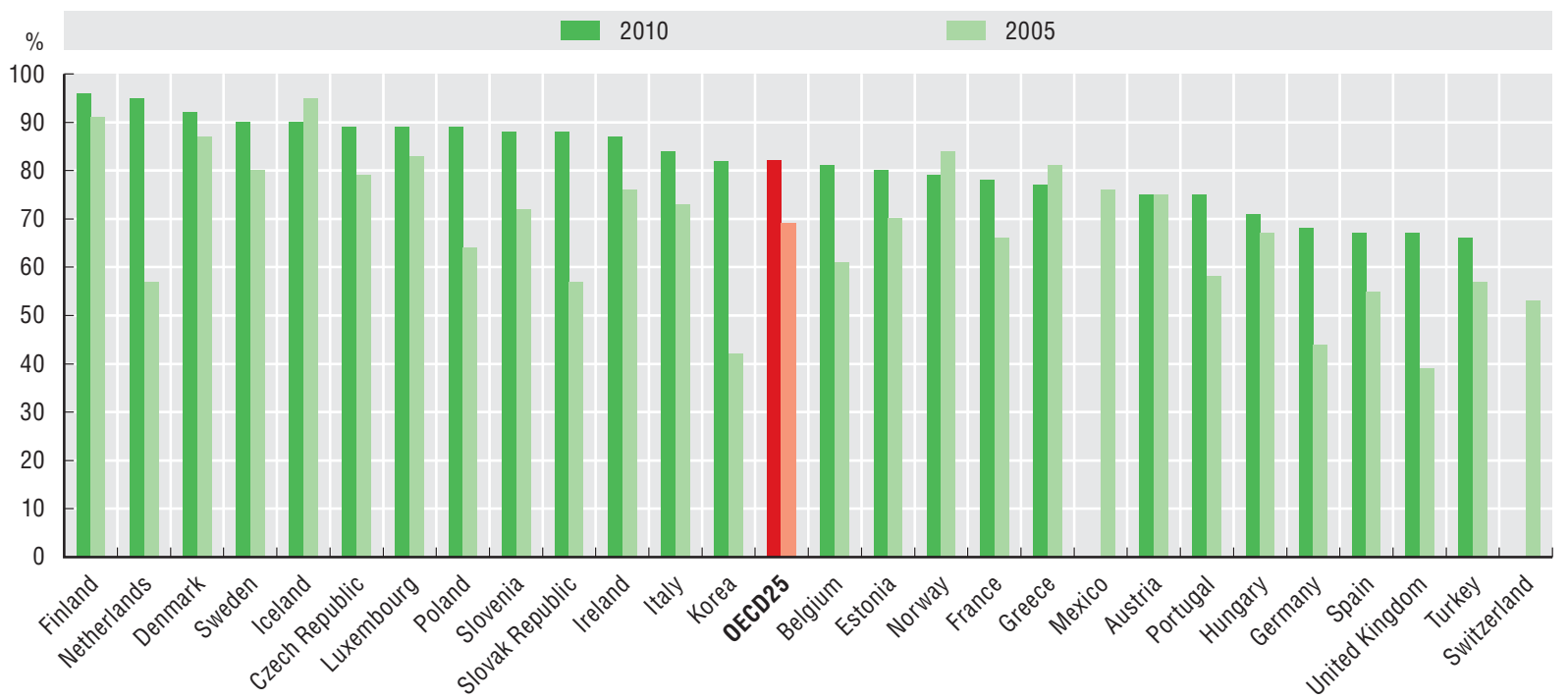

Source: Eurostat, Information Society Statistics Database and OECD, ICT Database and Korean Survey by Ministry of Public Administration and Security on ICT usage. 
Volunteer community groups partnering with local police to increase safety in their neighbourhoods; patients with chronic illnesses taking control over their health with the support of health-care professionals; young parents using online social networks supported by social workers to get guidance and share advice regarding their children's upbringing. These are all examples of user-centred collaborative approaches in service delivery (also referred to as "co-production") where citizens or service users design, commission, deliver or evaluate a public service in partnership with service professionals. In co-production, because at times users may take responsibility over the initiative for service development, the line between service delivery and policy making can be sometimes blurred.

In a time of increased budgetary pressure and growing demand for public services, these approaches can be a source of innovation leading to greater individual and community empowerment, increased user satisfaction and reduced production costs. The results of an OECD survey on service delivery indicate that for the majority of OECD countries that have adopted some forms of co-production, the objectives being primarily to increase the involvement of citizens and achieve better quality service delivery (60\%) rather than to reduce costs $(23 \%)$.

However, despite an increased focus by OECD countries on user-centricity, co-production as a form of service delivery remains developmental. Indeed, the majority of member countries have some experiences of co-production in one or more public service categories, but few of them (e.g. Canada, Norway, the United States, Finland, and the United Kingdom) have gone beyond piloting this approach to embed these schemes in the delivery of some public services.

Governments face several barriers to adopting co-production as a means of service delivery. A shortage of resources (42\%), organisational resistance to change (36\%), and lack of financial incentives (31\%) are the most frequent obstacles identified by government officials. Additionally, there is still limited understanding and measurement by governments of the benefits and costs of co-production schemes, as also reflected by the scarce development of standardised business cases; $29 \%$ of respondents from OECD countries reported that they lacked evidence of the potential benefits of co-production.

Survey results suggest that the implementation of co-production may require a set of changes within public service delivery organisations. Leadership and commitment from senior public officials and the willingness to engage with users and citizens are identified as the top two levers leading to effective citizen and user input in service delivery. Clear accountability and financial frameworks (73\% of respondents) are also identified as a critical factor of success, especially in more complex forms of co-production involving resource transfers to service users (e.g. self-directed budgets). Finally, as co-production alters the professional roles and responsibilities of traditional service providers, new skill sets and competencies for service professionals may need to be introduced across services.

\section{Methodology and definitions}

Co-production can be defined as a way of planning, designing, delivering and evaluating public services, drawing directly from citizens and/or civil society organisations. Co-production schemes represent a step forward from simple forms of citizen involvement (e.g. consultation and feedback on service quality) towards a more in-depth and systematic association of citizens, service users and non-government organisations. These actors are invited to contribute their own resources (e.g. time, knowledge and efforts) in the design and delivery of public services. Co-production is also distinct from common contractual practices (such as outsourcing), as it refers to an undefined and rather unspecified invitation to contribute to the service delivery process as opposed to a contractual agreement with specific organisations to perform an activity for the government. When analysing the use of co-production, countries' own internal systems for service delivery need to be taken into account, as do different contexts for public engagement.

Data were collected through the 2010 OECD Survey on Innovation in Public Services. Central government officials responsible for service delivery responded to the survey. Respondents in 20 OECD member countries replied to the survey. Government officials in Brazil, Egypt, the Russian Federation and Ukraine also completed the survey.

Many different agencies or organisations within the central government contributed to answering the survey. The percentages in the figures refer to the sum of the affirmative responses to each of the question items for all respondents in each country divided by the total number of responses to this question for all countries. Thus, $100 \%$ would indicate that all respondents in all countries answered affirmatively to this question for all service categories.

\section{Further reading}

OECD (2009), Focus on Citizens: Public Engagement for Better Policies and Services, OECD Publishing, Paris.

OECD (forthcoming), Partnering with Citizens and Civil Society for Innovative Service Delivery, OECD Publishing, Paris. 


\subsection{Reasons for partnering with citizens in public services delivery (2010)}

$\%$ of all respondents for all service categories

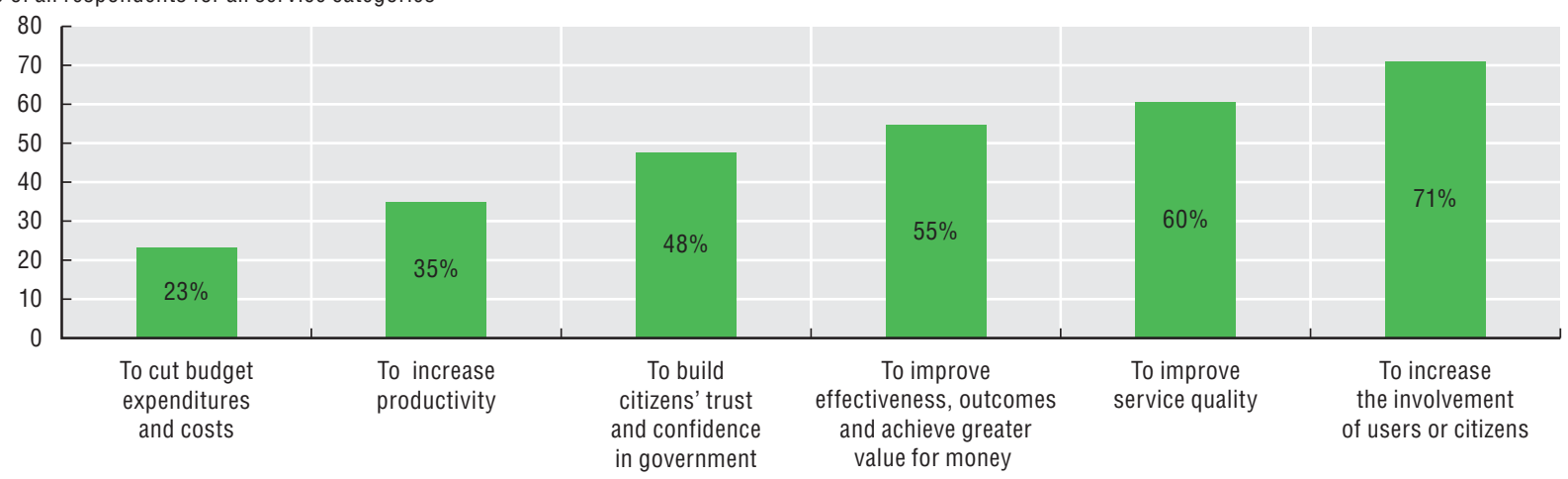

Source: 2010 OECD Survey on Innovation in Public Services.

50.2 Barriers to partnering with citizens in public services delivery (2010)

$\%$ of all respondents for all service categories

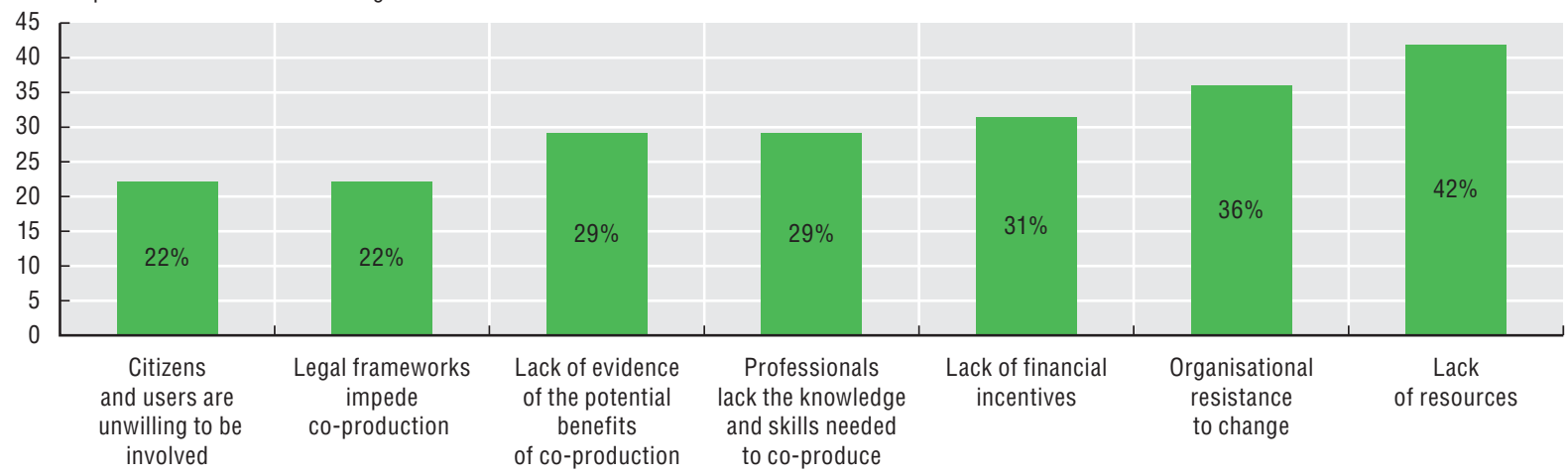

Source: 2010 OECD Survey on Innovation in Public Services.

50.3 Factors leading to effective partnership with citizens in public services delivery (2010)

$\%$ of all respondents for all service categories

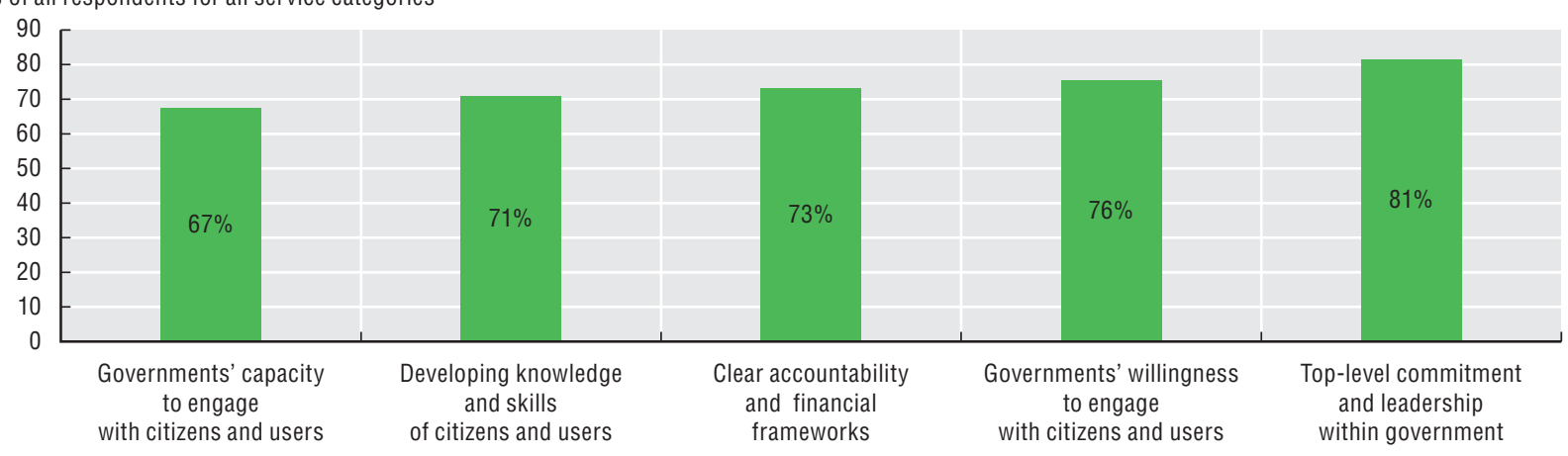

Source: 2010 OECD Survey on Innovation in Public Services. 


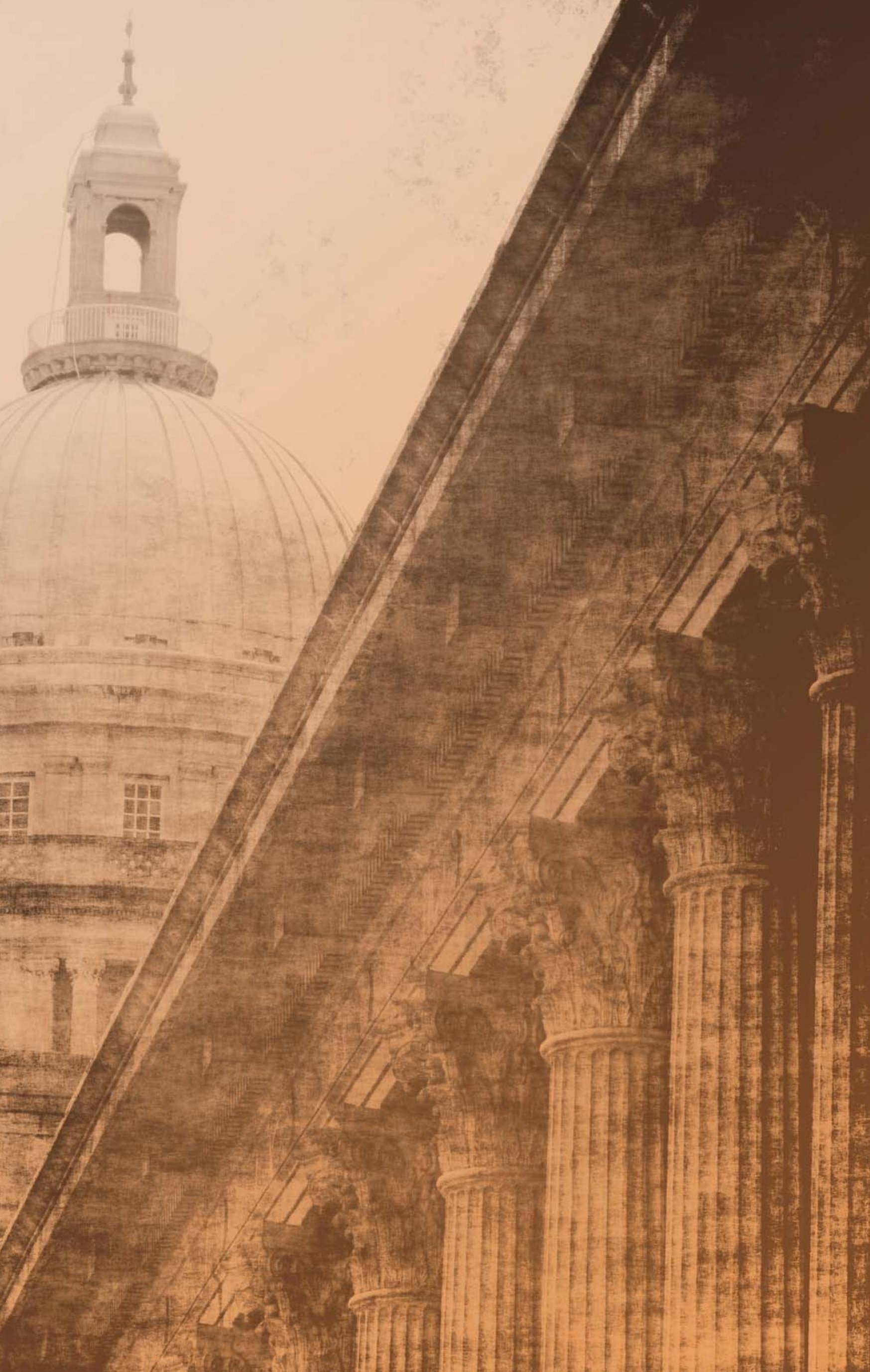




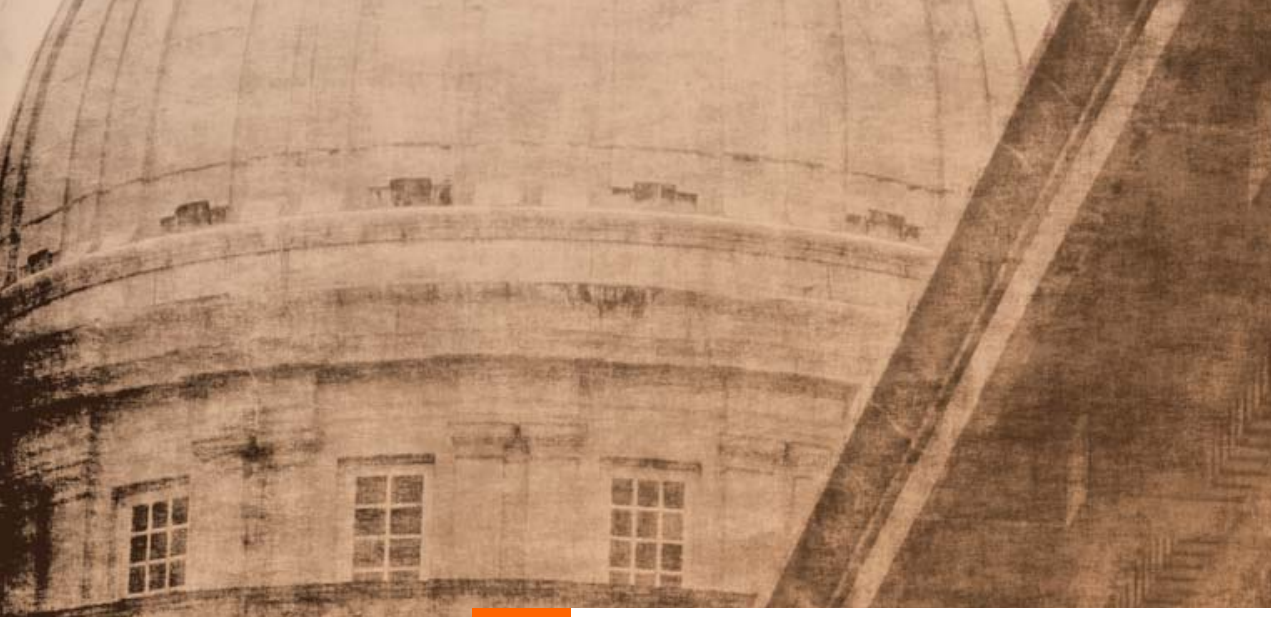

\section{GOVERNMENT PERFORMANCE INDICATORS FROM SELECTED SECTORS}

One of the main goals of governments is to achieve a better-performing public sector. High performing public services are important for maintaining economic competitiveness and improving societal well-being. In addition, citizens and businesses want to know that their taxes are used efficiently to provide quality services.

This chapter first looks at the equity objectives pursued by governments in their redistributive policies, comparing the role of governments in reducing income inequality across OECD countries. Next, it presents data on access to services and includes output and outcome measures for two policy sectors: education and health. These services are of special interest to those benchmarking government performance, as they are fundamental to the economic and physical well-being of citizens and to society. Furthermore, these sectors constitute large ticket items in terms of government expenditures; the efficiency and effectiveness of education and health systems are of major consequence to taxpayers and governments alike. Finally, while government tax revenues and tax structures have already been described by Indicators 2 and 3, the efficiency of tax administrations is examined in this chapter. Indicators such as the average cost incurred to raise a given amount of revenue are presented for member countries, offering an example of how to systematically measure the efficiency of a key government function.

This chapter relies on data that have already been published in other OECD and "at a Glance" publications. By bringing selected input, process, output and outcome indicators together for some key sectors it shows how critical it will be to work horizontally to advance in the fields of evaluation and governance. 
One important responsibility of governments is ensuring that the benefits of economic growth and development are shared across society. Income inequality in the population increased in almost two-thirds of OECD countries between the mid-1980s and mid-2000s. There is no agreement, however, on how much equality or inequality in income distribution is "optimal". Complete equality in the distribution of economic resources is neither attainable nor beneficial in terms of economic growth, and non-market mechanisms for income redistribution can reduce incentives to work and save. On the other hand, more unequal countries generally have higher poverty rates and worse aggregate educational and health outcomes, and higher levels of inequality can threaten long-term growth prospects.

Most OECD countries operate social protection systems aimed at reducing inequality via a mix of redistribution between rich and poor, income maintenance or insurance in the face of adverse risks (unemployment, disability, sickness), and redistribution across the lifecycle, either to periods when individuals have greater needs (e.g. when there are children in the household) or would otherwise have lower incomes (such as in retirement). The main features of social protection systems are cash transfers and progressive taxes. In-kind public expenditures on education and health are also important policy instruments for reducing inequality.

In 2007 , cash transfers constituted some $11 \%$ of GDP on average. In-kind transfers for health and education represented $6 \%$ and $5 \%$ of GDP, respectively. Nordic countries spend most on in-kind transfers while countries such as Austria, Italy and Poland rely more heavily on cash transfers.

Except for Chile, most OECD countries have a progressive income tax system to a certain extent, with Poland and Estonia differentiating less between income levels than countries such as Ireland and Israel. The effect of government tax and transfer policies on inequality can be assessed by looking at the Gini coefficient before and after taxes and transfers. By this measure, Belgium achieves the most redistribution (a reduction of about $45 \%$ ), while Chile achieves the least (less than $2 \%$ ).

\section{Methodology and definitions}

The main indicator of income distribution used is the Gini coefficient. The values of the Gini coefficient range between 0 , in the case of "perfect equality" (i.e. each share of the population gets the same share of income), and 1, in the case of "perfect inequality" (i.e. all income goes to the individual with the highest income). Redistribution is measured by comparing Gini coefficients for market income (i.e. gross income including public cash transfers and household taxes) and for disposable income (i.e. net of transfers and taxes).

The tax data, derived from the OECD Taxing Wages framework, use tax rates applicable to the tax year. For Australia, New Zealand and the United Kingdom, the tax year is not the calendar year. The data show the difference between two scenarios: a single person without dependents earning $67 \%$ of the average wage, and a single person without dependants earning $167 \%$ of the average wage. The average rates are expressed as a percentage of gross wage earnings. Average wage (in national currency), measures the average annual gross wage earnings of adult, full-time manual and non-manual workers in the industry.

\section{Further reading}

OECD (2008), Growing Unequal? Income Distribution and Poverty in OECD Countries, OECD Publishing, Paris.

OECD (2011), Society at a Glance 2011: OECD Social Indicators, OECD Publishing, Paris.

OECD (2011), Taxing Wages 2010, OECD Publishing, Paris.

\section{Figure notes}

51.1: Data on education services for Greece, Luxembourg and Turkey are for 2005. Expenditures on other social services, health and education represent in-kind transfers. The following services are included in cash transfers and other social services: assistance to the elderly, survivors, disabled persons, families and the unemployed, as well as those related to housing and social assistance.

51.2: The difference for Chile is $0.1 \%$.

51.3: Before and after data are unavailable for Greece, Israel, Estonia, Hungary, Mexico, Slovenia, Spain and Turkey.

Information on data for Israel: http://dx.doi.org/10.1787/888932315602. 
51.1 Public expenditure for in-kind and cash transfers as a percentage of GDP (2007)

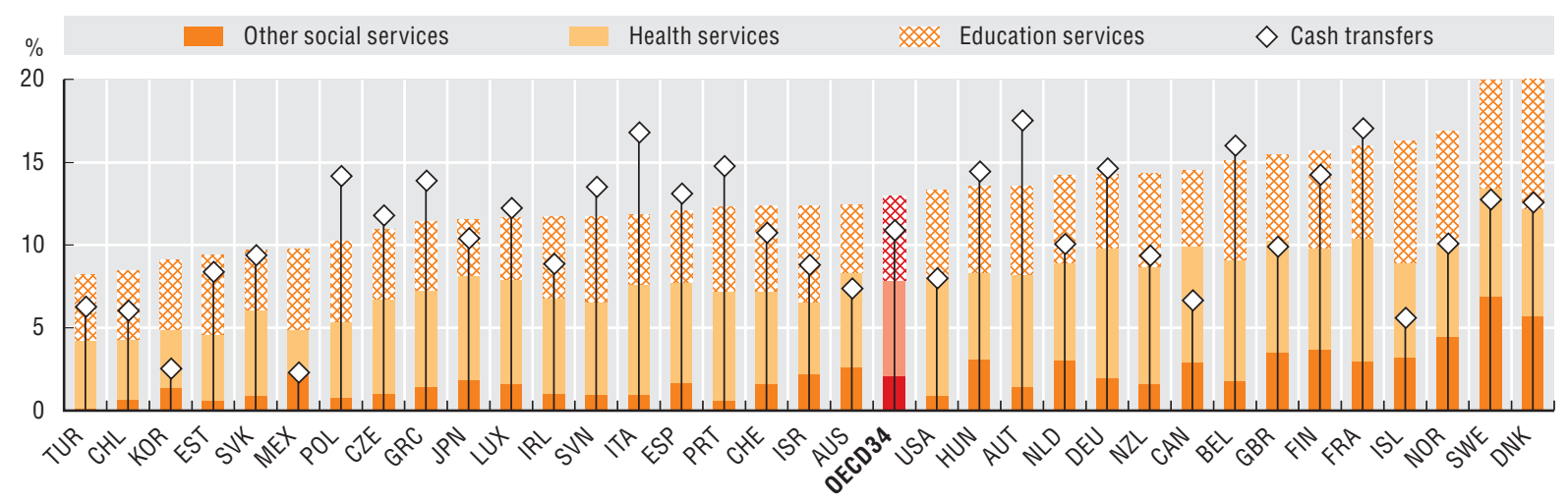

Source: OECD Social Expenditure Database (www.oecd.org/els/social/expenditure) and OECD Education Database (www.oecd.org/education/database). StatLink Aists http://dx.doi.org/10.1787/888932391393

\subsection{Difference between average tax rate on single persons earning $167 \%$ and $67 \%$ of average earnings (without dependents) (2010)}

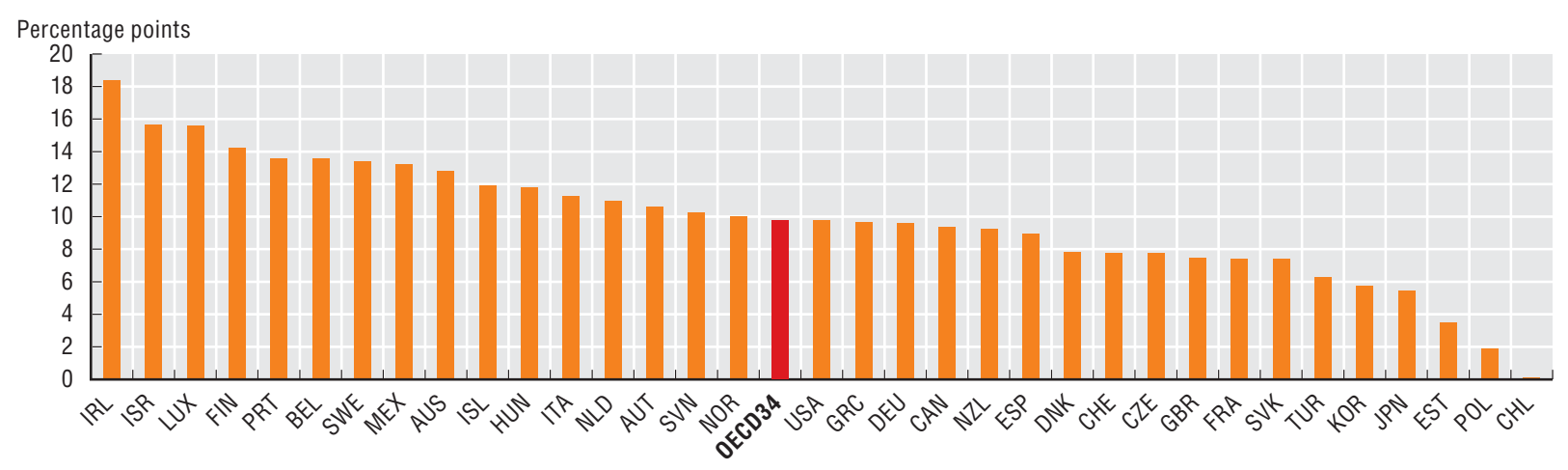

Source: OECD (2011), Taxing Wages 2010, OECD Publishing, Paris.

StatLink 에s http://dx.doi.org/10.1787/888932391412

51.3 Differences in income inequality pre- and post-tax and government transfers (mid-2000s)

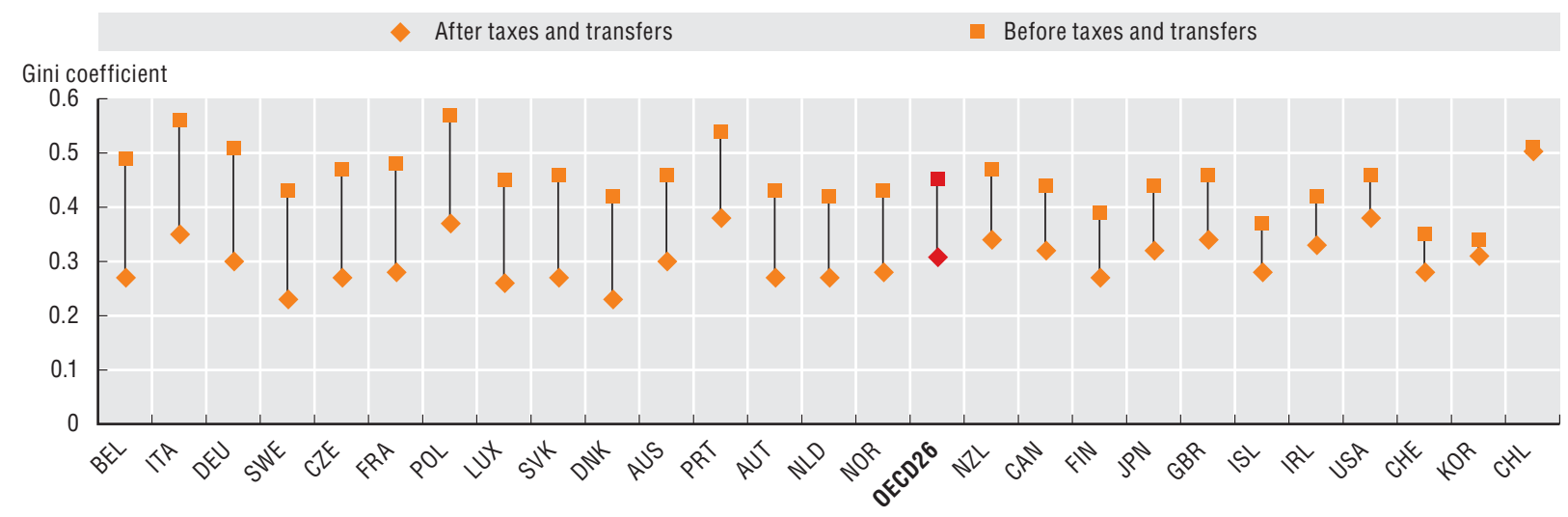

Source: OECD (2008), Growing Unequal? Income Distribution and Poverty in OECD Countries, OECD Publishing, Paris.

StatLink ताISt http://dx.doi.org/10.1787/888932391431 
The long-term social and financial costs of educational inequalities can be high, as those without the competencies to participate in society fully may not realise their potential and they are likely to generate higher costs for health, income support, child welfare and security. For these reasons, governments have a vested interest in reducing disparities in access to education, including those based on geography (e.g. distance) or socio-economic status.

In trying to provide students with equitable learning opportunities, education systems aim to reduce the extent to which a student's socio-economic background affects his or her performance in school. On average across OECD countries, $14 \%$ of the variation in students' reading performance can be explained by their socio-economic backgrounds. Students with more socio-economically advantaged backgrounds generally perform better. Across OECD countries, this advantage averages to 38 score points in reading for each increase of one standard deviation in socio-economic background, which is roughly equivalent to one year's worth of schooling. However, in Korea and Finland, the OECD countries with the highest reading performance, the link between student background and performance is weaker than on average, suggesting that equity and performance are not opposing or impossible policy objectives.

In some countries, the size or location of the community in which a school is located is strongly related to student performance. The variation in performance reflects differences in educational opportunities available in rural and urban areas, and the characteristics of these locations, such as population density, distribution of labour markets, and the extent to which urban and suburban areas are sought and populated by individuals from different backgrounds. In large communities or densely populated areas, more educational resources may be available for students. Isolated communities might need targeted support or specific educational policies to ensure that students attending schools in these areas reach their full potential. Across OECD countries, students in urban schools score an average of 23 points higher in reading than students in other areas, even after accounting for socio-economic background. The difference is the largest in Hungary, where 15 -year-olds in city schools are at least one proficiency level ahead of those in rural schools. The performance gap between students living in urban and rural areas is at least half a proficiency level in Chile, the Czech Republic, Italy,
Mexico, Portugal, the Slovak Republic, Slovenia and Turkey. School location and student performance, however, are not strongly related after accounting for socio-economic differences in Belgium, Finland, Germany, Greece, Iceland, Ireland, Israel, the Netherlands, Poland, Sweden, the United Kingdom and the United States.

\section{Methodology and definitions}

Socio-economic background is measured according to the PISA index of social, cultural and economic status, which is based on information, provided by students, about their parents' education and occupations and their home possessions. On this index, one "unit" is equivalent to one standard deviation across all OECD students meaning that across all OECD countries, about two-thirds of students are from a socioeconomic background that is one unit above and one unit below the average.

The achievement scores were based on assessments of 15-year olds administered as part of the OECD's PISA programme, which focussed on reading in 2009.

\section{Further reading}

OECD (2010), Education at a Glance 2010: OECD Indicators, OECD Publishing, Paris.

OECD (2010), PISA 2009 Results: Overcoming Social Background - Equity in Learning Opportunities and Outcomes, Vol. II, OECD Publishing, Paris.

\section{Figure notes}

52.1: Values that are statistically significantly different from the OECD average are indicated in dark orange.

52.2: Data are not available for France. Countries are ranked in descending order of the average performance of students in cities (cities and large cities). For Korea, only two schools are represented in the "village hamlet or rural area" category, and the results cannot be generalised.

Information on data for Israel: http://dx.doi.org/10.1787/888932315602. 


\section{GOVERNMENT PERFORMANCE INDICATORS FROM SELECTED SECTORS}

52.1 Average reading score point difference associated with socio-economic background (2009)

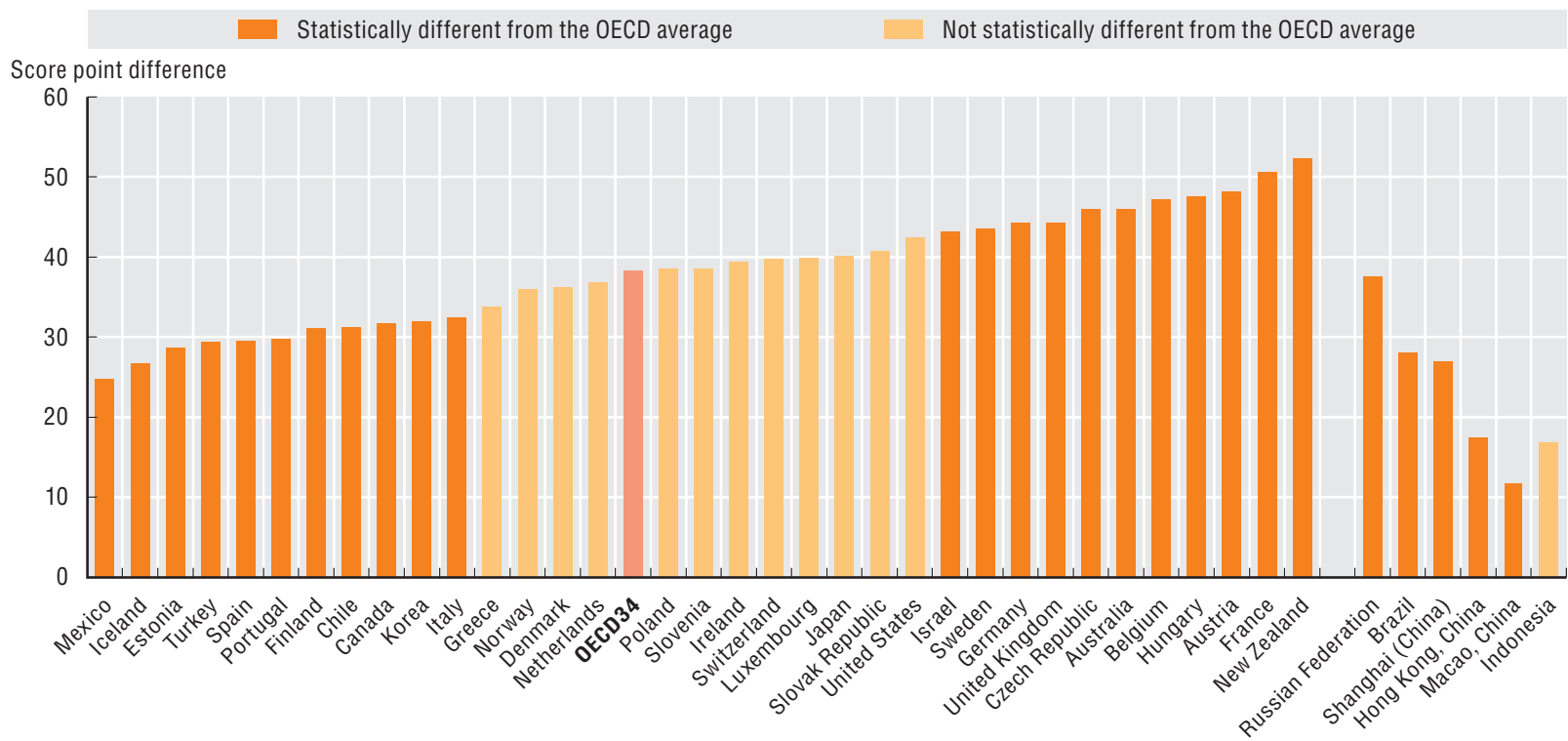

Source: OECD, PISA 2009 Database, Table II.3.2.

\subsection{Reading performance, by school location (2009)}

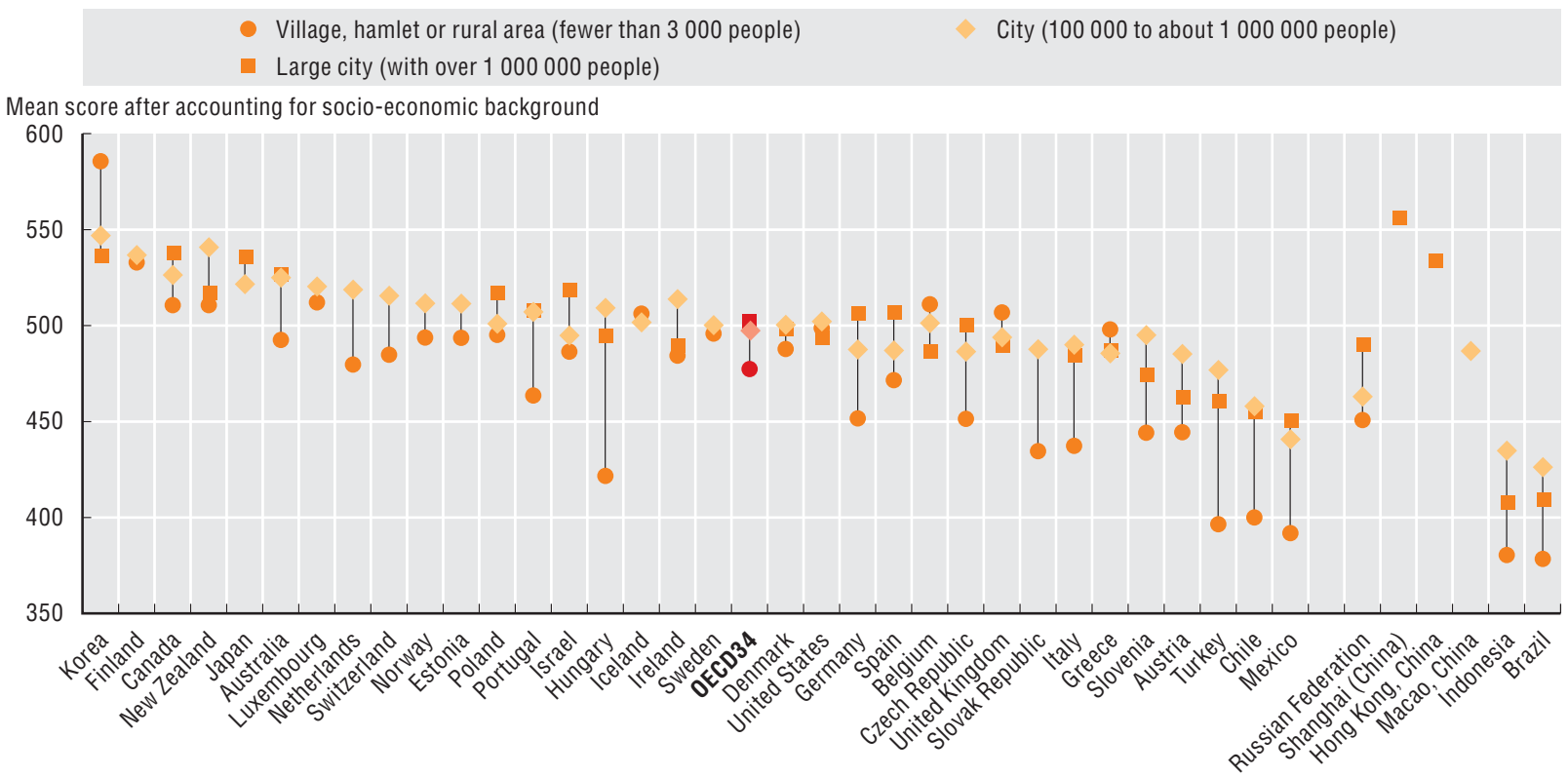

Source: OECD (2010), PISA 2009 Results: Overcoming Social Background - Equity in Learning Opportunities and Outcomes, Vol. II, OECD Publishing, Paris, Figure II.2.6. 
Education systems are integral to ensuring that countries have a strong, skilled workforce and an active citizenry to engage in democratic governance. Graduation rates and levels of educational attainment provide good measures of what education systems are producing.

Graduating from university (tertiary-type A) programmes is increasingly important in the OECD for individuals to find employment. On average, over $60 \%$ of students graduate from upper secondary school programmes oriented towards entering into type A tertiary education. Yet, just over half (56\%) of these students actually go on to enter into tertiary-type A. In countries such as Ireland, France, Estonia and Belgium, the gap between those who graduate with an upper secondary education and enrol in university is more than 30 percentage points, suggesting that some people who could go on to university do not do so. Factors such as mandatory military service or the prevalence of vocationally-oriented tertiary education account for some of the gap. In Australia and New Zealand, the higher tertiary entry rates relative to upper secondary graduation rates can be explained partly by the large presence of international students.

Tertiary university entry rates, however, do not show how many students complete tertiary education. Education levels amongst the adult population, especially over time or between age groups, provide a better indication of the human capital or skills available in a population or labour force and whether these are improving over time or not. Tertiary attainment levels have increased considerably over the past 30 years. In almost all countries, 25-34 year-olds have higher tertiary attainment levels than the generation about to leave the labour market (55-64 year-olds).

Examining the relationship between education resources invested and learning performance according to standardised international assessments provides some insight into which systems can achieve the best student performance given the inputs used. There is a positive relationship between expenditures on primary and secondary education per student and reading test scores, but not a strong one. In addition to expenditures, learning outcomes depend on the quality of teachers, socio-economic backgrounds of students and school management practices, among other factors. Countries such as Korea, New Zealand and Finland spend less than average per student, however attain relatively better performance in reading. Austria, Italy and Luxembourg spend more yet performance is lower than average.

\section{Methodology and definitions}

Upper secondary graduation rates (ISCED 3A) are net graduation rates, which represent the estimated percentage of the age cohort that will complete education at those levels. The entry rate into tertiary-type A education for a specific age is calculated by dividing the number of first-time entrants of that age by the total population in the corresponding age group.

Data on expenditures per student refer to the 2007 financial year and are based on data collection on education statistics administered by the OECD in 2009. Expenditures include educational core services and ancillary services such as transport, meals, housing provided by institutions and R\&D. Spending per student equals the total expenditure by education institutions divided by the corresponding full-time equivalent enrolment. Due to differences across countries in the duration of courses, annual spending per student may not fully reflect the total spent on a student. See Chart B1.5 in Education at a Glance 2010 for additional estimations. The achievement scores were based on assessments of 15-year olds administered as part of the OECD's PISA programme, which focussed on reading in 2009.

\section{Further reading}

OECD (2010), Education at a Glance 2010: OECD Indicators, OECD Publishing, Paris.

\section{Figure notes}

53.1: Data on upper secondary graduation rates are not available for New Zealand, Portugal, the United Kingdom and the United States. For Australia, graduation rates refer to 2007. Austrian data include ISCED 4A programmes (Berufsbildende Höhere Schulen).

53.2: Data for the Russian Federation refer to 2002. See Annex 3 of Education at a Glance 2010 for a complete set of notes (www.oecd.org/edu/eag2010).

53.3: Data are not available for Greece and Turkey. Expenditure data for Canada refer to 2006 and for Chile refer to 2008. Expenditure data for Hungary, Italy, Luxembourg, Poland, Portugal, Slovenia, Switzerland, the Russian Federation and Brazil refer to public institutions only.

Information on data for Israel: http://dx.doi.org/10.1787/888932315602. 


\subsection{Access to tertiary-type A education for upper secondary graduates (2008)}

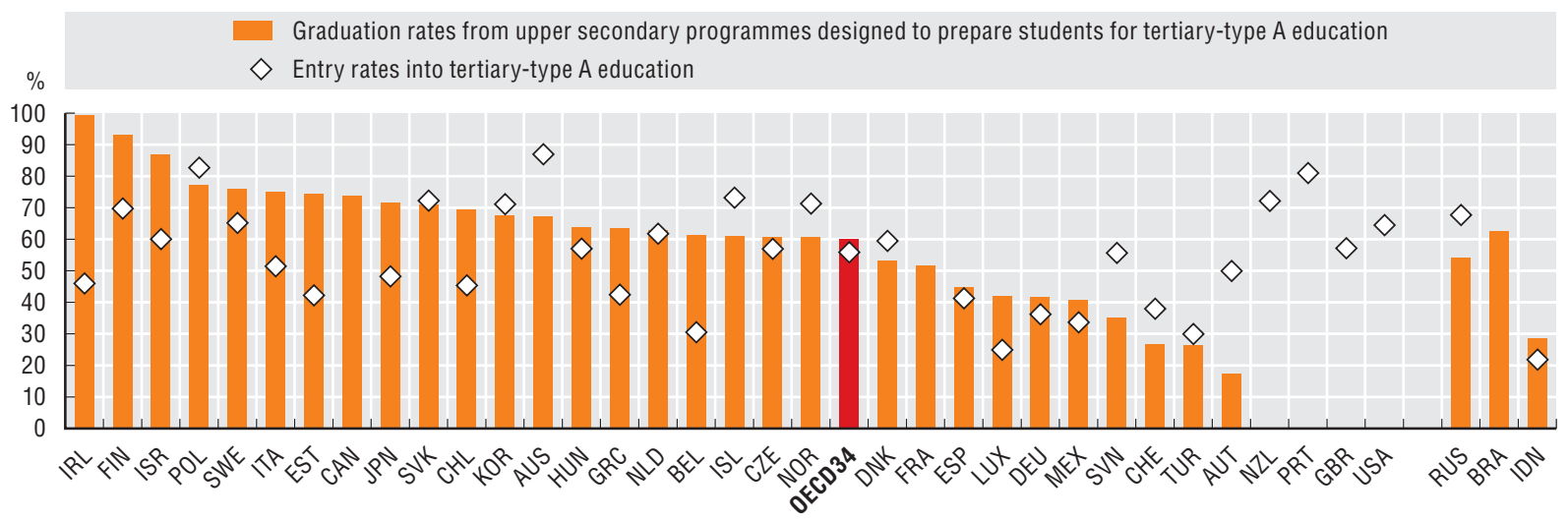

Source: OECD (2010), Education at a Glance 2010: OECD Indicators, OECD Publishing, Paris. Chart A2.2 based on Tables A2.1 and A2.3 (www.oecd.org/edu/eag2010).

53.2 Percentage of the population that has attained tertiary education (2008)

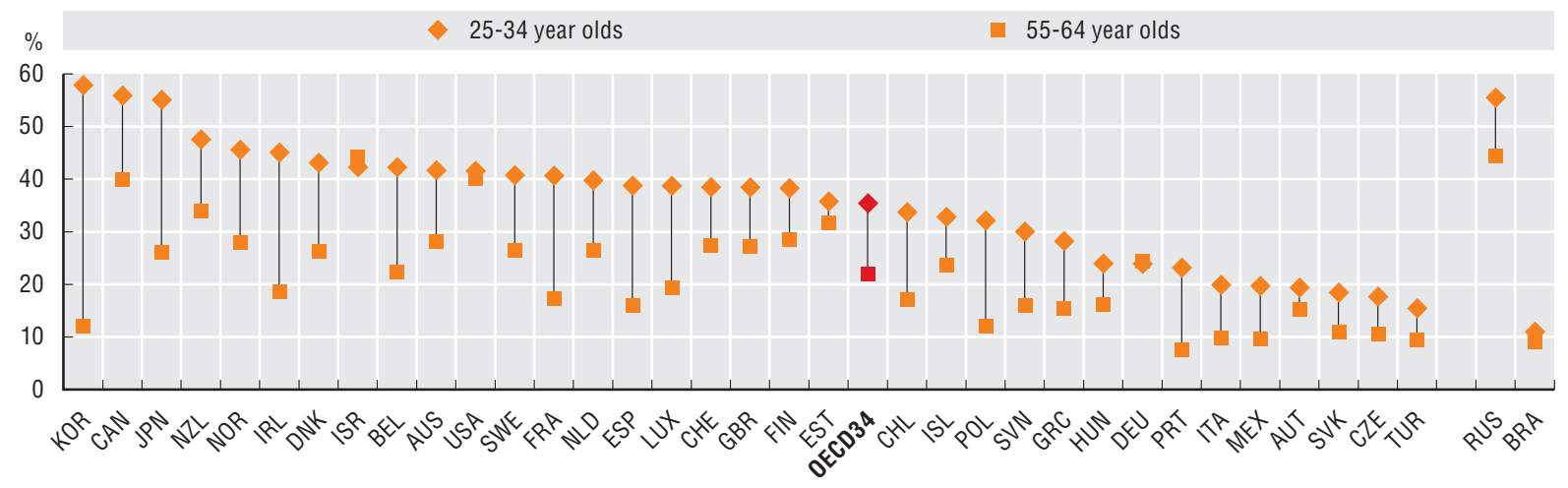

Source: OECD (2010), Education at a Glance 2010: OECD Indicators, OECD Publishing, Paris. Chart A1.1 and Table A1.3a.

StatLink तiाs http://dx.doi.org/10.1787/888932391507

\subsection{Performance in 2009 PISA reading and total cumulative expenditure per student for primary and secondary education in USD PPP (2007)}

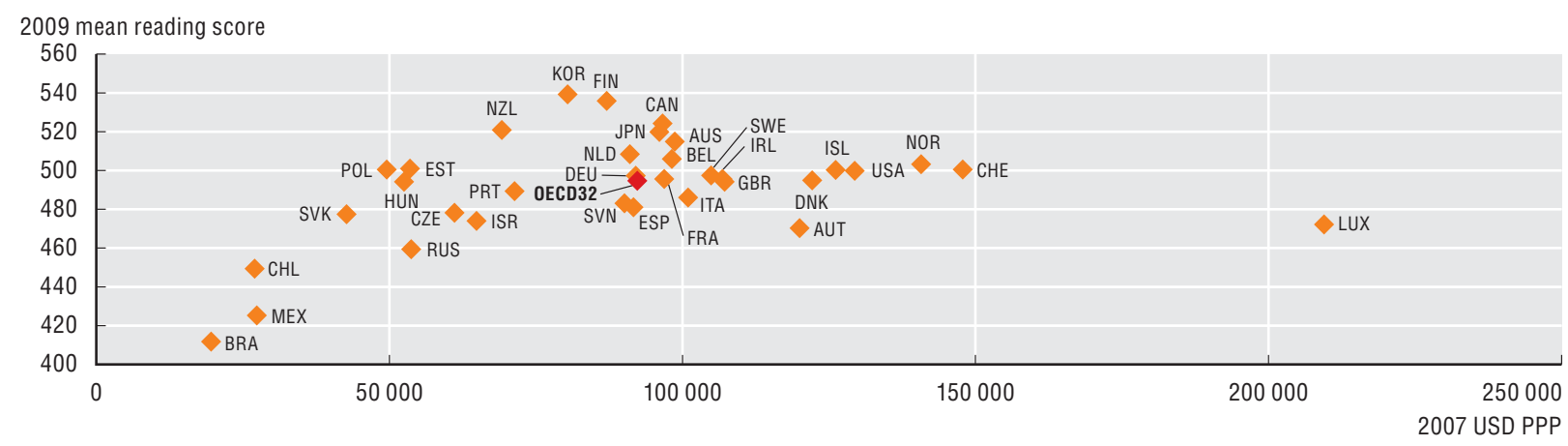

Source: OECD (2010), Education at a Glance 2010: OECD Indicators, OECD Publishing, Paris, Table B1.3a and OECD (2010), PISA 2009 Results: What Students Know and Can Do - Student Performance in Reading, Mathematics and Science, Vol. I, OECD Publishing, Paris, Table I.2.3. 
Key outcomes of education systems include increasing employment and raising the life-long earnings of individuals - which also brings net benefits for governments via increases in the revenue-base and lower public spending on unemployment insurance or other social assistance programmes.

The more education an individual has, the more likely he or she is to find employment. On average in OECD countries, $85 \%$ of the population with tertiary education is employed, compared to $76 \%$ of individuals with upper secondary and post-secondary non-tertiary education, and to $56 \%$ of those without an upper secondary education. In countries such as Belgium, the Czech Republic, Hungary, Israel, Poland, the Slovak Republic and Turkey, over half of those with less than an upper secondary education are unemployed.

Better employment prospects bring private economic benefits to individuals. The private net present value (NPV) of education refers to the economic returns acquired over an individual's working life, after considering the costs of attaining their education such as tuition fees and forgone earnings. Apart from the earnings differential, major components of the return to education are directly linked to public policy: access to education, the level of taxes and the costs of education for the individual. On average across OECD countries, the NPV of investing in tertiary education is USD 146000 for men. For upper secondary or postsecondary non-tertiary education, the NPV falls to USD 68000 . These high private returns suggest that education may need to be expanded by increasing access and by making loans more readily available to individuals, rather than lowering the costs of education.

Government and society also gain economic benefits from more schooling via additional revenues raised when more people enter the labour market and their earnings rise. On average across OECD countries, the net public return from investment in tertiary education (taking into account the cost to government of providing education) exceeds USD 86000 for a male student. This is almost triple the amount of public investment in tertiary education, and provides a strong incentive for governments to expand higher education. Germany, Belgium and Hungary attain the greatest public NPV from investing in upper secondary and tertiary education.

\section{Methodology and definitions}

The employment rate refers to the number of persons 25-64 years old in employment as a percentage of the population aged 25 to 64 . The employed are those who work for pay or profit for at least one hour a week, or who have a job but are temporarily not at work due to illness, leave or industrial action.

Educational attainment is measured according to the International Standard Classification of Education (ISCED 97): Upper secondary (Level 3), post-secondary non-tertiary (Level 4) and tertiary education (Levels 5 and 6).

The private and public economic returns to education for men are measured in terms of net present value. Private (lifetime) costs include after-tax foregone earnings adjusted for the probability of finding a job (unemployment rate) and direct private expenditures on education. Private benefits factor in gross earnings benefits as well as the unemployment effect. The discount rate is set at $3 \%$, which largely reflects the typical interest on an investment in long-term government bonds in an OECD country. Public costs include lost income tax receipts during the schooling years, and public expenditures related to tertiary education. The benefits for the public sector are additional tax and social contribution receipts associated with higher earnings, and savings from transfers (housing benefits and social assistance) that the public sector does not have to pay above a certain level of earnings.

\section{Further reading}

OECD (2007), Understanding the Social Outcomes of Learning, OECD Publishing, Paris.

OECD (2010), Education at a Glance 2010: OECD Indicators, OECD Publishing, Paris.

\section{Figure notes}

54.2: Countries are ranked in order of private NPV returns for upper secondary education. Data for Korea refer to 2003. Data for Spain refer to 2004. Data for Australia, Belgium and Turkey refer to 2005. Data are not available for Chile, Estonia, France, Greece, Iceland, Ireland, Israel, Japan, Luxembourg, Mexico, the Slovak Republic, Slovenia, Switzerland and the United States.

54.3: Countries are ranked in descending order of the public NPV returns for tertiary education. Data for Korea refer to 2003. Data for Ireland and Spain refer to 2004. Data for Australia, Belgium and Turkey refer to 2005 .

Information on data for Israel: $h$ ttp://dx.doi.org/10.1787/888932315602. 


\subsection{Employment rates by level of educational attainment (2008)}

- Tertiary education Upper secondary and post-secondary non-tertiary

- Below upper secondary

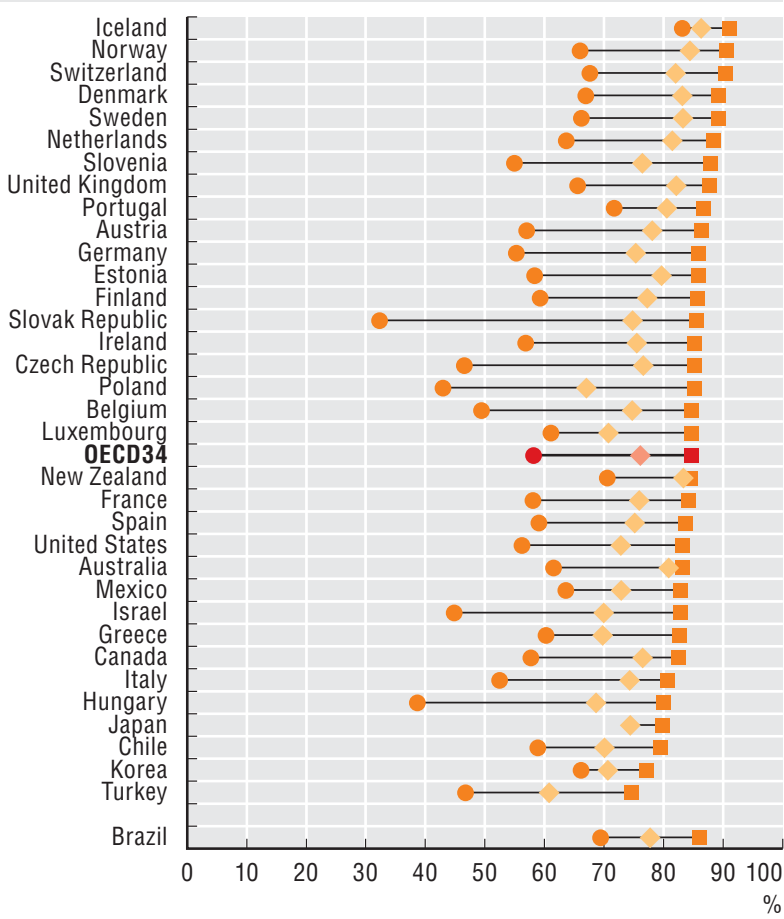

Source: OECD (2010), Education at a Glance 2010: OECD Indicators, OECD Publishing, Paris, Table A6.3a. See Annex 3 for notes, www.oecd.org/edu/ eag2010.

StatLink Aाs $h t$ ttp://dx.doi.org/10.1787/888932391545

\subsection{Cumulative private net present value for a male obtaining higher levels of education (2006)}
Upper secondary or post-secondary non-tertiary education Tertiary education

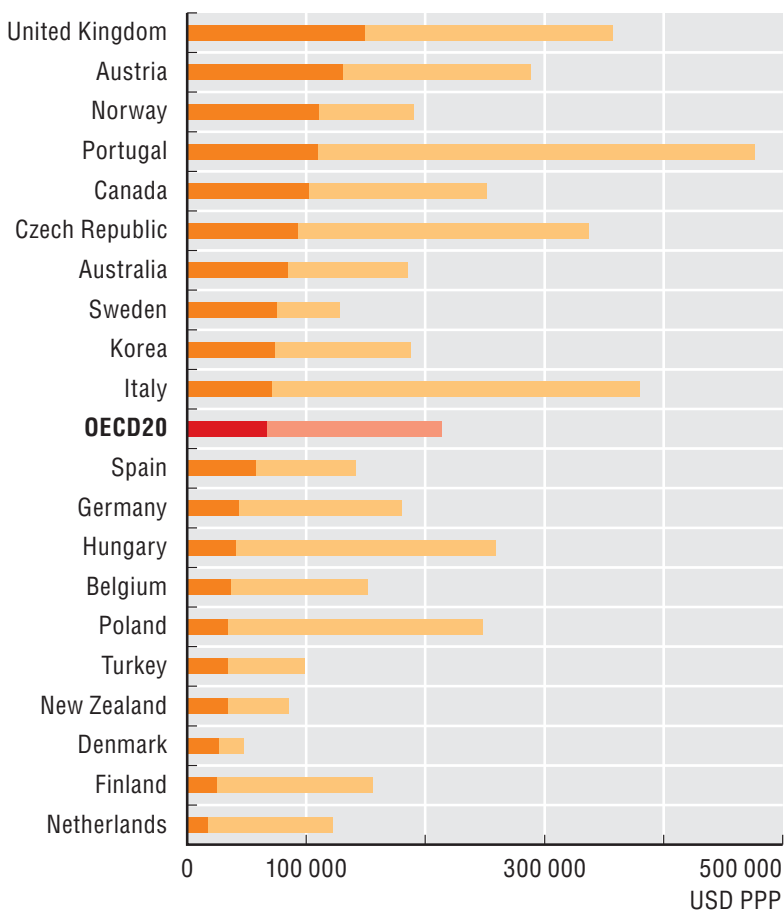

Source: OECD (2010), Education at a Glance 2010: OECD Indicators, Indicator A8, OECD Publishing, Paris. See Annex 3 for notes, www.oecd.org/ edu/eag2010.

StatLink काIsL $h t t p: / / d x . d o i . o r g / 10.1787 / 888932391564$

\subsection{Public net present value for a male obtaining upper secondary or post-secondary non-tertiary education and tertiary education (2006)}

Public benefits

Upper secondary or post-secondary non-tertiary education Net presen
value

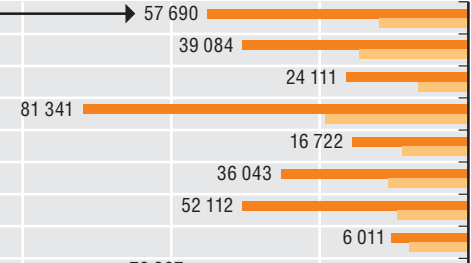

42162

35902

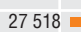

19650

86177

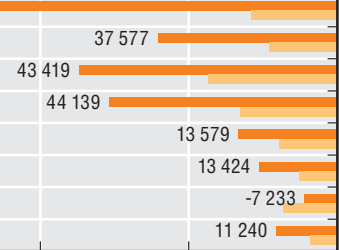

250000200000 USD PPP
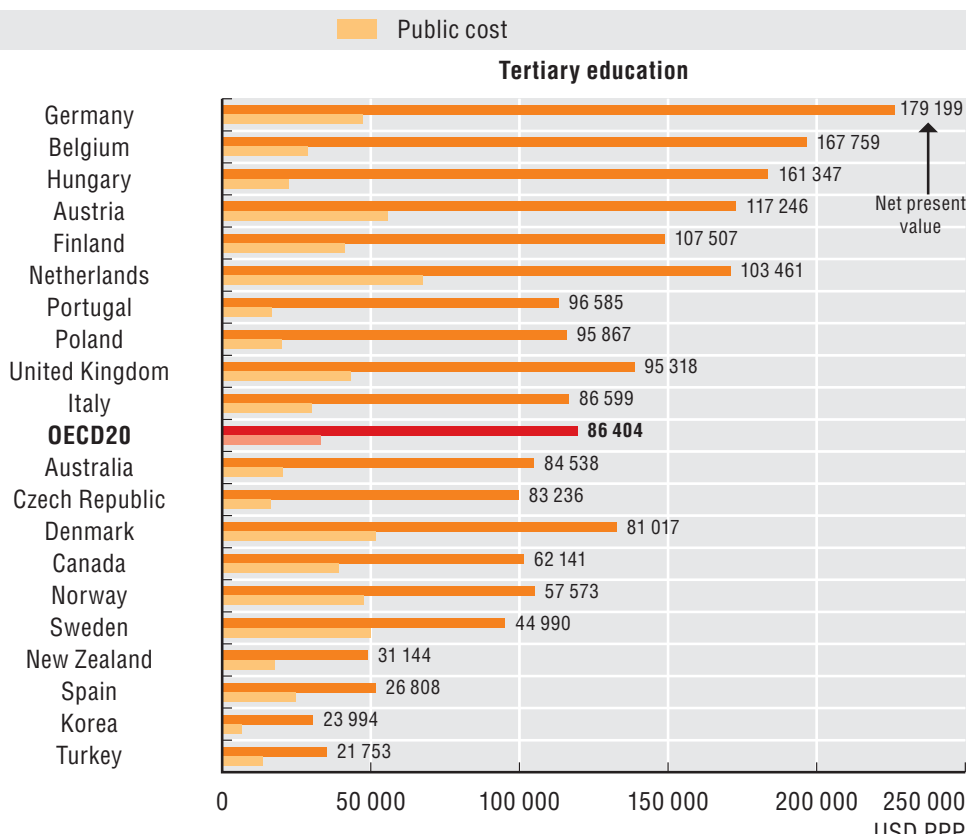

Source: OECD (2010), Education at a Glance 2010: OECD Indicators, OECD Publishing, Paris. Tables A8.3 and A8.4. See Annex 3 for notes, www.oecd.org/edu/eag2010. StatLink काIsL $h t t p: / / d x . d o i . o r g / 10.1787 / 888932391583$ 
Reducing inequalities in access to health care remains an important policy goal for governments, regardless of different health care systems' designs. Most OECD governments seek to reduce potential barriers to access to health care which can be financial; geographic; racial; cultural and informational; or time-related.

Health insurance coverage promotes access to health care goods and services and provides financial security against unexpected or serious illness. Most OECD countries have achieved universal coverage of health care for a core set of services, with the exception of Mexico, Turkey, the United States and Chile. Mexico has recently introduced reforms to provide coverage for the poor or uninsured, and the United States has recently passed legislation that will mandate health insurance coverage for almost everyone.

Despite having insurance, patients may be asked to pay some costs directly when consulting a doctor or being hospitalised, or when they purchase pharmaceutical drugs. Such direct costs may lead some households to delay or even forgo medical care. On average, out-of-pocket expenditures for health care represented $3.3 \%$ of final household consumption in 2008, ranging from $6 \%$ in Switzerland to less than $1.5 \%$ in the Netherlands, Luxembourg and France. The distribution of out-of-pocket expenditures across income groups can vary considerably within countries as well. While many countries have put in place exemptions and caps on out-of-pocket expenditures for lower-income groups to protect health care access, poorer households often allocate a higher proportion of their income or their consumption to pay health care than high-income households (Banthin et al., 2008; De Graeve and Van Ourti, 2003; Westert et al., 2008).

Regional inequities in access to health care can also exist within countries. In general, there are greater numbers of physicians in urban areas than in rural regions, where a shortage of physicians can lead to delayed treatment or larger distances travelled to get care.

\section{Methodology and definitions}

Data are derived from OECD Health Data 2010 which are based on official national statistics. Population coverage is the percentage of the population receiving a defined set of health care goods and services (typically including consultations with doctors, hospitalisation, the purchase of prescribed pharmaceutical drugs and dental care) under public programmes or private insurance. Public coverage refers to government programmes (generally financed by taxation) and social health insurance (generally financed by payroll taxes). Uptake of private insurance is often voluntary, although in some countries it may be compulsory by law. Coverage includes individuals as well as their dependents.

Out-of-pocket payments are expenditures borne directly by a patient where insurance does not cover the full cost of the health goods or services. They include cost-sharing, self-medication and other expenditures paid directly by private households. In some countries they may also include estimations of informal payments to health care providers.

The number of physicians includes general practitioners and specialists actively practicing medicine in a region in both public and private institutions. The geographical classification used to measure the number of physicians is TL2 which for the most part corresponds to national administrative regions.

\section{Further reading}

OECD (2009), Health at a Glance 2009: OECD Indicators, OECD Publishing, Paris.

OECD (2011), Regions at a Glance 2011, OECD Publishing, Paris.

\section{Figure notes}

55.1: Coverage as percentage of the population for a core set of services. Data for Australia, Luxembourg and Japan refer to 2007. Data for Spain refer to 2006. Data for Turkey are from OECD Health Data 2011 to be released June 2011.

55.2: Data for Turkey, Japan, Australia and Denmark refer to 2007. Data for Luxembourg and Portugal refer to 2006. Data for Greece are estimated.

55.3: Data are not available at regional level for Turkey.

Information on data for Israel: http://dx.doi.org/10.1787/888932315602. 
55.1 Health insurance coverage (2008)

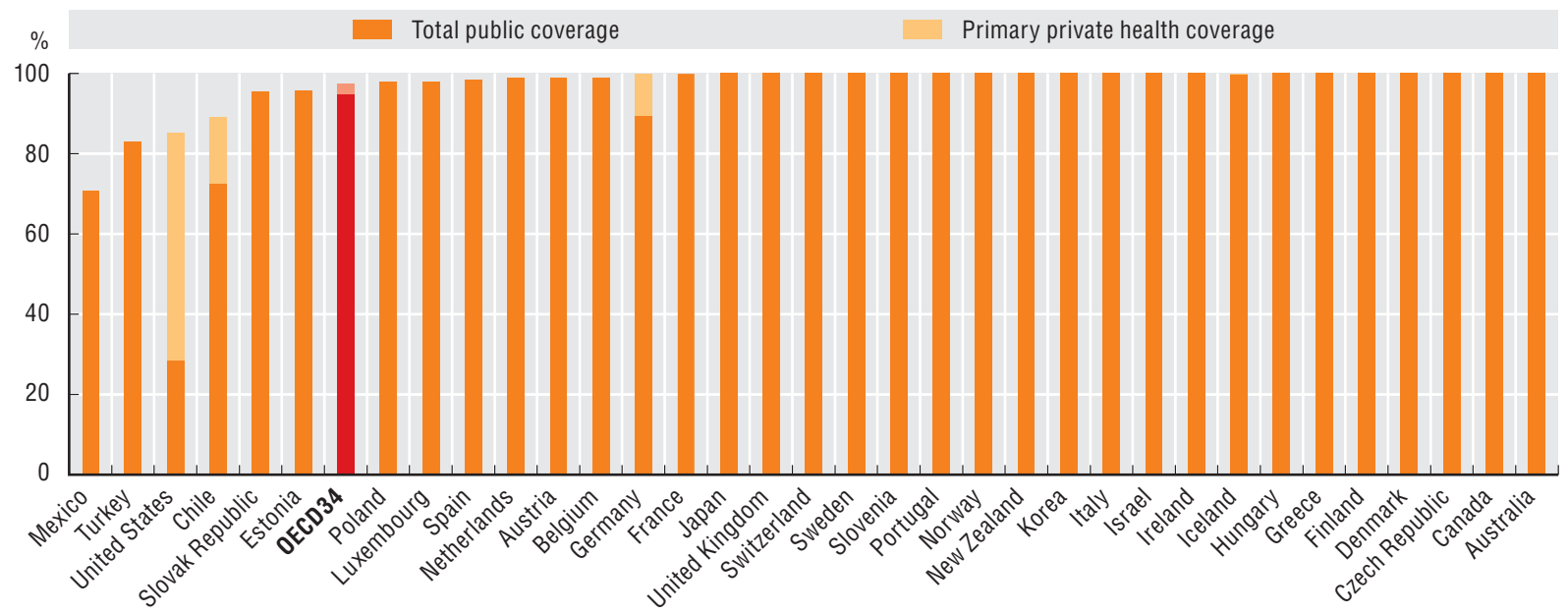

Source: OECD Health Data 2010.

55.2 Out-of-pocket health expenditure as a share of final household consumption (2008)

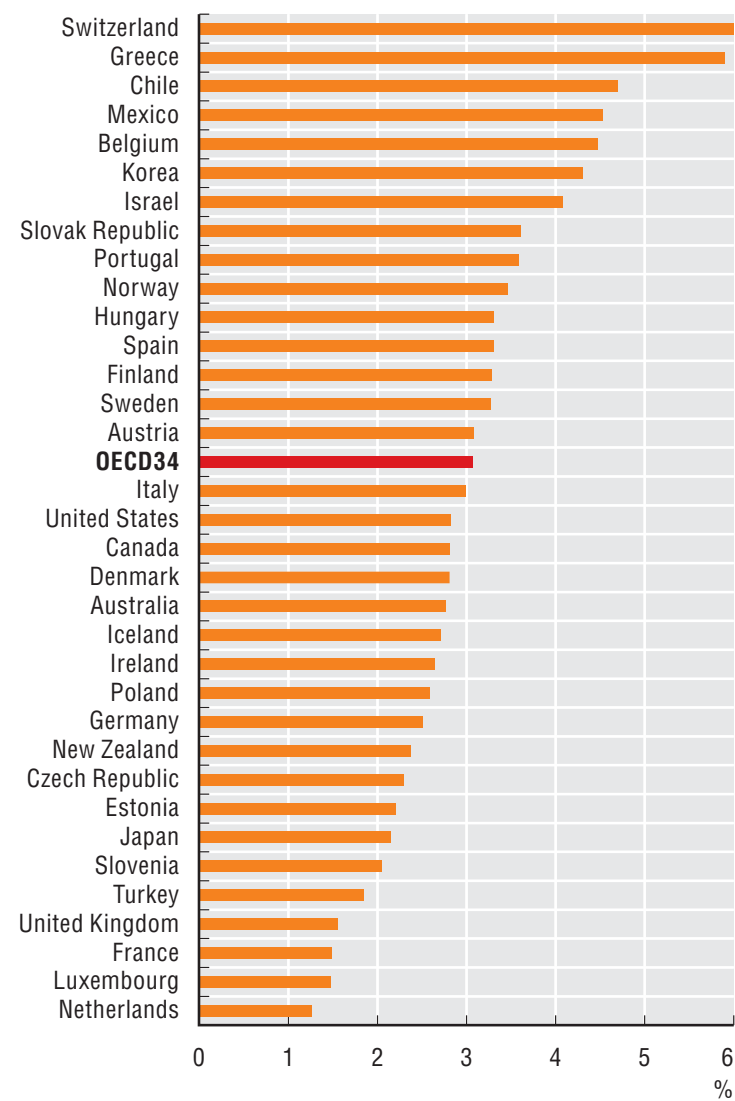

Source: OECD Health Data 2010.

StatLink (iाsस http://dx.doi.org/10.1787/888932391621
55.3 Inter-regional disparities in physician density for each TL2 region (2008)

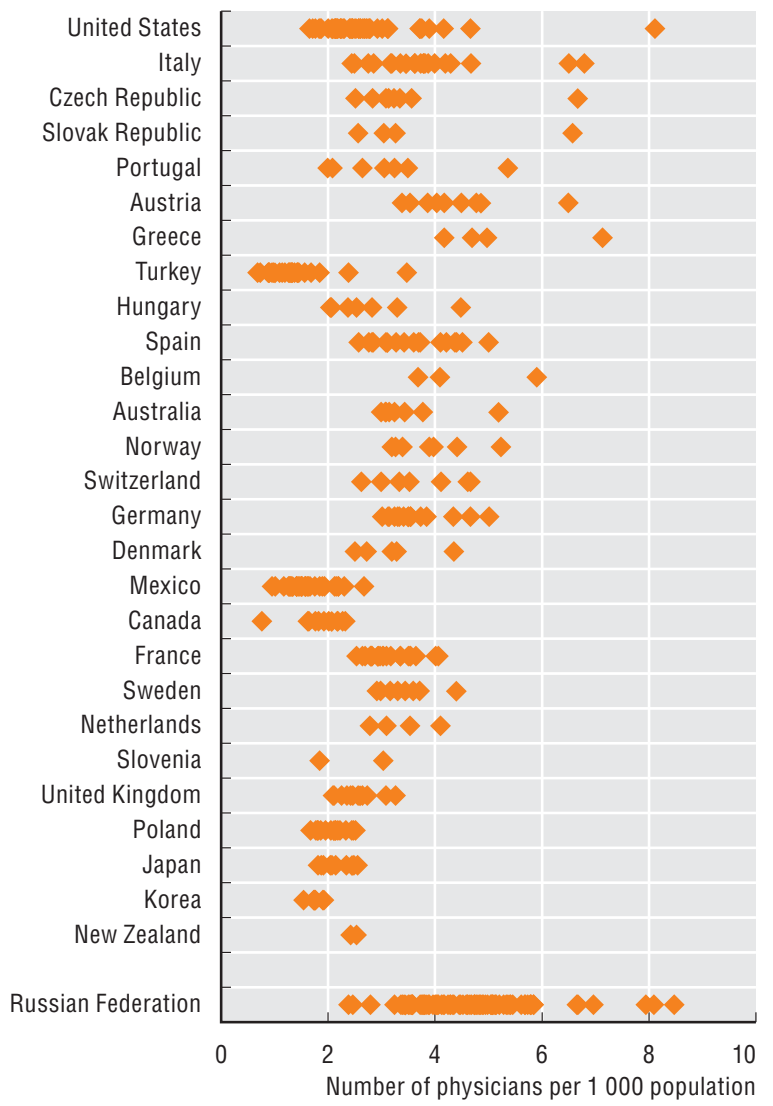

Source: Regions at a Glance 2011.

StatLink जाISt http://dx.doi.org/10.1787/888932391640 
Health output indicators provide information on the quantity of goods and services provided by health care systems. When considered together with input indicators, they can provide some measures of productivity or efficiency in health care delivery. Key indicators of health care activities include doctor consultations, the occupancy rates of hospital beds and the average length of stay in hospitals. In 2008, the average number of doctor consultations per person in the OECD was 6.9 per year, a slight increase from 2000. In Sweden and Finland, the low number of doctor consultations may be partly explained by the fact that many first contacts with patients are carried out by nurses.

In 2008 , on average across the OECD, $76 \%$ of available acute care hospital beds were utilised for curative care. Israel and Norway report the highest occupancy rates, while the Netherlands and Mexico had the lowest rates. As the number of acute care hospital beds has decreased over the years in most countries, occupancy rates have tended to increase.

The average length of stay in hospitals has decreased in OECD countries, reflecting the expansion of early discharge programmes, the planned shift to day-case surgery for suitable procedures, and the use of less invasive procedures and improvements in pre-admission assessment facilitating day-of-surgery admission, where appropriate. This reduction has been particularly rapid in Japan, Poland and the Netherlands. The average length of stay in hospitals for acute care is often considered a measure of efficiency. All other things being equal, a shorter stay will reduce the cost per discharge and shift care from inpatient to less expensive post-acute settings. However, shorter stays tend to be more service-intensive and costly per day. Too short a stay could even signal a potential for more adverse health outcomes.

\section{Methodology and definitions}

Consultations with doctors refer to the number of contacts with a doctor in a given year, and include visits with both general practitioners and specialists under both public and private delivery or funding. Data come from administrative sources, although data are estimated from health interview surveys in some countries: Italy, the Netherlands, Spain, Switzerland, general practitioner consultations in the United Kingdom and specialist consultations in New Zealand. Data for the Netherlands exclude consultations for maternal and child care. Data for Portugal and Turkey exclude visits to private practitioners, while data for the United Kingdom exclude private consultations with specialists.
The occupancy rate for acute care beds is calculated as the number of hospital bed-days related to acute care divided by the number of available acute care beds (which is multiplied by 365 days). Acute care beds are those available for "curative care" as defined by the OECD's Manual A System of Health Accounts (OECD, 2000). Comparisons should consider that, in some countries, acute care beds can also be utilised for other purposes (long-term care, rehabilitation and/or palliative care). In the Netherlands, the calculation is based on the number of licensed beds rather than number of available beds. In Hungary and Ireland, the indicator does not include, or only partially includes, private sector beds. Data for Finland are estimated.

Average length of stay for acute care is the average number of days that patients spend in hospital for curative care as defined in the Manual.

\section{Further reading}

OECD (2009), Health at a Glance 2009: OECD Indicators, OECD Publishing, Paris.

\section{Figure notes}

Population data are from OECD statistics.

56.1: Data are not available for Ireland, Spain and Norway. Data for 2000 are not available for Chile and this country is not included in the OECD average. Data for the following countries differ from 2000: Switzerland and Korea (2002); New Zealand (2003). Data for the following countries differ from 2008: Italy (2005); Sweden and Greece (2006); Switzerland, the United States, Portugal, New Zealand, Canada, Luxembourg, Belgium and Japan (2007); Israel (2009).

56.2: Data are not available for Denmark, Finland, Iceland, Korea, New Zealand, Poland and Sweden. Data for the following countries differ from 2008: Australia and Greece (2006); Italy and Portugal (2007). Data for Luxembourg are only available for 2007. Data for Canada are estimated for 2007. Data for Chile and Estonia are for 2003 rather than 2000.

56.3: Data are not available for Korea and Chile. Data for the following countries differ from 2008: Denmark and New Zealand (2005); Australia and Greece (2006); Belgium, Canada, Italy, Luxembourg, Portugal, and Sweden (2007); Israel (2009). Data for Estonia are for 2003 rather than 2000.

Information on data for Israel: http://dx.doi.org/10.1787/888932315602. 


\subsection{Doctors' consultations per person (2000 and 2008)}

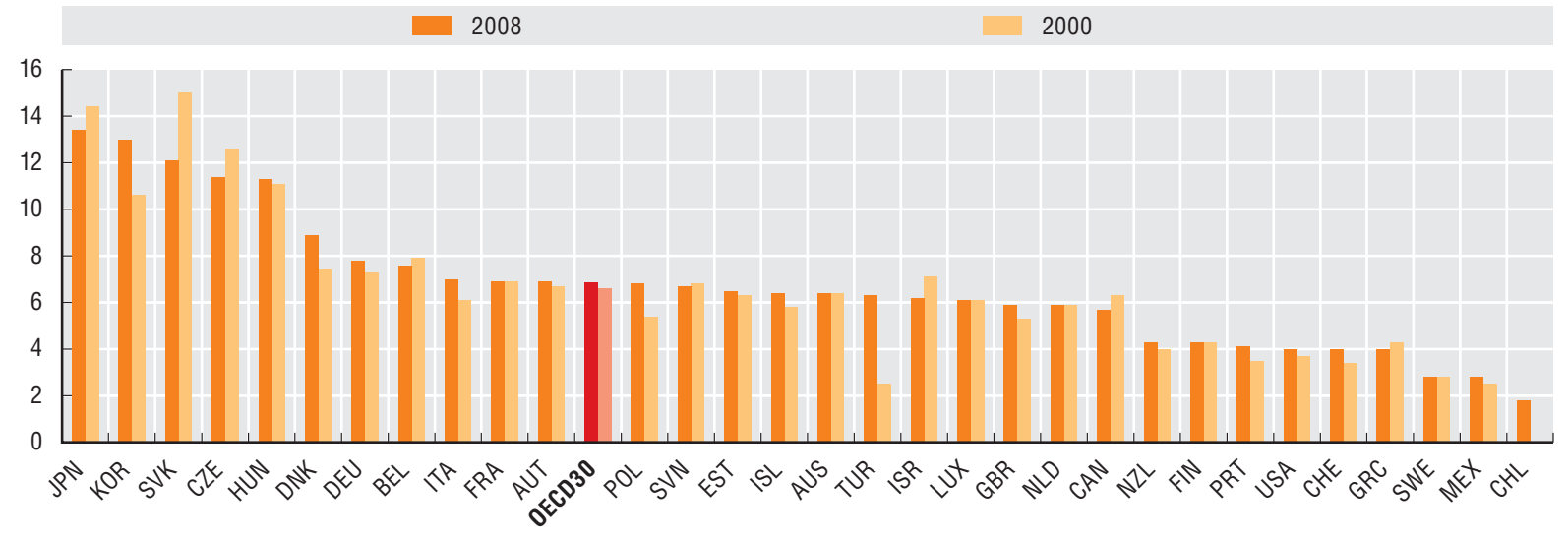

Source: OECD Health Data 2010.

56.2 Occupancy rate of acute care hospital beds, percentage (2000 and 2008)

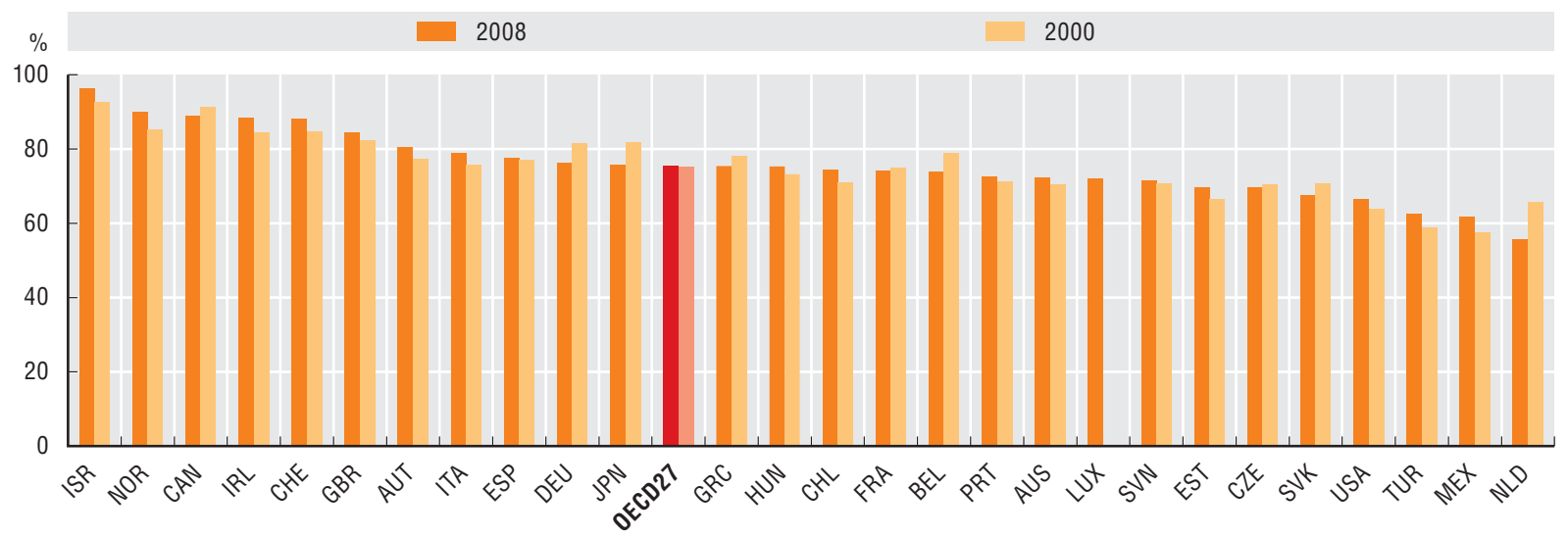

56.3 Average length of stay for acute care (2000 and 2008)

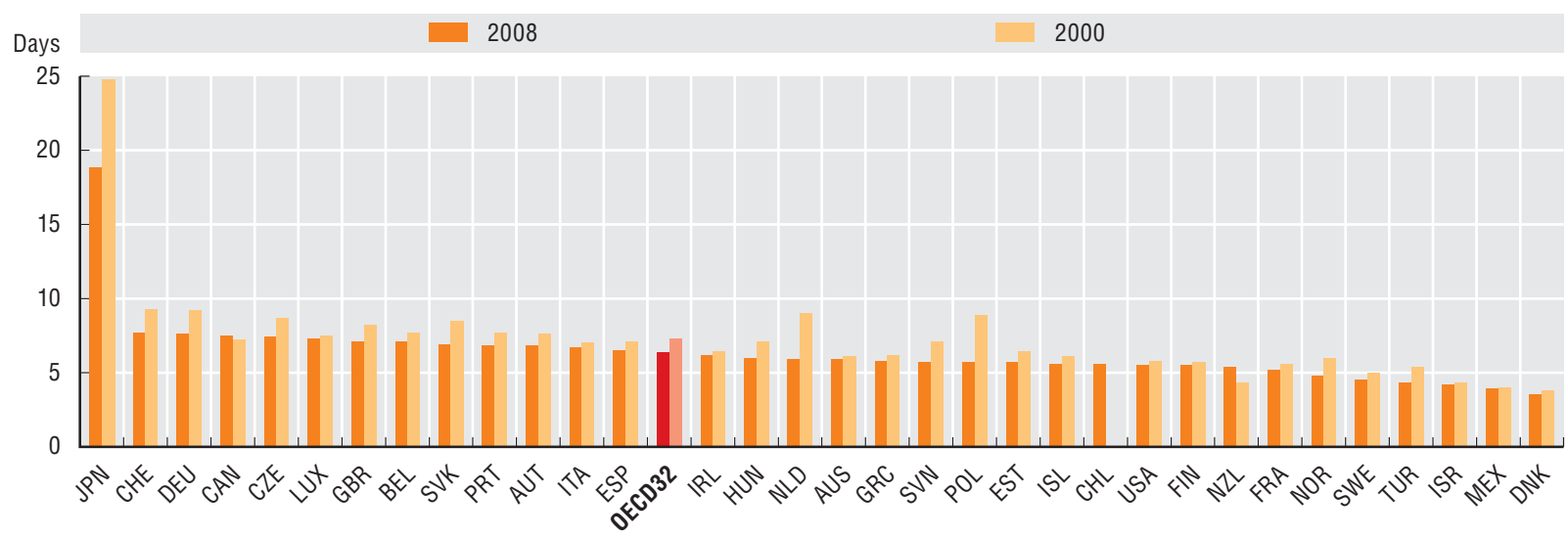


A key policy challenge for governments is to improve health outcomes (such as life expectancy) while containing cost pressures in health care provision. This is particularly important given that the public sector is the main source of health financing in OECD countries and public spending on health care is one the largest government expenditure items, representing on average $6 \%$ of GDP. Furthermore, with ageing populations, cost pressures are expected to increase in the near future.

Life expectancy remains the most common measure of a population's health. Life expectancy at birth has continued to increase remarkably in OECD countries over the past few decades, reflecting sharp reductions in mortality rates at all ages. These gains in longevity can be attributed to a number of factors, including rising living standards, improved lifestyle and better education, as well as greater access to quality health services. Other factors addressed by public policy, such as better nutrition, sanitation and housing also play a role. On average across OECD countries, life expectancy at birth for the whole population reached 79.3 years in 2008, a gain of nearly 11 years since 1960 . Of all member countries, Korea has experienced the largest increase since 1960. In 2008, its citizens are expected to live nearly 28 years longer than they did in 1960. In almost one-half of OECD countries, life expectancy at birth in 2008 exceeded 80 years. The country with the highest life expectancy was Japan, at 82.7 years. At the other end of the scale, life expectancy in OECD countries was the lowest in Turkey, followed by Hungary and Estonia. However, while life expectancy in Hungary has increased modestly since 1960, it has increased sharply in Turkey, so that it is rapidly catching up with the OECD average.

There is a positive relationship between life expectancy at birth and health expenditure per capita across OECD countries. A recent OECD study estimated that up to $40 \%$ of the increase in life expectancy since the early 1990s could be attributed to increased total health spending (Joumard et al., 2010). Given their levels of health spending, Japan and Korea stand out as having relatively high life expectancies, and the United States, Denmark and Hungary relatively low.

\section{Methodology and definitions}

Life expectancy measures how long on average people would live based on a given set of age-specific death rates. However, the actual age-specific death rates of any particular birth cohort cannot be known in advance. If age-specific death rates are falling (as has been the case over the past decades in OECD countries), actual life spans will be higher than life expectancy calculated with current death rates. Life expectancy at birth for the total population is calculated by the OECD Secretariat for all countries, using the unweighted average of life expectancy of men and women.

Total expenditure on health measures the final consumption of health goods and services (i.e. current health expenditure) plus capital investment in health care infrastructure. This includes spending by both public and private sources on medical services and goods, public health and prevention programmes, and administration. Countries' health expenditures are converted to a common currency (USD) and adjusted using PPPs for GDP to take account of the different purchasing power of the national currencies.

\section{Further reading}

Joumard, I., C. Andre and C. Nicq (2010), "Health Care Systems: Efficiency and Institutions", OECD Economics Department Working Papers, No. 769, OECD Publishing, Paris.

OECD (2009), Health at a Glance 2009: OECD Indicators, OECD Publishing, Paris.

\section{Figure notes}

57.1: Data for 1960 are not available for Chile, Estonia and Israel and these countries are not included in the average. Data for the following countries refer to 2007 rather than 2008: Belgium, Canada, Italy, the United Kingdom and the United States. Data for the following countries refer to 1961 rather than 1960: Canada, Italy and New Zealand.

57.2: Life expectancy data for Belgium, Canada, Italy, the United Kingdom and the United States refer to 2007. Health spending data for Austria, Denmark, Greece, Japan and Turkey refer to 2007; and for Portugal and Luxembourg refer to 2006.

Information on data for Israel: http://dx.doi.org/10.1787/888932315602. 


\section{GOVERNMENT PERFORMANCE INDICATORS FROM SELECTED SECTORS}

57.1 Life expectancy at birth (1960 and 2008)

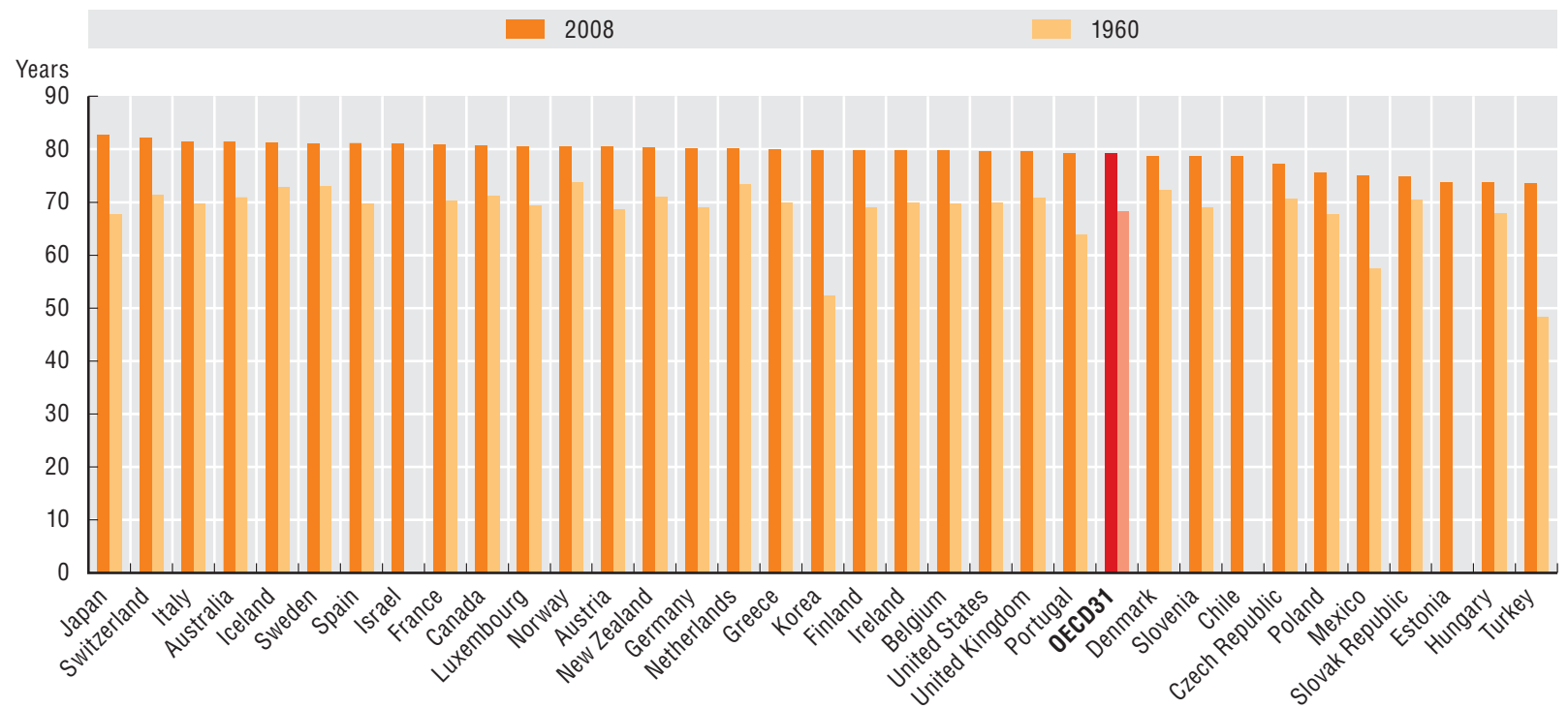

Source: OECD Health Data 2010.

57.2 Life expectancy at birth and total expenditure on health per person (2008)

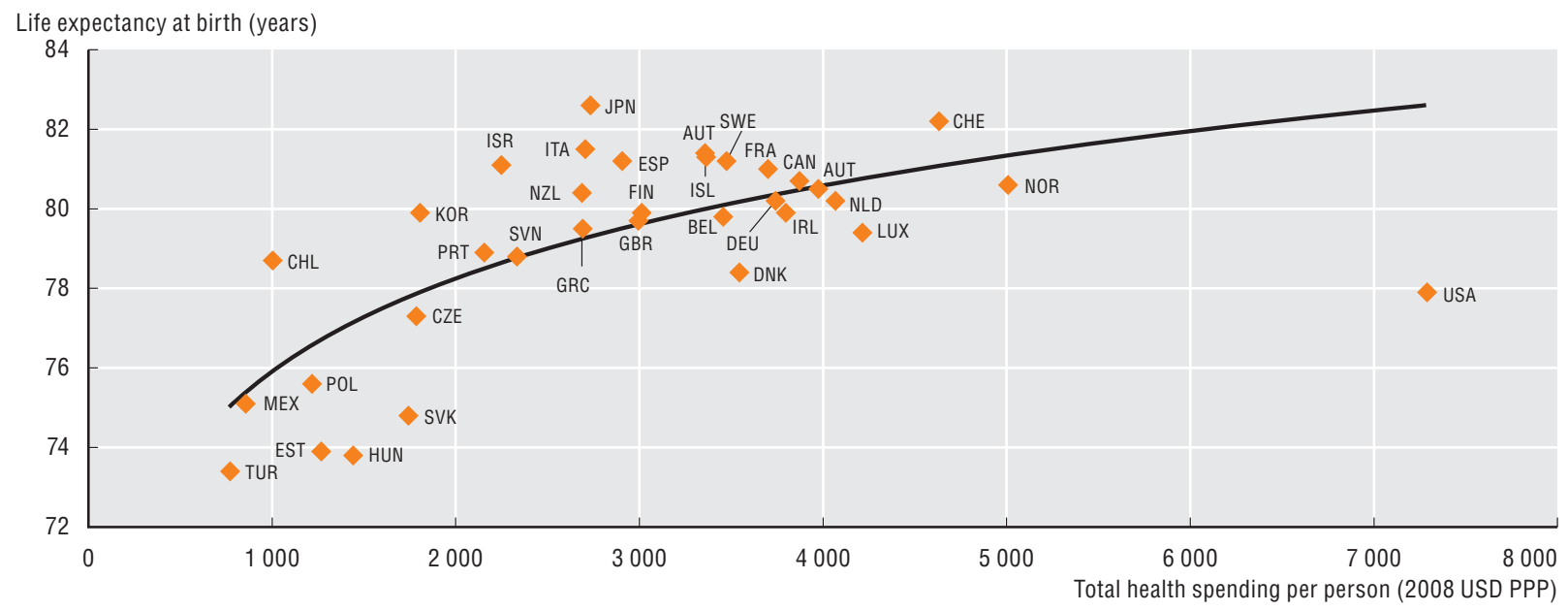

Source: OECD Health Data 2010. 
Government activities, including the provision of public services, rely on taxes collected from citizens and businesses. Government tax administrations perform the important functions of interpreting tax legislation; collecting various taxes and social security contributions; and enforcing tax laws.

As governments look to consolidate finances, many have placed stricter limits on the funds available to tax revenue bodies. As a result, there is growing attention on increasing the efficiency of tax administrations in order to reduce costs while providing better services to citizens and businesses. Efficiency gains depend on how well these organisations design their internal organisational structures; how well they allocate budgeted funds to meet new or changed priorities; how they utilise ICTs and e-government initiatives to reduce costs; and how they determine the levels, remuneration and mix of their staff.

The cost of collection ratio compares the annual costs of administration incurred by a revenue body with the total revenue collected over the course of a fiscal year. Observed over time, a downward trend can constitute evidence of a reduction in relative costs (i.e. improved efficiency) and/or improved tax compliance (i.e. improved effectiveness). For the vast majority of revenue bodies, there is a decreasing trend in their ratios up to 2007 most likely due to reduced costs (i.e. increased efficiency) or strong economies that boosted tax collections. However, for many revenue bodies, ratios increased in 2009 most likely as a result of reduced economic activity and tax receipts in the aftermath of the global financial and economic crisis.

A second commonly used performance indicator for tax revenue bodies is total revenue body expenditure as a percentage of GDP, a measure which has not changed much in most OECD countries between 2005 and 2009. In 2009, $0.26 \%$ of GDP was spent on tax administrations on average in the OECD. Austria and Denmark show the most marked reductions in tax administration spending relative to GDP from 2005 to 2009. Hungary and New Zealand, on the other hand, show increases in this ratio.

International comparisons of the efficiency of tax administrations, however, must be made with caution. Differences in tax rates and the overall legislated tax burden; variations in the range and in the nature of taxes collected (including social contributions); macroeconomic conditions affecting tax receipts; and differences in the underlying cost structures resulting from institutional arrangements (e.g. multiple bodies involved in revenue administration, as in Italy), and/or the conduct of non-tax functions (e.g. customs) are all issues which influence the efficiency ratios presented here.

\section{Methodology and definitions}

Data are provided by surveyed revenue bodies or extracted from official country reports (e.g. annual performance reports). Tax administration expenditures include three categories: administrative costs, salary costs and IT costs. IT expenditure was defined as the total costs of providing IT support for all administrative operations (both tax and non-tax related). For comparison purposes, efforts have been made to separately identify the resources used and the costs of tax and non-tax related functions. Data for GDP were either supplied by member countries' Ministries of Finance, OECD Revenue Statistics, CIA World Factbook or the IMF Statistics Database.

\section{Further reading}

OECD (2011), Tax Administration in OECD and Selected Non-OECD Countries: Comparative Information Series (2010), OECD Publishing, Paris.

\section{Figure notes}

Data are not available for Greece. For Luxembourg, data relate to direct tax and VAT directorates. For Sweden, operational staff are assumed for tax-related functions with figures adjusted accordingly.

58.1: Data for 2009 for the Slovak Republic and for 2005 and 2007 for Iceland and Israel are not available and these countries are not included in the average (OECD30). Data are per the revenue body's annual report for Australia (2007) and Turkey (2005). For Estonia, the 2007 ratio includes customs operations that are not included in subsequent years. Data for Mexico are from the Tax Report by the Tax Administration Service. Data for Sweden refer to net revenue of 2005 in Taxes in Sweden (7th edition). The ratios for the United States vary from IRS publications owing to the use of net, and not gross, revenue collections as the denominator.

58.2: The following countries are not included in the average (OECD24) due to missing data: Spain (2005); Estonia, Israel, Italy and Slovenia (2005 and 2007); Iceland, Poland, the Slovak Republic and Switzerland (2009). See StatLink below figure for full notes.

Information on data for Israel: http://dx.doi.org/10.1787/888932315602. 
58.1 Ratio of aggregate tax administration costs per 100 units of net revenue collection $(2005,2007$ and 2009)

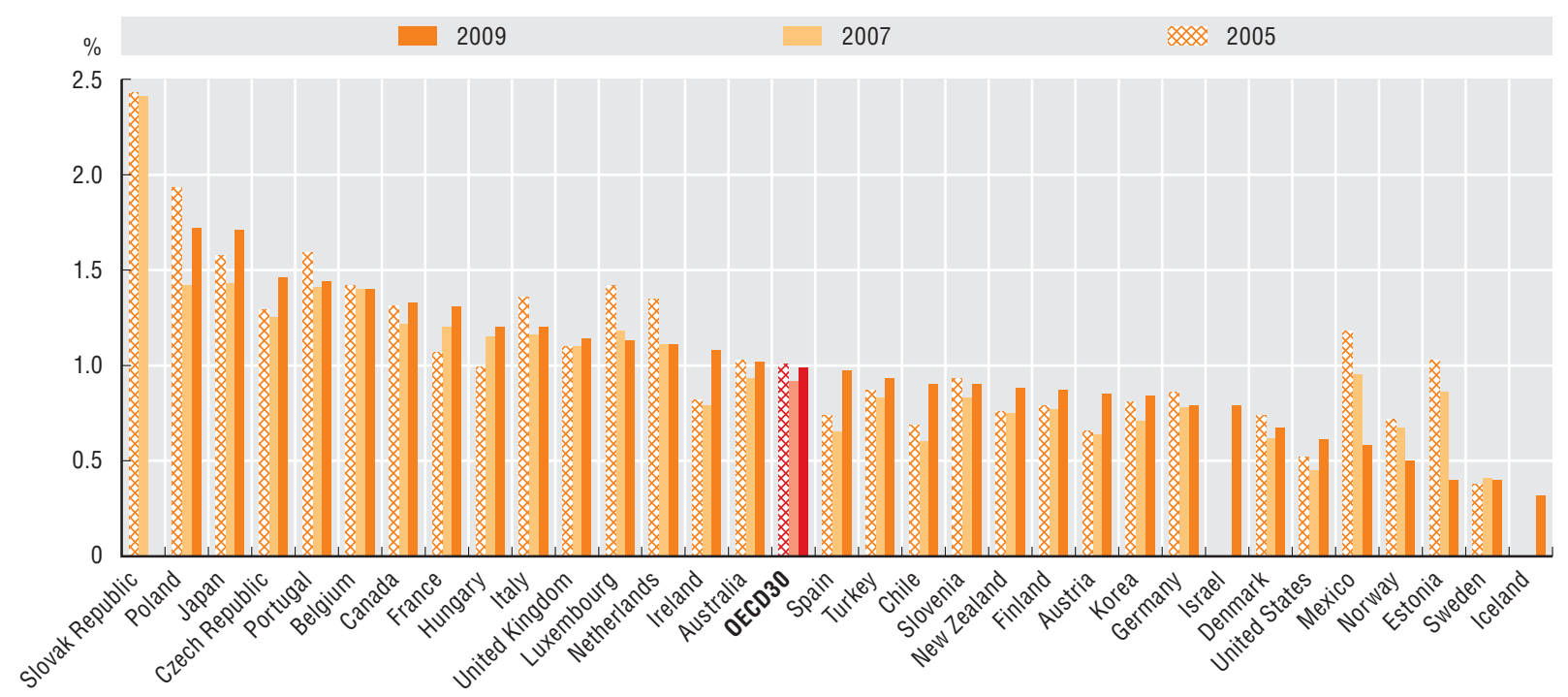

Source: OECD (2011), Tax Administration in OECD and Selected Non-OECD Countries: Comparative Information Series (2010), OECD Publishing, Paris, Table 18.

StatLink क्ञाजय http://dx.doi.org/10.1787/888932391754

58.2 Total revenue body expenditure as percentage of GDP (2005, 2007 and 2009)

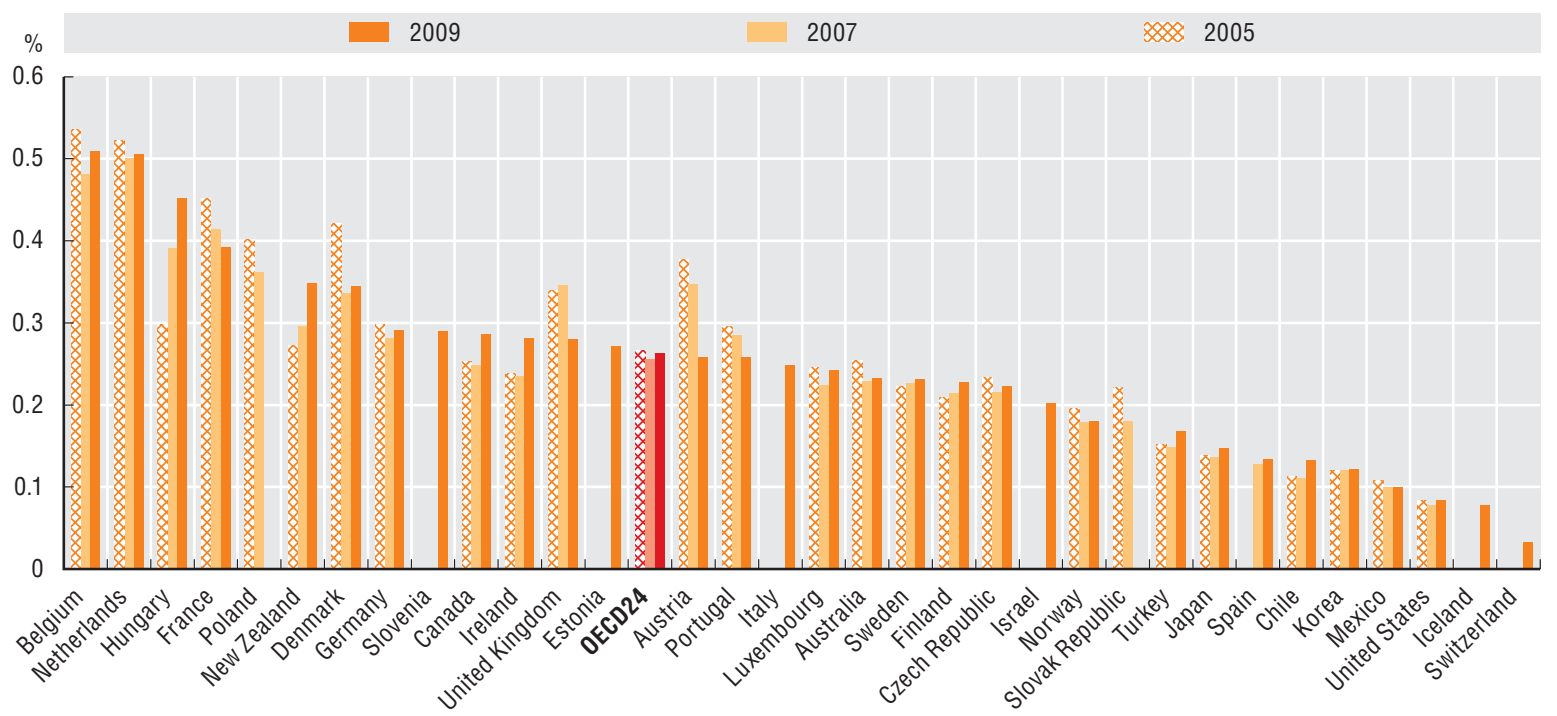

Source: OECD (2011), Tax Administration in OECD and Selected Non-OECD Countries: Comparative Information Series (2010), OECD Publishing, Paris, Table 19. 



\section{ANNEX A \\ Methodology for Revenue Aggregates}

The following table provides detailed information about how the aggregates of taxes, social contributions, and grants and other revenues presented in Indicators 1-3 were constructed from the OECD National Accounts Data.

\section{Table A.1. Revenue aggregates}

\begin{tabular}{|c|c|c|}
\hline Label in Government at Glance & Label in the System of National Accounts & $\begin{array}{l}\text { Code in } O E C D \text { National Accounts Data } \\
\text { (Table 12: Main aggregates of general government) }\end{array}$ \\
\hline \multicolumn{3}{|l|}{ Taxes } \\
\hline Indirect taxes & Taxes on production and imports, receivable & GD2R \\
\hline Direct taxes & Current taxes on income and wealth, receivable & GD5R \\
\hline Capital taxes & Capital taxes & GD91R \\
\hline \multicolumn{3}{|l|}{ Social contributions } \\
\hline Social contributions & Social contributions & GD61R \\
\hline \multicolumn{3}{|l|}{ Grants and other revenues } \\
\hline \multirow[t]{2}{*}{ Current and capital grants } & Other current transfers, receivable & GD7R \\
\hline & Other capital transfers and investment grants, receivable & GD92R_D99R \\
\hline \multirow[t]{2}{*}{ Sales and fees } & Market output and output for own final use & GP11_P12R \\
\hline & Payments for other non-market output & GP131R \\
\hline Property income & Property income, receivable & GD4R \\
\hline Subsidies & Other subsidies on production, receivable & GD39R \\
\hline Total revenues & Total revenues & GTR \\
\hline
\end{tabular}




\section{ANNEX B}

\section{Classification of the Functions of Government (COFOG)}

\section{First- and second-level COFOG}

Developed by the OECD, the Classification of the Functions of Government (COFOG) classifies government expenditure data from the System of National Accounts by the purpose for which the funds are used. As Table B.1 illustrates, first-level COFOG splits expenditure data into ten "functional" groups or sub-sectors of expenditures (such as defence, education and social protection), and second-level COFOG further splits each first-level group into up to nine sub-groups. While first-level COFOG data are available for 31 out of the 34 OECD member countries, second-level COFOG data are currently only available for 21 OECD European member countries.*

Table B.1. First and second level COFOG

\begin{tabular}{|c|c|}
\hline First-level & Second-level \\
\hline General public services & $\begin{array}{l}\text { - Executive and legislative organs, financial and fiscal affairs, external affairs. } \\
\text { - Foreign economic aid. } \\
\text { - General services. } \\
\text { - Basic research. } \\
\text { - R\&D general public services. } \\
\text { - General public services n.e.c. } \\
\text { - Public debt transactions. } \\
\text { - Transfers of a general character between different levels of government. }\end{array}$ \\
\hline Defence & $\begin{array}{l}\text { - Military defence. } \\
\text { - Civil defence. } \\
\text { - Foreign military aid. } \\
\text { - R\&D defence. } \\
\text { - Defence n.e.c. }\end{array}$ \\
\hline
\end{tabular}

\footnotetext{
* First-level COFOG data are not available for Chile, Mexico and Turkey. Until recently, second-level COFOG data were available in some national statistical offices, but were not collected by international organisations. Moreover, the second-level COFOG data were not comparable among countries because the SNA/UN guide and the International Monetary Fund Manual on Government Finance Statistics do not provide much practical information on the application of COFOG concepts. However, in 2005, Eurostat established a task force to develop a manual on the application of COFOG to national account expenditure data and to discuss the collection of second-level COFOG data for European countries. Second-level COFOG data are not available for Switzerland and all non-European member countries of the OECD: Australia, Canada, Chile, Japan, Israel, Korea, Mexico, New Zealand and the United States. In addition, these data are available only for selected COFOG divisions in some members of the EU. Efforts are underway to reach agreement with these countries about the submission of these data to the OECD.
} 
Table B.1. First and second level COFOG (cont.)

\begin{tabular}{|c|c|}
\hline First-level & Second-level \\
\hline Public order and safety & $\begin{array}{l}\text { - Police services. } \\
\text { - Fire-protection services. } \\
\text { - Law courts. } \\
\text { - Prisons. } \\
\text { - R\&D public order and safety. } \\
\text { - Public order and safety n.e.c. }\end{array}$ \\
\hline Economic affairs & $\begin{array}{l}\text { - General economic, commercial and labour affairs. } \\
\text { - Agriculture, forestry, fishing and hunting. } \\
\text { - Fuel and energy. } \\
\text { - Mining, manufacturing and construction. } \\
\text { - Transport. } \\
\text { - Communication. } \\
\text { - Other industries. } \\
\text { - R\&D economic affairs. } \\
\text { - Economic affairs n.e.c. }\end{array}$ \\
\hline Environmental protection & $\begin{array}{l}\text { - Waste management. } \\
\text { - Waste water management. } \\
\text { - Pollution abatement. } \\
\text { - Protection of biodiversity and landscape. } \\
\text { - R\&D environmental protection. } \\
\text { - Environmental protection n.e.c. }\end{array}$ \\
\hline Housing and community amenities & $\begin{array}{l}\text { - Housing development. } \\
\text { - Community development. } \\
\text { - Water supply. } \\
\text { - Street lighting. } \\
\text { - R\&D housing and community amenities. } \\
\text { - Housing and community amenities n.e.c. }\end{array}$ \\
\hline Health & $\begin{array}{l}\text { - Medical products, appliances and equipment. } \\
\text { - Outpatient services. } \\
\text { - Hospital services. } \\
\text { - Public health services. } \\
\text { - R\&D health. } \\
\text { - Health n.e.c. }\end{array}$ \\
\hline Recreation, culture and religion & $\begin{array}{l}\text { - Recreational and sporting services. } \\
\text { - Cultural services. } \\
\text { - Broadcasting and publishing services. } \\
\text { - Religious and other community services. } \\
\text { - R\&D recreation, culture and religion. } \\
\text { - Recreation, culture and religion n.e.c. }\end{array}$ \\
\hline Education & $\begin{array}{l}\text { - Pre-primary and primary education. } \\
\text { - Secondary education. } \\
\text { - Post-secondary non-tertiary education. } \\
\text { - Tertiary education. } \\
\text { - Education not definable by level. } \\
\text { - Subsidiary services to education. } \\
\text { - R\&D education. } \\
\text { - Education n.e.c. }\end{array}$ \\
\hline Social protection & $\begin{array}{l}\text { - Sickness and disability. } \\
\text { - Old age. } \\
\text { - Survivors. } \\
\text { - Family and children. } \\
\text { - Unemployment. } \\
\text { - Housing. } \\
\text { - Social exclusion n.e.c. } \\
\text { - R\&D social protection. } \\
\text { - Social protection n.e.c. }\end{array}$ \\
\hline
\end{tabular}

n.e.c.: "Not elsewhere classified". 


\section{ANNEX C}

\section{Fiscal Consolidation Model Assumptions}

\section{Summary of key assumptions underlying fiscal sustainability scenarios}

This annex provides information regarding the assumptions underlying the model utilised to calculate the estimated fiscal consolidation efforts required by governments to stabilise and reduce public debt as a ratio of GDP by 2026. The model estimates the fiscal consolidation efforts required to stabilise or reduce gross debt-to-GDP ratios. The size of these efforts may differ in terms of net debt-to-GDP ratios. The assumptions underpin the data presented in Indicator 15 of Chapter IV (Strategic Foresight and Leadership). Data for Indicator 15, as well as the information presented here, are drawn from the Preliminary Version of the OECD Economic Outlook, No. 89 released in May 2011 and are subject to revision in future Outlook publications.

\section{Assumptions underlying the baseline scenario}

Fiscal consolidation efforts refer to the total change required in the underlying primary balance between 2010 and 2026 in order to either stabilise or reduce public debt. These estimations for Figures 15.1 and 15.2 are conditional upon assumptions regarding: i) macroeconomic factors; and ii) countries' fiscal policies and trajectories. The assumptions change over time over the period 2010-26.

\section{Macroeconomic assumptions}

- Long-term growth projections are underpinned by projections of potential GDP output. The model assumes that the gap between actual and potential output is eliminated by 2015. Thereafter, GDP grows in line with potential output. There are some exceptions however, where the output gap remains large in 2012. In these cases, for every 2 percentage points by which the output gap exceeds $6 \%$ at the end of 2012, it is assumed to take an additional year to close the gap. This means that for Greece the output gap closes in 2018. For Ireland, Portugal and Spain the gap closes in 2016. Once the gap is closed, GDP grows in line with potential output.

- The effects of pension reforms legislated up to 2009 have been incorporated.

- Unemployment returns to its estimated structural rate by 2015. Historical estimates of the structural unemployment rate are based on Gianella et al. (2008), on which is imposed a post-crisis hysteresis effect. The structural unemployment rate is assumed to eventually return to pre-crisis levels but at a speed which differs across countries based on previous historical experience (Guichard and Rusticelli, 2010); for those countries with more flexible labour markets structural unemployment returns to pre-crisis levels by 2018 and for other countries by 2026 . 
- Non-oil commodity prices remain unchanged in real terms, while oil prices rise by 1\% per annum in real terms after 2012.

- Exchange rates remain unchanged in real terms in OECD countries; real exchange rates for non-OECD countries appreciate in line with growth differentials (through the so-called Balassa-Samuelson effect) from 2012.

- Policy interest rates continue to normalise as output gaps close and beyond that are directed to bring inflation in line with medium-term objectives. For Japan it is assumed that once the output gap has closed and inflation returns to $1 \%$ in 2015 , the target rate of inflation for monetary policy will be fixed at $2 \%$.

- The adverse effects on the level of potential output resulting from the crisis (through adjustments to capital intensity, structural unemployment and labour force participation) have reached their peak by about 2013.

- After 2012, non-OECD economies show a slow convergence to US growth rates in per capita income (measured in purchasing power parity) (Duval and de la Maisonneuve, 2009).

- For the period 2015 to 2026, OECD countries experience a slow convergence to annual labour productivity growth of $13 / 4$ per cent.

It is important to note two exceptions with regards to the estimations for the fiscal consolidation efforts needed to stabilise debt: for Japan and the United States, the required consolidation to stabilise debt is so large in 2012 that is it not achieved in the baseline scenario by 2026 given the assumed pace of consolidation. The estimated number of years of consolidation for these and other OECD countries is provided in Table 4.3 of the OECD Economic Outlook, No. 89 and is an estimate of when debt would be stabilised assuming consolidation continues at the assumed place.

\section{Fiscal assumptions}

- The change in the underlying fiscal primary balance required to stabilise or reduce debt-to-GDP ratios to the stated targets takes 2010 as the base year; for 2011 and 2012, the model assumes governments consolidate in line with the OECD Economic Outlook, No. 89 fiscal projections for each country; from 2013 onwards, in countries where the debt-to-GDP ratio is rising, there is a gradual and sustained increase in the underlying fiscal primary balance sufficient to ensure the ratio of government debt-to-GDP is stable over the medium term given long-term growth and current long-term interest rates. In countries where the ratio is falling from 2013 onwards, it is assumed they do not undertake fiscal expansion.

- The number of years of fiscal consolidation required beyond 2012 varies by country. The model assumes a reduction in the primary deficit of $1 / 2$ per cent of GDP for each year in which the debt-to-GDP ratio is not stable (e.g. Figure 15.1) and/or does not meet the stated targets (e.g. Figure 15.2).

- There are no further losses to government balance sheets as a result of asset purchases or guarantees made in dealing with the financial crisis.

- Effects on budgets from population ageing and continued upward pressures on health spending are not explicitly included, but are implicitly assumed to be offset by other budgetary measures.

See Box 4.1 and Tables 4.1- 4.3 of the Preliminary Version of the OECD Economic Outlook, No. 89 for country-specific information regarding the aforementioned assumptions. 


\section{Projected changes in ageing-related public spending for selected OECD countries}

- OECD projections for increases in the costs of health and long-term care have been derived assuming unchanged policies and structural trends. The corresponding hypotheses are detailed in OECD (2006) under the heading "cost-pressure scenario". For European countries, projections of pension expenditures are drawn from the European Commission Sustainability Report (2009). An exception is Greece where the pension expenditure estimates incorporate OECD estimate of the effects of very recent pension reforms. For non-EU countries, projections of public pension spending are taken from the CBO (2010) Long-term Budget Outlook and Visco (2005) for the United States, from the Office of the Parliamentary Budget Officer (2010) and Visco (2005) for Canada, from Fukawa and Sato (2009) for Japan, from Commonwealth of Australia (2010) for Australia, from New Zealand Treasury (2009) for New Zealand, from Visco (2005) for Switzerland and from Dang et al. (2001) for Korea. In some cases this has required linear interpolation to derive the effects over the period 2010-26.

See Box 4.2 for further information. See "Bibliography" in this publication for complete references. 
ANNEX D

\section{Methodology and Additional Notes on Compensation of Government Employees}

\section{Occupations}

The Survey on Compensation of Government Employees aims to collect information on the annual compensation of employees for a sample of occupations in central/federal/ national government. The purpose is to build a database on remuneration levels for typical positions in central government in core and key sectoral Ministries that will contribute to a better understanding of the salary structures and pay levels in the central governments in OECD countries.

The survey focuses on the central government level and excludes local levels and social security institutions if they are separate from the central level in general statistics and/or in terms of functionality. The survey excludes all public and quasi-public corporations at all government levels. In some countries, the central government is referred to as the national or federal government.

In this publication, the data from the survey cover information concerning 12 occupations within central government grouped into four basic headings: top managers, middle managers, professionals, and secretaries. The selected occupations are considered representative and relatively comparable across countries. Information for those positions is collected from six Ministries: three core Ministries (Interior, Finance and Justice) and three sectoral Ministries (Education, Health and Environment). Depending on the institutional structure of its government, a country may have provided data for more or fewer Ministries. The survey focuses on employees under the general employment framework or statute excluding consultants and short-term staff.

The classification and the definition of the occupations are an adaptation of the International Standard Classification of Occupations (ISCO-08) developed by the International Labour Organization (ILO). The reason for the adaptation is that not all countries follow the ISCO model to classify their occupations in government, thus using ISCO-08 may create confusion in some member countries.

Box D.1 contains the definitions of the occupations covered in this survey which are considered to be typical positions in every government. Since there is no common definition of managerial positions and the number of managerial levels varies across countries, for the purpose of this survey, D1 denotes the highest managerial level below the Minister/Secretary of State (who are designated by the President/Prime Minister) and appointed by the Minister (sometimes designated by the President/Prime Minister). This survey covers up to D4 managerial level positions but D5 and D6 Levels have been included if they are reported by participating countries as part of middle management. 


\section{Box D.1. Classification of occupations*}

\section{Senior managers}

- D1 managers (ISCO-08 1112) are top public servants below the Minister or Secretary of State. They could also be members of the senior civil service and/or appointed by the government or head of government. They advise government on policy matters, oversee the interpretation and implementation of government policies and, in some countries, have executive powers. D1 managers may be entitled to attend some cabinet meetings. They provide overall direction and management to the Minister/Secretary of State or a particular administrative area. In countries with a system of autonomous agencies, decentralised powers, flatter organisations and empowered managers, D1 managers correspond to Directors General.

- D2 managers (ISCO-08 11 and 112) formulate and review the policies and plan, direct, co-ordinate and evaluate the overall activities of the Ministry or special directorate/unit with the support of other managers. They may be part of the senior civil service. They provide guidance in the co-ordination and management of the programme of work and leadership to professional teams in different policy areas. They determine the objectives, strategies and programmes for the particular administrative unit/department under their supervision.

\section{Middle managers}

- D3 managers (ISCO-08 12) plan, direct and co-ordinate the general functioning of a specific directorate/ administrative unit within the Ministry with the support of other managers, usually within the guidelines established by a board of directors or a governing body. They provide leadership and management to teams of professionals within their particular area. These officials develop and manage the work programme and staff of units, divisions or policy areas. They establish and manage budgets, control expenditures and ensure the efficient use of resources. They monitor and evaluate performance of the different professional teams.

- D4 managers (ISCO-08 121) formulate and administer policy advice, and strategic and financial planning. They establish and direct operational and administrative procedures, and provide advice to senior managers. They control selection, training and performance of staff; prepare budgets and oversee financial operations; control expenditures; and ensure the efficient use of resources. They provide leadership to specific professional teams within a unit.

- D5 managers (optional) (ISCO-08 1211, 1212 and 1213) may be senior professionals whose main responsibility is to lead the execution of the work programme and supervise the work of other professionals and young professionals.

- D6 managers (optional) (ISCO-08 1211, 1212 and 1213) may be professionals whose main responsibility is to lead the execution of the work programme and supervise the work of other professionals or young professionals.

\section{Professionals}

- Economists/policy analysts (ISCO-08 242 and 2422) develop and analyse policies guiding the design, implementation and modification of government operations and programmes. These professionals review existing policies and legislation in order to identify anomalies and out-of-date provisions. They analyse and formulate policy options, prepare briefing papers and recommendations for policy changes. Moreover, they assess the impact, financial implications and political and administrative feasibility of public policies. Staff in this group have the possibility of becoming managers through career progression. Their areas of expertise may vary from law, economics, politics, public administration or international relations to engineering, environment, pedagogy, health economics, etc. This is a large occupational category and differences in weight between junior and senior staff may be very significant. Thus, countries are asked to provide information on the senior staff (i.e. senior economists) rather than on all economists. 


\section{Box D.1. Classification of occupations* (cont.)}

- Statisticians (ISCO-08 2120) conduct research and improve or develop statistical concepts or engage in their practical application to support government's operations. They plan and organise surveys and other statistical collections and design questionnaires. They evaluate, process, analyse and interpret statistical data and prepare them for publication. They advise on or apply various data collection methods and statistical methods and techniques to determine the reliability of findings.

\section{Secretarial positions}

- Administrative executive secretaries (ISCO-08 3343) perform liaison, co-ordination and organisational tasks in support of managers and professionals and prepare correspondence, reports and records of proceedings and other specialised documentation. They draft administrative correspondence; and assist in the preparation of budgets, monitoring of expenditures, drafting of contracts and purchasing or acquisition orders. They supervise the work of clerical support workers.

- Secretaries (general office clerks) (ISCO-08 411 and 4110) perform a range of clerical and administrative tasks in connection with money-handling operations, travel arrangements, requests for information and appointments. They record, prepare, sort, classify and fill information; sort, open and send mail; prepare reports and correspondence of a routine nature; record issue of equipment to staff; respond to telephone or electronic enquiries or forward to appropriate person; check figures, prepare invoices and record details of financial transactions made; transcribe information onto computers; and proofread and correct copy.

* The ISCO-08 number has been added to the definition for comparative purposes only.

Although the OECD methodology invited countries to provide precise information regarding the definition of the occupations for which data have been requested, there is no doubt that the boundaries of occupations continue to differ across countries to a varying degree depending on the occupation. The most coherent groups are likely to be the D1 Level (but see below the issue of "flatter governments") and secretarial positions. As expected, the category that suffers the most from differing occupational definitions across countries is professionals followed by middle management, both of which have more unclear boundaries. Seniority within those groups also varies across countries.

Data about D1 Levels and sometimes D2 are comparable but not without difficulties. One of the difficulties lies in the differing organisational structure of Ministries. Sweden, for example, is a special case where the government is entirely organised into agencies and the number of D1 Levels is very high. There are other countries for which the high numbers of D1 are less clearly justified suggesting less-than-full comparability. The analysis of the maximum and minimum salary data received for the D1 Level shows that the variation is limited even for those countries having lots of D1 Level staff, indicating that the data are probably correct. However, many countries did not provide data about the maximum and minimum salaries. In consequence, this analysis cannot be carried out for those specific cases.

The number of staff covered by the data in each occupational group is presented in Table D.1. In a few cases, the data are reported for the whole of central government, while in others for the six representative Ministries/Departments (or less).

\section{Compensation}

For the analysis of compensation, the survey builds on elements from the International Standard Classification of Labour Costs (ISCLC) developed by the International Labour Organization (ILO) and from the System of National Accounts (SNA). However, it departs slightly from these classifications to better facilitate comparability across countries. 
Table D.1. Number of staff included in each occupational group

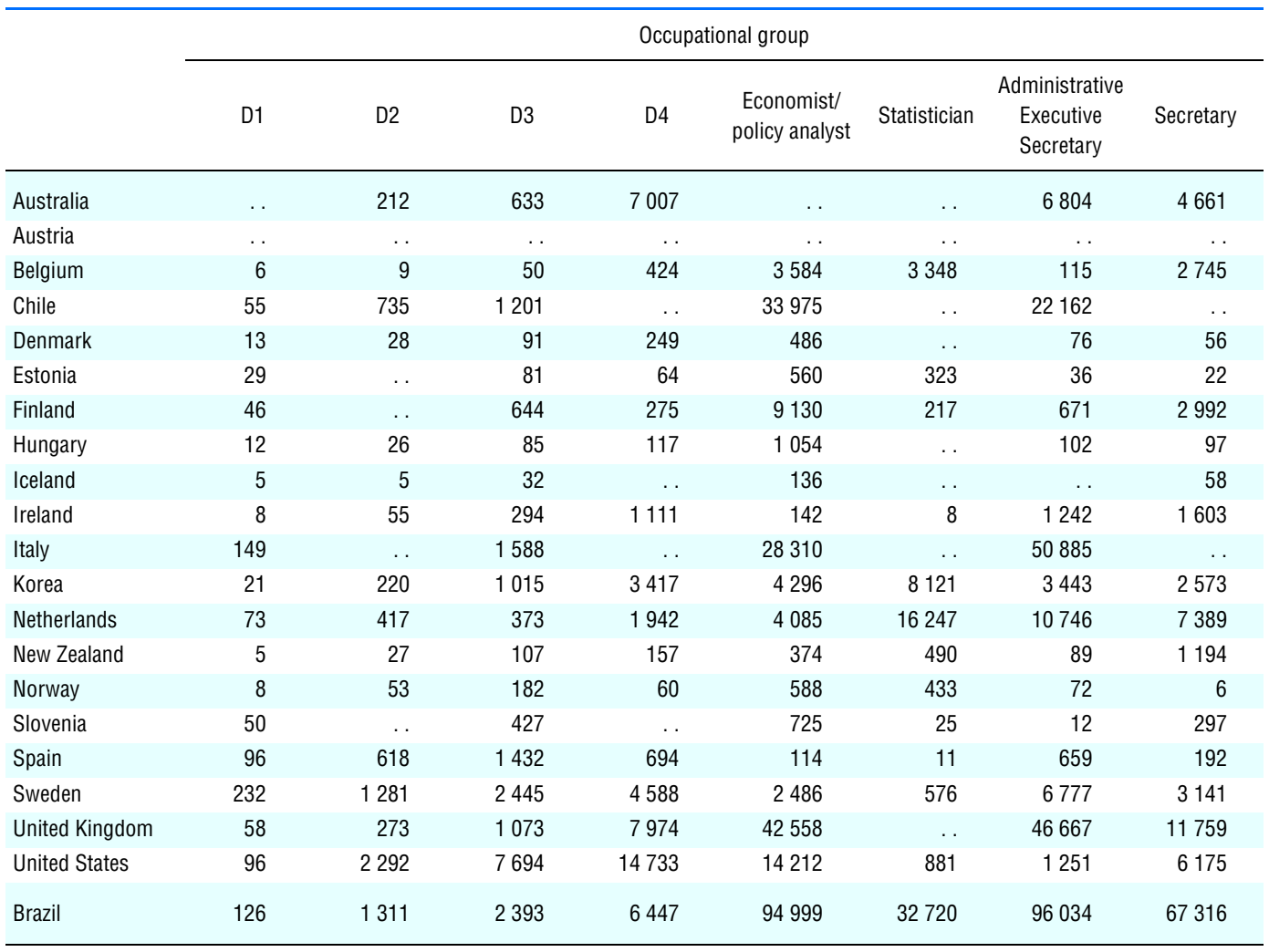

Notes: Austria: Data are provided for the total federal government.

Belgium: Ministries of Education and Environment are excluded (they are at the regional level).

Iceland: Ministry of Interior is not included.

Ireland: No Ministry of Interior is not included.

Norway: Ministry of Interior is not included but information is provided for the Ministry of Government Administration, Reform and Church Affairs.

Source: 2010 OECD Survey on Compensation of Government Employees.

The survey focuses on total compensation, which includes wages and salaries and employers' social contributions. Given the large variation in the size of social contributions across countries, the analysis of the compensation of employees has two main components: wages and salaries, and employers' social contributions. Governments remunerate their employees via social contributions or via higher wages and salaries to varying degrees, which underlines the importance of focusing on total compensation.

Total compensation includes the following:

1. Gross Wages and Salaries which include the values of any contributions, income taxes, etc., payable to the employee even if they are actually withheld by the employer for administrative convenience or other reasons and paid directly to social insurance schemes, tax authorities, etc., on behalf of the employee. Wages and salaries may be paid in various ways, including goods or services provided to employees as remuneration in kind instead of, or in addition to, remuneration in cash. Gross wages and salaries include:

- Basic wages and salaries (as set out in the salary scales) refer to the regular annual payments to employees for their time worked and services delivered to government. Although salaries and wages are paid at regular weekly, monthly or other intervals, for the purposes of this survey the annual salary is requested. 
- Additional payments - total: This refers to the total of all allowances and bonuses paid to employees.

- Guaranteed and regularly paid allowances refer to allowances for working away from home or in hazardous circumstances, expatriation allowances for working abroad, overtime payments, cost-of-living allowances, and housing allowances to cover the cost of travel to and from work, but excluding social benefits.

- Remunerations for time not worked make reference to annual vacation, other paid leave, including long-service leave; public holidays and other recognised holidays; other time off granted with pay (e.g. birth or death of a family member, marriage of employees, union activities, etc.). This applies only to countries where it is indicated in the system.

- Bonuses and gratuities regularly paid ${ }^{1}$ refer to year-end and seasonal bonuses; profit-sharing bonuses; and additional payments in respect of vacation, supplementary to normal vacation pay, and other bonuses and gratuities.

- Bonuses and gratuities not paid in a regular fashion (performance-related pay) refer to ad hoc bonuses or other exceptional payments linked to the overall performance of the employee to which he/she may be entitled.

2. Employers' social contributions (actual paid) are social contributions payable by employers to social security funds or other employment-related social insurance schemes to secure social benefits for their employees:

- Employers' contributions to statutory social security schemes or to privately funded social insurance schemes for covering old age, pension, invalidity and survivors, sickness, maternity, sickness leave, employment injury, unemployment, etc.

- Unfunded ${ }^{2}$ employees' social benefits paid by employers in the form of:

- Children's, spouse's, family, education or other allowances in respect of dependants.

- Payments made at full or reduced wage or salary rates to workers absent from work because of illness, accidental injury, maternity leave, etc.

- Severance payments to workers or their survivors who lose their jobs because of redundancy, incapacity, accidental death, etc.

The data include unfunded pension payments that are made through the state budget rather than through employers' social contributions (this is mostly the case in pay-as-you-go systems).

The analysis of the results of the survey should take the following difficulties into account:

1. Not all countries have been able to include the social contribution element in their survey responses (mainly because for unfunded pension schemes the contribution is imputed) and as a consequence it has been necessary to estimate this component using other data sources (for those countries): namely the data used in constructing the National Accounts, where imputations for unfunded pension schemes are made in a conceptually consistent way across countries. Table D.2 indicates the rates of employers' social contributions that are reported in the different existing databases regarding government employment. The rate that was chosen to calculate compensation costs in the data in this publication is indicated in dark blue. They have been chosen after investigation and discussions with the different countries and after comparing the different data sources. 
Table D.2. Employers' rate of social contributions (general rates)

\begin{tabular}{|c|c|c|c|c|c|c|c|c|}
\hline \multirow{2}{*}{$\begin{array}{l}\text { Provider: } \\
\\
\text { Source: }\end{array}$} & \multicolumn{5}{|c|}{ OECD } & \multicolumn{3}{|c|}{ EUROSTAT } \\
\hline & $\begin{array}{c}\text { Average } \\
\text { calculated } \\
\text { from survey } \\
(\%)\end{array}$ & $\begin{array}{c}\text { Public } \\
\text { administration, } \\
\text { total economy, } \\
\text { STAN Database } \\
(\%)\end{array}$ & $\begin{array}{c}\text { General } \\
\text { government, } \\
\text { sector accounts } \\
(\%)\end{array}$ & $\begin{array}{c}\text { Total economy, } \\
\text { sector accounts } \\
(\%)\end{array}$ & $\begin{array}{l}\text { Total economy, } \\
\text { value added and } \\
\text { its components } \\
\text { by activity, } \\
\text { national accounts } \\
\text { (\%) }\end{array}$ & $\begin{array}{c}\text { Public } \\
\text { administration } \\
\text { and community } \\
\text { services, activities } \\
\text { of households, } \\
\text { national accounts } \\
(\%)\end{array}$ & $\begin{array}{l}\text { General } \\
\text { government, } \\
\text { European sector } \\
\text { accounts } \\
(\%)\end{array}$ & $\begin{array}{c}\text { Total economy, } \\
\text { European sector } \\
\text { accounts } \\
(\%)\end{array}$ \\
\hline Australia & 16 & 13 & .. & .. & 12 & .. & .. & .. \\
\hline Austria & . & 26 & 34 & 24 & 26 & $\ldots$ & 34 & 24 \\
\hline Belgium & 8 & 25 & 42 & 36 & 25 & $\ldots$ & 42 & 36 \\
\hline Chile & 16 & . & . & . & . & . & . & . \\
\hline Denmark & 14 & 12 & 14 & 10 & 12 & 12 & 14 & 10 \\
\hline Estonia & 37 & 31 & 43 & 34 & 31 & 37 & 43 & 34 \\
\hline Finland & 2 & 21 & 28 & 24 & 22 & 21 & 28 & 24 \\
\hline Hungary & 37 & 28 & 34 & 27 & 28 & 28 & 34 & 27 \\
\hline Iceland & 22 & . & . & . & . & . & . & . \\
\hline Ireland & 11 & 5 & . & . & 5 & 5 & . & . \\
\hline Italy & & 30 & 41 & 37 & 30 & 30 & 41 & 37 \\
\hline Korea & 9 & . & . & . & . & . & . & . \\
\hline Netherlands & 23 & 29 & 37 & 28 & 29 & 29 & 37 & 28 \\
\hline New Zealand & 7 & .. & .. & .. & .. & .. & .. & .. \\
\hline Norway & 27 & 26 & 29 & .. & 25 & 25 & 29 & 23 \\
\hline Slovenia & 16 & 17 & . & . & 17 & 17 & $\ldots$ & . \\
\hline Spain & 25 & 24 & 29 & 28 & 24 & .. & 29 & 28 \\
\hline Sweden & 48 & 27 & 33 & 31 & 27 & 26 & 33 & 31 \\
\hline United Kingdom & & . & 27 & 18 & . & . & 27 & 19 \\
\hline United States & 37 & 28 & 40 & 24 & 29 & . & . & .. \\
\hline Brazil & .. & .. & 28 & .. & .. & .. & .. & .. \\
\hline
\end{tabular}

Notes: Data in bold refer to 2009; all other data are for 2006 to 2008 (closest date to 2009 was used). Cells shaded in dark blue indicate the rate used in this publication to calculate compensation costs.

When possible, the survey data have been used. When not possible, data have been drawn from the System of National Accounts, which covers different areas of government. The closest match is public administration, after which is general government and total economy. Australia: Survey data used that correspond to the latest data from STAN Database. The figures include federal, state and territory public services.

Austria: Rates of social contributions are not available in the survey. STAN Database provides timely statistics on social contributions.

Belgium: Rates of social contributions provided in the survey are not supported by other statistical sources. Share of STAN Database of year 2007 used instead.

Chile: Survey data used (no other source available).

Denmark: Survey data used and correspond to available statistics

Estonia: Survey data used and correspond to available statistics.

Finland: Survey data used and correspond to available statistics.

Hungary: Survey data used and corresponds to available statistics.

Iceland: Survey data used (no other source available).

Ireland: Social contributions rates are for staff hired after 1995 and exclude unfunded pension schemes through the pay-as-you-go system. Italy: Rates of social contributions not available in the survey. Eurostat Database provides up-to-date statistics on social contributions.

Korea: Survey data used (no other source available).

Netherlands: Survey data used.

New Zealand: Survey data used (no other source available).

Norway: Survey data used and correspond to available statistics.

Slovenia: Rates of social contributions not available in the survey. Eurostat Database provides up-to-date statistics on social contributions. The calculated figure does not include the premium of collective supplementary pension scheme for civil servants that the employer pays to all civil servants.

Spain: Survey data used and correspond to available statistics.

Sweden: Survey data used.

United States: Rates of social contributions not available in survey. 
2. In all countries, the same shares of employers' social contributions are used across all occupational groups, because only very few countries have provided differences across occupations. This does, of course, have an impact on the quality of the results and some care is necessarily needed in interpretation. The National Accounts data provide ratios of social security contributions as a share of total compensation of employees for all government employees; in other words for an average employee. Using this ratio will not be able to accommodate any differences that may exist within each institution relating to the proportions of individuals with funded rather than unfunded schemes or if the ratio of social contributions is not invariant to the underlying wages and salaries.

For the countries which have provided data for employers' social contributions in the survey, exact data have not been provided systematically across occupations. For that reason, the OECD calculated a country-specific average percentage of employers' social contributions that applies to all occupations for each country. ${ }^{3}$ Data show that variations in the percentage of employers' social contributions across occupations are probably not large enough to justify a different approach, except maybe in a few countries (Australia, Ireland, New Zealand and Chile) for specific occupations.

3. The level of social contributions is only a proxy. The quantity and quality of benefits that employees get through their employers' and employees' social contributions depend on the quality and efficiency of the management of the funds and services in each country. For example, most importantly, some countries provide realistic funding of their future pensions, while others do not. This means that compensation may appear higher in a country which realistically forecasts and covers future pension costs than in another country with unrealistic pension funding. One can always say, however, that the data remain comparable because in the country with unrealistic pension funding, pensions will inevitably have to decrease, or future taxes on employees and retirees increase (or possible future contributions of employees increase).

4. Finally, a number of countries are moving away from pay-as-you-go systems to funded pension schemes where contributions may be drawn out of salaries. For countries whose data on social contributions are taken from the National Accounts, it is possible that the percentage adds to a level of salaries that is higher, due to the move from one system to another for that specific position.

\section{Overtime pay}

Information on the number of overtime hours worked has not been collected as part of this survey. The weekly wage estimated is thus overstated because it includes overtime pay (for occupations in which overtime is paid).

\section{Purchasing power parities (PPPs)}

Calculations have been made in USD using the PPP methodology with the numbers in Table D.3. This compensates for differences in exchange rates and in relative price levels.

The PPP does not take into account the relatively different costs of living in capital cities within and across countries. In many countries, the majority of central government employees are employed in capital cities especially for non-service delivery occupational groups. There are a number of countries where the costs of living in capital cities are particularly high, and relatively higher than in other countries. Wages and salaries tend to make up for that difference and those countries thus tend to have higher salaries. 
Table D.3. Purchasing Power Parities and exchange rates (2009)

\begin{tabular}{lrr}
\hline & Purchasing Power Parities for GDP, national currency per USD & Exchange rates, national currency per USD \\
\hline Australia & 1.452 & 1.282 \\
Austria & 0.845 & 0.720 \\
Belgium & 0.866 & 0.720 \\
Chile & 377.126 & 560.860 \\
Denmark & 7.958 & 5.361 \\
Estonia & 8.240 & 11.257 \\
Finland & 0.910 & 0.720 \\
Hungary & 128.186 & 202.342 \\
Iceland & 127.782 & 123.638 \\
Ireland & 0.903 & 0.720 \\
Italy & 0.779 & 0.720 \\
Korea & 804.718 & 1276.930 \\
Netherlands & 0.848 & 0.720 \\
New Zealand & 1.501 & 1.600 \\
Norway & 8.847 & 6.288 \\
Slovenia & 0.629 & 0.720 \\
Spain & 0.711 & 0.720 \\
Sweden & 8.939 & 7.654 \\
United Kingdom & 0.642 & 0.642 \\
United States & 1.000 & 1.000 \\
Brazil & 1.558 & 1.999 \\
\hline
\end{tabular}

Source: OECD National Accounts; data for Brazil are from the World Bank.

\section{Working time adjustment}

In order to build comparable data, the difference between the time people actually work and the annual average compensation (annual average gross salary plus employers' social contributions) is calculated so as to obtain an adjusted annual average compensation. Indeed, to put the compensation of employees reported on a comparable basis across countries, the difference in the working time (number of hours worked per week in the civil service, annual leave entitlements (holidays) and statutory holidays) is used for the calculation of the adjusted annual average compensation. For senior managers, since weekly working time applies very unevenly to this category of employees, data were adjusted only for holidays.

\section{Computations for comparing annual compensation}

Average comparative annual compensation is as:

$$
W_{c o}^{a *}=\frac{\left(\frac{W_{c o}^{a} S_{c}^{*}}{P_{c}}\right)}{H_{c}^{a *}}
$$

where:

$W_{c o}^{a *}=$ Average annual compensation of employees in PPP in country c within occupational group 0 .

$W_{c o}^{a}=$ Average annual wages and salaries in domestic currency in country $c$ within occupational group 0 .

$P_{c} \quad=$ Purchasing power parity of country $\mathrm{c}$.

$S_{c}^{*} \quad=$ Ratio of social contribution in country $c$, where:

$S_{c}^{*}=\left(1+\frac{S_{c}}{w_{c}}\right)$, and

$S_{c} \quad=$ Paid social contributions in country c (from survey data or general statistics). 


\section{Table D.4. Working time and working time correction}

\begin{tabular}{|c|c|c|c|c|c|c|c|c|c|}
\hline & $\begin{array}{c}\text { Contractual } \\
\text { working time, } \\
\text { h/week }\end{array}$ & $\begin{array}{l}\text { Number } \\
\text { of holidays }\end{array}$ & $\begin{array}{l}\text { Number } \\
\text { of average } \\
\text { public holidays } \\
\text { that apply to } \\
\text { the civil service }\end{array}$ & $\begin{array}{l}\text { Holidays } \\
\text { as maximum, } \\
\text { extra } \\
\text { or by special } \\
\text { agreement }\end{array}$ & $\begin{array}{c}\text { Average } \\
\text { working days } \\
\text { per year } \\
\text { in country }\end{array}$ & $\begin{array}{c}\text { Average } \\
\text { working hours } \\
\text { per year } \\
\text { in country }\end{array}$ & $\begin{array}{c}\text { Coefficient } \\
\text { for working time } \\
\text { corrections, } \\
\text { weekly hours and } \\
\text { holidays }\end{array}$ & $\begin{array}{c}\text { Coefficient } \\
\text { for working time } \\
\text { correction, } \\
\text { holidays }\end{array}$ & $\begin{array}{c}\text { Coefficient } \\
\text { for working time } \\
\text { correction, } \\
\text { no correction }\end{array}$ \\
\hline Australia & 37.5 & 20 & 10 & & 231 & 1730 & 0.830 & 0.885 & 1.000 \\
\hline Austria & 40 & 25 & 10 & 5 & 223 & 1786 & 0.856 & 0.856 & 1.000 \\
\hline Belgium & 38 & 26 & 10 & 9 & 220 & 1674 & 0.802 & 0.845 & 1.000 \\
\hline Chile & 44 & 15 & 13 & & 233 & 2048 & 0.982 & 0.893 & 1.000 \\
\hline Denmark & 37 & 30 & 10.3 & & 220 & 1631 & 0.782 & 0.845 & 1.000 \\
\hline Estonia & 40 & 25 & 12 & 10 & 219 & 1750 & 0.839 & 0.839 & 1.000 \\
\hline Finland & 36.25 & 30 & 9 & 8 & 218 & 1578 & 0.757 & 0.835 & 1.000 \\
\hline Hungary & 40 & 25 & 9 & 11 & 221 & 1770 & 0.848 & 0.848 & 1.000 \\
\hline Iceland & 37.08 & 24 & 14 & 6 & 220 & 1629 & 0.781 & 0.843 & 1.000 \\
\hline Ireland & 34.75 & 20 & 10 & 11 & 225 & 1565 & 0.750 & 0.864 & 1.000 \\
\hline Italy & 36 & 24 & 4 & & 233 & 1676 & 0.803 & 0.893 & 1.000 \\
\hline Korea & 40 & 20 & 14 & & 227 & 1814 & 0.870 & 0.870 & 1.000 \\
\hline Netherlands & 36 & 23 & 8 & & 230 & 1654 & 0.793 & 0.881 & 1.000 \\
\hline New Zealand & 40 & 20 & 11 & & 230 & 1838 & 0.881 & 0.881 & 1.000 \\
\hline Norway & 37.5 & 25 & 10 & 5 & 223 & 1674 & 0.803 & 0.856 & 1.000 \\
\hline Slovenia & 40 & 20 & 13 & 5 & 225 & 1802 & 0.864 & 0.864 & 1.000 \\
\hline Spain & 37.5 & 22 & 14 & 6 & 222 & 1663 & 0.797 & 0.850 & 1.000 \\
\hline Sweden & 39.75 & 28 & 11 & 7 & 218 & 1735 & 0.832 & 0.837 & 1.000 \\
\hline United Kingdom & 37 & 25 & 8 & 5 & 225 & 1667 & 0.799 & 0.864 & 1.000 \\
\hline United States & 40 & 20.76 & 10 & & 230 & 1840 & 0.882 & 0.882 & 1.000 \\
\hline Brazil & 40 & 30 & 10 & & 221 & 1766 & 0.847 & 0.847 & 1.000 \\
\hline
\end{tabular}

Notes: Maximum working days per year if 5 out of 7 days per week are worked: 261 .

Maximum working hours per year if $8 \mathrm{~h}$ per working day: 2088 .

Contractual working time, hours/week does not include lunch breaks.

Maximum and extra holidays, special agreement: Total is maximum reported holidays reduced by minimum number of holidays (formula: $\min$. holidays + (max. holidays - min. holidays) $/ 2$ = average holidays).

Australia: $60.6 \%$ of Australian public service (APS) employees are covered by agreements requiring them to work a 7 hours 30 minutes day (or a $37 \frac{1}{2}$ hours week) within a flex-time bandwidth. A substantial number of APS employees (38\%) are covered by agreements that require a slightly lower standard working day/week. A small number of APS employees are covered by agreements requiring a longer working day/week. Estonia: Number of holidays is calculated on the basis of calendar days in Estonia. In the case of Estonia, 35 calendar days ideally equals 25 working days (+ maximum 10 days holiday after 3 years in public service). Concerning the number of average public holidays, it is important to mention that if the public holiday falls on a weekend, it is not possible to receive extra day off from work during the previous or following work week in Estonia.

Finland: Weekly working time as full office hours. Extra holidays after 15 years of service

Hungary: The length of paid annual leave varies by length of service (in the case of non-managers) or the hierarchical level of managers. Basic paid annual leave: 25 days. Additional paid annual leave varies by the length of service in the case of professionals: $1-3$ years: 3 days; 3-8 years: 5 days; 8-16 years: 7 days.

Iceland: Special holidays are 17 in total, of which 8 are major holidays. Of those 17 days: 7 holidays are on fixed dates and can be on a weekend, 7 holidays are on certain weekdays, and 3 during certain weekends (Saturday or Sunday). The length of annual leave depends on age. The minimum length of vacation is two days or 16 obligatory hours for each earned month of full-time work. For those younger than 30 years old, the annual leave is 24 days (192 working hours); for $30-37$ years old, the annual leave is 27 days (216 working hours); and for those older than 38 , the annual leave is 30 days (240 working hours).

Italy: Public managers do not have any legal obligation in terms of working time, as their performance is evaluated on results rather than on the presence at the workplace. However, based on habits and on the previous regulation on public managers' working time (d.p.r. No. 748 of 1972) that indicated 10 weekly hours more than other employees, the conventional contractual working time of public managers is estimated at 45 hours per week.

Korea: Civil servants are entitled to 3-21 days of annual leave per year depending on length of service.

Norway: All workers in Norway are entitled to 5 weeks/25 working days holiday per year. Workers from the age of 60 are entitled to one more week/ 5 working days. In addition, civil servants from the age of 62 are entitled to a further 8 working days +6 days optional - the optional days have to be negotiated locally.

Sweden: The number of holidays varies with age according to the central collective agreement. Employees under 30 years of age have 28 days holiday; between 30 and 39 years of age they have 31 days holiday; and employees 40 years or older have 35 days holiday.

Slovenia: The length of annual leave depends on seniority, job complexity, work performance, working conditions, social and health conditions, and age. As for seniority, there is a maximum of 24 days annual leave as follows: up to 3 years' service: 16 days, over 3 to 7 years' service: 17 days; over 7 to 10 years: 18 days; over 10 to 15 years of service: 20 days; over 15 to 20 years' service: 22 days; over 20 to 25 years' service: 23 days; over 25 years' service: 24 days. Employees get up to 5 additional days depending on work performance, working conditions, social and health conditions and age. 
$W_{c}=$ Paid wages and salaries in country c (from survey data or general statistics).

$H_{c}^{a *}=$ Ratio of average working time in country $c$.

Where:

$$
H_{c}^{a *}=\frac{H_{c}^{a}}{2088}, \text { and }
$$

$H_{c}^{a}=$ Average annual working hours in country c (from survey data).

The number 2088 equals the theoretical working hours in year with 40 hours of work per week and no holidays or leave of any kind. This also results in an average of 261 working days per year with each working day including 8 hours of work.

\section{Notes}

1. Please note that an allowance is paid for who the person is (for pre-existing individual attributes) and bonuses and benefits are paid based on performance. An allowance is something that has to be paid because a special skill is possessed even though it may never be used at work, such as the knowledge of another language. The bonuses and gratuities, like end-of-year pay, are guaranteed payments but the time span to be granted may be longer. Other bonuses and gratuities, like payments for supplementary work, have a more voluntary connotation.

2. The term "unfunded" refers to social benefits for which no social security fund exists.

3. The average for employers' social contributions has been calculated through an unweighted average of employers' social contributions reported for occupations of top management, middle management, professionals and secretarial positions. This average has been applied to all occupations. 


\section{ANNEX E \\ Composite Indexes for Human Resources Management Practices}

The composite indexes presented in Government at a Glance summarise discrete, qualitative information on key aspects of human resources management (HRM) practices. Composite indexes are developed and utilised because they can often help examine trends and findings as opposed to assessing several variables individually. However, their interpretation should be made with caution, and only after understanding what they are meant to measure and how they are generated.

The OECD has taken several steps to avoid and address the common problems associated with composite indexes. The HRM composites presented in Chapters IV and VII of this publication adhere to the steps identified in the Handbook on Constructing Composite Indicators (Nardo et al., 2008) that are necessary for the meaningful construction of composite or synthetic indexes:

- Each composite index is based on a theoretical framework representing an agreed upon concept in the area it covers. The variables composing the indexes are selected based on their relevance to the concept by a group of experts within the OECD and in consultation with country delegates to the Public Employment and Management Working Party.

- The survey questions used to create the indexes are the same across countries, ensuring they are comparable.

- Various statistical tools - such as factor analysis and the computation of Cronbach's alpha - were employed to establish that the variables composing each index are correlated and represent the same underlying concept.

- Different methods for imputing missing values have been explored.

- All sub-indicators and variables were normalised for comparability.

- To build the composites, all sub-indicators were aggregated using a linear method according to the accepted methodology.

- Sensitivity analysis was carried out in order to establish the robustness of the indicators to different weighting options (e.g. equal weighting, factor weights and expert weights).

It is important to note that the HRM indexes do not purport to measure the overall quality of human resource management systems. To do so would require a much stronger conceptual foundation and normative assumptions. Rather, the composite indexes presented in Government at a Glance are descriptive in nature, and have been given titles to reflect this.

Additional details regarding the theoretical framework, construction and weightings of each composite are available at: www.oecd.org/gov/indicators/govataglance. 


\section{ANNEX F}

\section{Detailed Data on Conflict-of-Interest Disclosure from the 2010 OECD Survey on Integrity}

This annex provides data for each responding country on the types of private interests that they require central government decision makers to disclose as well as the level of transparency of these disclosures. The data underlie the summary of data presented in Figure 39.1 and 39.2. 
Table F.1. Level of disclosure of private interests in the three branches of government by country (2010)

\begin{tabular}{|c|c|c|c|c|c|c|c|c|c|c|c|c|c|c|c|c|c|c|c|c|c|c|c|c|c|c|c|c|c|c|c|c|c|c|c|c|c|c|c|c|c|c|c|c|c|}
\hline & & & $\stackrel{\infty}{\mathcal{Z}}$ & 占 & 岗 & $\sum_{0}^{2}$ & 공 & 嵌 & 产 & 芘 & & $\sum_{4}$ & 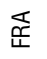 & 㟔 & 永 & 쪼 & $\underline{\underline{\omega}}$ & $\underline{9}$ & & 息 & $\Xi$ & $\varliminf_{9}$ & ֻै & $\frac{\sigma}{2}$ & 爻 & 层 & 总 & $\vec{N}$ & z & 울 & 홍 & $\stackrel{\underline{\alpha}}{\alpha}$ & 产 & $\sum_{\text {d }}^{\vdots}$ & 空 & & 惢 & 喆 & 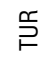 & 㩊 & 秀 & 里 & 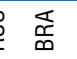 & 总 & $\stackrel{?}{y}$ \\
\hline \multirow{24}{*}{ 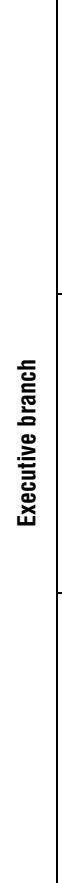 } & \multirow{8}{*}{ 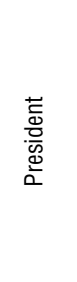 } & Assets & n.a. & 0 & n.a. & n.a. & $\bullet$ & 0 & n.a. & • & & ○ & - & O & - & - & O & & & n.a. & n.a. & n.a & & • & & - & n.a. & & & n.a. & - & - & - & - & n. 2 & & n.a. 1 & n.a. & - & n.a. & - & • & - & 口 & - \\
\hline & & Liabilities & n.a. & O & n.a. & n.a. & $\bullet$ & O & n.a. & $\bullet$ & & O & $\bullet$ & O & O & $\bullet$ & O & $\mathrm{n}$. & a. $r$ & n.a. & n.a. & n.a & & $\bullet$ & .. & $\bullet$ & n.a. & n.a & a. $n$ & n.a. & $\bullet$ & $\bullet$ & $\bullet$ & $\bullet$ & $\mathrm{n} . \mathrm{c}$ & a. $n$ & n.a. । & n.a. & $\bullet$ & n.a. & $\bullet$ & $\bullet$ & $\bullet$ & घ & $\bullet$ \\
\hline & & Income source & n.a. & O & n.a. & n.a. & $\bullet$ & O & n.a. & $\bullet$ & & O & O & O & $\bullet$ & $\bullet$ & O & $\mathrm{n}$. & a. $r$ & n.a. & n.a. & n.a & & $\bullet$ & .. & - & n.a. & & .a. $n$ & n.a. & O & $\bullet$ & $\bullet$ & $\bullet$ & n. & a. $n$ & n.a. । & n.a. & $\bullet$ & n.a. & $\bullet$ & $\bullet$ & $\bullet$ & $\boldsymbol{\square}$ & O \\
\hline & & Income amount & n.a. & O & n.a. & n.a. & O & O & n.a. & . $\bullet$ & & O & O & O & $\bullet$ & $\bullet$ & O & $\mathrm{n}$ & a. $r$ & n.a. & n.a. & n.a & & $\bullet$ & .. & - & n.a. & & .a. $n$ & n.a. & O & $\bullet$ & $\bullet$ & - & n.c & & n.a. । & n.a. & $\bullet$ & n.a. & $\bullet$ & $\bullet$ & $\bullet$ & O & $\bullet$ \\
\hline & & Outside position: paid & n.a. & $P$ & n.a. & n.a. & $\bullet$ & O & n.a. & $\bullet$ & & O & O & $P$ & $P$ & $P$ & O & $\mathrm{n}$. & a. $r$ & n.a. & n.a. & n.a & a. & $\mathbf{\square}$ & 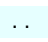 & $\bullet$ & n.a. & n.a & a. $n$ & n.a. & O & $P$ & $\bullet$ & $\bullet$ & $\mathrm{n} . \mathrm{c}$ & & n.a. । & n.a. & $P$ & n.a. & $\bullet$ & O & $\bullet$ & $P$ & $\bullet$ \\
\hline & & Outside position: non-paid & n.a. & $P$ & n.a. & n.a. & $\bullet$ & O & n.a. & . 0 & & ○ & O & $P$ & $P$ & $P$ & O & $\mathrm{n}$. & a. $r$ & n.a. & n.a. & n.a & & $\mathbf{a}$ & . & O & n.a. & n.a & a. $n$ & n.a. & O & $P$ & $\bullet$ & $\bullet$ & n. & & n.a. & n.a. & 口 & n.a. & $\bullet$ & O & $\bullet$ & $P$ & $\bullet$ \\
\hline & & Gifts & n.a. & $P$ & n.a. & n.a. & $\mathrm{P}$ & O & n.a. & - & & O & O & O & - & $\bullet$ & O & $\mathrm{n}$ & a. $r$ & n.a. & n.a. & n.a & & • & .. & $\bullet$ & n.a. & n.a & a. $n$ & n.a. & O & $\bullet$ & O & $\bullet$ & n. & & n.a. & n.a. & $\bar{P}$ & n.a. & $\bullet$ & $\mathrm{P}$ & O & $P$ & O \\
\hline & & Previous employment & n.a. & O & n.a. & n.a. & $O$ & O & n.a. & $\bullet$ & & ○ & O & O & O & O & $\mathrm{O}$ & $\mathrm{n}$. & a. $r$ & n.a. & n.a. & n.a & & $\bullet$ & .. & $\bullet$ & n.a. & n.a & a. $n$ & n.a. & O & $\bullet$ & $\bullet$ & $\bullet$ & n.c & a. $n$ & n.a. । & n.a. & घ & n.a. & $\bullet$ & $\bullet$ & $\bullet$ & $\mathbf{\square}$ & $\bullet$ \\
\hline & \multirow{8}{*}{ 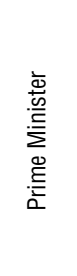 } & Assets & - & - & घ & - & n.a. & - & - & $\bullet$ & & - & - & 0 & - & $\bullet$ & • & c & & - & - & & & & & n.a. & O & - & • & - & - & & - & - & $\bullet$ & & - & O & - & - & n.a. & & n.a. & $\mathbf{\square}$ & - \\
\hline & & Liabilities & $\bullet$ & $\bullet$ & O & $\bullet$ & n.a. & - & O & $\bullet$ & & $\bullet$ & $\bullet$ & O & O & $\bullet$ & O & 0 & $\partial$ & $\bullet$ & - & घ & & $\bullet$ & .. & n.a. & - & $\bullet$ & $\bullet$ & O & $\bullet$ & $\bullet$ & $\bullet$ & $\bullet$ & $\bullet$ & b & $O$ & O & - & $\bullet$ & n.a. & $\bullet$ & n.a. & - & $\bullet$ \\
\hline & & Income source & $\bullet$ & $\bullet$ & $O$ & $\bullet$ & n.a. & - & $\bullet$ & $\bullet$ & & $\bullet$ & O & O & $\bullet$ & $\bullet$ & $\bullet$ & 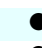 & & $\bullet$ & 口 & 口 & & $\bullet$ & .. & n.a. & 口 & $\bullet$ & $\bullet$ & $\bullet$ & O & $\bullet$ & $\bullet$ & $\bullet$ & $\bullet$ & & 口 & O & $\bullet$ & $\bullet$ & n.a. & $\bullet$ & n.a. & घ & O \\
\hline & & Income amount & O & - & O & - & n.a. & घ & - & - & & - & O & 0 & - & - & O & 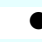 & $\bullet$ & $\bullet$ & - & $\boldsymbol{\square}$ & & $\bullet$ & .. & n.a. & $\bullet$ & O & $\partial$ & O & O & $\bullet$ & $\bullet$ & $\bullet$ & $\bullet$ & & $\mathbf{\square}$ & O & $\bullet$ & $\bullet$ & n.a. & & n.a. & - & $\bullet$ \\
\hline & & Outside position: paid & $\bullet$ & $\mathrm{P}$ & $\bullet$ & $P$ & n.a. & - & $P$ & P & & $\bullet$ & $O$ & $\mathrm{P}$ & $P$ & $P$ & $\bullet$ & $\bullet$ & & $P$ & $\bullet$ & $\mathrm{P}$ & & $\mathbf{a}$ & . & n.a. & $P$ & $\bullet$ & $\bullet$ & $\bullet$ & O & $P$ & $\bullet$ & $\bullet$ & - & & $P$ & $\mathrm{P}$ & $P$ & $\bullet$ & n.a. & P & n.a. & $P$ & $\bullet$ \\
\hline & & Outside position: non-paid & - & $P$ & - & - & n.a. & [ & $P$ & 0 & & - & 0 & - & $P$ & $P$ & - & o & o & O & - & 0 & & च & .. & n.a. & $\mathrm{P}$ & - & • & - & O & $P$ & - & - & - & & $P$ & $\mathrm{P}$ & - & - & n.a. & 0 & n.a. & $\mathrm{P}$ & • \\
\hline & & Gifts & - & $P$ & O & - & n.a. & घ & - & घ & & - & O & - & - & - & - & c & & $\mathrm{P}$ & $P$ & घ & & 匹 & .. & n.a. & $\mathrm{P}$ & - & • & - & घ & - & O & - & e & & घ & 0 & $\mathrm{P}$ & - & n.a. & $\mathrm{P}$ & n.a. & $P$ & 0 \\
\hline & & Previous employment & O & $O$ & O & $\bullet$ & n.a. & O & $\bullet$ & $\bullet$ & & ○ & O & O & O & O & $\bullet$ & o & $\partial$ & $\bullet$ & - & O & & - & .. & n.a. & - & O & 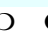 & $\bullet$ & O & $\bullet$ & $\bullet$ & - & 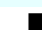 & $\square$ & O & $O$ & - & O & n.a. & 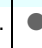 & n.a. & घ & $\bullet$ \\
\hline & & Assets & $\bullet$ & $\bullet$ & - & $\bullet$ & $\bullet$ & - & $\bullet$ & $\bullet$ & & $\bullet$ & - & O & $\bullet$ & $\bullet$ & $\bullet$ & $\bullet$ & $\bullet$ & - & $\bullet$ & $\mathbf{\square}$ & & & & $\bullet$ & O & & $\bullet$ & - & $\bullet$ & $\bullet$ & - & $\bullet$ & & & - & O & $\bullet$ & $\bullet$ & - & 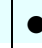 & - & - & - \\
\hline & & Liabilities & $\bullet$ & - & O & $\bullet$ & $\bullet$ & घ & O & $\bullet$ & & $\bullet$ & - & $\mathrm{O}$ & O & $\bullet$ & O & o & $\mathrm{O}$ & $\bullet$ & - & & & $\bullet$ & .. & $\bullet$ & O & $\bullet$ & • & O & $\bullet$ & $\bullet$ & $\bullet$ & $\bullet$ & $\bullet$ & 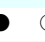 & O & O & - & $\bullet$ & घ & 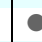 & $\bullet$ & 口 & $\bullet$ \\
\hline & $\bar{E} \bar{\Phi}$ & Income source & - & - & 0 & - & - & घ & • & - & & - & O & 0 & - & - & - & 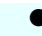 & & - & घ & 0 & & - & .. & - & O & • & • & - & O & - & - & - & e & & घ & O & - & - & घ & $\bullet$ & - & घ & 0 \\
\hline & 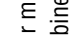 & Income amount & $\mathrm{O}$ & - & 0 & - & O & घ & • & - & & - & O & O & - & - & 0 & c & - & - & घ & $\mathrm{O}$ & & - & .. & - & O & 0 & o & O & $\mathrm{O}$ & - & - & - & e & & घ & 0 & - & - & घ & • & - & घ & - \\
\hline & $\begin{array}{l}5 \overline{0} \\
\text { is }\end{array}$ & Outside position: paid & - & $P$ & - & $P$ & - & घ & $P$ & $\mathrm{P}$ & & • & 0 & $P$ & $P$ & $P$ & - & 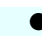 & • & $P$ & - & $\mathrm{P}$ & & च & .. & - & $\mathrm{P}$ & $\bullet$ & • & - & O & $\mathrm{P}$ & - & - & - & & $P$ & $\mathrm{P}$ & $P$ & - & च & $\mathrm{P}$ & - & $P$ & • \\
\hline & $\frac{50}{0}$ & Outside position: non-paid & $\bullet$ & $P$ & $\bullet$ & $\bullet$ & $\bullet$ & घ & $P$ & O & & $\bullet$ & O & $\bullet$ & $P$ & $P$ & $\bullet$ & o & $\mathrm{O}$ & O & $\bullet$ & O & & a & .. & $\mathrm{O}$ & $P$ & $\bullet$ & • & $\bullet$ & O & $P$ & $\bullet$ & - & $\mathbf{E}$ & & $P$ & $P$ & $\bullet$ & $\bullet$ & घ & $\mathrm{O}$ & $\bullet$ & $P$ & $\bullet$ \\
\hline & & Gifts & $\bullet$ & $P$ & O & $\bullet$ & $P$ & घ & $\bullet$ & O & & $\bullet$ & O & $\bullet$ & $\bullet$ & $\bullet$ & $\bullet$ & & $\bullet$ & $P$ & $P$ & O & & 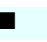 & .. & $\bullet$ & $P$ & & $\bullet$ & $\bullet$ & - & $\bullet$ & O & $\bullet$ & $\bullet$ & & घ & O & $P$ & $\bullet$ & - & $\mathrm{P}$ & $P$ & $P$ & O \\
\hline & & Previous employment & O & $O$ & $O$ & $\bullet$ & O & $\mathrm{O}$ & $\bullet$ & $\bullet$ & & O & O & $O$ & $O$ & O & $\bullet$ & & O & - & - & O & & $\square$ & .. & $\bullet$ & $\mathbf{\square}$ & O & 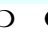 & $\bullet$ & O & $\bullet$ & $\bullet$ & - & - & $\square$ & $O$ & O & $\bullet$ & O & - & $\bullet$ & $\bullet$ & $\mathbf{\square}$ & $\bullet$ \\
\hline \multirow{16}{*}{ 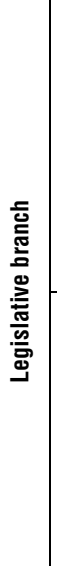 } & \multirow{8}{*}{ 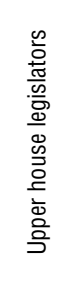 } & Assets & $\bullet$ & O & घ & घ & $\bullet$ & घ & n.a. & n.a & & n.a. & - & n.a. & n.a. & n.a. & n.a & & - $r$ & n.a. & $\mathbf{\square}$ & घ & & a. & & घ & O & n.a & a. $n$ & n.a. & $\bullet$ & n.a. & n.a. & - & & $n$ & n.a. & 0 & n.a. & . & घ & $\bullet$ & घ & - & n.a. \\
\hline & & Liabilities & - & 0 & O & घ & - & घ & n.a. & n.a & & n.a. & - & n.a. & n.a. & n.a. & n.a & & $0 \mathrm{r}$ & n.a. & - & घ & & a. & .. & [ & 0 & & a. $n$ & n.a. & - & n.a. & n.a. & - & & $n$ & n.a. & 0 & n.a. & . 0 & घ & $\bullet$ & घ & - & n.a. \\
\hline & & Income source & - & - & O & घ & - & 口 & n.a. & n.a & & n.a. & O & n.a. & n.a. & n.a. & n.a & & - $\mathrm{r}-2-a r$ & n.a. & - & a & & a. & .. & घ & a & & a. $n$ & n.a. & - & n.a. & n.a. & $\bullet$ & & ? & n.a. & O & n.a. & $\bullet$ & च & & a & & n.a. \\
\hline & & Income amount & O & - & O & - & 0 & घ & n.a. & n.a & & п.a. & O & n.a. & n.a. & n.a. & n.a & & - $r$ & n.a. & - & $\boldsymbol{\square}$ & & la. & .. & - & O & & a. $n$ & n.a. & $\bullet$ & n.a. & n.a. & ○ & & $n$ & n.a. & O & n.a. & $\bullet$ & घ & $\bullet$ & $\mathbf{\square}$ & & n.a. \\
\hline & & Outside position: paid & $\bullet$ & $\bullet$ & $\bullet$ & - & $\bullet$ & $\mathbf{\square}$ & n.a. & n.a & & n.a. & O & n.a. & n.a. & n.a. & n.a & 1. & • $r$ & n.a. & $\mathbf{\square}$ & घ & & a. & & $\mathbf{\square}$ & $\mathbf{\square}$ & n.a & a. $n$ & n.a. & $\bullet$ & n.a. & n.a. & $\bullet$ & & n $n$ & n.a. & $\bullet$ & n.a. & $\bullet$ & - & $P$ & - & & n.a. \\
\hline & & Outside position: non-paid & - & 0 & - & घ & - & घ & n.a. & n.a & & n.a. & 0 & n.a. & n.a. & n.a. & n.a & & $0 \mathrm{r}$ & n.a. & घ & O & & a. & .. & $\mathrm{P}$ & घ & & a. $n$ & n.a. & - & n.a. & n.a. & • & & D $n$ & n.a. & - & n.a. & . & घ & O & घ & - & n.a. \\
\hline & & Gifts & - & 0 & O & घ & $P$ & घ & n.a. & n.a & & n.a. & 0 & n.a. & n.a. & n.a. & n.a & a. & - $\mathrm{r}$ & n.a. & $\mathrm{P}$ & घ & & a. & .. & - & $P$ & & a. $n$ & n.a. & - & n.a. & n.a. & $\bullet$ & & o $n$ & n.a. & 0 & n.a. & . & घ & $\mathrm{P}$ & O & P & n.a. \\
\hline & & Previous employment & O & O & O & घ & O & O & n.a. & n.a & & n.a. & O & n.a. & n.a. & n.a. & n.a & & $O r$ & n.a. & - & O & & a. & .. & $\boldsymbol{\square}$ & घ & n.a & a. $n$ & n.a. & O & n.a. & n.a. & $\bullet$ & & D $n$ & n.a. & O & n.a. & . $O$ & - & O & - & - & n.a. \\
\hline & \multirow{8}{*}{ 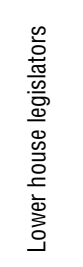 } & Assets & - & 0 & घ & - & - & घ & - & - & & O & - & 0 & - & - & • & & • & - & घ & [ & & 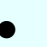 & & - & 0 & & & - & & & - & - & & • & & 0 & - & - & ש & & - & - & - \\
\hline & & Liabilities & - & 0 & O & - & - & घ & o & - & & O & - & O & 0 & - & 0 & & o & - & घ & घ & & - & .. & - & 0 & - & • & O & - & - & - & - & & • & O & 0 & - & - & घ & - & - & घ & - \\
\hline & & Income source & - & - & O & - & - & घ & - & - & & O & 0 & - & - & - & - & $\bullet$ & $\bullet$ & - & - & घ & & $\bullet$ & .. & $\mathbf{\square}$ & घ & $\bullet$ & • & $\bullet$ & $\bullet$ & $\bullet$ & $\bullet$ & $\bullet$ & & $\bullet$ & - & O & - & $\bullet$ & घ & $\bullet$ & $\bullet$ & - & O \\
\hline & & Income amount & O & $\bullet$ & O & $\bullet$ & O & घ & O & - & & O & O & $\bullet$ & $\bullet$ & $\bullet$ & $\mathrm{O}$ & $\bullet$ & $\bullet$ & $\bullet$ & - & घ & & $\bullet$ & .. & $\mathbf{\square}$ & घ & O & $\partial$ & O & $\bullet$ & $\bullet$ & $\bullet$ & • & $\bullet$ & $\bullet$ & - & O & - & $\bullet$ & - & & $\bullet$ & - & $\bullet$ \\
\hline & & Outside position: paid & - & - & $\bullet$ & - & - & a & • & • & & O & 0 & - & $P$ & $P$ & $\bullet$ & & • & $P$ & घ & घ & & a & & $\mathrm{P}$ & घ & & & & - & • & • & - & & & & - & $P$ & - & च & $\mathrm{P}$ & - & 口 & - \\
\hline & & Outside position: non-paid & - & 0 & $\bullet$ & O & - & घ & 0 & • & & O & 0 & - & $P$ & $\mathrm{P}$ & - & & 0 & $\mathrm{P}$ & घ & 0 & & a & . & $\mathrm{P}$ & घ & • & • & - & - & - & - & - & • & • & $P$ & - & - & O & घ & 0 & - & घ & $\bullet$ \\
\hline & & Gifts & $\bullet$ & O & O & $\bullet$ & $\mathrm{P}$ & घ & $\bullet$ & O & & O & O & $\bullet$ & $\bullet$ & $\bullet$ & 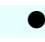 & & $\bullet$ & $P$ & $P$ & घ & & $\mathbf{\square}$ & & घ & $P$ & $\bullet$ & $\bullet$ & $\bullet$ & $\bullet$ & $\bullet$ & O & • & O & b & O & O & $P$ & $\bullet$ & - & $\mathrm{P}$ & O & $P$ & O \\
\hline & & Previous employment & 0 & 0 & O & - & 0 & o & O & - & & O & O & - & O & O & - & & o & 0 & घ & 0 & & - & & घ & घ & 0 & D & - & 0 & - & - & - & e & • & घ & 0 & - & 0 & घ & 0 & $\bullet$ & घ & • \\
\hline
\end{tabular}




\begin{tabular}{|c|c|c|c|c|c|c|c|c|c|c|c|c|c|c|c|c|c|c|c|c|c|c|c|c|c|c|c|c|c|c|c|c|c|c|c|c|c|c|c|c|}
\hline & & & $\stackrel{2}{2}$ & 蛋 & $\overrightarrow{ }$ & 疍 & 㐊 & 썽 & 产 & 留 & ఔ & $\underset{\mathbb{\Psi}}{\mathbb{4}}$ & 㟔 & 惫 & 로 & $\underline{\underline{\omega}}$ & $\overrightarrow{\underline{\underline{ }}}$ & 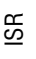 & $\Xi$ & 쪽 & $\begin{array}{l}\text { ro } \\
\stackrel{0}{0}\end{array}$ & 局 & 层 & 总 & $\stackrel{\vec{N}}{z}$ & 옹 & 홍 & $\stackrel{\text { 또 }}{a}$ & के & क & 点 & & 莖 & $\stackrel{\cong}{\stackrel{2}{上}}$ & 畄 & 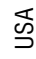 & & 芯 & & $\stackrel{\text { }}{3}$ \\
\hline \multirow{16}{*}{ 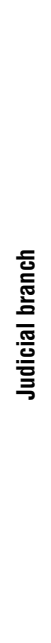 } & \multirow{8}{*}{$\begin{array}{l}\text { बूँ } \\
\text { 잏 }\end{array}$} & ssets & 0 & 0 & O & 0 & घ & O & O & - & - & 0 & 0 & - & - & 0 & $\mathrm{O}$ & - & [ & 0 & - & .. & घ & O & O & O & 0 & 0 & - & - & 0 & 0 & 0 & - & 0 & & घ & - & & \\
\hline & & bilities & - & 0 & O & 0 & घ & 0 & O & • & - & 0 & 0 & - & - & O & O & • & घ & O & • & .. & घ & $\mathrm{O}$ & O & O & O & O & • & - & O & O & O & - & 0 & $\mathbf{\square}$ & - & - & $\mathbf{\square}$ & \\
\hline & & Income source & 0 & 0 & O & 0 & घ & O & - & - & - & 0 & 0 & - & - & - & O & • & च & - & $\bullet$ & .. & घ & O & O & • & O & O & • & - & O & • & O & - & O & - & ש & • & $\mathbf{\square}$ & \\
\hline & & Income amount & O & 0 & 0 & 0 & 0 & O & - & - & - & 0 & O & - & - & O & O & • & घ & - & • & .. & घ & • & $O$ & O & O & O & $\bullet$ & $\bullet$ & O & च & $O$ & • & O & 口 & च & • & ש & \\
\hline & & Outside position: paid & - & - & - & 0 & घ & O & - & $\mathrm{P}$ & घ & 0 & - & $\mathrm{P}$ & $\mathrm{P}$ & - & O & $P$ & घ & - & घ & . & $P$ & • & O & • & 0 & $P$ & • & • & • & 口 & - & $\mathrm{P}$ & $P$ & $\square$ & $P$ & $P$ & $P$ & \\
\hline & & Outside position: non-paid & - & - & - & 0 & घ & O & - & 0 & घ & 0 & - & $P$ & $\mathrm{P}$ & 0 & O & • & घ & - & घ & .. & घ & • & O & • & 0 & $P$ & 0 & • & • & • & - & - & 0 & $\mathbf{\square}$ & O & $P$ & $P$ & \\
\hline & & Gifts & $\mathrm{O}$ & $\mathrm{P}$ & $\mathrm{P}$ & 0 & $\mathrm{P}$ & O & $P$ & $\mathrm{P}$ & 0 & 0 & $\mathrm{P}$ & $\mathrm{P}$ & - & O & $O$ & • & $P$ & O & च & .. & $P$ & $P$ & O & $P$ & O & $P$ & O & • & O & $\bullet$ & $O$ & P & 0 & $\square$ & P & O & P & \\
\hline & & Previous employment & - & - & O & 0 & 0 & O & O & - & O & 0 & - & O & 0 & O & O & - & घ & 0 & घ & .. & घ & O & O & - & 0 & 0 & 0 & - & 0 & - & $\mathrm{O}$ & - & 0 & - & - & - & घ & \\
\hline & \multirow{8}{*}{ 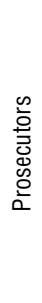 } & Assets & 0 & 0 & O & - & घ & O & $\mathrm{O}$ & - & - & 0 & 0 & - & - & O & - & - & घ & 0 & - & . & घ & 0 & O & O & 0 & 0 & - & - & 0 & 0 & 0 & - & 0 & 0 & - & - & [ & \\
\hline & & Liabilities & 0 & 0 & O & - & घ & O & O & - & - & 0 & O & - & - & O & $O$ & - & च & O & $\bullet$ & .. & घ & O & $O$ & O & O & O & O & • & O & O & $O$ & - & O & $O$ & • & • & 口 & \\
\hline & & Income source & 0 & O & 0 & 0 & घ & O & O & - & - & 0 & 0 & - & - & - & $O$ & • & च & - & $\bullet$ & . & E & O & $\mathrm{O}$ & O & O & O & O & • & O & 口 & $O$ & - & O & O & • & • & [ & \\
\hline & & Income amount & O & O & O & O & O & O & O & $\bullet$ & $\bullet$ & O & O & $\bullet$ & $\bullet$ & O & O & - & - & $\bullet$ & $\bullet$ & .. & - & O & O & O & O & O & O & - & O & 口 & O & - & O & 0 & [ & - & च & \\
\hline & & Outside position: paid & - & - & 0 & - & घ & O & 0 & $\mathrm{P}$ & घ & 0 & - & $P$ & $\mathrm{P}$ & - & - & $P$ & घ & - & घ & .. & $\mathrm{P}$ & - & O & - & 0 & $\mathrm{P}$ & - & - & - & - & - & $\mathrm{P}$ & $\mathrm{P}$ & 0 & $\mathrm{P}$ & - & $\mathrm{P}$ & \\
\hline & & Outside position: non-paid & - & - & 0 & - & घ & O & O & 0 & घ & 0 & - & $\mathrm{P}$ & $\mathrm{P}$ & 0 & O & O & घ & - & घ & . & घ & - & O & - & 0 & $P$ & 0 & - & - & - & - & - & 0 & 0 & 0 & - & $\mathrm{P}$ & \\
\hline & & Gif & - & $P$ & 0 & - & $P$ & 0 & $P$ & 0 & O & 0 & $P$ & $\mathrm{P}$ & - & O & - & $P$ & $\mathrm{P}$ & घ & घ & . & $\mathrm{P}$ & $\mathrm{P}$ & 0 & $\mathrm{P}$ & 0 & $\mathrm{P}$ & 0 & - & 0 & O & - & $\mathrm{P}$ & O & O & $\mathrm{P}$ & 0 & $P$ & \\
\hline & & Previous employment & 0 & - & 0 & 0 & 0 & 0 & $\mathrm{O}$ & - & 0 & 0 & - & O & 0 & O & 0 & 0 & & 0 & & & & $\theta$ & 0 & & 0 & 0 & 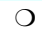 & 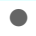 & 0 & & 0 & 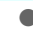 & 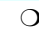 & & 0 & $\bullet$ & & \\
\hline
\end{tabular}

- Information is disclosed and publicly available online or print.

- Information is disclosed and not publicly available.

- Information is disclosed and publicly available upon request.

O Disclosure is not required.

P Prohibited.

n.a.: Indicates not applicable (e.g. country has no President).

$\therefore$ Indicates that data are missing.

Notes: Data reflect practices in member countries. Norway: Data regarding judges exclude lay judges and judges in conciliation boards.

Australia: Data regarding tax and customs officials refer to tax officials. Data regarding financial authorities refer to employees of the Australian Prudential Regulation Authority (APRA) and board members of the Australian Securities and Investments Commission (ASIC).

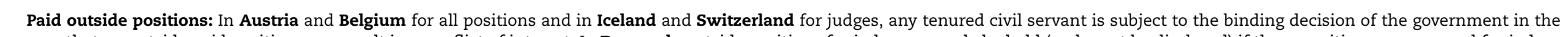
case that an outside paid position may result in a conflict of interest. In Denmark, outside positions for judges can only be held (and must be disclosed) if these positions are reserved for judges by law or if permitted to by a special board. In Estonia, paid outside positions are prohibited by law for the Prime Minister, Ministers, judges and prosecutors, with the exceptions of research and teaching which should be disclosed.

Previous employment: In Estonia, no regulation requires members of the executive and legislature to publish information about previous employment; however in practice this information is proactively published.

Assets, liabilities, amounts and sources of income, and gifts: In Estonia, the disclosure of assets, liabilities and income of prosecutors are not publicly available, except for the Chief Public Assets, liabilities, amounts and sources of income, and gifts: In Estonia, the disclosure of assets, liabilities and income of prosecutors are not publicly available, except for the Chief Public
Prosecutor. In Iceland, the Prime Minister is only required to disclose loans that have been written off or changed to their benefit. In Ireland, Parliamentarians' salaries and allowances are publicly available. In addition, all parliamentarians including office holders must disclose their personal interests, i.e. income from other sources (i.e. outside paid positions), shares, directorships, land, gifts, below cost supply of a service or travel, consultancy work, and any interest in a public contract in annual statements of interests under the Ethics Acts. These interests are publicly available on the Registers of Members' Interests. In Japan, if the Minister is a member of the parliament, disclosure is required of income amount and gifts. In Mexico, gifts must be declared if they amount to equal or greater value of 10 times the minimum wage. Information on public servants is publicly published online if authorised by the public servants. In practice, about $66 \%$ of public servants make the information publicly available.

Source: OECD Survey on Integrity (2010). 


\begin{tabular}{|c|c|c|c|c|c|c|c|c|c|c|c|c|c|c|c|c|c|c|c|c|c|c|c|c|c|c|c|c|c|c|c|c|c|c|c|c|c|c|c|}
\hline & & $\stackrel{\infty}{2}$ & $\stackrel{5}{⿺}$ & 㟧 & 主 & 폰 & 惢 & 兰 & $\stackrel{5}{\breve{M}}$ & $\geqq$ & 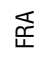 & 咨 & 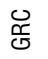 & 辛 & $\underline{\omega}$ & $\overrightarrow{\underline{\underline{x}}}$ & 寒 & $\Xi$ & 쪽 & 吃 & 当 & $\stackrel{\text { 盾 }}{ }$ & 呈 & $\stackrel{\vec{N}}{z}$ & 옹 & $\vec{\circ}$ & 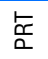 & 产 & ङ & 穹 & 岕 & 岌 & $\stackrel{\Upsilon}{\rightleftharpoons}$ & 㩊 & 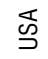 & $\stackrel{2}{\not}$ & 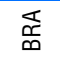 & ટે & 愛 \\
\hline \multirow{8}{*}{ 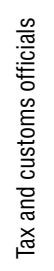 } & Assets & - & O & घ & - & घ & घ & 0 & $\bullet$ & $\bullet$ & o & 0 & - & - & 0 & - & $\bullet$ & O & O & - & & - & - & O & O & 0 & 0 & - & 0 & 0 & - & O & - & O & - & - & - & a & 0 \\
\hline & Liabilities & - & O & O & - & a & a & O & - & - & 0 & - & - & - & 0 & O & - & O & O & $\bullet$ & .. & - & $\bullet$ & O & 0 & O & 0 & O & O & 0 & O & O & - & O & - & - & - & a & O \\
\hline & Income source & - & 0 & O & 0 & $\overline{\mathbf{a}}$ & $\bar{\square}$ & 0 & - & - & 0 & - & - & - & 0 & 0 & - & a & 0 & • & .. & - & $\bullet$ & O & 0 & O & 0 & O & O & 0 & O & 0 & - & O & $\bullet$ & - & $\bullet$ & $\overline{\mathbf{a}}$ & O \\
\hline & Income amount & - & O & O & O & 0 & घ & O & - & - & 0 & - & - & - & O & O & - & घ & - & - & .. & - & - & 0 & 0 & O & O & O & O & 0 & 0 & - & - & O & - & - & - & a & 0 \\
\hline & Outside position: paid & - & - & • & - & च & a & 0 & - & घ & 0 & - & $\mathrm{P}$ & - & 0 & $\bullet$ & $P$ & $\bullet$ & - & a & .. & $\bullet$ & $\bullet$ & a & - & O & - & - & - & - & 0 & - & $P$ & $P$ & - & - & 0 & $P$ & O \\
\hline & Outside position: non-paid & - & - & - & - & घ & घ & 0 & 0 & - & o & - & $P$ & - & 0 & o & 0 & - & - & घ & .. & O & - & a & - & 0 & - & O & • & - & O & O & - & O & - & O & O & $P$ & O \\
\hline & Gifts & - & $P$ & $P$ & - & $\mathrm{P}$ & - & $\mathrm{P}$ & O & O & O & $\bullet$ & $\mathrm{P}$ & $\bullet$ & O & $\bullet$ & $\mathrm{P}$ & $\mathrm{P}$ & a & a & . & $\mathrm{P}$ & $\mathrm{P}$ & a & - & o & $\mathrm{P}$ & 0 & - & 0 & 0 & - & $\mathrm{P}$ & O & - & $\mathrm{P}$ & 0 & $P$ & 0 \\
\hline & Previous employment & O & $\bullet$ & O & O & 0 & O & 0 & - & 0 & 0 & O & O & 0 & 0 & 0 & - & - & O & घ & .. & - & - & 0 & - & 0 & O & 0 & 0 & 0 & O & O & - & O & - & - & 0 & घ & O \\
\hline \multirow{8}{*}{ 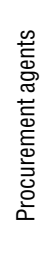 } & Assets & n.a. & o & घ & - & घ & घ & 0 & - & n.a. & O & O & .. & - & 0 & - & - & n.a. & O & - & .. & - & O & O & 0 & 0 & 0 & - & 0 & 0 & n.a. & 0 & - & O & - & - & - & घ & 0 \\
\hline & Liabilities & n.a. & O & O & - & च & घ & O & - & n.a. & O & O & .. & - & O & O & - & n.a. & O & - & .. & - & O & O & O & O & O & O & O & O & n.a. & O & - & O & - & - & - & a & O \\
\hline & Income source & n.a. & O & 0 & O & च & घ & O & - & n.a. & O & - & .. & - & 0 & 0 & - & n.a. & - & - & & - & - & O & 0 & O & 0 & O & 0 & 0 & n.a. & - & - & O & - & - & - & a & 0 \\
\hline & Income amount & n.a. & O & O & O & O & घ & O & - & n.a. & O & - & .. & - & 0 & 0 & - & n.a. & - & - & .. & - & - & O & 0 & O & 0 & O & 0 & 0 & n.a. & - & - & O & - & - & - & घ & 0 \\
\hline & Outside position: paid & n.a. & - & • & - & च & a & O & - & n.a. & O & - & .. & - & 0 & - & $\mathrm{P}$ & n.a. & - & घ & & - & - & a & 0 & O & - & - & O & - & n.a. & - & $P$ & $P$ & - & - & - & $P$ & 0 \\
\hline & Outside position: non-paid & n.a. & - & - & - & घ & घ & O & O & n.a. & O & $\mathrm{P}$ & .. & - & 0 & 0 & 0 & n.a. & - & घ & & O & - & घ & 0 & O & - & o & 0 & - & n.a. & 0 & - & 0 & - & 0 & - & $P$ & 0 \\
\hline & Gifts & n.a. & $\mathrm{P}$ & $\mathrm{P}$ & - & $P$ & घ & $\mathrm{P}$ & O & n.a. & O & $P$ & .. & - & 0 & - & $\mathrm{P}$ & n.a. & घ & घ & .. & $P$ & - & घ & 0 & 0 & $\mathrm{P}$ & 0 & 0 & 0 & n.a. & - & $P$ & 0 & - & $\mathrm{P}$ & 0 & $P$ & 0 \\
\hline & Previous employment & n.a. & $\bullet$ & O & O & O & O & O & $\bullet$ & n.a. & O & O & & O & O & O & $\bullet$ & n.a. & O & $\mathbf{\square}$ & & $\bullet$ & $\bullet$ & O & O & O & O & O & O & O & n.a. & O & - & O & $\bullet$ & $\bullet$ & $\bullet$ & $\mathbf{\square}$ & O \\
\hline \multirow{8}{*}{ 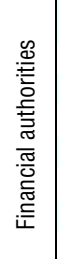 } & Assets & $\bullet$ & O & 0 & $\bullet$ & घ & - & - & - & $\bullet$ & - & O & .. & - & - & - & - & - & O & & & - & - & O & - & 0 & 0 & - & 0 & 0 & - & O & - & घ & - & - & - & घ & - \\
\hline & Liabilities & - & O & 0 & - & च & घ & - & - & - & O & 0 & .. & - & - & O & - & - & O & - & & - & O & O & - & 0 & O & O & 0 & 0 & - & O & - & O & - & - & - & a & - \\
\hline & Income source & 0 & 0 & 0 & 0 & घ & - & 0 & - & - & 0 & - & .. & - & - & 0 & - & - & - & - & & - & - & 0 & - & O & 0 & 0 & 0 & 0 & 0 & O & - & O & - & - & - & ש & 0 \\
\hline & Income amount & 0 & 0 & 0 & O & 0 & घ & 0 & - & - & 0 & - & .. & - & 0 & 0 & - & - & - & - & .. & - & - & 0 & - & O & 0 & 0 & 0 & 0 & O & O & - & 0 & - & - & - & घ & - \\
\hline & Outside position: paid & - & - & 0 & - & घ & घ & - & 0 & घ & - & - & .. & - & 0 & - & $P$ & - & - & घ & & - & - & घ & 0 & 0 & - & - & • & - & O & - & $P$ & - & - & - & $P$ & $P$ & - \\
\hline & Outside position: non-paid & - & - & 0 & - & च & - & 0 & 0 & - & - & $P$ & .. & - & 0 & 0 & 0 & O & - & a & .. & O & $\bullet$ & a & 0 & O & - & o & • & - & O & - & - & - & - & O & 0 & $P$ & - \\
\hline & Gifts & - & $P$ & 0 & - & $\mathrm{P}$ & घ & $\mathrm{P}$ & 0 & 0 & - & $\mathrm{P}$ & & - & 0 & - & $\mathrm{P}$ & $P$ & घ & घ & & $\mathrm{P}$ & - & घ & 0 & 0 & $\mathrm{P}$ & 0 & - & 0 & 0 & $\mathrm{P}$ & $\mathrm{P}$ & - & - & $\mathrm{P}$ & $P$ & $P$ & 0 \\
\hline & Previous employment & 0 & - & O & O & 0 & O & O & - & 0 & - & O & & 0 & 0 & 0 & - & - & O & a & & - & - & O & 0 & O & O & O & 0 & 0 & O & • & • & $\bullet$ & • & • & O & $\square$ & • \\
\hline
\end{tabular}

- Information is disclosed and publicly available online or print.
Information is disclosed and not publicly available.

- Information is disclosed and publicly available upon request.

O Disclosure is not required.

P Prohibited.

n.a.: Indicates not applicable (e.g. country has no President).

$\therefore$ Indicates that data are missing.

Notes: Norway: Data regarding judges exclude lay judges and judges in conciliation boards.

Australia: Data regarding tax and customs officials refer to tax officials. Data regarding financial authorities refer to employees of the Australian Prudential Regulation Authority (APRA) and board members of the Australian Securities and Investments Commission (ASIC)

Paid outside positions: In Austria and Belgium for all positions and in Iceland and Switzerland for judges, any tenured civil servant is subject to the binding decision of the government in the case that an outside paid position may result in a conflict of interest. In Denmark, outside positions for judges can only be held (and must be disclosed) if these positions are reserved for judges by law or if permitted to by a special board. In Estonia, paid outside positions are prohibited by law for the Prime Minister, Ministers, judges and prosecutors, with the exceptions of research and

Previous employment: In Estonia, no regulation requires members of the executive and legislature to publish information about previous employment; however in practice this information is proactively published.

Assets, liabilities, amounts and sources of income, and gifts: In Estonia, the disclosure of assets, liabilities and income of prosecutors are not publicly available, except for the Chief Public Prosecutor. In Iceland, the Prime Minister is only required to disclose loans that have been written off or changed to their benefit. In Japan, if the Minister is a member of the parliament, disclosure is required of income amount and gifts. In Mexico, gifts must be declared if they amount to equal or greater value of 10 times the minimum wage. Information on public servants is publicly
published online if authorised by the public servants. In practice, about $66 \%$ of public servants make the information publicly available. 


\section{ANNEX G \\ Detailed Data from the 2010 OECD Survey on Public Procurement}

This annex provides data for each responding country on the transparency of the public procurement cycle, as well as the online availability of public procurement information and the central government review and remedy mechanisms available for bidders. The data underlie the summaries of data presented in Chapter IX, specifically, for Indicators 41 and 42. 
Table G.1. Mechanisms to routinely involve citizens in key stages of the procurement cycle at the central level of government (2010)

\begin{tabular}{|c|c|c|c|c|c|}
\hline & $\begin{array}{c}\text { Consultations } \\
\text { on definition of needs }\end{array}$ & $\begin{array}{l}\text { Oversight of bid } \\
\text { opening process }\end{array}$ & $\begin{array}{c}\text { Public hearing on terms } \\
\text { of a contract }\end{array}$ & $\begin{array}{c}\text { Complaints } \\
\text { and dissatisfaction } \\
\text { during implementation }\end{array}$ & $\begin{array}{l}\text { Monitoring contract } \\
\text { delivery }\end{array}$ \\
\hline Australia & - & O & O & - & - \\
\hline Austria & O & 0 & O & O & O \\
\hline Belgium & O & - & O & O & O \\
\hline Canada & O & O & O & O & O \\
\hline Chile & O & O & O & O & O \\
\hline Czech Republic & - & 0 & - & - & - \\
\hline Denmark & O & O & O & O & O \\
\hline Estonia & O & O & O & O & O \\
\hline Finland & O & O & O & O & O \\
\hline France & O & O & O & O & O \\
\hline Germany & O & O & O & O & O \\
\hline Greece & O & O & O & O & O \\
\hline Hungary & O & O & O & O & O \\
\hline Iceland & O & O & O & O & O \\
\hline Ireland & O & O & O & O & O \\
\hline Israel & - & O & O & O & O \\
\hline Italy & O & O & O & O & O \\
\hline Japan & $\bullet$ & $\bullet$ & O & $\bullet$ & O \\
\hline Korea & - & - & $\bullet$ & - & - \\
\hline Luxembourg & O & O & O & O & O \\
\hline Mexico & O & - & - & O & O \\
\hline Netherlands & O & 0 & 0 & O & 0 \\
\hline New Zealand & O & O & O & O & O \\
\hline Norway & O & O & O & ○ & O \\
\hline Poland & O & $\bullet$ & $\bullet$ & $\bullet$ & - \\
\hline Portugal & O & 0 & O & - & $\bullet$ \\
\hline Slovak Republic & O & O & O & O & O \\
\hline Slovenia & O & - & O & O & - \\
\hline Spain & O & O & $O$ & - & O \\
\hline Sweden & O & O & O & O & O \\
\hline Switzerland & O & O & O & O & O \\
\hline Turkey & O & - & 0 & O & O \\
\hline United Kingdom & O & O & O & O & O \\
\hline United States & $\bullet$ & $\bullet$ & $\bullet$ & $\bullet$ & $\bullet$ \\
\hline Brazil & O & - & - & $\bullet$ & $\bullet$ \\
\hline Egypt & O & O & O & O & O \\
\hline Ukraine & O & O & O & O & O \\
\hline \multicolumn{6}{|l|}{ Total OECD34 } \\
\hline - Mandatory & 2 & 3 & 1 & 2 & 1 \\
\hline Voluntary & 4 & 6 & 4 & 6 & 6 \\
\hline O No participation & 28 & 25 & 29 & 26 & 27 \\
\hline
\end{tabular}

Note: Information is not available for Israel on oversight of bid opening process, public hearing on terms of a contract, complaints and dissatisfaction on the implementation, and monitoring contract delivery. Source: OECD 2010 Survey on Public Procurement. 
Table G.2. Central government review and remedy mechanisms available for public procurement (2010)

\begin{tabular}{|c|c|c|c|}
\hline & Special review bodies & Courts & Alternative dispute mechanisms \\
\hline Australia & O & $\bullet$ & $\bullet$ \\
\hline Austria & $\bullet$ & $\bullet$ & $\bullet$ \\
\hline Belgium & $\bullet$ & $\bullet$ & $\bullet$ \\
\hline Canada & $\bullet$ & $\bullet$ & $\bullet$ \\
\hline Chile & $\bullet$ & $\bullet$ & $\bullet$ \\
\hline Czech Republic & $\bullet$ & $\bullet$ & $\bullet$ \\
\hline Denmark & $O$ & $\bullet$ & O \\
\hline Estonia & $\bullet$ & $\bullet$ & $\bigcirc$ \\
\hline Finland & O & $\bullet$ & $\bigcirc$ \\
\hline France & O & $\bullet$ & - \\
\hline Germany & $\bullet$ & $\bullet$ & $\bigcirc$ \\
\hline Greece & $O$ & $\bullet$ & O \\
\hline Hungary & $\bullet$ & $\bullet$ & $\bullet$ \\
\hline Iceland & - & ○ & $\bullet$ \\
\hline Ireland & O & $\bullet$ & O \\
\hline Israel & $O$ & $\bullet$ & $\bullet$ \\
\hline Italy & $O$ & - & $\bullet$ \\
\hline Japan & $\bullet$ & $\bullet$ & O \\
\hline Korea & $\bullet$ & $\bullet$ & $\bullet$ \\
\hline Luxembourg & $O$ & $\bullet$ & $\bullet$ \\
\hline Mexico & $\bullet$ & $\bullet$ & $\bullet$ \\
\hline Netherlands & O & $\bullet$ & $\bigcirc$ \\
\hline New Zealand & O & $\bullet$ & $\bullet$ \\
\hline Norway & - & $\bullet$ & $\bullet$ \\
\hline Poland & $\bullet$ & $\bullet$ & $O$ \\
\hline Portugal & $O$ & $\bullet$ & 0 \\
\hline Slovak Republic & $\bullet$ & $\bullet$ & $O$ \\
\hline Slovenia & $\bullet$ & O & O \\
\hline Spain & $\bullet$ & $\bullet$ & $\bullet$ \\
\hline Sweden & O & $\bullet$ & O \\
\hline Switzerland & $\bullet$ & $\bullet$ & O \\
\hline Turkey & $\bullet$ & $\bullet$ & O \\
\hline United Kingdom & O & $\bullet$ & $\bullet$ \\
\hline United States & $\bullet$ & $\bullet$ & 0 \\
\hline Brazil & $O$ & $\bullet$ & $O$ \\
\hline Egypt & $\bullet$ & $\bullet$ & $O$ \\
\hline Ukraine & $\bullet$ & $\bullet$ & $\bigcirc$ \\
\hline Total OECD34 & 20 & 33 & 20 \\
\hline
\end{tabular}

Yes.

No.

Source: OECD Public Procurement Survey. 
Table G.3. Online availability of selected public procurement information in central governments (2010)

\begin{tabular}{|c|c|c|c|c|c|c|c|c|c|c|}
\hline & $\begin{array}{c}\text { Specific } \\
\text { guidance } \\
\text { on application } \\
\text { procedures }\end{array}$ & $\begin{array}{l}\text { Laws and } \\
\text { policies }\end{array}$ & $\begin{array}{l}\text { General } \\
\text { information } \\
\text { for potential } \\
\text { bidders }\end{array}$ & $\begin{array}{l}\text { Procurement } \\
\text { plan }\end{array}$ & $\begin{array}{l}\text { Selection and } \\
\text { evaluation } \\
\text { criteria }\end{array}$ & $\begin{array}{c}\text { Contract } \\
\text { award }\end{array}$ & $\begin{array}{c}\text { Tender } \\
\text { documents }\end{array}$ & $\begin{array}{c}\text { Justification } \\
\text { for awarding } \\
\text { contract } \\
\text { to selected } \\
\text { contractor }\end{array}$ & $\begin{array}{c}\text { Contract } \\
\text { modifications }\end{array}$ & $\begin{array}{l}\text { Tracking } \\
\text { procurement } \\
\text { spending }\end{array}$ \\
\hline Australia & $\bullet$ & $\bullet$ & $\bullet$ & $\bullet$ & $\bullet$ & $\bullet$ & $\bullet$ & O & $\bullet$ & n.a. \\
\hline Austria & $\bullet$ & O & - & $\bullet$ & $\bullet$ & $\bullet$ & $\bullet$ & n.a. & $\bullet$ & n.a. \\
\hline Belgium & $\bullet$ & O & $\bullet$ & $\bullet$ & $\bullet$ & $\bullet$ & $\bullet$ & O & O & n.a. \\
\hline Canada & $\bullet$ & $\bullet$ & $\bullet$ & n.a. & $\bullet$ & $\bullet$ & $\bullet$ & O & n.a. & n.a. \\
\hline Chile & $\bullet$ & $\bullet$ & $\bullet$ & $\bullet$ & $\bullet$ & $\bullet$ & $\bullet$ & $\bullet$ & $\bullet$ & $\bullet$ \\
\hline Czech Republic & $\bullet$ & $\bullet$ & $\bullet$ & $\bullet$ & $\bullet$ & $\bullet$ & $\bullet$ & $\bullet$ & $\bullet$ & $\bullet$ \\
\hline Denmark & $\bullet$ & $\bullet$ & $\bullet$ & $\bullet$ & $\bullet$ & $\bullet$ & $\bullet$ & $\bullet$ & $\bullet$ & n.a. \\
\hline Estonia & $\bullet$ & $\bullet$ & $\bullet$ & $\bullet$ & $\bullet$ & $\bullet$ & O & $\bullet$ & O & $\bullet$ \\
\hline Finland & $\bullet$ & $\bullet$ & $\bullet$ & $\bullet$ & $\bullet$ & $\bullet$ & O & $\bullet$ & n.a. & n.a. \\
\hline France & $\bullet$ & $\bullet$ & $\bullet$ & $\bullet$ & $\bullet$ & $\bullet$ & $\bullet$ & O & $\bullet$ & O \\
\hline Germany & n.a. & $\bullet$ & $\bullet$ & n.a. & $\bullet$ & $\bullet$ & $\bullet$ & n.a. & n.a. & n.a. \\
\hline Greece & $\bullet$ & $\bullet$ & $\bullet$ & $\bullet$ & $\bullet$ & $\bullet$ & $\bullet$ & $\bullet$ & n.a. & n.a. \\
\hline Hungary & $\bullet$ & $\bullet$ & O & $\bullet$ & O & O & O & O & O & O \\
\hline Iceland & $\bullet$ & $\bullet$ & $\bullet$ & $\bullet$ & $\bullet$ & $\bullet$ & $\bullet$ & $\bullet$ & $\bullet$ & $\bullet$ \\
\hline Ireland & $\bullet$ & $\bullet$ & $\bullet$ & • & $\bullet$ & $\bullet$ & $\bullet$ & $\bullet$ & - & n.a. \\
\hline Israel & $\bullet$ & $\bullet$ & $\bullet$ & $\bullet$ & $\bullet$ & $\bullet$ & $\bullet$ & O & $\bullet$ & n.a. \\
\hline Italy & $\bullet$ & $\bullet$ & $\bullet$ & $\bullet$ & $\bullet$ & $\bullet$ & $\bullet$ & O & $\bullet$ & O \\
\hline Japan & $\bullet$ & $\bullet$ & $\bullet$ & $\bullet$ & $\bullet$ & $\bullet$ & $\bullet$ & $\bullet$ & - & O \\
\hline Korea & $\bullet$ & $\bullet$ & $\bullet$ & $\bullet$ & $\bullet$ & $\bullet$ & $\bullet$ & $\bullet$ & $\bullet$ & $\bullet$ \\
\hline Luxembourg & $\bullet$ & $\bullet$ & $\bullet$ & $\bullet$ & $\bullet$ & $\bullet$ & $\bullet$ & O & O & O \\
\hline Mexico & $\bullet$ & $\bullet$ & $\bullet$ & $\bullet$ & $\bullet$ & $\bullet$ & $\bullet$ & $\bullet$ & $\bullet$ & $\bullet$ \\
\hline Netherlands & $\bullet$ & $\bullet$ & $\bullet$ & $\bullet$ & $\bullet$ & $\bullet$ & $\bullet$ & $\bullet$ & • & n.a. \\
\hline New Zealand & $O$ & $\bullet$ & $\bullet$ & $\bullet$ & $\bullet$ & $\bullet$ & $\bullet$ & O & O & n.a. \\
\hline Norway & $\bullet$ & $\bullet$ & • & • & $\bullet$ & $\bullet$ & $\bullet$ & O & O & O \\
\hline Poland & $\bullet$ & $\bullet$ & $\bullet$ & $\bullet$ & $\bullet$ & $\bullet$ & $\bullet$ & $\bullet$ & O & n.a. \\
\hline Portugal & $\bullet$ & $\bullet$ & $\bullet$ & $\bullet$ & $\bullet$ & $\bullet$ & $\bullet$ & $\bullet$ & O & $\bullet$ \\
\hline Slovak Republic & $\bullet$ & $\bullet$ & $\bullet$ & $\bullet$ & $\bullet$ & $\bullet$ & O & n.a. & $\bullet$ & n.a. \\
\hline Slovenia & $\bullet$ & O & $\bullet$ & $\bullet$ & $\bullet$ & $\bullet$ & $\bullet$ & $O$ & $\bullet$ & $O$ \\
\hline Spain & $\bullet$ & $\bullet$ & $\bullet$ & $\bullet$ & $\bullet$ & $\bullet$ & O & $\bullet$ & $\bullet$ & n.a. \\
\hline Sweden & $\bullet$ & $\bullet$ & $\bullet$ & $\bullet$ & $\bullet$ & $\bullet$ & $\bullet$ & $\bullet$ & n.a. & n.a. \\
\hline Switzerland & $\bullet$ & $\bullet$ & $\bullet$ & n.a. & $\bullet$ & $\bullet$ & $\bullet$ & $\bullet$ & n.a. & $\bullet$ \\
\hline Turkey & $\bullet$ & $\bullet$ & $\bullet$ & $\bullet$ & $\bullet$ & $\bullet$ & $\bullet$ & O & O & $\bullet$ \\
\hline United Kingdom & $\bullet$ & $\bullet$ & $\bullet$ & $\bullet$ & n.a. & $\bullet$ & n.a. & $\bullet$ & n.a. & n.a. \\
\hline United States & $\bullet$ & $\bullet$ & $\bullet$ & $\bullet$ & $\bullet$ & $\bullet$ & $\bullet$ & n.a. & n.a. & $\bullet$ \\
\hline Brazil & O & $\bullet$ & $\bullet$ & n.a. & $\bullet$ & $\bullet$ & $\bullet$ & O & $\bullet$ & n.a. \\
\hline Egypt & $\bullet$ & $\bullet$ & $\bullet$ & n.a. & $\bullet$ & $\bullet$ & $\bullet$ & n.a. & $\bullet$ & n.a. \\
\hline Ukraine & $\bullet$ & $\bullet$ & $\bullet$ & $\bullet$ & $\bullet$ & $\bullet$ & $\bullet$ & O & n.a. & n.a. \\
\hline \multicolumn{11}{|l|}{ Total OECD34 } \\
\hline - Yes & 32 & 31 & 33 & 31 & 32 & 33 & 28 & 18 & 17 & 10 \\
\hline O No & 1 & 3 & 1 & 0 & 1 & 1 & 5 & 12 & 9 & 7 \\
\hline
\end{tabular}

n.a.: Not applicable (e.g. information not public).

Source: OECD 2010 Survey on Public Procurement. 
Table G.4. Most common services offered by the governmental single-entry e-procurement website (2010)

\begin{tabular}{|c|c|c|c|c|c|c|c|c|c|c|c|c|}
\hline & \multicolumn{7}{|c|}{ Applications that facilitate the interface with potential bidders } & \multicolumn{4}{|c|}{ Contract management tools } & \multirow[b]{2}{*}{ 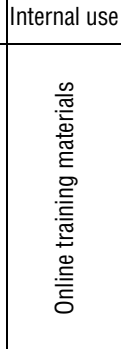 } \\
\hline & 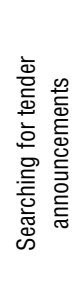 & 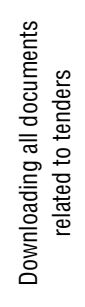 & 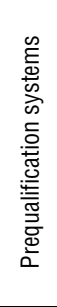 & 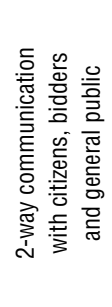 & 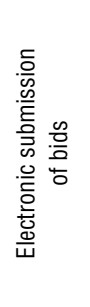 & 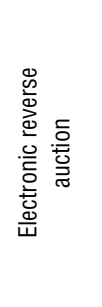 & 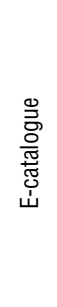 & 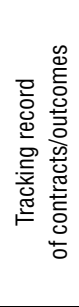 & 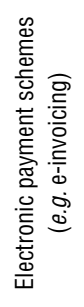 & 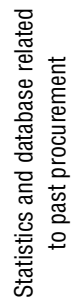 & 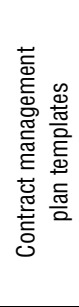 & \\
\hline Australia & $\bullet$ & - & $\bullet$ & $\bullet$ & $\bullet$ & O & O & 0 & O & - & O & O \\
\hline Austria & n.a. & n.a. & n.a. & n.a. & n.a. & n.a. & n.a. & n.a. & n.a. & n.a. & n.a. & n.a. \\
\hline Belgium & n.a. & n.a. & n.a. & n.a. & n.a. & n.a. & n.a. & n.a. & n.a. & n.a. & n.a. & n.a. \\
\hline Canada & - & - & 0 & O & 0 & 0 & $\mathrm{O}$ & 0 & 0 & $\mathrm{O}$ & 0 & 0 \\
\hline Chile & $\bullet$ & $\bullet$ & O & $\bullet$ & $\bullet$ & O & $\bullet$ & $O$ & $\bullet$ & $\bullet$ & $\bullet$ & $\bullet$ \\
\hline Czech Republic & n.a. & n.a. & n.a. & n.a. & n.a. & n.a. & n.a. & n.a. & n.a. & n.a. & n.a. & n.a. \\
\hline Denmark & $\bullet$ & $O$ & $O$ & $O$ & $O$ & O & $O$ & O & $O$ & $O$ & $O$ & O \\
\hline Estonia & $\bullet$ & $\bullet$ & $\bullet$ & O & O & O & O & $\bullet$ & $O$ & - & $O$ & - \\
\hline Finland & - & $\bullet$ & O & O & $\bullet$ & O & O & O & O & $\bullet$ & O & O \\
\hline France & $\bullet$ & $\bullet$ & O & $\bullet$ & $\bullet$ & $\bullet$ & $\bullet$ & $\bullet$ & $\bullet$ & O & O & $\bullet$ \\
\hline Germany & n.a. & n.a. & n.a. & n.a. & n.a. & n.a. & n.a. & n.a. & n.a. & n.a. & n.a. & n.a. \\
\hline Greece & n.a. & n.a. & n.a. & n.a. & n.a. & n.a. & n.a. & n.a. & n.a. & n.a. & n.a. & n.a. \\
\hline Hungary & n.a. & n.a. & n.a. & n.a. & n.a. & n.a. & n.a. & n.a. & n.a. & n.a. & n.a. & n.a. \\
\hline Iceland & n.a. & n.a. & n.a. & n.a. & n.a. & n.a. & n.a. & n.a. & n.a. & n.a. & n.a. & n.a. \\
\hline Ireland & $\bullet$ & $\bullet$ & $\bullet$ & $\bullet$ & $\bullet$ & $O$ & O & O & $O$ & $\bullet$ & O & O \\
\hline Israel & $\bullet$ & $\bullet$ & • & $O$ & O & • & O & $\bullet$ & $\bullet$ & - & $\bullet$ & O \\
\hline Italy & $\bullet$ & $\bullet$ & $\bullet$ & $\bullet$ & $\bullet$ & $\bullet$ & $\bullet$ & $\bullet$ & O & $\bullet$ & O & O \\
\hline Japan & n.a. & n.a. & n.a. & n.a. & n.a. & n.a. & n.a. & n.a. & n.a. & n.a. & n.a. & n.a. \\
\hline Korea & $\bullet$ & $\bullet$ & $\bullet$ & $\bullet$ & $\bullet$ & $\bullet$ & $\bullet$ & $\bullet$ & $\bullet$ & $\bullet$ & $\bullet$ & $\bullet$ \\
\hline Luxembourg & $\bullet$ & $\bullet$ & $O$ & $O$ & $O$ & $O$ & $O$ & $O$ & $O$ & O & $O$ & O \\
\hline Mexico & $\bullet$ & $\bullet$ & O & $\bullet$ & $\bullet$ & $\bullet$ & $\bullet$ & $\bullet$ & $O$ & O & O & O \\
\hline Netherlands & n.a. & n.a. & n.a. & n.a. & n.a. & n.a. & n.a. & n.a. & n.a. & n.a. & n.a. & n.a. \\
\hline New Zealand & $\bullet$ & $\bullet$ & O & $\bullet$ & O & O & O & O & O & $\bullet$ & O & O \\
\hline Norway & n.a. & n.a. & n.a. & n.a. & n.a. & n.a. & n.a. & n.a. & n.a. & n.a. & n.a. & n.a. \\
\hline Poland & $\bullet$ & $O$ & $O$ & $O$ & $O$ & $\bullet$ & O & $O$ & $O$ & $O$ & $O$ & $\bullet$ \\
\hline Portugal & $\bullet$ & $O$ & $O$ & $O$ & O & O & O & $\bullet$ & $O$ & O & $O$ & O \\
\hline Slovak Republic & O & $\bullet$ & O & $\bullet$ & $\bullet$ & $\bullet$ & O & $\bullet$ & O & $\bullet$ & $\bullet$ & $\bullet$ \\
\hline Slovenia & $\bullet$ & $\bullet$ & $\bullet$ & $\bullet$ & O & O & O & O & O & $\bullet$ & O & O \\
\hline Spain & $\bullet$ & $\bullet$ & $\bullet$ & $\bullet$ & $\bullet$ & O & $\bullet$ & $\bullet$ & $O$ & - & O & O \\
\hline Sweden & n.a. & n.a. & n.a. & n.a. & n.a. & n.a. & n.a. & n.a. & n.a. & n.a. & n.a. & n.a. \\
\hline Switzerland & $\bullet$ & $\bullet$ & $O$ & $\bullet$ & $\bullet$ & O & O & $\bullet$ & O & O & O & $\bullet$ \\
\hline Turkey & $\bullet$ & $\bullet$ & O & O & O & O & $O$ & $\bullet$ & $O$ & $\bullet$ & O & $\bullet$ \\
\hline United Kingdom & n.a. & n.a. & n.a. & n.a. & n.a. & n.a. & n.a. & n.a. & n.a. & n.a. & n.a. & n.a. \\
\hline United States & $\bullet$ & $\bullet$ & O & O & O & O & O & O & O & $\bullet$ & O & O \\
\hline Brazil & $\bullet$ & $\bullet$ & O & O & O & - & - & O & $\bullet$ & $\bullet$ & O & $\bullet$ \\
\hline Egypt & $\bullet$ & $\bullet$ & O & $\bullet$ & O & O & $O$ & $O$ & $O$ & O & $O$ & O \\
\hline Ukraine & • & • & O & O & O & O & O & O & $O$ & - & $O$ & O \\
\hline \multicolumn{13}{|l|}{ Total 0ECD34 } \\
\hline - Yes & 21 & 19 & 8 & 12 & 11 & 7 & 6 & 11 & 4 & 14 & 4 & 8 \\
\hline O No & 1 & 3 & 14 & 10 & 11 & 15 & 16 & 11 & 16 & 8 & 18 & 14 \\
\hline n.a.: Not applicable & 132 & 12 & 12 & 12 & 12 & 12 & 12 & 12 & 12 & 12 & 12 & 12 \\
\hline
\end{tabular}

Note: In the majority of cases, an n.a. response indicates country does not have a single-entry procurement website. However, e-procurement services may be available on other websites.

Source: OECD Public Procurement Survey. 


\section{ANNEX H}

\section{Contextual Factors}

This annex provides data on administrative and institutional features of each country, including: the composition and electoral system of the legislature, the structure of the executive branch, the division of power between one central and several regional or local governments, and key characteristics of the judicial system. It also provides basic data on population and GDP for 2009. Compared to Government at a Glance 2009, this annex includes data for the Russian Federation (currently in the process of accession to the OECD) and Brazil. It also provides data on the number of municipalities, provinces, states and/or regions.

Political and institutional frameworks influence who formulates and implements policy responses to the challenges currently facing governments. For example, the type of electoral system employed has a number of potential consequences on the nature and tenure of government, including the diversity of views represented and the ability of the legislature to create and amend laws. Major differences in legislative institutions can affect the way a country's bureaucratic system works. The extent that power is shared between the legislative and executive branches, exemplified by the system of executive power (parliamentary, presidential or dual executive), the frequency of elections and term limits, the ease of constitutional amendments, and the ability of the judiciary to review the constitutionality of laws and actions, set the constraints within which policies and reforms can be enacted and implemented. The way that governments are structured, including the division of responsibilities vertically (across levels of governments) and horizontally (between Departments or Ministries), is a key factor underlying the organisational capacity of government. Different structures and responsibilities require different sets of competencies, including oversight, monitoring and evaluation and co-ordination.

While many contextual factors are products of a country's historical development and cannot be easily changed by policy makers, they can be used to identify countries with similar political and administrative structures for comparison and benchmarking purposes. In addition, for countries considering different policies and reforms, the indicators can illustrate structural differences that may affect their passage and implementation.

\section{Methodology and definitions}

With the exception of data on population and GDP, all information is from member country constitutions and websites and is current as of 31 December 2010. GDP data are from OECD National Accounts Statistics except for data for Brazil (data from IMF, World Economic Outlook Database, October 2010). Population data are from OECD Population Statistics, except for Estonia and Slovenia (data from Eurostat), and Brazil (data from IMF, World Economic Outlook Database, October 2010). 
Federal states have a constitutionally delineated division of political authority between one central and several regional or state autonomous governments. While unitary states often include multiple levels of government (such as local and provincial or regional), these administrative divisions are not constitutionally defined.

Under the parliamentary form of executive power, the executive is usually the head of the dominant party in the legislature and appoints members of that party or coalition parties to serve as Ministers. The executive is accountable to Parliament, who can end the executive's term through a vote of no confidence. Several countries with parliamentary systems also have a president, whose powers are predominately ceremonial in nature. Under the presidential system, the executive and members of the legislature seek election independently of one another. Ministers are not elected members of the legislature but are nominated by the president and may be approved by the legislature. The dual executive system combines a powerful president with an executive responsible to the legislature, both responsible for the day-to-day activities of the state. It differs from the presidential system in that the cabinet (although named by the president) is responsible to the legislature, which may force the cabinet to resign through a motion of no confidence.

Data on the frequency of governments cover the period between 1 January 1990 and 31 December 2010, except for the Czech Republic (1992), Poland (1991) and the Slovak Republic (1993). A coalition government is defined as the joint rule of executive functions by two or more political parties. The number of governments is determined by the number of terms served by the head of the executive branch (where a term is either defined by a change in the executive or an election that renewed support for the current government). Data on the frequency of coalition governments are only applicable for countries that have a parliamentary or dual executive.

A Ministry is an organisation in the executive branch that is responsible for a sector of public administration. In some countries, such as the United States and Norway, Ministries are called "Departments". Common examples include the Ministries of Health, Education and Finance. While sub-national governments may also be organised into Ministries, the data only refer to central government. Ministers advise the executive and are in charge of either one or more Ministries, or a portfolio of government duties. In most parliamentary systems, Ministers are drawn from the legislature and keep their seats. In most presidential systems, Ministers are not elected officials and are appointed by the president. The data refer to the number of Ministers that comprise the cabinet at the central level of government and exclude Deputy Ministers.

Bicameral legislatures have two chambers (usually an Upper House and a Lower House), whereas unicameral legislatures are composed of only a Lower House. Electoral systems are usually characterised as single member (First Past the Post or Preferential and Two-Round) or multi member (Proportional Representation or Semi-Proportional Representation). The types of electoral systems are defined as follows:

- Under First Past the Post, the winner is the candidate with the most votes but not necessarily an absolute majority of votes.

- Under Preferential and Two-Round, the winner is the candidate who receives an absolute majority (i.e. over $50 \%$ ) of votes. If no candidate receives over $50 \%$ of votes during the first round of voting, the Preferential system makes use of voters' second preferences while the Two-Round system uses a second round of voting to produce a winner.

- Proportional Representation (PR) systems allocate parliamentary seats based on a party's share of national votes. 
- Semi-proportional systems feature attributes of both single-member and PR systems. They allow two votes per person: one for a candidate running in the voter's district and one for a party. As in PR, party seats are allocated proportional to the party's share of national votes.

Data on the frequency of elections reflect statutory requirements. In reality, elections may be held more frequently in parliamentary systems if governments collapse.

Judicial review refers to the ability of the courts or a separate body to review the constitutionality of laws and actions. It is usually enshrined in the constitution. In countries with limited judicial review, the courts only have the ability to review the constitutionality of specific types of laws or actions or under specific circumstances.

\section{Table H.1. Australia ${ }^{1}$}

\begin{tabular}{|c|c|}
\hline Population mid-2009 estimate (in millions) & 22.0 \\
\hline GDP in 2009 (PPP in USD billion at current prices) & 876.5 \\
\hline Member of the EU & No \\
\hline State structure & Federal \\
\hline \multicolumn{2}{|l|}{ Number of tiers of government } \\
\hline State/regional & $6+2$ \\
\hline Provincial & Not applicable \\
\hline Local & 717 \\
\hline System of executive power & Parliamentary \\
\hline Head of state & Monarch \\
\hline Head of government & Prime Minister \\
\hline \multicolumn{2}{|l|}{ Existence of term limits for presidents } \\
\hline Is there a president? & No \\
\hline Term limit (years) & Not applicable \\
\hline \multicolumn{2}{|l|}{ Governments at the central level between 1990 and 2010} \\
\hline Total number of governments & 10 \\
\hline Number of coalition governments & 4 \\
\hline Number of executives serving non-consecutive terms & 5 \\
\hline Number of Ministers at the central level of government (2010) & 20 \\
\hline Number of Ministries or Departments at the central level of government (2010) & 20 \\
\hline \multicolumn{2}{|l|}{ Upper House (central government) } \\
\hline Existence & Yes \\
\hline Membership based on regional considerations? & Yes \\
\hline Frequency of elections (in years) & 6 \\
\hline Size - number of seats & 76 \\
\hline \multicolumn{2}{|l|}{ Lower House (central government) } \\
\hline Electoral system & Single - preferential \\
\hline Frequency of elections (in years) & 3 \\
\hline Size - number of seats & 150 \\
\hline Existence of system of judicial review of the constitutionality of laws and actions & Judicial review \\
\hline
\end{tabular}

1. Australia has 6 states and 2 territories. The Australian Constitution recognises two levels of government: 565 local governing bodies operate under the six states and the Northern Territory. 
Table H.2. Austria

Population mid-2009 estimate (in millions)

8.4

324.7

Yes

Federal

State structure

Number of tiers of government

State/regional

9

Provincial

Not applicable

2357

Local

System of executive power

Head of state

Head of government

Parliamentary

President

Chancellor

Existence of term limits for presidents

Is there a president?

Term limit (years)

Yes

12

Governments at the central level between 1990 and 2010

Total number of governments

9

Number of coalition governments

Number of executives serving non-consecutive terms

Number of Ministers at the central level of government (2010)

Number of Ministries or Departments at the central level of government (2010)

Upper House (central government)

Existence

Membership based on regional considerations?

Frequency of elections (in years)

Size - number of seats

Lower House (central government)

Electoral system

Frequency of elections (in years)

Size - number of seats

Existence of system of judicial review of the constitutionality of laws and actions

\begin{tabular}{|c|c|}
\hline Population mid-2009 estimate (in millions) & 8.4 \\
\hline GDP in 2009 (PPP in USD billion at current prices) & 324.7 \\
\hline Member of the EU & Yes \\
\hline State structure & Federal \\
\hline \multicolumn{2}{|l|}{ Number of tiers of government } \\
\hline State/regional & 9 \\
\hline Provincial & Not applicable \\
\hline Local & 2357 \\
\hline System of executive power & Parliamentary \\
\hline Head of state & President \\
\hline Head of government & Chancellor \\
\hline \multicolumn{2}{|l|}{ Existence of term limits for presidents } \\
\hline Is there a president? & Yes \\
\hline Term limit (years) & 12 \\
\hline \multicolumn{2}{|l|}{ Governments at the central level between 1990 and 2010} \\
\hline Total number of governments & 9 \\
\hline Number of coalition governments & 9 \\
\hline Number of executives serving non-consecutive terms & 5 \\
\hline Number of Ministers at the central level of government (2010) & 13 \\
\hline Number of Ministries or Departments at the central level of government (2010) & 13 \\
\hline \multicolumn{2}{|l|}{ Upper House (central government) } \\
\hline Existence & Yes \\
\hline Membership based on regional considerations? & Yes \\
\hline Frequency of elections (in years) & Not elected \\
\hline Size - number of seats & 62 \\
\hline \multicolumn{2}{|l|}{ Lower House (central government) } \\
\hline Electoral system & Multi-member - Proportional \\
\hline Frequency of elections (in years) & 5 \\
\hline Size - number of seats & 183 \\
\hline Existence of system of judicial review of the constitutionality of laws and actions & Judicial review \\
\hline
\end{tabular}

9

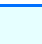


Table H.3. Belgium

Population mid-2009 estimate (in millions)

10.6

GDP in 2009 (PPP in USD billion at current prices)

391.8

Member of the EU

State structure

Yes

Federal

Number of tiers of government

State/regional

Provincial

Local

589

System of executive power

Parliamentary

Head of state

Monarch

Head of government

Prime Minister

Existence of term limits for presidents

Is there a president?

No

Term limit (years)

Not applicable

Governments at the central level between 1990 and 2010

Total number of governments

9

Number of coalition governments

Number of executives serving non-consecutive terms

Number of Ministers at the central level of government (2010)

Number of Ministries or Departments at the central level of government (2010)

Upper House (central government)

Existence

Membership based on regional considerations?

Frequency of elections (in years)

Size - number of seats

Lower House (central government)

Electoral system

Frequency of elections (in years)

Size - number of seats

Existence of system of judicial review of the constitutionality of laws and actions

9

6

14

14

Yes

Yes

4

71

Multi-member - Proportional

\section{4}

150

Limited judicial review 
Table H.4. Canada ${ }^{1}$

Population mid-2009 estimate (in millions)

33.7

GDP in 2009 (PPP in USD billion at current prices)

1275.6

Member of the EU

State structure

No

Federal

Number of tiers of government

State/regional

Provincial

Not applicable

$10+3$

Local

3700

System of executive power

Parliamentary

Head of state

Monarch

Head of government

Prime Minister

Existence of term limits for presidents

Is there a president?

No

Term limit (years)

Not applicable

Governments at the central level between 1990 and 2010

Total number of governments

9

Number of coalition governments

Number of executives serving non-consecutive terms

Number of Ministers at the central level of government (2010)

Number of Ministries or Departments at the central level of government (2010)

38

32

Upper House (central government)

Existence

Membership based on regional considerations?

Yes

No

Frequency of elections (in years)

Size - number of seats

Not elected

105

Lower House (central government)

Electoral system

Single - First Past the Post

Frequency of elections (in years)

5

Size - number of seats

308

Existence of system of judicial review of the constitutionality of laws and actions

Limited judicial review

1. Canada has 10 provinces and 3 territories. 
Table H.5. Chile

Population mid-2009 estimate (in millions)

17.0

GDP in 2009 (PPP in USD billion at current prices)

242.9

Member of the EU

State structure

No

State structure

Unitary

Number of tiers of government

State/regional

15

Provincial

53

Local

System of executive power

346

Head of state

Presidential

Head of government

President

Existence of term limits for presidents

President

Is there a president?

Term limit (years)

Governments at the central level between 1990 and 2010

Total number of governments

Number of coalition governments

Number of executives serving non-consecutive terms

Number of Ministers at the central level of government (2010)

Number of Ministries or Departments at the central level of government (2010)

\section{Yes}

4

5

Not applicable

5

22

20

Upper House (central government)

Existence

Membership based on regional considerations?

Frequency of elections (in years)

Size - number of seats

Lower House (central government)

Electoral system

Frequency of elections (in years)

Size - number of seats

Existence of system of judicial review of the constitutionality of laws and actions

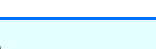

9

Yes

No

8

38

Single - First Past the Post

\author{
4
}

120

Limited judicial review 
Table H.6. Czech Republic

Population mid-2009 estimate (in millions)

10.5

GDP in 2009 (PPP in USD billion at current prices)

268.2

Member of the EU

State structure

Yes

Unitary

Number of tiers of government

State/regional

14

Provincial

Not applicable

Local

6249

System of executive power

Parliamentary

Head of state

President

Head of government

Prime Minister

Existence of term limits for presidents

Is there a president?

Term limit (years)

Yes

10

Governments at the central level between 1990 and 2010

Total number of governments

11

Number of coalition governments

Number of executives serving non-consecutive terms

Number of Ministers at the central level of government (2010)

Number of Ministries or Departments at the central level of government (2010)

Upper House (central government)

Existence

Membership based on regional considerations?

Frequency of elections (in years)

Size - number of seats

Lower House (central government)

Electoral system

Frequency of elections (in years)

Size - number of seats

Existence of system of judicial review of the constitutionality of laws and actions

\section{9}

9

15

14

Yes

No

6

81

Multi-member - Proportional

$$
4
$$

200

Judicial review 
Table H.7. Denmark

Population mid-2009 estimate (in millions)

5.5

GDP in 2009 (PPP in USD billion at current prices)

208.1

Yes

Unitary

State structure

Number of tiers of government

State/regional

5

Provincial

Local

System of executive power

Head of state

Head of government

Existence of term limits for presidents

Is there a president?

Term limit (years)

Governments at the central level between 1990 and 2010

Total number of governments

Number of coalition governments

Number of executives serving non-consecutive terms

Number of Ministers at the central level of government (2010)

Number of Ministries or Departments at the central level of government (2010)

Upper House (central government)

Existence

Membership based on regional considerations?

Frequency of elections (in years)

Size - number of seats

Lower House (central government)

Electoral system

Frequency of elections (in years)

Size - number of seats

Existence of system of judicial review of the constitutionality of laws and actions
Not applicable

98

Parliamentary

Monarch

Prime Minister

No

Not applicable

10

10

4

19

18

No

Not applicable

Not applicable

Not applicable

Multi-member - Proportional

\section{4}

179

Judicial review 
Table H.8. Estonia

Population mid-2009 estimate (in millions)

GDP in 2009 (PPP in USD billion at current prices)

Member of the EU

State structure

Number of tiers of government

State/regional

Provincial

Local

System of executive power

Head of state

Head of government

Existence of term limits for presidents

Is there a president?

Term limit (years)

Governments at the central level between 1990 and 2010

Total number of governments

1.3

26.6

Yes

Unitary

15

Not applicable 227

Parliamentary

President

Prime Minister

Number of coalition governments

Number of executives serving non-consecutive terms

Number of Ministers at the central level of government (2010)

Number of Ministries or Departments at the central level of government (2010)

Upper House (central government)

Existence

Membership based on regional considerations?

Frequency of elections (in years)

Size - number of seats

Lower House (central government)

Electoral system

Frequency of elections (in years)

Size - number of seats

Existence of system of judicial review of the constitutionality of laws and actions
Yes

10

12

4

10

13

11

No

Not applicable

Not applicable

Not applicable

Single - First Past the Post

4

101

Judicial review 
Table H.9. Finland

Population mid-2009 estimate (in millions)

5.3

GDP in 2009 (PPP in USD billion at current prices)

188.1

Yes

Unitary

State structure

Number of tiers of government

State/regional

20

Provincial

Local

System of executive power

Head of state

Head of government

Existence of term limits for presidents

Is there a president?

Term limit (years)

Governments at the central level between 1990 and 2010

Total number of governments

Number of coalition governments

Number of executives serving non-consecutive terms

Number of Ministers at the central level of government (2010)

Number of Ministries or Departments at the central level of government (2010)

Upper House (central government)

Existence

Membership based on regional considerations?

Frequency of elections (in years)

Size - number of seats

74

416

Dual executive

President

Prime Minister

Yes

12

Lower House (central government)

Electoral system

Frequency of elections (in years)

Size - number of seats

Existence of system of judicial review of the constitutionality of laws and actions

8

6

20

12

No

Not applicable

Not applicable

Not applicable

Multi-member - Proportional

\section{4}

200

No judicial review 
Table H.10. France ${ }^{1}$

Population mid-2009 estimate (in millions)

62.6

GDP in 2009 (PPP in USD billion at current prices)

2173.3

Member of the EU

State structure

Yes

Unitary

Number of tiers of government

State/regional

26

Provincial

100

Local

36683

System of executive power

Head of state

Head of government

Dual executive

President

Existence of term limits for presidents

Is there a president?

Term limit (years)

Prime Minister

Governments at the central level between 1990 and 2010

Total number of governments

Yes

10

Number of coalition governments

10

Number of executives serving non-consecutive terms

Number of Ministers at the central level of government (2010)

Number of Ministries or Departments at the central level of government (2010)

Upper House (central government)

Existence

Membership based on regional considerations?

Frequency of elections (in years)

Size - number of seats

Lower House (central government)

Electoral system

Frequency of elections (in years)

Size - number of seats

Existence of system of judicial review of the constitutionality of laws and actions

3

9

21

16

Yes

No

6

343

Single - Two rounds

$$
5
$$

577

Limited judicial review

1. The number of coalition governments represents periods of cohabitation. The number of governments represents the number of Prime Ministers. 
Table H.11. Germany ${ }^{1}$

Population mid-2009 estimate (in millions)

81.9

GDP in 2009 (PPP in USD billion at current prices)

2975.3

Member of the EU

State structure

Yes

Federal

Number of tiers of government

State/regional

16

Provincial

323

Local

System of executive power

Head of state

Head of government

12312

Parliamentary

President

Chancellor

Existence of term limits for presidents

Is there a president?

Term limit (years)

Yes

10

Governments at the central level between 1990 and 2010

Total number of governments

7

Number of coalition governments

Number of executives serving non-consecutive terms

Number of Ministers at the central level of government (2010)

Number of Ministries or Departments at the central level of government (2010)

Bundesrat

Existence

Membership based on regional considerations?

Frequency of elections (in years)

Size - number of seats

Bundestag

Electoral system

Frequency of elections (in years)

Size - number of seats

Existence of system of judicial review of the constitutionality of laws and actions

The German legislature is composed of the Bundestag and the Bundesrat. Members of the Bundesrat aremembers of state governments and are indirectly chosen by the electorate through state elections. 
Table H.12. Greece

Population mid-2009 estimate (in millions)

11.2

GDP in 2009 (PPP in USD billion at current prices)

330.7

Member of the EU

State structure

Yes

Unitary

Number of tiers of government

State/regional

50

Provincial

Not applicable

1034

Local

System of executive power

Parliamentary

Head of state

President

Head of government

Prime Minister

Existence of term limits for presidents

Is there a president?

Term limit (years)

Yes

10

Governments at the central level between 1990 and 2010

Total number of governments

8

Number of coalition governments

Number of executives serving non-consecutive terms

Number of Ministers at the central level of government (2010)

Number of Ministries or Departments at the central level of government (2010)

Upper House (central government)

Existence

Membership based on regional considerations?

Frequency of elections (in years)

Size - number of seats

Not applicable

Not applicable

Lower House (central government)

Electoral system

Frequency of elections (in years)

Multi-member - Proportional

Size - number of seats

4

Existence of system of judicial review of the constitutionality of laws and actions

300

Judicial review 
Table H.13. Hungary

Population mid-2009 estimate (in millions)

10.0

GDP in 2009 (PPP in USD billion at current prices)

203.3

Member of the EU

State structure

Yes

State structure

Unitary

Number of tiers of government

State/regional

19

Provincial

Not applicable

Local

System of executive power

3175

Head of state

Head of government

Parliamentary

President

Existence of term limits for presidents

Is there a president?

Term limit (years)

Prime Minister

Governments at the central level between 1990 and 2010

Total number of governments

Yes

10

Number of coalition governments

Number of executives serving non-consecutive terms

Number of Ministers at the central level of government (2010)

Number of Ministries or Departments at the central level of government (2010)

Upper House (central government)

Existence

Membership based on regional considerations?

Frequency of elections (in years)

Size - number of seats

Lower House (central government)

Electoral system

Frequency of elections (in years)

Size - number of seats

Existence of system of judicial review of the constitutionality of laws and actions

386

Judicial review 
Table H.14. Iceland

Population mid-2009 estimate (in millions)

0.3

GDP in 2009 (PPP in USD billion at current prices)

11.7

Member of the EU

State structure

No

Unitary

Number of tiers of government

State/regional

8

Provincial

Not applicable

$$
76
$$

System of executive power

Parliamentary

Head of state

President

Head of government

Prime Minister

Existence of term limits for presidents

Is there a president?

Yes

Term limit (years)

No term limit

Governments at the central level between 1990 and 2010

Total number of governments

10

Number of coalition governments

Number of executives serving non-consecutive terms

Number of Ministers at the central level of government (2010)

Number of Ministries or Departments at the central level of government (2010)

Upper House (central government)

Existence

Membership based on regional considerations?

Frequency of elections (in years)

Size - number of seats

Not applicable

Not applicable

Lower House (central government)

Electoral system

Frequency of elections (in years)

Multi-member - Proportional

Size - number of seats

Existence of system of judicial review of the constitutionality of laws and actions 


\section{Table H.15. Ireland ${ }^{1}$}

Population mid-2009 estimate (in millions)

4.5

GDP in 2009 (PPP in USD billion at current prices)

176.8

Yes

Unitary

State structure

Number of tiers of government

State/regional

8

Provincial

Local

System of executive power

Head of state

Head of government

Existence of term limits for presidents

Is there a president?

Term limit (years)

Governments at the central level between 1990 and 2010

Total number of governments

Number of coalition governments

Number of executives serving non-consecutive terms

Number of Ministers at the central level of government (2010)

Number of Ministries or Departments at the central level of government (2010)

Upper House (central government)

Existence

Membership based on regional considerations?

Frequency of elections (in years)

Size - number of seats

Lower House (central government)

Electoral system

Frequency of elections (in years)

Size - number of seats

Existence of system of judicial review of the constitutionality of laws and actions

1. Members of the Upper House are elected indirectly by universities and panels composed of members of the Lower House and elected country officials. 
Table H.16. Israel

Population mid-2009 estimate (in millions)

7.3

GDP in 2009 (PPP in USD billion at current prices)

205.8

Member of the EU

State structure

No

Unitary

Number of tiers of government

State/regional

6

Provincial

Local

System of executive power

Head of state

Head of government

Existence of term limits for presidents

Is there a president?

Term limit (years)

Governments at the central level between 1990 and 2010

Total number of governments

Number of coalition governments

Number of executives serving non-consecutive terms

Number of Ministers at the central level of government (2010)

Number of Ministries or Departments at the central level of government (2010)

Upper House (central government)

Existence

Membership based on regional considerations?

Frequency of elections (in years)

Size - number of seats

Lower House (central government)

Electoral system

Frequency of elections (in years)

Size - number of seats

Existence of system of judicial review of the constitutionality of laws and actions t applicable

252

Parliamentary

President

Prime Minister

Yes

7

10

10

8

37

30

No

Not applicable

Not applicable

Not applicable

Multi-member - Proportional

\section{4}

120

No judicial review 
Table H.17. Italy

Population mid-2009 estimate (in millions)

59.8

1953

GDP in 2009 (PPP in USD billion at current prices)

Yes

Member of the EU

State structure

Unitary

Number of tiers of government

State/regional $\quad 20$

Provincial 103

$\begin{array}{lr}\text { Local } & 8101\end{array}$

System of executive power

Parliamentary

Head of state

President

Head of government

Prime Minister

Existence of term limits for presidents

Is there a president?

Term limit (years)

Yes

No term limit

Governments at the central level between 1990 and 2010

Total number of governments

14

Number of coalition governments

Number of executives serving non-consecutive terms

Number of Ministers at the central level of government (2010)

Number of Ministries or Departments at the central level of government (2010)

Upper House (central government)

Existence

Membership based on regional considerations?

Frequency of elections (in years)

Size - number of seats

Lower House (central government)

Electoral system

Frequency of elections (in years)

Size - number of seats

Existence of system of judicial review of the constitutionality of laws and actions
Multi-member - Semi-proportional 
Table H.18. Japan

Population mid-2009 estimate (in millions)

127.5

GDP in 2009 (PPP in USD billion at current prices)

4135.2

Member of the EU

State structure

No

Number of tiers of government

State/regional

Unitary

Provincial

47

Local

Not applicable

$$
1727
$$

System of executive power

Parliamentary

Head of state

Monarch

Head of government

Prime Minister

Existence of term limits for presidents

Is there a president?

No

Term limit (years)

Not applicable

Governments at the central level between 1990 and 2010

Total number of governments

19

Number of coalition governments

Number of executives serving non-consecutive terms

Number of Ministers at the central level of government (2010)

Number of Ministries or Departments at the central level of government (2010)

Upper House (central government)

Existence

Membership based on regional considerations?

Frequency of elections (in years)

Size - number of seats

Lower House (central government)

Electoral system

Frequency of elections (in years)

Size - number of seats

Existence of system of judicial review of the constitutionality of laws and actions
15

14

17

13

Yes

No

6

242

Multi-member - Semi-proportional

Judicial review 
Table H.19. Korea

Population mid-2009 estimate (in millions)

48.7

GDP in 2009 (PPP in USD billion at current prices)

1321

Member of the EU

State structure

No

Unitary

Number of tiers of government

State/regional

16

Provincial

Not applicable

Local

System of executive power

Head of state

Head of government

Not available

Presidential

President

Existence of term limits for presidents

Is there a president?

Term limit (years)

Prime Minister

Governments at the central level between 1990 and 2010

Total number of governments

Number of coalition governments

Number of executives serving non-consecutive terms

Number of Ministers at the central level of government (2010)

Number of Ministries or Departments at the central level of government (2010)

Upper House (central government)

Existence

Membership based on regional considerations?

Frequency of elections (in years)

Size - number of seats

Lower House (central government)

Electoral system

Frequency of elections (in years)

Size - number of seats

Existence of system of judicial review of the constitutionality of laws and actions

\section{Yes}

5

5

Not applicable

5

16

15

No

Not applicable

Not applicable

Not applicable

Multi-member - Semi-proportional

$$
4
$$

299

Judicial review 
Table H.20. Luxembourg

Population mid-2009 estimate (in millions)

0.5

GDP in 2009 (PPP in USD billion at current prices)

42.2

Member of the EU

State structure

Yes

Number of tiers of government

State/regional

Unitary

Provincial

3

Local

System of executive power

applicable

116

Head of state

Parliamentary

Head of government

Monarch

Existence of term limits for presidents

Is there a president?

Prime Minister

Term limit (years)

No

Governments at the central level between 1990 and 2010

Total number of governments

Not applicable

Number of coalition governments

Number of executives serving non-consecutive terms

Number of Ministers at the central level of government (2010)

Number of Ministries or Departments at the central level of government (2010)

Upper House (central government)

Existence

Membership based on regional considerations?

Frequency of elections (in years)

Size - number of seats

Not applicable

Not applicable

Lower House (central government)

Electoral system

Frequency of elections (in years)

Multi-member - Proportional

Size - number of seats

Existence of system of judicial review of the constitutionality of laws and actions

Judicial review 
Table H.21. Mexico

Population mid-2009 estimate (in millions)

107.6

GDP in 2009 (PPP in USD billion at current prices)

1540.4

Member of the EU

State structure

No

Number of tiers of government

State/regional

Federal

Provincial

31

Local

System of executive power

applicable

2438

Presidential

of state

President

Head of government

President

Existence of term limits for presidents

Is there a president?

Term limit (years)

Yes

6

Governments at the central level between 1990 and 2010

Total number of governments

Number of coalition governments

Number of executives serving non-consecutive terms

Number of Ministers at the central level of government (2010)

Number of Ministries or Departments at the central level of government (2010)

Upper House (central government)

Existence

Membership based on regional considerations?

Frequency of elections (in years)

Size - number of seats

applicable

4

19

18

Yes

No

6

128

Lower House (central government)

Electoral system

Frequency of elections (in years)

Multi-member - Semi-proportional

Size - number of seats

500

Existence of system of judicial review of the constitutionality of laws and actions

Judicial review 
Table H.22. Netherlands

Population mid-2009 estimate (in millions)

16.5

GDP in 2009 (PPP in USD billion at current prices)

674.5

Member of the EU

State structure

Number of tiers of government

State/regional

Provincial

Local

System of executive power

Head of state

Head of government

Existence of term limits for presidents

Is there a president?

Term limit (years)

Governments at the central level between 1990 and 2010

Total number of governments

Number of coalition governments

Number of executives serving non-consecutive terms

Number of Ministers at the central level of government (2010)

Number of Ministries or Departments at the central level of government (2010)

Upper House (central government)

Existence

Membership based on regional considerations?

Frequency of elections (in years)

Size - number of seats

Lower House (central government)

Electoral system

Frequency of elections (in years)

Size - number of seats

Existence of system of judicial review of the constitutionality of laws and actions
Yes

Unitary

12

Not applicable

443

Parliamentary

Monarch

Prime Minister

No

Not applicable

8

8

4

12

11

Yes

Yes

4

75

Multi-member - Proportional

\section{4}

150

No judicial review 
Table H.23. New Zealand

Population mid-2009 estimate (in millions)

4.3

GDP in 2009 (PPP in USD billion at current prices)

124.6

Member of the EU

State structure

Number of tiers of government

State/regional

Provincial

Local

System of executive power

Head of state

Head of government

Existence of term limits for presidents

Is there a president?

Term limit (years)

Governments at the central level between 1990 and 2010

Total number of governments

Number of coalition governments

Number of executives serving non-consecutive terms

Number of Ministers at the central level of government (2010)

Number of Ministries or Departments at the central level of government (2010)

Upper House (central government)

Existence

Membership based on regional considerations?

Frequency of elections (in years)

Size - number of seats

Lower House (central government)

Electoral system

Frequency of elections (in years)

Size - number of seats

Existence of system of judicial review of the constitutionality of laws and actions
No

Unitary

$16+1$

Not applicable

67

Parliamentary

Monarch

Prime Minister

No

Not applicable

10

5

6

20

32

No

Not applicable

Not applicable

Not applicable

Multi-member - Semi-proportional

\author{
3
}

120

No judicial review 
Table H.24. Norway

Population mid-2009 estimate (in millions)

4.8

GDP in 2009 (PPP in USD billion at current prices)

269.1

Member of the EU

State structure

No

Unitary

Number of tiers of government

State/regional

19

Provincial

Not applicable

435

Local

System of executive power

Parliamentary

Head of state

Monarch

Head of government

Prime Minister

Existence of term limits for presidents

Is there a president?

No

Term limit (years)

Not applicable

Governments at the central level between 1990 and 2010

Total number of governments

Number of coalition governments

Number of executives serving non-consecutive terms

Number of Ministers at the central level of government (2010)

Number of Ministries or Departments at the central level of government (2010)

18

Upper House (central government)

Existence

Membership based on regional considerations?

No

Frequency of elections (in years)

Size - number of seats

Not applicable

Not applicable

Not applicable

Lower House (central government)

Electoral system

Frequency of elections (in years)

Multi-member - Proportional

Size - number of seats

4

Existence of system of judicial review of the constitutionality of laws and actions

169

Judicial review 


\section{Table H.25. Poland}

Population mid-2009 estimate (in millions)

38.2

GDP in 2009 (PPP in USD billion at current prices)

722.2

Member of the EU

State structure

Yes

Unitary

Number of tiers of government

State/regional

16

Provincial

314

Local

2478

System of executive power

Head of state

Head of government

Dual executive

President

Existence of term limits for presidents

Is there a president?

Term limit (years)

Prime Minister

Governments at the central level between 1990 and 2010

Total number of governments

Yes

10

Number of coalition governments

Number of executives serving non-consecutive terms

Number of Ministers at the central level of government (2010)

Number of Ministries or Departments at the central level of government (2010)

Upper House (central government)

Existence

Membership based on regional considerations?

Frequency of elections (in years)

Size - number of seats

Lower House (central government)

Electoral system

Frequency of elections (in years)

Size - number of seats

Existence of system of judicial review of the constitutionality of laws and actions

\section{4}

12

14

18

18

Yes

Yes

4

100

Multi-member - Proportional

Judicial review 
Table H.26. Portugal

Population mid-2009 estimate (in millions)

10.6

GDP in 2009 (PPP in USD billion at current prices)

265.6

Member of the EU

State structure

Yes

State structure

Unitary

Number of tiers of government

State/regional

2

Provincial

Not applicable

Local

$$
308
$$

System of executive power

Head of state

Head of government

Dual executive

President

Existence of term limits for presidents

Is there a president?

Term limit (years)

Prime Minister

Governments at the central level between 1990 and 2010

Total number of governments

Number of coalition governments

Number of executives serving non-consecutive terms

Number of Ministers at the central level of government (2010)

Number of Ministries or Departments at the central level of government (2010)

Upper House (central government)

Existence

Membership based on regional considerations?

Frequency of elections (in years)

Size - number of seats

Lower House (central government)

Electoral system

Frequency of elections (in years)

Size - number of seats

Existence of system of judicial review of the constitutionality of laws and actions

10

Yes

8

2

5

17

14

No

Not applicable

Not applicable

Not applicable

Multi-member - Proportional

\section{4}

230

Judicial review 
Table H.27. Slovak Republic

Population mid-2009 estimate (in millions)

5.4

GDP in 2009 (PPP in USD billion at current prices)

123.9

Yes

Unitary

State structure

Number of tiers of government

State/regional

8

Provincial

Local

System of executive power

Head of state

Head of government

Existence of term limits for presidents

Is there a president?

Term limit (years)

Governments at the central level between 1990 and 2010

Total number of governments

Number of coalition governments

Number of executives serving non-consecutive terms

Number of Ministers at the central level of government (2010)

Number of Ministries or Departments at the central level of government (2010)

Upper House (central government)

Existence

Membership based on regional considerations?

Frequency of elections (in years)

Size - number of seats

Lower House (central government)

Electoral system

Frequency of elections (in years)

Size - number of seats

Existence of system of judicial review of the constitutionality of laws and actions
Not applicable

2928

Parliamentary

President

Prime Minister

\section{Yes}

10

7

7

6

13

13

No

Not applicable

Not applicable

Not applicable

Multi-member - Proportional

\section{4}

150

Judicial review 
Table H.28. Slovenia

Population mid-2009 estimate (in millions)

2.0

GDP in 2009 (PPP in USD billion at current prices)

56.2

Member of the EU

State structure

Yes

Unitary

Number of tiers of government

State/regional

Not applicable

Provincial

Local

Not applicable

$$
210
$$

System of executive power

Parliamentary

Head of state

Head of government

President

Existence of term limits for presidents

Is there a president?

Term limit (years)

Prime Minister

Governments at the central level between 1990 and 2010

Total number of governments

Yes

10

Number of coalition governments

Number of executives serving non-consecutive terms

Number of Ministers at the central level of government (2010)

Number of Ministries or Departments at the central level of government (2010)

Upper House (central government)

Existence

Membership based on regional considerations?

Frequency of elections (in years)

Size - number of seats

9

9

7

19

15

Yes

Yes

Not directly elected

40

Lower House (central government)

Electoral system

Frequency of elections (in years)

Size - number of seats

Multi-member - Proportional

Existence of system of judicial review of the constitutionality of laws and actions
4

90

Judicial review 
Table H.29. Spain ${ }^{1}$

Population mid-2009 estimate (in millions)

45.9

1481.4

Yes

Member of the EU

State structure

See note

Number of tiers of government

State/regional

17

Provincial

Local

8111

System of executive power

Parliamentary

Head of state

Head of government

Monarch

President of the Government (Prime

Minister equivalent)

Existence of term limits for presidents

Is there a president?

No

Term limit (years)

Not applicable

Governments at the central level between 1990 and 2010

Total number of governments

Number of coalition governments

Number of executives serving non-consecutive terms

Number of Ministers at the central level of government (2010)

Number of Ministries or Departments at the central level of government (2010)

Upper House (central government)

Existence

Membership based on regional considerations?

Frequency of elections (in years)

Size - number of seats

Lower House (central government)

Electoral system

Frequency of elections (in years)

Size - number of seats

Existence of system of judicial review of the constitutionality of laws and actions

12

15

Yes

Yes

4

264

Multi-member - Proportional

4

350

Limited judicial review

1. Spain is a strongly decentralised state with 17 autonomous communities and 2 autonomous cities. 
Table H.30. Sweden

Population mid-2009 estimate (in millions)

9.3

GDP in 2009 (PPP in USD billion at current prices)

345.6

Yes

Unitary

State structure

$18+2$

Number of tiers of government

State/regional

Not applicable$$
290
$$

Local

System of executive power

Parliamentary

Head of state

Monarch

Head of government

Prime Minister

Existence of term limits for presidents

Is there a president?

No

Term limit (years)

Governments at the central level between 1990 and 2010

Total number of governments

Number of coalition governments

Number of executives serving non-consecutive terms

Number of Ministers at the central level of government (2010)

Number of Ministries or Departments at the central level of government (2010)

Upper House (central government)

Existence

Membership based on regional considerations?

Frequency of elections (in years)

Size - number of seats

Lower House (central government)

Electoral system

Frequency of elections (in years)

Size - number of seats

Existence of system of judicial review of the constitutionality of laws and actions
Not applicable

9

3

5

24

11

No

Not applicable

Not applicable

Not applicable

Multi-member - Proportional

4

349

Limited judicial review 
Table H.31. Switzerland

Population mid-2009 estimate (in millions)

7.7

349.6

No

Federal

State structure

Number of tiers of government

State/regional

26

Provincial

Local

System of executive power

Head of state

Head of government

Existence of term limits for presidents

Is there a president?

Term limit (years)

Governments at the central level between 1990 and 2010

Total number of governments

Number of coalition governments

Number of executives serving non-consecutive terms

Number of Ministers at the central level of government (2010)

Number of Ministries or Departments at the central level of government (2010)

Upper House (central government)

Existence

Membership based on regional considerations?

Frequency of elections (in years)

Size - number of seats

Lower House (central government)

Electoral system

Frequency of elections (in years)

Size - number of seats

Existence of system of judicial review of the constitutionality of laws and actions
Not applicable

2889

Parliamentary

President

President

No

Not applicable

Not applicable

Not applicable

Not applicable

7

7

Yes

Yes

4

46

Multi-member - Semi-proportional

$$
4
$$

200

Limited judicial review 
Table H.32. Turkey

Population mid-2009 estimate (in millions)

71.9

GDP in 2009 (PPP in USD billion at current prices)

1024

Member of the EU

State structure

No

Unitary

Number of tiers of government

State/regional

7

Provincial

Local

923

System of executive power

Parliamentary

Head of state

Head of government

President

Existence of term limits for presidents

Is there a president?

Term limit (years)

Prime Minister

Governments at the central level between 1990 and 2010

Total number of governments

10

Number of coalition governments

Number of executives serving non-consecutive terms

Number of Ministers at the central level of government (2010)

Number of Ministries or Departments at the central level of government (2010)

Upper House (central government)

Existence

Membership based on regional considerations?

Frequency of elections (in years)

Size - number of seats

Not applicable

Not applicable

Lower House (central government)

Electoral system

Frequency of elections (in years)

Multi-member - Proportional

Size - number of seats

4

Existence of system of judicial review of the constitutionality of laws and actions

550

Limited judicial review 
Table H.33. United Kingdom

Population mid-2009 estimate (in millions)

60.9

GDP in 2009 (PPP in USD billion at current prices)

2172.5

Member of the EU

State structure

Yes

Unitary

Number of tiers of government

State/regional

3

Provincial

$34+1$

434

Local

System of executive power

Parliamentary

Head of state

Monarch

Head of government

Prime Minister

Existence of term limits for presidents

Is there a president?

No

Term limit (years)

Governments at the central level between 1990 and 2010

Total number of governments

Number of coalition governments

Number of executives serving non-consecutive terms

Number of Ministers at the central level of government (2010)

Number of Ministries or Departments at the central level of government (2010)

Upper House (central government)

Existence

Membership based on regional considerations?

Frequency of elections (in years)

Size - number of seats

Lower House (central government)

Electoral system

Frequency of elections (in years)

Size - number of seats

Existence of system of judicial review of the constitutionality of laws and actions
Not applicable

8

1

5

23

17

Yes

Not elected

Not elected

618

Single - First Past the Post

646

No judicial review 
Table H.34. United States ${ }^{1}$

Population mid-2009 estimate (in millions)

307.0

GDP in 2009 (PPP in USD billion at current prices)

14043.9

Member of the EU

No

State structure

Federal

Number of tiers of government

State/regional

$50+1+5$

Provincial

3143

Local

19429

System of executive power

Presidential

Head of state

Head of government

President

President

Existence of term limits for presidents

Is there a president?

Yes

Term limit (years)

8

Governments at the central level between 1990 and 2010

Total number of governments

6

Number of coalition governments

Not applicable

Number of executives serving non-consecutive terms

Number of Ministers at the central level of government (2010)

4

16

Number of Ministries or Departments at the central level of government (2010)

15

Upper House (central government)

Existence

Membership based on regional considerations?

Frequency of elections (in years)

Yes

Yes

Size - number of seats

Lower House (central government)

Electoral system

Single - First Past the Post

Frequency of elections (in years)

Size - number of seats

Existence of system of judicial review of the constitutionality of laws and actions

Judicial review

1. The United States consists of 50 states, the District of Columbia and 5 territories: Puerto Rico, Guam, the Northern Mariana Islands, American Samoa and the US Virgin Islands. 
Table H.35. Brazil ${ }^{1}$

Population 2009 estimate (in millions)

191.5

GDP in 2009 (PPP in USD billions at current prices)

2010.3

Member of the EU

State structure

No

Number of tiers of government

State/regional

Federal

Provincial

$26+1$

Local

System of executive power

n.a.

5564

Head of state

Presidential

Head of government

President

President

Existence of term limits for presidents

Is there a president?

Term limit (years)

Yes

Governments at the central level between 1990 and 2010

Total number of governments

Number of coalition governments

Number of executives serving non-consecutive terms

Number of Ministers at the central level of government (2010)

Number of Ministries or Departments at the central level of government (2010)

8

Upper House (central government)

Existence

Electoral system based on regional considerations?

Frequency of elections (in years)

Size - number of seats

7

Lower House (central government)

Electoral system

Frequency of elections (in years)

Size - number of seats

Not applicable

Existence of system of judicial review of the constitutionality of laws and actions

37

38

Yes

Yes

8

81

Multi-member - Proportional

\section{4}

513

Judicial review

1. 26 States and 1 Federal District. 
Table H.36. Russian Federation

Population 2008 estimate (in millions)

141.4

GDP in 2009 (PPP in USD billions at current prices)

2685.5

Member of the EU

State structure

No

Number of tiers of government

State/regional

Federal

Provincial

Local

System of executive power

Head of state

Head of government

President

Existence of term limits for presidents

83

Prime Minister

Is there a president?

Term limit (years)

Governments at the central level between 1990 and 2010

Total number of governments

Number of coalition governments

Number of executives serving non-consecutive terms

Number of Ministers at the central level of government (2010)

Number of Ministries or Departments at the central level of government (2010)

Upper House (central government)

Existence

Electoral system based on regional considerations?

Frequency of elections (in years)

Size - number of seats

Yes

12

5

Not applicable

3

26

18

Yes

Yes

Not elected

166

Lower House (central government)

Electoral system

Frequency of elections (in years)

Multi-member - Proportional

Size - number of seats

5

450

Existence of system of judicial review of the constitutionality of laws and actions
Judicial review 


\section{ANNEX I}

\section{Members of the Steering Group}

\begin{tabular}{|c|c|c|c|}
\hline & Name & Title/position & Ministry \\
\hline Australia & Ms. Carmel McGregor & Deputy Public Service Commissioner & Australian Public Service Commission \\
\hline Austria & Ms. Angelika Flatz & Director General & $\begin{array}{l}\text { Federal Chancellery, Public Service } \\
\text { and Innovative Administrative Development }\end{array}$ \\
\hline Belgium & Mr. Jacques Druart & Head International Co-ordination & $\begin{array}{l}\text { Federal Public Service Personnel } \\
\text { and Organisation }\end{array}$ \\
\hline Canada & Mr. Nick Wise & Executive Director & Treasury Board Secretariat \\
\hline Denmark & Mr. David Fjord Nielson & Special Advisor & Ministry of Finance \\
\hline Finland & Ms. Katju Holkeri & Head of Government Policy Unit & Ministry of Finance \\
\hline France & Mr. Daniel Aunay & Chef de la mission des relations internationales & $\begin{array}{l}\text { Ministère du Budget, des Comptes publics, } \\
\text { de la Fonction publique et de la Réforme } \\
\text { de l'État }\end{array}$ \\
\hline Italy & Dr. Pia Marconi & Director General & Department of Public Administration \\
\hline Japan & Mr. Shinya Shimada & First Secretary & Permanent Delegation of Japan to the OECD \\
\hline Netherlands & Mr. Dick Hagoort & $\begin{array}{l}\text { Head of the Department on Analysis, } \\
\text { Labour Market and Macro Economic Counselling }\end{array}$ & $\begin{array}{l}\text { Ministry of the Interior and Kingdom } \\
\text { Relations }\end{array}$ \\
\hline Norway & Mr. Lasse Ekeberg & Deputy Director General & $\begin{array}{l}\text { Ministry of Government Administration } \\
\text { and Reform, Department of ICT Policy } \\
\text { and Public Sector Reform }\end{array}$ \\
\hline Sweden & Mr. Claes Elmgren & Advisor & Statskontoret \\
\hline United Kingdom & Ms. Liz McKeown & Deputy Director, Analysis and Insight & Cabinet Office \\
\hline
\end{tabular}




\section{Glossary}

Term

Cash transfers

Collective goods

and services

Composite index

Dataset

Efficiency

Effectiveness

European Systems

of National Accounts

Federal state

Full-time equivalent

General government

\section{Use in Government at a Glance}

Benefits provided to eligible individuals by governments that are not required to be spent on a specific good or service. Examples of cash transfers include pensions, unemployment benefits and development aid.

Goods and services that benefit the community at large. Examples include government expenditures on defence, and public safety and order.

An indicator formed by compiling individual indicators into a single index on the basis of an underlying model (Nardo et al., 2005).

A set of indicators or variables concerning a single topic (e.g. regulatory quality).

Achieving maximum output from a given level of resources used to carry out an activity (OECD Glossary of Statistical Terms).

The extent to which the activity's stated objectives have been met (OECD Glossary of Statistical Terms).

An internationally compatible accounting framework used by members of the European Union for a systematic and detailed description of a total economy (that is a region, country or group of countries), its components and its relations with other total economies (OECD Glossary of Statistical Terms). It is fully consistent with System of National Accounts (SNA).

A country that has a constitutionally delineated division of political authority between one central and several regional or state autonomous governments.

The number of full-time equivalent jobs, defined as total hours worked divided by average annual hours worked in full-time jobs (OECD Glossary of Statistical Terms).

The general government sector consists of: a) all units of central, state or local government; $b$ ) all social security funds at each level of government; c) all non-market non-profit institutions that are controlled and mainly financed by government units. The sector does not include public corporations, even when all the equity of such corporations is owned by government units. It also does not include quasi-corporations that are owned and controlled by government units. However, unincorporated enterprises owned by government units that are not quasi-corporations remain integral parts of those units and, therefore, must be included in the general government sector (1993 System of National Accounts). 
Governance

Gross domestic product (GDP)

In-kind goods

and services

Indicator

Individual goods

and services

Input

Labour force

Outcome

Output

Productivity

Public sector
The exercise of political, economic and administrative authority. The standard measure of the value of the goods and services produced by a country during a period. Specifically, it is equal to the sum of the gross values added of all resident institutional units engaged in production (plus any taxes, and minus any subsidies, on products not included in the value of their outputs). The sum of the final uses of goods and services (all uses except intermediate consumption) measured in purchasers' prices, less the value of imports of goods and services, or the sum of primary incomes distributed by resident producer units (OECD Glossary of Statistical Terms).

Government provides (or contracts for the provision of) these goods and services directly or reimburses households for their expenses. Examples of in-kind goods and services include housing vouchers, police, and most health and education services. “... quantitative or qualitative measure derived from a series of observed facts that can reveal relative positions (e.g. of a country) in a given area. When evaluated at regular intervals, an indicator can point out the direction of change across different units and through time" (Nardo et al., 2005).

Goods and services that mainly benefit individuals. Examples include education, health and social insurance programmes. Units of labour, capital, goods and services used in the production of goods and services.

"Taking the health service as an example, input is defined as the time of medical and non-medical staff, the drugs, the electricity and other inputs purchased, and the capital services from the equipment and buildings used" (Lequiller, 2005).

The labour force, or currently active population, comprises all persons who fulfil the requirements for inclusion among the employed or the unemployed during a specified brief reference period (OECD Glossary of Statistical Terms).

Refers to what is ultimately achieved by an activity. Outcomes reflect the intended or unintended results of government actions, but other factors outside of government actions are also implicated (OECD Glossary of Statistical Terms).

In performance assessment in government, outputs are defined as the goods or services produced by government agencies (e.g. teaching hours delivered, welfare benefits assessed and paid) (OECD Glossary of Statistical Terms).

Productivity is commonly defined as a ratio of a volume measure of output to a volume measure of input use (OECD Statistical Glossary). Economists distinguish between total productivity, namely total output divided by change in (weighted) input(s) and marginal productivity, namely change in output divided by change in (weighted) input(s) (Coelli et al., 1999).

The general government sector plus (quasi) public corporations (1993 System of National Accounts). 
Public sector process

System of National

Accounts

Unitary states

Variable
Structures, procedures and management arrangements with a broad application within the public sector.

The System of National Accounts (SNA) consists of a coherent, consistent and integrated set of macroeconomic accounts, balance sheets and tables based on a set of internationally agreed concepts, definitions, classifications and accounting rules (SNA1.1).

The System of National Accounts 1993 (SNA) has been prepared under the joint responsibility of the United Nations, the International Monetary Fund, the Commission of the European Communities, the OECD and the World Bank (OECD Glossary of Statistical Terms).

Countries that do not have a constitutionally delineated division of political authority between one central and several regional or state autonomous governments. However, unitary states may have administrative divisions that include local and provincial or regional levels of government.

A characteristic of a unit being observed that may assume more than one of a set of values to which a numerical measure or a category from a classification can be assigned (e.g. income, age, weight, etc., and "occupation", "industry", "disease", etc.) (OECD Glossary of Statistical Terms). 


\section{Bibliography}

Anderson, B. and J.J. Minarik (2006), “Design Choices for Fiscal Policy Rules”, OECD Journal on Budgeting, Vol. 2006/4, OECD Publishing, Paris, pp. 159-208.

Anderson, B. (2009), "The Changing Role of Parliament in the Budget Process", OECD Journal on Budgeting, Vol. 2009/1, Paris, pp. 37-47.

Audet, D. (2002), “The Size of Government Procurement Markets”, OECD Journal on Budgeting, Vol. 2002/3, aris, pp. 149-194.

Banthin, J.S., P. Cunningham and D.M. Bernard (2008), "Financial Burden of Health Care, 2001-2004", Health Affairs, Vol. 27, pp. 188-195.

Bertok, J. et al. (2006), "Issues in Outcome Measurement for 'Government at a Glance", OECD GOV Technical Paper 3, No. 3, GOV/PGC(2006)10/ANN3, OECD Publishing, Paris.

Blöndal, J. (2001), "Budgeting in Canada”, OECD Journal on Budgeting, Vol. 2001/2, OECD Publishing, Paris, pp. 39-82.

Commonwealth of Australia (2010), Australia to 2050: Future Challenges, January.

Congressional Budget Office (CBO) (2010), The Long-Term Budget Outlook, June.

Cordova-Novion, C. and S. Jacobzone (2011), "Strengthening the Institutional Setting for Regulatory Reform", OECD Working Papers on Public Governance, No. 19, OECD Publishing, Paris.

Curristine, T. et al. (2007), "Improving Public Sector Efficiency: Challenges and Opportunities", OECD Journal on Budgeting, Vol. 2007/1, OECD Publishing, Paris, pp. 1-41.

Dang, T.T., P. Antolín and H. Oxley (2001), "Fiscal Implications of Ageing: Projections of Age-Related Spending", OECD Economics Department Working Papers, No. 305, OECD Publishing, Paris.

De Graeve, D. and T. Van Ourti (2003), “The Distributional Impact of Health Financing in Europe: A Review", The World Economy, Vol. 26, pp. 1459-1479.

Dooren, W. van et al. (2006), “Issues in Output Measurement for 'Government at a Glance'”, OECD GOV Technical Paper 2, GOV/PGC(2006)10/ANN2, Paris.

Dooren, W. van et al. (2007), "Institutional Drivers of Efficiency in the Public Sector", GOV/PGC(2007)16/ANN, Paris.

Drucker, P. (1969), The Age of Discontinuity; Guidelines to Our changing Society, Harper and Row, New York.

Duval, R. and C. de la Maisonneuve (2009), "Long-Run GDP Growth Framework and Scenarios for the World Economy", OECD Economics Department Working Papers, No. 663, OECD Publishing, Paris.

European Commission (2008), Public Procurement for a Better Environment, Communication from the Commission to the European Parliament, the Council, the European Economic and Social Committee and the Committee of Regions, European Commission, Brussels.

European Commission (2008), Industrial Relations in Europe, Office for Official Publications of the European Communities, Luxembourg.

European Commission (2008), Measurement of Indicators for the Economic Impact of Public Procurement Policy, Working Document, European Commission, Brussels.

European Commission (2009), Impact of Ageing Populations on Public Spending, Brussels.

Fukawa, T. and I. Sato (2009), "Projection of Pension, Health and Long-Term Care Expenditures in Japan through Macro Simulation", The Japanese Journal of Social Security Policy, Vol. 8.

Gianella, C. et al. (2008), "What Drives the NAIRU? Evidence from a Panel of OECD Countries", OECD Economics Department Working Papers, No. 649, OECD Publishing, Paris.

Guichard, S. et al. (2007), "What Promotes Fiscal Consolidation: OECD Country Experiences", OECD Economics Department Working Papers, No. 553, OECD Publishing, Paris. 
Guichard, S. and E. Rusticelli (2010), "Assessing the Impact of the Financial Crisis on Structural Unemployment in OECD Countries”, OECD Economics Department Working Papers, No. 767, OECD Publishing, Paris.

Joumard, I., C. Andre and C. Nicq (2010), "Health Care Systems: Efficiency and Institutions", OECD Economics Department Working Papers, No. 769, OECD Publishing, Paris.

Ketelaar, A., N. Manning and E. Turkisch (2007), "Performance-Based Arrangements for Senior Civil Servants OECD and other Country Experiences", OECD Working Papers on Public Governance, No. 5, OECD Publishing, Paris.

Kings, J., E. Turkisch and N. Manning (2007), "Public Sector Pensions and the Challenge of an Ageing Public Service", OECD Working Papers on Public Governance, No. 2, OECD Publishing, Paris.

Lequiller, F. (2005), "Measurement of Non-Market Volume Output", Clarification Item C10 for Fourth Meeting of the Advisory Expert Group on National Accounts, 30 January-8 February 2006, OECD Publishing, Paris.

Lonti, Z. and M. Woods (2008), “Towards Government at a Glance: Identification of Core Data and Issues related to Public Sector Efficiency", OECD Working Papers on Public Governance, No. 7, OECD Publishing, Paris.

Manning, N. et al. (2006), "How and Why Should Government Activity Be Measured in 'Government at a Glance'?”, OECD GOV Technical Paper 1, GOV/PGC(2006)10/ANN1, Paris.

Matheson, A. et al. (2007), "Study on the Political Involvement in Senior Staffing and on the Delineation of Responsibilities Between Ministers and Senior Civil Servants", OECD Working Papers on Public Governance, No. 6, OECD Publishing, Paris.

Nardo, M. et al. (2005), “OECD Handbook on Constructing Composite Indicators: Methodology and User Guide”, OECD Statistics Working Paper, Vol. 2005/3, OECD Publishing, Paris.

Nardo, M. et al. (2008), Handbook on Constructing Composite Indicators, joint publication of the OECD and European Commission, Paris and Brussels.

New Zealand Treasury (2009), "Challenges and Choices, New Zealand's Long-Term Fiscal Statement", Statements in the Long-Term Fiscal Position, October.

OECD (1995), Reference Checklist for Regulatory Decision-Making, OECD Publishing, Paris.

OECD (2000), Government of the Future, OECD Publishing, Paris.

OECD (2002), "OECD Best Practices for Budget Transparency", OECD Journal on Budgeting, Vol. 2002/3, OECD Publishing, Paris, pp. 7-14.

OECD (2003), The e-Government Imperative, OECD Publishing, Paris.

OECD (2003), Open Government: Fostering Dialogue with Civil Society, OECD Publishing, Paris.

OECD (2003), Recommendation of the Council on Guidelines for Managing Conflict of Interest in the Public Service, OECD Publishing, Paris.

OECD (2003), Recommendation of the Council on Improving the Environmental Performance of Public Procurement, OECD Publishing, Paris.

OECD (2004), Policy Brief - Public Sector Modernisation: Modernising Public Employment, OECD Observer, OECD Publishing, Paris.

OECD (2005), Policy Brief - Public Sector Modernisation: Open Government, OECD Publishing, Paris.

OECD (2005), Teachers Matter: Attracting, Developing and Retaining Effective Teachers, OECD Publishing, Paris.

OECD (2006), "Projecting OECD Health and Long-Term Care Expenditures: What are the Main Drivers?", OECD Economics Department Working Papers, No. 477, OECD Publishing, Paris.

OECD (2007), Ageing and the Public Service: Human Resource Challenges, OECD Publishing, Paris.

OECD (2007), Improving the Environmental Performance of Public Procurement: Report on Implementation of the Council Recommendation, OECD Publishing, Paris.

OECD (2007), Integrity in Public Procurement: Good Practice from A to Z, OECD Publishing, Paris.

OECD (2007), OECD Guidelines for Managing Conflict of Interest in the Public Service: Report on Implementation, OECD Publishing, Paris.

OECD (2007), "Political Advisors and Civil Servants in European Countries", Sigma Papers, No. 38, OECD Publishing, Paris. 
OECD (2007), "Public Procurement Review and Remedy Systems in the European Union", SIGMA Papers, No. 41, OECD Publishing, Paris.

OECD (2007), “Towards Better Management of Government”, OECD Working Papers on Public Governance, Vol. 2007/1, OECD Publishing, Paris.

OECD (2007), Understanding the Social Outcomes of Learning, OECD Publishing, Paris.

OECD (2008), Growing Unequal? Income Distribution and Poverty in OECD Countries, OECD Publishing, Paris. OECD (2008), Public Private Partnerships: In Pursuit of Risk Sharing and Value for Money, OECD Publishing, Paris.

OECD (2008), The State of the Public Service, OECD Publishing, Paris.

OECD (2008), "Taxation and Economic Growth", Economics Department Working Papers, No. 620, OECD Publishing, Paris.

OECD (2009), Regulatory Impact Analysis: A Tool for Policy Coherence, OECD Publishing, paris.

OECD (2009), Evaluating and Rewarding the Quality of Teachers: International Practices, OECD Publishing, Paris. OECD (2009), Focus on Citizens: Public Engagement for Better Policies and Services, OECD Publishing, Paris.

OECD (2009), Government at a Glance 2009, OECD Publishing, Paris.

OECD (2009), Health at a Glance 2009: OECD Indicators, OECD Publishing, Paris.

OECD (2009), "Indicators of Regulatory Management Systems", OECD Publishing, Paris, www.oecd.org/ regreform/indicators.

OECD (2009), Measuring Government Activity, OECD Publishing, Paris.

OECD (2009), OECD Principles for Integrity in Public Procurement, OECD Publishing, Paris.

OECD (2009), Pensions at a Glance 2009, OECD Publishing, Paris.

OECD (2009), Rethinking e-Government Services: User-Centred Approaches, OECD Publishing, Paris.

OECD (2010), Cutting Red Tape - Why Is Administrative Simplification So Complicated?, OECD Publishing, Paris.

OECD (2010), Denmark: Efficient e-Government for Smarter Public Service Delivery, OECD Publishing, Paris.

OECD (2010), OECD Economic Outlook, Vol. 2010/2, OECD Publishing, Paris

OECD (2010), Education at a Glance 2010: OECD Indicators, OECD Publishing, Paris.

OECD (2010), Enhancing Integrity in Public Procurement: A Toolbox, available at www.oecd.org/governance/ procurement/toolbox.

OECD (2010), "Fiscal Policy across Levels of Government in Times of Crisis", OECD Network on Fiscal Relations across Levels of Government, OECD Working Paper, OECD Publishing, Paris.

OECD (2010), “Getting it Right”, Document prepared for the annual meeting of the Public Employment and Management Working Party, OECD/GOV/PGC/PEM(2010)4, OECD Publishing, Paris.

OECD (2010), "Health Care Systems: Getting More Value for Money", OECD Economics Department Policy Notes, No. 2, OECD Publishing, Paris.

OECD (2010), Making Reform Happen: Lessons from OECD Countries, OECD Publishing, Paris.

OECD (2010), Measuring Innovation: A New Perspective, OECD Publishing, Paris.

OECD (2010), The OECD Innovation Strategy: Getting a Head Start on Tomorrow, OECD Publishing, Paris.

OECD (2010), OECD Public Governance Reviews: Finland 2010 - Working Together to Sustain Success, OECD Publishing, Paris.

OECD (2010), OECD Reviews of Human Resource Management in Government - Brazil 2010: Federal Government, OECD Publishing, Paris.

OECD (2010), “Open Government and E-Rulemaking: A Discussion Note”, paper prepared for the Regulatory Policy at the Crossroads Conference, Paris, 28-29 October 2010, OECD Publishing, Paris.

OECD (2010), PISA 2009 Results: Overcoming Social Background - Equity in Learning Opportunities and Outcomes, Vol. II, OECD Publishing, Paris.

OECD (2010), Post-Public Employment: Good Practices for Preventing Conflict of Interest, OECD Publishing, Paris.

OECD (2010), Regulatory Policy and the Road Toward Sustainable Growth, OECD Publishing, Paris, www.oecd.org/regref/eu15. 
OECD (2010), Restoring Fiscal Sustainability: Lessons for the Public Sector, Paris.

OECD (2010), Revenue Statistics 1965-2009, OECD Publishing, Paris.

OECD (2010), Risk and Regulatory Policy: Improving Governance of Risk, OECD Publishing, Paris.

OECD (2010), OECD Science, Technology and Industry Outlook 2010, OECD Publishing, Paris.

OECD (2010), “Tax Competition Between Sub-Central Governments: Main Issues”, OECD Network on

Fiscal Relations across Levels of Government, Paris.

OECD (2011), OECD Economic Outlook, Vol. 2011/1, OECD Publishing, Paris.

OECD (2011), National Accounts at a Glance 2010, OECD Publishing, Paris.

OECD (2011), Pensions at a Glance 2011, OECD Publishing, Paris.

OECD (2011), OECD Public Governance Reviews: Estonia 2011, OECD Publishing, Paris.

OECD (2011), "Restoring Public Finances", Special Issue of the OECD Journal on Budgeting, Vol. 2011/2, Paris.

OECD (2011), Society at a Glance 2011: OECD Social Indicators, OECD Publishing, Paris.

OECD (2011), Tax Administration in OECD and Selected Non-OECD Countries: Comparative Information Series (2010), OECD Publishing, Paris.

OECD (2011), Taxing Wages 2010, OECD Publishing, Paris.

OECD (forthcoming), Budgeting Practices and Procedures in OECD Countries, OECD Publishing, Paris

OECD (forthcoming), OECD Public Procurement Review of the United States, OECD Publishing, Paris.

OECD (forthcoming), Partnering with Citizens and Civil Society for Innovative Service Delivery, OECD Publishing, Paris.

OECD (forthcoming), Public Servants as Partners for Growth: Strengthening a Leaner and More Equitable Public Service, OECD Publishing, Paris.

OECD (forthcoming), OECD Regions at a Glance 2011, OECD Publishing, Paris.

OECD (forthcoming), Society at a Glance 2011: OECD Social Indicators, OECD Publishing, Paris.

OECD (forthcoming), Transparency in Strategic Decision Making: Ministerial Advisors, Paris.

Office of the Parliamentary Budget Officer (2010), "Fiscal Sustainability Report", February.

Pilichowski, E., E. Arnould and E. Turkisch (2007), Ageing and the Public Sector: Challenge for Financial and Human Resources, OECD Publishing, Paris.

Pilichowski, E. and E. Turkisch (2008), "Employment in Government in the Perspective of the Production Costs of Goods and Services in the Public Domain", OECD Working Papers on Public Governance, No. 8, OECD Publishing, Paris.

Robinson, M. (2009), “Accrual Budgeting and Fiscal Policy”, OECD Journal on Budgeting, Vol. 2009/1, Paris.

Schick, A. (2009), "Budgeting for Fiscal Space”, OECD Journal of Budgeting, Vol. 2009/2, OECD Publishing, Paris.

Schick, A. (2010), "Post-Crisis Fiscal Rules: Stabilising Public Finance while Responding to Economic Aftershocks", OECD Journal on Budgeting, Vol. 2010/2, Paris.

Visco, I. (2005), "Ageing and Pension System Reform: Implications for Financial Markets and Economic Policies”, Financial Market Trends, November 2005 Supplement, OECD Publishing, Paris.

Westert, G.P. et al. (ed.) (2008), “Dutch Health Care Performance Report 2008”, RIVM National Institute for Public Health and the Environment, Bilthoven.

Wilkinson, R.G. and K.E. Pickett (2006), "Income Inequality and Population Health: A Review and Explanation of the Evidence", Social Science and Medicine, Vol. 62, No. 7, pp. 1768-84.

Zussman, D. (2009), Political Advisors, OECD Publishing, Paris. 


\section{ORGANISATION FOR ECONOMIC CO-OPERATION AND DEVELOPMENT}

The OECD is a unique forum where governments work together to address the economic, social and environmental challenges of globalisation. The OECD is also at the forefront of efforts to understand and to help governments respond to new developments and concerns, such as corporate governance, the information economy and the challenges of an ageing population. The Organisation provides a setting where governments can compare policy experiences, seek answers to common problems, identify good practice and work to co-ordinate domestic and international policies.

The OECD member countries are: Australia, Austria, Belgium, Canada, Chile, the Czech Republic, Denmark, Estonia, Finland, France, Germany, Greece, Hungary, Iceland, Ireland, Israel, Italy, Japan, Korea, Luxembourg, Mexico, the Netherlands, New Zealand, Norway, Poland, Portugal, the Slovak Republic, Slovenia, Spain, Sweden, Switzerland, Turkey, the United Kingdom and the United States. The European Union takes part in the work of the OECD.

OECD Publishing disseminates widely the results of the Organisation's statistics gathering and research on economic, social and environmental issues, as well as the conventions, guidelines and standards agreed by its members. 


\section{Government at a Glance}

This second edition of Government at a Glance almost doubles the number of available indicators of OECD governments and their performance, to nearly 60 . The report also offers two special chapters, on leveraged governance and on the policy implications of fiscal consolidation. The indicators are presented in ten chapters covering:

- Public finance and economics

- Strategic foresight and leadership

- Employment in general government and public corporations

- Compensation in selected public sector occupations

- Human resources management practices

- Transparency in governance

- Public procurement

- Regulatory governance

- Ways of delivering public services

- Government performance indicators from selected sectors

Readers can also find more information at www.oecd.org/gov/indicators/govataglance.

Further reading

OECD Public Governance Reviews: Estonia 2011 (2011)

OECD Public Governance Reviews: Finland 2010 (2010)

Measuring Government Activity (2009)

Please cite this publication as:

OECD (2011), Government at a Glance 2011, OECD Publishing.

http://dx.doi.org/10.1787/gov_glance-2011-en

This work is published on the OECD iLibrary, which gathers all OECD books, periodicals and statistical databases.

Visit www.oecd-ilibrary.org, and do not hesitate to contact us for more information.

\section{1}

